UNIVERSIDADE DE SĀO PAULO

\title{
LIVRO DIDATICO E CONHECIMENTO HISTÓRICO: UMA HISTÓRIA DO SABER ESCOLAR
}

Circe Maria Fernandes Bittencourt

Tese de doutoramento apresentada ao Departamento de História da Faculdade de Filosofia, Letras $\theta$ Ciências Humanas da Universidade de São Paulo sob a orientação da Profa. Dra. Raquel Glezer

SAOO PAULO

1993 


\section{LIVRO DIDÁTICO E CONHECIMENTO HISTÓRICO : UMA HISTÓRIA DO SABER ESCOLAR}

Circe Maria Fernandes Bittencourt

Tese de doutoramento apresentada ao Departamento de História d a Faculdade de Filosofia, Letras e Clênclas Humanas da Universidade de São Paulo : sob a orientação da Profa. Dra. Raquel Glezer 


\section{Agradecimentos}

A elaboração de uma tese possui sempre uma história na qual vários personagens participam direta ou indiretamente, e esta não foi diferente, permeada de encontros e reencontros, surpresas agradáveis e dissabores.

Os agradecimentos serão poucos para muitos que colaboraram nesse trabalho e os amigos perdoarão os inevitáveis esquecimentos.

Na França contei com a acolhida do professor Fréderic Mauro que me recebeu no Institut des Hautes Études de l'Amérique Latine, possibilitando contatos com pesquisadores e escolas. Na Sorbonne, o apoio constante e a amizade de Katia de Queiroz Mattoso foram fundamentais para o delineamento da pesquisa. o caloroso entusiasmo pelo trabalho, assim como as sugestões bibliográficas e metodológicas do professor Jean Glénisson permitiram o encaminhamento do trabalho na França e posteriormente no Brasil. Agradeço as importantes contribuiçōes de André Chervel iniciadas no Institut National de Recherche Pédadogique de Paris e continuadas quando de sua estadia na USP. Também no INRP, a colaboração de Alain choppin foi fundamental para as descobertas do mundo editorial dos livros didáticos.

Registro meus agradecimentos a J.Moreira da editora Itatiaia em Belo Horizonte que gentilmente possibilitou acesso à documentação da editora Garnier. Agradeço igualmente aos editores da F.T.D. que facilitaram o contato com seu acervo didático e forneceram informaçōes sobre a história da empresa. Impedimentos incompreensíveis impossibilitaram o acesso à documentação da editora Francisco Alves.

Na Biblioteca Nacional do Rio de Janeiro contei com as solicitudes das bibliotecárias da seção de obras raras e devo um agradecimento especial à Ana Virgínia Pinheiro pelo enriquecimento do acervo iconográfico sobre livros e escola. 
Meus agradecimentos se estendem a amigos e colegas da Faculdade de Educação da USP e em especial do Departamento de Metodologia do Ensino e Educação Comparada. Expresso um agradecimento especial à professora Ana Maria Pessoa de Carvalno que me incentivou constantemente, auxilianco na reajização de viagens para as pesquisas em Belo Horizonte e Rio de Janeiro. As professoras Elza Nadai e Rosa Kulcsar substituiram-me nas atividades didáticas, possibilitando o afastamento por dois anos na França. Marina dos Santos Almeida colaborou com a pesquisa na Biblioteca da FEUSP, especialmente quanto ao acervo da Biblioteca "Paulo Bourrould". Lilian Curiel L. Passeri da Seção de Recursos Audio - Visuais auxiliou na organização e apresentação do acervo iconográfico da pesquisa. Roberto de Moraes Carloto com seu domínio técnico em fotocópias, favoreceu com dedicação e capricho, a reprodução da tese.

No Departamento de História da USP contei com o apoio fundamental de amigas que atentamente realizaram leituras críticas e sugestivas. Ana Maria de Almeida Camargo incentivou-me de várias formas, indicando e fazendo empréstimos de bibliografia preciosa. Zilda Yokoi demonstrou inestimável solidariedade, lendo atentamente o trabalho, identificando questões críticas. De forma especial agradeço a Sylvia Basseto, leitora crítica, que compartilhou das angústias e dúvidas que permearam a construção dessa pesquisa.

o apoio financeiro concedido pela bolsa do CNPq foi essencial para a pesquisa na França e aquisição de reproduções de livros da Bibliothèque Nationale de Paris.

Diomar, solidário e companheiro de todas as etapas do trabalho, cuidou da revisão final. Agradeço a meus filhos, Maíra e Diogo, pela paciência com as minhas impaciências.

Finalmente, agradeço à orientação de Raquel Glezer que mais uma vez acreditou e confiou no trabalho, incentivando e enriquecendo-o em todos os momentos. 


\section{Resumo}

A história do livro didático brasileiro é recuperada neste trabalho no período correspondente à instalação do Estado Nacional, juntamente com a criação das escolas públicas elementares e secundárias, até a primeira década do século atual, com as propostas de ampliação da rede escolar do regime republicano. Nesta trajetória, acompanhamos a construção do saber escolar organizado pelo poder educacional, dividido entre o Estado civil e a Igreja Católica. Em meio às disputas entre os dois setores, o livro escolar desempenhava um papel fundamental na concretização dos projetos educacionais de ambas as tendências. o livro didático foi se transformando em uma importante mercadoria das empresas editoriais que se aliaram ao Estado na divulgação dessa produção cultural que tendia a se ampliar. o saber escolar contido no livro didático é analisado pelas disciplinas História Geral e do Brasil, desvendando o processo de transposição do saber erudito para o saber a ser ensinado. Dentro dessa problemática, situamos o papel dos autores dos livros didáticos de História e o "lugar" de sua produção. A partir da confeç̧ão do livro didatico, na qual pudemos identificar os inúmeros agentes que interferiam em sua composição, buscamos identificar como este objeto cultural era usado por professores e alunos nos diferentes espaços escolares, detectando as questōes que envolveram o processo de ensino e aprendizagem do período.

\section{PALAVRAS - CHAVES}

Livro didático

Compêndios

Livro de leitura

Editora

Saber escolar

Transposição didática
Ensino de História

Disciplina escolar

História Sagrada

História do Brasil

História da Civilização

Aprendizagem 
Página

INTRODUÇÃO

1 a Parte

Literatura e Estado

CAPÍTULO I

LIVRO DIDÁTICO E CONSTRUÇÃO DO SABER ESCOLAR

1. Concepçōes e projetos de redação do livro didático

1.1 Concepções iluministas do livro didático 18

1.2 Planos de redação dos livros didáticos

2. Livros didáticos e concepções de ensino

2.1 Instrução para quem?

2.2 Livros de leitura e ensino elementar

2.3 Livros e compêndios para o ensino secundário

3. Vigilância e controle da produção didática

3.1 Legis lação sobre o livro didático

3.2 Vigilância dos Conselhos de Instrução

CAPÍTULO II

ESTADO E EDITORAS: CONFECÇÃO E DIFUSÃO DA PRODUÇÃO DIDATICA

1. Editoras e poder institucional

1.1 Nascimento das editoras de livros didáticos

1.2 Editoras nas províncias

2. Comercialização do livro didático

2.1 A "carne" da produção de livros

2.2 Estratégias de produção e venda

3. Divulgação oficial da literatura escolar

3.1 Política de distribuição de livros

3.2 Bibliotecas escolares e exposições pedagógicas 


\author{
2a Parte \\ Transposição didática e livros de História
}

CAPÍTULO III

LIVROS DIDÁTICOS E ENSINO: DA HISTÓRIA SAGRADA A HISTÓRIA PROFANA

1. A História nos programas curriculares: constituição de uma disciplina

1.1 História nos programas curriculares do ensino secundário

1.2 História nas escolas elementares e profissionais

2. Da História Sagrada à História profana

2.1 História sagrada nos livros didáticos

2.2 Moral profana e livros de Instrução Cívica

3. Confrontos na produção didática : História Universal ou História da Civilização?

3.1 o predomínio dos franceses na História Universal

3.2 Divergências entre os autores de História da Civilização

CAPÍTULO IV

HISTÓRIA DO BRASIL NOS LIVROS DIDÁTICOS

1. Autores e compêndios de História do Brasil

1.1 Militares e História nacional

1.2 Os sócios do IHGB e a História oficial do Brasil

1.3 Expansão da produção

2. Temas e periodização da História do Brasil

2.1 Cronologia e "heróis nacionais"

2.2 "Nacionalismos"

3. A noção de tempo e espaço nas obras do cônego Fernandes Pinheiro e de João Ribeiro

3.1 O tempo sagrado na obra do cônego

3.2 As temporalidades da História do Brasil de João Ribeiro 


$$
\begin{gathered}
\text { 3a Parte } \\
\text { Usos do Iivro didático }
\end{gathered}
$$

CAPITULO $\mathrm{V}$

LIVROS DIDÁTICOS E PROFESSORES

1. Mestres normalistas ou leigos?

1.1 Primeiras Escolas Normais

1.2 Condições de trabalho dos "mestres de primeiras letras"

11.3 Mestres e livros

2. Professores secundários: leitores e autores

2.1 Professores de liceus

2.2 Professores- autores

3. Diálogos dos autores com os docentes

3.1 Metodologias de ensino

3.2 A imagem do professor e da escola nas obras didáticas

CAPÍTULO VI

LIVROS DIDÁTICOS NAS SALAS DE AULA

1. Métodos pedagógicos e formas de leitura

1.1 Exercícios e conceitos de aprendizagem

1.2 Ilustraçōes e aprendizagem

1.3 A "memorização" no processo de aprendizagem

2. Salas de aula e práticas de leitura

2.1 Imposiçōes de normas de leitura

2.2 Ler e escrever

2.3 Transgressões 


\section{Lista de figuras}

Página

Capítulo I

Figura 1 : Escolas de ensino mútuo elementar.

Fotografia de um cartaz ilustrado, 1817

Capítulo II

Figura 2: O derradeiro Mohicano. Página de rosto 86

Figura 3: Biblioteca do povo e das escolas, 1882. 88

Figura 4: Compêndio de geografia universal. 90

Figura 5: Silabário português.Livro impresso nos

Estados Unidos. [s. n.] 93

Figura 6: Gramática Geral de Sotero dos Reis 101

Figura 7: Livraria Garnier. Rio de Janeiro,1904 115

Figura 8: Gramática Latina de Pereira. Capa 116

Figura 9: Contra -capa do Novo Atlas Universal da Infância de J.M. de Lacerda 117

Figura 10:Livros premiados. Anúncios da editora

Francisco Alves 126

Figura 11:Biblioteca "Paulo Bourroul". Escola

Normal de são Paulo "Caetano de Campos" 129

Figura 12:D. Pedro II. Gravura de Victor Frond 132

Capítulo III

Figura 13:Quarta Época.Resumo da História Bíblica de D.Antonio de Macedo Costa 163

Capítulo IV

Figura 14:Episódios da História Pátria. Cônego Fernandes Pinheiro. Página de rosto 209

Figura 15:Cristovão Colombo e o ovo. Contos e Narraçōes 213

Figura 16:Contos Pátrios. Olavo Bilac 215 
Figura 17:Epítome da História do Brasil de

Moreira Pinto

Figura 18:Cônego Fernandes Pinheiro Fotografia

\section{Capítulo V}

Figura 19: Primeiro livro de leitura. Página de rosto 270 Figura 20:Livro das donas e donzelas de Julia Lopes de Almeida. Ilustração de Jeanne Mathieu

276

Figura 21:Silabário Português de R. Galvão 279

Figura 22:0 filho modelo ou discípulo exemplar.Segundo livro de leitura de Landelino Rocha 280

Figura 23:0s bons alunos.Silabário português 280

Figura 24:Adjetivos. Ensino prático de língua materna de Menezes Vieira

Figura 25:A Bíblia. Segundo livro de leitura de Landelino Rocha

Figura 26:Segundo livro de leitura de Abilio Cesar Borges. Página de rosto 284

Figura 27:Lição de Leitura.Silabário português 285

Figura 28:Empenho materno. Livro das donas e donzelas de Julia Lopes de Almeida

\section{Capítulo VI}

Figura 29:Ponderabilidade. Noções de física e química, 1876

Figura 30: O papagaio de papel. O amiguinho de Nhonho- leitura corrente expressiva

Figura 31:Fábulas (La Fontaine)

Figura 32:Indía Uapé. História do Brasil para escolas primárias

Figura 33:0 bandeirante. Contos pátrios

Figura 34:A morte do $1^{\circ}$ Bispo do Brasil. Quadros de História do Brasil

Figura 35: Matança do $1^{\circ}$ bispo da Bahia e seus companheiros 
Figura 36:Taba ou aldeia índia. Pequena história do

Brasil de J. Maria de Lacerda

Figura 37:Combate singular entre dois Aymorés.

Pequena história do Brasil. J.M. Lacerda

Figura 38:Dança guerreira e religiosa dos Tupinambás

Pequena história do Brasil

Figura 39:Ataque dos índios Guaycurus.Pequena

história do Brasil

305

Figura 40:Bataille de lansquenets. Histoire

de la civilisation. Ch. Seignobos

309

Figura 41:Os gauleses e os romanos. La deuxième année d'Histoire de France

Figura 42:Leitura do Pequeno Polegar. Fronstispício

dos Contos de Perrault

Figura 43:0 amor à instrução. Livro de leitura.

Landelino Rocha

Figura 44:Ilustração O Ateneu. Edição de 1905

Figura 45:Salas de aula em 1500. Bobeng, 1: 60

Figura 46:0 dorminhoco surpreso. Histtória da vida

privada

Figura 47:Sala de aula da Caetano de Campos.

Fotografia

Figura 48:0 dever de casa. Bico de pena. Musée

National de l'Éducation

Figura 49:A pena de escrever. Alfabeto português

Figura 50:A punição. Litografia do Sec. XIX. INRP, Musée National de I'Éducation 


\section{Introdução}

Este trabalho aborda a história do livro didático no processo do eisino ivolar brasileiro, visando ultrapassar limites itudos sobre a produção didática que pr aminantemente os abordam de maneira fragmentária. A proposta é pensar o livro didático de forma ampla, acompanhando os movimentos que vão da sua concepção à sua utilização em sala de aula. É uma reflexão sobre o papel do livro didático na construção do saber escolar que, por sua natureza, deve necessariamente ser considerado em um conjunto mais geral no qual aspectos sociais, culturais, políticos e econômicos se articulam, conferindo-lhe uma dimensão específica.

o tema

Livros escolares circulam aos milhões diariamente pelas mãos de professores e alunos. Editoras divulgam novos títulos e reeditam os mais vendidos, dando ao livro didático proeminência na indústria cultural. A literatura escolar é o produto de maior vendagem no quadro atual das editoras nacionais.

- livro didático é assunto polêmico, pois gera posições radicais entre professores, alunos e pesquisadores dos problemas educacionais.

Nossa experiência profissional como professor em escolas de primeiro e segundo graus e em cursos de formação inicial e contínua de professores nos permitiu perceber que, mesmo com ressalvas e em meio a práticas alternativas de trabalho com outros materiais didáticos, o livro escolar tem sido o instrumento pedagógico de maior utilização no quotidiano escolar. 1

1 A nossa experiência pessoal tem sido enriquecida pelos Relatórios de Estágios dos alunos de Prática de Ensino de História que registram o 
Constatamos que os consumidores de livros didáticos, professores e alunos, divergem na avaliação do papel exercido por ele na vida escolar.

Para uma parcela diminuta de professores, o livro didático é considerado como um obstáculo ao aprendizado, instrumento de trabalho a ser descartado em sala de aula. Para outros ele é material fundamental ao qual o curso é totalmente subordinado. Na prática, o livro didático tem sido utilizado pelo professor, independente de seu uso em sala de aula, para preparação de "suas aulas" em todos os níveis da escolarização, quer para fazer o planejamento do ano letivo, quer para sistematizar os conteúdos escolares, ou simplesmente como referencial na elaboração de exercícios ou questionários.

Entre os alunos, observamos avaliações divergentes sobre o livro didático. Parte deles considera o livro como organizador da "matéria", garantindo o conteúdo a ser estudado para as provas. O mesmo ocorre com os pais, principalmente os da classe média que buscam alguma garantia de eficiência e controle sobre os conteúdos. Para parcelas de alunos oriundos das camadas populares, a posse do livro associa-se a "status", embora represente um ônus em seu parco orçamento como exemplifica a argumentação de um aluno em reação à proposta da professora em não adotar livro em um curso da periferia de São Paulo, valorizando a segurança que este material oferecia quando das "batidas" de policiais em ônibus ou ruas. A posse do livro garantia uma certa situação social privilegiada, a possibilidade de um tratamento diferenciado pelas autoridades policiais. O uso e a posse do livro didático inserem-se, assim, em uma complexa teia de relações e de representações sociais.

o uso permanente do livro ligado ou não a métodos denominados "tradicionais" de ensino foi o ponto de partida do tema que foi se constituindo, permeado pelas indagações e dúvidas sobre a prática escolar que temos vivenciado.

A pertinência do tema é comprovada pelo considerável

trabalho de professores em salas de aula de escolas públicas de São paulo de 1985 em diante. 
volume de trabalhos e pesquisas sobre manuais escolares produzidos nos últimos anos no Brasil, conforme verificamos pelo Catálogo Analítico, publicado pela Universidade de Campinas (UNICAMP) em conjunto com o Instituto Nacional de Estudos Pedagógicos (INEP).2 A atualidade do tema é demonstrada pela produção crescente de pesquisas em vários países, notadamente França, Estados Unidos e Grã- Bretanha.

A análise destes trabalhos permite a observação das várias possibilidades de pesquisas, visto que o livro escolar é um objeto de "múltiplas facetas", cujo interesse está presente em muitos campos de investigação: história, ciências políticas e econômicas, pedagogia, sociologia, linguística, etc.

A natureza complexa do objeto explica o interesse que - livro didático tem despertado nos diversos domínios de pesquisa. $\hat{E}$ uma mercadoria, um produto do mundo da edição que obedece à evolução das técnicas de fabricação e comercialização pertencente aos interesses do mercado, mas é também um depositário dos diversos conteúdos educacionais, suporte privilegiado para se recuperar os conhecimentos e técnicas consideradas fundamentais por uma sociedade em una determinada época. Além disso, ele é um instrumento pedagógico "inscrito em uma longa tradição, inseparável tanto na sua elaboração como na sua utilização das estruturas, dos métodos e das condições do ensino de seu tempo." $3 \mathrm{E}$, finalmente, o livro didático deve ser considerado como veículo portador de um sistema de valores, de uma ideologia, de uma cultura.

Tais características fazem com que o livro didático seja objeto de pesquisas divergentes. É alvo de criticas contundentes ou de estudos que proclaman sua existência como fundamental no processo de ensino das escolas. Criticada ou elogiada, a obra didática tem se constituído em tema com. enfoques variados, em que se destaca uma linha que privilegia avaliações de seus diversos conteúdos. Nos

2 Universidade Estadual de Campinas - Catálogo Analítico - Que sabemos sobre livro didatico. Campinas: Editora da Unicamp, 1989.

3 CHOPPIN, Alain - L'histoire des manuels scolaires: une approche globale. Histoire de I'education. Paris, INRP, $\mathrm{n}^{\circ} 9: 1 \_25$, déc. 1980 . 
estudos mais críticos prevalecem as análises dos seus aspectos ideológicos e apenas recentemente, têm surgido trabalhos que cuidam das questões políticas que envolvem a produção e a divulgação da literatura didática. 4

A experiência pessoal e as divergências no tratamento do tema levaram-nos, em uma primeira instância, a considerar a possibilidade de conhecê-lo, acompanhando-o em uma trajetória mais longa, buscando sua gênese.

No Brasil existem poucos estudos sobre a história do livro didático. Em alguns casos aparecem como introduções para outros temas ou surgem como fonte para estudos da evolução de conceitos em trabalhos sobre a história de uma determinada disciplina. 5

Para obter um referencial mais amplo recorremos às pesquisas realizadas em outros países, especialmente as da França onde nos últimos anos avolumaram-se investigações sobre materiais didáticos e que hoje dispõe de importantes acervos em duas bibliotecas - Bibliothèque Nationale de Paris e Bibliothèque des Manuels Scolaires de l'Institut National de Recherche Pédagogique - nos quais estão incluídos obras didáticas brasileiras dos séculos XIX e XX.

Estes dois centros possibilitaram-nos contatos com alguns pesquisadores da área e um levantamento bibliográfico básico das diversas pesquisas sobre os manuais escolares. 6

Com a preocupação de alcançar uma dimensão mais ampla do significado do livro didático procuramos situá-1o no contexto da história do livro. Destaca-se, nos estudos brasileiros, a obra de Halewell, o livro no Brasil, que resgatou a vida dos editores e sua produção. o livro escolar é nele apresentado em vários momentos, sendo possível

4 Dentre outras obras, cito as de FREITAG, Bárbara e outros - o livro didático em questão. Sāo Paulo: Cortez, 1989 e o de OLIVEIRA, J.B.A.; GUIMARÃES, S. D. P.; BOMÉNY, H.M.B.- A política do livro didático. São Paulo: Summus ; Campinas: Ed. Unicamp., 1984.

5 cf. levantamento feito na citada obra que sabemos sobre o Iivro didatico

6 Nesses dois centros destacam-se os trabalhos de Alain CHOPPIN, pesquisador do INRP de Paris, de Ives GAULUPEAU do Musée National de I'Éducation do INRP, em Rouen e Christian AMALVI, encarregado do acervo didatico da Bibliothèque Nationale de Paris. As publicaçōes desses pesquisadores constam da bibliografia geral. 
visualizar a importância do material no conjunto editorial, desde os primórdios da imprensa nacional. ${ }^{7}$

Nem sempre, entretanto os estudos históricos incluem o livro didático, considerado, em certa perspectiva, cómo produção marginal. A produção didática surgiu na história do livro em trabalhos recentes e importantes, como a Histoire de I'édition française. Nela o livro didático apareceu em dois capitulos: o primeiro é referente ao Antigo Regime francês associado ao ensino religioso, e o outro dedicado ao século XIX, com o desenvolvimento da escola laica e obrigatória. 8

Os organizadores da obra traçaram propostas importantes. para a pesquisa histórica relativa a este produto cultural. Destacaram a importância do livro como um elemento de diferenciação entre os grupos sociais, não apenas entre as classes sociais, entre dominantes e dominados, mas como indicador, de oposições no interior das próprias elites. A partir desta formulação colocaram a questão sobre as variações do ato de ler e a necessidade de se realizar a história da leitura. Fazer a história da leitura implica em rever o problema do livro e seu caráter ambíguo. Proposto, em geral, para cimentar a uniformidade de pensamento, divulgar determinadas crenças, inculcar normas, regras de procedimento e valores, o livro pode também criar as diferenças porque a leitura que se faz nele ou dele, nunca é única. A leitura de um livro é ato contraditório e estudar seu uso é fundamental para o historiador compreender a dimensão desse objeto cultural.

Tais elementos se tornaram importantes para esta pesquisa que passou a ser definida pela inserçāo do livro escolar na história da cultura, associando-o à constituição de uma sociedade letrada, procurando determinar claramente

7 HALLEWELL, L. - o livro no Brasil: sua história. sāo paulo: T. A. Queiros/ EDUSP, 1985.

8 Esta obra que tem servido como marco referencial para estudos historicos sobre o livro na França, foi organizada por CHARTIER, Roger et MARTIN, Henri-Jean - Histoire de l' edition française. paris: Promodis, 1982 a 1985, 4 tomos. Os capitulos referentes aos livros didáticos são os de DOMINIQUe, Julia- Livres de classe et usages pedagogiques. T. 2: Le livre triomphant (1660-1830) pp.468-497 e o de CHOPPIN, Alain- Le livre scolaire. T. 4: Le livre concurrance, 19001950, pp. $280-305$ 
seus consumidores. Neste sentido foram sugestivas as obras de Carlos Ginzburg e a de Peter Burke, que têm por objeto a história da cultura popular se interrelacionando ou se afastando da cultura burguesa, à medida em que o mundo da leitura e da escrita se expandem na sociedade moderna. Ambos forneceram contribuições importantes para a busca e estudos indicativos da circularidade da cultura, dos problemas que envolvem a tradição oral, típica das sociedades précapitalistas, na constituição de um saber que pretende se comunicar por signos impressos em livros.9 Esta opção de encaminhamento foi reforçada pelos trabalhos de Jean Glénisson sobre o mundo da leitura infantil e da juventude. e os de Leonardo Arroyo, Marisa Lajolo e Regina Zilbermann.10

Procuramos inscrever o tema no conjunto das reflexões da produção cultural, especialmente a literária, situando o livro didático na história cultural mas de modo a apresentar suas peculiaridades na história educacional, estabelecendo seus vínculos com a escola.

o espaço escolar está associado intrinsecamente à construção do livro didático considerando que a escola é, fundamentalmente, uma instituição contraditória onde dominação e conflitos convivem no quotidiano de alunos e professores desde sua criação pelo Estado Nacional.

A análise da escola que realizamos é concebida sob perspectiva de um espaço cońtraditório, um lugar de produção de conhecimento e não apenas mera instância criada pelo Estado para transmitir e reproduzir sua ideologia. Sob esta ótica, buscamos aprofundar as leituras das teorias de Michael Apple sobre a relação entre educação e sociedade,

9 Dos autores mencionados, destacamos as obras: GINzBURG, Carlo - 0 queijo e os vermes. São Paulo: Companhia das Letras, 1987 e de BuRKE, Peter - Cultura popular na Idade Moderna. Sāo Paulo: Companhia das L̇etras, 1989.

10 Os principais trabalhos destes autores utilizados em nossa pesquisa foram: GLÉNISSON, Jean- Le livre pour la jeunesse. Histoire de I'édition française- Du romantisme à la Belle Époque - op. cit., p. 417-443 e anotaçōes dos cursos que ministrou na França e no Departamento de Historia, F.F.L.CH. /USP em 1990. Dentre os nacionais cito ARROYO, Leonardo - Literatura infantil brasileira - ensaio de preliminares para sua historia e suas fontes. São paulo: Melhoramentos, 1968, os de LAJOLO, Marisa-Usos e abusos da literatura na escola. Rio de Janeiro: Globo, 1982 e o livro didatico: velho tema revisitado. Em Aberto, Brasilia, ano $8, \mathrm{n}{ }^{\circ} 35$, jul.-set, 1987, pp. 1-9 e o de ZILBERMAN, Regina - o livro didatico e o ensino de literatura na escola. Leitura: Teoria \& Prática, Campinas, 3(4): 3-15, dez. 1984. 
procurando avançar na compreensão dos conceitos de hegemonia, contradição e resistência na instituição escolar. A escola, lugar onde o conhecimento é produzido e transmitido, além de ser o espaço da reprodutividade da divisão de trabalho, liga-se aos questionamentos sobre qual conhecimento ela produz efetivamente. Procuramos, desta maneira, investigar o conhecimento como capital cultural, verificando sua disseminação em um determinado momento da nossa história escolar. ${ }^{11}$

Esta preocupação levou-nos a considerar o livro didático abrangendo aspectos epistemológicos que envolvem sua construção. Situamos o livro didático discutindo o problema da elaboração dos conteúdos e métodos das diferentes disciplinas escolares e que são ligados a uma imagem de pedagogia. o estudo deste objeto nos levou à reflexão sobre os conceitos de disciplina e conteúdo do ensino escolar, visto que geralmente se aceita a idéia que os conteúdos das disciplinas escolares são meras "vulgarizações" do saber denominado erudito, cabendo aos pedagogos criar metodologias para que as ciências possam ser assimiladas por un público jovem.

o tema do livro didático e sua história somou-se aos problemas do saber escolar cuja essência buscamos definir. Esta reflexão é necessária uma vez que, frequentemente, o conteúdo dos manuais é confundido com o saber escolar por excelência. Trata-se de um conhecimento concebido como científico, ou criado com certo rigor em centros considerados academicamente como tal e que é proposto dentro de regras determinadas pelo poder constituído ou por instituições próximas a ele, construíndo-se, desta forma, o saber a ser ensinado difundido pelas disciplinas escolares distribuídas pelos programas e currículos escolares. 0 saber a ser ensinado transforma-se em saber ensinado na sala de aula onde o professor é elemento fundamental tanto na interpretação que fornece a este conhecimento proposto como nos métodos que utiliza em sua transmissão, com os meios de

11 Cf. APPLE, Michael - Educaçāo e poder; trad. Maria Monteiro, Porto Alegre: Artes Médicas, 1989. 
comunicação que dispõe. Finalmente, para a configuração integral do saber escolar, temos o saber apreendido, ou seja, o conhecimento entendido, incorporado e utilizado pelos alunos de acordo com a vivência de cada um deles, das condições sociais e das relações estabelecidas no espaço escolar.

A articulação entre saber erudito e saber escolar não tem sido abordada em pesquisas sobre a história das disciplinas, embora tais questões sejam eventualmente introduzidas sem maiores aprofundamentos, e apresentadas com dados pouco sistematizados.

Em proposta mais recente, André Chervel contribuiu para uma reflexão sobre as possibilidades de uma pesquisa sobre a história das disciplinas escolares de maneira a abrange-la em toda sua complexidade. A proposta desse pesquisador parte da constituição do saber específico construído pela disciplina escolar até a análise do uso que seus diversos agentes fazem dela. Partindo das reflexões de Chervel, preocupamo-nos em estabelecer dialeticamente o elo entre a escola e sua vida interna com o saber oriundo de fora, trazido por alunos e professores. Acreditamos que uma história do livro didático referenciada fundamentalmente na escola auxilia a compreensão do movimento pelo qual é criado um saber escolar, percebendo-se com clareza os limites de intervenção de professores e alunos no processo de produção deste conhecimento e questionando qual a liberdade do aluno em sua apreensão e no seu uso. 12

Para vincular o livro didático às questões epistemológicas e situá-lo na prática educacional, promovendo uma leitura de seus conteúdos e métodos, optamos por uma única disciplina, tendo recaído a escolha sobre a História, visto que nela se realizou nossa formação acadêmica e experiência profissional.

Para o estabelecimento de uma periodização, os critérios desviaram-se dos poucos trabalhos sobre a história do livro didático existentes entre nós, especialmente o de

12 Cf. CHERVEL, Andre - L'histoire des disciplines scolaires: reflexion sur un domaine de recherches. Histoire de 1 'Éducation. Paris, 38: 59-119, mai, 1988 . 
Guy de Hollanda, autor de um estudo sobre a bibliografia didática de História entre os anos de 1931 a 1956, fundamentado exclusivamente nas reformas dos programas de ensino, privilegiando as ações do Estado. ${ }^{13}$ Embora a questão das reformas dos programas se constituam efetivamente em marcos importantes para a elaboração dos livros didáticos, buscamos verificar outros agentes que intervieram na construção e nas mudanças dos livros escolares, pois nem sempre tais reformas transformaram substancialmente sua natureza e seus conteúdos.

Situamos o tema no período de instalação das primeiras escolas públicas pelo Estado Nacional na década de 20 do século XIX até 1910, por considerálo elucidativo da dimensão que a ele atribuímos. Inicíamos a pesquisa pelo período no qual foi possível resgatar a origem dos manuais editados em gráficas brasileiras, passando pela efetivação da produção nas décadas de 60 a 80 do século XIX, quando o ensino primário começou a ser ampliado em meio às questões políticas e sociais. Fechamos a periodização nas primeiras décadas do regime republicano quando, ao lado das medidas educacionais que, aparentemente, forjavam novos projetos para a escola, as empresas editoriais puderam fazer do livro didático a sua principal fonte de renda, o que significava. estar ele incorporado como objeto necessário e indispensável na transmissão do saber escolar. Este período de cem anos, aproximadamente, correspondeu à fase da constituição do saber escolar em uma sociedade brasileira escravagista que se transformava, chegando ao advento do trabalho livre e da nova concepção de cidadania.

Assim, a escolha do século XIX e primeira década do século atual se fez no sentido de prescrutar as transformações sofridas por este material de ensino e o saber por ele construído, a partir do momento da constituição do Estado Moderno Nacional até o período da construção do regime republicano que, segundo vários estudos

13 HOLLANDA, Guy de - Um quarto de seculo de programas e compêndios de historia para o ensino secundário brasileiro - 1931- 1956. Rio de Janeiro: INEP/MEC, 1957. 
sobre educação, tem sido considerado como um dos marcos da história brasileira em todos seus aspectos.

\section{Documentação e método de trabalho}

Uma questão inicial a ser apresentada sobre a documentação desta pesquisa refere-se à dificuldade para a constituição do "corpus" documental, uma vez que o livro didático é, neste trabalho, objeto de pesquisa e seu principal documento. Uma das primeiras dificuldades referese à diversidade da produção, com um intenso fracionamento do sistema escolar e a multiplicação das disciplinas. Um outro aspecto é a sua característica de produto a ser consumido em tempo breve, de acordo com os rítmos das reformas curriculares, criando um paradoxo: possui uma grande tiragem de exemplares desde seu início, mas é pouco preservado, raramente encontrado em locais adequados, na maior parte das vezes, em péssimo estado de conservação.

Este material encontra-se disperso e enfrentamos vários desafios, tanto para conseguir localizá-lo, como para ter acesso a ele. Sendo uma espécie de produção marginal, o livro escolar não foi e nem tem sido depositado em bibliotecas públicas. Alguns exemplares brasileiros do século XIX puderam ser encontrados nas seções de livros raros da Biblioteca Nacional do Rio de Janeiro e na "Mário de Andrade", de São Paulo, e em bibliotecas da Universidade de São Paulo que receberam acervos doados, como a Biblioteca "Paulo Bourroul" e "Macedo Soares" da Biblioteca da Faculdade de Educação da USP.

Alguns outros exemplares foram comprados em sebos ou doados por pessoas amigas que colaboraram na tarefa de coleta.

A maior parte, entretanto, do "corpus" documental foi obtida na Bibliothèque Nationale de Paris, pois um número significativo de manuais escolares brasileiros foi impresso na França e, de acordo com sua legislação sobre o "depôt legal", encontram-se preservados naquela instituição. 
Devemos frisar também que nela foi possível encontrar os livros em suas várias edições, dado relevante para nós no sentido de definir o período de uso da obra e para identificar sua aceitação perante o público.

A organização do acervo de livros didáticos correspondeu a um trabalho semelhante ao do arqueólogo, buscando os objetos escondidos em diferentes "sítios", que definirão as várias leituras. Os livros encontrados na Bibliothèque de Paris por razões da obrigatoriedade do "depôt" pouco dizem sobre seus leitores, mas com eles podemos acompanhar suas edições. Livros obtidos por doações de antigos alunos, professores ou encontrados em bibliotecas particulares fornecem indícios sobre possíveis formas de consumo e de leitura, pelos traços de uso neles existentes.

Para reconstituirmos o sentido amplo do objeto, conforme os objetivos enunciados, foi necessário considerar as relações estabelecidas em três polos: o texto, o objeto que the serve de suporte e a prática que dele se apodera.

Desta forma, a proposta de elaborar a história do livro didático constituiu-se como desafio, tanto na organização do "corpus", quanto na forma de tratamento da documentação, visto que a concebemos como problema a ser desvendado em toda sua complexidade, envolvendo-a em contextos abrangentes, associados ao espaço escolar e a seu público leitor.

Para cumprir tal propósito, pelo tipo específico de documentação, se fez necessário distinguir as várias leituras do material, visando o enfoque em todas suas dimensões.

Considerando-o como objeto da indústria cultural, o livro foi pesquisado pela documentação existente nos arquivos de editoras, sempre com dificuldades, vigiada pelos proprietários que restringem o acesso ao conjunto do acervo. os almanaques publicados pelas editoras e seus catálogos foram fontes importantes para se obter dados quantitativos, informações sobre métodos de vendagens e divulgação das obras. 
Para elucidar a relação entre o livro didático e escola fizemos leituras paralelas dos programas escolares propostos pelo Estado, pela Igreja ou demais instituições particulares que se encarregaram da organização educacional do período. Os textos destes programas foram acompanhados com a leitura da legislação, pareceres e relatórios de autoridades vinculadas à educação, somadas à literatura pedagógica então produzida. Para resgatar o uso do livro pela sociedade da época e suas transformações, buscamos informações em romances e biografias, sobretudo nos memorialistas com suas recordações da vida escolar. Para completar o quadro das complexas representações sociais sobre o papel do livro e do mundo letrado, recorremos primordialmente à "fala" do próprio livro didático sobre tais questões.

Dividimos o trabalho em três partes, subdivididas em seis capítulos. Iniciamos pela vinculação entre livro didático e a organização educacional do Estado Nacional, recuperando as formas como o poder instituído concebia o livro e o saber escolar. Trata-se de uma análise dos projetos sobre o livro escolar e o papel que deveria desempenhar, segundo os pressupostos oficiais e de intelectuais preocupados com a questão educacional. Considerando o público para o qual o livro escolar foi produzido, pudemos acompanhar como o saber proposto para eles se alterou no decorrer do processo de transformações sociais que ocorreram com a urbanização, imigração e com o estabelecimento de novas relaçōes a partir da introdução maciça da mão-de-obra livre. Neste sentido, buscamos verificar as mudanças que ocorreram na instituição escolar ainda em construção, sem marcos definidos, onde se alternavam discursos e projetos legislativos, veiculando uma educação para todos, obrigatória e gratuíta, e uma prática elitista, como provaram vários estudos e os dados estatísticos da época. No processo de constituição do ensino público, consideramos os confrontos oriundos da laicização da educação, as imbricações entre o saber da escola 
elementar e da secundária, além das questões existentes entre escola pública e privada.

o mundo editorial faz parte da problemática do segundo capítulo, desvendando suas relações com o poder político. A preocupação foi a de questionar as razōes aparentemente ambíguas do Estado, que exerceu uma constante vigilância sobre o material mas que sempre concedeu e favoreceu sua produção por empresários particulares. Neste contexto abordamos o livro didático também como mercadoria, como objeto da indústria cultural, ligada a interesses econômicos particulares, que aperfeiçoaram técnicas de difusão e comercialização.

A segunda parte do trabalho corresponde à investigação do processo de transposição do saber erudito para a obra didática. Como assinalamos, optamos pela disciplina de História para desvendar esse processo de construção do saber escolar. Livros e autores de História Sagrada, Geral e do Brasil, são os principais personagens dos capítulos III e IV. Preocupamo-nos, inicialmente, com a criação dos programas curriculares e como tal proposta foi transposta para a obra escolar.. Situamos autores e programas articulados com o lugar ou lugares, onde era produzido o chamado saber erudito. Estes dados se tornam relevantes à mèdida em que os autores de História fizeram interpretações destes programas, reelaborando temas e conceitos baseados nos mesmos conteúdos. Em ambos os capítulos acompanhamos a construção da História enquanto disciplina escolar, usando como documento básico livros de História das escolas primárias e secundárias, buscando estabelecer o vínculo entre a produção historiográfica acadêmica e oficial e a transposição desta historiografia para o livro escolar.

A terceira parte aborda as questões que envolveram a utilização da literatura didática pelos professores e alunos. o capítulo $\mathrm{V}$ trata das questões sobre a formação dos professores e a precariedade de instituições criadas para tal fim, buscando conhecer o papel que o livro didático desempenhou na construção do saber dos mestres das escolas primárias e lentes dos cursos secundários. Buscamos 
1a Parte

Literatura escolar e Estado 
"Atendendo ao que propôs a Inspetoria geral de instrução do Município da Côrte: $1^{\circ}$ nenhum livro, mapa ou objeto de ensino será adotado nas escolas públicas sem prévia aprovação do ministro do Império, ouvido o Conselho diretor, que dará parecer fundamentado; a adoção dos livros ou compêndios que contenham matéria de ensino religioso, precederá também a aprovação do bispo diocesano."

(Decreto 9.397 de 7 de março de 1885. Rio de Janeiro) 


\section{CAPITULO I}

\section{LIVRO DIDATICO E CONSTRUÇÃO DO SABER ESCOLAR}

A origem do livro didático está vinculada ao poder instituído. A articulação entre a produção didática e o nascimento do sistema educacional estabelecido pelo Estado distingue esta produção cultural dos demais livros, nos quais há menor nitidez da interferência de agentes externos em sua elaboração.

Esta característica da literatura escolar levou-nos a iniciar a pesquisa da história do livro didático por uma abordagem externa. Os documentos oficiais sobre a literatura escolar são indicativos dos limites impostos em sua criação e das interferências institucionais que presidiram sua construção e que antecederam a atuação dos demais agentes participantes de sua confecção.

A questão fundamental desta parte do trabalho referese ao desvendamento das concepções de livro didático engendradas pelo Estado Nacional e das formas como ele organizou o controle sobre esta produção cultural, no sentido de perceber as possíveis mutações em sua história enquanto projeto associado a políticas mais amplas de educação. Nessa perspectiva, procuramos conhecer o livro didático não apenas em sua singularidade mas como parte integrante de um sistema de ensino institucionalizado.

No Brasil, Estado e Igreja, afastando-se ou aproximando-se, produziram e efetivaram projetos educacionais variados no decorrer do século XIX e primeiro decênio do atual, provocando conflitós ou conciliando interesses que expressavam a contradição inerente da educação escolar proposta a partir das transformações econômicas e políticas configuradas pela Revolução Francesa.

A educação escolar deveria ser estendida ao conjunto da população, obedecendo aos princípios de legitimidade impostos pelo ideário liberal europeu. o poder exercido 
deveria estar subordinado à vontade da nação, expressa pelo voto, pressupondo, portanto, a educação do eleitor para o exercício do poder. A legitimação do poder político pelo voto obrigou as classes dirigentes a estabelecer que parcela da população gozaria de tal privilégio.

o Estado liberal, ao determinar os setores sociais que teriam direitos civis e politicos, viu-se obrigado a definir os critérios para a constituição dos conceitos de cidadania e de nação. o Estado brasileiro, em formação, buscava acompanhar o ideário liberal, adaptando-o a seus interesses.

Assim, a questão da cidadania política brasileira colocava-se como garantia da manutenção de privilégios das classes dominantes, embora estas tivessem que enfrentar confrontos à medida em que mudanças sociais e econômicas exigiam ampliações dos direitos dos cidadãos. Os direitos civis, politicos e sociais, elementos que constituem a cidadania, foram sendo estendidos, lentamente, aos grupos sociais não pertencentes aos setores agrário e do grande comércio. A passagem do voto censitário ao do alfabetizado, determinando os direitos politicos do cidadão, foi acompanhada de mutações nas definições sobre o papel da escola na construção da cidadania, na constituição de uma população letrada.

A escola não poderia continuar a dedicar-se, exclusivamente, à educação da classe dirigente tradicional, de aristocratas. Existiam outras necessidades oriundas de novos empreendimentos que precisavam garantir o aumento da produtividade. As exigências dos projetos de modernização compreendiam novas formas de adquirir e usar o saber. Nesse processo, o Estado brasileiro teve de se defrontar com o problema da abolição do trabalho escravo e com a constituição de uma educação que deveria incluir trabalhadores livres, situação que interferiu nas concepções de escola e objetivos do seu ensino.

o estabelecimento da educação escolar foi planejado e acompanhado pelo poder governamental que passou a se utilizar de vários mecanismos para direcionar e controlar o saber a ser disseminado. Dentro de tais perspectivas, o 
livro didático constituiu-se em instrumento privilegiado do controle estatal sobre o ensino e aprendizado dos diferentes níveis escolares.

Ao desvendarmos a atuação do poder governamental na construção do livro escolar, tivemos o cuidado de situá-la paralelamente às concepçōes de ensino e aprendizagem que permearam os discursos de parlamentares e de educadores, utilizando como documentos básicos os textos legislativos de educação e a literatura pedagógica nacional e estrangeira do período.

\section{Concepções e projetos de redação do livro didático}

1.1 Concepções iluministas do livro didático

Os manuais didáticos foram tema de debates dos parlamentares que decidiam sobre a criação e a organização do sistema educacional do novo Estado que se formava e permaneceu durante todo o transcorrer do século XIX.

As propostas relativas ao livro didático contidas nos discursos de ministros de Estado, presidentes de Províncias/Estados, deputados e senadores, administradores, inspetores escolares, revelaram dois momentos diferenciados para a elaboração dessa produção.

A fase inicial correspondeu a projetos que insistiam sobre a necessidade de se construir livros seguindo modelos estrangeiros, notadamente franceses e alemães. A geração de intelectuais do início do oitocentos determinou que os livros escolares fossem adaptados de obras estrangeiras, podendo-se "mesmo traduzir-se alguns, que há nas outras naçōes cultas, particularmente a alemã, que mais se tem assinalado nesta espécie de instrução, apropriando-os ao sistema estabelecido neste plano.." 1

1 ANDRADA, Martim Francisco- Memoria sobre a reforma de estudos da capitania de São Paulo. In: RIBEIRo, J. Quirino- A memória de Martim Francisco sobre a reforma dos estudos da capitania de são Paulo. São Paulo, Separata do Boletim LIII da F.F.C.L / USP, ${ }^{\circ}$ 5, 1945, p. 104. O texto foi escrito provavelmente em $1815^{\text {e }}$ foi indicado pela Assembleia Constituinte de 1823 para servir de guia para posteriores projetos educacionais. 
Relatórios oficiais relativos à escolarização nas primeiras décadas do Império registraram constantes reclamações sobre a ausência de manuais escolares nas escolas. A escassez da literatura escolar explicava parcialmente as deficências encontradas:

"Un dos defeitos- é a falta de compêndios- no interior por que os não há- nas Capitais, por que nāo há escolha, ou foi mal feita; - por que a escola não é suprida, e os pais relutam em dar os livros exigidos, ou repugnam aos mestres os admitidos pelas autoridades." 2

o relatório de Gonçalves Dias sobre as províncias do Norte e Nordeste, datado de 1852, possui indicadores da fase posterior de projetos para a elaboração dos manuais escolares. Ele contem críticas aos Conselhos de Instrução por preterirem obras de autores nacionais "dando preferência à gramática de Monteverde, quando as há melhores na Bahia; há tão boas aritméticas como a de Monteverde, e em igualdade de circunstâncias era justiça, premiar o nobre esforço desses autores, em vez de injuriar alem de os desfavorecer." 3 As críticas em relação aos livros estrangeiros aumentaram nas décadas de 70 e 80 , aparecendo, então, projetos de construção de obras didáticas "genuinamente nacionais" .

o diagnóstico de José Veríssimo, de 1890, é representativo da tendência nacionalista que passou a presidir as intenções dos construtores de obras didáticas:

"São os escritores estrangeiros que, traduzidos, trasladados ou quando muito, servilmente imitados, fazem a educação de nossa mocidade.

Seja-me permitida uma recordação pessoal. Os meus estudos feitos de 1867 a 1876 foram sempre em livros estrangeiros. Eram portugueses e absolutamente alheios ao Brasil os primeiros livros que 1i. O Manual Enciclopédico de Monteverde, a Vida de D.João de Castro, de Jacinto Freire (1), os Lusíadas, de Camões e, mais tarde, no Colégio de

2 DIAS, Antonio Gonçalves- Relatorio sobre Instrução Pública em diversas províncias do norte. in ALMEIDA, José Ricardo Pires- História da Instruçāo Publica no Brasil (1500-1889), Trad. Antonio Chizzotti. São Paulo:EDUC; Brasilia, DF: INEP/MEC, 1989, p. 363

3 DIAS, Antonio Gonçalves- op. cit., p. 363 
Pedro II, o primeiro estabelecimento de instrução secundária do País, as seletas portuguesas de Aulete, os Ornamentos da memória, de Roquette- foram os livros em que recebi a primeira instrução..."

E propôs mudanças:

"Neste levantamento geral, que é preciso promover a favor da educação nacional, uma das mais necessárias reformas é a do livro de leitura. Cumpre que ele seja brasileiro, não só feito por brasileiro, que não é o mais importante, mas brasileiro pelos assuntos, pelo espírito, pelos autores trasladados, pelos poetas reproduzidos e pelo sentimento nacional que o anime." 4

As propostas de "nacionalização" da literatura escolar corresponderam ao período de crescimento da rede escolar, decorrente, em parte, das mudanças sociais surgidas com a urbanização, imigração, do esfacelamento do trabalho escravo e modernizações tecnológicas nos meios de comunicação. As reivindicaçōes de novos grupos sociais, que incluíram a questão educacional, foram parcialmente incorporadas pelos politicos Iiberais que se revezavam no poder com os conservadores. Entretanto, é necessário destacar no discurso nacionalista de educadores e políticos do período, o confronto com a Igreja Católica.

Os projetos "civilizatórios" de uma parcela da geração de educadores e políticos liberais da segunda metade do século XIX pretendiam uma total separação entre Estado e Igreja, incluindo a construção de uma escola secularizada, rejeitando as premissas dos liberais do período da Independência que a idealizaram atrelada à Igreja.

A polêmica entre o grupo conservador católico, ligado ao ideário da Igreja tramontina e o de liberais mais radicais, positivistas ou cientificistas e republicanos, acirrou-se durante a reforma de Leôncio de Carvalho de 1878, que tornou o ensino religioso facultativo e teve prosseguimento nos anos seguintes até a implantação do regime republicano. As divergências entre os dois setores do

4 VERISSIMo, José- A educação nacional. Porto Alegre: Mercado Aberto, 1985,32 edição, p. 54 e 55 
poder nos anos finais do século passado marcaram um momento diferenciado em relaçāo à primeira fase de elaboraçāo de projetos educacionais durante os debates da 1 a Constituição brasileira, período em que parlamentares e a maioria dos intelectuais pensaram o sistema escolar, seus métodos e programas de ensino, de maneira a conciliar Estado e Igreja.

As propostas de "nacionalização" da obra didática representavam o grupo de educadores favoráveis ao domínio do Estado na escola pública, em detrimento do poder da Igreja, evidenciando conflitos de setores em luta pelo poder no nível central ou para obter o controle político nas esferas regionais.

Mas, nos dois momentos, permaneceu a crença na força do livro escolar como peça importante na viabilização dos projetos educacionais. A obra didática era concebida como principal instrumento para divulgação do ideario educacional, dependendo dela, a formação do professor e do aluno.

A ênfase no papel dos manuais didáticos para a efetivação do programa de ensino partia do conceito que vigorava entre os franceses do período da Revolução: um livro lido é um livro apropriado que induz a novos hábitos. Um dos politicos mais entusiastas das reformas educacionais do período revolucionário francês, François de Neufchâteau, dizia que "il n'est plus de tyrans pour quiconque sait lire." 5

A permanência da 'concepção iluminista do caráter poderoso da palavra impressa, contida na literatura escolar, pode ser percebida pelo cuidado constante com que as elites intelectualizadas das classes dominantes tiveram no processo de construção dessa produção cultural. Para os intelectuais que se dedicaram aos projetos educacionais, o livro escolar deveria condicionar o leitor, refrear possiveis liberdades frente à palavra escrita, impressa. o leitor - professor, criança e jovem - deveria abordar a leitura de forma

5 Apud JULIA, Dominique- L'enfance et citoyennete. Bilan historiographique et perspectives de recherches sur l'education et 1 'enseignement pendant la periode revolutionnaire. Histoire de l'education, Paris, $n^{\circ} 49$, jan. 1991, p. 19 
homogênea, tendo uma compreensão exata das palavras, com um sentido único. o temor deles, residia, exatamente, nas possibilidades múltiplas que oferecem as práticas de leitura. 6

Um texto escolar deveria resultar, desta forma, diferentemente de outros livros, de um cuidadoso plano engendrado pelo poder constituído, articulado com outros discursos que definiam o saber escolar.

Condorcet, em plena fase revolucionária francesa, no seu texto second Mémoire sur l'Instruction Publique, concebeu dois tipos de livros didáticos. Um para o professor e outro destinado aos alunos. Existiriam os compêndios ou manuais escolares, dos alunos, e os livros dos mestres ou dos professores. A confeç̧ão do livro do mestre era importante porque conteria "des remarques sur la méthode d'enseigner, des éclaircissements nécessaires pour permettre aux instituteurs de répondre aux questions des enfants, des définitions des mots difficiles".7 o livro do mestre serviria, sobretudo, para suprir as deficiências dos docentes mal preparados, recrutados de maneira pouco rigorosa devido a ausência de cursos especializados em sua formação.

A concepção de livro didático fornecida por Condorcet, distinguindo as duas obras, destacando a do professor e acentuando a articulação que deveria existir entre ambas, foi bastante conhecida por nossos legisladores. O texto educacional de Martim Francisco d'Andrada, "Memória sobre a

6 Cf. CHARTIER, Roger- A historia cultural- entre praticas e representaçōes. Trad. Maria Emanuela Galhardo. Lisboa: Difel ; Rio de Janeiro: Editora Bertrand Brasil, 1990, p. 122 a 124.

7 o texto de Condorcet é apud TRENARD, Louis - Une Révolution ... Ia naissance du manuel scolaire-1760-1800 In Les Cahiers Aubois. Colloque sur les manuels scolaires. Paris, numero spécial, 1986, p. 61. Os franceses fazem uma nitida distinçāo entre o professor secundario e do ensino superior, denominado de professeur e 0 do primário, o instituteur. No Brasil do seculo XIX e inicio do XX existia uma preocupação menos acentuada, mas igualmente discriminatoria, quanto ao emprego da palavra professor que geralmente é usada segundo o nível que ocupava: professor secundario e professor primário. Os textos oficiais usam mais, entretanto o termo "lente" para designar o professor secundario concursado das escolas oficiais e mestre o assistente de tais professores. Para o ensino primário usouse o termo "mestre de 1 letras" e na República foi usual o termo "professor primário", seguindo-se hierarquicamente o termo de interinos (mestres não concursados)e adjuntos ou substitutos. 
reforma de estudos da Capitania de São Paulo", foi praticamente uma tradução adaptada da obra de Condorcet. Durante a Constituinte de 1823 , a Comissão de Instrução Pública propôs que este trabalho servisse "de guia aos atuais professores e estímulo aos homens de letras para a composição de compêndios elementares, enquanto não se dá uma adequada forma à instrução pública".8

A questão da constituição de um corpo docente leigo colocada pelo filósofo francês assemelhava-se ao caso brasileiro e, encontramos entre nossos intelectuais preocupações idênticas quanto à idoneidade e competência do novo quadro burocrático que se constituía. Compreende-se as razōes da divulgação dos pensadores franceses no Brasil, porque debatia-se igualmente um problema que se arrastava desde a segunda metade do século XVIII, com a expulsão dos jesuítas.

A reforma pombalina, com o intuito de substituir a orientação pedagógica da Companhia de Jesus, determinara a implementação do Novo Método, baixando decretos, organizando estatutos e enviando instruções várias em que se constatava claramente a importância dada aos livros. Embora a proposta educacional do marquês de Pombal não fosse totalmente leiga, contando sempre com o apoio de outras ordens religiosas para sua efetivação, ela pressupunha a constituição de um novo quadro de professores. Os problemas que se originaram da nova proposta duplicaram. Houve a necessidade de formular um novo saber escolar, substituindo o Ratio studiorum com seu minucioso método e regras pormenorizadas dos jesuítas e das ordens religiosas que os seguiam, por um outro projeto pouco detalhado nos conteúdos e métodos e houve o problema de transmiti-lo a um corpo docente leigo, que passaria a ser remunerado, compondo o quadro do funcionalismo público.

Para realizar esta tarefa, a escolha e impressão de Iivros didaticos tornaram-se pontos básicos da reforma, tendo havido instruções para "queimar todos os livros que

8 Anais do Parlamento Brasileiro: Assembleia Constituinte, 1823, $1^{\circ}$ vol., Tomo I, sessāo de 7 de julho de 1823, p. 43, apud XAVIER, Maria Elizabete sámpaio Prado- Poder polftico e educação de elite. são Paulo: Cortez, p. 24 . Neste texto a autora refere-se às adaptaçōes feitas por Martim Francisco no texto do autor francês. 
serviam de ensinar Gramática Latina pelo método antigo, reprovado por sua Majestade".9 Uma das primeiras medidas tomadas por Portugal para a implementação da reforma pombalina foi a distribuição do texto "Memória dos livros aconselháveis e permitidos para o Novo Método", onde era apresentada uma listagem completa das obras a serem utilizadas nas escolas régias e a quantidade de livros novos a serem impressos. Para o ensino elementar, mesmo não sendo a preocupação dos governantes da época, existiram ordens régias determinando que se ensinasse os meninos "por impressos ou manuscritos de diferente natureza, especialmente pelo Catecismo pequeno do Bispo de Montpellier, de Carlos Joaquim Colbert, mandado traduzir pelo arcebispo de Évora". 10 Os cuidados expressos para a seleção de Iivros a serem adotados não foram, entretanto, os mesmos empregados para garantir que chegassem às māos dos professores. Uma das dificuldades apontadas para a substituição do antigo método jesuítico, no Brasil, foi a ausência de novos compêndios:"as dificuldades brotaram a flux, porque se tornava difícil conseguir livros apropriados e professores aptos que estivessem dispostos a seguir, com convição a nova ordem imposta. As primeiras ediçôes dos compêndios quase se esgotaram em Lisboa e província, recebendo o Brasil muito poucos, até se proceder a reimpressão " 11

o livro escolar aparecia, em meados do século XVIII, como principal instrumento para a formação do professor, garantindo, ao mesmo tempo, a veiculação de conteúdo e método de acordo com as prescrições do poder estabelecido. A questão, entretanto, não residia no papel a ser desempenhado pelo livro no ensino mas na criação de novos textos pedagógicos segundo uma visão educacional secularizada. 0 discurso pombalino educacional, baseado em Verney e Ribeiro Sanches, apresentava questões que ultrapassavam à natureza das disciplinas e a orientação dos manuais. Tratava-se da

9 ANDRADE, Antonio Alberto Banha de- A reforma pombalina dos estudos secundariós no Brasil. São Paulo: EDUSP; Saraiva, 1978. p.15,

10 Idem, p. 23. Grifo meu

11 Idem, p. 115 
criação de uma educação institucionalizada por um outro tipo de Estado e por uma escola pública. ${ }^{12}$

A literatura didática produzida no decorrer do século XIX era herdeira dessa concepção de educação formal, cabendo-lhe uma dupla tarefa. Deveria assegurar ao professor o domínio de um conteúdo básico a ser transmitido aos alunos e garantir a ideologia desejada pelo sistema de ensino, suprindo "la déficience d'esprit philosophique qui peut exister chez certains mâ̂tres." 13

Os livros a serem utilizados pelos professores foram pensados em dois níveis. Inicialmente, pelo custo e raridade de obras propriamente didaticas, impunha-se aos professores o uso de livros de autores consagrados, sobretudo as obras religiosas. Os professores fariam ditados $e$ os alunos copiariam trechos ou ouviriam as preleçōes em sala de aula. Tal era o método imaginado para as primeiras décadas do século XIX.

As propostas de produção de livros escolares concentraram-se, primordialmente, na elaboração de textos didáticos para uso exclusivo dos professores, dando-se preferência às traduções.

Um segundo tipo de livro destinado aos professores surgiu com a criação, às vezes efêmera, das Escolas Normais para a formação de professores. Tiveram inicio novas concepções de produção didática que não corresponderiam, apenas, aos livros a serem usados na sala de aula. A Reforma de 1872, do ministro João Alfredo, para as escolas do município da Corte, classificou os livros dos professores em três grupos principais: $1^{\circ}$ os que eram destinadas aos professores e mestres para sua formação, referindo-se às obras das "ciências pedagógicas", $2^{\circ}$ os que se dirigiam particularmente aos alunos $e, 3^{\circ}$ as obras administrativas que se destinariam "a fazer conhecer ou recordar aos funcionários da instrução pública as leis e os regulamentos que regem a matéria." 14

12 Cf. FALCON, Francisco Jose Calazans- A época pombalina. São Paulo: Atica., p. 363-364.

13 CONDORCET - Sur 1'instruction publique: Second Memoire, 1791 in Oeuvres complètes, 1847, t. VII, apud TRENARD, Louis, op. cit., p. 61

14 Cf. ALMEIDA, Jose Ricardo Pires de- op. cit., p. 158 
o livro didático visava, portanto, nos seus primórdios, prioritariamente atender ao professor. No decorrer do século XIX, embora o manual escolar mantivesse esse caráter intrínsico em sua elaboração, ele passou a ser considerado também como obra a ser consumida diretamente por crianças e adolescentes, passando estes a ter o direito de posse sobre ele.

As concepções dos franceses sobre o livro didático para alunos, assimiladas e copiadas pelos educadores brasileiras, estabeleciam algumas distinções entre ele. Existiriam os "abrégés" e o "livre élémentaire", termos transpostos por alguns brasileiros como "compêndios" e "livros populares".15 Um compêndio "peut n'être qu'un tableau exact, court et précis d'une science, ou d'un art, tel qu'il existe au moment où 1 'auteur écrit. Mais un livre élémentaire est un système d'enseignement; il embrasse un plan dirigé dans la vue de l'instruction. L'auteur se propose moins de rassembler tous les faits, toutes les vérités connues que de faire un choix heureux des choses qui, étant liées, présentent de nouveaux rapprochements, des rapports vrais et essentiels. Il sert alors à exercer l'esprit, il fait germer les idées, il suppose dans son auteur des connaissances étendues, même un grand exercice, et comme $I$ 'habitude de la science ou de $I$ 'art qu'il veut faire connâ̂tre. L'abrégé sert à la mémoire, un livre élémentaire agit plus immédiatement sur l'esprit, il se dirige vers $I$ 'entendement." 16

Ao lado da definição de livros didáticos, especificando sua natureza e finalidades das obras de acordo com seu público consumidor, os administradores encarregados dos projetos educacionais tiveram o cuidado de estabelecer as formas como seriam elaborados os textos e quem deveria escrevê-los.

15 Abilio Cesar Borges, diretor de instrução da Bahia no relatorio para o presidente da província Alvaro Tibério Moncorvo, utilizou os termos compêndios e livros populares. Apud MOACYR, Primitivo- A Instrução e as províncias. Rio de Janeiro: Companhia Editora Nacional, 1939, $2^{\circ}$ v., p. 101 a 104.

16 Esta concepção de compêndio escolar e livro elementar foi expressa na sessão de 16 de fevereiro de 1799 pelo ministro de Instruçāo Pública da França, apud JULIA, Dominique, op. cit. p.33 e 34 . 
1.2 Planos de redação dos livros escolares

Segundo a "Memória" de Martim Francisco os livros poderiam "ser feitos ou pelos mestres encarregados deste trabalho em benefício de sua pátria, voluntariamente ou por ordem superior."17 A confecção de uma obra didática seria uma tarefa patriótica, um gesto honroso, digno das altas personalidades da "nação" .

Os discursos dos relatórios de ministros demonstraram a preocupação em incentivar os mais célebres intelectuais para elaborá-los. Partindo do pressuposto de que uma obra didática deveria difundir a "verdadeira ciência", nossos politicos incorporaram as idéias dos iluministas que confiavam aos "sábios" a realização de uma tarefa que asseguraria a felicidade das gerações futuras: " Ce sont les plus grands savants qui doivent dégager les idées fondamentales d'une science. Ces livres, s'ils s'orientent vers le perfectionnement de la raison et la prospérité de la nation, faciliteront la tâche du professeur et serviront de base aux leçons." 18

Várias personagens da nossa elite cultural assumiram a tarefa "patriótica" que lhes era destinada, mas cabe destacar uma das primeiras obras didáticas produzidas por um "eminente cidadão" e atuante político do governo de D. João VI e de D. Pedro I, pelas concepções que forneceu relativas ao poder da palavra impressa. Trata-se do livro Escola brasileira ou instrução útil a todas as classes extraída da Sagrada Escritura para usó da mocidade de José da Silva Lisboa, o visconde de Cairu, escrito em 1827. Obra dedicada "aos mestres das primeiras letras", teve, segundo o autor, como base para sua construção, os conhecimentos "religiosos, econômicos e morais" provenientes da Escritura Sagrada que é "a coluna da civilização".19

17 ANDRADA, Martim Francisco d'- op. cit. p. 104

18 Relatorio de Louis- François Arbogast, professor de matematica da escola de Artilharia de Strasbourg, de 1792 , apud TRENARD, Louis, op. cit. p.62

19 LISBOA, Jose da Silva (visconde de Cairu)-Escola brasileira ou instrução útil a todas as classes extraida da Sagrada Escritura para 
$\mathrm{Na}$ introdução do livro estão explicitadas as razões pelas quais parte da nossa intelectualidade se dispôs a realizar esse trabalho. Percebia-se sua preocupação com a disseminação da alfabetização e com o saber a ser veiculado pela escola, a nova instituição que se impunha como necessidade da vida civilizada. Cairu expressou seu temor pela difusão da palavra escrita, e seu trabalho pretendia ser modelar quanto à nova moral que desejava difundir. Acentuou o perigo da disseminação do livro, importante e contraditório veículo de comunicação, para o conjunto da população e mais precisamente sobre o perigo que poderia haver ao se difundir "as luzes" para as classes inferiores. De acordo com seu pensamento liberal sobre a constituição de cidadania, fêz sérias advertências sobre os malefícios da leitura porque, se os jovens estavam habilitados "a ler bons livros, também podem ler maus livros, de que já há dilúvio em todas as línguas e que só servem para a completa perdição dos leitores". 20 o prestigiado político temia ainda o risco que as classes dominantes correriam em perder uma preciosa mão-de-obra subserviente: "as péssoas necessárias aos trabalhos mecânicos, adquirindo conhecimentos superficiais , se desgostam da sua laboriosa condição, e aspirando à mudança de estado, são facilmente seduzidas para Revoluçōes por insidiosos demagogos." 21 José da Silva Lisboa confirmava que estava "à espreita de perigo de novas atrocidades revolucionárias", e que conhecia, sem dúvida, o sucesso que - Direito dos homens de Thomas Paine havia tido na Inglaterra e França, entre as classes populares, escrito que além do seu caráter subversivo, também reclamava a instrução universal para todos, até a idade de 14 anos.

os homens de "confiança" do poder seriam, evidentemente, o grupo ideal de autores de obras didáticas mas, com o decorrer do tempo, o número limitado de obras que surgiram de autores famosos fez com que as nossas autoridades educacionais aceitassem pessoas menos

uso da mocidade. Rio de Janeiro: Tipografia de P. Plancher-Seignot, 1827.

20 Idem - op. cit., p.21

21 Idem, Ibidem 
nobilitadas. Os relatórios de inspetores de instrução das províncias eram mais modestos quanto às credenciais de autores de livros escolares: "Prêmios serão garantidos a professores ou quaiquer outras pessoas que compuserem compêndios ou obras para uso das escolas, e aos que traduzirem em português as de língua estrangeira, depois de aprovadas (..) . "22

A legislação educacional passou a prever prêmios para autores de obras didáticas, com honrarias ou com dinheiro. Por exemplo, na regulamentação do decreto $\mathrm{n}^{\circ} 1331$ de $1^{\circ}$ de fevereiro de 1854, o artigo 95 conferia "prêmios na conformidade da 2 a parte do artigo 56 aos que compuserem $p u$ traduzirem compêndios os quais serão sujeitos à disposição do $\$ 4$ do artigo $3^{\circ}$ combinando com a do artigo $4^{\circ}$." 23

A abertura de concursos para confecção de livros não foi uma prática muito comum, e pudemos constatar denúncias quanto à discriminação na distribuição dos prêmios: "(-)os prêmios prometidos pela lei aos autores de livros que merecessem a adoção nem sempre eram conferidos quando eram de professores primários." 24

No período republicano, a política de premiações teve continuidade como aconteceu com o Compêndio de História da América, de Rocha Pombo. Trata-se de um texto que ganhou o concurso proposto pelo Conselho superior de. Instrução pública do Distrito Federal em agosto de 1897, tendo o autor recebido a soma de 4:000\$000 (quatro mil réis) e a municipalidade se encarregou da impressão de uma primeira edição de mil exemplares "para distribuir aos membros do magistério primário, normal e profissional". 25

22 Relatorio de um inspetor de instrução ao presidente da Província do Grão Pará, Abel Graça, em 1871, apud MOACYR, Primitivo- Inst. e prov. op. cit., $1^{\circ}$ vol., p. 159. Existem várias outras propostas do mesino teor em relatórios das diversas províncias brasileiras e citadas pelo mesmo autor.

23 Regulamento da instrução primária e secundaria do município da Corte. Decreto $n^{\circ} 1.331$ de 17 de fevereiro de 1854 . Revista do Ensino, Rio de Janeiro, $\mathrm{n}^{\circ} 7$, ano 1 , julho de 1883 , p. 108 .

24 SABINo, Januario dos Santos- Parecer da 1 seção sobre métodos e programas de ensino nas escolas primárias. Sua reforma. Adoção de livros. Atas e pareceres do Congresso da Instrução do Rio de Janeiro. Rio de Janeiro: Tipografia Nacional, 1884, 6a questão p. 10. 25 parecer do Conselho superior de Instruçāo Pública do Distrito Federal de 4 de Agosto de 1897, publicado na introdução da obra de 
Com o aumento das instituições escolares e avanços das "ciências em educação", houve a tendência de incentivar os autores por sua experiência pedagógica. Assim, em 1907, um Diretor de Instrução, solicitou a aprovação de uma obra didática escrita por um professor, justificando o valor de seu conteúdo nacionalista e por ser fruto de um trabalho experimentado e testado em sala de aula.

No decorrer do século XIX e anos iniciais do século atual, os textos oficiais incentivaram transformações no que se refere ao processo de "nacionalização" da obra didática. Este "espírito nacionalista se verifica pelos apelos quanto ao aperfeiçoamento da linguagem a ser utilizada. As críticas aos livros estrangeiros, sobretudo portugueses, recaíam no uso de termos desconhecidos do público brasileiro, insistindo na necessidade de produzir livros com temas sobre o país, sua natureza e costumes.

A concepção de livro didático, entretanto, permaneceu. - livro era fundamental para a formação dos professores e para garantir os diversos conhecimențos a serem divulgados pela escola.

Parte de dirigentes brasileiros estava atenta, na passagem do século, às necessidades culturais necessárias à construção do Estado nacional moderno. A educação escolar precisava de novos métodos e disciplinas escolares, tendo que enfrentar as exigências das denominadas ciências modernas - Física, Matemática, Química para aperfeiçoamento dos exércitos, novos meios de comunicação, toda uma tecnologia para o aparelhamento material da nação. Havia necessidade de garantir uma unidade linguística, criando e aperfeiçoando a Língua nacional. Era essencial garantir a difusão do vínculo nação-território, necessitando-se dos estudos de Geografia para o conhecimento do espaço físico do "país" e da História Nacional para legitimar as formas de conquista do "continente que é o Brasil".26

ROCHA POMBO, Jose Francisco da- Compendio de História da America. Rio de Janeiro: Læmmert \& Cia. Editores, 1900.

26 Sobre as concepçōes de nação e de Estado Moderno, consideramos fundamental o trabalho de Eric Hobsbawm no qual defende a tese de que o conceito de nacionalismo precede o de naçăo: "As naçōes não formam os Estados e os nacionalismos, mas sim o oposto." HOBSBAWN, EricNações e nacionalismos desde $1780-$ programa, mito e realidade. Trad. 
Os Iivros didáticos deveriam sistematizar e divulgar tais conhecimentos e o Estado incentivou uma produção local capaz de auxiliar a fórmação do "sentimento nacionalista" sem deixar, entretanto, que as futuras geraçōes de letrados perdessem o sentimento de pertencer ao mundo civilizado ocidental.

\section{Livros didáticos e concepçōes de ensino}

\subsection{Instrução para quem?}

Os dirigentes dos Estados Modernos, imbuídos de teorias liberais mais progressistas ou mais conservadoras, buscaram organizar os programas curriculares sistematizando os novos conhecimentos transformados em disciplinas escolares, estruturando os diferentes níveis de escolarização, delimitando etapas e estágios de aprendizagem.

Martim Francisco d'Andrada, ao especificar os três níveis de ensino que deveriam compor a escolarização formal brasileira, preocupou-se em detalhar as características das obras destinadas a cada um dos graus de educação.

Sugeriu, para o caso dos livros destinados ao ensino elementar, que estes deveriam ser "compostos debaixo da vigilância, e da inspeção do Estado". Haveria livros de leitura com histórias morais para despertar os bons sentimentos, benevolência, amizade e tolerância. o capítulo $\mathrm{XI}$ da "Memória" determinava que os livros destinados ao ensino elementar estariam sob vigilância constante do Estado para que sua doutrina não fosse deturpada "pela superstição ou negligência".

Para o segundo grau de instrução, ou nível secundário, diferentemente, o autor aconselhava uma maior liberdade para o professor na escolha dos compêndios, alegando que "desta

Maria Célia Paoli e Anna Maria Quirino. Rio de Janeiro: Paz e Terra, 1990 , p. 19 a 32 
maneira mantem-se nele uma atividade útil, ata-se-1he um novo motivo de emulação, e se lhe concede a liberdade de comunicar aos seus discípulos as descobertas úteis e curiosas, que o progresso não interrompido das ciências pode oferecer". 27

Estas propostas nos levaram a indagar sobre as especificidades dos livros concebidos para os diferentes graus do ensino escolar. Quais as diferenças essenciais entre as obras destinadas ao ensino elementar $e$ as que serviriam para os alunos do nivel secundário? Haveria distinçōes fundamentais entre o público estudantil do primeiro grau de instrução e o dos graus posteriores, exigindo, por esta razão, outras simplificações que não simplesmente as ditadas pela faixa etária dos leitores?

o ensino primário, como o concebemos hoje, é importante sublinhar, estava sendo criado. As denominações variadas, "estudo de primeiras letras", "ensino elementar", "primeiro grau de ensino", "ensino popular" e "ensino primário", sāo evidências das dificuldades em construir e sistematizar o ensino elementar. O número de anos destinado a este grau de ensino, idades apropriadas e organização de classes, horas de estudo, também diferiam mesmo após o estabelecimento da escola seriada, organizada nos grupos escolares do período republicano.

Os discursos das autoridades eram, praticamente, unânimes en afirmar que o grau elementar de instrução seria destinado ao conjunto da população:

"Dos três ramos da instrução pública, o ensino primário é, sem dúvida, o que mais nos deve interessar, porque se ele é condição essencial dos dois outros, destinase ao mesmo tempo à maioria da população. A constituição a garante a todos os cidadãos. 0 esforço feito pelos legisladores e pelo Governo para distribuir convenientemente a instrução primária a todas as classes da sociedade não é outra coisa que a realização de uma promessa solene feita no

27 ANDRADA, Martim Francisco- op. cit. , p. 104 
momento em que o Estado se formava e onde se assentavam as bases de nossa organização política". 28

- planejamento da instrução elementar foi sendo elaborado lentamente pelos grupos dirigentes mas nem sempre foi consensual a idéia de que o ensino primário seria, obrigatoriamente, atribuição do Estado. A criação e o financiamento das escolas de "primeiras letras" foram temas de discussões entre os parlamentares das variadas províncias e continuaram quando da organização educacional dos estados da República Federativa.

Para os conservadores, a tarefa do ensino elementar deveria ser atribuição das famílias e da Igreja. Os liberais mais progressistas discordavam da presença dominante da Igreja na educação como um todo e almejavam o controle do Estado sobre a rede escolar pública, estabelendo uma nítida distinção entre escola pública e escola particular. Para os liberais, a Igreja Católica teria pleno poder apenas sobre suas escolas confessionais.

Havia uma posição intermediária, a mais difundida nos discursos parlamentares, que separava o papel da escola e o da educação fornecida pela família e pela Igreja. Liberato Barroso, o defensor parlamentar mais notório de tal postura, distinguia educação de instrução.

Para ele, a escola primária forneceria a instrução e deveria desenvolver e completar a educação mas, o "germe da moral, os princípios da educação, o homem recebe no lar doméstico, no seio da família". A verdadeira educação só seria completa com a religião, "que forma o coração humano".29 A instrução fundamentava-se nas ciências e caberia ao mestre difundí-las. As ciências serviriam para capacitar o homem para uma sólida organização da vida social, do trabalho "harmônico", elevando a inteligência dos indivíduos, mas era impotente para preencher os ensinamentos morais necessários para se atingir a grande "missão da humanidade". o progresso moral deveria articular-se com o

28 ALMEIDA, José Ricardo Pires de- op. cit., p.116

29 BARRoso, José Liberato- A Instrução Pública no Brasil. Rio de Janeiro: B.L. Garnier, 1867, p.xxx da Introdução 
progresso material e político, porque o espirito da civilização moderna era eminentemente liberal e religioso.

A tendência predominante entre os legisladores foi a de aceitar a intervenção do Estado na organização de um vasto sistema de instrução elementar, garantindo-lhe organicidade e uniformidade, mas sem rejeição quanto à presença da Igreja na vida educacional mesmo na fase republicana, quando, aparentemente, os discursos dos educadores aceitaram as premissas do predomínio estatal sobre a rede pública. Todos os discursos eram também unânimes quanto o papel das escolas particulares, confessionais ou leigas, consagrando-lhes uma posição privilegiada na ação educativa. Os princípios de "liberdade do ensino", sinônimo de escola particular, eram defendidos pelos mais variados parlamentares, conservadores, liberais, monarquistas ou republicanos, discordando-se apenas sobre as subvençōes a serem fornecidas pelo Estado para a manutenção de tal "liberdade".

Ainda no Império, em muitas províncias, decretou-se a obrigatoriedade da instrução primária, detalhando-se as multas para os pais de famílias ou tutores que não cumprissem as determinaçōes legais.-.Evidentemente, tratavase de legislação que ficou restrita aos papéis oficiais, medida que correspondeu a uma atitude predominante, durante todo o período estudado. Existiam as leis mas pouco se fazia, efetivamente, para difundir a educação letrada escolar. Havia um descompasso entre a magnitude das propostas relativas ao ensino primário e sua realização efetiva.

Vários estudos de história da educação brasileira criticam a atuação das elites do Império quanto à efetivação de uma política educacional para o ensino elementar. Um dos pontos cruciais do fracasso educacional reside, segundo alguns historiadores, na "importação" de idéias alheias à realidade do país e na prioridade da organização do ensino superior e secundário, relegando-se a segundo plano, o 
ensino primário. 30 A op̧ão das classes dominantes assentadas no poder em priorizar o ensino superior e secundário foi evidente mas, cabe-nos perguntar : por que agiriam diferentemente?

É importante destacar que, nos primeiros oitenta anos do século passado, os países europeus também se debatiam diante da necessidade da expansão do ensino elementar, não havendo nenhum modelo "pronto" a ser copiado.

Para o caso da França, país considerado principal exportador das idéias educacionais para o Brasil, o ideário da fase revolucionária do final do século XVIII, não se efetivou, preocupando-se o governo, a partir de Napoleão, prioritariamente, com o ensino superior e secundário. A primeira metade do século XIX caracterizou-se pela construção do ensino universitário laico e com o secundário. Os chefes políticos que se revezavam no poder, independente da posiçāo política, priorizaram tais graus de ensino como garantia do estabelecimento de novas relações de poder, considerando que não poderiam se apoiar em bases hereditárias ou democráticas. Era fundamental compor novos quadros burocráticos, tanto para a estruturação legislativa, como também para a organização militar. ${ }^{31}$

As leis de Guizot de 1833 e a Lei Falloux de 1850 deram início à organização da instituição primária sob o controle do Estado, mas dividindo o poder com a Igreja, nas pequenas comunas espalhadas pela França. O ensino elementar obrigatório e gratuíto se efetivou apenas com a IIIa República de Jules Ferry, a partir das leis de 1882.

os estadistas brasileiros, sempre com os olhos voltados para o exterior, acompanhavam a política de educação internacional mas, estavam, sobretudo, atentos para os problemas internos.

30 Dentre tais estudos podemos citar BERGER, Manfredo- Educação e dependência. Porto Alegre: Difel, 1976 e o de RIBEIRO, Maria Luiza Santos- Historia da educação brasileira-, organização escolar brasileira. São Paulo: Cortez, 1986. Sobre as questōes relativas à "importação de idéias" baseamo-nos no debate de FRANCo, Maria sylviaAs idéias estão no lugar. Cadernos de Debates $\mathrm{n}^{\circ} 1$, São Paulo: Brasiliense, 1976 , p. 60-72.

$31 \mathrm{Cf}$. PROST, Antoine- Histoire de 1 'enseignement en France 1800-1967. Paris: Librairie Armand Colin,1968. Première partie- L'école des notables de 1802 à 1880 . 
Não foram como simples "copiadores" de idéias estrangeiras que D.João VI e D. Pedro I deram prioridade ao ensino superior e militar, mas como respostas à exigência da nova ordem imposta com a criação do Estado Moderno. E, com mais razão, decidiram que "a educação do povo" podia esperar. J Nada os pressionava nesse sentido, como no caso europeu. O catolicismo no Brasil predominava sem grandes concorrências, sem lutas religiosas, não se vendo forçado a cuidar de aumentar as leituras dos textos religiosos para seus fiéis, como na França, que desde o século XVI teve que se haver com os protestantes. Também para o Estado, não havia necessidade de impor a escola para obter uma unidade linguística, em território sem dialetos, após a derrota sobre os índios, mortos ou espalhados pelas selvas. E, os setores agrários, dominantes da vida política, desconfiavam das "luzes" para as classes inferiores, que em nada fortaleceriam seus empreendimentos $e$ menos ainda concorreriam para a manutenção de seus privilégios.

Assim, a primeira Constituição brasileira, de acordo com os princípios liberais, afirmou simplesmente: "A instrução primária é gratuíta para todos os cidadãos", cabendo sublinhar que o Brasil foi um dos países pioneiros a instituir a gratuidade do ensino primário.

A gratuidade do ensino primário representou um discurso democratizante de nossas elites, sem dúvida, mas a questão da educação das camadas populares, só passou a preocupar, efetivamente, parte dos grupos dirigentes, quando se acentuaram os conflitos entre os defensores da mão-deobra servil e a dos que reclamavam a necessidade do trabalho livre, dividindo as lideranças econômicas e políticas a partir dos anos 70 .

A marginalização de parte considerável da população, impedindo seu acesso à escola, era sentida como negativa por alguns intelectuais que duvidavam do sucesso dos projetos educacionais oriundos do "mundo civilizado" junto a uma mocidade que vivia rodeada de costumes "pervertidos" e "bárbaros" provenientes da "outra classe, que entremeada com a população livre, [tinha] sobre ela uma ação 
desmoralizadora, que não procuramos remediar". E ponderavam: "Quero crer perigoso dar-se-lhe instrução; mas por que não se há de dar uma educação moral e religiosa?" 32

Posteriormente, surgiram os discursos que apresentavam a escola dentro de um caráter regenerador. Esta concepção permeou a reforma liberal do paulista Leôncio de Carvalho, quando ministro de Estado, para quem a instrução deveria ser destinada a "todas as classes da nossas sociedade" como forma de evitar o vício e o crime, de diminuir as despesas do Estado com hospitais, asilos e cadeias. A escola primária seria um instrumento de moralização do povo. 33

o caráter da escola como instituição "regeneradora do povo" estava presente junto aos setores urbanos que pretendiam ampliar a economia do país em outras áreas, utilizando o capital proveniente da exportação do café e de demais produtos agrícolas em atividades industriais. o tema da industrialização ligava-se à questão da formação de uma classe operária e da criação de escolas profissionais que deveriam atender a objetivos duplos. A escola de formação de trabalhadores urbanos serviria como "remédio contra os efeitos da crise social, para afugentar a miséria" e "como meio de moralizar o povo- porque o operário que lê e que se instrui, que reflete e que discute, afasta-se da taberna para aproximar-se da caixa econômica." 34

Os republicanos, quando se tornaram os "donos do poder", colocaram a alfabetização como condição para a populaçāo participar da vida política da nação. A medida governamental não se tornou, paradoxalmente, em motor da nossa escolarização. Embora os dados estatísticos mostrem crescimento do número de alfabetizados, estes são

32 DIAS, Gonçalves- op. cit.,p. 364

33 A réforma de Leôncio de Carvalho data de 1878 e entre outras mudanças instituia o ensino primario obrigatório nas escolas do municipio da corte, assentando-a nas seguintes bases: a obrigatoriedade compreenderia todos os indivíduos de um e de outro sexo que tivessem mais de sete e ate quatorze anos. Os pais poderiam encarregar-se do ensino de primeiras letras em seus lares com a condição de que os filhos se submetessem a exames anuais. In MOACYR, Primitivo-A Instruçāo e o Império. Rio de Janeiro:Ed. Nacional, 1937, $2^{\circ} \mathrm{v}, \mathrm{p} .184$

34 Apud MORAES, Carmem Sylvia vidigal A socialização da força de trabalho: instrução popular e qualificaçāo profissional; Estado de São Paulo- 1873 a 1934. Tese de doutorado. São Paulo: F.F.L.C.H./USP, 1990, p. 61 
significativos em apenas alguns estados do país, como são Paulo, junto à população urbana e de imigrantes, devendo-se destacar que tal crescimento teve início nos anos finais do Império e estava ligado às diversidades do setor econômico e à intensificação do processo de urbanização. ${ }^{35}$

A mudança do critério político para a configuração dos eleitores "esclarecidos", de censitário para alfabetizado, foi uma das artimanhas de setores dos nossos políticos para elitizar ainda mais o poder, como demonstra com habilidade Sérgio Buarque de Holanda, desvendando a luta política que se travou em 1879, em torno do projeto da reforma eleitoral que pretendia impedir o voto aos analfabetos. Ele mostrou a constituição do ideário criado em meados do século passado onde o saber letrado surgiu como "fonte milagrosa de todas as virtudes cívicas e privadas, que não se julgava sequer lícito por em discussão essa crença. Nem se duvidava de que esse saber mágico poderia reduzir-se ao saber ler e escrever". 36

A ideologia criada sobre o voto do alfabetizado servia para justificar a exclusão da grande maioria do povo das decisões políticas porque, com a República, ficou evidente que o Estado não se encarregaria de alfabetizar o conjunto da população. José veríssimo, criticando a falta de educação política dos brasileiros em 1890, denunciava que a esta questão devia acrescentar-se " a escassez do eleitorado que, até dois anos, era apenas de pouco mais de $200 \mathrm{mil}$

35 varios estudos sobre o período republicano confirmam a morosidade de crescimento da alfabetizaçāo brasileira, destacando, entretanto, as diferenças regionais: "Os dados censitarios referentes ao Brasil revelam que nos primeiros vinte anos do corrente século, a taxa de alfabetização manteve-se praticamente a mesma, enquanto que neste mesmo período, en são paulo, o peso relativo de sua população alfabetizada (considerada a população total) subiu de 24,72t para $29,82 \%$, atestando o dinamismo que posteriormente colocaria são Paulo en posição de vanguarda. INFANTOSI, Ana Maria- A escola na república velha. São Paulo: EDEC, 1983, p.50. O crescimento do $n^{\circ}$ de alfabetizados no período é tambem apresentado por outra historiadora que identifica os momentos iniciais do crescimento da população escolarizada paulista. Na segunda metade do século XIX os dados apresentados são os seguintes: 1855- 159 escolas com 5.559 alunos; 1872 - 576 escolas; 1880 - 740 escolas; $1887-1030$ escolas com 26.939 alunos. BRESCIANI, Stella- Liberalismo: ideologia e controle social: um estudo sobre São paulo. Tese de doutorado. F.F.L.C.H./USP, 1976-, p. 94 .

HOLANDA, Sergio Buarque de- o Brasil monarquico- Do Imperio à República. São Paulo : Difusão Européia do Livro, 1972, Tomo II, 50 vol., p. 184 ( Novo sistema eleitoral) 
eleitores, em uma população de cerca de 15 milhões de habitantes." 37 os insistentes protestos do Executivo contra os gastos a serem dispensados à "educação popular" provam a ausência de uma vontade politica sobre a questão e perpetuaram-se os lamentos do nosso "atraso educacional". Os limites da ação política devem ser compreendidas pela extensão da tarefa, mas também pela ausência de pressões políticas e sociais efetivas, como no caso europeu.

Um dos poucos fatos que irritavam nossas elites governamentais, como ocorre ainda nos dias atuais, eram os dados estatísticos. O número dos alfabetizados brasileiros, quando comparados aos paises "civilizados", incluindo, no final do século XIX, a Argentina e Chile, constrangiam nossos políticos. Era uma realidade que impedia o Brasil de ser considerado como "igual" perante os países europeus e os Estados Unidos. A lenta expansão da rede de escolas elementares apenas os deixavam preocupados nesse sentido e, por vezes, faziam jogos com os números em relação à população para tentar justificar o atraso no processo de escolarização, trabalhando com dados sobre as perspectivas futuras. 38

O crescimento do número de alfabetizados no Brasil, expresso pelos dados abaixo, confirmam o rítmo brasileiro na constituição de uma sociedade letrada que dependia de sua existência para legitimar o poder político e definir os direitos de cidadania:

37 VERISSIMO, Jose- op. cit., ed., p.70.

38 o livro de pires de Almeida, citado anteriormente, é considerado o primeiro livro de historia da educação brasileira, foi escrito no final do Imperio e contém vários dados e tabelas sobre $n^{\circ}$ de alunos e escolas e especialmente despesas com instrução. Nas suas páginas conclusivas explica: "Se o Imperio sulamericano esta longe de ocupar o primeiro lugar na classificação baseada no custo per capita, ocupa um lugar honroso quando se compara a sona dispendida anualnente con a instruçăo e a receita global única base equitativa para se fazer julgawento que deve ser feito(..). Os númerbs que apresentamos acina provam eloquentemente o que procuramos demonstrar neste livro: $1^{\circ}$, que - Brasil não está atrasado en relação a instrução pública; $2^{\circ}$, que chegara logo a ocupar o primeiro plano intelectual entre as naçóes sul anericanas, se os dispendios com a instrução seguirea a progressão constada nos quadros, a partir do exercicio de 1874-1875." p.301-302. 
QUADRO 1

População alfabetizada: dados de crescimento $(1872-1920)$

\begin{tabular}{|l|l|c|c|}
\hline Ano & População* & Alfabetizados* & g \\
\hline 1872 & 9.930 .000 & 1.560 .000 & 15,7 \\
\hline 1890 & 14.333 .000 & 2.120 .000 & 14,8 \\
\hline 1900 & 17.320 .000 & 4.450 .000 & 25,7 \\
\hline 1920 & 30.640 .000 & 7.490 .000 & 24,4 \\
\hline
\end{tabular}

*Os números são arredondados

Fontes: ALMEIDA, J.R. Pires de- História da instrựão pública no Brasil (15001889), p. 167-169 e HALLEWELL, L. O livxo no Brasil.p. 157

Os números do quadro revelam que havia uma quantidade considerável de excluídos do saber letrado. Além dos setores privilegiados da população, minoria que frequentemente dispensava as escolas e iniciava seus estudos com preceptores, quem poderia efetivamente frequentar as escolas entāo construídas?.

A escola pública idealizada pelo liberalismo deveria servir à formação dos cidadãos. O saber sistematizado pelas disciplinas escolares deveria submeter-se aos interesses da constituição de um cidadão modelado para viver a política do Estado. A instrução escolar asseguraria às crianças sua entrada à vida cívica da nação.

o direito de cidadania expresso na constituição oude brasileira de 1824 excluía simplesmente os escravos. Temos, lew assim, de início, que a construção do saber escolar era destinada a uma parcela da população, proibindo legalmente-à maioria dos trabalhadores o direito à escolarização.

O Ato Adicional de 1834 promoveu a descentralização do ensino segundo $\circ$ artigo $10^{\circ}, \$ I I$, que atribuiu às Assembléias Legislativas provinciais o direito de legislar sobre a instrução primária e secundária. O regime republicano assegurou a descentralização para o primário, 
permitindo dubiamente, aos estados, criar escolas secundárias e superiores. 39

As leis provinciais, que datam do final dos anos trinta, eram, inicialmente, bastante genéricas em suas disposições sobre métodos e conteúdos para a escola elementar e suas normatizações eram vagas quanto ao sistema disciplinar, frequência dos alunos, idades permitidas, horários. As regulamentações efetivas, no sentido de definição mais explícita do grau elementar de ensino ocorreu com a reforma de Coutto Ferraz entre os anos de 1854 e 1859. Tratava-se de legislação que serviu de parâmetro para as demais províncias.

o regulamento do Município da Corte sobre a instrução primária e secundária de 1859, impedia de frequentar as escolas :

"a) os meninos que padeciam de moléstias contagiosas; b) os que não tiverem sido vacinados; c) os escravos. As 1 ições ordinárias das escolas não poderão ser admitidos alunos menores de 5 anos e maiores de 15." 40

o conteúdo da regulamentação de coutto Ferraz reforçava apenas o que estava explícito na Constituição, ao reiterar a proibição dos escravos à escolarização. Imporța destacar, no entanto, o estigma de escravo ou descendente de escravo que perdurou na legislação do Império. Na Província do Rio de Janeiro, eram proibidos de frequentar as escolas públicas "os que padecerem de moléstias contagiosas, os escravos e os pretos africanos, ainda que sejam libertos ou livres". 41

Para os "ingênuos", o direito à escola nunca ficou totalmente esclarecido. A decretação da obrigatoriedade do ensino primário a todo menino maior de 7 anos e menor de 14 ,

39 Pela Constituição de 1891 "à Uniāo competia privativamente legislar sobre o ensino superior na Capital da República, cabendo-1hes, mas não privativamente, criar instituiçōes de ensino secundário nos Estados e promover a instrução no Distrito Federal; (-) e aos estados se permitia organizar os sistemas escolares, completos; - Apud RIBEIRO, Maria Luisa S.- op. cit., p. 70 .

40 MOACYR, Primitivo- Inst. e Imp.. $2^{\circ}$ vol., p. 25

41 CLDR/RJ- Regulamento de instrução, 1. 9.1847. Apud ALVES, Claudia Maria Costa-Estado conservador e educação no Brasil: o caso do liceu provincial de Niter6i(1847-1851) In:NUNES, C.(org)- O passado sempre presente. São Paulo:Cortez, 1992, p. 58 
e menina maior de 7 e menor de 12, em 1871, na província do Rio de Janeiro, por exemplo, excluia de tal obrigação "os filhos de mulheres escravas", ou seja, os libertos. Em outro documento datado de 1883 encontramos um pedido de autorização feito por um professor para admitir em suas aulas públicas os "ingênuos", alegando a condição "livre" das crianças. O pedido era endereçado ao Diretor Geral de Instrução da Província da Bahia que deferiu o pedido do professor desde que os "ingênuos" possuíssem permissão "dos senhores, das mães ou de quaisquer outras pessoas em poder, ou sob autorização dos quais se achassem". 42

As crianças do sexo feminino possuíam direitos à escola, embora com um currículo diferenciado. Os debates entre educadores, que obtivemos pelas publicações de conferências pedagógicas, a partir da década de 70 , sugeriram a criação de escolas mistas para alunos com menos de dez anos de idade. Argumentavam sobre as vantagens de um ensino dado em comum para ambos os sexos, incluindo a diminuição de gastos mas, paradoxalmente, acabavam ponderando que a "sua adoção no Brasil poderia produzir males consideráveis, por causa dos vícios da educação doméstica e a ausência dos sentimentos religiosos." 43

Era consensual que para o sexo frágil bastava o ensino de primeiras letras. o ensino nas escolas femininas, geralmente, deveria ser administrado por mestras e o currículo seria organizado tendo em vista a preparação de "boas mães" para que se desenvolvessem "nossos costumes mais polidos, desaparecendo da sociedade muitos crimes que atestam a falta de morigeração e inteira ignorância." 44

Para as meninas pobres ou órfãs, pensou-se na criação de estabelecimentos especiais de ensino, espécies de asilos ou orfanatos sob a administração de irmandades religiosas. Em alguns relatórios de diretores de províncias existem notícias sobre projetos de criação de Escolas de trabalhos das mulheres, algumas noturnas, financiadas graças à

42 MOACYR, Primitivo- A Inst. e as Prov.- op. cit. p.182

43 ALMEIDA, J.R. Pires de- op. cit., p.153

44 Relatório de inspetor de instrução pública de Pernambuco de 1852. Apud MOACYR, Primitivo- Inst. e prov.,op. cit. v. 2, p. 497 
"caridade pública" e às grandes e "generosas proteções" de eminentes figuras. As escolas femininas destinadas às moças desemparadas possuíam como objetivo maior fornecer uma educação voltada para o serviço doméstico ou para se tornarem mestras quando revelassem "aptidāo para isto".

o ensino de "primeiras letras", com diferenciações significativas, dependendo do público escolar a que se destinava, passou, lentamente, a ter contornos cada vez mais nitidos, constituindo-se em curso com um sistema completo de instrução, fechado em si mesmo e, principalmente, distinto do secundário. Havia cursos diurnos fornecidos em escolas públicas e particulares. Quando se criaram escolas noturnas e dominicais de instrução primária, estas deviam possuir conteúdos próprios, concebidos para um público composto por trabalhadores. o saber escolar não deveria ser o mesmo para todas as classes sociais. As autoridades educacionais cuidaram de organizar estudos específicos para cada situação de escolarização.

Martim Francisco, ao definir a divisão da instrução em três graus de ensino, fundamentava-se em dois pontos: as "diferentes idades do homem" e a divisão social "natural" da sociedade. o primeiro grau de instrução era comum a todos, abrangendo "todos os conhecimentos que são mais úteis, $e$ necessários ao homem", com três anos de duração e que deveria atingir alunos dos nove aos doze anos. 45 Esta idade e este tempo de estudo eram suficientes para capacitar os alunos, mesmo os mais pobres, no domínio da escrita e de cálculos básicos e, para despertar "sentimentos morais". Como partia do princípio de que existe a desigualdade de fortuna dos pais, o primeiro grau de instrução deveria evitar un tempo excessivo de estudos de maneira a limitar os conhecimentos a serem transmitidos, fornecendo apenas os que fossem úteis em suas atividades futuras. Considerava a idade de estudos dos "filhos dos pobres" até no máximo 12 anos como conveniente porque ainda, nesta faixa etária, nāo eram tão necessários para o serviço da família podendo, assim, consagrar diariamente algumas horas ao estudo.

45 ANDRADA, Martim Francisco- op. cit., p.95 
Em 1856, Abilio Cesar Borges, futuro barão de Macaúbas, inspetor de ensino do governo de Alvaro Tibério Moncorvo Lima da Bahia, lembrava que "a mesma divisão natural da sociedade em classes inferiores, média e superior parece aconselhar e exigir estabelecimentos de instrução correspondente, onde todas as classes sociais possam achar e receber aquela de que hão mister. Ninguém dirá por certo que para os indivíduos das primeiras camadas sociais a instrução elementar tal como se dá em nossas escolas não seja suficiente. (-) " 46 .

Em outro discurso, a posição de um outro inspetor de instrução foi mais explícita: "cumpre, entretanto, manifestar um pensamento meu, que não é de hoje(...). Nesta instrução o que se procura antes de tudo é a difusão e não a perfeição. Saiba o filho do povo bem ou mal ler, escrever e contar, e guarde-se a ortografia para os que tem tempo e meios de aprendê-la. (...) " 47

A definição dos graus de ensino entre primário, que ensinava "ler, escrever e contar" e secundário, com seu conteúdo humanístico, não foi suficiente para resolver as questões educacionais.

Havia setores sociais intermediários que deveriam ser atendidos. A solução encontrada foi propor a divisão do ensino primário em dois níveis que se denominaram de $1^{\circ}$ e de $2^{\circ}$ grau ou instrução primária elementar e instrução primária superior ou complementar. A primeira lei que instituiu tais escolas foi a citada de 1854 e limitava-se ao município da Corte. Em relatórios das províncias onde o ensino estava mais organizado, como a Bahia, encontramos propostas que confirmavam o intuito dos politicos em atender aos interesses de comerciantes e de outros profissionais, além do próprio setor administrativo do baixo escalão governamental:

"Há uma lacuna que convém suprir, entre o ensino primário elementar e o secundário. Os jovens que não tendo

46 Relat6rio apresentado ao presidente da Província da Bahia. Apud MOACYR, Primitivo- Inst. e prov.-.op. cit., v.2, p. 103

47 Relatorio do conselheiro D. Leite Ribeíro, diretor de instrução da Província do Rio de Janeiro no ano de 1866. Apud MOACYR, Primitivoidem, op. cit., p. 239 
bastante fortuna nem talentos para seguirem as letras e ciências, possuem contudo meios de tomar a nobre carreira da indústria, não devem ficar circunscritos à instrução elementar; precisam de escolas médias onde recebam algum desenvolvimento intelectual e moral em relação à sua condição para que não sejam induzidos a seguir as humanidades ou as faculdades cientificas, espiritos medíocres com o perigo de adquirirem gostos e hábitos incompatíveis com as divisões da terra que habitamos; de história pela qual deixamos de ser estranhos ao destino dos homens que nos precederam, principalmente da nossa pátria que nos identifica com ela, como observa um sábio escritor. " 48

Assim, as escolas cuidariam de solidificar as diferenças sociais, conservando "cada qual no seu devido lugar", seguindo o ideário expresso por Abílio Cesar Borges, quando diretor de instrução da Bahia:

"Como demonstrou tem a instrução nacional diversos limites assinados a cada uma das classes sociais: compete pois à autoridade superior vedar, quanto puder, que individuos que se devem naturalmente contentar com a instrucão primária, alcancem a média, e que, os que com esta avancem à secundária, a qual principalmente deve ser mais dificultada àqueles que, já pela classe a que pertencem já por the falecerem talentos, não podem seguir as carreiras liberais ou científicas." 49

Para os setores menos favorecidos da sociedade, operários ou outros trabalhadores, os programas deveriam ser "adequados" aos fins a que desejavam chegar. Oscar Thompson, em relatório de 1909, ao se referir aos programas de ensino para os cursos noturnos de São Paulo, criticava a extensão dos mesmos para o público em questão, alegando que "está muito além das modestas aspiraçōes do humilde trabalhador manual, que necessita de conhecimentos de imediato alcance prático" e acrescentava:

48 Discurso do presidente da Provincia da Bahia, João Mauricio Wanderley, em 1853. Apud MOACYR, Primitivo - idem- op. cit. p.90. Grifo do autor

49 MOACYR, Primitivo- idem. op. cit., p.104. Grifos do autor. 
"Esta última parte "liçōes gerais" deve compreender apenas conhecimentos de alcance prático que habilitem o proletariado às condições e exigências do mundo moderno, fazendo-o conhecer, rudimentarmente embora, as mais comuns aplicaçōes das ciências físico-naturais à industria, ao comércio, à agricultura, ou, de modo geral, as artes e oficios" . 50

Para os filhos das classes abastadas que começavam a frequentar internatos confessionais ou leigos, havia. a preocupação com a qualidade do ensino. Projetos educacionais inovadores originavam-se, geralmente, de escolas particulares que visavam melhorar a qualidade da formação das elites mas que tinham como objetivos fundamentais garantir alunos para suas empresas educacionais. Não faltaram, principalmente na década de oitenta, propostas de reformas e reformulaçōes de programas e métodos de ensino que buscavam "modernizar" a educação escolar incorporando os avanços pedagógicos dos países europeus e norte-americanos.

\subsection{Livros de leitura e ensino elementar}

Dentro deste contexto é que podemos situar a politica do livro didático pára a escola de "primeiras letras" ou elementar. Tratava-se de uma escola onde se alternavam projetos de cursos preparatórios para os graus superiores ou de cursos destinados a setores mais amplos da sociedade, com programas restritos ao ensino da escrita, leitura e cálculos rudimentares. Como deveriam as autoridades educacionais, então, estabelecer normas de elaboração do Iivro elementar? Como deveria ser um manual escolar para a escola primária?

Podemos dividir a literatura escolar do ensino primário em dois gêneros.

Existia o livro da disciplina organizado por nível de Idade, cuja complexidade dos conteúdos buscava acompanhar as diversas fases de aprendizagem do aluno, evoluindo segundo os programas de ensino. o outro gênero foi o denominado

50 Relatorio de Oscar Thompson ao secretario do Interior do Estado de São Paulo. Anuário do Ensino do Estado de São Paulo. São Paulo: Tipografia do "Diário oficial", 1910, p.66. 
livro de leitura, um tipo específico de literatura para a infância. A caracterização do livro de leitura é difícil porque, segundo os estudiosos da literatura infantil, não há uma "nitida separação entre os livros de entretenimento puro e o de leitura para aquisição de conbecimentos e estudo nas escolas, durante o século passado". 51

Para o primeiro nível de ensino existiram os projetos da produção didática referentes o tema da alfabetização. Para aprender a ler, escrever e contar, os ideólogos educacionais mais conservadores, propuseram os catecismos, seguindo a tradição dos educadores religiosos que buscavam, prioritariamente, garantir o conteúdo moral.

- Decreto das Escolas de Primeiras Letras, de 1827, a primeira lei sobre a instrução nacional do Império do Brasil, dispunha que tais escolas deveriam seguir o método "mútuo". 52

o ensino mútuo baseava-se nos princípios pedagógicos dos ingleses Bell e Lancaster. Era um método criado no inicío do século XIX, quando se buscava uma maior eficiência no ensino de crianças oriundas das classes populares. 0 "sistema de Lancaster" como também era denominado, consistia em utilizar os alunos mais habilidosos e, geralmente, mais velhos como "monitores", para ensinar os mais novos e atrasados. A lição era primeiramente explicada aos monitores, pelo mestre, que em seguida era transmitida aos demais alunos. O mestre ensinava a leitura e a escrita, simultaneamente, utilizando-se de grandes tábuas murais, sendo quase desnecessário o uso de manuais escolares. Para exercitar a escrita, cada aluno deveria possuir uma pedra de ardósia, material mais barato que o papel.

As leis educacionais que se seguiram ao Ato Adicional estabeleceram, na maioria das províncias o ensino mútuo como "método oficial" até meados do século. Este método seduzia as autoridades governamentais pelo aspecto econômico que apresentava, solucionando a carência de mestres mas

51 ARROYO, Leonardo- op. cit.p. 93. O autor, na mesma obra afirma que a literatura infantil propriamente dita partiu do livro escolar "do livro útil e funcional, de objetivo eminentemente didático." ,p.94

52 Cf. XAVIER, Maria Elizabete S. P.- op. cit. ,p.5 
garantindo a alfabetização de um número significativo de crianças. As elites liberais européias foram atraídas pela possibilidade de expandir o ensino elementar com poucos gastos para o Estado, razão também presente nos argumentos dos legisladores brasileiros ao aceitarem o projeto.

Um relatório ministerial de 1832 afirmava ser o método lancasteriano o mais apropriado para ser aplicado na instrução pública por ser o menos dispendioso de todos os métodos de ensino, informando que "no Brasil, nas cidades mais populosas, contada é a escola lancasteriana, de inegável proveito e economia, que tenha 150 meninos, quando sua despesa anual não custa à Nação menos de 800\$000, termo médio; não entrando o aluguel da casa e outros utensilios". 53

o ensino mútuo, embora tenha se estendido, na prática, a poucas escolas no Brasil, foi sempre alvo de polêmicas, principalmente nos países europeus que o adotaram em maior escala. 54

o aspecto fundamental que dividia as opiniões dos educadores, quanto ao método lancasteriano, concentrava-se, sobretudo, no papel que o livro didático tendia a desempenhar na formação "espiritual" do educando. Era um método que propiciava um ensino não sectário o que contrariava as autoridades eclesiásticas e seus adeptos mais fervorosos.

Para o caso inglês, a divergência ocorria partindo dos seus criadores, o pastor anglicano Bell, da Igreja oficial e Lancaster, quaker. Nas escolas organizadas pelo "The Royal Lancastrian Society", a Bíblia era sempre o livro básico, mas não havia nenhum "catecismo especifico" imposto aos alunos, e os textos bíblicos eram lidos mas não comentados.

53 Relatorio do ministro Lino Coutinho procurando incentivar os presidentes das províncias a adotarem o método de Lancaster. Apud MOACYR, Primitivo- Inst. e Imp., v.1,op. cit., p.194

54 a política de adoção do método de ensino mútuo e as oposições de que foi alvo tem alguns estudos entre os quais destacamos, para 0 caso francês, o que foi realizado pelo INRP, Musée National de l'Éducation- Lire, écrire, compter: 2.000 ans d'alphabetisation. Rouen, 1981 e o trabalho de BAUDEMONT, Suzanne- L'histoire et 1a légende dans I'école elementaire victorianne 1862-1901. Paris: klincksieck, 1980 . 


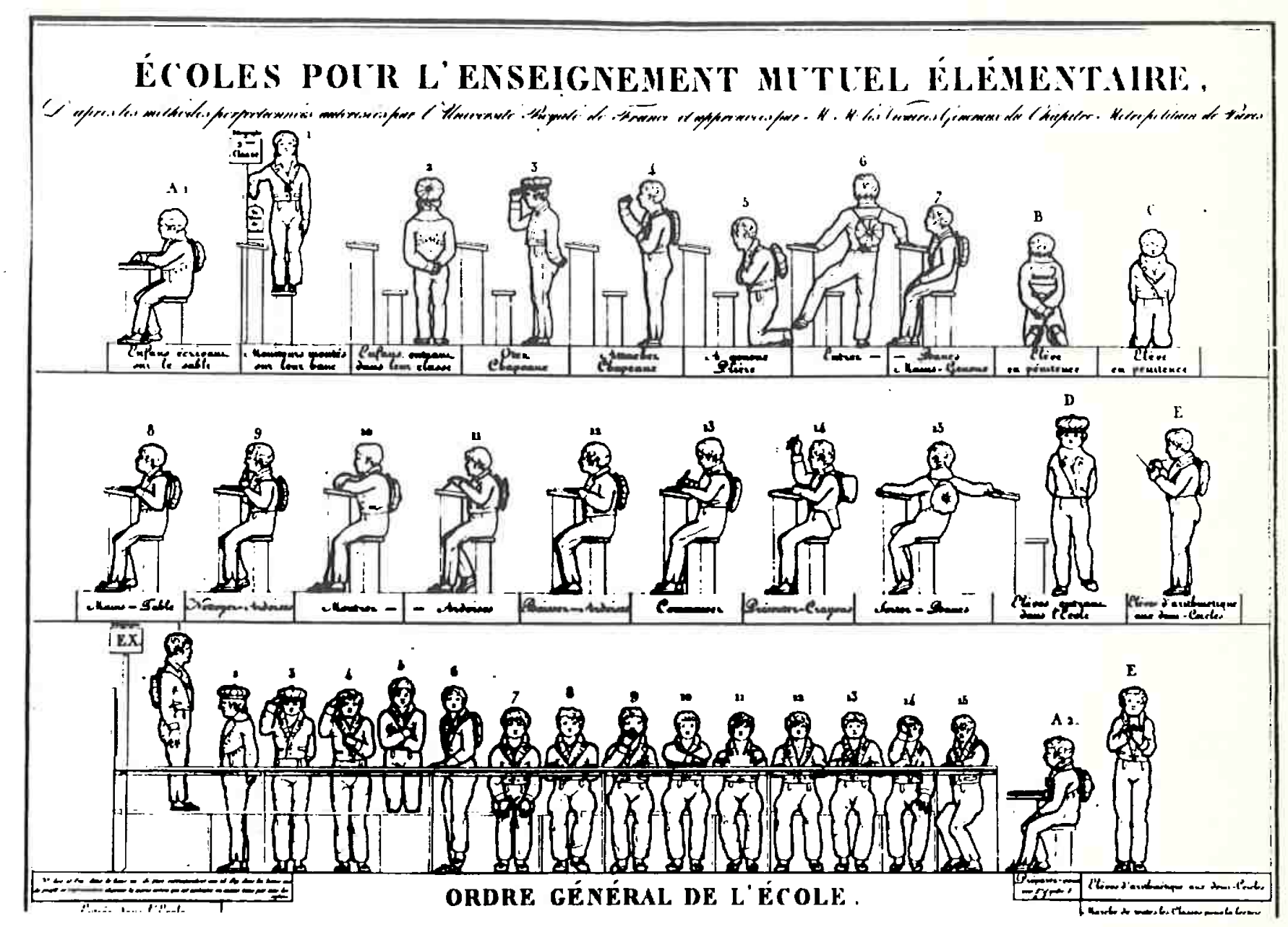

Fig. 1

Escolas de ensino mútuo elementar. Fotografia de um cartaz ilustrado, 1817. INRP, Musée National de l'Éducation. Lire, écrire, compter: 2.000 ans d' alphabétisation, p. 52 
A Igreja Anglicana, percebendo os riscos que corria, tratou rapidamente de denunciar o perigo que representava um ensino destinado às crianças das classes populares que não servia como doutrinação da religião oficial.

o ministro francês Guizot, apesar de ser protestante, acatando as críticas dos "ultras" católicos franceses, proibiu em 1833 o ensino mútuo na França exatamente porque era um método que escapava à tutela da Igreja. A Igreja Católica francesa, diante de tal método, não possuía meios de impor seus catecismos e muito menos controlar "as falas" transmitidas por jovens "despreparados moralmente".

No Brasil, quando da aprovação do projeto que estabeleceu o ensino mútuo nas escolas públicas, parecia que os parlamentares não conheciam exatamente o método e suas preocupações giravam, então, em torno dos gastos relativos ao ensino. Os legisladores do $I^{\circ}$ Império limitaram-se, inicialmente, a aconselhar o uso do método inglês e a indicar umas poucas obras a serem adotadas, tendo sido estabelecido, no texto final sobre o ensino elementar que "os professores ensinarão a ler, escrever, as quatro operações de aritmética, prática de quebrados, decimais e proporçōes, as noções mais gerais de geometria prática, a gramática da língua nacional, os princípios de moral cristã e de doutrina da religião católica e apostólica romana, proporcionadas à compreensão dos meninos; preferindo para o ensino da leitura a Constituição do Império e História do Brasil." 55

As críticas dos nossos intelectuais não tardaram e não foram diferentes das elites conservadoras européias. Um expressivo depoimento sobre o sistema mútuo está contido no relatório de um dos membros da comissão de instrução, instituída pelo governo, visando reformar o ensino na capital do Império. Embora o documento se posicionasse contra o método mútuo com alegações quanto à inadaptação de prédios, sendo necessário edificios próprios e mais

55 Apud Xavier, M. Elizabete- op. Cit., p.54 
espaçosos para abrigar um grande número de alunos, o ponto crucial da crítica residia em sua fluidez dogmática:

"O saber ler e escrever, considerado independentemente do ensino religioso e da educação, pode conduzir tanto ao mal como ao bem. Essa primeira ciência que recebemos na aurora da existência não é um fim, é um meio subordinado ao aperfeiçoamento moral, e sem a qual seria talvez antes prejudicial que útil. Ora o ensino religioso é nulo no sistema de monitores, porque reduz-se à simples recitação material da cartilha. A educação, também aí não existe, porque a intervenção do mestre desaparece diante dos olhos da quase totalidade de seus alunos para ser substituida pela de outros meninos, sem nenhuma autoridade moral sobre seu espírito.

Que admoestações, que direções fortes e fecundas podem ser dadas por monitores de 10 ou 12 anos, de modo que sejam aceitas por seus jovens companheiros? 0 mestre e o discípulo apenas se conhecem; nenhum laço de simpatia os une; $e$ a palavra prestigiosa do mestre, que em um ensino todo dogmático impõe a crença e força a obediência, não soa aí ao ouvido do menino." 56

Muitos outros textos comprovavam os "malefícios" da educação pouco dogmática e este método acabou por ser proibido em nossas escolas, processo iniciado pelo município da corte e que se estendeu às demais regiões. Durante os anos iniciais, entretanto, a adoção oficial desse sistema fez com que nossas elites educacionais pouco se preocupassem com a produção de material escolar para a alfabetização, aceitando obras originárias do período pombalino e outros catecismos portugueses ou traduzidos pelos portugueses.

o catecismo foi um tipo" de texto escolar constantemente mencionado pelos educadores no decorrer do período estudado. Embora variasse quanto à sua natureza, conforme a disputa ideológica que se travava, encontramos nos relatórios dos membros dos conselhos de instrução das

56 Projeto de reforma de instrução pública apresentada em 1847 pelo deputado Torres Homem.Citado por MOACYR, Primitivo- Inst. e Imp., op. cit.- $1^{\circ}$ vol., p.257-258 
províncias várias sugestões de leitura escolar em "catecismos de agricultura".57

A partir dos anos 80 , as propostas dos intelectuais republicanos visavam a produção de catecismos cívicos para imposição de uma moral laica em substituição da moral religiosa. Dentro da concepção de secularização, o catecismo cívico deveria assumir "a nobre" missão de desenvolver o patriotismo, de expor os "direitos do homem" e os princípios de liberdade, conforme os preceitos dos liberais do final do século XVIII. A confecção dos catecismos proposta não diferia substancialmente dos catecismos católicos quanto à forma, substituindo as leituras áridas dos textos da Constituição ou até do "Código criminal" sugeridas pelos parlamentares.

As discussões sobre os métodos de alfabetização e material mais adequado tornaram-se bastante intensas a partir dos anos 70, estendendo-se pelo século XX. Os avanços dos estudos pedagógicos expressavam as novas necessidades educacionais com as tendências para um ensino que deveria atender a um número cada vez maior de alunos. A adoção do método analítico, sugerido pelos pedagogos, foi resultado dos avanços das ciências de educação, mas temos que considerar que as novas propostas para a composição e adoção de cartilhas, texto didático que substituiu o catecismo no processo de alfabetização, estavam ligadas aos confrontos entre os cientificistas e os setores mais conservadores apoiados pela Igreja Católica.

No projeto de Reforma de Rui Barbosa, em 1882, as divergências entre os dois grupos foi flagrante. No capítulo V, Da Escola Leiga, Rui Barbosa fez um longo levantamento das tendências de vários países, destacando a França e os Estados Unidos da América, no sentido da secularização do ensino. Criticou o conservadorismo pedagógico da Espanha que

57 Estas sugestōes eram mais comuns de serem encontradas nos relatorios de instrução das províncias do Norte e do Nordeste. Primitivo Moacyx faz referências de pedidos das autoridades para que se confeccionassem catecismos para uso das escolas. Na província do Grão-Pará, um relatório de 1877 impunha que nas "escolas efetivas" o ensino constaria da "leitura do codigo criminal e do catecismo da agricultura aplicada a lavoura do pais". MOACYR, Primitivo- Inst. e prov., v.1, op. cit. p.148 
mantinha o ensino religioso obrigatório, do primário ao superior, e acusou "o decreto de 19 de abril" brasileiro como "conciliador", obrigando os mestres das escolas públicas a ensinar religião quando da falta de clérigos. Para Rui Barbosa criara-se uma situação insustentável e ainda "violou uma lei pedagógica, desconhecendo a incompetência do professor leigo para o ensino religioso, e esqueceu uma das faces do principio liberal, ferindo com imposição de encargo tal liberdade do magistério civil".58 Alegava a incoerência existente entre a questão da obrigatoriedade do ensino elementar e a obrigação do ensino religioso na escola:

"Se o Estado exige de todos a presença escolar, a todos há de proporcionar escolas onde não sofra a consciência de ninguém, ouvindo contestar a sua religião, ou afirmar a de outrem." 59

Rui Barbosa deixou claro, porém, nas críticas que fêz ao "método tradicional" e aos livros de leituras e cartilhas utilizadas, a ideologia que combatia:

" Aprendem por livros, onde se lhes fala no pecado original, atual, mortal, e venial, em igreja militante, paciente e triunfante, em jejum natural e eucarístico, em latria, dulia e hiperdulia, em graca atual, habitual e santificante, em indulgência parcial e plenária, em impedimentos impedientes e dirimentos, em matéria e forma dos sacramentos." 60

Na segunda metade do século começaram a surgir os adeptos do método analítico, sendo a maioria de seus defensores intelectuais ligados ao positivismo, ou grupos anti-clericais, maçons em geral, incluindo, nas argumentações favoráveis ao novo método, a "nacionalização" dos materiais e métodos do ensino elementar.

Oscar Thompson, depois de expor as vantagens para aprendizagem de um método em que o aluno partia da idéia geral de uma sentença para chegar às partes, do todo para

58 BARBOSA, Rui- Reforma do ensino primario e várias instituiçōes complementares da instruçāo pública. Rio de Janeiro:MEC, 1947, vol. X, Tomo I, p. 310

59 Idem, P. 311

60 Idem.- Tomo 2, p. 44 . Grifos do autor. 
chegar à sílaba, contrário, portanto, ao método "silabário", insistia sobre a necessidade de confeccionar e adotar oficialmente obras "nacionais" porque "por melhor que seja a tradução de um livro desta natureza não poderá ele certamente adaptar-se às condições especiais de processuação do método exigido pela índole da língua materna.

os elementos fônicos, a ordem e correlação dos vocábulos e sentenças que devem constituir um escolhido conjunto de liçōes, não se podem obter por meio de traduções de cartilhas estrangeiras. "61

A opção do método de alfabetização não se explicava apenas por razōes didáticas. Ela expressou os conflitos políticos que percorreram os anos finais de 70 até o início do século atual.

A escolha do método analítico na alfabetização, em oposição ao usual método sintético, representava a posição dos grupos de educadores defensores de uma escola laica. Os seguidores do método analítico eram, em sua maioria, republicanos com discursos voltados para uma democratização do saber escolar e contrários ao espírito tradicional de educação, com o ensino calcado em métodos da Igreja.

No curso elementar, entretanto, a obra didática que passou a ser considerada como fundamental, capaz de induzir e formar "o espírito" dos meninos foi o livro de leitura. E, nos projetos para a elaboração de livros de leitura para a infância, definiam-se com precisão, a concepção de leitura: " $1^{\circ}$ o que constitui propriamente a arte de ler (conhecimento das letras, seus nomes e valores, combinações, e da pronunciação das palavras por elas formuladas), e $2^{\circ}$ a leitura como instrumento para a aquisição de idéias e noções úteis à infância". 62

Martim Francisco evidenciara a característica desta produção, sendo minucioso no conteúdo a ser construído, na linguagem do texto, especificando o cuidado na escolha dos vocábulos, "não esquecendo de empregar as palavras técnicas não só porque a linguagem filosófica é mais exata, que a

61 Thompson, Oscar- op. cit. p.10

62 CAVALCANTI, Joāo B. Uchoa- op. cit., p. 93 
vulgar, mas também porque iguais vocábulos exprimem noções mais precisas, designam objetos mais distintos e correspondem a idéias de mais fácil análise."63

Os politicos e administradores do setor educacional sugeriam ainda o cuidado que os escritores deveriam ter quanto às qualidades literárias da obra. Os livros de leitura deveriam fornecer conhecimentos variados e incentivar o gosto pela leitura. o estilo seria importante para desenvolver este gosto, porque, "temos visto livros dedicados à instrução da infância cujo contexto é de um excessivo pedantismo; outros sāo viciosos no método ou de estilo fastidioso, narcotizam o leitor em vez de provocarThe a curiosidade." 64

Ao lado da preocupação em fornecer subsídios técnicos para a construção dos livros de leitura, a ênfase recaia sobre o conteúdo moral que tais obras deveriam possuir.

Enquanto predominou a imposição da moral religiosa católica, legisladores e educadores sugeriam traduções de obras de vida de santos ou da vida de personagens que pudessem servir de exemplo para os jovens. Eram recomendadas, preferencialmente, as fábulas, alegando que "enquanto os outros livros se esforçam em demonstrar um fato, as fábulas ensinam um princípio, e tanto mais seguramente quanto o menino é doutrinado, sem o perceber, por meio de um exemplo trivial de que ele vai por si mesmo tirar a conclusão, que vem ser a máxima para a vida. "65

Os projetos de elaboração de livros de leitura do final do século esmeraram-se em substituir o conteúdo moralreligioso por um conteúdo moral-cívico ao mesmo tempo em que reivindicavam temas de cunho nacionalista. José Veríssimo era enfático no papel a ser desempenhado pelos livros de leitura: "o livro de leitura, por sua vez, o livro de leitura, que é por acaso a mola real do ensino, mantém a mesma indiferença patriótica e suas páginas são brancas

63 ANDRADA, Martim Francisco- op. cit. p.98

64 OTAVIANO, Francisco- Ensaios administrativos, publicados no Jornal do Comércio, Rio de Janeiro, 1851 . Apud MOACYR, Primitivo- Inst. e Imp.-op. cit., v.2., p. 561 .

65 Idem, p. 561 
para a geografia e história da Pátria" 66 e sugeria que os livros de leitura privilegiassem os textos dos poetas e prosadores brasileiros e que, principalmente contivessem temas brasileiros, narrativas dos "grandes viajantes que percorreram nosso Pais, como Martius, como Agassiz, como Coutto Magalhães, como Saint-Hilaire, como Severiano da Fonseca, ou dos que fizeram a nossa História, os Rocha Pittas, os Southeys, os Porto Seguros, os João Lisboas. 67

As mudanças nos programas da escola elementar, durante a fase republicana, eram sustentadas por propostas que conferiam ao livro de leitura proeminência sobre os demais.

o parecer da Comissão incumbida de rever a lista de obras adotadas nas escolas públicas paulistas, em 1908, chegou a recomendar que os alunos só se utilizassem dos livros de leitura. Para as demais disciplinas bastariam as explicações do mestre. Os membros da Comissão estadual, em posição radical, concluíram que "ao espírito construtivo da educação moderna repugna o uso rotineiro do compêndio", e sua utilização "exaure e atrofia a inteligência do aluno".68

2.3 Iivros e compêndios para o ensino secundário

Em que seriam diferentes os livros para escola secundária?

Para o ensino secundário, onde os díscipulos estariam com as "faculdades mais desenvolvidas", os programas e disciplinas ou "matérias" foram estabelecidas de maneira mais centralizada. Também não se cogitava em ampliar o curso para setores populares da sociedade.

Segundo Martim Francisco, o curso secundário deveria articular-se ao ensino superior, contendo disciplinas de caráter propedêtico. Este primeiro projeto propunha que se estudassem " 10 , as noções fundamentais da gramática latina, e seu estudo, juntando-se a ele o da língua francesa, no que

66 VERISSIMO, Jose- op. cit. , p. 56

67 Idem, ibidem- p. 64

68 Parecer apresentado ao secretario do Interior pela comissāo revisora dos livros didáticos.Anuário do Ensino do Estado de São Paulo. São Paulo: Tipografia Augusto Siqueira Cia., 1907-1908, p.384 
pode depender-se dois anos; $2^{\circ}$ a metafísica, lógica e moral; $3^{\circ}$ as ciências físicas fundadas na observação e experiência; $4^{\circ}$ as matemáticas e a parte das ciências físicas, fundadas no cálculo; $5^{\circ}$ a história e a geografia, juntando-se a elas retórica, ou a arte de exprimir as idéias." 69

Este primeiro projeto não foi o vencedor, lembrando que como o ensino primário, o secundário foi outra criação educacional do século XIX. Um currículo voltado para as letras era mais conveniente para os jovens que iriam seguir a vida política, necessitando de exercitar a oratória, escrevendo e citando nomes da literatura clássica. As atividades industriais estavam distantes dos sonhos dos filhos de proprietários agrícolas.

o ensino régio da reforma pombalina tem sido constantemente considerado pelos historiadores da educação como ensino secundário mas, é preciso determinar sua especificidade para evitarmos anacronismos.

Os colégios e liceus, termos utilizados para designar as escolas secundárias, criados no decorrer do século XIX, corresponderam à transição da escola régia, preconizada pelos iluministas portugueses, para os ginásios, com cursos seriados e sequenciais da fase republicana do século XX. As escolas régias eram cursos preparatórios para a Universidade, compostos de aulas avulsas que ensinavam, isoladamente, aos alunos, determinados conteúdos, especialmente o latim, que seriam a base dos estudos posteriores. 70

Um estudo de André Chervel sobre o nascimento do curso secundário, na França, mostra as especificidades desse nível de ensino. O ginásio e liceu organizado em séries, foram moldados segundo os ditames $e$ interesses da burguesia liberal do século XIX. Tratava-se de um curso que necessitava legitimar uma nova divisão social fundamentandoa no domínio do saber letrado, em uma sociedade que não mais

69 ANDRADA, Martim Francisco- op. cit., p.101

$70 \mathrm{Cf}$. ANDRADE, Antonio A. Banha- op. cit. 
podia conservar seus privilégios, apenas, pelo sangue e pelos títulos de nobreza. ${ }^{71}$

Entre nós, o secundário representava, igualmente, um meio de preservar privilégios e manter a separação entre a elite identificada com o mundo branco europeu e o restante da população, composta de mestiços, negros, e índios. Eram cursos reservados a alunos em condições econômicas favoráveis, conservando-se, sempre, como um curso pago.' A aceitação tranquila pelos políticos brasileiros de um ensino elementar gratuito e, ao contrário, as dificuldades em estabelecer um ensino secundário grátis, fato que só ocorreu após 1945, comprova a natureza elitista do curso, criado para atender as classes dirigentes, além de ser um curso exclusivamente reservado aos jovens do sexo masculino. o ensino secundário feminino foi apenas objeto de eventuais propostas, limitando-se a ser exercido em poucas escolas confessionais ou particulares leigas.

o ensino secundário brasileiro teve, entretanto, duas características próprias que a distinguiram das escolas francesas que, em princípio, foram seu modelo.

A denominada escola secundária brasileira era composta, além do Colégio pedro II, de alguns liceus estatais espalhados pelas províncias, de colégios confessionais com um ensino mais organizado em séries e "aulas" sequenciais, os seminários "menores" com um programa curricular próprio para a formação de clérigos e, por cursos esparsos, constando de aulas avulsas de latim e demais disciplinas exigidas para os exames preparatórios. Eram, assim, diferentemente da França, incluídos na categoria de ensino secundário, os cursos preparatórios para as escolas superiores, compostos de aulas isoladas das disciplinas exigidas pela Faculdade escolhida pelo candidato.

Os dados estatísticos sobre o secundário foram sempre difíceis de computar pela liberdade de criação de escolas e aulas avulsas sem qualquer controle oficial. Alguns

71 Cf. CHERvel, André- Quando surgiu o secundario? Trad. Circe M.F. Bittencourt. Revista da Faculdade de Educaçāo. São Paulo, v. 18, $n^{\circ} 1$, p. 99- 112, jan./ jun., 1992 
levantamentos, entretanto, são suficientes para provar a outra caracteristica marcante do ensino secundário brasileiro: sempre foi um ensino predominantemente particular.

As acusações encontradas, em grande parte dos discursos dos legisladores, sobre a inviabilidade de um ensino secundário público por ser apenas um "luxo desnecessário", residiam na crença da natureza elitista que dominava este grau do ensino. A argumentação fazia parte da lógica liberal defensora da liberdade de atuação do setor particular, com um mínimo de interferência do Estado, em áreas onde houvesse possibilidade de lucros privados.

Manter escolas secundárias públicas, para este grupo de ideólogos liberais, seria inviabilizar vantagens financeiras para o setor privado e impedir a disseminação ideológica mais efetiva, especialmente a oriunda dos setores religiosos.

Coutto Ferraz, em 1847, propôs a supressão dos liceus públicos criados na província do Rio de Janeiro, sugerindo que fossem substituídos por particulares "vigiados zelosamente pela autoridade" para que a instrução deixasse de ser "um luxo dispendioso". A proposta de "vigiar zelosamente" os estabelecimentos particulares era feita porque tais instituições seriam subvencionadas pelo Estado. $E$, esta é outra tendência dos liberais: as escolas de instrução secundária deveriam ser particulares mas, subvencionadas pelos cofres do Estado. Para receber ajuda financeira dos cofres públicos era suficiente fornecer algumas vagas para alunos pobres. 72

72 A proposta de Coutto Ferraz está registrada por Primitivo Moacyr no $2^{\circ}$ volume da Instrução e as províncias, p. 208. Sobre as condiçōes de subvenções oferecidas aos colégios secundários particulares, os vários relatorios dos presidentes de província atestavam as condiçóes dos "pobres" que poderiam frequentar os colegios particulares: "Dois até agora tem sido os colégios que se colocaram nas condiçóes da lei, os de que são diretores o sr. João Batista Calógeras, em Petropolis, e - sr. Joāo Henrique Freese em Nova Friburgo; Ambos eles ofereceram, alem do ensino gratito aos 20 meninos pobres externos que a lei exige, da-10 tamber a internos; (-) Para aproveitar quanto antes os oferecimentos desses diretores mandei anunciar pelas follas publicadas que serial preferidos, para o internato dos referidos colegios, os alunos pobres que se tivessem distinguido por seus talentos, aplicaçăo, e moralidade, os filhos dos enpregados e professores públicos con mais de 10 anos de serviço e sobrecarregados de fanília e pobre." Apud Moacyr, Primitivo, Inst.e prov.-op. cit., v.2, p.224 
o número de estabelecimentos e alunos do ensino secundário em 1883 é uma amostra do que se repetiu no desenrolar da história desse grau do ensino:

\section{Quadro 2}

Estabelecimentos e Alunos dos Cursos Secundários-1883

\begin{tabular}{|l|c|c|c|}
\hline ESCOLA & ESTABELECIMENTOS & ALUNOS & ALUNAS \\
\hline Pública & 58 & 3783 & --- \\
\hline Particular & 205 & 4038 & 721 \\
\hline
\end{tabular}

Fonte:HAIDAR, Maria de Lourdes Mariotto - o ensino secundário no Imperio, p. 61

Os programas do ensino secundário cujos conteúdos explicitavam seu caráter propedêtico, sendo destinado a servir como preparatório para aqueles que seguiriam as carreiras liberais foi constantemente alvo de críticas. As inúmeras reformulações dos programas curriculares do Colégio Pedro II representam os conflitos entre os educadores para se estabelecer um saber escolar consensual para a formação dos setores burocráticos e do quadro de intelectuais do Estado.

O projeto de Rui Barbosa de 1882, foi representativo da natureza das críticas realizadas, restringindo as mudanças ao aperfeiçoamento curricular da escola secundária. o restante de suas características deveria ser mantido.

o projeto de Rui Barbosa aproximava-se dos setores sociais urbanos voltados para projetos de modernizaçāo, exigindo cursos mais práticos e técnicos, o que levou o deputado a propor reformas curriculares para o Colégio Pedro II, pretendendo ampliar os cursos para que o secundário não se reduzisse à formação de bacharéis. Os cursos propostos eram denominados de especializados, com um prazo menor de estudos em relação ao bacharelado de seis anos. Os cursos especializados seriam de finanças, comércio, agrimensura e 
direção de trabalhos agrícolas, de maquinista, industrial, relojoaria e instrumentos de precisão. ${ }^{73}$

Muitos documentos oficiais de ensino do período, relativos ao ensino secundário, incluem alguns dos raros cursos profissionais na categoria de secundários.

As escolas profissionais públicas limitavam-se às Escolas Normais, com aproximadamente 20 cursos até 1883 e 7 institutos de ensino profissional.74 As Escolas Normais foram criadas com programas curriculares variados, muitas de curta duração por falta de recursos das províncias. A estruturação das Escolas Normais ocorreu com a instalação do regime republicano, destacando-se o Estado de são Paulo que se engajou na construção de um ensino pedagógico mais consequente, prevendo uma formação mais sólida para os futuros mestres.

Efetivamente os cursos secundários eram os preparatórios para o superior, dominado pelo interesse dos alunos em adquirir um saber que lhes possibilitasse ingressar nas faculdades de Direito, de Medicina ou outra escola do mesmo nível.

Definida a classe social e os fins do ensino secundário, programas e compêndios escolares deveriam seguir - padrão internacional, básico para a formação da elite letrada do país, de acordo com o desejo do poder instituído de seguir, enquanto classe dominante, o caminho dos demais países "civilizados" do mundo ocidental.

Não houve mudanças quanto à concepção da obra didática para o curso secundário. No decorrer do período, encontramos como preocupação básica para a elaboração de compêndios, as adaptaçōes e traduções ou mesmo a leitura na língua original de livros didáticos estrangeiros. o cuidado concentrou-se na seleção das "obras mais adequadas" a serem usadas pelo professor. O regimento do Colégio Pedro II exigia que os livros adotados devessem passar pela aprovação do ministro do Império e de uma comissão presidida pelo reitor do estabelecimento. No nível de projeto educacional, quanto aos

73 Cf. BARBosa, Rui- Reforma do ensino secundário e superior. Rio de Janeiro: Mec, 1947, v. IX, t. 1 ,

74 Cf. HAIDAR, M.L. Mariotto- op. cit. , p.61 
métodos de adoção de obras didáticas houve, portanto, consenso entre as autoridades políticas.

As escolas confessionais dependiam única e exclusivamente do aval das autoridades eclesiásticas e as demais escolas particulares ficavam subordinadas ao diretor ou proprietário do estabelecimento. As exigências dos exames para os cursos superiores e o padrão do Colégio Pedro II davam uma certa homogeneidade às obras, conforme observamos do relatório do então deputado Justiniano José da Rocha, em 1850, sobre as escolas secundárias da Corte:

"... quanto aos métodos e livros de ensino, se não há perfeita identidade, também não há diferenças capitais entre eles. Na falta de livros elementares aprovados e impostos por quem tenha direito de impor e de aprovar, são geralmente adotados os livros antigos, notando-se em alguns colégios um progresso: a adoção dos livros da Universidade de França, cujo texto é mais acurado, cuja escolha é melhor regulada pela gradação das dificuldades." 75

o discurso liberal aceitava uma maior liberdade do professor na escolha do manual a ser adotado mas a vigilância era mais acirrada e facilitada pela concentração das escolas em centros mais populosos, en geral, a capital da província.

As regulamentações especificavam, para cada província, os compêndios a serem adotados. A leitura dos clássicos permaneceu. Virgílio, Horácio, Cícero, Tito Lívio eram obrigatórios. Para o estudo de gramática predominavam os autores portugueses e livros franceses para as demais áreas. o incentivo para obras nacionais foi quase inexistenté, limitando-se às matérias como Geografia e História do Brasil. A gramática e a literatura nacionais foram introduzidas com certa relutância no final do século mas, restringiam-se a livros de autores portugueses mais dedicados à produção de obras dessa natureza.

75 Relatorio de 1850 do dr. Justiniano Jose da Rocha, encarregado pelo governo de inspecionar nas escolas do municipio da Corte. Apud MOACYR, Primitivo- Inst. e Imp., v. 1, p.313, 


\section{Vigilância e controle da produção didática}

3.1 Legislação sobre os livros escolares

A censura sobre o livro é constante e a história está repleta de exemplos sobre as medidas tomadas pelo poder para a destruição de obras "perigosas". O medo em relação à palavra impressa, característica do poder instituído, demonstra uma aparente contradição, considerando-se que, a partir do século XVII, o livro passou a assumir um papel de destaque na configuração da cultura ocidental enquanto se difundia a idéia da construção de uma sociedade letrada, expressa com veemência pelos liberais do século XVIII.

o Estado liberal brasileiro, ao incorporar os discursos sobre a disseminação do saber letrado, temia os perigos do texto escrito, especialmente daquele que, tendencialmente, estaria ao alcance de um número considerável de jovens e crianças.

Ficou evidente para as autoridades governamentais que não seria suficiente definir normas para confeç̧ão do livro didático. Os administradores públicos deveriam permanecer vigilantes quanto à adoção das obras "adequadas" à idade e ao público escolar. Os livros eram fundamentais porque evitariam que professores usassem textos impressos quaisquer ou mesmo manuscritos que poderiam tratar de assuntos "subversivos" aos desígnios educacionais, além de causarem problemas metodológicos. 76

o presidente da Paraíba, em 1858, referendou o pedido feito pelo diretor de Instrução para que o governo fornecesse compêndios para as escolas elementares uma vez que "não se deve deixar ao alvedrio de cada um levar para escola impressos e manuscritos quaisquer: alguns impressos imorais e cartas intimas inçadas de erros ortográficos." 77

76 o relatorio de Gonçalves Dias explica a necessidade de adoçāo de livros pelos professores, entre outras razōes, porque os livros evitariam diferenças "na sequência de um aprendizado em letras impressas e letras manuscritas." , op. cit., p. 363

77 Relatorio de um presidente da província da Parasba. Apud MOACYR, Primitivo- Inst. e prov., v.1, p. 437. 
A maioria dos discursos das autoridades educacionais apresentava "os perigos" dos textos escolares em dois níveis. Alegavam o risco que representava a utilização de impressos com falhas de conteúdo, com erros gramaticais ou outras omissōes, inclusive falhas de impressão. Mas, uma outra questão era enfatizada. Além do manual escolar ser correto quanto às suas informações e estar atualizado com as inovaçōes científicas, com os novos padrões linguísticos, deveria expressar os valores e a moral de sua época, evitando assim, qualquer desvio de natureza "espiritual" em sala de aula.

Para assegurar a qualidade desejada do livro escolar, necessitava-se de uma legislação para prescrever quais obras poderiam ser adotadas e como deveriam ser usadas. O governo central e o provincial deixaram legislaçāo esparsa, mas que demonstra a coerência com que as autoridades políticas e religiosas tentavam controlar a literatura escolar .

A leitura do "corpus" legislativo sobre a literatura didática nos informou que o livro era entendido como a possibilidade de unificar a educação escolar em todo território nacional, favorecendo a inserção de determinadas categorias de jovens em uma mesma comunidade cultural, dominando uma única e determinada forma de se expressar e de se comunicar. A visão de que os livros escolares possibilitariam a manutenção de uma certa uniformização do conteúdo educativo para o conjunto do país foi uma constante para os legisladores e autoridades religiosas do período.

No relatório de Gonçalves Dias, em suas conclusões, há a insistência sobre a necessidade da uniformização do ensino a nível nacional, enfatizando a instrução primária como "uma das faces da nacionalidade" e exigia a "unidade no sistema, constância nos princípios, persistência na execução."78 Para atingir estes fins, os compêndios deveriam ser os mesmos para todo o Império.

o desejo de unificar o ensino foi, contudo, defendido com maior empenho pelos liberais do fim do Império e os organizadores da República, tanto para o ensino primário

78 DIAS, Gonçalves- op. cit., p.365 
como para o secundário. o secretário do Interior do Estado de São Paulo, ao criar uma comissão incumbida de rever as obras adotadas no curso preliminar, justificava a medida por ser "assunto tão importante, principalmente no que diz respeito à uniformização do ensino. (...)." 79

A descentralização do ensino pelo Ato Adicional, acusada de ser uma das causas do insucesso da escolarização da fase imperial pelos historiadores escolanovistas, não era questão desconhecida pelos encarregados da educação escolar do Império e da nascente República. A questão de métodos e temas uniformes para a constituição da nacionalidade foram debatidos reitaradamente depois da segunda metade do século XIX.

$\mathrm{E}$, efetivamente, os assuntos educacionais, a partir de 1834, nunca deixaram de ser controlados de forma centralizada, apesar da aparente descentralização legal. Havia o controle pela subordinação dos presidentes de províncias aos ditames ao governo imperial, lembrando que estes eram nomeados pelo poder central e a educação era totalmente dependente de seu poder. Desta forma, o governo imperial possuía uma determinada garantia de uniformidade educacional através de um corpo coeso de políticos que, em princípio, deveriam ser fiéis seguidores das determinações do centro do poder.

Esta obediência pode ser apreendida pela legislaçāo de cada província que variou pouco, podendo-se perceber uma quase total submissão aos princípios do Município da Corte, mesmo quando adotavam medidas excepcionais, próprias das particularidades de cada região.

Pudemos observar pela legislação duas formas de controle do texto escolar impresso. Foram elas o veto e a autorização.

Nas primeiras décadas do oitocentos, pela escassez de obras, predominou o sistema de autorizações. Antes da organização proposta pelo governo central de constituir os Conselhos fiscais e inspetores distritais para supervisionar

79 parecer da comissão encarregada de estudos sobre adoção de obras didáticas. Anuário do Estado de São Paulo, 1907, op. cit., p.383 
- ensino, as primeiras regulamentações feitas nas províncias, esmeraram-se em incentivar a confecção de compêndios de acordo com o programa estabelecido e que seriam "submetidos ao conhecimento da Assembléia legislativa para escolber e aprovar aqueles que desempenharem $o$ fim. Os compêndios aprovados passarão a ser gerais e únicos das aulas de primeiras letras da província. Uma vez aprovados os compêndios, a Assembléia arbitrará ao seu autor uma retribuição pecuniária, ficando o mesmo sem a propriedade de sua obra." 80

Organizaram-se normas constantes para a confecção de livros e prometeram prêmios aos professores ou "qualquer pessoa" que se dispusesse a redigi-los", forçando os autores a seguir os programas existentes.

As exigências requeridas para a apresentação do texto a ser aprovado pelas autoridades educacionais incentivaram a participação das editoras em seu processo de elaboração. o incentivo ocorria ao se exigir que o autor apresentasse às autoridades o texto impresso antes de ser autorizado, para futura adoção. Oficialmente, a obrigatoriedade da apresentação de texto impresso apareceu na legislação de 1885 da Corte: "20 a aprovação será requerida ao Inspetor geral pelo autor ou editor ou solicitada ex-oficio por qualquer membro do Conselho diretor; para se resolver sobre a aprovação, deverão ser entregues na Inspetoria 12 exemplares da obra afim de serem distribuidos pelos membros do Conselho; os exemplares ficarão arquivados. "81 Prevaleceu, portanto, a publicação de uma primeira edição que era submetida ao controle estatal e na edição seguinte surgia, na página de rosto, a confirmação da aprovação oficial.

Como garantia para a aprovação, os autores tiveram por hábito dedicar a obra a alguma autoridade, tecendo elogios do tipo "o mais acrisolado protetor das letras na mesma província" e, às vezes, acompanhava carta com pedido de aprovação. 82

80 Apud MOACYR, Primitivo- Inst. e prov.- op. cit., v.2, p. 487.

81 Apud MOACYR, P. - Inst. e Imp.- op. cit., v.2, p. 532

82 A correspondência entre o autor Joaquim Frederico Kiappe da Costa Rubim e as autoridades provinciais do Ceará expressam a dependência e 
Um autor, em um dos primeiros compêndios de desenho publicados no Brasil, foi mais explícito na justificativa para a oferta da obra ao Imperador D. Pedro II:

"Três são os motivos, que obrigam os Escritores a dedicar suas obras aos Grandes Príncipes: procurar que possam correr por todas as partes livres de censura, a que se expõem as obras públicas; esperar do conhecimento de tão altos senhores uma pia correção; e finalmente ganhar por este meio suas Imperiais considerações: e como todas estas circunstâncias me assistem para com vossa MAJEstade IMPERIAL, não poderia, sem que fosse taxado de ingrato, dedicar este meu primeiro trabalho senão a vOSSA MAJESTADE IMPERIAL, que pondo-me a coberto de qualquer censura, ao mesmo tempo me assegura do acolhimento que devo esperar de todos, que a exemplo de vOSSA MAJESTADE IMPERIAL, se dedicam ao conhecimento das Artes e das Ciências." 83

o regime republicano não modificou a situação e o mesmo hábito permaneceu: "Ao glorioso Governo que fêz a reforma do ensino público em são Paulo e que espalhou escolas por toda a parte" foi a dedicatória de Tancredo do Amaral em seu livro de Ensino Cívico.84

As providências tomadas por autores e editores para a aceitação das obras não impediam, no entanto, o veto que passou a ser mais frequente à medida em que ocorria o crescimento de exemplares à disposição dos professores. Ampliaram-se, assim novas formas de vigilância sobre o

\footnotetext{
a subserviência que caracterizaram as relaçōes editor-autorautoridades politicas:

"IIm e Exmo Sr. Presidente da província

Joaquim Frederico Kiappe da Costa Rubin precisa que $v$. Ex. Ihe mande por certidão e teor do ofício do Ilmo Sr. diretor geral de instrução pública, no qual participa a $V$. Ex. haver o Conselho Diretor exaninado, aprovado e adotado para uso das aulas da província a gramatica em verso, que o suplicante teve a honra de compor, ofertar, e consagrar a $V$. Ex., e pelo deferimento.

Cearé, 14 de fevereiro de 1861.

Joaquim Frederico Kiappe da Costa Rubim

Palácio do governo do Ceara, 14 de fevereiro de 1861. Nunes Gonçalves"

In: RUBIM, Joaquim Kiappe da Costa- Novo método da gramática portuguesa. Fortaleza: Tipografia Cearense, 1861 .

83 SILVA, Roberto Ferreira- Elementos de desenho e pintura. Rio de Janeiro: Læmmert, 1841 .

84 AMARAL, Tancredo do - o Estado de São Paulo. Rio de Janeiro; sāo Paulo: Alves \& Cia., Editores, 1896.
} 
livro. O controle da literatura escolar levou à criação de orgãos burocráticos especiais.

\subsection{Vigilância dos Conselhos de Instrução}

A regulamentação sobre adoção ou proibição de livros escolares caminhou de maneira uniforme nas várias províncias do Império e posteriormente sob o regime republicano. As normas oficiais foram criadas juntamente com o estabelecimento de um corpo burocrático que se encarregava de acompanhar a organização administrativa escolar em geral.

Nas primeiras décadas do século passado previa-se que as aulas de ensino mútuo seriam vigiadas pelas Câmaras municipais que dariam "anualmente ao governo informação circunstanciada sobre o estado das aulas, adicionando-lhes reflexōes que julgar própria ao melhoramento da instrução pública. Câmaras e juizes de paz serão obrigados a participar ao governo os desleixos e mais prevaricaçōes dos professores para que ele proceda como incumbe a lei" 85 .

Em Minas Gerais, a primeira legislação provincial sobre o ensino elementar contou com a colaboraçāo das Câmaras Municipais na tarefa do ensino mas, criaram formas mais centralizadas de controle pelo governo provincial. A Província ficou dividida em 15 Círculos literários, cada um chefiado por um delegado nomeado pelo chefe do governo com poderes amplos, podendo suspender professores, nomear substitutos, encarregar pessoas para fiscalizarem as escolas ou indicar os "visitadores", como os fiscais eram denominados. Em 1848 foi criada a Diretoria Geral de Instrução pública que centralizava as informações dos delegados dos círculos literários e enviava os resultados diretamente ao Presidente da Província. 86

As leis provinciais sobre as formas de fiscalização escolar seguiram os princípios da regulamentação de 1854,

85 Decreto de 25 de março de 1835, Província de sergipe. Apud MOACYR, Primitivo- Inst. e prov.- op. cit., v. 2, p.3,

86 Cf. MOURÃO, Paulo R. Correa- O ensino em Minas Gerais no tempo do Imperio. Belo Borizonte, [s. n.], p. 10- 11 . 
para o município da Corte, assinada pelo Ministro do Império, Coutto Ferraz. Esta regulamentação que perdurou oficialmente, em suas linhas mestras, até o final do Império, determinava que a supervisão das escolas de instrução primária e secundária seria exercida:

"Pelo Ministro e Secretário de Estado dos Negócios do Império,

Por um Inspetor Geral,

Por um Conselho Diretor,

Por Delegados de Distrito." 87

Na legislação e regulamentos das províncias, a partir da década de 50, encontramos poucas mudanças, variando a composição dos conselhos e parte de suas atribuições. variava, em alguns momentos, a divisão das tarefas do inspetor ou delegado distrital compartilhando o poder com o presidente da Câmara dos vereadores ou com o pároco.

A interferência do poder religioso nas escolas públicas, quanto à inspeção, foi diminuindo, chegando-se no final do regime monárquico a propostas que priorizavam o poder civil, com conselhos fiscais municipais, com participação de pais. Foi significativo o veto do presidente de Província de São Paulo, o barão de Parnahyba, ao projeto sobre a a criação, para cada município, de um Conselho de Instrução Pública denominado Conselho Municipal "cujos membros [seriam] eleitos pelos pais, tutores ou protetores de alunos de ambos os sexos, matriculados nas escolas públicas e particulares do município e pelos professores públicos e particulares. "88 A alegação do barão para vetar o projeto residiu exatamente no perigo em se atribuir poder a grupos não diretamente subordinados ao sistema estabelecido, dada a forma de eletividade dos membros.

De maneira constante, permaneceu como critério para escolha de comissões e dos inspetores distritais ou delegados literários, o "favor político". o cargo de inspetor distrital representava uma forma de poder e passou

87 Regulamento da Instrução Primaria e secundaria do Município da Corte. Decreto $n^{\circ} 1.331$ de 17 de fevereiro de 1854 . Revista do Ensino, Rio de Janeiro, $\mathrm{n}^{\circ} 1$, fev. de 1883, p. 3

88 Apud MOACYR, Primitivo- Inst. e prov.- op. cit., v.2, p. 403. 
a ser disputado à medida em que tal tarefa começou a ser favorecida por vantagens pecuniárias. A ineficência da atuação dos inspetores ocorria, segundo os relatórios dos Inspetores gerais ou presidentes de províncias, pela falta de tempo e compromisso desses elementos, situação que se resolveria se o cargo fosse remunerado, evitando-se que exercessem outra profissão para sobreviver.

As atribuições desse corpo burocrático que se criava para gerenciar os assuntos educacionais, incluiam a vigilância sobre as obras didáticas.

Os Conselhos deveriam "rever os compêndios adotados, corrigi-los ou faze-los corrigir e substituílos quando for necessário".89 os Conselhos, por sua vez, contavam com o auxílio dos inspetores escolares que desempenhavam o papel de vigilantes das determinações centrais. Os inspetores tiveram pouca importância, inicialmente, como agentes de controle escolar. As autoridades governamentais, inicialmente, preferiram os representantes eclesiásticos e o número escasso de escolas facilitava a fiscalização.

o papel dos inspetores mudou no regime republicano, ampliando-se seu poder. A criação de Grupos Escolares, organizados sob a autoridade de um diretor, possibilitou uma nova divisão de poder na esfera educacional. Nos primeiros anos do século $\mathrm{XX}$, os textos oficias passaram a divulgar a idéia de que uma boa escola dependia essencialmente de um bom diretor. Popularizou-se o lema "Boa direção, boa escola". Para facilitar e avaliar o desempenho dos diretores seria então importante a figura do inspetor que "louvando, animando, aconselhando e corrigindo, contribuirá para que (...) cada escola vá tomando feição nova."90 o cargo de inspetor de distrito foi reestruturado, com atribuições mais detalhadas quanto às formas de fiscalização e tornou-se remunerado. Qualquer comunicaçāo dos professores com as

89 Apud AZAMBUJA, (Conselheiro d')-Doutrinas pedagógicas. Pará: J. Cardoso, 1884, p.92

90 Relatorio de oscar Thompson. Anuário do Estado de São Paulo - op. cit., p. 60 
demais autoridades educacionais deveria ser feita por intermédio dos diretores e dos inspetores. 91

o papel dos inspetores e diretores quanto ao livro didático, entretanto, não se alterou substancialmente. Eram os encarregados da vigilância sobre a adoção das obras mas o veto ou a proibição de adoção de determinados livros nas escolas continuou a ser atribuição do Conselho de Instrução ou Conselho Superior. No início do século $\mathrm{xx}$, em alguns estados, passou a ser usual a nomeação de comissões especiais encarregadas de "rever Iistas de obras adotadas no curso preliminar". 92

As regulamentações referentes aos "deveres" ou "obrigações" dos professores apresentavam sistematicamente artigos explícitos sobre o uso dos livros didáticos adotados pelas autoridades educacionais competentes. Os professores que usassem livros proibidos estavam sujeitos a puniçōes, admoestações dos superiores, com possibilidades de suspensão do exercício ou multas. Era comum encontrar regulamentações como esta de 1869:

"Art. 115. A pena de multa se imporá nos seguintes casos:

$\$ 1^{\circ}$ Quando os professores usarem livros e exemplares para o ensino não autorizados competentemente, serão multados em quinze mil réis. 93

Para o ensino secundário a legislação era mais centralizada, entre outras razões, pelo pequeno número de colégios públicos de nível secundário. Professores e alunos do Colégio Pedro II deveriam seguir as instruções dadas diretamente pelo poder do Rio de Janeiro, pelos decretos dos ministros do Império.

Nos dois momentos considerados, a escolha dos livros foi determinada minuciosamente e aprovada partindo dos

91 SÃo PAULO(Secretaria do Interior)- Decreto $n^{\circ} 218$ do Regulamento da lei $n^{\circ} 88$ de 1892 e da lei $n^{\circ} 169$ de 1893 da Secretaria dos Negócios do Interior do Estado de São Paulo.

92 Parecer apresentado ao Dr. Gustavo de oliveira Godoy, Secretário do Interior do Estado de sāo Paulo. Anuario do Ensino do Estado de São Paulo,op. cit., 1908 , p. 383 .

93 O Regulamento da Instruçāo provincial de são paulo ordenava o seguinte: Barão de Itauna- Regulamento de 1869 referente à lei de 19 de Agosto de 1868 da província de são paulo. Coleção de leis provinciais, sāo Paulo, 1894 
planos ou programas de ensino. O regulamento do Ginásio Nacional, nova designação do Colégio Pedro II, reformulou parcialmente o poder interno, com uma direção aliada a uma Congregação formada pelos lentes do estabelecimento. Os programas de ensino eram acompanhados de uma lista de livros a serem adotados em cada uma das disciplinas e estes programas só se efetivarian mediante a aprovação do Ministro da Justiça e Negócios Interiores. Para a adoção dos livros, - regulamento de 1908 do Ginásio Nacional livrou a Congregação da atribuição de escolher os compêndios diretamente. o professor ficou encarregado da escolha dos livros indicados em uma lista apresentada pela Congregação do estabelecimento. 94

Esta foi a tendência iniciada nos anos finais do Império que passou a prevalecer na fase republicana, inclusive para as escolas primárias. O regimento interno das escolas elementares da província da Amazônia, de 28 de março de 1883, por exemplo, fornecia possibilidade ao professor de "propor ao diretor geral, por intermédio do inspetor do distrito, a adoção de qualquer outro compêndio que the pareça mais conveniente." 95

A liberdade de escolha do livro escolar pelo professor, direito que estaria de acordo com os princípios liberais, deve ser entendida, entretanto, dentro de certos limites. Havia sempre a presença de uma comissão para a triagem das obras possíveis de serem adotadas para os alunos e organizava-se uma relação de "compêndios e manuais que pudessem servir de guia aos professores no ensino das diversas disciplinas do programa."96 A prática de possibilitar "alguma escolha" pelo professor fornecia a legitimidade na ação de controle do Estado, fazendo com que os docentes dessem o consentimento na adoção do livro que, na realidade, era outorgado e controlado pelo poder oficial. o livro didático para entrar na escola pública precisava do

94 Cf. FORJAz, Djalma - Do ensino e fiscalização - nos Institutos de instruçāo secundária equiparados ao Ginásio Nacional. São Paulo: Tipografia Maré, Monti \& C., s. d., p. 163

95 AZAMBUJA, Conselheiro Joaquim Maria de- op. cit. , p 54

96 Anuário de Ensino do Estado de São Paulo- 1907 - op. cit. p.384 
burocráticos educacionais e editores e autores buscavam meios para obter o "referendum" oficial.

Diversamente do controle excessivo exposto nos textos legislativos para as escolas públicas, as autoridades educacionais pouco intervieram no âmbito do ensino particular. A regulamentaçāo de Coutto Ferraz sobre o ensino particular, que prevaleceu durante todo $\circ$ período do Império, estabeleceu que "os professores e diretores de estabelecimentos particulares poderão adotar quaisquer compêndios e métodos que não forem expressamente proibidos"97. O artigo era válido também para o ensino elementar.

Os estabelecimentos católicos deveriam ter suas obras aprovadas pela autoridade religiosa local.

A legislação liberal organizada pelos políticos em relação à fiscalização sobre as escolas e colégios particulares pode ser desvendada à medida que acompanhamos os debates que ocorreram nos anos 70 e 80 sobre "a liberdade de ensino", onde os liberais maçons reivindicavam uma menor intervenção do Estado sobre tais escolas, pretendendo que se abolissem as exigências sobre a formação do magistério particular, previstas por lei. A partir dai, os conservadores católicos deixaram de reivindicar a ausência do Estado no ensino, temendo a concorrência das demais escolas particulares e ainda mais a proliferação de escolas que professassem outras crenças religiosas. Cunha Figueiredo, deputado ultramontano, media a extensão do perigo, pela adoção de livros didáticos:

"Há liberdade de ensino, dispensa de prova de capacidade profissional, e como consequência o arbítrio dos mestres na escolha de compêndios. Admitamos que estes não ofendam propriamente certos preceitos da moral, mas podem conter noções que de alguma sorte contrariem certos dogmas da religião do Estado, a nossa forma de governo e os princípios da nossa legislação." 98

97 HAIDAR, M. de Lourdes- op. cit., p.203

98 Idem, p. 175 
Igreja e Estado vigiavam a adoçāo dos livros nas diferentes escolas, públicas e particulares, primárias ou secundárias, durante o Império. Posteriormente, na República, o Estado empreendeu sozinho a tarefa de vigiar as escolas públicas, reforçando o poder fiscalizador dos inspetores e diretores. A Igreja Católica, apesar de separada do Estado, continuou a exercer seu domínio sobre a produção didática, conseguindo estender sua rede de ensino a partir do final do século XIX, com a vinda de várias ordens religiosas européias, atingindo com maior extensão o ensino feminino. 99

O Estado Nacional concebeu diferentes níveis de ensino e saberes diferenciados para as diversas classes sociais, conforme prescrições do pensamento liberal. o poder imperial ou o republicano, para empreender a tarefa de difundir a escolarização, enfrentou desafios, menor em relação ao plano doutrinário e, aparentemente contraditório no plano de aplicação social. Para a efetivação do projeto civilizatório, no qual a escola era entendida como o caminho necessário para o sucesso do programa liberal, o Estado, conciliando ou separando-se da Igreja, procurou controlar a educação escolar, interferindo no poder familiar sobre as crianças e jovens, intervindo em esferas onde o saber era produzido e nas formas como era utilizado e disseminado.

- Os livros didáticos foram concebidos para que o Estado pudesse controlar o saber a ser divulgado pela

99 Oscar Beozzo fez um estudo sobre os religiosos durante o século XIX até a Revolução de 1930. O crescimento maior das ordens religiosas ocorreu entre 1890 a 1930 , sendo fundadas nesse período 93 congregaçōes. Entre 1880 a 1930 entraram 109 congregações femininas, predominando as de origem "francesa, con 28 institutos, seguidas pela Italia com 24, da Alemanha e Espanha, com 9 cada uma e a Bélgica con 5. Portugal entra con apenas $3(-)^{\prime \prime}$. As congregaçóes religiosas femininas, cujos efetivos crescem velozmente, sāo responsaveis pela vasta rede de escolas e colegios do pafs. Esses colegios estavan voltados, quase sempre, para o atendimento das elites e funcionaval sob o regime de internato. Os mais apreciados eram os de origem francesa, que continuaval ministrando o ensino segundo os programas e os livros empregados na França e utilizando-se inclusive da lingua francesa. Mas havia també as religiosas que se dedicavam à educaçăo dos mais simples, con una rede importante de escolas primarias. Este fenómeno porém está praticamente restrito as regióes de imigraçāo europeía italiana e alemã do sul do pass." BEOzzo, José OscarDecadência e morte, restauraçāo e multiplicaçāo das ordens e Congregaçōes religiosas no Brasil - 1870-1930. In AZzI, orlando (org).- A vida religiosa no Brasil- enfogues historicos. Sāo paulo: Paulinas, 1983, p. 127- 128 . 
escola. Os discursos de grupos de intelectuais instalados no poder ou próximo a ele, compostos por administradores, politicos e ou educadores expressaram a forma como o Estado liberal brasileiro elaborou sua política cultural, procurando disseminá-la, primordialmente, pela instituição escolar. A política do livro escolar representou um dos traços característicos da produção cultural feita por uma elite que procurava se inserir no mundo "civilizado", preservando, paradoxalmente, de maneira intransigente, privilégios de uma sociedade hierarquizada e aristocrática. A manutenção desse controle exigiu a criação de uma legislação para evitar "desvios", comprovando que o projeto concebido pelo poder estatal sofria "distorções" em seu processo de elaboração. 


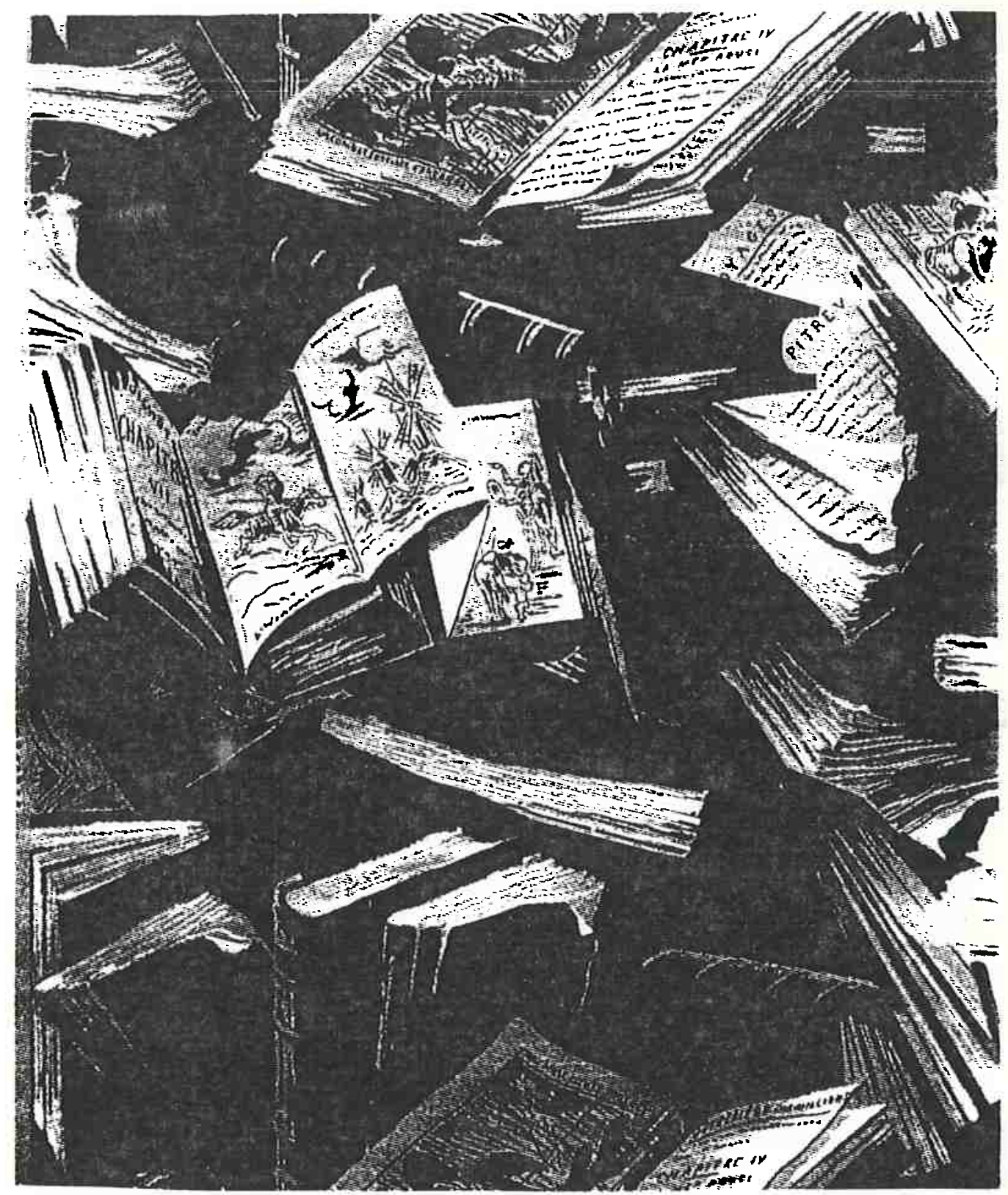

"O livro é como o dinheiro mais vale o que mais circula"

Citação de Carlos Rizzini em $O$ livro, o jornal e a imprensa no Brasil 
ESTADO E EDITORAS: CONFECÇÃO E DIFUSÃo DA PRODUÇÃo DIDATICA

o livro escolar foi concebido pelo poder instituído como um poderoso instrumento para fixar e assegurar uma determinada postura educacional, veículo privilegiado para inculcar normas e ortodoxias. o livro didático proposto a partir da instalação de instituições escolares públicas deveria se encarregar de uniformizar o saber escolar, de construir uma forma de pensar a ciência e de reforçar a disseminação de crenças religiosas oficiais.

o Estado liberal, embora considerasse este objeto cultural peça fundamental na transmissão do saber escolar, cedeu à iniciativa particular o direito de fabricá-lo. Tal atitude, aparentemente paradoxal, instigou-nos a discernir as articulações entre Estado e empresa particular e seus interesses na construção e disseminação do livro escolar.

As editoras, ao conquistarem o direito de fabricar e divulgar o livro didático, trataram de transformá-lo em uma mercadoria inserida na lógica capitalista. Para captar esse processo, buscamos seguir a trajetória das principais editoras das obras didáticas acompanhando a transformaçāo de objeto cultural em bem de consumo, em "um produto típico da indústria cultural, um bem destinado ao consumo que editores e autores têm interesse em comercializar, uma mercadoria entre outras que circula pelo mercado e produz lucro, muito 1ucro."1

Para efetivar a transformação de um material didático no produto de maior consumo da cultura escolar, os editores associaram-se ao Estado, engendrando atuações conjuntas em

1 zAmBONI, Ennesta- Que historia é essa?- uma proposta analftica dos livros paradidáticos de Historia. Tese de doutorado. Campinas: Unicamp, 1991, p.6 
suas formas de circulação. Estabeleceram-se entre ambos tramas, por intermédio das quais o livro didático disseminouse no quotidiano escolar, transformando-se no principal instrumento do professor na transmissão do saber.

As questões que envolveram a fabricação e as formas de divulgação do livro didático para um público crescente nos levaram a abordá-lo em sua materialidade, como um objeto que dá suporte ao texto. Nessa perspectiva, partimos da reflexāo de R. E. Stoddard sobre a relação entre autores e editores: "Façam o que fizerem, os autores não escrevem livros. Os livros não são de modo nenhum escritos. São manufaturados por escribas e outros artesãos, por mecânicos e outros engenheiros, e por impressoras e outras máquinas. ${ }^{2}$ Estas consideraçōes tornaram-se base para a apreensão do livro em outra dimensão, investigando seu formato tipográfico, capa, paginação, qualidade do papel, enfim as relações entre signos e imagens, concretudes que direcionam o leitor em sua apropriação da palavra escrita e os elementos que incitam seu consumo.

As questões relativas à expansão dessa produção obrigaram-nos a realizar levantamentos quantitativos, que pudemos obter parcialmente pela leitura de catálogos e listas de livros adotados nas escolas. As fontes de pesquisa dessa parte do trabalho foram acrescidas por documentos das próprias editoras que, sendo empresa privada, limitaram o acesso ao material de seus arquivos. Utilizamos contratos e algumas trocas de correspondência entre autores e editores, além de anúncios de livros em jornais e revistas, catálogos de exposições didáticas e informações fornecidas por uma bibliografia escassa.

\footnotetext{
2 Apud CHARTIER, Roger- Historia c. -op. cit., p.126. Roger Chartier acredita ser fundamental distinguir o texto manuscrito e o impresso, entre o trabalho de escrita realizado pelo autor e o da fabricação do livro com a interferência do editor. Torna-se necessário, na reconstituição das obras impressas analisar "os dispositivos que resultam da passagem a livro ou impresso, produzidos pela decisão editorial ou pelo trabalho da oficina, tendo em vista leitores ou leituras que podem não estar de modo algum em conformidade com os pretendidos pelo autor" - op. cit., p. 127
} 


\section{Editoras e poder institucional}

1.1 Nascimento das editoras de livros didáticos

A Imprensão Régia, órgão oficial criado em 1808, possuía como um de seus objetivos o auxílio à expansão e melhorias de materiais para a educação pública. Nela foram produzidos os primeiros manuais para cursos criados por D.João VI, notadamente os da Real Academia Militar. A maioria dos manuais impressos era composta de traduções francesas sobre matemática, física e alguns de filosofia e moral, além de livros para atender os Cursos de Cirurgia e Anatomia transformados logo após, no Curso de Medicina do Rio de Janeiro. 3

o viajante inglês Luccock, em sua passagem pelo Rio de Janeiro em 1818, analisando os trabalhos da editora oficial do Estado, escreveu que "a imprensa licenciada, porém, produziu mais algumas obras úteis além das que se referem a questões militares" e citou um livro para o ensino elementar - "Tesouro dos meninos" que tratava da "Moral, virtude e boas maneiras" dedicada ao segundo filho de D.João VI, D. Miguel" pois que não há menino que tanto necessite dos seus ensinamentos como esse; sua educação foi muito limitada e infeliz". 4

De maneira geral, a produção da Imprensão Régia estava direcionada para temas da organização do aparelho administrativo do Estado, predominando publicações sobre Economia Política, Geografia, Agrimensura, Saúde Pública, incluindo-se obras ligadas ao currículo das escolas criadas

3 Nelson Werneck Sodré cita como Iivros mais importantes da Imprensāo Régia as traduçōes de compêndios didáticos, especialmente os de Legendre, Elementos de Geometria e Tratado de Trigonometria, Elementos de Algebra de Euler, Tratado de Aritmetica de Lacroix, Tratado Elementar de Física de Haüy. Até 1822, ainda segundo sodré, "sairam de seus prelos 1.154 trabalhos, incluindo avulsos e opúsculos." SODRE, $N$. W.- Historia da Imprensa no Brasil. São Paulo : Martins Fontes, 1983, 39 ed., p. 36 .

4 LUCCOCK, John- Notas sobre o Rio de Janeiro e partes meridionais do Brasil. Trad. Milton Silva Rodrigues. Belo Horizonte: Itatiaia; São Paulo: EDUSP, 1975, p. 380 
no período joanino, que visavam formar especialistas e técnicos para a criação do corpo burocrático do Estado.

Com o fim do monopólio da Imprensão Régia em 1822, seguiu-se o descompromisso estatal com publicações de compêndios escolares e a segunda década do século XIX marcou a transferência da produção didática para as editoras particulares que começaram a surgir no Brasil, além das que produziam material escolar em Portugal e na França.

Para identificar as primeiras editoras de livros didáticos usamos como referência o Catálogo do Museu Escolar Nacional, publicado em 1885, do qual destacamos 318 publicações nacionais assim distribuídas pelas editoras: 5

\section{QUADRO 3}

Editoras de livros didáticos- 1885

\section{Bditora wo de títulos}

B.L.Garnier............ $68 \ldots \ldots \ldots \ldots \ldots \ldots \ldots .21,58$

E.\&H.Læmmert............ $39 \ldots \ldots \ldots \ldots \ldots \ldots \ldots . \ldots \ldots$

Nicolau Alves........... 33..............10,48

J.G. de Azevedo.......... 23.............. 7,38

Tip. Nacional............ $06 \ldots \ldots \ldots \ldots \ldots \ldots$ 1,98

Editoras do Rio de Janeiro... $63 \ldots \ldots \ldots \ldots \ldots \ldots \ldots \ldots 19,98$

Editoras das províncias..... $38 \ldots \ldots \ldots \ldots \ldots \ldots \ldots . \ldots 11,98$

Editoras estrangeiras...... $44 \ldots \ldots \ldots \ldots \ldots \ldots \ldots$. . . 9 \%

Sem nome da editora........ $03 \ldots \ldots \ldots \ldots \ldots \ldots \ldots \ldots 1,0$ 8

Fonte: Catálogo do Museu Escolar Nacional. Rio de Janeiro, 1885

Desse quadro, distinguimos três aspectos significativos quanto à caracterização das editoras: a concentração da produção em um número relativamente limitado

5 Cf. FRANCO, Julio de Lima (org)- Catálogo da Biblioteca do Museu Escolar Nacional. Rio de Janeiro:Tipografia de G. Leuzinger \& Filhos, 1885. No total de 318 obras didaticas obtidas do referido catálogo não inclui obras didaticas estrangeiras, mesmo as portuguesas, embora fossem eventualmente utilizadas em nossas escolas. Faziam parte do acervo do Museu, livros didaticos franceses, alemäes, portugueses, ingleses, norte-americanos, italianos e belgas. 
de empresas, a participação de editoras estrangeiras e a preferência pelo Rio de Janeiro como sede.

As três empresas que se destacaram na confecção do textó escolar, a B.L. Garnier, E. \& H. Læmmert e Nicolau Álves \& Cia, responsáveis por $44,2 \%$ da produção, representam uma tendência monopolista que teve continuidade nos anos seguintes, à medida que se expandia a rede escolar e consequentemente o público consumidor.

Baptiste Louis Garnier, segundo Hallewell, foi "o primeiro editor a fazer um esforço real para atender às necessidades de livros escolares brasileiros", correndo um "risco comercial por sua própria iniciativa". 6

Este francês começou seu trabalho com livros no Brasil instalando-se inicialmente como livreiro no Rio de Janeiro. Baptiste Garnier pertencia a uma família de editores e foi com eles, em Paris, que aprendeu o ofício de livreiro antes de se decidir a emigrar para o Brasil. Em 1846, recémchegado, instalou uma livraria na rua do Ouvidor, passando a dedicar-se à edição de livros somente no final dos anos cinquenta. A produção inicial da B.L. Garnier era voltada, preferencialmente, para obras de literatura, tendo sido responsável pela maioria dos romances de José de Alencar, Machado de Assis, Joaquim Manuel de Macedo, além de inúmeras traduções francesas. Em 1857, iniciou a produção de livros destinados à instrução secundária de História, Gramática e Literatura, expandindo sua produção no transcorrer da década de sessenta, com livros para a escola elementar.

A Garnier tem sido mais citada pelos trabalhos literários, pelas obras do romantismo que divulgou, mas o papel do setor didático da editora não pode ser substimado. o enterro de Baptiste Garnier simbolizou as duas vertentes mais lucrativas de sua empresa. Nele compareceram apenas "sua viúva e seus empregados (que dificilmente poderiam evitar essa obrigação) e apenas três outros acompanhantes: Luis Leopoldo Fernandes Pinheiro, o jornalista Alexandre José de Melo Moraes Filho e seu principal autor, Machado de

6 HALLEWELL, L. - op. cit. ,p. 144 
Assis."7, ressaltando que Luís Leopoldo Fernandes Pinheiro era sobrinho do cônego Fernandes Pinheiro e responsável pelas atualizações das obras didáticas do tio, conhecido autor de inúmeros trabalhos para a escola elementar e secunđária.

Os manuais escolares permaneceram com certo destaque nos catálogos da Garnier com o herdeiro da firma brasileira, Hipollite Garnier, mas este e seus sucessores, preferiram o trabalho de edição de obras literárias, relegando a produção de livros didáticos para uma situação menos privilegiada, limitando-se a reeditar textos dos autores escolares mais famosos.

A editora dos irmãos Læmmert, mais antiga do que a Garnier, surgiu da iniciativa de Eduard Læmmert, nascido em Baden e que chegou ao Brasil como sócio da firma do livreiro francês Bossange. Em 1838, resolveu criar sua própria firma e associou-se a seu irmão Heinrich, abrindo uma oficina tipográfica, a Tipografia Universal que, diferentemente de Louis Baptiste Garnier, se encarregou durante toda sua existência da edição completa de todas as obras.

A E. \& H. Læmmert foi praticamente a substituta da Tipografia Nacional, nova denominação da Impressão Régia, que então limitava-se a produções esporádicas de textos didáticos. ${ }^{8}$ A Læmmert foi responsável pelas primeiras obras de História e Geografia, tendo saido de suas oficinas o polêmico compêndio de José Inácio de Abreu Lima, em 1844,

\footnotetext{
7 Idem- p. 136

8 Encontramos apenas 6 obras publicadas pela Tipografia Nacional no referido Catálogo da Biblioteca do Museu Escolar Nacional e eram predominantemente da area de matemática, Compêndio de aritmética composto para uso das escolas primárias no Brasil, sem nome do autor, de 1863, de B. de oliveira, Compendio de Aritmetica, tambem de 1863 e o Sistema métrico. Tabelas para conversão das medidas metricas, sem autor e de 1865. Uma de grámatica, a de Cirilo Dilermando da Silveira, Compêndio de gramatica portuguesa da primeira idade, publicada em 8 é edição no ano de 1855 e ainda de Otaviano Hudson, Método de leitura de 1879 além de um manual escolar para os alunos da Academia militar, de Silva Veiga, Curso regimental ou livro do soldado, de 1883 . Pudemos ainda acrescentar mais 3 titulos da Tipografia Nacional: CAIRU, Jose da Silva Lisboa-( visconde)- Cartilha da escola brasileira para instruçāo elementar na religiāo do Brasil, 1831; MONT'ALVERNE- Frei Francisco deCompêndio de filosofia, de 1859 e uma obra para o Liceu de Artes e off́cio de MENEZES, Francísco Xavier oliveira- Lições de fisica, de 1881.
} 
além de ter sido pioneira em manuais escolares da área de Matemática confeccionada por autores nacionais. 9

A primeira grande editora de livro didático no Brasil foi, entretanto, a firma de Francisco Alves. A instalação da editora Francisco Alves deveu-se a um livreiro português, Nicolau Alves que, como Garnier, iniciou-se no comércio de livros com a Livraria Clássica. Nicolau Alves dedicava-se à produção de manuais didáticos antes de ampliar os negócios, no início dos anos 80 , quando convidou seu sobrinho, Francisco Alves, como sócio no promissor empreendimento editorial. Segundo relatos sobre a vida de Francisco Alves, seu caráter difícil acabou por transformá-lo no único proprietário da firma no ano de 1897, depois da saída do tio, comprando as partes dos outros sócios. A partir daí, Francisco Alves resolveu investir decididamente na literatura didática, enfrentando o número crescente de concorrentes.

Empenhou-se na compra dos direitos de obras com algum sucesso de vendas pertencentes a pequenas editoras, anunciando tais compras com certo alarde. Entusiasticamente, por exemplo, Francisco Alves avisou os "srs. livreiros e diretores de colégios" que havia adquirido várias obras escolares por contrato com autores e "outras por termos comprado o resto dos exemplares ao editor $\mathrm{Sr}$. Dias da Silva Junior".10 o editor Francisco Alves lutou para monopolizar, ou obter o predomínio na produção didática, chegando a comprar firmas concorrentes:/Muitas dessas aquisições, houve pelo menos dez delas- foram feitas para conseguir determinados direitos de edição. Francisco Alves comprou a pequenina livraria da Viuva Azevedo, no Rio de Janeiro, apenas para obter os direitos de Antologia nacional de Fausto Barreto e Carlos Laet ( primeira edição em 1887), amplamente adotada nas escolas. A Livraria Melilo, de são

9 Constam do acervo da Biblioteca "Paulo Bourroul" os seguintes livros da editora dos irmãos Lxmmert, editados durante a decada de quarenta : SILVA, Roberto Ferreira da- Elementos de desenho e pintura com regras gerais de perspectiva, 1841 e de PARANAGUA, Marquês de- Elementos de geometria. de 1846 .

10 A lista de obras compradas do editor Dias da silva Junior foi anunciada na Revista do Ensino, Rio de Janeiro, $\mathrm{n}^{\circ} 1$, ano 1,1883 
Paulo, foi comprada porque os livros de João Röpke por ela editados eram os principais competidores dos de Felisberto Rodrigues Pereira de Carvalbo, editados pela Alves."11

Em 1909, após um incêndio na livraria da firma Lxmmert, então sob a direção de herdeiros dos irmãos Eduardo e Henrique, a Francisco Alves adquiriu seus direitos autorais, assim como sua "clientela e reputaçāo". Desta forma, o acervo didático da Læmmert engrossou a coleção da Francisco Alves.

Uma outra editora especializada em livros escolares que despontou no início do século $\mathrm{XX}$ foi a F.T.D. Esta editora foi criada pela Congregação dos Irmãos Maristas, de origem francesa, em data um pouco incerta, entre 1902 ou 1903. Seus livros eram impressos, en sua maioria, pela Imprimerie Vitte, na cidade de Lyon, sede da Congregação. Durante a fase inicial da F.T.D., houve uma certa ligação entre esta e a livraria Francisco Alves, que aparece em catálogos como co-editora e distribuidora de algumas das obras.

A instalação da editora F.T.D. no início do século atual, em são Paulo, correspondeu à demanda de obras marcadamente européias, provenientes dos novos colégios católicos implantados pelas ordens religiosas que se expandiam, especialmente, nas áreas de imigração, incluindo os próprios Colégios Maristas criados em São Paulo e Minas Gerais. 12

Assim, a produção didática, ao terminar a primeira década do século $\mathrm{XX}$, concentrava-se em três grandes empresas editoriais. A H. Garnier, em fase de estagnação, a Francisco Alves que, praticamente monopolizava a produção da literatura escolar e, paralelamente a F.T.D. que começava seu percurso empresarial, alcançando atualmente o segundo

11 HALLEWELL, L.-op. cit., p. 211.

12 Os demais colégios maristas criados ate o início do seculo xx foram: Ginásio do Carmo (1899) e Arquidiocesano (1907) em são Paulo; Colégio do Rio Comprido (1904) e de uberaba (1904) em Minas Gerais. Cf. BRASIL, Etienne- La France au Brésil. Rio de Janeiro: Bernard Frères, 1920, p. 181 
lugar dentre as maiores editoras de livros didáticos do país. ${ }^{13}$

Considerando um segundo aspecto da listagem do Catálogo de 1885, temos a significativa participação de editoras estrangeiras na produção da literatura escolar brasileira. Os livros didáticos nacionais publicados por casas editoriais estrangeiras perfaziam aproximadamente 148 do total de obras, destacando-se dois centros principais: Lisboa e Paris.

As editoras portuguesas tiveram uma relativa importância no mercado de livros didáticos. Havia importação de traduçōes portuguesas, mantendo-se ligaçōes confusas entre a produção dos dois países. Houve autores portugueses publicados por editoras nacionais, assim como textos de brasileiros que foram editados em Portugal. Muitas obras portuguesas, pela falta de legislação que protegesse os direitos autorais, foram, paulatinamente, incorporados pelas casas editoriais brasileiras, especialmente traduções de livros ingleses e franceses. Uma firma francesa, a editora Aillaud, aproveitou-se dos dois públicos de língua portuguesa e cooptou autores brasileiros e portugueses, desfrutando de vendagens mais garantidas. 14

No final do Império, um editor português, David Corazzi, passou a divulgar livros escolares a preços módicos, tornando-se bastante conhecido do público escolar brasileiro, principalmente depois de instalar uma livraria

13 A pesquisa de Ernesta zamboni mostra que as maiores editoras de livros didáticos no final de 1980 eram a Editora do Brasil, F.T.D., Atica e IBEP. Op. cit., p. 10

14 A produção didática da editora Aillaud aparece em todo 0 transcorrer do periodo estudado, tendo esta editora surgido, segundo Hallewell, em 1808, interessando-se desde logo pelo mercado de lingua portuguesa. As publicaçōes iniciais que temos referencias apresentavam-na como Livraria Portuguesa de J.P. Aillaud em Paris, Na década de 50 a firma era pertencente à viúva de Aillaud e estava associada a Monlon. (Livraria Portuguesa de Va J. P. Aillaud, Monlon \& C.), com outro endereço mas igualmente em Paris e se credenciavam como "livreiros de suas Majestades o Imperador do Brasil e El-rei de Portugal." Em 1890 assumiu a diregāo da firma o genro Julio Monteiro Aillaud que abriu uma filial em Lisboa, comprando a editora Bertrand e nesta época estabeleceu relaçōes com Francisco Alves, tornando-se socios. Um autor brasileiro, Caetano Lopes de Moura, natural da Bahia, escreveu e traduziu varias obras editadas pela Aillaud, destacando-se a tradução dos 24 volumes de sir walter scott. Cf. HALLEWELL, L.- op. cit. p. 161 


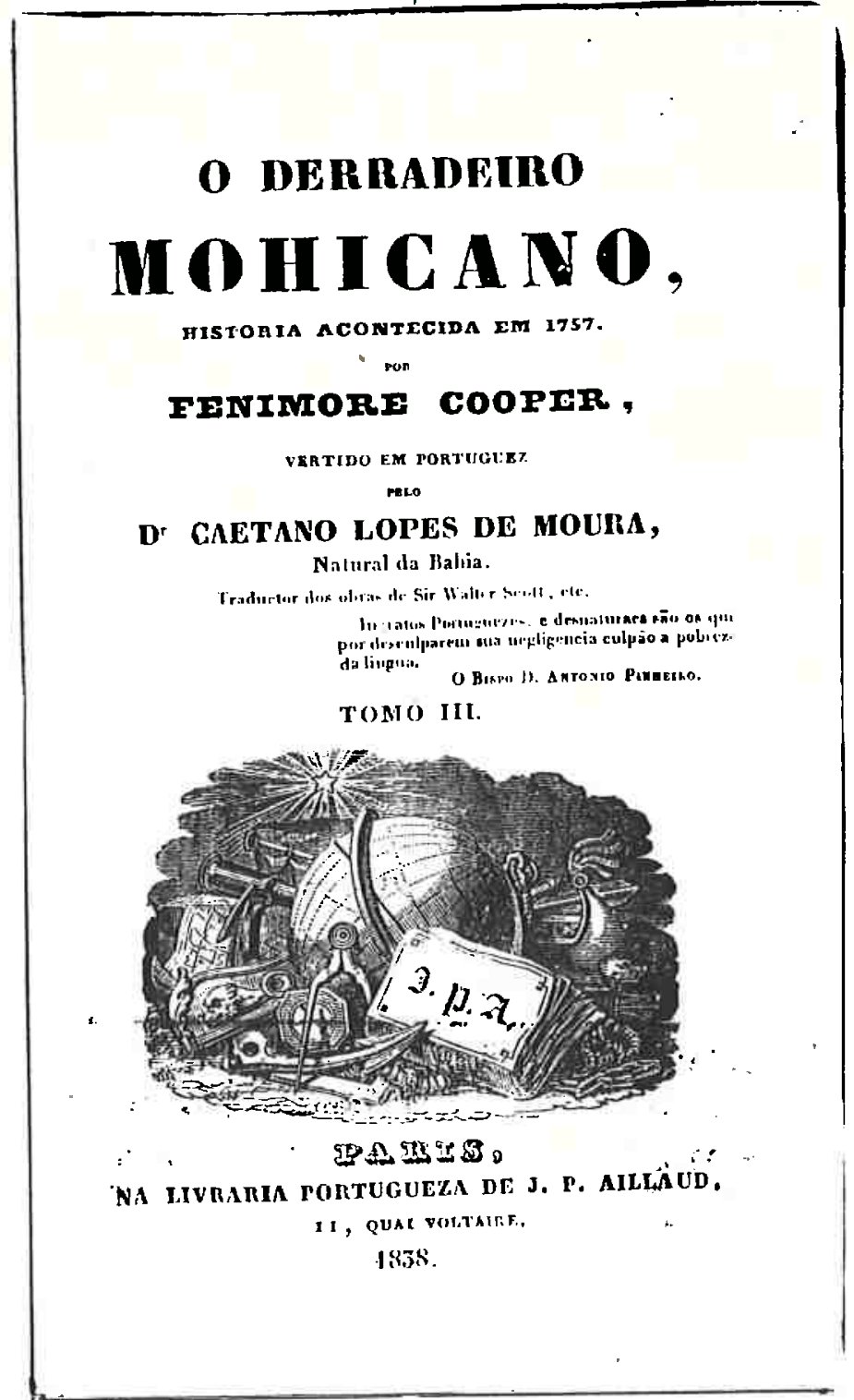

Fig. 2

O derradeiro Mohicano. Página de rosto. Biblioteca "Paulo Bourould", Feusp. 
no Rio de Janeiro, na rua da Quitanda. David Corazzi criou a Biblioteca do Povo e da Escola, coleção que assemelhava-se aos atuais paradidáticos. Eram volumes pequenos, menores do que o apresentado pelo padrão francês (in-12), com poucas páginas, "de composição cheia, edição estereotipada", com ilustrações e "exposto de forma sucinta e concisa, mas clara, despretenciosa, popular, ao alcance de todas as inteligências". Esta série de livros caracterizava-se pela publicação de dois livros por mês e destinava-se a "formar em Biblioteca econômica uma verdadeira enciclopédia de conhecimentos humanos, um curioso repositorio onde os indoutos possam aprender $e$ os doutos se não enfastiem de recordar. 15

As obras de David Corazzi devem ter alcançado grande sucesso de vendas porque Francisco Alves tratou de adquirila, incorporando os direitos da série de Dicionários de José Joaquim Ferreira Lobo e a tradução portuguesa de Julio Verne, autor muito popular naquela época. 16

Apesar da atuação dos portugueses na produção e comércio de livros brasileiros, o estilo de composição do livro didático brasileiro foi dado pelas casas editoriais da França. Os franceses tiveram interferência direta na produção, com obras editadas inteiramente em Paris, destacando-se a firma Aillaud, Guilhard \& Cia e de maneira indireta pela dependência dos editores brasileiros quanto às tarefas de impressão dos livros.17

Baptiste L. Garnier sempre preferiu ter seus textos impressos em Paris e por esta atitude foi constantemente criticado pelos tipógrafos cariocas, o que o levou a instalar em 1873, uma tipografia sob a responsabilidade de um seu conterrâneo, mas que teve vida efêmera. Ao que

15 Propaganda de instruçāo para portugueses e brasileiros. In: Biblioteca do povo e das escolas. Lisboa: David Corazzi, vol. 6. David Corazzi era especialista também em vendagens de dicionários, dentre eles os Dicionários do Povo, " linguisticos e de todas as especialidades, portáteis, completos, econômicos, indispensáveis em todas as escolas, bibliotecas, famflias, escritorios comerciais e repartições públicas" Idem, op. cit., contra- capa do volume.

16 Cf. HALLEWELL, L.- op. cit. p. 210

17 Pelo Catálogo de 1885, Paris destacava-se como principal centro editorial, sendo responsável por 38 de um total de 44 obras. 


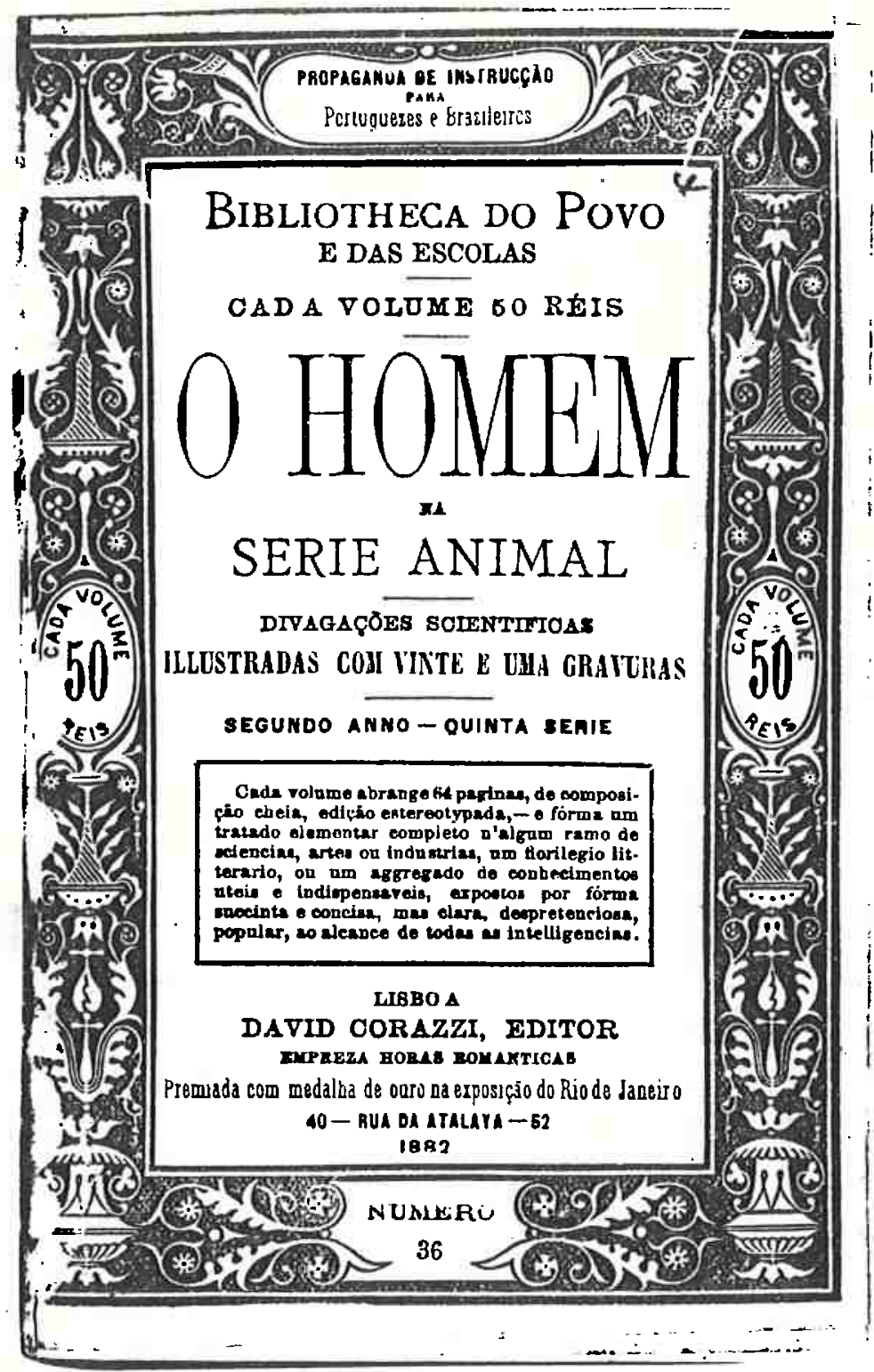

Fig. 3

Biblioteca do povo e das escolas. 1882 Editor David Corazzi.

Biblioteca "Paulo Bourroul, Feusp 
parece, foram razōes comerciais que fizeram Baptiste Louis continuar optando por casas de impressão francesas. A continuidade de impressão em tipografias parisienses serviu para fortalecer os modelos franceses na confecção de livros didáticos, tendo sido atribuído a Garnier a introdução no Brasil do formato in-8 ${ }^{\circ}$, lançado na França por Calmann-Lévy, que passou a ser predominante em nossa literatura didática. ${ }^{18}$

Francisco Alves variou bastante quanto à impressão dos seus livros, utilizando tipografias nacionais, como a Montenegro da rua do Ouvidor mas, ao buscar a expansão dos seus negócios, aliou-se à Tipografia de Guillard, Aillaud \& Cia. de Paris. Interesses comerciais explicam uma aproximação ainda maior após 1910 com a Aillaud e, encontramos nos livros desse período, a designação de Francisco Alves \& Cia com firma sediada no Rio de Janeiro associada a Paris e Lisboa com Aillaud, Alves \& Cia e livraria Bertrand.

A história da literatura didática brasileira não escapou, portanto, ao domínio francês sobre a vida cultural brasileira do século XIX. A produção do livro didático constituiu-se em mais um dos elementos do quadro de relações culturais entre Brasil e França.

A aceitação e opção pela França entre setores de nossas camadas dominantes devem ser entendidas na trama de interesses econômicos e culturais estabelecida entre os dois países e não como simples decorrência de "importação de idéias" feita pelas classes dirigentes. Havia interesses de ambos os lados para a implantaçāo de uma "cultura francesa" no Brasil.

A França, em seu processo de expansão capitalista, desejava penetrar em uma região, aparentemente monopolizada pelo comércio inglês. Um dos poucos estudos sobre o comércio francês no Brasil no decorrer do século XIX desvenda o alcance e a importância das relações econômicas entre os dois países, recuperando os produtos de importação e

18 Cf. LIMA-BARBOSA, Mario de- Les français dans l'histoire du Brésil. trad. Clement Gazet. Rio de Janeiro: F. Briguiet; Paris: Albert Blanchard, 1923, p. 418 


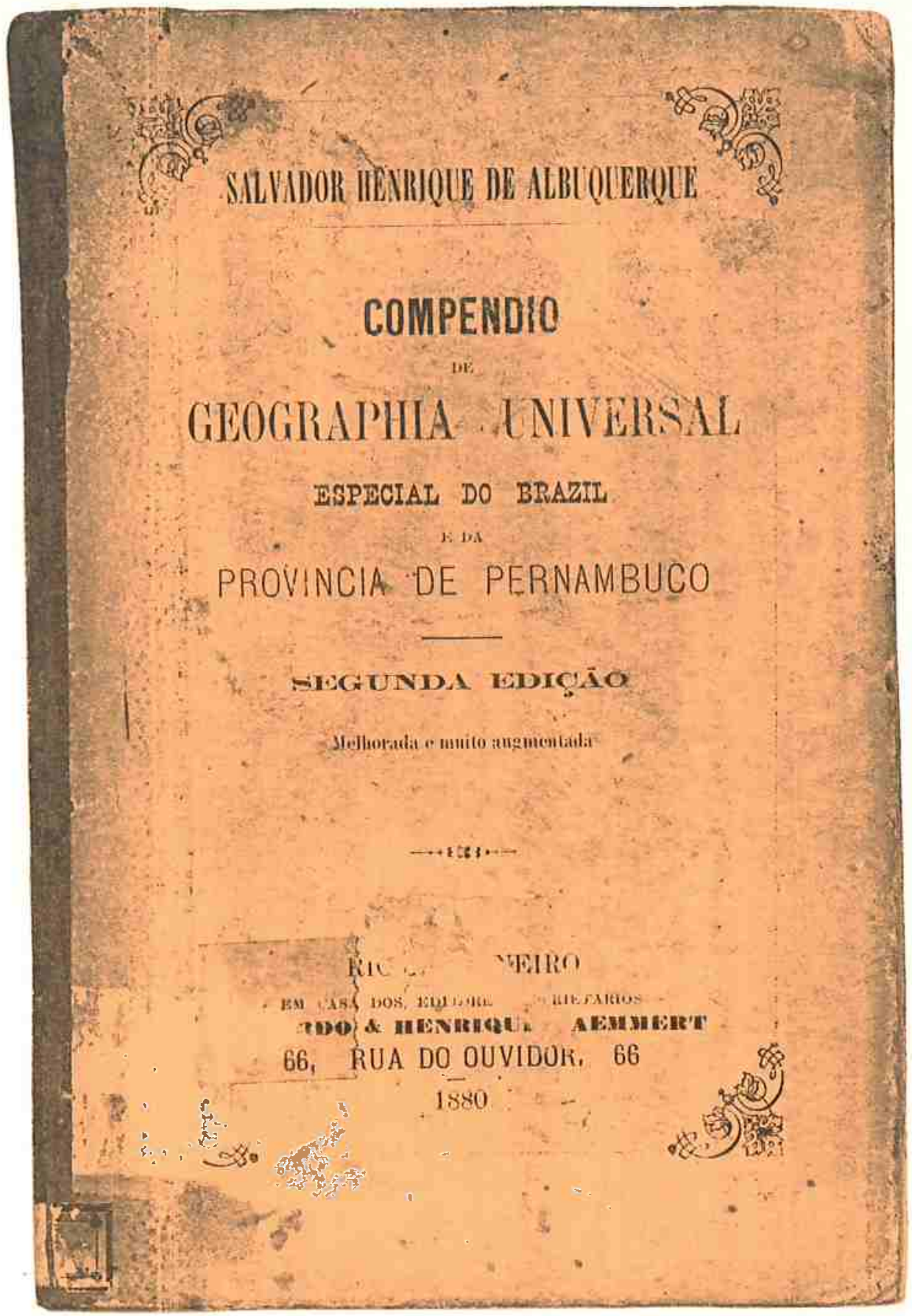

Fig. 4

Compêndio de geografia universal. Além do padrão in $8^{\circ}$, as capas dos livros seguiram os modelos franceses, em tons pastéis indicando a sobriedade da obra. 
exportação, os principais setores e locais onde ocorreu a comercialização. 19 Tais empreendimentos possibilitaram à França ocupar o segundo lugar em importância comercial para - Brasil, no período compreendido entre 1850 e 1880 .

Houve, portanto, um esforço da França na ocupação de determinados setores comerciais no Brasil e as relaçōes culturais entre os dois países vinculam-se a tal projeto.20

A preferência nativa pelos franceses quanto à produção cultural, além dos interesses econômicos, pode ser entendida por outras razões. O catolicismo brasileiro aproximava-se da mentalidade francesa que, por seu lado, esmerava-se em difundir seu ideário concebido como universalista. A educação "à francesa" tornava-se uma mercadoria considerada moderna e necessária para nosso processo "civilizatório", um capital cultural a ser apropriado e consumido pela juventude das nossas elites. Era um modo de ser "moderno" mais próximo dos valores católicos de setores conservadores desconfiados do mundo inglês protestante.

A afinidade com os valores franceses pode ser ainda percebida pela maior identificação com o desenvolvimento econômico francês até meados do século XIX, país predominantemente agrário, com uma política industrial mesclada pelos interesses da produção agrícola e que, evidentemente, exerciam um papel substantivo na construção do saber escolar a ser disseminado, incluindo a organização curricular e a literatura que a acompanhava.

19 Trata-se da tese de doutorado de TAKEYA, Denise Monteiro- Europa, França e Ceará a expansão comercial francesa no Brasil e as casas comerciais. São Paulo, F.F.L.CH., 1992

20 Alguns estudos franceses buscam atualmente recuperar o alcance da expansāo cultural francesa no mundo ocidental especialmente nas colônias africanas e americanas. Os estudos sobre livros didaticos de Alain Choppin, já citados, incluem estas preocupaçōes, buscando localizar quantitativamente, entre outras questōes, as editoras escolares e o alcance de sua produção por traduçōes ou exportaçōes diretas de obras. No campo da historia econômica, Albert Broder tem se dedicado à questāo da "transferência de tecnologia" francesa e inclui em suas pesquisas as traduçōes de manuais para o ensino superior em áreas como física, química, etc. A publicação sobre as relações culturais entre os dois paises organizada por MARTINIéRE, Guy e CARDOSO, Luiz Claudio- France - Brésil-vingt ans de coopération( science et technologie).Paris: IHEAL/PUG, 1989, com versão em português, reflete, igualmente, estas tendências. 
Desta forma, as relações culturais entre França e Brasil, em especial no setor livreiro, foram constantes no decorrer do século XIX, sofrendo alguma concorrência com a introdução de escolas americanas de confissão protestante em áreas de imigração que, juntamente com alguns educadores contrários ao domínio da Igreja Católica na área, buscaram novos modelos educacionais nos Estados Unidos. Muitos textos didáticos norte-americanos foram, então, traduzidos, preferindo-se, coerentemente, as impressões de livros didáticos de gráficas dos Estados Unidos. 21

Um terceiro dado que se obtem do Catálogo refere-se à questão do lugar da produção didática nacional, concentrada na capital do Império. O Rio de Janeiro foi o local onde se instalaram as maiores editoras e onde encontravam-se várias outras pequenas e desconhecidas, mas responsáveis pela produção de aproximadamente 208 do total de títulos. A sede do Império, pelo inventário de 1885, atingiu 73,38 da produção de livros escolares. Fora da capital do Império o número de obras corresponde a 82 títulos dos quais 44 são de editoras estrangeiras e o restante de algumas de nossas províncias: São Paulo (5), Bahia (4), Rio Grande do Sul (12), Maranhão (3), Pará e Amazonas(8).

A preferência das editoras em se estabelecerem no Rio de Janeiro ligava-se à situação privilegiada que desfrutava a cidade, local das decisões políticas e centro cultural do país. O Rio de Janeiro, com a chegada da corte portuguesa, começou a sobrepujar os antigos centros urbanos, como Recife e Salvador, favorecendo-se pela criação de uma série de estabelecimentos culturais, tornando-se sede de inúmeras escolas, de bibliotecas e museus inauguradas pelos chefes de governo desde a chegada de D.João VI.

A trajetória do livro didático analisada no âmbito do espaço onde era produzido mostrou-nos, com mais clareza, as

21 Várias obras didáticas editadas nos Estados Unidos são citados por BARBANTI, Maria Lucia Spedo Hisldorf.- Escolas americanas de confissão protestante na Província de Sāo Paulo: um estudo de suas origens. Dissertação de Mestrado São Paulo: Faculdade de Educação da USP. , 1977, pp.169 e 170 

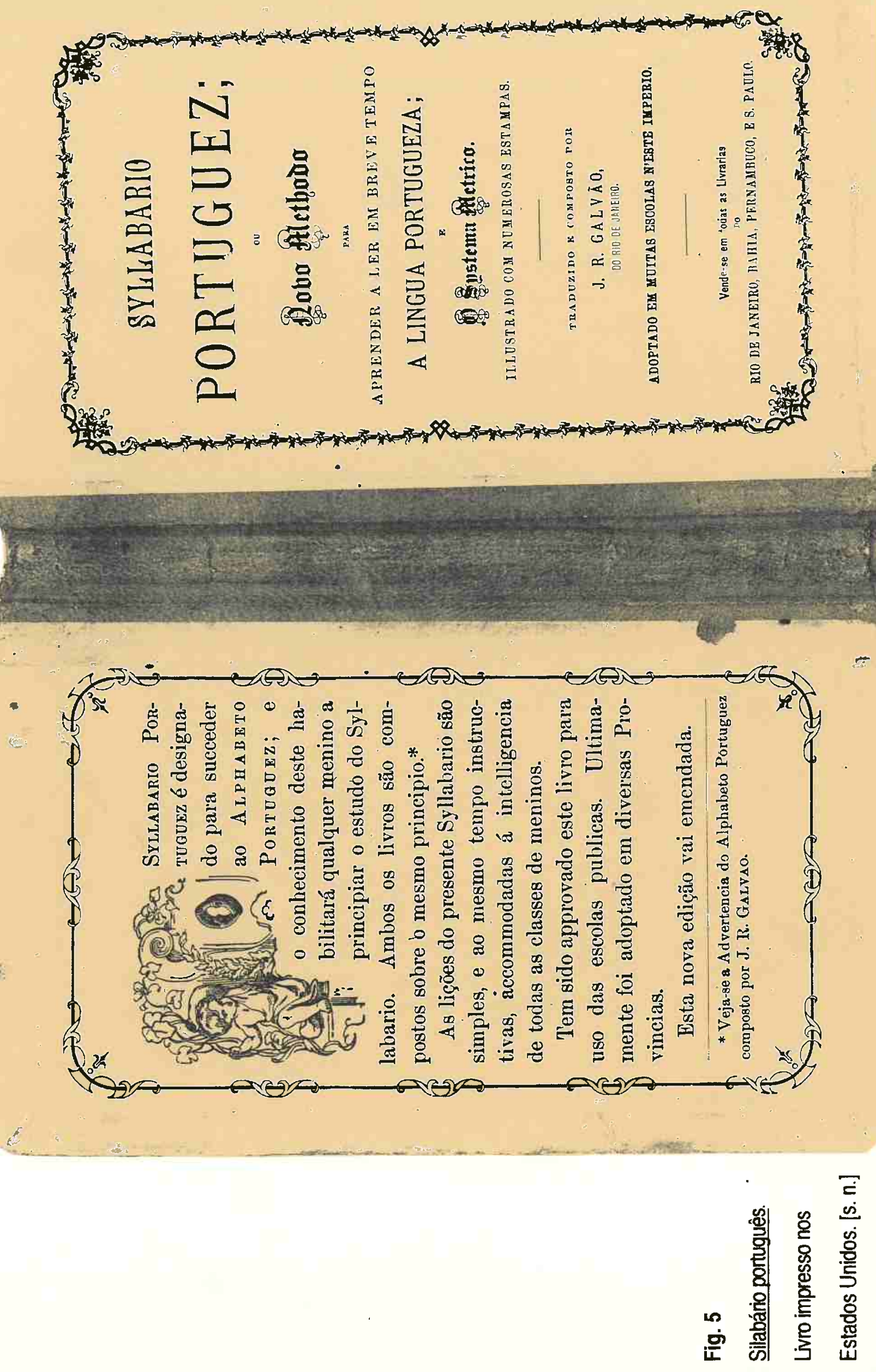
relações e articulaçōes entre empresa privada e poder oficial na confecção e difusão da literatura escolar.

Os editores que iniciaram seu trabalho no Rio de Janeiro desenvolveram uma eficiente política de aproximação com o poder. Dentre as posturas estabelecidas pelos editores para criar vínculos com o governo, percebe-se que evitavam definições políticas partidárias e tentavam obter títulos honoríficos, prática usual do Império para incentivar uma espécie de mecenato para obras assistenciais e educacionais, especialmente.

Baptiste Louis Garnier requereu uma condecoração ao Gabinete do Império, justificando seu pedido por ter sido "o Editor da maior parte das obras científicas, literárias e elementares da instrução pública que existem no país",22 acabando por receber o título de oficial da Ordem Imperial da Rosa. Os irmãos Læmmert já haviam sido agraciados por condecoração semelhante alguns anos antes.

o editor Francisco Alves, para conseguir êxito em sua iniciativa educacional, soube elaborar e articular uma eficiente política de aproximação com o poder constituído, notadamente durante a República quando a literatura escolar passou a sofrer uma vigilância mais estreita das autoridades dos Estados.

o redimensionamento do papel dos inspetores escolares e do diretor frente ao trabalho do professor foi percebido, por certo, por Francisco Alves, que procurou aproximar-se cautelosamente das autoridades locais para defender e divulgar sua empresa.

Francisco Alves escolhia cuidadosamente suas amizades. Uma delas foi a que manteve com Teófilo das Neves Leão, "a maior autoridade em matéria de ensino em seu tempo", secretário da educação na gestão de Prudente de Moraes e incentivador da abertura de uma livraria em são Paulo, cidade que, então, despontava no cenário educacional da República. A inauguração da Livraria Alves de São Paulo, em 1894, foi descrita como "muito significativa" pelos jornais

22 Manuscrito sem data, Arquivo do marquês de olinda, IHGB: 1ata 214, doc 61 ; Apud HALLEWELL, L.- op. cit., p.125 
da época, entendendo-se como um ato de política cultural importante:

"A hora marcada ( 1 hora da tarde) estavam presentes: - Dr. Bernardino de Campos, presidente do Estado, dr. Cerqueira Cesar, vice-presidente, dr. Cesário Mota, Ministro do Interior e da Instrução Pública, dr. Lauro Müller, representante do ministro da Guerra. Muitas e muitas outras pessoas gradas assistiram ao ato: politicos, professores, jornalistas, médicos, advogados, negociantes... Recebidos os representantes do governo de são Paulo pelo fundador da firma, o velho Francisco Alves e Julio Aillaud, foram-1hes mostradas as belas coleçōes de livros didáticos, especialidade da casa". ${ }^{23}$

A capital nacional, sede das principais editoras do país, foi também local de pequenas editoras que se dedicaram à produção de didáticos. Houve um número significativo de livros impressos em tipografias de jornais e por editoras de vida efêmera, caracterizando-se como uma prestaçāo de serviço esporádica e eventual.24 Uma dessas pequenas editoras, a J.G. de Azevedo aparece 1885 com 23 compêndios escolares, correspondendo a $7,5 \%$ do total das obras elencadas mas, obtivemos poucas informações sobre ela. Ao que parece, era uma livraria que passou a editar exclusivamente livros escolares para a escola elementar, tendo tido alguns de seus trabalhos premiados na Primeira Exposição Pedagógica do Rio de Janeiro, em 1883.25 No

23 MENEZES, Raimundo de- As primeiras e mais antigas livrarias de são Paulo. Revista do Arquivo Municipal, São Paulo, n¹82, p. 206, 1971 24 No Catálogo de 1885 encontramos obras impressas, entre outras, pela Gazeta de Notícias do Rio de Janeiro: SABINo, Januário e Costa e CUNHA, Estevão- Curso metódico de leitura. Rio de Janeiro, Tipografia da Gazeta de Noticias, 1878 e do jornal o Fluminense, de Niterói PONTES, A.M. da Silva- Compêndio de pedagogia para uso dos alunos da escola Normal. Niter6i: Tipografia do Fluminense, 1881

25 As referências que dispomos sobre esta editora encontram-se nas Atas dos pareceres da Primeira Exposiçāo Pedagógica do Rio de janeiro de 1884 , tendo sido uma das editoras premiadas "pelos livros de leitura do professor Joāo José Povoas Pinheiro" - op. cit. p. 69 e "pela exposiçāo de vários compêndios de aritmética elementar de que é editor" p. 84. J. G. Azevedo e um dos poucos pequenos editores que consta do catálogo de obras aprovadas para uso das escolas públicas no ano de 1891. (Garnier, Alves Cia e a Læmmert) Revista Pedagogica. Rio de Janeiro, Livraria Classica de Alves, ano $1, n^{\circ} 2, p .55$ a 58 , abril/ set., 1891. Temos ainda informações em 1893, indicando que a editora gozava de certo prestígio :" No próximo fascículo trataremos 
Catálogo do material e livros aprovados para uso das escolas públicas primárias no ano de 1891 da capital da República, ela figurou com apenas 3 obras de um total de 49 títulos e era a única editora de pequeno porte. ${ }^{26}$ Estes números refletem a tendência monopolista que se delineou com maior precisão a partir desse período.

As pequenas editoras ou gráficas prestavam-se, geralmente, para imprimir as obras encomendadas pelos próprios autores. Ao acompanharmos as edições dos livros escolares, observamos que ao obter sucesso de vendagem, havia a transferência ou compra de obras ou dos direitos autorais pelas editoras maiores.27 Esta prática de se utilizar de pequenas gráficas para a produção de material didático, na capital do país, foi, entretanto, desaparecendo no final do século, predominando a concentração nas três grandes editoras sediadas na capital do pais.

\subsection{Editoras nas províncias}

Fora da sede governamental, surgiram tipografias de pequeno porte, nascidas principalmente, para publicações de periódicos mas que contribuíram para uma "produção ocasional de livros escolares, para os quais ainda não existia um

das obras didáticas: $2^{\circ}$ livro de Ieitura de Santos Sabino e Costa Cunha e da Gramatica Portuguesa de Alfredo Gomes, as quais nos foram gentilmente oferecidas à última hora pelo conhecido editor $J$. $G$. Azevedo, livreiro nesta Capital." Revista pedagogica. Rio de Janeiro, $30(5): 376,1883$.

26 Este Catálogo encontra-se na Revista Pedagógica, ano 2, $n^{\circ} 2,1891$

27 o caso de Joaquim Manuel de Macedo e tipico desse processo. Seus primeiros livros didáticos de historia foram publicados, a seu pedido. o primeiro deles, Liçoes de historia do Brasil para uso dos alunos do Colégio de Pedro II foi feito pela Tipografia de I. M. N. Garcia em 1861 e a primeira ediçāo do seu mais famoso texto escolar, Liçōes de historia do Brasil para uso das escolas de instrução primaria foi realizada pela editora D.J. Gomes Brandāo. Este editor vendeu-a a B. L. Garnier conforme atesta o seguinte documento do arquivo da editora Garnier: "Transfiro ao sr. B.L. Garnier o direito de imprimir e vender a segunda ediçāo da obra acima declarada. Rio de Janeiro, 27 de setembro de 1871. Dr. J. Gomes Brandão. Fico ciente Dr. Joaquim Manuel de Macedo." Manuscrito - Arquivo da Editora Itatiaia, Belo Horizonte. 
mercado nacional." 28 Tais editoras também dependiam do poder oficial, sendo obrigadas a enfrentar ou a servir os chefes locais em suas lutas políticas internas e regionais.

As pequenas editoras das províncias, nascidas como livrarias ou pequenas tipografias tiveram, sempre, que enfrentar problemas relativos ao domínio de novas técnicas além de aquisição e adaptação de equipamentos. Havia falta de informação sobre os avanços tecnológicos desenvolvidos no exterior e mesmo os que chegavam à capital do Império dificilmente eram transmitidos às províncias mais distantes. Os trabalhos desenvolvidos por estas pequenas casas de edição eram marcados por técnicas artesanais.

o trabalho destas primeiras oficinas de tipografia mostra as contradições da passagem do trabalho artesanal para o fabril. Na Memória sobre a tipografia maranhense, obra escrita pelo editor Frias, constata-se a dificuldade de se obter mão-de-obra devido aos baixíssimos salários oferecidos. Na oficina de Frias trabalhavam, além dele, um escravo e dois compositores. O restante dos trabalhadores era composto de quatro menores, fazendo parte da equipe seu filho $e$ um menino de seis anos de idade. 29

As pequenas editoras enfrentavam a falta de capitais para aquisiçāo de equipamentos, de tintas e papel, tendo muitas vezes de recorrer a financiamentos e subsídios do governo local. (A importação de papéis era outra questão que estabelecia relações de dependência entre poder oficial e as empresas editoriais. As taxas sobre o papel eram mais elevadas do que a estabelecida para livros importados, fato que agravava as já precarias condições da indústria nacional. o pagamento de taxas sobre o papel, além disso, foi sempre instável. o tratamento dispensado à importação de papel variava segundo critérios pessoais de funcionários da alfângeda. As vezes ele era tratado como papel para jornal, sobre o qual incidia uma tarifa extremamente baixa e às

28 HALLEWELL, L. -op. cit., p. 122

29 Cf. HALLEWELL, L. - op. cit. p. 102 
vezes como papel para escrever o que, comumente era taxado mais fortemente que o papel destinado a livros.30

Outro aspecto a ser considerado sobre as relações de dependência dos editores com o governo local e provincial, refere-se à questão das disputas político- partidárias.

Negociaçōes e conflitos estavam presentes nas tipografias provinciais, responsáveis pelos periódicos locais. As lutas partidárias representaram, muitas vezes, o nascimento e a morte de muitas delas. As mudanças do mando local colocavam certos editores à margem, comprometendo a continuidade de um trabalho que exigia aperfeiçoamentos técnicos constantes. o caso do impressor maranhense Belarmino Mattos é exemplar. Este impressor, verdadeiro artista das artes gráficas, segundo seu biógrafo, teve desentendimentos com os liberais quando estes chegaram ao poder, tendo impresso o jornal do grupo conservador e terminou por ser preso por razões de falta de pagamento. Esta prisão resultou em seu declínio. Tendo contraído beribéri na cadeia, transformou-se em um homem debilitado física e moralmente e, sem conseguir recuperar seu negócio prejudicado pela sua ausência, acabou por falecer em menos de três anos após sua libertação, em 1870, com 39 anos de idade. 31

o estudo de Werneck Sodré sobre a história da imprensa brasileira mostra inúmeros casos de condenação e prisão de jornalistas e impressores, como Cipriano Barata, cujos escritos eram mais condenáveis do que sua militância revolucionária. "Barata permaneceu longos anos nas prisõesenvelheceu nelas".32 A ação repressiva do regime vigente marcou a imprensa desde o seu nascimento e a sobrevivência de editoras deveu-se muito às manobras políticas a que estas acabavam por se submeter.

30 Idem, p. 131. Neste estudo, Hallewell chama a atenção para o fato dos proprietarios das gráficas não se utilizarem da produção local de papel, informando sobre a existência de varias fábricas de papel desde a instalaçāo da Imprensa Régia.

31 Bellarmino Mattos é considerado como um verdadeiro artista por Hallewell, sendo seu trabalho bastante destacado na sua historia do livro brasileiro. Cf. HALLEWELL; op. cit. p.106 e 107

32 SODRÉ, Nelson W.- op. cit., p. 171 
A produção de obras didáticas nas províncias era realizada sob as mesmas condições precárias, mas diferentemente dos periódicos que podiam estar ligados a grupos políticos, ela necessitava do aval do poder educacional para sobreviverem, pois dependia da aprovação das autoridades educacionais para a circulação e adoção de livros nas escolas. Autores e editores de obras didáticas tiveram que se submeter às imposições governamentais, tendo - agravante de ser o governo o principal consumidor dessa literatura.

É difícil inventariar a produção didática fora do âmbito das empresas editoriais da capital do país, pela insuficência de registros, inexistência de catálogos e desaparecimento dessa literatura marginalizada. o Catálogo de 1885 indicou um número reduzido de obras editadas nas províncias, perto de 128 da produção total. A consulta a outras fontes, almanaques, revistas e alguns jornais, revelou, no entanto, que o número de livros confeccionados nas províncias foi maior e mais significativo do que o elenco contido no Catálogo de 1885, desempenhando um papel importante no processo de escolarização, principalmente para o ensino elementar.

Foram nas pequenas tipografias criadas nas províncias que surgiram as primeiras obras didáticas nacionais dedicadas ao ensino das primeiras letras e as de Gramática. A Cartilha Imperial de Felipe Petroni Martins Maciel Parente, foi editada no ano de 1840, em Belém, na firma de Justine Honório José dos Santos. Vários outros livros didáticos continuaram a ser confeccionados em Belém e Manaus no decorrer do Império, É interessante observar que esta região, diferentemente de outras províncias que produziam, na maioria dos casos, obras de Gramática e de Aritmética, especializou-se em livros de Geografia. A região amazônica, começava a ser objeto de interesse econômico e necessitavase aprofundar estudos de seu espaço, considerando que iniciava-se a exploração da borracha e a navegação do Amazonas despertava a cobiça internacional. 
No Norte foi, no entanto, a província do Maranhão que mais se destacou com uma significativa produção cultural, sendo considerada como "o mais importante centro editorial das províncias, e o único de importância nacional, mas também o lugar em que a qualidade do trabalho dos melhores impressores ultrapassava toda e qualquer realização da corte". 33

Dos trabalhos impressos pelos dois mais importantes editores maranhenses, Belarmino de Mattos e José Maria Corrêa de Frias, destacaram-se as obras didáticas para as escolas elementar e secundária. Uma delas, publicada por Frias logo no início de seu ofício foi o Livro do povo de Antonio Marques Rogrigues, em uma primeira edição em 1861 com 4.000 exemplares, alcançou, em poucos anos, uma tiragem de mais de quarenta mil exemplares e foi lida, com suas mais de duzentas páginas ilustradas e muito "bem impressas", por "sucessivas geraçōes de crianças brasileiras, particularmente no nordeste". 34

o editor Bellarmino Mattos foi o encarregado da fabricação das obras didáticas de Língua portuguesa do professor Francisco Sotero dos Reis e dos livros de Aritmética de'J. A. Coqueiro e encontramos, dentre a produção didática maranhense, uma das raras obras escrita por uma mulher, "uma professora pública de primeiras letras da vila de Cururupu". 35

o nordeste, região de importante elite cultural e política do século XIX, destacou-se pela produçāo de obras escolares em suas acanhadas casas editoriais, no decorrer do século XIX. Pernambuco secundou o Maranhão como local de

33 HALLEWELL, L. -op. cit., p. 96

34 ARROYO, L. - op. cit. pp. 101 e 169

35 Temos um levantamento das seguintes obras didáticas editadas por Belarmino de Mattos:

COQUEIRO, J.A.- Metrologia moderna- aplicaçōes interessantes ao comercio e indústria. (1863)

REIS, Francisco Sotero dos- Postillas de Gramatica Geral aplicada à lingua portguesa pela análise dos clássicos. , 1863 - Comentários de Caio Julio Cesar (1863)

- Gramatica da lingua portuguesa (1866)

- Curso de literatura portuguesa e brasileira (1866-68) 4 v.

SOUSA, Herculana Firmina vieira de- Resumo da historia do Brasil. (1868) 


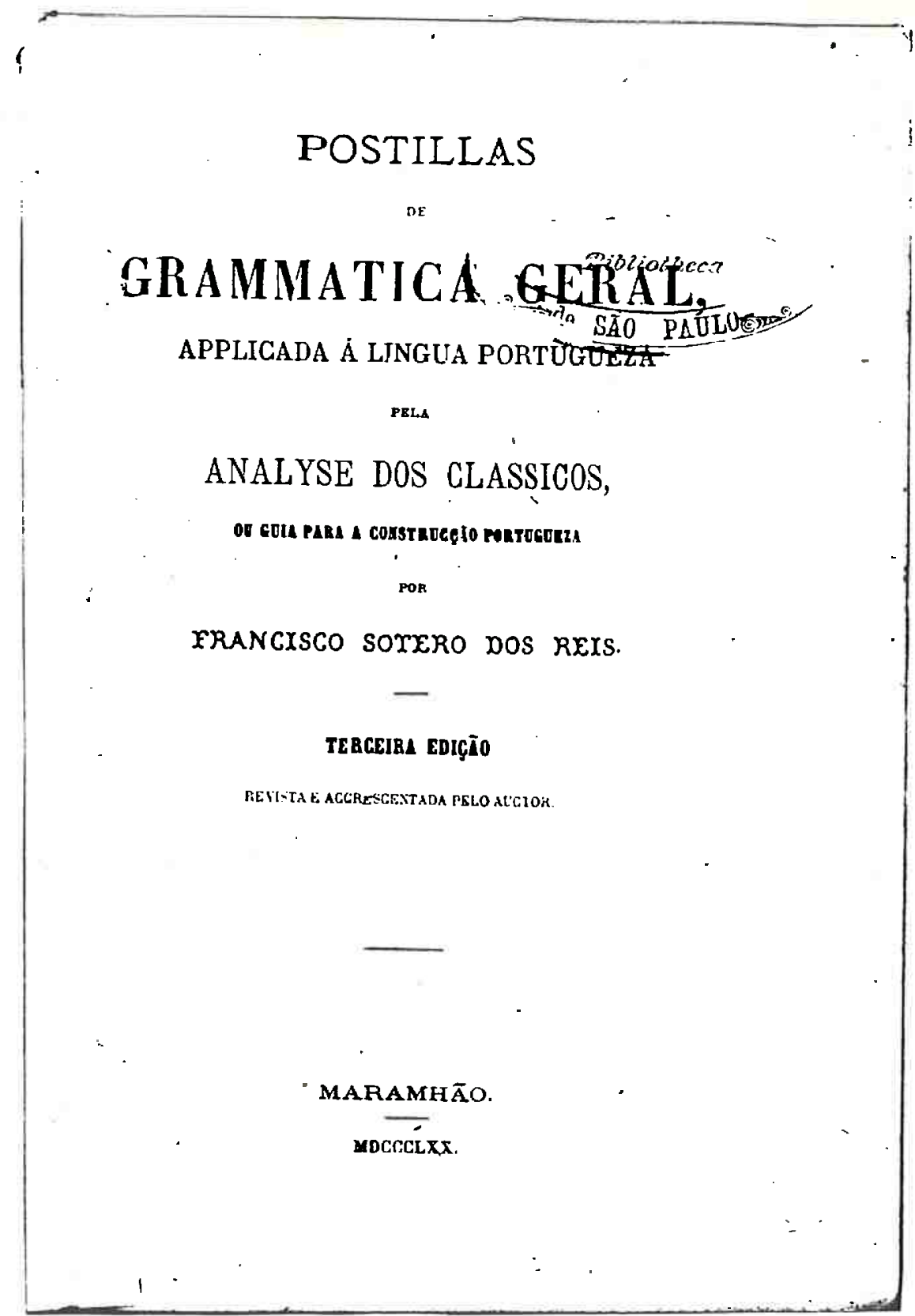

Fig. 6

Gramática Geral de Sotero dos Reis. Livro editado em São Luiz por Bellarmino Mattos 
importante elite intelectual e de produção de livros mas, temos poucas informações sobre trabalhos didáticos de suas casas tipográficas. As tipografias locais foram importantes no desempenho das publicações locais, embora predominassem as editoras francesas que provavelmente atuavam por intermédio de suas livrarias, especialmente a Livraria Francesa. Um dado interessante nos foi fornecido por um livro, Elementos de agricultura para uso das escolas primárias, cujo autor apenas se identificou como um sócio do Grêmio de Professores Primários de Pernambuco e foi impresso pela "própria corporaçāo".36

A Bahia, embora tivesse tido nomes famosos de educadores, não foi local de muitas produções, preferindo os autores de obras escolares enviarem seus textos para publicação no Rio de Janeiro ou no exterior. Encontramos referências esparsas, como os livros de História e Geografia da Tipografia de Affonso Ramos \& Cia e da casa editora de Lopes da Silva Lima \& Amaral.37

Nos anos finais do século XIX, a Província de são Paulo começou a esboçar um movimento cultural que sofreu avanços maiores na fase republicana. A capital da província paulista possuía alguma tradição em produção de impressos

\footnotetext{
36 Esta obra está relacionada no Catálogo do Museu Escolar Nacional de 1885 já referido.De Pernambuco, temos ainda os livros escolares de: ALBUQUERQUE, Salvador Henrique d'- Resumo da historia do Brasil. Pernambuco: Tipografia Imparcial de S. Caminha, 1848

- Compéndio da Historia do Brasil. Pernambuco, G. de Lailhacar, 1869 CAVALCANTI- Dr. Joāo Barbalho Uchoa- Leituras seletas para uso das escolas primárias. excertos de obras clássicas e científicas, coligidos e ofertados ao Grêmio de professores primários. Pernambuco: Tipografia Central, 1880

MELLO, Capitolino- Pernambucanas ilustres. Pernambuco: Tipografia Mercantil, 1879

ROCHA, Landelino- Primeiro livro de leitura ou carta do ABC para uso da infáncia. Recife: J.w. de Medeiros, 1883 (7\% edição)

RODRIGUES, João José- Cartas sistemáticas para aprender a ler. Recife: Livraria Francesa, 1867

37 As obras de Historia e a de Geografia referidas são as de PEREIRA, Dr. Jerônimo Sodré- Compêndio de geografia elementar, especialmente do Brasil. Bahia: Lopes da Siva \& Amaral, 1884 e SEIXAS, Romualdo Antonio de - Sinopse da historia do Brasil composta sob um plano especial para a instrução primária e secundária. Bahia: Tipografia de Affonso Ramos \& C. , 1878. No Catálogo de 1885 encontramos obras de outras tipografias pouco conhecidas, como as de FRANCO MEIRELLES, Dr. Antonio de- Elementos de gramática inglesa. Bahia, Tipografia Tourinho, 1867 e uma tradução: FABER, J. Henrique- Física elementar- leitura para escolas. Bahia: Tipografia do Monitor, 1877
} 
devido à presença da Faculdade de Direito que fomentava autores a desenvolver, adaptar ou compilar trabalhos para os cursos preparatórios à Academia. Em 1839 a gráfica de Costa Silveira "produziu um livro didático, o Resumo de história universal para uso da aula de história e geografia, adaptado por Julio Frank da obra alemã de H. L. Politz". ${ }^{8}$

Estas casas impressoras dedicavam-se, igualmente, às publicações das criações literárias dos estudantes de Direito, feitas sob encomenda dos autores. A firma de Jorge Seckler, fundada em 1862, funcionando na rua Direita $n^{\circ} 14$, foi a tipografia que mais se destacou nos primórdios da produção de livros paulistas. Entre outras publicações Jorge Seckler encarregou-se da organização do Almanaque da Província de são Paulo e na linha editorial de livros didáticos, publicou, entre outros autores, os primeiros trabalhos didáticos de Júlio Ribeiro e o de Thomas Galhardo.39 Um editor que se preocupou também com textos escolares foi José Maria Lisboa utilizando-se da Tipografia da Província para confeç̧ão de seus livros. Dos livros didáticos publicados por José Maria Lisboa dois deles se destacaram, o de Américo Brasiliense e de Julio Albergaria, mais pelo nome dos autores, conhecidos pela militância política, do que pela qualidade didática da obra. 40

Com a República houve um significativo crescimento de publicações didáticas paulistas tanto em pequenas gráficas como a Tipografia King, Tipo-litografia Ribeiro como em firmas mais bem instaladas como a dos editores Duprat \& Cia.

38 HALLEWELL, L.- op. cit., p.224. Hallewell cita varias outras gráficas em são paulo mas as obras citadas apenas as dos Irmāos Teixeira e a gráfica da Casa Ecletica se dedicaram ao fabrico de obras didáticas .

39 Dos livro didáticos publicados por Jorge seckler, tivemos acesso aos de RIBEIRO, Julio Cesar- Gramatica portuguesa para uso dos alunos de 10 letras, com 1 edição em 1881 e a Gramática portuguesa, editada no mesmo ano, além do livro de TRAJANo, Antonio- Arimetica progressiva, publicado em 1: ediçāo em 1879. Do Catálogo de 1885 temos informações sobre a 4 a ediçāo de FREIRE DA SILVA, bacharel Augusto Compendio de gramatica portuguesa para uso dos alunos de humanidades que frequentam as aulas de portugues, de 1883 e do mesmo autor e ano, Rudimentos de gramática portuguesa para uso dos alunos de primeiras letras.

40 MELO, Americo Brasiliense de Almeida- Liçōes de história pátria. Sāo Paulo: Jose Maria Lisboa editor; Tipografia da Província, 1876; ALBERGARIA, Julio de-Coisas e lousas. São Paulo: José Maria Lisboa editor, $1878,28 \mathrm{ed}$. 
e a Teixeira \& Irmãos, além da F.T.D., empresas em fase de expansão.

Hallewell destacou a produção editorial gaúcha somente a partir da la Guerra Mundial. Constamos, entretanto, que o Rio Grande do sul foi uma das províncias pioneiras em publicações de textos escolares. Em 1835, foi publicada na cidade de Porto Alegre, o Compêndio da lingua nacional dedicado "à mocidade rio-grandense", primeira obra de Gramática de um escritor brasileiro, Antonio Alvares Pereira Coruja, sem indicação da casa editora, mas que efetivamente ocorreu em gráfica do Rio Grande do Sul, onde o autor residia. 41

A província gaúcha foi a que mais se sobressaiu nas últimas décadas do século passado quanto à produção de literatura escolar, preocupando-se em produzir textos para escolas secundárias e primárias. No Catálogo de 1885, existem referenciadas 13 obras confeccionadas pela editora Carlos Pinto \& Cia., em suas gráficas de Porto Alegre e Pelotas. Outras documentações esparsas nos indicaram um crescimento constante dessa literatura. Assim, duas obras adotadas em escolas gaúchas, uma datada de 1883 e que nos inícios da década de 10 do século atual encontrava-se na 24 a edição e uma sobre a História e Geografia locais atingiu igualmente um elevado o número de edições. ${ }^{42}$

A literatura didática continuou sendo publicada nas pequenas oficinas espalhadas pelo país, mesmo após o crescimento do setor empresarial, como demonstram os anúncios de venda de livros didáticos das livrarias. No Almanaque Garnier de 1904, por exemplo, uma propaganda da Libro-papelaria Bivar da cidade de Fortaleza anunciava a venda de livros da Garnier e mais 14 obras da "edição da

41 A obra está citada sem maiores indicaçōes sobre seus editores por HALLEWELL, L.- op. cit. p. 121

42 Trata-se das seguintes obras: GUIMARĀES, J. Pinto- o Rio Grande do Sul para as escolas. 10 ed. Pelotas: Carlos Pinto, 1898,e PINTO, Alfredo Clemente- Seleta em prosa e verso dos melhores autores brasileiros e portugueses. 24 ediçāo. Porto Alegre: Selbach \& Mayer, 1912 . 
casa", das quais 9 eram didáticas, predominando obras de alfabetização e de história e geografia locais.43

Pudemos, desta forma, constatar que a produção regional teve uma existência regular e permanente, sobretudo, confeccionando obras destinados aos cursos elementares e o nascimento de obras nacionais escolares para - público infantil ocupou aí um lugar privilegiado. Constata-se que nas províncias depois estados foi possível uma sobrevivência precária da produção de obras didáticas em pequenas editoras ou tipografias mas, nos principais centros urbanos do centro-sul do país, a tendência foi o lento desaparecimento de tais firmas que sucumbiram, paulatinamente, frente ao domínio de editoras que se constituíram em grandes empresas, transformando o livro didático em uma das mercadorias mais rentáveis do setor à medida em que ocorreu a expansāo educacional do país. Estas editoras foram responsaveis pela transformação da fase artesanal do livro para a era industrial. A "fabricação do livro" inscreveu-se em outra divisão do trabalho, o trabalho da fábrica, no qual o editor deixou de ser um técnico ou artista e transformou-se em um empreendedor de negócios. As editoras que passaram por estas transformações, entre nós, estiveram concentradas inicialmente no Rio de Janeiro e, posteriormente, nos anos iniciais do atual século, ampliaram sua rede de produção, expandindo-se em direção à são Paulo.

Importa ressaltar que em ambas as situações, editoras das províncias ou editoras da Corte, a submissāo ao poder governamental foi marcante para a existência e sobrevivência do livro.

As editoras que se dedicaram à produção da literatura escolar, submetendo-se aos poderes educacionais dominantes, a partir das últimas décadas do século XIX, puderam se

43 As obras didaticas editadas pela Libro-papelaria Bivar eram as de PEREIRA, Francisco Marcondes - Apontamentos de aritmetica, (1903); SOUZA, Thomas Pompeu de- Lições de geografia geral (s. d.); SANTOS, Joāo Brígido- Resumo da história do Ceará (s. d.); SoBREIRA, Joāó Gonçalves Dias- Resumo da geografia do Ceará, (s.d.) e do mesmo autor o Resumo da Gramatica portuguesa; VIEIRA, Joaquim Jose (bispo da diocese) - Catecismo da doutrina cristā. (s.d.) e sem nome dos autores Pequeno catecismo da doutrina cristā, Taboada ou Primeiras noçōes de aritmetica e Cartas do $A B C$ ou Primeiras noçōes de leitura. 
dedicar quase que com exclusividade a este produto cultural. - Catálogo de 1885 demonstra que, na década de oitenta, predominavam os livros didáticos nacionais mesmo que continuassem, majoritariamente, sendo impressos no exterior. A opçäo pela impressão no exterior parece ter sido ditada meramente por interesses comerciais, exemplificado pela questão dos preços instáveis do papel, ou por problemas de financiamento para adquirir equipamentos modernos, como ocorreu com todo o processo inicial da industrialização brasileira. Era possivel qualificar técnicos para artes gráficas, como provaram os maranhenses em suas editoras mas, as dificuldades maiores dos proprietários das editoras ocorreram face às decisões políticas, ditadas por oligarcas voltados para os interesses agrícolas em detrimento do desenvolvimento de uma indústria nacional autônoma.

\section{Comercialização do livro didático}

2.1 A "carne" da produçāo de livros

Um artigo do jornal do Comércio do Rio de Janeiro de 1851 informava que "em Inglaterra, de Goldsmith para cá, escrever e publicar livros para crianças (children-books) tem sido um manancial de grandes 1ucros". 44

Desta data até nossos dias, o Brasil confirmou plenamente o que estava acontecendo na Inglaterra do século XIX. A produção de livros para crianças, especialmente os didáticos, tornou-se uma fonte de lucros capaz de sustentar, nos dias atuais, dezenas de editoras especializadas neste produto cultural.

Francisco Alves, ao optar pela continuação da produção de manuais escolares, ousando ampliar tal produção dando-lhe prioridade, estava, sem dúvida, atento ao status da escolarização do mundo ocidental. A Inglaterra havia

44 OTAVIANo, Francisco- Ensaios administrativos. Jornal do Comercio, Rio de Janeiro, 1851. Apud MOACYR, Primitivo- Inst. e prov.-op. cit, v.2,p. 561 . 
decretado a obrigatoriedade escolar em 1880 e as leis de Jules Ferry na III a República francesa demonstravam a tendência de uma "escolarização para todos os franceses" acompanhando as decisões que os prussianos haviam tomado duas décadas antes.

o levantamento feito por Rui Barbosa, em 1882 e 1883, sobre a educação escolar nos mais importantes países do mundo, revelava que nossos liberais deveriam tomar medidas para ampliar o processo de alfabetização das crianças e jovens das classes populares e este era um processo irreversível mesmo que lento e descontínuo.

Os dados quantitativos sobre as escolas e alunos matriculados foram certamente acompanhados pelos editores e podemos visualizar a tendência de crescimento pelos dados que se seguem.

QUADRO 4

Crescimento escolar $-1869-1889$

\begin{tabular}{|l|c|c|c|c|}
\hline ANO & ESCOLAS & ALUNOS & ESCOLAS & ALUNOS \\
\hline & \multicolumn{2}{|l|}{ SECUNDARIAS } & \multicolumn{2}{|c|}{ ELEMENTARES } \\
\hline 1869 & 230 & 11.529 & 3.723 & 125.017 \\
\hline 1889 & 138 & 24.889 & 8.064 & 266.084 \\
\hline
\end{tabular}

Fonte:ALMEIDA, J. Ricardo Pires de - História da instrução pública no Brasil (1500-1889).

A importância comercial do livro didático fez com que os editores passassem a considerá-lo como "a carne" da produção de livros em contraposição às obras de literatura ou "científicos", que corresponderiam aos "ossos". A publicação de um romance ou qualquer obra de ficção, principalmente de autor desconhecido, era um risco maior do que o livro escolar que, depois de aprovado pelas autoridades educacionais, possuía público cativo e compulsório. Os editores precisavam unicamente cuidar dos 
preços que deveriam ser módicos, acessíveis a uma clientela mais popular. As preocupações dos editores e as comparações que faziam entre os dois gêneros literários podem ser entendidas quando verificamos o número de tiragens entre ambos.

Os livros publicados no Brasil possuíam uma tiragem variável mas, raramente, excedia a 1.000 exemplares. Livros de boa vendagem atingiam cerca de oitocentos exemplares por ano. Houve, evidentemente exceções, como Machado de Assis e José de Alencar, que conseguiram vender mais de mil exemplares em um ano mas, a maioria das obras literárias não ultrapassava 500 exemplares anuais. Os contratos da Garnier com seus autores de textos didáticos informam uma cifra bem maior de tiragens em relação ao livro de ficção ou mais ainda em relação aos de caráter científico. Os manuais destinados às escolas primárias, em suas primeiras edições variavam entre 2.000 a 4.000 exemplares e os de maior receptividade conseguiram constantes reedições, às vezes anuais, que chegavam a 6.000 exemplares. 45

os contratos da Garnier indicaram que a década de setenta foi indicativa do futuro promissor que a literatura didática reservava aos editores, destacando que eram casos raros os livros didáticos com apenas 2 edições. o Livro do povo, anteriormente citado, alcançou uma distribuição, em uma década, de 40.000 exemplares. Um autor muito conhecido, Abilio Cesar Borges, barão de Macaúbas, que se encarregava

45 o contrato firmado entre Joaquim Manuel de Macedo e o editor Domingos José Gomes Brandão, de 9 de junho de 1864 nos fornece os seguintes dados sobre $0 n^{\circ}$ de volumes impressos : "Recebi do sr. Domingos José Gomes Brandāo a quantia de seis contos e duzentos mil réis pela licença que pelo presente lhe concedo, para mandar imprimir e vender por sua conta a obra de minha composiçāo "Compêndio da história do Brasil para uso das escolas" sendo duas ediçōes de seis mil exemplares cada um, fazendo-se a primeira já e com a maior brevidade e a segunda logo que a outra estiver esgotada.(...) Manuscrito - Arquivo da Editora Itatiaia, BH. Há ainda o contrato de B. L. Garnier com um dos seus autores prediletos, o Cônego Fernandes Pinheiro: "Recebi do Sr. B. L. Garnier a quantia de três contos trezentos e noventa mil rêis, sendo um conto e noventa mil réis pela sexta ediçāo do "Catecismo", impressa a quatro mil trezentos e sessenta exemplares; um conto e quinhentos mil réis pela sexta edição dos "Episodios" impressa a três mil exemplares; e oitocentos mil réis, em conta ou por saldo da primeira edição da "Historia do Brasil" de dois mil exemplares, conforme se estabelece o preço da venda segundo nosso contrato. Rio de Janeiro, 14 de fevereiro de 1870. Manuscrito- Arquivo da Editora Itatiaia, Belo Horizonte 
de sua própria produção didática, chegou, pelo conjunto de seus textos, a uma tiragem de cerca de 400.000 volumes em cerca de 20 anos de produção. 46

o Iivro didático tornou-se, rapidamente, o texto impresso de maior circulação, atingindo uma população que se estendia por todo o país. A obra didática caracterizou-se, desde seus primórdios, por tiragens elevadas comparando-se à produção de livros em geral. A circulação dos livros escolares superava todas as demais obras de caráter erudito, possuindo um status diferenciado $e$ até certo ponto privilegiado, considerando-se que a sociedade se iniciava no mundo da leitura. Este poder de penetração explica, em parte, porque autores eruditos, em número significativo, utilizaram-se da literatura escolar para divulgar seu trabalho.

A "carne" da produção livresca, no entanto, caracteriza-se por ter vida efêmera, situação que criava certas complicaçōes para as editoras. A condição de seguidor dos programas oficiais obrigava-os à adaptações e ampliações constantes ou ao seu desaparecimento pela defasagem em relação ao saber proposto nos currículos. Esta peculiaridade da obra didática levou fabricantes a criarem fórmulas de produção e vendas especiais.

\subsection{Estratégias de produção e venda}

Uma das estratégias de venda dos editores foi o cuidado com os títulos. A introdução do termo "novo" nos títulos das obras escolares foi, e tem sido, uma das técnicas mais usuais para facilitar a comercialização de textos aparentemente inovadores, mas que, na realidade, são meras repetições dos mesmos livros. 47 Foi comum nos deparamos

46 Cf. ALVES, Isaias- Vida e obra do Barāo de Macaúbas. São Paulo: Cia. Editora Nacional, 1942, p. 144 e 145

47 Sobre este tema existem os artigos de GLEZER, Raquel- Novos livros \& velhas ideias. Revista Brasileira de História. São Paulo, 4 (7):149/54, mar. 1984 e ABUD, Katia- O livro didático e a popularização do saber 
com A Nova Gramática, Novíssimo compêndio de..., Novo método de gramática portuguesa... O "novo" dos títulos servia para credenciar a obra junto ao seu público consumidor, mas nem sempre correspondia a mudanças efetivas do texto.

Considerando a necessidade de renovação constante da obra, ao acompanharmos a vida de alguns livros escolares, nos deparamos com situações contraditórias que reforçam a concepção sobre a natureza ambigüa da obra didática. Foi possivel encontrar livros de grandes tiragens, verdadeiros "best-sellers", conhecidos por toda uma geração mas que não sobreviveram após o desaparecimento de seus autores. Mas, o surpreendente foi a descoberta de livros de "longa vida", perpassando várias geraçōes de alunos, alguns chegando a cem anos de duração. Livros que efetivamente foram altamente lucrativos.

Existiram livros didáticos cujas primeiras ediçōes datam da segunda metade do século XIX e que perduraram até a década de 70 do século atual. Alguns desses livros são textos que tornaram-se os "clássicos da literatura escolar", como o caso dos Lusíadas, leitura obrigatória de gerações incontáveis.

As fábulas constituíram outra leitura aceita como texto obrigatório para as escolas. Esopo e La Fontaine foram conhecidos pelos alunos brasileiros de várias gerações, iniciando-se as traduçōes ou adaptações, pelos meados do século XIX. Justiniano José da Rocha compôs a Coleção de fábulas imitadas de Esopo e de La Fontaine em 1852 e encontramos uma reedição dessa obra em 1927, a 11 a da Francisco Alves e Aillaud. O barão de Paranapiacaba traduziu as Fábulas de La Fontaine, em 1886, explicando que procurou adaptar o estilo dos textos franceses para melhor compreensão dos alunos e ofereceu 1.000 exemplares às escolas, custeadas pelo governo imperial.48

Livros de autores estrangeiros, considerados hoje como pertencentes à literatura infanto-juvenil, foram utilizados

historico. In SILVA ( org). Repensando a historia. Rio de Janeiro: Marco Zero, 1984, p. 81-87.

48 Cf. ARROYO, L. op. cit., p. 171. 
pelos professores, acompanhando, em certa medida, a leitura dos jovens das elites européias.

Robinson Crusoé teve várias traduções portuguesas com difusão permanente no Brasil. Os "contos" do cônego Schmid foram elogiados pelas autoridades eclesiásticas brasileiras e incluidos em listas de obras a serem adotadas para as escolas públicas por mais de um século. O autor português I.J. Roquette foi outro clérigo muito difundido nos diferentes níveis de escolarização, sendo um dos autores mais conhecidos da segunda metade do século XIX, estando suas obras indicadas tanto para colégios público masculinos, como para colégios femininos. 49

A permanência de certos autores, como Schmid e Roquette, ambos religiosos, figurantes dos catálogos da Garnier e Læmmert, demonstra a presença da Igreja no campo educacional, mesmo após a República com a instituição do ensino laico nas escolas públicas. Entre nós, não houve uma "guerra de manuais" como ocorreu na França, degladiando-se autores católicos contra autores laicos. o ensino religioso não desapareceu das escolas públicas brasileiras após a República. Sua exclusão limitou-se aos discursos pedagógicos, sendo possível encontrar no catálogo da Francisco Alves de 1904 o Catecismo da doutrina cristã, aprovado pelo bispo do Rio de Janeiro e "adotado pelo conselho superior de instrução pública para ser ensinado nas escolas do Governo". 50

Os editores contaram ainda com compêndios escolares que podemos denominar "livros de longa duraçāo". Embora o compêndio seja considerado, em princípio, como instrumento de divulgação dos avanços do conhecimento científico, prevendo-se uma vida curta para eles, existiram textos utilizados por vários gerações de estudantes, garantindo

49 o livro de Roquette, ornamentos da memoria e exercícios seletos para formar o bom gosto e verdadeiro estilo na língua portuguesa cuja primeira edição foi de 1849 estava ainda relacionada no catálogo de 1907 da Editora H. Garnier e os livros de Daniel de Foë (sic) , Robinson Crusoe, os Contos de Schmid, os de walter scott, Ivanhoe e outros continuaram a ser reeditados em 1928 . Cf . Catalogo Geral da Livraria Garnier, 1928 e Catálogo das Ediçōes de F. Briguiet \& Cia (ex- Livraria Garnier), 1936

50 Catálogo da Livraria Clássica de Alves \& Cia, 1894 
vendagens constantes, cabendo aos editores realizar simples adaptações de ordem ortográfica ou inovaçōes mais condizentes com os programas curriculares.

o ensino de Matemática teve dois autores cujos textos figuraram entre os raros livros didáticos usados no país do século passado até 1970. Antonio Maria Barker e sua tabuada, editada pela primeira vez em 1853, foi um deles. O livro de Barker teve um considerável número de edições, atravessando - século e chegando até os anos 70 do século XX.51

Duas obras de Antonio Trajano pertencem a essa "raridade", o que levou a comentários como esse: "Seguramente nenhum livro didático de matemática teve, no Brasil, vida mais longa e atingiu mais gerações de crianças e jovens do que a Aritmética Ilustrada de Antonio Trajano." 52 Outro destaque da produção de Trajano foi a sua Aritmética progressiva para o ensino secundário que teve a seguinte apreciação quando de seu lançamento:

"Cordialmente agradeço a V.S. a mimosa oferta de um exemplar do seu ótimo compêndio de Aritmética progressiva onde não sei que mais admire, se a exatidão e clareza das definições, se a simplicidade das regras, se a aplicação do método intuitivo, se o desenvolvimento das questões, se a felicidade da escolha dos problemas. 53

Ao lado das obras de Matemática, um texto que merece destaque pela continuidade de edições é a Cartilha de Thomas Galhardo, editada por volta dos inícios dos anos oitenta e que em 1968 teve a sua 219 ạ edição. ${ }^{54}$

51 Segundo Sacramento Blake, Antonio Maria Barker nasceu na cidade do Porto em 1792 chegou ao Brasil em 1810 e aqui faleceu em 1853. Deixou vários livros didáticos publicados após seu falecimento. o Rudimentos aritmeticos foi o de maior tiragem, tendo atingido em 1862 a 10 a ediçāo e em 1891 o editor Nicolau Alves fêz nova reedição, "completada por um professor". Cf. BLAKE, Sacramento- Dicionario Bibliografico Brasileiro. Rio de Janeiro: Imprensa Nacional, 1937, vol.1, p. 255. Pfromm Neto diz que esta obra passou a denominar-se Tabuada de Barker e reeditada até 1970 . Cf. PFROMM Neto, samuel e outros- o livro na educação. Rio de Janeiro: Primor, INL, 1974. ,p.76 e 160

52 Idem-op. cit., p. 77

53 A avaliaçāo foi assinada por Antonio X. de Araujo Pitada, "capitão do mar e guerra, professor de matemáticas na escola Normal e no Liceu de Artes e Off́cios da cidade de Desterro" In: Obras, anexo no livro TRAJANO, Antonio- Algebra elementar. Rio de Janeiro: Leuzinger Filhos, 1888 .

54 PFROMM NETO, S. e outros- op. cit., p. 160 
Para atingir cifras de vendagens significativas e garantir lucros por longos anos, as editoras empenharam-se na divulgação de obras por todo o território nacional. A questão da comercialização dos livros tornou-se um aspecto fundamental para a garantia de sucesso do livro, não bastando o aval do governo. Era necessário que o livro didático fosse acessível a alunos e professores, em preço e possibilidade de aquisição nos vários recantos do país. Aperfeiçoaram, por exemplo, técnicas de capas do tipo brochado $e$, geralmente as editoras adotaram o padrão in-8 ${ }^{\circ}$ introduzido pela Garnier, cujo tamanho possibilitava a venda por preços mais acessíveis. Assim, uma obra erudita era normalmente encadernada e seu preço variava entre $5 \$ 000$ a $10 \$ 000$ réis enquanto os livros didáticos eram cartonados, em papel de pior qualidade, possibilitando preços entre $\$ 500$ a $2 \$ 000$ réis.

A comercialização dos livros didáticos correspondeu a outro fator de diferenciação entre as atividades das grandes editoras $e$ as de pequeno porte, sediadas no Rio de Janeiro.. A Garnier, Læmmert e Francisco Alves cuidaram de instalar ou estabelecer acordos comerciais com livrarias dos principais centros urbanos, além das lojas que mantinham no Rio de Janeiro. 55

\footnotetext{
55 A editora Alves \& C. anunciava pela Revista do Ensino onde os professores poderiam comprar suas publicaçōes :

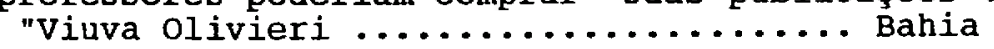

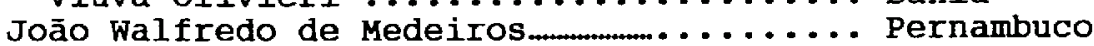

Joaquim Jose de oliveira \& C........... Ceara

M.F. da Silva e Ce.................. Pará

Antonio Pereira Ramos de Almeida \& Ca... Maranhão

Joaquim Alves Leite Sucessor............ Porto Alegre

Carlos Pinto \& $\mathrm{C} . \ldots . . . . . . . . . . . . .$. .... Pelotas

Joaquim Dolivanes Nunes................. sāo Paulo

Rodrigo Antonio Pereira................ Juiz de Fora

Manuel Tomas Teixeira................ Ouro Preto

Jose Marques Nogueira Guerra........... Diamantina "

In Revista do Ensino, Rio de Janeiro, ano $1, \mathrm{n}^{\circ} 5, \mathrm{p} .80$, maio, 1883

A editora B.L. Garnier havia incentivado seu ajudante Anatole

Garraux a estabelecer uma loja em São Paulo e mais tarde o Almanaque da Garnier de 1904 forneceu o nome de livrarias em são paulo e de outras regiōes brasileiras:

"Livraria Magalhães - são Paulo (maior depósito das ediçōes da Livraria H. Garnier)

Livraria Comercial. - Pelotas

Livraria Contemporânea - Pernambuco

Livraria Rodrigues - Piracicaba". Almanaque Garnier, Rio de Janeiro, 1904
} 
As editoras buscavam sempre novos espaços para a difusão e comercialização de seus produtos. As publicações de periódicos, almanaques e jornais traziam sempre propagandas de diversos materiais didáticos à venda em livrarias, não se limitando apenas a livros. Os periódicos faziam publicidade de cadernos, papéis, tintas e demais materiais didáticos que começaram a se constituir em mercadorias especiais na configuração de uma cultura escolar, distinguindo crianças e jovens pela posse de tais objetos.

Quando autores se encarregavam da publicação de seus próprios textos, tinham o hábito de enviar um exemplar aos jornais, sendo que, várias vezes, os elogios jornalísticos eram incorporados nas edições sequenciais dos livros:

"JUIZO DA IMPRENSA SOBRE A SEGUNDA EDIÇÃO

Recebemos um exemplar da Geografia Elementar, por Tancredo do Amaral professor pela escola Normal de são Paulo.

É um trabalho em que o autor revela brilhantes conhecimentos expostos de modo claro e conciso e que satisfaz plenamente o fim a que se destina.

Um excelente compêndio para praticantes.

$$
\text { (D'O Tempo)" } 56
$$

Outra forma de divulgação utilizada pelos editores era a apresentação de catálogos nos próprios livros didáticos, apresentando ao público escolar suas edições ou obras que se achavam à venda em suas livrarias. No final do século, os editores aproveitavam a contra-capa dos livros para tal finalidade, limitando-se por vezes em divulgar as obras de um determinado autor e de determinada disciplina.

Em São Paulo havia se estabelecido a Livraria Læmmert \& Cia na rua Quinze desde a década de setenta. MENEzES, Raimundo de - op. cit., p. 196

56 Apud AMARAL, Tancredo do- Geografia elementar. 8 ed. Rio de Janeiro: Livraria Francisco Alves \& Cia., 1904. 


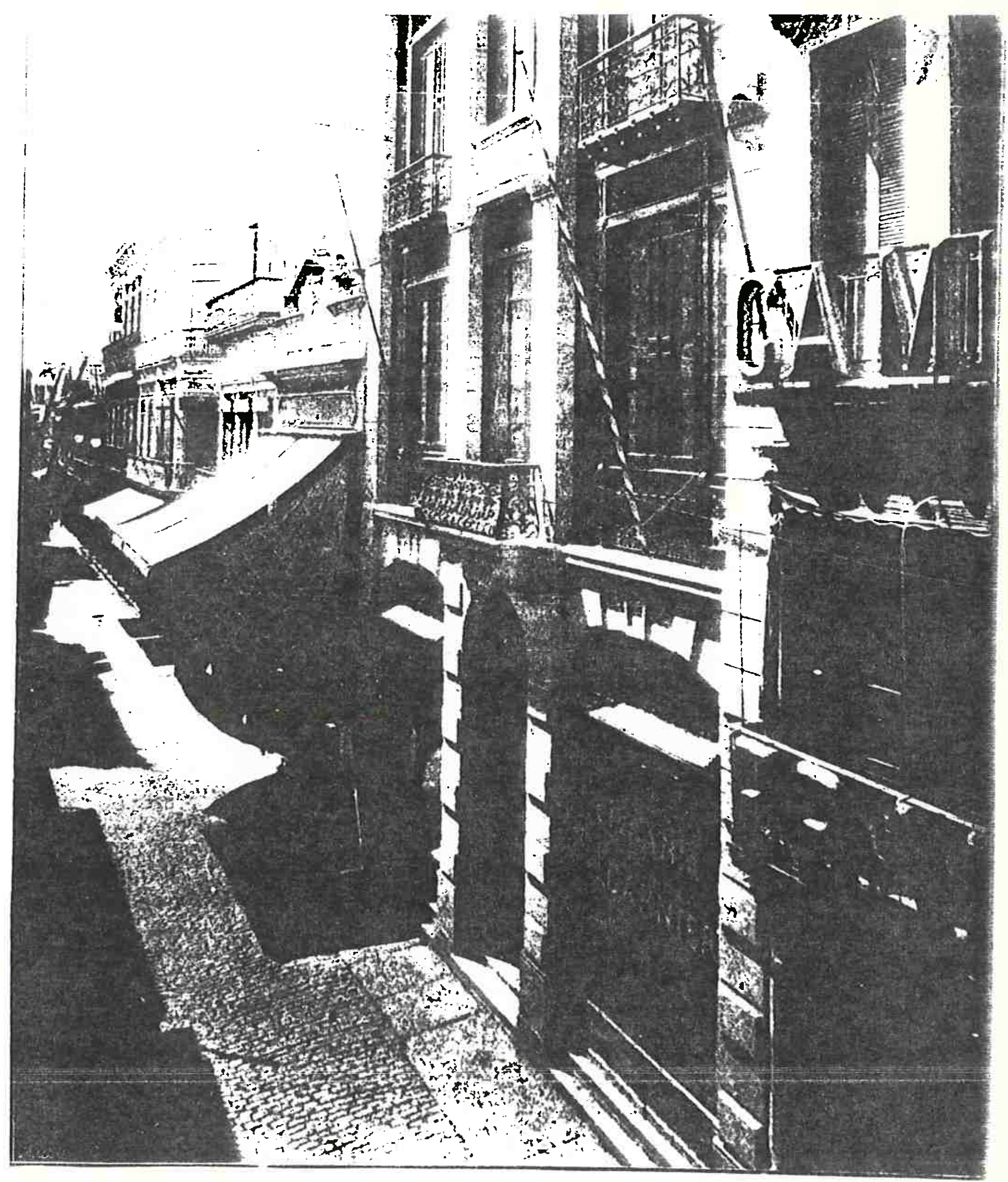

Fig. 7

Livraria Garnier. Rua do Ouvidor: Rio de Janeiro. Foto do Almanaque Garmier . 1904 


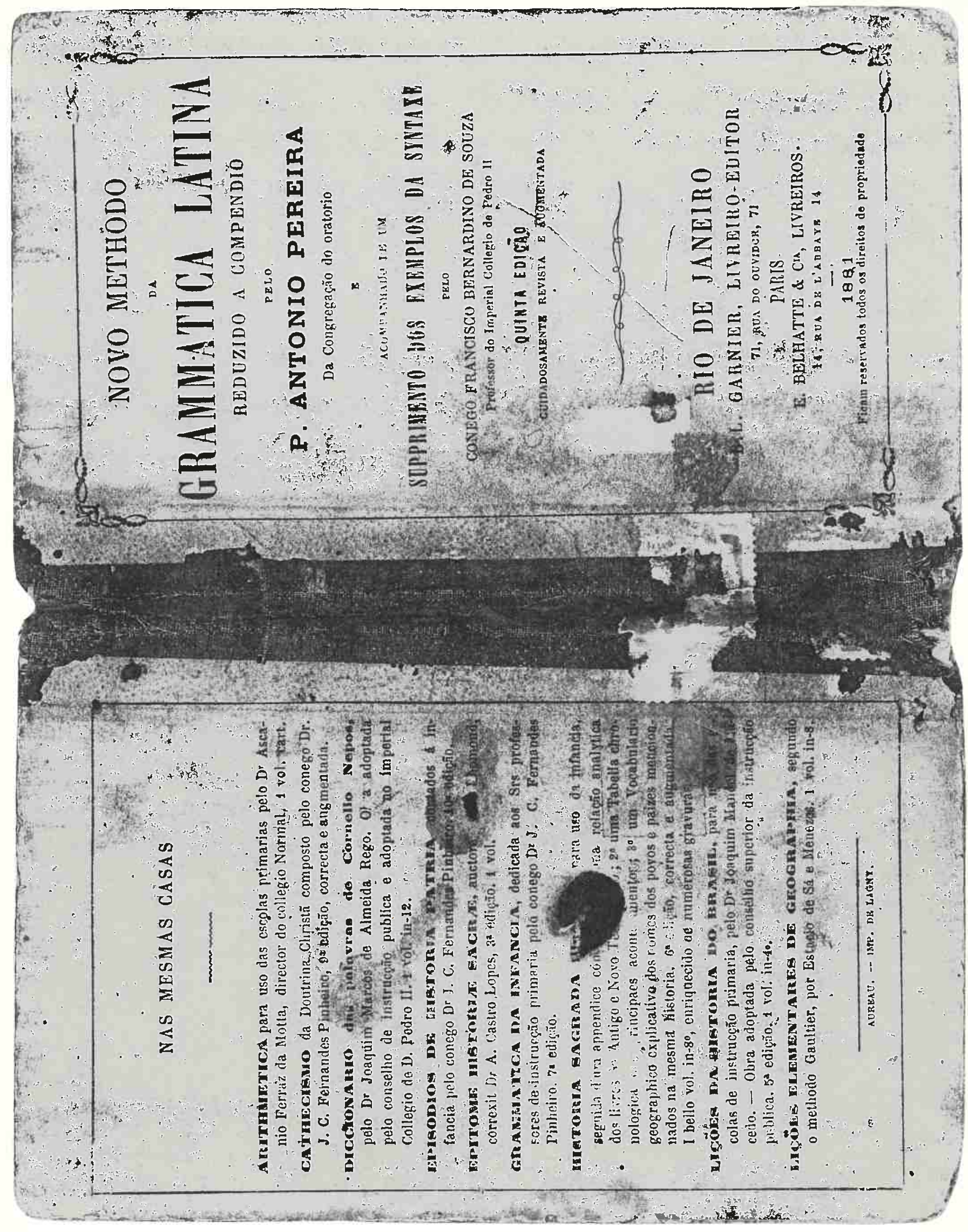

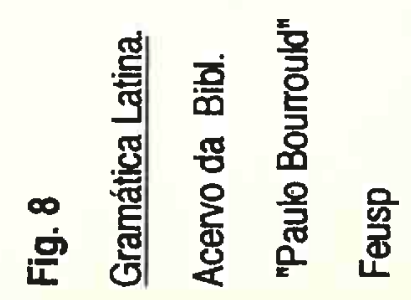




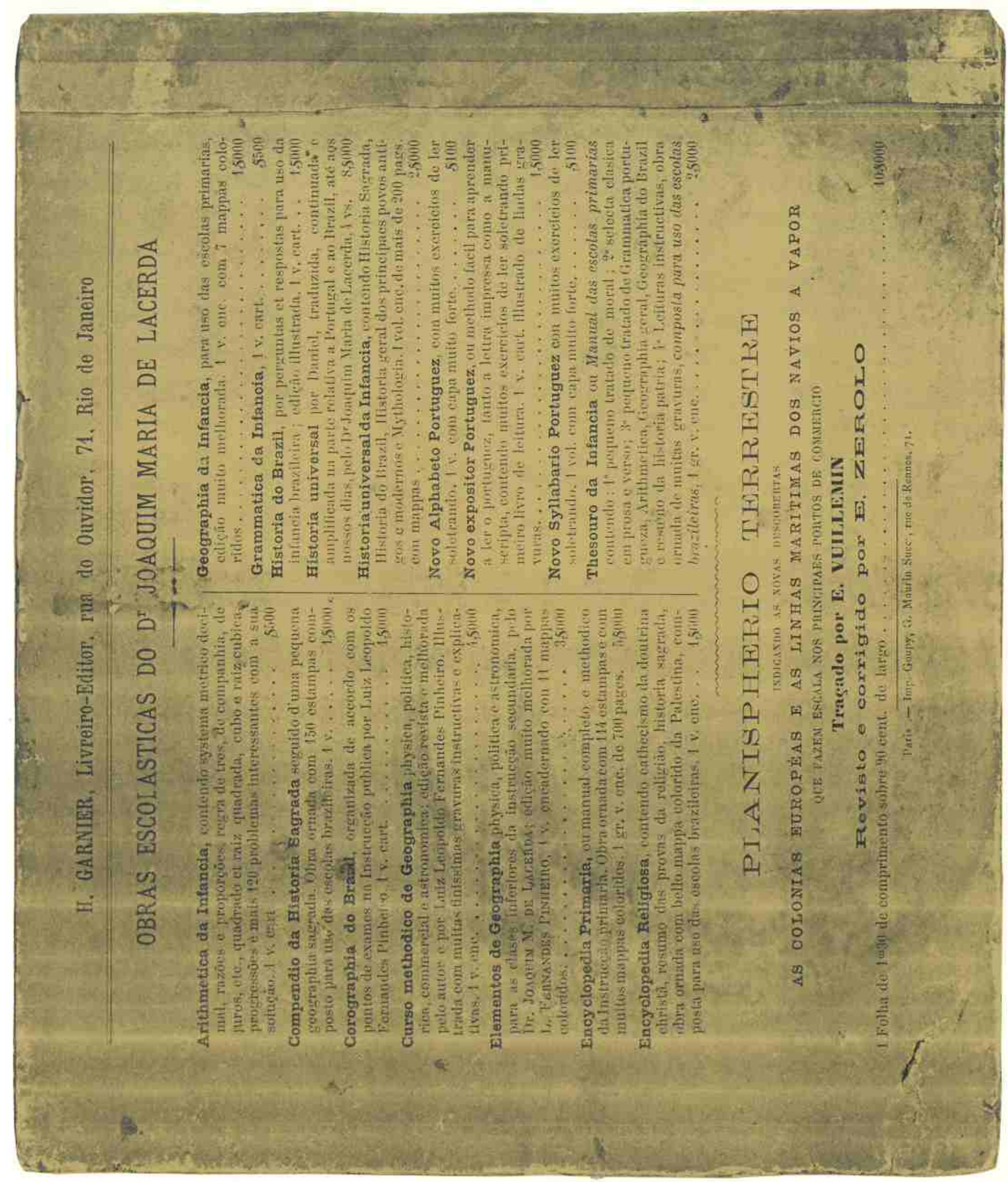

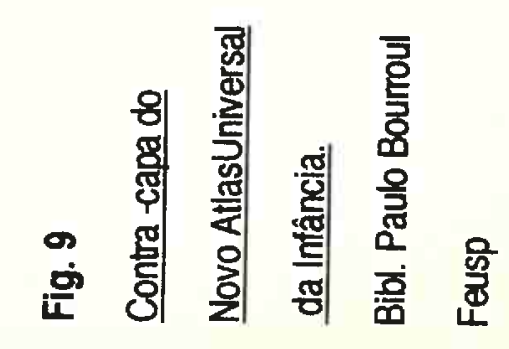


As revistas pedagógicas tornaram-se importante veículo de divulgação das editoras. A Revista Pedagógica, uma publicação oficial de educação editada pela Livraria Clássica de Alves \& Cia, trazia no final de cada número um catálogo das obras à venda em suas casas comerciais. Tratando-se da prestação de um serviço, a Revista Pedagógica era encarregada, entre outras tarefas, de publicar o catálogo do material e livros aprovados para uso das escolas públicas primárias que, em princípio, eram renovados no início de cada ano letivo. Misturavam-se, assim, os interesses da empresa editorial com o Estado, situação que se observa pelo número crescente de obras da editora Francisco Alves, aprovadas e adotadas nas escolas. Ressaltase ainda que o diretor da revista, Menezes Vieira e o subdiretor secretário, Felisberto R. P. de Carvalho eram escritores de livros didáticos contratados pela Alves \& Cia. e seus textos eram anunciados com destaque:

"Novo livro de leitura.- o nosso infatigável companheiro Felisberto de Carvalho entregou aos editores Alves \& Cia um primeiro livro de leitura e escrita, destinado_às escolas primárias brasileiras." 57

A Revista Pedagógica, dirigida por um ardoroso defensor da iniciativa privada no setor educacional, foi representativa do consórcio entre o poder governamental e os interesses privados, cujos interesses eram expressos em artigos da revista:

"O valor da convergência dos esforços da administração pública e da iniciativa particular recebeu ainda o ano passado neste Pedagogium modesta, porém, significativa consagração.

Os trabalhos didáticos dos editores Alves \& Cia. em 1893, não deixam a menor dúvida a esse respeito.

Foram eles: - Os livros de leitura do professor Felisberto de Carvalho, sub-diretor deste Pedagogium, o Método para o ensino de desenho pelo professor olavo Freire, conservador do Pedagogium e o globo geográfico para as

57 In Revista Pedagogica. Rio de Janeiro: Livraria Clássica Alves \& Cia., $\pi^{\circ} 1, \mathrm{v} .2,1891$, p.135, 
escolas primárias, construído conforme as indicaçōes fornecidas por aquele estabelecimento." 58

A Escola Pública, revista publicada em são Paulo por um grupo de professores com subsidios do governo estadual, criou um espaço denominado Bibliografia onde apresentavam pequenas resenhas das obras enviadas pelas editoras:

"Da Livraria Civilização, dos srs Costa \& silva, recebemos um exemplar do pequeno livro recentemente publicado por essa casa editora "As crianças e os animais"(-)

"Dos conhecidos livreiros Alves \& Cia estabelecidos com casa filial nesta capital, recebemos uma coleção de sete cadernos de desenho para o curso elementar, organizados pelo inteligente e incansável olavo Freire". 59

Os editores tiveram que buscar o apoio das lideranças educacionais para divulgação de seus produtos e seguir os pressupostos pedagógicos norteadores da política educacional vigente. No final do século, com o crescimento da participação do setor particular na educação escolar, os proprietários das editoras procuraram aproximar-se de diretores de escolas e das nascentes associações de professores que começaram a se organizar, enviando livros para uma possível avaliação e posterior divulgação.

Os editores precisaram, desta forma, preocupar-se com a escolha de autores "certos" para a redação de textos adequados às propostas educacionais vigentes. A linha editorial deveria ser marcada pelo que foi expresso por Francisco Alves em 1883: "sempre havemos de combater livros

58 Relatorio de Menezes de Vieira. Revista Pedagógica. Rio de Janeiro, 31, tomo VI, 1894, p.85-87. Neste artigo Menezes Vieira explicitou o papel das editoras junto ao setor público de educaçāo, devendo gozar dos privilégios inerentes à sua condiçāo, afirmando no mesmo artigo que "Hoje, em todos os países civilizados os governos não sugam, não asfixiam a iniciativa particular; pelo contrário protege, socorre aos que lutam nesse terreno, porque nele se firma a verdadeira grandeza do pais." p. 85

59 A Escola Pública. São Paulo, ano 1, no 1, abril , 1896, p.62_- 64 . A Revista era publicada pela secretaria de Estado dos Negócios do Interior, sendo membros da comissão de redaçāo Oscar Thompson, Romão Puiggari e Joaquim de Sant'Anna.,p. 62 
de ensino que tentam solapar os princípios da moral e da Igreja." 60

Os autores mais ousados ou de pouca projeção no meio educacional podiam contar com as pequenas editoras ou tipografias para encomendar, por conta própria, seus textos.

Editores mais renomados, como Garnier e H. Læmmert, preferiam escolher autores dentre os professores do Colégio Pedro II, da Escola Militar ou da Escola de Marinha, especializando-se, em princípio, na produção de livros de determinadas disciplinas.

\section{Divulgação oficial da literatura escolar}

\subsection{Política de distribuição de livros}

As grandes editoras foram especialistas em articulações com o poder educacional. Além do Estado ter o poder de credenciar as obras escolares, ele era também o principal comprador das obras didáticas por sua política de distribuição de livros para " alunos pobres" que, embora inconstante, tendia a se avolumar no período republicano onde predominava o discurso da disseminação da escola pública elementar mencionado com destaque nos diversos relatórios dos Diretores de Instrução. 61

60 Revista do Ensino. Rio de Janeiro, ano 1, $\mathrm{n}^{\circ} 1$, jan. 1883, p.1

61 Com o crescimento do número de escolas, a porcentagem de compras por parte do poder público tendeu a crescer, conforme anotamos por alguns dos relatórios dos encarregados da administração escolar. "Autorizou-me $V$. Exe para fazer a compra de oitencentos exemplares do metodo de ensinar a ler e escrever- pelo dr. Augusto Freire, e quinhentas da obraLiçōes de história patria- pelo Dr. Américo Brasiliense d'Almeida Mello, para serem deistribuidos pelos alunos pobres das escolas mais frequentadas." In CARVALHO, Francisco de Souza (bacharel) -Relatorio sobre o estado da instrução na Província de são Paulo no ano de 1879 . Santos: Tipografia a vapor do Diário de Santos, 1880, p.13. (grifos meus) Da lista de material pedagógico fornecido em 1890 às escolas públicas primárias do Distrito Federal, constava a doaçāo de 5. 967 livros de leitura, indicativo do aumento de aquisiçōes de obras didáticas pelo governo apesar da politica descontinua sobre o fornecimento de 
A obrigatoriedade do ensino de primeiras letras fez aparecer regulamentos para nortear a distribuição gratuita de livros para os alunos "indigentes". Foi comum aprovaremse leis como esta de 1868 de Alagoas: "Artigo $3^{\circ}$ Uniformizar o ensino por compêndios escolbidos e adotados por esta inspetoria que deveriam ser anual e convenientemente distribuídos pelas escolas, fornecendo-se aos meninos pobres de acordo com as forças da província, tornando-se efetivo um dispositivo do regulamento de 1853."62 Pela maioria dos regulamentos, os livros não seriam doados, mas emprestados, devendo ser devolvidos ao final do ano letivo e ficar sob a guarda dos professores.

Como sabemos, a obrigatoriedade do ensino prevista em regulamentos e decretos não se concretizou e também não se efetivou, de modo sistemático, a distribuição de livros para alunos. A politica de distribuição de livros escolares existiu em algumas províncias e estados mas esta prática governamental não foi permanente, dependente das disponibilidades orçamentárias, vontades e interesses políticos. Estas situaçōes podem ser observadas pelas prestaçōes de conta dos presidentes de províncias:

"Dos 2:000\$000 réis consignados na lei do orçamento para compra de livros há um saldo de 1: 350\$000, tendo sido gasta até agora a quantia de 650\$000. Calculo, diz o diretor, em 4:000\$000 o que provavelmente tem de ser despendido no próximo ano com a aquisição de exemplares de história do Brasil, de que há falta, e bem assim de sistema métrico e ainda a aritmética de Coruja, cuja aprovação pende do Conselho de Instrução". 63

o fortalecimento do poder do livro didático como depositário privilegiado do saber escolar transformou, em várias ocasiões, as distribuições de materias escolares em atos politicos. Os chefes de governos provinciais encarregavam-se de alardear as doações realizadas,

material escolar. Revista Pedagógica, Rio de Janeiro, 6, n 2, p.437, set. 1891. Grifos meus

62 Apud MOACYR, Primitivo- op. cit., p. 595

63 Relatório do presidente Eloi de Barros Pimentel da província do Rio de Janeiro em 1866. Apud MOACYR, Primitivo-op. Cit., p.240. 
convertendo a obrigação educacional em formas de atuação da politica clientelística. Os informes dos relatórios demonstram os interesses propagandísticos das autoridades locais:

"A contar de agosto de 1873 até esta data tem sido distribuído com as escolas 9.203 exemplares de livros apropriados ao ensino dos quais foram em diferentes ocasiōes por mim oferecidos 5.113. Também fiz o donativo de mil exemplares de traslados caligraficos e ultimamente o de 23 exemplares do catecismo de agricultura do doutor Antonio de Castro Lopes.No número de exemplares fornecidos estão incluidos 800 da preciosa obrinha "Conselhos às minhas alunas" da distinta professora desta capital Isabel Gondim, e 500 do utilíssimo opúsculo "Curso elementar de direito penal" pelo doutor Filgueiras Sobrinho, os quais foram comprados por conta da província." 64

o sistema perdurou com a República que contava com as revistas de ensino para realizar a propaganda governamental:

"COISAS BRASILEIRAS- O governo acaba de fazer aquisição de 4.000 exemplares do livro de leitura, cujo título encima estas linhas para serem distribuidas pelas escolas públicas do estado.

É como os nossos leitores já devem saber, produção do infatigável professor Romão Puigari." 65

Nas escolas francesas foi criado um ritual em torno dos manuais, visando difundir entre a população, o poder sagrado do livro. Tratava-se da entrega anual dos "livros de prêmio" (livres de prix) para os melhores alunos, uma forma de premiação que havia sido criada nos grandes colégios jesuítas do século XVII. Este ritual escolar se generalizou durante o século XIX, organizado pelas municipalidades francesas, passando a se constituir em uma festa cívica no final de cada ano letivo, com a participação das autoridades locais, das famílias e, evidentemente, dos jovens e

64 Relatório do presidente da Província do Rio Grande do Norte, J.C. Bandeira de Mello de 1875. Apud MOACYR, Primitivo- Inst. e prov., vol. 1 , p. 411

65 A Escola Pública, São Paulo, nº 3, v.1,p.293, set., 1896. 
crianças. Nossas autoridades tentaram imitar os franceses e encontramos referências sobre doações de livros como prêmios aos alunos que mais se distinguiram nos estudos. 66

A distribuição de livros escolares como doações nas escolas ou como prêmio para o desempenho de alunos representava, com maior força, uma outra faceta da ação politica. As autoridades governamentais inseriam-se na política de difusão da cultura letrada, característica dos Estados modernos ocidentais.

\subsection{Bibliotecas escolares e exposições pedagógicas}

A Primeira Exposição Pedagógica do Rio de Janeiro de 1883 foi um momento interessante no qual percebemos a importância crescente da produção dos materias didáticos e a efetivação do consórcio entre empresa privada e Estado.

As Atas das diversas comissões encarregadas das premiações sobre os melhores livros didáticos, incluindo amostras de editores estrangeiros, mostram o empenho das editoras para a obtenção das menções honrosas e diplomas e como os interesses políticos e econômicos se articulavam.

o editor pouco conhecido J. G. Azevedo enviou vários ofícios para possíveis reconsiderações sobre as decisões do juri, muitas vezes, sem sucesso. Outras editoras menores e autores que expuseram, isoladamente, também tiveram que recorrer a oficios para que seus trabalhos fossem reconsiderados. A discussão sobre a obra Catecismo Brasileiro de Cyriaco Antonio dos Santos Silva exposto por S. J. Zeferino Rangel de S. Paio teve o seguinte desfecho:

66 segundo o trabalho da historia do primeiro ginásio público de são Paulo, a autora informa que "no Almoxarifado da Instruçăo Pública havia quase dois mil exemplares dos livros de Silvio Romero A Historia do Brasil ensinada pela biografia de seus heróis e de João Ribeiro Gramatica Portuguesa, ambos com o objetivo de " premiar os alunos das escolas públicas". NADAI, Elza- o ginásio do Estado de São Paulo: uma preocupação republicana' 1889-1896). (Estudos e Documentos), Sāo Paulo : FEUSP, 1987, p.125 
"A Comissão do $4^{\circ}$ grupo, atendendo à representação apresentada pelo sr. Paranhos Pederneiras e pela mesa enviada, declara que lhe não escapou o livro Catecismo Brasileiro, ao contrário teve dele perfeito conhecimento e por isso mesmo não o considerou livro de leitura. (...)

Entretanto como the foi distribuido e a comissão não desconhece o mérito da obra e o resultado que pode dar na escola primária, bem como o esforço de seu autor em torná-la um livrinho inteiramente nacional, propōe que seja conferido um diploma de $3 \underline{a}$ classe ao sr. J. Z. Rangel de s. Paio, expositor do Catecismo Brasileiro por C $C_{Y r i a c o}$ Antonio dos Santos silva, bem como pelas citadas razões de 2 a classe ao Compêndio Elementar de Física de Paula Barros, exposto pelo próprio autor. Rio, 3 de Dezembro- José João de Povoas Pinheiro, - João Carvalho de Souza. - João José Pereira de Azurara." 67

As premiações conferidas às editoras mais renomadas foram substancialmente superiores em relação às de menor porte. Sem dúvida, podemos averiguar uma certa inferioridade quanto às qualidades de impressão ou do nível do conteúdo do livro de certas editoras que reclamaram sobre as decisões mas ficaram evidentes duas tendências da politica educacional da época.

A primeira delas foi o reforço à permanência dos mesmos modelos de livros didáticos ou seja o padrão francês, impresso no exterior, não fazendo parte da política cultural favorecer as pequenas editoras nacionais, embora pudessem existir um discurso nacionalista que ocorria eventualmente, como no caso citado, para justificar alguns critérios de premiações.

Um segundo ponto, refere-se ao projeto liberal que buscava incenti,var a maior participação do setor privado na educação.

Os grandes premiados da exposição foram as obras do professor Menezes Vieira e Abilio Cesar Borges,

67 Atas do Juri da Exposiçāo Pedagogica do Rio de Janeiro. Primeira Exposição Pedagógica do Rio de Janeiro. - op. cit., pp. 101 e 102. 
proprietários e diretores de escola, além de autores de livros didáticos impressos por conta própria.

A valorização dos dois educadores foi flagrante :

"A representação brasileira está distribuída em duas salas. Uma delas foi cheia pelo Colégio abilio com todos os objetos possíveis que se relacionam com o ensino. Ali se ve, como propriedade deste colégio, quase tudo que nas outras salas é exposto por paises diferentes, e causam uma bela impressão as instalaçōes de ginásticas e esgrima do colégio. o dr. Abílio, (aliás barāo de Macaúbas), sabe fazer valer a sua mercadoria, e não cochilou. Não menos grandioso, e talvez mesmo mais importante é o mostruário do Colégio Menezes Vieira, que segue completamente o sistema alemão, e que por isto é o o único a exibir, em toda a exposição, uma bandeira alemã ao lado da brasileira. Este colégio apresenta excelentes instrumentos de ensino e ginástica, coleçōes, etc, tudo de origem alemã e também todos os objetos usados no chamado "Jardim-da-Infância". Um busto de Fröebel orna o recinto e me interessou particularmente. Menezes Vieira será feito barão, como Abílio? Não o creio, pois ele não sabe se exibir tão bem como o outro, que desta vez passará seguramente a visconde." 68

Alguns autores que apresentaram seus compêndios e foram premiados, terminaram por ser cooptados pelas editoras, especialmente por Francisco Alves. Foi a partir das premiações da Exposição de 1883 que Hilário Ribeiro, gaucho com publicações pela editora Carlos Pinto \& Cia, tornou-se um dos autores mais famosos da editora Francisco Alves.

As exposiçōes de objetos escolares tornaram-se frequentes após a de 1883 e embora não tivessem a magnitude e o destaque da primeira, serviram para os editores divulgarem seus trabalhos.

A difusão das obras didáticas e de leitura, em geral, foi realizada por um movimento em torno da construção de

68 KOSERITZ, Carl von- Imagens do Brasil. Trad. Afonso Arinos de Melo Franco. Belo Horizonte: Itatiaia; São Paulo: EDUSP, p. 137 


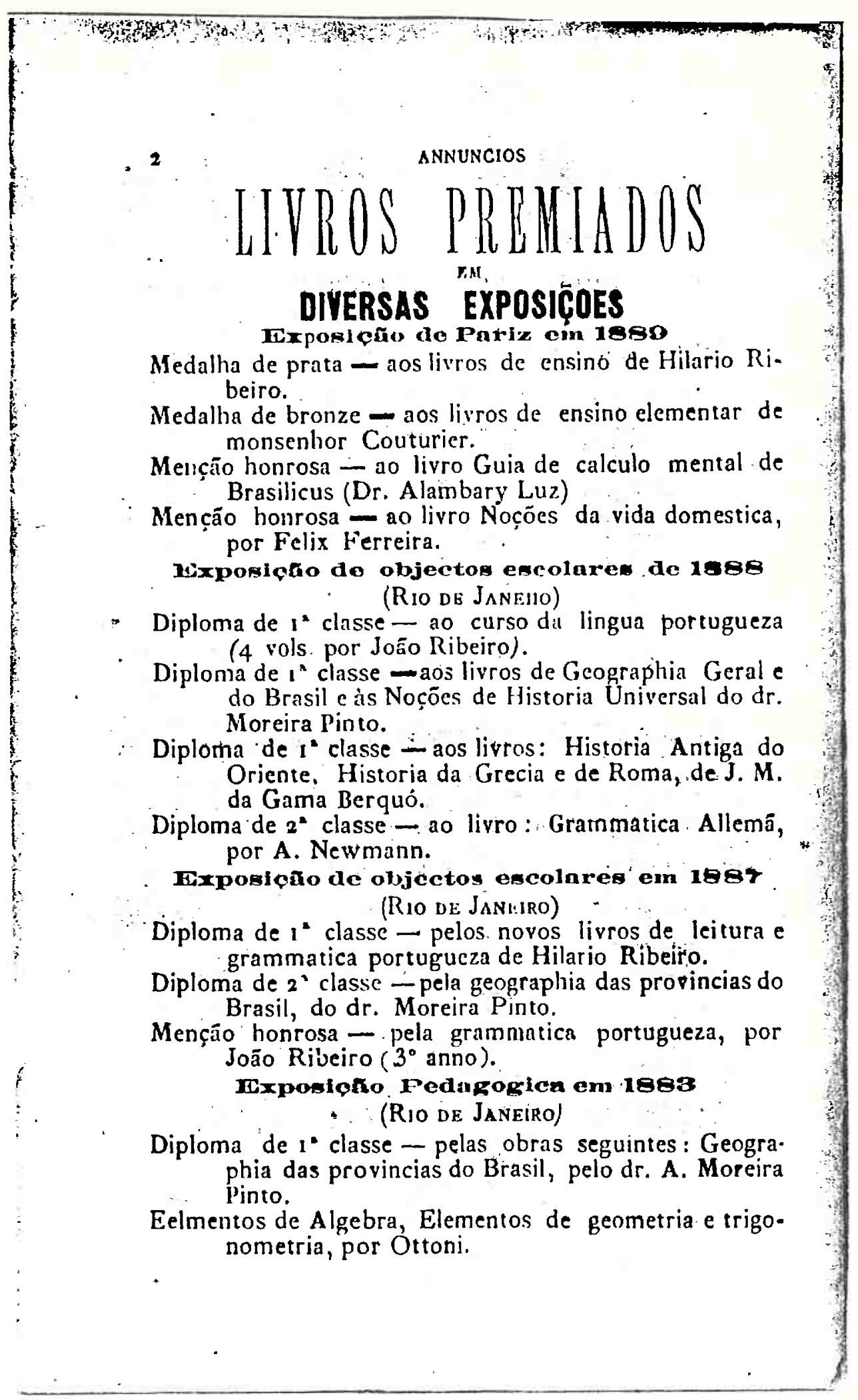

Fig. 10

\section{Livros premiados. Anúncios da editora Francisco Aves na Revista Pedagógica. Rio de Janeiro, 1891}


bibliotecas públicas ou populares, como eram denominadas, além de projetos sobre as bibliotecas escolares.

A argumentação apresentada para a execução de projetos sobre as bibliotecas escolares, registrava com nitidez o sentido da política de divulgação do saber pelos livros: "se fosse necessário justificar semelhante instituição, bastaria dizer que é preciso criar nos meninos - gosto pela leitura e facilitar-lhes Iivros úteis: os que merecerem pelo seu bom procedimento poderão levar para a casa as obras cuja leitura preferirem, e o livro emprestado ao menino naturalmente há de ser lido em família; não é a ele só que aproveita, mas também ao pai, à mãe, aos irmãos; e assim vão disseminando conhecimentos úteis." 69

Os projetos de construção de bibliotecas escolares detalhavam os tipos de obras que deveriam fazer parte do acervo. Tais acervos deveriam possuir obras elementares, com temas de atualidade sobre descobertas cientificas, artes, e livros referentes à pedagogia para professores.

Muitas destas bibliotecas foram projetadas minuciosamente, contando com planos orçamentários. Para a Corte, foi assinado pelo Imperador, um decreto para o estabelecimento de bibliotecas escolares nas escolas públicas de ensino primário, destacando que os livros deveriam ser aprovados pelo conselho de Instrução ou passados pela censura do inspetor do distrito escolar. 70

É difícil constatar se efetivamente foram criadas bibliotecas para escolas primárias, considerando a precariedade de instalações e condições do trabalho do professor que seria o encarregado da tarefa de sua manutenção e uso. Temos notícias de bibliotecas escolares instaladas em Liceus provincias, como no da Bahia, formadas por doações dos próprios professores do estabelecimento e de

69 CAVALCANTI, João Uchoa - op. cit. , p. 56

70 Cf. Regulamento do decreto $\mathrm{n}^{\circ} 7247$ de 19 de abril de 1879 assinado por Pedro Leão Velloso em 17 de maio de 1883. Revista do Ensino, Rio de Janeiro, 1 (5): 71-72, maio, 1883 . 
algumas obras cedidas pela Biblioteca Pública por existirem mais de um exemplar. 71

Para as Escolas Normais, surgiram projetos para a instalação de um tipo especial de acervo, as bibliotecas pedagógicas. As obras deveriam ser cuidadosamente escolhidas para que pudessem colocar os professores "a par do movimento cientifico das matérias que formam objeto do seu magistério". 72

Da Escola Normal da Província de são Paulo, temos informações mais concretas sobre a instalação de uma biblioteca pedagógica:

"Em 1881, A Escola Normal foi transferida do edifício do Tesouro Provincial para o sobradāo da rua da Boa Morte, 39. (.) Ainda nesse ano, o dr. Bourroul, indo à Europa, Iá comprou um laboratório igual ao das escolas normais da França; o resto dos seis contos de réis que recebeu do Governo para isso, empregou-o na compra de 200 volumes para a biblioteca da escola." 73

o movimento cultural de difusão da leitura não se limitou às esferas públicas. Entidades civis, leigas e religiosas, contribuiram para a ampliação da leitura como veículo de comunicação da cultura que se impunha. Ao lado de bibliotecas mais tradicionais existentes em conventos e seminários, no decorrer da segunda metade do século XIX,

71 "Foi criada nas salas superiores do edifício do Liceu, a Biblioteca de Instrução pública, que tem recebido donativos importantes feitos pelo diretor e vice-diretor da instruçāo, pelos professores Luis Alvares dos Santos, dr. Demétrio Ciríaco Tourinho, dr. Francisco Macedo Costa consistindo todos em livros e alguns em guantias que foram subscritas e que serāo provavelmente aplicadas em aquisiçāo de estantes ou de revistas estrangeiras. Também tem sido oferecidas obras pelo governo das que na Biblioteca Pública existem em duplicata, e portanto pode ter algumas centenas de exemplares." Relatorio do presidente da província da Bahia de 1871. Apud MOACYR, Primitivo-op . cit., p.156

72 Cf. CAVALCANTI, Joāo Barbalho Uchoa- op. cit., 56

73 EscoBAR, José Ribeiro- Histórico da instrução pública paulista. Revista da Educação, São Paulo, p. 169. A biblioteca iniciada por Paulo Bourroul que foi diretor da Escola Normal entre 1882 a 1884 , recebeu o nome do seu criador, tendo sido anexada à Biblioteca do Instituto de Educação Caetano de Campos estando sob a guarda do Arquivo do Estado. A Faculdade de Educação da USP pediu a transferência da referida Biblioteca, com um acervo de 8.000 volumes e onde se encontra atualmente e tem sido usado para pesquisas.Cf. ALMEIDA, Marina dos Santos e MAEDA, Elza Yukie- Método de fichamento preliminar de grandes doaçōes: uma experiência da FEUSP. Porto Alegre, 1977 ( texto datilografado) 


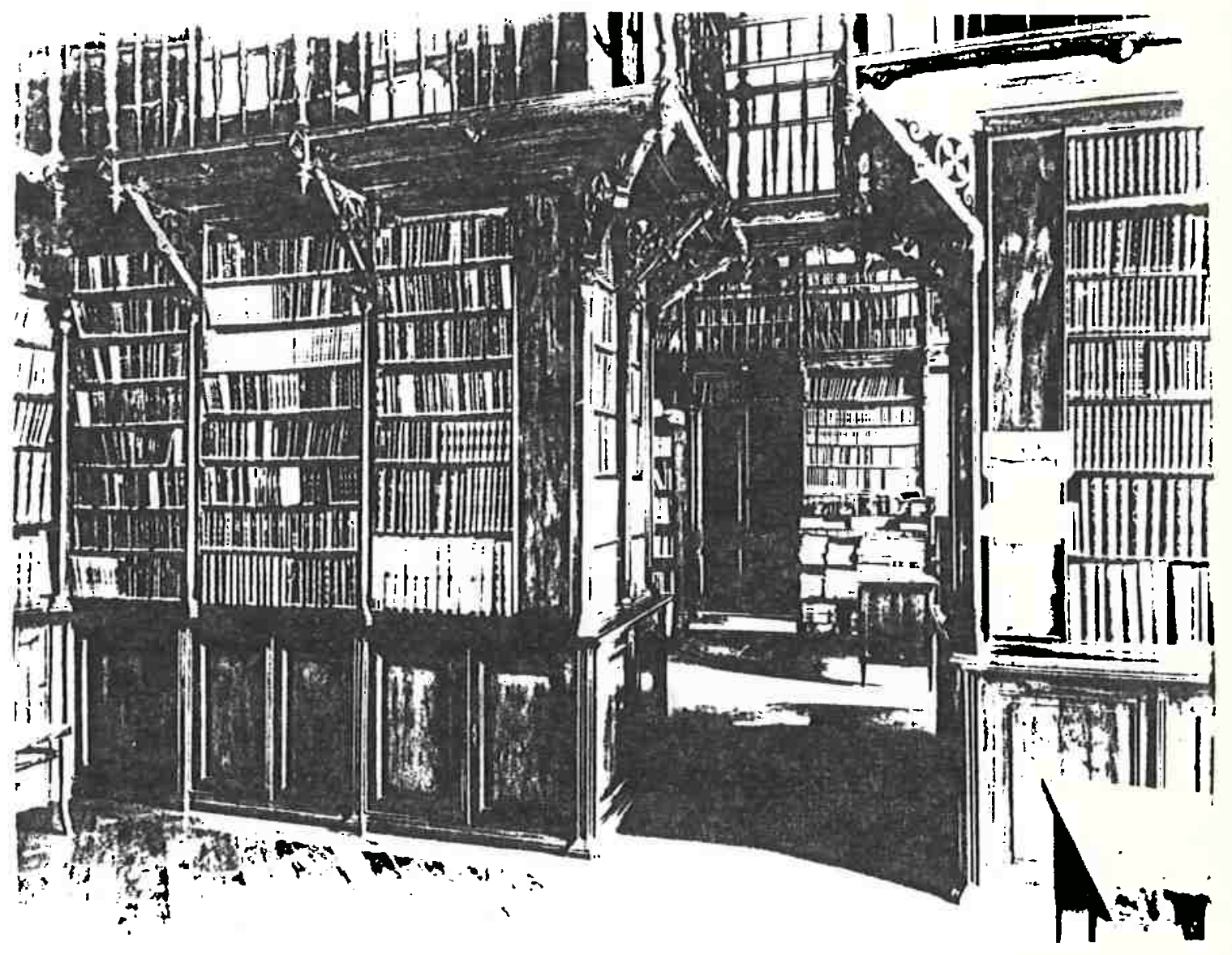

Fig.11

Biblioteca "Paulo Bourroul" da antiga Escola Normal de São Paulo "Caetano de Campos". Reprodução fotográfica de Jorge Maruta. 
foram criados novos espaços culturais por instituições leigas, destacando-se, os Gabinetes de Leitura. Almeida Pires fez uma descrição desta instituição cultural no Rio de Janeiro, tecendo elogios sobre a relevância de seu papel cultural, especialmente pela "magnifica biblioteca de 60.000 volumes, além de estampas; quadros, medalhas, etc."74

Nas províncias, destacando-se a de são Paulo, foram instalados inúmeros Gabinetes de Leitura por intelectuais de vários matizes ideológicos, maçons, em sua maioria. Esses espaços culturais criados nas décadas finais do Império destacaram-se na difusāo do mundo da escrita entre a população interiorana e prestaram serviços como centros educacionais, fornecendo cursos de alfabetização para adultos. 75

De acordo com as perpectivas da política de difusão da ação educacional promovida pelo governo imperial em consonância com os interesses da iniciativa particular no campo escolar, foi organizado o Museu Pedagógico Nacional no Rio de Janeiro. o Museu, além de organizar uma biblioteca especializada em pedagogia, incluindo livros e materiais didáticos, deveria realizar exposições permanentes das recentes aquisições pedagógicas para favorecer o intercâmbio a nível nacional e internacional de experiências educacionais em todos os níveis.

A criação do Museu Pedagógico Nacional ocorreu após a organização de um controvertido e frustrado Congresso de Educação e da referida Exposição Pedagógica de 1883 na capital do Império. Com o material da Exposição, o governo determinou o estabelecimento do Museu Escolar que permaneceu com suas atividades na fase republicana, passando a denominar-se Pedagogium.

Bibliotecas escolares e Exposições Pedagógicas constituíram-se em espaços para a divulgação do saber letrado. Foram instituições pouco disseminadas pelo país mas

74 ALMEIDA, Jose Ricardo Pires de- op. cit., p.256

75 Cf. MARTINS, Ana Luisa - Gabinetes de leitura da província de são Paulo: a pluralidade de um espaço esquecido (1847-1890). Dissertação de mestrado. São Paulo: F.F.L.C.H.J USP, 1990 
reveladoras das diferenças que se acentuavam entre as várias regiōes brasileiras e da perfeita articulação dos interesses públicos e privados na configuração da cultura escolar.

A literatura escolar se inseria em um contexto mais amplo no qual articulavam-se e convergiam os poderes público e privado.

- livro era, ou ainda é, um dos símbolos da civilização ocidental, como afirma Henri-Jean Martin. o livro, passando por etapas lentas, foi o motor de uma verdadeira revolução que consagrou o divórcio entre o escrito e o falado através de "maneiras de ler introduzidas no texto". A escrita e com ela a cultura livresca, passou a predominar como forma de comunicação, fazendo com que se renunciasse à transmissão oral, " à magia do verbo". O livro foi se tornando um objeto sacralizado, acabando por se transformar em "modelo da cultura ocidental".76

Nossos estadistas, no século XIX, expressaram o acordo na construção da simbologia do livro, cuidando de difundí-lo de variadas maneiras.

D.Pedro II, como chefe de Estado, esforçou-se em passar para o público, uma imagem de soberano sábio, um homem letrado, sendo inúmeras vezes representado junto a livros.

Pires de Almeida ao dedicar algumas páginas da sua história da educação brasileira ao Imperador, destacou-o como um chefe de governo exemplar, um estadista intelectual:

"Pela extensão e variedade de seus conhecimentos, pela solidez de seu julgamento, o imperador situa-se, na nossa admiração, ao lado dos maiores sábios, acima dos maiores príncipes.

Falemos, entretanto só da biblioteca. (-.)". ".77

A divulgação da literatura didática empreendida pelas autoridades e editoras inseria-se, portanto, na politica cultural do Estado, na qual o livro, como símbolo da

76 Cf. MARTIN, Henri-Jean- Histoire et pouvoirs de l'écrit. Paris: Librairie Academique Perrin, 1988 e cf. MARTIN Henri- Jean- Le livre français sous l'Ancien Régime. Paris: Promodis, 1987, especialmente o capitulo pour une histoire de la lecture, p. 227-246.

77 ALMEIDA, Jose R. Pires de- op. cit., p. 257 

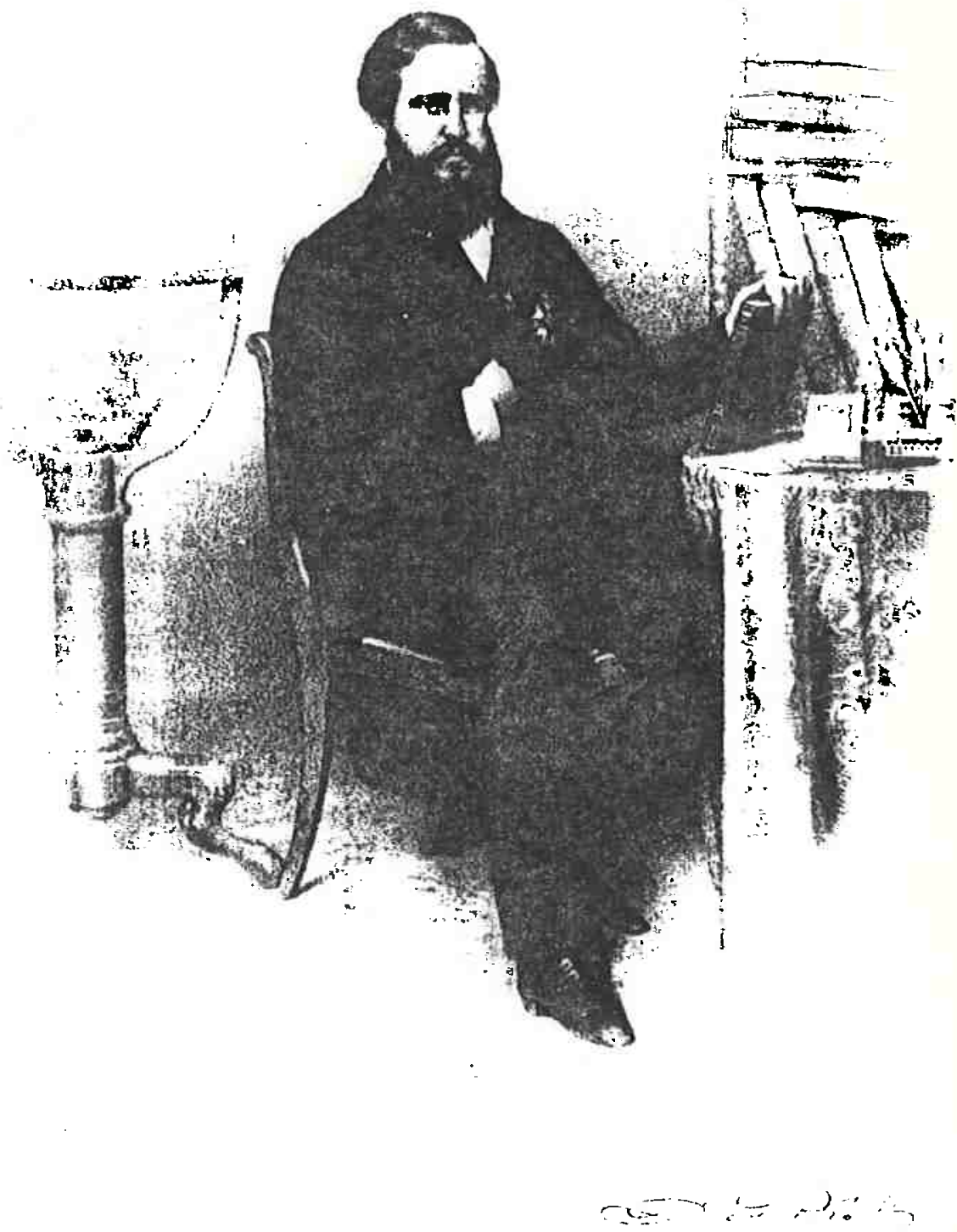

Fig. 12

D. Pedro II. Gravura de Victor Frond. Reproduzido em Ribeyrolles, Charles- Brasil Pitoresco. 
civilização ocidental, representava um papel de grande destaque.

o consumo do livro didático tornou-se quase que obrigatório nas escolas. O saber escolar contido em suas páginas era confeccionado por normas empresariais marcadas, majoritariamente, pelo modelo francês. As formas de leitura do livro didático, estabelecidas entre poder educacional e setor privado, representavam mais um dos elementos que tem caracterizado a história da educação brasileira: a permanente presença e interferência empresarial na vida escolar. 
2a Parte

Transposição didática e livros de História 


\title{
CONIPEVIIIO
}

DI

\section{IIISI'ORLL UNIYLRSIL.}

11)

\author{
JUSTIRLIIO JOSE DI Rocillh
}

() I, I:M1: ।

\section{HISTUIRA ANTIGA.}
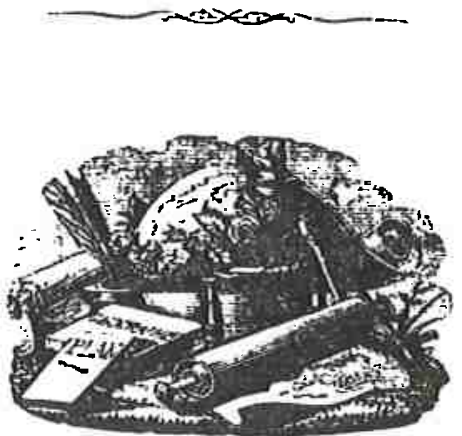

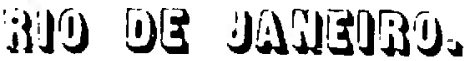

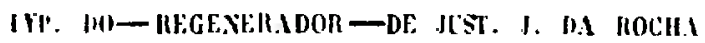

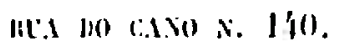

ISAC.

"Escritos para franceses, esses livros dão largo desenvolvimento aos acontecimentos da França: é justa e louvável mas que justiça pode haver em obrigar a mocidade brasileira a fatigar-se com tantos merovingeos e carloríngeos, com tantos crimes $e$ enredos de Brunegildas e Fredegundas, enquanto mal se lhe diz quais os fundadores da bela e livre monarquia a que pertenceram seus pais?!

Justiniano José da Rocha. Compêndio de história universal 


\section{CAPITULO III}

\section{LIVROS DIDATICOS E ENSTNO: DA HISTÓRIA SAGRADA À HISTÓRIA PROFANA}

o livro didático, concebido pelo Estado e fabricado pelo editor, encontra no autor o agente que elabora o seu conteúdo e nele reside seu poder de transmissibilidade.

A transposição do conhecimento erudito para o saber a ser ensinado realizada pelos autores, sofre a interferência do editor, além da subordinação aos programas curriculares, indicadores dos temas constitutivos do saber escolar. Foram os dirigentes dos Estados Modernos, conservadores ou progressistas, que organizaram os programas curriculares, sistematizando os novos conhecimentos transformados em disciplinas escolares.

Programas curriculares e livros didáticos foram sendo produzidos concomitantemente, um auxiliando o outro na elaboração dos conteúdos das diversas disciplinas a serem transmitidos pela educação formal. Os programas de ensino passaram a preceder a elaboração dos compêndios, somente no decorrer do século XIX, com a consolidação das disciplinas escolares.

Inicialmente, a elaboraçāo do livro escolar era fundamental para sistematizar saberes dispersos, oriundos do mundo erudito e que deveria servir de cabedal para a formação das futuras gerações.

Compreende-se, assim, os debates legislativos sobre o livro escolar durante as discussões na Constituinte de 1823 e, posteriormente, na redefinição do poder do Estado, nas últimas décadas do século XIX, com a implementação do regime republicano. Era inviável separar os projetos de construção de programas curriculares das discussões sobre o papel a ser desempenhado pelo livro didático. Durante o período de elaboração das reformas educativas, o livro didático 
continuou a representar, para seus idealizadores, a concretização do novo saber proposto.

Os autores dos livros escolares, ao redigirem seus textos, deveriam transpor o conhecimento erudito para a forma didática baseando-se nas normas oficiais estabelecidas e criar um estilo de exposição assimilável por um público heterogêneo. Os autores responsabilizaram-se por agrupar o corpo de conhecimentos prescritos pelo poder, dando-lhes uma lógica interna, articulada em sub-temas ou capitulos organizados em planos sucessivos. Criava-se, desta forma, o "conteúdo explicíto" de cada disciplina.

o livro escolar inscreve-se, assim, na história da disciplina à medida em que ocorria a construção do saber escolar.

As disciplinas escolares se constituíram em um meio de legitimação de determinados conhecimentos. Esse processo de construção não foi linear. Foi permeado de confrontos entre os diferentes grupos que compartilhavam as esferas do poder. A criação da História como disciplina escolar e as transformações que sofreu se inserem dentro deste quadro de conflitos.

Assim, a história do livro didático e da disciplina escolar estão intrinsicamente vinculadas nesta parte do trabalho. O desvendamento da História como disciplina partiu de uma determinada concepçāo de disciplina escolar, entendida como um corpo dinâmico de conhecimentos elaborados por especialistas que não compartilham de maneira pacífica os conteúdos, métodos e pressupostos, sendo composta por segmentos diferentes e divergentes, atuando em sua elaboração alianças e conflitos. As disciplinas escolares têm sido constantemente redefinidas de acordo com compromissos temporários que se estabelecem em um contexto educacional historicamente determinado. 1

o ensino de História proposto a partir dos primeiros programas escolares da escola pública imperial sofreu mutaçōes, foi objeto de disputas à medida em que

1 Cf. MOREIRA, Antonio Flavio B.- Curriculos e programas no Brasil. Campinas: Papirus, 1990 e CHERVEL, André- Hist. das disciplinas. op.cit. 
especialistas interferiam e lutavam pelo domínio do saber a ser transmitido. A disputa entre as facções das classes dominantes, no âmbito do conhecimento histórico, foi visível no embate entre o predomínio de uma História Sagrada em contraposição à constituição de uma História laica, de caráter positivista ou cientificista. Por outro lado, a História desempenhou papéis diferenciados segundo as concepções de um programa predominantemente humanístico e um outro voltado para os estudos denominados "científicos" no momento em que o tema da "universalidade" se defrontava com o do "nacionalismo".

As questões que emergiram desses conflitos nos levaram a investigar o nascimento da História enquanto disciplina escolar, e seu papel na construção de uma História oficial a ser disseminada pelas escolas secundárias e primárias.

Este capítulo situou os objetivos do ensino da História Universal propostos para o ensino secundário e os da História Sagrada difundida pelas diversas escolas, incluindo a elementar, acompanhando os discursos dos programas escolares paralelamente ao dos textos dos livros escolares. Em meio a tais propostas, localizamos as concepçōes de ensino humanístico engendradas pelo pensamento conservador do século XIX, em confronto com as propostas de currículos científicos, aparentemente originárias de grupos mais progressistas, buscando explicitar o sentido das mutações das disciplinas históricas. Trata-se de uma abordagem específica do saber escolar contido no iivro de uma determinada disciplina - a História - buscando identificar a mediação que os manuais estabeleceram entre saber erudito e saber a ser ensinado.

- "corpus" central da documentação foi formado pelos livros didáticos de História Universal e de História Sagrada, ao lado de programas curriculares das diferentes escolas elementares e secundárias, públicas e particulares. 
1.A História nos programas curriculares: constituição de uma disciplina

1.1 História nos programas curriculares do ensino secundário

o estudo de História, inicialmente considerado como simples anexo do Latim, disciplina todo-poderosa dentro da concepção do currículo humanístico ou literário, percorreu caminhos tortuosos até tornar-se um corpo de conhecimento sistematizado, possível de ser ensinado e transmitido nas escolas.

A constituição da História como disciplina escolar definiu-se inicialmente pelas propostas dos liberais brasileiros envolvidos nos debates educacionais da década de vinte do século passado. Parte dos intelectuais pretendia construir uma História laica, uma espécie de "ciência social" da nação que se criava sob a dominação de um Estado independente mas, não desejava abolir os princípios educativos da Igreja Católica.

Essa tendência conciliatória foi visível nos programas curriculares propostos pelos legisladores de 1827 para as escolas "de primeiras letras": "Os professores ensinarão a ler, escrever, as quatro operações de aritmética, prática de quebrados, decimais e proporçōes, as noçōes mais gerais de geometria prática, a gramatica da língua nacional, e os primeiros princípios da moral crista e da doutrina da reliqião católica e apostólica romana, proporcionados à compreensão dos meninos, preferindo para as leituras a Constituicão do Império e a História do Brasil. " 2

Para o nível médio ou secundário, no projeto de Januário da Cunha Barbosa, de 1826, houve a proposta da criação de uma cadeira de Geografia e História civil, cabendo ao professor de " história civil e cronológica, depois de dar uma noção abreviada das idélas morais e religiosas dos povos antigos e de expor os diversos modos porque marcavam e exprimiam a ordem sucessiva dos tempos,

2 PARANHos, José Maria da Silva- Cartas ao Amigo ausente. Rio de Janeiro, Ministério das Relaçōes Exteriores - Instituto Rio Branco, 1953, p. 333. . Grifos meus 
[em seguida] passaria a expor os fatos mais importantes relativos à sua política, costumes e usos mais notáveis, de maneira que o seu curso de história e cronologia tenha menos em vista o conhecimento dos indivíduos que o das causas que influíram para elevação e decadência das naçōes e fixar as épocas mais notáveis relativamente à prosperidade e desgraças dos povos." 3

Em outra proposta, debatida na Assembléia dos Deputados em 1827 que previa a criação de uma escola especial de nível médio, o Colégio de Belas-Artes, existiria um ensino de história subdividido em história geral profana, história sagrada e história do Império do Brasil. o estudo da História era concebido, assim, com nítidas separações entre uma História Sagrada, com seu tempo determinado por desígnios divinos e uma outra História "profana" ou "civil" com marcos temporais definidos pelo Estado com datações organizadas por una sequência cronológica. 4

É importante assinalar que nesse período em que se delineavam os primeiros projetos educacionais, a História era concebida como necessidade social, devendo estar presente no ensino elementar e médio. Foi, entretanto, nos cursos secundários que se iniciou a organização e a estruturação das disciplinas de história.

- plano de estudos de 1837 do primeiro colégio brasileiro de nível secundário, o Colégio Pedro II, incluiu a Historia como disciplina obrigatória e assim ela se manteve no decorrer do período estudado.

Ao acompanharmos as várias reformulações dos programas curriculares do Colégio Pedro II, depois denominado na fase republicana de Ginásio Nacional, foi possível desvendar os diferentes momentos políticos em que os estudos escolares de História estavam sendo elaborados para uma escola voltada para a formação da elite política e intelectual do país. Entre 1838 e 1901 , houve 10 regulamentos ou decretos, reformulando os planos de estudos. 5

\footnotetext{
3 MOACYR, P.- op. cit., p.565.

4 Idem- p. 566

5 Foram eles: Regulamento $n^{\circ} 8$ de 31 de janeiro de 1838 ; Decreto $n^{\circ} 62$ de $1^{\circ}$ de fevereiro de 1841; Regulamento da instruçāo primária e
} 
Os planos de estudos do Pedro II foram criados tendo em vista o atendimento de uma escola montada em regime de internato com 8 séries, que não corresponderiam necessariamente a 8 anos, podendo o aluno completar os estudos em um número menor de anos ou se estender por outros tantos, no caso de reprovações. A estruturação seriada sofreu variadas reformas e algumas das quais não tiveram tempo sequer de se concretizar. Os planos de estudos definiam as disciplinas, o tempo destinado a cada uma delas e o número de séries do total do curso. Após 1841, consolidou-se um curso de 7 anos.

Segundo os discursos dos seus criadores, o Colégio Pedro II foi inspirado nos colégios franceses do período napoleônico, inspiração que poderia aproximar-se do estilo militar embora tivesse sido nomeado um clérigo, o Bispo de Anemuria, como primeiro reitor do instituto, fato que gerava críticas quanto ao caráter a ser imprimido nesta primeira escola pública secundária.

A História era ensinada em duas aulas semanais, a partir da 6a série, em um total de 25 "lições" ou aulas, correspondendo a seis anos ou "aulas" de estudos dessa disciplina

Nas reformas subsequentes encontramos o ensino de história especificado por períodos mais definidos, como pode ser visto nos exemplos abaixo:

Em 1855:

-Geografia e História Moderna ( $3^{\circ}$ ano)

-Geografia e História Moderna e Corografia Brasileira e História Nacional ( $4^{\circ}$ ano)

-Geografia e História Antiga ( $5^{\circ}$ ano)

-Geografia e História da Idade Média ( $6^{\circ}$ ano)

secundaria do município da corte de 17 de fevereiro de 1855 ; Decreto $n^{\circ}$ 2.006 de 24 de outubro de 1857 ; Decreto $n^{\circ} 2.883$ de $1^{\circ}$ de fevereiro de 1862; Decreto $n^{\circ} 4.468$ de 1870 ; Decreto $n^{\circ} 6.130$ de $1^{\circ}$ de março de 1876 ; Decreto $n^{\circ} 6.884$ de 20 de abril de 1878; Decreto $n^{\circ} 8.051$ de 25 de março de 1881; Decreto $n^{\circ} 3.914$ de 26 de janeiro de 1901 . Cf. PILETTI, Nelson- evoluçāo do currículo do curso secundario no Brasil. Revista da Faculdade de Educação, São Paulo, 13 (2):27-72, jul./dez., 1987 e FORJAZ, Djalma- op. cit. São Paulo: Tipografia Maré, Monti \& C. [1907] 


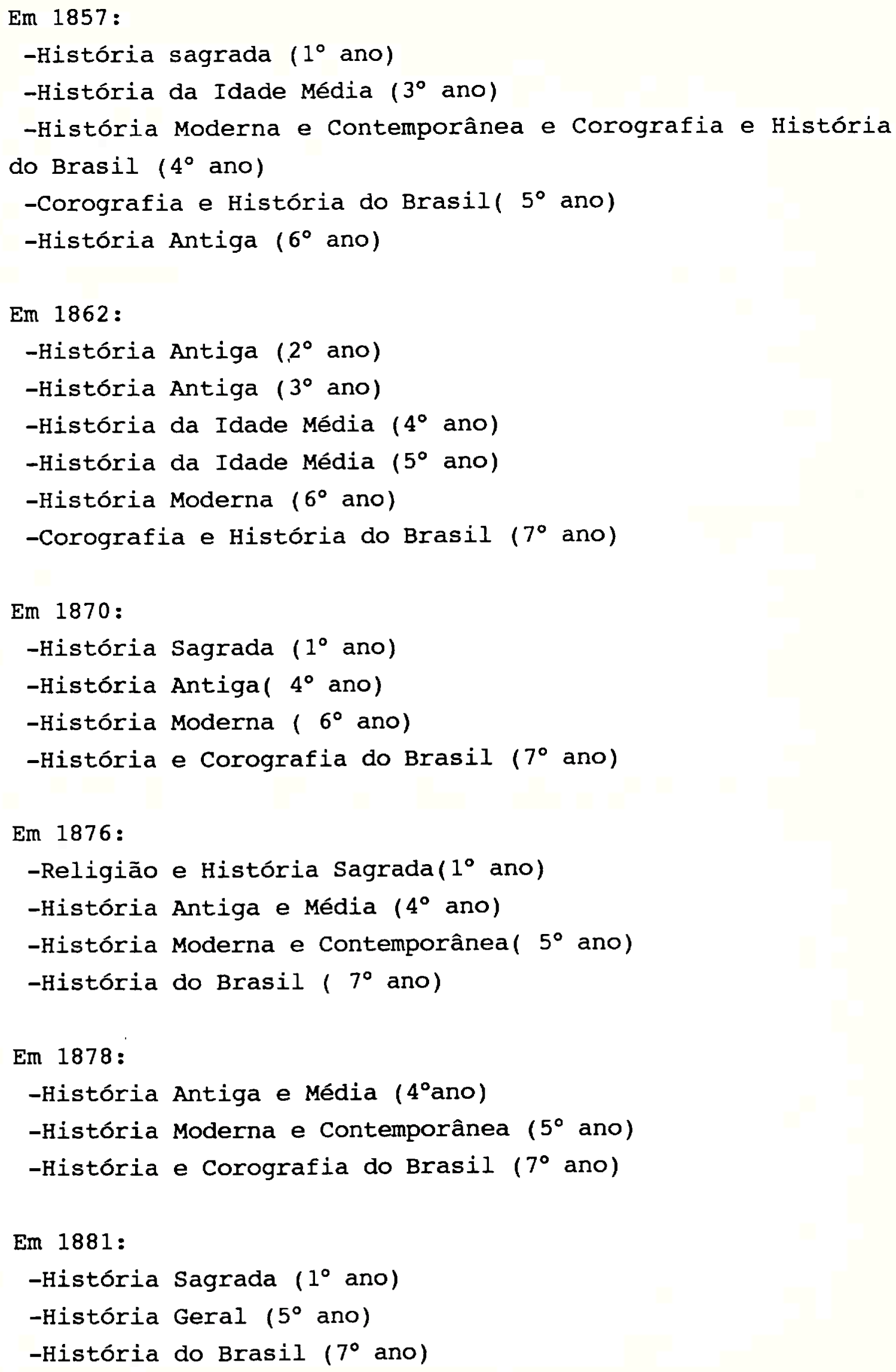

Em 1878:

-História Antiga e Média ( $4^{\circ}$ ano)

-História Moderna e Contemporânea ( $5^{\circ}$ ano)

-História e Corografia do Brasil ( $7^{\circ}$ ano)

Em 1881:

-História Sagrada ( $1^{\circ}$ ano)

-História Geral ( $5^{\circ}$ ano)

-História do Brasil ( $7^{\circ}$ ano) 
Em 1901:

-História Universal ( $4^{\circ}$ ano)

-História Universal ( $5^{\circ}$ ano)

-História do Brasil ( $6^{\circ}$ ano)

Pelos planos de estudos, se percebe a separação das cadeiras de História e Geografia em 1862 e a introdução de História do Brasil pelo Regulamento de 1855, como disciplina autônoma. O ensino da História Geral, predominante quanto ao número de anos e tempo destinado ao seu estudo, era compreendido como a História profana da humanidade e teve de coexistir em alguns anos com a História Sagrada. História Geral e História Sagrada conviveram no currículo escolar a partir na década de cinquenta, na fase da Conciliação, período que alguns historiadores consideram fértil para o avanço da educação mas onde nota-se com clareza, o caráter conservador de que ele era revestido. 6

Nos anos cinquenta, houve efetivamente uma maior preocupação com os temas educacionais, consolidando-se legislação, realizando-se reformas nas escolas secundárias e elementares. Os projetos educacionais desse período foram, entretanto, marcadas pela ação do grupo conservador fluminense originário de importantes famílias produtoras de café, empenhado na manutenção da escravidão. Na esfera educacional, valorizavam a instrução, concebendo-a como meio de manutenção de privilégios, como forma de "ilustrar" parcelas selecionadas da população. Explica-se assim a ênfase dos projetos sobre a valorização da escola privada e do papel da Igreja na cultura escolar. 7

o conservadorismo educacional é perceptível pela introdução da Religião como matéria obrigatória e, sobretudo

6 o trabalho de Marioto Haidar ê um dos que reforça esta idéia sobre a fase da Conciliação, reforçando a corrente de historia da educação pela qual a educação escolar prosperou no Brasil apenas em seus periodos de paz, sem lutas partidárias internas, lutas provinciais ou externas .

7 cf. MATros, Ilmar Rohloff-o tempo saquarema. São Paulo: Hucitec ; Brasilia: INL, 1987 
pela ênfase do currículo calcado nos estudos Literários e na Retórica. 8

Não foi casual que a Reforma de 1853 e os regulamentos de 1855 e 1857 tivessem sido inspirados pela Reforma francesa de 1850, denominada Lei Falloux, responsável pela reintrodução do poder religioso nas decisões educacionais francesas. O ensino público passou a ser vigiado pela moral religiosa católica para evitar que professores disseminassem doutrinas socialistas ao invés "de prêcher la résignation à 1 'ordre voulu par Dieu." 9 A opção dos legisladores pela lei francesa explica-se pelas soluções apontadas para a disseminação de escolas particulares, ou escolas de ensino livre, como eram denominadas.

Para os estudos históricos este foi o momento da História Sagrada entrar em disputa com a História civil ou profana, disputa que representava formas de legitimar os agentes históricos do poder instituído, situando a Igreja como parceira inseparável do poder civil.

A disputa entre as duas visōes e construções históricas foi retomada na década de 70 e, com a Reforma de Leôncio de Carvalho de 1878, a Religião e a História Sagrada, enquanto matérias do secundário, desapareceram provisoriamente, do ensino oficial.

Os programas do currículo do Pedro II, propostos para um ensino seriado, com conteúdos ordenados e sistematizados, foram entendidos, por Mariotto Haidar, como um ideal jamais concretizado, vitimado pela imposição dos exames parcelados de preparatórios para o ensino superior:

"A função atribuída aos estudos secundários, encarados no Império, quase que exclusivamente, como canais de acesso aos cursos superiores, os reduziu, de fato, aos preparatórios exigidos para a matrícula nas Faculdades. Consubstanciando os requisitos mínimos necessários ao ingressso nos estudos maiores, os conhecimentos requeridos nos exames preparatórios constituíram o padrão ao qual

8 Os decretos educacionais que introduziram o ensino de Historia Sagrada nas escolas foram os de 17 de fevereiro de 1855 e 0 artigo $5^{\circ}$ de 1857 para o Colégio Pedro II.

9 Cf. PROST, Antoine- op. cit.-p. 173 
procuraram ajustar-se os estabelecimentos provinciais e particulares de ensino secundario." 10

A prática dos exames parcelados foi responsável, sem dúvida, pelo número insignificante de alunos que concluíam o curso do colégio Pedro II. Vimos, por exemplo, que em 1878, para 269 alunos matriculados no Colégio, apenas três receberam o diploma de bacharel. 11

Tais resultados não representavam somente o descaso dos alunos por uma escolarização prolongada e dotada de um extenso currículo a ser seguido mas eram fruto da forma como era estabelecido o acesso aos cursos superiores, que prescindia de tal estágio educacional. Era suficiente, aos estudantes, a aprovação nos diversos exames parcelados preparatórios. Contavam os alunos também com o auxílio de uma politicagem de compadrio e malandragens: "As irregularidades de toda a ordem registradas nos exames de preparatórios desencorajavam estudos sérios e perseverantes: uma boa carta de empenho poderia abrir portas muitas vezes fechadas ao mérito e ao saber."12

A situação irregular de tais exames levou o governo central a várias tentativas de reformulações dos exames mas que acabaram por se limitar a reformas dos Cursos Anexos das Faculdades de Direito e de Medicina. Tais reformulaçōes foram simples medidas paleativas que não mudaram a natureza dos exames preparatórios.

Predominaram tanto os interesses de agentes do setor privado que auferiam lucros com o sistema de exames sem exigências de estudos regulares e sistematizados como a mentalidade de nossas elites, sempre prontas ao jogo do poder, fazendo valer suas influências.

As classes dirigentes não podiam legislar sobre a educação secundária e superior no sentido de transformar tais niveis de ensino em estudos sérios, exigindo uma formação intelectual mais profunda porque desejavam preservar os privilégios politico e social de que gozavam.

10 HAIDAR, M. - op. cit., p.36

11 Idem, p. $11 \overline{6}$

12 Idem, P. 38 
Para elas bastava o título de "doutor", adquirido com estudos superficiais.

Um relato sobre os exames preparatórios de Recife em 1860 demonstra o quadro fraudulento predominante em nossas instituições para a "formação" dos quadros políticos e intelectuais: "Suponho não poder encontrar-se nesta terra uma pessoa qualificada que não tenha sido uma vez patrono de exames, que não tenha vergado do peso de considerações extrínsicas. Pede-se a cada canto, multiplicam-se as cartas, fazem-se questões de ponto de honra, dão-se rompimento de relações, e em resultado, lá chega a injustiça relativa, vai-se a força moral dos juízes e a forja dos superficiais. continua a trabalhar." 13

o capital cultural adquirido nos cursos de Direito ou de Medicina servia para reforçar a diferenciação social, para aumentar as desigualdades das classes sociais por intermédio de diplomas de estudos superiores. Era um "ritual de iniciação" que se prestava ainda para a aprendizagem dos jovens nos caminhos da política do clientelismo.

- capital cultural a ser adquirido pelos futuros dirigentes da nação, no decorrer do curso secundário deveria, portanto, ser condizente com $\circ$ que se pretendia para o ensino superior. o currículo literário para este setor social era o mais adequado.

o currículo de "línguas" do Pedro II contou sempre com - predomínio do Latim e, curiosamente, o estudo da Língua Portuguesa teve que enfrentar a rivalidade do ensino do Francês, língua nobre e internacional cujo aprendizado dava status. Comparando três planos de estudos do famoso colégio temos :

Em 1855:

Português - 3 anos de estudos

Francês - 6 anos de estudos

Latim - 6 anos de estudos

13 GUIMARÃES, Aprígio Justiniano da Silva- Estudos sobre o ensino público pelo Dr. Aprigio Justiniano da Silva Guimarães. Recife: Geraldo H; de Meira, 1860, p.81. Citado por haIDAR, M.- op cit. , p.41 
Em 1878:

Português- (incluindo literatura) 2 anos de estudos Francês-2 anos de estudos

Latim- 3 anos de estudos

Em 1901:

Português- 4 anos de estudos

Francês- 4 anos de estudos

Latim- 3 anos de estudos

Os defensores do ensino das línguas antigas "ou mortas" argumentavam que, principalmente, o estudo do Latim era "uma ginástica intelectual" indispensável ao homem culto. Estudar Latim não significaria um total domínio da língua mas, uma forma de adquirir "cultura". Ter "cultura clássica" serviria para ler os clássicos, para ler os textos originais e admirá-los. De forma semelhante aos currículos franceses, o latim era, na realidade, um saber decorativo, servindo para formar juristas e políticos, profissionais que necessitavam de um arsenal de citações latinas para seus discursos.

Mais marcante para o fortalecimento das diferenciaçōes culturais da sociedade brasileira, entre nós, foi o ensino do Francês. O domínio do Francês foi outra marca de distinção social. A importância do seu aprendizado residia no domínio de uma língua aristocrática de um dos mais importantes paises civilizados, língua em que se exprimiram grandes pensadores, língua dos "notáveis". Aprender Francês era importante igualmente para futuras citações, para uma oratória parlamentar, para a construção de um discurso erudito impossível de ser compreendido pela população iletrada. Tal é o espírito das determinações do regulamento das Aulas preparatórias das Faculdades de Direito de 1856 , em seu Artigo 6:

"Não obstante a disposição do segundo preceito do artigo precedente, nenhum aluno poderá matricular-se nas aulas de retórica e filosofia sem que tenha aprendido latim e francês; nem na de história e geografia, sem que mostre 
saber francês.A prova nestes dois casos será dada por atestado passado por professor público ou por professor particular autorizado pelo governo para lecionar." 14

A História, inserida no currículo de "humanidades" moldado para a formação das classes dirigentes do país, tinha como objetivo auxiliar a compor uma casta de privilegiados brasileiros, inculcando-lhes os padröes culturais do mundo ocidental cristão, fazendo com que se identificassem com o mundo exterior civilizado. Esta missão da história explica sua manutenção como disciplina obrigatória nos exames preparatórios das Faculdades de Direito, de Medicina, da Escola Militar, Escola Politécnica, Escola de Minas de Ouro Preto, no Colégio Naval.15

A história educacional tem realizado várias críticas em relação ao predomínio do currículo humanístico nas escolas brasileiras, considerado-o responsável pelo "atraso" do país, pela permanência de uma visão conservadora, sobretudo, a nível econômico.16

Acreditamos, contudo, que seria anacrônico se pensar na configuração de um currículo baseado em disciplinas de carater "cientifico" antes do final do século XIX, principalmente em um país agrário e escravagista. As propostas de mudanças curriculares visando uma formação de caráter mais "científico", só ocorreram no final do século XIX, quando efetivamente iniciava-se o processo de industrialização em una sociedade que se urbanizava.

Caetano de Campos, ao reformar a Escola Normal de são paulo e as escolas modelos, transformadas em escolas anexas, previu 3 graus de ensino para estas últimas. $01^{\circ}$ grau corresponderia ao ensino primário e previa a construçāo do $2^{\circ}$ grau, abrangendo a idade que vai dos 10 aos 15 anos e um posterior, de $3^{\circ} \mathrm{grau}$, dos 15 aos 18 anos. Para esse educador, $\circ 2^{\circ}$ grau seria a continuação natural do $1^{\circ}$ grau e - $3^{\circ}$ grau teria uma tarefa dupla: "ou leva o moço às

14 Regulamento das Aulas Preparatórias das Faculdades de Direitoportaria de 4 de maio de 1856. Apud HAIDAR, M.- op. cit., p. 68

15 os estatutos e regulamentaçōes sobre as matérias dos exames preparat6rios constam do trabalho de HAIDAR,-op. cit.- p. 48, 66, 77 . 16 o citado trabalho de Mariotto Haidar é o mais representativo dessa tendência. 
Academias, e para isso completa sua educação, ensinando-1hes as Iinguas estrangeiras, ou limita-se a estudos complementares da ordem dos que interessam mais particularmente o homem, e essas humanidades são o pórtico das locubraçōes abstratas que no correr da vida o podem preocupar." 17

Caetano de Campos, inspirado em Francis Parker, conferia às Ciências Naturais um lugar privilegiado e predominante na organização das matérias que compunham o currículo. A formação do pensamento se fazia, segundo ele, pelas ciências naturais, únicas com possibilidade de dar os elementos de uma "disciplina mental" e é por esta razão que os modernos pensadores faziam das ciências experimentais a base da educação: "procurar a verdade no mundo concreto que nos rodeia é, segundo o critério atual, o mais útil processo para aprender, pois com esse hábito de investigação chega-se à posse das maiores aquisições intelectuais." 18

As disciplinas escolares, partindo desses pressupostos, estruturavam-se de modo integral, de forma conectada, de maneira interdependente. A sequência de estudos seria constituída gradualmente, cabendo somente ao fim do curso, a aquisição das "humanidades", concebida diferentemente dos programas anteriores. As "humanidades" eram compostas por disciplinas politicas, fundamentalmente. Eram elas: Educação Cívica, Economia Política, História Geral e da Pátria, Noçōes de Escrituração Mercantil.

A proposta de Caetano de Campos representava a posição de educadores que se opunham aos defensores das "humanidades clássicas", segundo os quais estas eram as únicas disciplinas verdadeiramente formadoras do espírito. Os debates travados colocavam as disciplinas literárias em oposição às científicas que até então eram consideradas como ensinamento técnico e prático, estando ausente de seus objetivos, as exigências de uma formação do "espírito, do intelecto". Neste contexto surgiu a constituição mais

17 CAmpos- Antonio caetano de-Relatorio sobre as escolas de $1^{\circ}$ e $2^{\circ}$ graus anexas a Escola Normal.São Paulo: Tipografia de Vanorden cia., $1891, \mathrm{p} .18$

18 Idem, ibidem 
explícita das disciplinas escolares como um corpo formal de conhecimentos a serem transmitidos, distinguindo-se disciplina literária e disciplina científica. A disciplina escolar começou, a partir dessas oposições, a se emancipar da concepção de "uma ginástica intelectual" para se configurar como conhecimento delimitado por objetivos e métodos pedagógicos cujos conteúdos se originavam das ciências de referência. 19

1.2 História nas escolas elementares e profissionais *

o ensino de História não foi exclusividade do ensino secundário, estando previsto como disciplina optativa nos curriculos das escolas elementares e profissionais. Os planos de estudos das escolas elementares de $2^{\circ}$ grau das províncias que as criaram, na maioria das vezes, incluíram "Noçōes de geografia e de história, principalmente a nacional" como disciplinas "permitidas" pelas autoridades e consideradas como facultativas ao ensino elementar.

Ao lado da História Nacional, a História Sagrada apareceu como matéria constitutiva do programa das escolas primárias depois de 1855 mas era, geralmente, conteúdo integrante de "educação moral e religiosa." o "método de ensino" de Instrução Religiosa das escolas municipais da Corte de 1877, não deveria ter sido diferente dos demais do período e dele constava a seguinte sequência de matéria:

"1ㅇ Da criação, do pecado do primeiro homem.

$2^{\circ}$ Caim e Abel, corrup̧̧ão geral, dilúvio

$3^{\circ}$ Torre de Babel, dispersão dos povos, vocação de Abraão.

$4^{\circ}$ Ismael, Isaac, Esaú e Jacó.

$5^{\circ}$ José do Egito, Moisés

$6^{\circ}$ Recapitulação das cinco classes precedentes.

$7^{\circ}$ Viagem do deserto, entrada na terra de Canaã.

$8^{\circ}$ Governo dos Anciãos e dos Juízes. Realeza em Israel.

19 Sobre as disputas entre as disciplinas humanísticas e as cientificas ver CHERVEL, André- Historia das disciplinas.,,op. cit. e GARIN, Eugenio- L'éducation de l'homme moderne.Traduit de l'italien par Jacqueline Humbert. Paris: Fayard, 1968. 
$9^{\circ}$ Cisma Samaritano, cativeiro da Babilônia.

$10^{\circ}$ os profetas, volta do cativeiro.

$11^{\circ}$ Os macabeus.

$12^{\circ}$ Recapitulação geral- Erames" 20

Os programas curriculares das escolas elementares foram sendo ampliados no decorrer dos anos 70, variando, entretanto, de acordo com as províncias.

As idéias cientificistas de alguns dos intelectuais que atuavam em cargos da burocracia educacional das províncias começaram a aparecer nos planos de estudos. 0 regulamento de 1874 de Pernambuco determinava que constasse do ensino das escolas públicas, além do ensino de Língua e Aritmética, "noções de ciências físicas aplicáveis dos usos da vida; noções de agricultura; geometria elementar e agrimensura; desenho linear." 21

A incorporação de estudos das Ciências ocorria seguindo os preceitos metodológicos de"Lições das coisas" entendidos "como meio de instrução" para as "ciências físicas, a história natural e os objetos que serven aos usos diarios da vida ordinária". 22

Para transpor os "rudimentos científicos" em saber a ser transmitido e ensinado para crianças, ampliando os conteúdos curriculares, houve propostas detalhadas:

"Mas essas matérias de que se sobrecarrega assim o programa escolar não são por demais vastas e superiores à compreensão dos que frequentam as escolas primárias?

E esta uma objeção que alguns fazem e que tem sua força aparente. Com efeito, como é que ciências tão importantes e que envolvem as mais altas concepções do espírito humano podem revestir a simples forma elementar e pôr-se ao alcance de inteligências que agora se iniciam nos conhecimentos mais rudimentares?

A isto tem respondido que distinguem-se nas ciências em geral duas partes que é facil separar: uma se ocupa das

20 CAVALCANTI, João Barbalho Uchoa- Relatorio...-op. cit., p.19

21 Idem, p. 11

22 Idem, p. 159 
fórmulas e da indagação e estudo das leis, a outra recolbe os resultados pela primeira obtidos, proclama-1hes os princípios e deles expõe a síntese.

Aquela, só acessível aos sábios, escapa por sua natureza a toda vulgarização propriamente dita; mas a segunda como que pertence ao domínio público das inteligências e é muito fácil que a compreendam mesmo as crianças de certa idade. (...) . "23

E, juntamente com "as liçōes das coisas", o autor da proposta incluia alguns tópicos sobre História e Geografia Universal e do Brasil, acrescentando História regional.

Dentro das perspectivas dos educadores desejosos de ampliar as disciplinas do ensino elementar, o ensino de Historia teria dois objetivos. Serviria como lições de leitura, com temas menos áridos, para "incitar a imaginação dos meninos" e para fortificar o "senso moral", aliando-se à Instrução Cívica, disciplina que deveria substituir a "Instrução Religiosa".

No final da década de setenta os responsáveis pelas reformulações dos currículos da escola primária criaram um programa de Historia profana mais extenso, eliminando-se a História Sagrada. O ensino de História se iniciaria por "pequenos contos historicos, que [serviriam] para despertar a curiosidade dos alunos, interessálos neste gênero de estudos; depois vêu as notícias biográficas dos personagens célebres, - episódios importantes da história de cada povo, - noções sobre a origem, vida e costumes de cada um, - um esboço geral da história universal, com o desenvolvimento de certas épocas que mereçam estudo especial". 24

Os programas diferiam de província para província e assim prosseguiram após o regime republicano. O número de anos de estudos fornecidos pela escola primária foi muito variável $(3,4$ ou 5$)$, divididos en graus, denominados de $1^{\circ}$ e $2^{\circ}$ graus ou, escola primaria elementar e escola primária complementar.

23 Idem, p. 41

24 Idem, p. 194 
Na República, São Paulo representou a vanguarda na organização seriada das escolas primárias, criando os grupos escolares, distribuindo em seus programas, o tempo destinado a cada uma das disciplinas. O tempo esćolar era de 5 horas, sendo a História ensinada a partir do $1^{\circ}$ ano, para as sessões femininas ou masculinas. A História Pátria era prevista para $\circ 1^{\circ}$ ano, duas vezes por semana, perfazendo um total de 30 minutos semanais. Para as séries seguintes este tempo foi dobrado, podendo ser distribuido em três dias da semana. 25

Entre as propostas curriculares e sua efetivação em sala de aula existiu sempre um hiato. A sala de aula foi palco de uma prática extremamente mais simplificadora. A criação de escolas de $2^{\circ}$ grau elementar ou de "aperfeiçoamento", ou ainda de ensino "primário superior ou complementar" ocorreu de forma limitada, existindo em alguns centros urbanos mais desenvolvidos. Atentas a essa realidade, as autoridades educacionais acabavam por exigir dos professores uma parte obrigatória, composta da leitura e escrita, noções de Gramática, princípios de Aritmética, com a exigência do estudo do sistema métrico de pesos e medidas e o ensino da Doutrina Religiosa que permaneceu mesmo após o advento da República. As disciplinas consideradas facultativas eram raramente ensinadas, conforme atestam relatório de Diretores de Instrução:

"Os fenômenos mais simples da natureza, aqueles mesmo que incessantemente se passam em torno de nós, são uma novidade, um mistério para ele, se lhes perguntam a respeito de alguma coisa, se deles the peden qualquer explicação ! não possui os conhecimentos mais elementares sobre a matéria e origem dos objetos que estão todos os dias sob suas vistas! Não conhece os agentes naturais utilizados pelo homem em sua indústria. Os animais, as flores, os metais, todo o universo visível, lhe são estranhos !" 26

Os planos de estudos para as escolas populares, denominação que as escolas elementares para crianças e

25 Cf. Anuario do Ensino do Estado de são Paulo- op. cit., 1907/8, $p_{\dot{6}} 416$ a 423 .

26 CAVALCANTI, Joāo B.-_ op. cit., p.38 
adultos passaram a ter no final do século XIX, surgidos depois dos anos 70 e nos primeiros anos do século atual, representaram os conflitos entre grupos de intelectuais, alguns já em postos de importância no meio educacional desde - Império, que consideravam viável a disseminação do conhecimento escolar para um número mais significativo da população. Entretanto, mais do que questões quantitativas, as tensões se colocavam face ao projeto futuro do país, sua dependência frente ao mundo tecnológico e dos grandes capitais financeiros e imperialistas. Como preparar, ou educar, uma geração para enfrentar os desafios do capitalismo em país produtor de café, de açúcar, cujas elites se degladiavam pela manutenção da escravidão ou pela implementação de mão-de-obra-livre, pela imigração branca européia?

Parte dos intelectuais engajados nos projetos de modernização pela via da industrialização, considerava a História da pátria, ao lado da Geografia que delimitava os contornos territoriais do país, como disciplinas fundamentais a serem disseminadas para o conjunto da população estudantil.

A História era entendida como componente da formação nacional sem perder seu caráter universal. Em primeiro lugar viria o conhecimento da pátria e depois a inserção do homem brasileiro na História da humanidade, na História das Civilizações.

Outros educadores adeptos da educação popular possuíam objetivos menos abrangentes para a presença da História no ensino das classes trabalhadoras. Concebiam uma História a serviço da "moralização do povo". Para promover a instrução popular era necessário fazer das escolas elementares, especialmente as noturnas, "grandes centros de reação contra os elementos desmoralizadores das classes populares." 7 Enfatizava-se o papel específico de algumas disciplinas curriculares e da importância da leitura dos livros didáticos: "Os livros de leitura, os compêndios de geografia

27 CORREIA, Conselheiro- Discurso na Associação Promotora da Instrução. Revista Pedagogica, Rio de Janeiro, 2, 1(15), abril 1891, p. 436 
econômica e industrial, de história pátria, de economia doméstica, de higiene procuram menos armazenar ciência e muito mais moralizar o povo, precave-1o contra as teorias subversivas dos que abusam do livro, do jornal, da tribuna. "28

Para a maioria dos educadores que concordava com a escolarização estendida às classes populares, a História a ser ensinada desde $01^{\circ}$ ano escolar para os trabalhadores livres que emergiam em substituição aos escravos, deveria inculcar determinados valores para a preservação da ordem, da obediência à hierarquia para chegar ao progresso. 0 conceito de cidadania, criado com o auxílio dos estudos de História, serviria para situar cada indivíduo em seu lugar na sociedade: cabia ao político cuidar da política e ao trabalhador comum restava o direito de votar e de trabalhar dentro da ordem institucional. Os feitos dos "grandes homens", de seres predestinados, haviam criado a nação e representantes destas mesmas elites cuidariam de levar a nação ao seu destino.

Parte desses intelectuais foi responsável, nas últimas décadas do século XIX, pela criação de lojas maçônicás que atuaram em campanhas abolicionistas. Seus seguidores eram, majoritariamente, republicanos, compondo "as elites modernizantes". As iniciativas educacionais desse grupo deram origem a escolas voltadas para a educação popular, oferecendo cursos noturnos de instrução primária. Em são Paulo, a mais importante instituição criada por este grupo foi a "Propagadora da Instrução Popular" de 1873 que mais tarde, em 1883, sob a liderança de Leôncio de Carvalho, transformou-se no Liceu de Artes e ofícios.

Para estas escolas,organizaram-se currículos que se estendiam além do primário, oferecendo um plano de estudos onde encontramos disciplinas de formação geral e técnicas. Seriam elas: "leitura e caligrafia, elementos de aritmética, elementos de geometria, desenho linear, lingua portuguesa, lingua francesa, sistema métrico, história pátria, geografia- com especialidade da América-, noções de moral e

28 Idem, ibidem 
análise da Constituição do Império e previa-se os cursos de mecânica, física, química e de outros ramos das ciências naturais, além de elementos de agrimensura e uso prático dos instrumentos." 29

Assim, em escolas profissionais, destinadas aos trabalhadores, como as dos Liceus de Artes e ofício, do Rio de Janeiro ou de São Paulo, surgiu um tipo de ensino escolar em que se mesclavam disciplinas do primário e do secundário, destinando-se à História, principalmente, o ensino do passado político do país.

o ensino feminino das escolas primárias oficiais, como foi assinalado, pouco divergia do que era destinado aos meninos, acrescido de prendas dométicas e restringindo a aritmética. Embora tivessem existido propostas de criação de escolas secundárias públicas para as meninas, estas não se efetivaram. Apenas escolas particulares investiram em estudos de nível médio para as jovens. As escolas confessionais, sob regime de internato, eram as preferidas das elites aristocráticas e cresceram numericamente no decorrer do período estudado.

As propostas educacionais desenvolvidas nos internatos femininos, como os das Irmãs de São José de Chamberry, eram condizentes com os propósitos de uma sociedade dominada por uma elite ciosa de se modernizar sem deixar, entretanto, qualquer espaço para mudanças que pudessem trangredir seus privilégios e sua formas de dominação. A educação da mulher era concebida nos moldes a conferir a sustenção de um ideário liberal conservador, da mulher como "boa esposa e boa mãe". A mulher não deveria estar ausente do mundo letrado mas deveria conhecer seu papel no mundo dos homens, na educação dos filhos segundo preceitos da religião.

A educação feminina deveria ser refinada, objetivando preparar a mulher para o convívio social dentro de regras precisas para exercer condignamente suas funções de esposa fiel e mãe dedicada ao lar. Predominavam nas escolas privadas, o "ensino de Francês, piano, desenho, pintura e

29 MORAES, C. S. Vidigal-op. cit., p. 54 
"obras de gosto" (confecção de flores, crochê) ao lado de algumas das demais disciplinas "instrumentais."30

Os programas de ensino da Congregação de São José, de 1850 a 1919, em Itu e de Taubaté, pouco mudaram, sem acréscimos significativos, demonstrando que o projeto das escolas católicas conceituadas pelas elites permaneceu inalterado, no que se refere à concepção de educação feminina. O ensino de História profana servia como instrumento de ornamento cultural e a História Sagrada era concebida como fundamento da permanência e imutabilidade dos costumes e do lugar da mulher na sociedade.

As disciplinas históricas nas Escolas Normais foram estabelecidas na década de setenta quando se registrou avanço, em algumas províncias, quanto à questão dos cursos de formação do magistério, surgindo no Rio de Janeiro e são Paulo propostas mais consequentes para a profissionalização dos docentes.

A construção dos programas curriculares das diferentes Escolas Normais esbarrava continuamente nos problemas referentes à prática docente e na inclusão dos estudos pedagógicos ao lado dos conteúdos das disciplinas específicas. Os programas, com raras exceções, eram criados circunstancialmente, segundo se constata pelos Relatórios de Instrução dos presidentes de províncias:

"Sem desconhecer que me faltava competência para reformar(..), não deixei todavia de atender à urgente necessidade de faze-1o para dar vida regular à escola Normal. Por ato de 14 de de fevereiro(..) criei a cadeira de física, química, botânica, zoologia e francês. Reduzi a dois anos o curso normal que era de três. (..) Para que o programa se tornasse exequível, apesar da nova cadeira, dispensei os estudos de logarítmos na aritmética, da algebra e da cosmografia, da qual se darão as noções necessárias no ensino de geografia." 31

30 Cf. MANOEL, Ivan- Igreja e educação feminina: os colégios das Irmās de São José de Chambery (1859_1919).Tese de doutorado. São Paulo,F.F.L.C.H./USP, 1988, p. 190

31 Relatório de Marcondes de Andrade, Presidente da Província do Rio de Janeiro, 1880. Apud MOACYR- Inst, e prov.,ap. cit. v2.,p.276 
As disciplinas de História dos programas das Escolas Normais não divergiam das demais escolas, contemplando a História Sagrada que desapareceu dos currículos no período republicano e História Universal acrescida de História do Brasil.

Os programas curriculares produzidos e concebidos para as escolas primárias e profissionais caracterizaram-se por constantes mudanças, variando as disciplinas a serem ministradas. Neles, geralmente, o ensino de História era considerado como necessário, prevalecendo como objetivo fundamental a formação moral, concebendo-se a História como exemplo para futuras gerações. o currículo do ensino secundário, mais debatido e estruturado, com disciplinas mais definidas, existiu precariamente, subordinando-se aos interesses financeiros da indústria particular que se ampliava e pela politica nefasta das elites "clientelísticas" que colocaram o saber escolar como objeto de trocas e favores políticos.

\section{Da História Sagrada à História profana}

\subsection{História Sagrada nos livros didáticos}

Na obra didática a disputa entre a História Sagrada e a profana aparece de diferentes formas. o conteúdo de História sagrada pode ser encontrado em vários textos escolares, nos livros de leitura para o ensino das primeiras letras ou em compêndios de História Universal para o ensino secundário. No ensino primário, a História Sagrada competia com os demais conteúdos históricos, podendo-se encontrá-la na maioria dos textos destinados à alfabetização. A medida em que as disciplinas históricas dividiam-se em História Sagrada, História Universal (ou da Civilização) e História do Brasil, houve um aprimoramento na confecção de obras especificas do passado cristão.

A História Sagrada ensinada nas diversas escolas possuía, diferentemente da História profana, objetivos 
delimitados com bastante precisão, sendo definida por um historiador francês como"l'ensemble des événements d'ordre historique contenus dans la Bible et qui groupe les récits de $I$ 'Ancien et du Nouveau Testament d'une manière cohérente et parénétique (c'est à dire à des fins d'exhortation morale). " 32

A cultura histórica acessível à maioria da população era marcada pelos ensinamentos da História sagrada, fornecedora de lendas, de dramas, epopéias com heróis que se difundiam e eram transmitidos oralmente pela Igreja Católica. Esta memória histórica passou a ser sistematizada pelos programas escolares e, mais detalhadamente, pelos livros didáticos especialmente confeccionados para o ensino institucional. Neles podemos encontrar um plano elaborado sob uma determinada concepção pedagógica, buscando uma comunicação narrativa adequada a crianças e jovens. 0 conhecimento histórico servia para uma catequese, como um método mais agradável para apreender a moral cristã. A difusão da História santa era feita, inicialmente ou paralelamente, pela oralidade das pregaçōes dos padres, pelo visual das imagens das igrejas e gestos das cerimônias religiosas. No plano do ensino, o livro escolar complementava a estratégia da Igreja na preservação e divulgação crescente de seus ensinamentos e de sua moral.

Nos livros de leitura elaborados para os primeiros passos do processo de alfabetização encontravam-se vários textos extraídos da Bíblia, narrando episódios de exortação moral. O último capítulo do segundo livro de leitura do famoso barão de Macaúbas, "Criação do mundo", narrava, por exemplo, em 10 páginas, com uma linguagem simplificada, os episódios bíblicos até a morte de Abel. Outro autor da literatura infantil, Landelino Rocha, dedicou em seu Segundo livro de Leitura 12 capítulos à vida de Jesus, além de outros tantos resumos das párabolas do Novo Testamento, tais como o "Bom Samaritano", o "Fariseu e o Publicano".33

32 Definição de Pierre ZIND, apud CRUBELIER, Maurice- De I'histoire sainte à l'histoire de France. Les Cahiers Aubois. Paris, $\mathrm{n}^{\circ}$ spécial, 1986 , p. 91

33 Cf. ROCHA, Landelino- Segundo livro de leitura para uso da infância brazileira. 59 ed. Recife: J.W. de Medeiros, 1883. 
Os livros didáticos de História Sagrada eram, majoritariamente, traduções de textos europeus, produzidos por clérigos, além dos de autores portugueses. Eram obras isentas da autorização civil, cuja divulgação dependia exclusivamente das autoridades eclesiásticas das províncias. os catálogos das editoras indicaram que vários textos de História Sagrada foram reeditadas por muitos anos, sendo pertencentes ao grupo de livros de "longa vida". Foi o caso do Catecismo histórico em compêndio resumindo a história sagrada e doutrina cristã de Fleury 34

Dentre as obras nacionais, destacou-se a História Sagrada ilustrada para uso da infância, composta pelo cônego Dr. J. C. Fernandes Pïnheiro, dividido em quatro partes: " $1^{\circ}$ uma relação analítica dos livros do antigo e novo Testamento; $2^{\circ}$ uma tabela cronológica dos principais acontecimentos; $3^{\circ}$ um vocabulário geográfico explicativo dos nomes dos povos e países mencionados na mesma história; $4^{\circ}$ um rocabulário dos nomes próprios bíblicos." 35

Pela constância com que aparecem nos catálogos das editoras, os textos de Joaquim Maria de Lacerda parecem ter sido os preferidos. Havia uma História Sagrada contida em vários capítulos do Tesouro da Infância e outro especificamente confeccionado para a divulgação da História Bíblica, o Compêndio da história sagrada," obra ornada com 115 lindas estampas e um mapa colorido da Palestina." 36

34 FLEURY - Catecismo histórico em compêndio resumindo a historia sagrada e a doutrina cristā. Rio de Janeiro: Felix Ferreira, s.d. 0 Catecismo de Fleury era obra recomendada desde a decada de trinta pelas autoridades educacionais e a partir de 1883 ele constou do Catálogo da firma Alves \& Cia.

35 PINHEIRO, J.C.Fernandes- Historia sagrada ilustrada. Rio de Janeiro: B. L. Garnier. Catálogo da Livraria de B. 1 . Garnier. Rio De Janeiro, 1866

36 Catalogo de vendas da Livraria Garnier sobre as obras do autor, apresentada na contra-capa de LACERDA, Joaquim Maria de - Pequena historia do Brasil. 6a ed., Rio de Janeiro: B.L. Garnier, 1887. J. Maria de Lacerda foi autor de inúmeros livros didaticos e após seu falecimento teve suas obras reeditadas pela Garnier. Era "filho do capitāo de mar e guerra João Maria Pereira de Lacerda, nasceu no Rio de Janeiro em 1838 e faleceu em Paris em 1886. Formado em Direito, membro da Arcádia Romana e de várias associaçōes literárias da Europa, dedicou-se com inexcedivel aplicação e solicitude à educaçāo da mocidade principalmente nos seus ultimos anos de existência, escrevendo e dando a publicidade muitas obras nesse sentido." BLARE, S- op. cit., v.IV, p. 193 . 
A listagem dos catálogos da Garnier e da Francisco Alves serve para demonstrar que no período republicano não cessaram as publicações sobre História Sagrada. Em 1893 a editora de Francisco Alves anunciava o Compêndio de história sagrada, seguida da geografia sagrada do monsenhor $\boldsymbol{C}$. Couturier, 1 v. e a História Sagrada para a infância por J.L.C. Renaudin, traduzida por D. Maria E. Leal, ornada de gravuras." 37

Uma outra obra muito consumida nas escolas, especialmente nas confessionais católicas, foi o Resumo da historia bíblica de D.Antonio de Macedo Costa, bispo do Pará. 38

As escolas confessionais metodistas ou presbiterianas igualmente adotavam livros de História Sagrada. No relatório da escola Americana de São Paulo, de 1888, constava que juntamente com as obras de Hilário Ribeiro e o "Bom Pastor", os alunos deveriam ler histórias da Bíblia, resumidas do próprio texto bíblico. ${ }^{39}$

A questão principal desta literatura que nos interessa, refere-se ao conteúdo histórico que disseminava, notadamente nas escolas primárias. Crubelier afirma que os textos de História Sagrada, com objetivos morais definidos, tendiam a limitar o ler-escrever a um papel de auxiliar da memória. Os alunos liam os textos de História Sagrada para rememorar e não para descobrir algo novo, para se aperfeiçoarem e não para se informarem. 40

o índice das matérias dos livros de História Sagrada demonstra um domínio sobre o tempo, expresso em uma cronologia definida em épocas para o Antigo Testamento e períodos para a "história de Nosso Senhor Jesus Cristo".

Jacques Le Goff nos adverte sobre a importância do cristianismo para a difusão de uma concepção de tempo: "Le christianisme a marqué un tournant dans $I$ 'histoire et dans

37 Catálogo de livros e material escolar da Livraria Clássica de Alves \& C.. Rio de Janeiro, 1893

38 Costa, D. Antonio de Macedo- Resumo da historia biblica ou narrativas do Velho e Novo Testamento. Nova-York: Carlos \& Nicolao Benziger irmãos, [1872]

39 Cf. BARBANTI, Maria Lucia H.- op. cit., p.170

40 Cf. CRUBELIER, M.- Lire -1880-1980. Au cœur d'une histoire culturelle. Histoire de 1 éducation. Paris, $\overline{53}$, janvier, 1992, p. 5 
la façon d'écrire h'histoire parce qu'il a combiné au moins trois temps: le temps circulaire de la liturgie liée aux saisons et récupérant le calendrier païen, le temps chronologique, homogène et neutre calculé par le comput et le temps temps linéaire téléologique ou temps eschatologique" e acrescenta citando Carr "Les Juifs, et après eux les chrétiens, introduisirent un élément entièrement nouveau en supposant un but vers lequel tendait le processus historique- la conception téléologique de I'histoire. L'histoire acquérait ainsi une signification et un projet, mais elle $y$ perdait son caractère séculierL'histoire devint une théodicée." 41

o objetivo da História Sagrada e a concepção de tempo que divulgava foi expressa com bastante evidência na literatura didática:

"É uma imperdoável falta ignorarmos a história da nossa Religião santa, e por que? porque essa história forma a base de todo o edifício cristão, e como bem se disse, mais nos confirmamos em nossas crenças quando as vemos iluminadas com todo o esplendor da divindade desde o berço do mundo; porque esta história é a mais antiga, a mais autêntica; a mais sublime, a mais instrutiva de quantas há sobre a terra: a história dos feitos de Deus na criação e salvação da humanidade. É preciso sabe-la. É preciso saber como foi criado este universo em que vivemos; a origem do gênero humano e sua lastimosa queda; como se perpetuaram, no meio dos horrores da idolatria, a noção e o culto do verdadeiro Deus, com a esperança do futuro Redentor. Escolba do povo judaico, depositário das divinas promessas; fases interessantíssimas da vida desse povo, educado, por assim dizer, por Deus mesmo; história dos prodígios, mas de prodígios públicos, notórios, passados a face de uma nação inteira, que se obstina ainda a viver - ou antes que Deus conserva miraculosamente, - para dar testemunho à verdade; enfim, depois de 4.000 anos de universal expectativa, a VINDA do SALVADOR; suas virtudes admiráveis, as palavras de

41 LE GOFF, Jacques- Histoire et memoire. Paris: Gallimard, 1986, p. 231 e 260 
vida eterna que saem de seus lábios, e que formam um código moral tão puro e tão sublime, que só Deus o podia promulgar; assombrosos prodígios com que confirmou sua missão divina; sua morte, ressurreição, subida ao Céu; fundação da Igreja; conquista maravilhosa e tomada de posse do mundo por essa mesma Igreja, destinada a levar a todas as gerações humanas até o fim dos séculos a palavra e a graça da Redenção divina." 42

Era uma História tranquila, com um caminho seguro, construída como uma narrativa. As épocas da História Santa eram articuladas por acontecimentos maiores, cuja importância eram indiscutiveis, dentro de um quadro cronológico preciso- "História primitiva desde Adão até Abraão- do ano 4.000 até cerca de 2.000 antes de Cristo" 43 os fatos eram selecionados de maneira a priorizar os religiosos vindo em sequência os principais acontecimentos políticos e militares. Os heróis eram valorizados pelas virtudes morais, pela piedade, caridade e sobretudo pela fé "no verdadeiro Deus".

A História Sagrada teve seus acontecimentos construídos segundo uma "espécie de trilogia". Primeiramente uma longa preparação que se inicia com os patriarcas, seguindo-se os tortuosos eventos do Exodo até a instalação do povo de Deus na Terra Santa, a experiência monárquica em que se destacaram David e Salomão, a queda de Jerusalém e os profetas anunciadores do Messias. A segunda parte desta História é a vida de Jesus Cristo, quando a História Sagrada revela "seu sentido" e a terceira parte corresponde a uma História da Igreja que "existirá até o fim dos séculos" 44

Além da construção da História sagrada segundo um plano determinado, simplificando os acontecimentos, os encarregados das obras didáticas cuidaram com esmero da confeç̧ão desta literatura.

As ilustrações desempenharam um forte atrativo e as figuras santas podem ser encontrados por toda esta

42 CosTA, D. Antonio de Macedo- Resumo da -- op. cit. p. VII e VIII.

43 Idem- P. 1

44 Idem, ibidem 


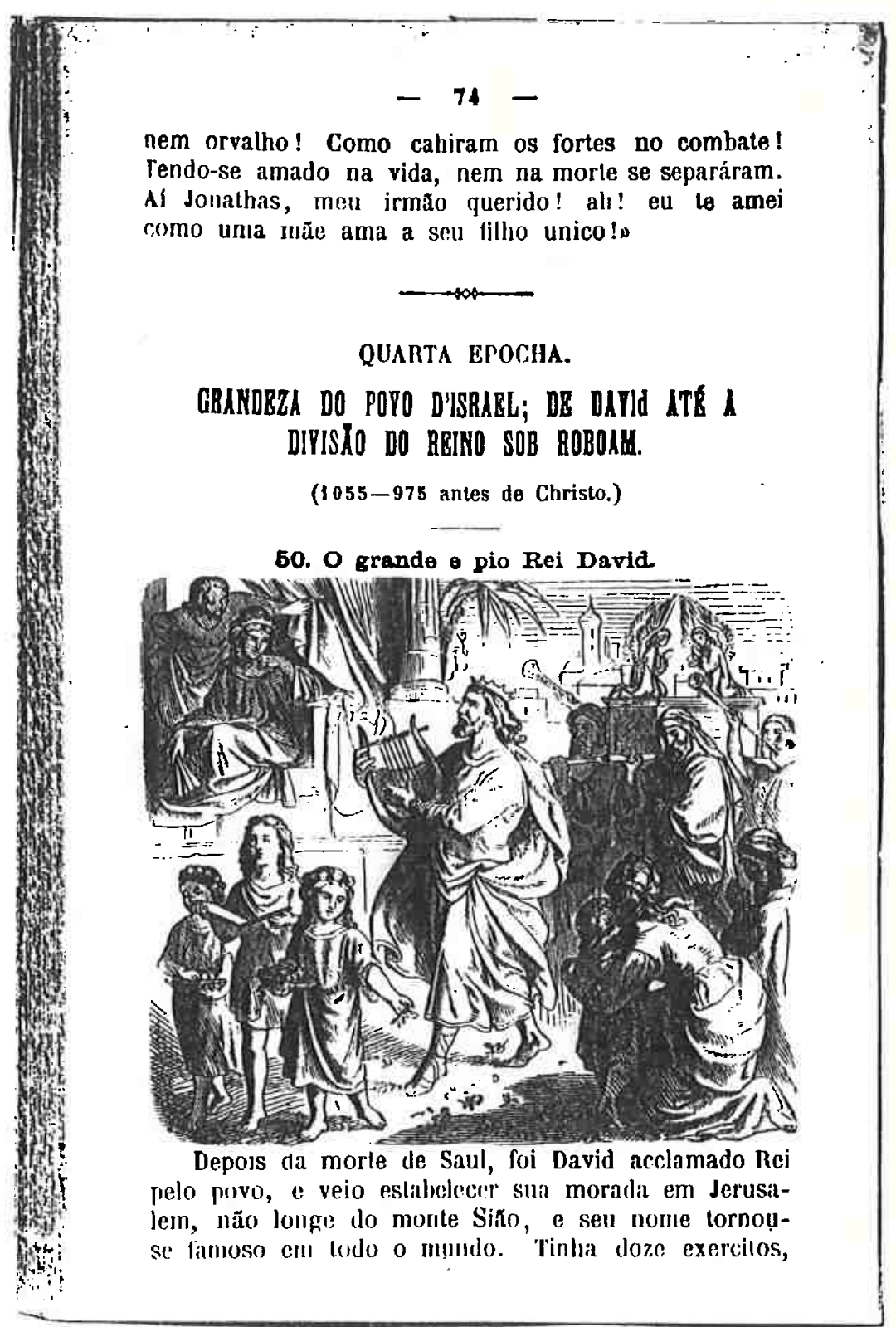

Fig. 13

Quarta Época .Resumo da História Biblica de D. Antonio de Macedo

Costa, bispo do Pará. Editado em New York, 1872 
Iiteratura, surgindo obras com "cerca de 200 estampas". A editora Læmmert já em 1862 orgulhava-se em proporcionar aos leitores uma edição da História Sagrada Pitoresca, com "sessenta estampas coloridas." 45

A História Sagrada perdeu parte de seu prestígio nas escolas públicas com a República sem, entretanto, desaparecer e continuou presente nos programas das escolas confessionais que se expandiram nos inícios do século $\mathrm{xx}$.

Ao lado da História Sagrada emergiu a História profana que conseguiu suplantar com dificuldades e lentamente o saber histórico divulgado pela Igreja. Tratava-se de uma História Universal destinada ao elitizado curso secundário, restando para o ensino elementar a História Nacional. o sentido histórico geral continuou marcado pelo tempo sagrado, pela origem divina do mundo, visão popularizada pelos ensinamentos do catecismo.

2.2 Moral profana e livros de Instrução Cívica

A leitura dos livros didáticos nos revelou duas posições frente à questão da formação moral dos alunos. Um grupo de autores acatava os valores morais determinados pela Igreja Católica e a maioria deles concordava com Abilio Cesar Borges quando afirmara que na infância, na fase do despontar da razão deveria ser ensinado "o amor e o temor de Deus; é a verdade, a justiça e a caridade; é enfim a distinção prática do bem e do mal, ou, melhor, a moral e a fé em ação. Pois de mistura com as primeiras lições de leitura só se deve promover o desenvolvimento dos sentimentos e da razão, ou a continuação, propriamente dita, da educação moral e religiosa começada na família" 46

A concepção de infância como a fase em que a razão estava em formação, predominando os sentimentos, supunha o ensino de temas sobre o bem e o mal, evoluindo, em seguida,

45 Cf. Catálogo de 1862 de E. \& H. Læmmert encontrado no final do livro de ROQUETTE, J.I.- Alfabeto português ou novo método para aprender a ler. Rio de Janeiro: E.\&H. Læmmert, 1862.

46 BORGES, Abilio Cesar- Segundo livro...-op. cit; , p. VI 
para situaçōes concretas, tendo como sujeito principal das ações as próprias crianças.

As narrações eram repletas de situações sentimentais, maniqueístas, onde os bons eram sempre beneficiados e os maus eram punidos. A caridade, o consolo para com os pobres, a honestidade, a obediência para com os mais velhos e superiores, o companheirismo e, sobretudo, o amor de Deus eram as virtudes que perpassavam nos contos curtos, nos quais os autores se esforçavam na criação de uma linguagem que cativasse os jovens leitores:

\section{"MEU BOM MESTNO}

Como já podeis entender alguma coisa do que ledes, devo começar este livrinho, que compus para vossa instrução primária, pela vossa própria pessoa.

Sem dúvida sabeis o que sois, mas não sabeis ainda para que o Criador vos formou, nem qual será o vosso destino neste mundo" . ${ }^{47}$

Um outro grupo de autores, favoráveis à laicização da escola, foi responsável por outras leituras sobre a moral religiosa. Eram concordes com o papel do ensino moral a ser desempenhado pela escola, exigindo uma nitida separação entre a infância e adolescência, defendendo uma seriação rígida, uma "homogeneidade demográfica" com maior controle em cada etapa que se concretizou com a criação dos grupos escolares.

$\mathrm{Na}$ defesa de uma maior racionalização da instituição escolar, os autores dessa linha educacional expuseram em seus "prefácios" suas restrições quanto ao ensino de religião na escola, defendendo que este tipo de ensinamento, pela sua natureza, era tarefa da família a quem caberia a decisão de como ministrá-lo. Defenderam a permanência de uma educação moral que "não tem por fim o saber mas o querer [que] comove mais do que demonstra, e devendo atuar sobre o ser sensível, ela procede mais do coração que do raciocinio." 48 e nesse aspecto acreditavam que a moral ensinada na escola deveria limitar-se às noções essenciais

47 ROCHA, Landelino- Segundo livro -op. cit..7

48 SCROSOPPI, Horácio- Pequenas liçōes de instruçāo moral. São Paulo: Duprat \& Cia. , 1909,p. 4 
de moralidade humana, comuns a todas as doutrinas e necessárias a todos os homens "civilizados". Pretendiam inculcar a idéia de uma moral eterna e universal sem que forçosamente estivesse de acordo com os preceitos e dogmas da doutrina cristã, devendo o cidadão aprender a conviver com "as tradições, as crenças, as práticas de um culto cristão, israelita, ou qualquer outro" 49

Com o estabelecimento do regime republicano esta tendência foi reforçada, introduzindo-se uma-nova disciplina, Instrução Moral e Cívica, substituta das aulas de ensino religioso.

A moral profana da disciplina Instrução Moral e Cívica encarregava-se, em princípio, de ensinar dois conceitos básicos: família e pátria. Estes conceitos foram expressos pelos livros didáticos e não exatamente por programas estruturados e obrigatórios. Parecia consensual que a formação moral era tarefa da Igreja e a cívica do Estado que não poderia mais limitar-se a prescrever estudos sobre os direitos e deveres expressos na Constituição do país.

A moral profana a ser veiculada pela Instrução Moral e Cívica articulava civismo e História do Brasil, mesclando-se temas e conteúdos. João Ribeiro, no prefácio do livro didático de silvio Romero afirmou que o intuito principal do autor era substituir, pela biografia, "a instrução cívica que mal poderia ser incutida exclusivamente pela história."50 A introdução do ensino de Instrução Moral e Cívica nas escolas representou, dentro desta perspectiva, um apêndice da História, ou um acréscimo a esta disciplina, servindo para desenvolver o sentimento patriótico, direcionando a moral secular. Tal "sentimento patriótico" nāo possuiu uma unânimidade ențe os autores, variando entre ufanismos e a busca de um conhecimento capaz de gerar algumas atitudes de participação política.

A visão de João Ribeiro e Silvio Romero vinculava-se a esta última perspectiva. Recuperaram o sentido do civismo

49 Idem, p. 5

50 ROMERo, Silvio- A historia do Brasil ensinada pela biografia de seus herois. 99 ed. Rio de Janeiro: Livraria Francisco Alves, 1915. 
de Condorcet, na perspectiva de formação da cidadania, afirmando que a Instrução cívica "veio, como tantas outras trivialidades da democracia, da torrente assombrosa da revolução francesa. A declaracão dos direitos dos homens trouxe para a escola primária esse monopólio da política sobre todas as atividades da vida comum." 51

A formação de um cidadão devia alicerçar-se em uma reflexão política. Os direitos e deveres do cidadão, do eleitor eram conteúdos a serem desenvolvidos na escola primária, a escola a que todos, em princípio teriam acesso.

A Instrução Cívica voltada para a formação de uma atitude política democrática definia-se, concretamente pelo ensino da História: "Assim, pois, só existe um recurso verdadeiramente eficaz que possa inocular na escola a conduta cívica e patriótica. $\widehat{B}$ o exemplo dos grandes cidadãos, a história dos que a fizeram a ela própria, sobressaindo sobre a atividade anônima das massas, dirigindo-as aos seus destinos $e$ aos seus ideais." 52 A escolha dos vultos históricos não poderia ser fruto de uma postura emocional, parcial mas, ao contrário, "essas biografias, assim selecionadas pelo tato da critica científica, têm um valor excepcional e único, têm ó valor de um museu que, en vez de tipos da flora e da fauna regional, dános os especimens- tipos de nossa humanidade americana." 53

Era uma fase da configuração dos "grandes vultos da pátria", de cidadãos civis em substituição os heróis bíblicos, faltando ainda delinear os contornos dos "heróis nacionais".

Em outra versão patriótica, ligada ao ufanismo, surgiram vários exemplares, difíceis de sofrer apreciação quantitativa porque muitos eram produzidos regionalmente $e$ com curta duração. Estavam repletos de uma retórica decrépita, com frases como "colosso americano", "gigante majestoso". A mais famosa expressão do chauvinismo brasileiro foi por que me ufano de meu país escrito por

51 Idem, op. cit.p. VII. Grifo do autor

52 Idem, p. IX.

53 Idem, p. X. 
Afonso Celso para celebrar o $4^{\circ}$ centenário da Descoberta do Brasil. Dele temos a seguinte notícia: "Publicada em 1901, ela tornou-se imediatamente popular; a primeira edição foi totalmente vendida em meses e a obra tornou-se leitura obrigatória nas escolas secundárias por muitos anos." 54

Os livros de Instrução Cívica não eram confeccionados de maneira padronizada. Os programas de ensino definiam vagamente a disciplina e mesmo sua obrigatoriedade, sendo atributo de cada Estado da federação, estabelecer as Iinhas gerais do curso. os livros regionais, geralmente, faziam uma introdução onde descreviam o Estado em seus aspectos físicos, seguido de um resumo histórico e em seguida forneciam dados sobre a situação econômica e populacional. o Estado de São Paulo parece ter sido um dos que esforçou em demonstrar o "progresso" da região usando o ensino cívico como forma de desenvolver um sentimento "regionalista".

Mas, para evitar os excessos de um "nativismo" regional, possíveis de induzir sentimentos separatistas, os livros de civismo eram repletos de patriotismo:

\section{" A Patria}

Os homens não formam uma só sociedade.

Os que habitam o mesmo solo, que vivem sob as mesmas leis, que falam a mesma lingua, e sobretudo que têm a mesma história, os mesmos antepassados, que tiveram as mesmas alegrias e os mesmos sofrimentos, que têm os mesmos interesses, as mesmas aspirações, pertencem à mesma grande família, têm a mesma pátria.

Amamos o nosso pai e a nossa mãe; amamos nossos irmãos e nossas irmãs; amamos todos os nossos. Devemos amar os Brasileiros como nossos irmãos, e acima de tudo a pátria.

Nossa pátria é bela, grande e generosa: é o Brasil."55

A História difundida pelos manuais de civismo variou entre duas posturas temporais. Havia uma concepção de tempo

54 HALLEFELL, L.- op. cit., p. 170. Hallewell afirma que o livro de Afonso Celso foi a obra didática mais conhecida da editora lammert.

55 SCROSOPPI, H.- op. cit., p. 27 . Grifo meu 
longo, eterno, limitando-se a introduzir uma moral laica associada ao ensino cívico, buscando formar um aluno inserido ao mundo social e político, destacando a ação do Estado.

A "humanidade", segundo parte dos defensores de um ensino liberal, era determinada por uma moral contínua, existente desde sempre. A contradição existia na tentativa de conciliação entre uma moral da "humanidade", de todos, e o sentimento de patriotismo, da singularidade e que incluia - dever do "bom patriota" em servir a pátria, em fazer a guerra em nome da pátria. Alguns autores reforçaram o dever do serviço militar justificando a necessidade de guerrear porque a pátria sempre corria o risco de ser atacada. Ser patriota, assim, era defender a pátria:

" $\bar{E}$ ao soldado que cabe a missão especial de defender a Pátria. Todo o cidadão válido deve pois ser soldado. Aquele que procura subtrair-se a esta obrigação $e$ um covarde. A lei o pune." 56

Em alguns poucos textos encontramos uma concepção de tempo histórico expresso pelo "tempo da democracia" originário da Revolução Francesa. o texto da Declaração dos Direitos do Homem era a marca da moralidade que deveria ser imposta em substituição à moral dogmática da religião: "A soberania e a indivisibilidade da nação, a igualdade perante a lei, o espírito da liberdade individual, a igual participação dos cargos sociais, a igual acessão aos empregos públicos, o sufragio universal, o voto livre de condições e acima de tudo, a liberdade de consciência, todas estas conquistas, enfim da revolução francesa deverão ser ensinadas às crianças com respeito e reconhecimento. m57

As duas posturas temporais nāo pretenderam, entretanto, excluir a moral divina. Não se tratava de uma moral atéia. A crença nos princípios religiosos cristãos permaneceu, conciliando ensinamentos provenientes de fontes aparentemente contraditórias:

56 Idem-op. cit., p. 31

57 BARBOSA, Ricardo-Instrução moral e civica. la ed. Rio de Janeiro: $\mathrm{B}$. Lombært \& Cia., 1895. Preâmbulo, p. VII. Grifo meu 
"O livro, desde o Evangelho até o Contato Social, tem feito uma evolução, diz De Bonald.

o Evangelho e o Contrato social que beneficios germinaram?

A igualdade perante Deus e a razão, a virtude e a justiça gerou o Evangelho; a igualdade perante a lei e a reabitação do povo, o Contrato social." 58

E, a maioria dos autores dos textos de Instrução Moral e Cívica buscava situar o espaço privilegiado onde se desenvolveria a nova moral em substituição à catequese dos padres. A moral profana conciliada com uma nova religiosidade ocorreria na "escola onde as crianças aprendam a amar a Deus sem temor, a sociedade sem baixeza e a patria com entusiasmo." 59

3. Confrontos na produção didática: História Universal ou História da Civilização?

3.1 O predomínio dos franceses na História Universal

Pela análise do acervo de 33 títulos de História Geral que localizamos, fica flagrante a presença de traduções ou obras estrangeiras utilizadas na língua original nas escolas brasileiras.60 Guy de Holanda, em seu trabalho sobre a produção didática de história, informou que era frequente, até a reforma Rocha Vaz de 1924, o uso dos dois volumes de "Histoire de la Civilisation" de Charles Seignobos ou ainda - "Cours d'Histoire" de Albert Malet nas aulas dos ginásios oficiais. 61

A continuidade da utilização e adoção de livros estrangeiros, especialmente de franceses, foi uma das características da constituição da disciplinas históricas nas escolas secundárias, destacando-se o Colégio Pedro II, polo de divulgação da produção didática. Do período de sua

58 SILVA, J. Diogo Esteves da- Elementos de instrução moral e cívica. Rio de Janeiro: Alves \& Cia., 1897, p. XII

59 Idem, ibidem.

60 ver livros de Historia Geral na Bibliografia.

$61 \mathrm{Cf}$. HOLLANDA, Guy de- op. cit. 
criação ao final da primeira década do século XX, foram adotados 10 livros de História Universal utilizados na seguinte sequência:

\section{QUADRO 5}

\section{Livros de História Geral adotados no Colégio Pedro II 1838-1907}

\begin{tabular}{|c|c|c|c|}
\hline ANO & TITULO & AUTOR & ORIGEM \\
\hline 1838 & $\begin{array}{l}\text { Compêndio de } \\
\text { História } \\
\text { Antiga } \\
\text { Compêndio de } \\
\text { História } \\
\text { Romana }\end{array}$ & $\begin{array}{l}\text { Poirzon e Caiz } \\
\text { Derozoir e } \\
\text { Dumont }\end{array}$ & $\begin{array}{l}\text { França Trad. } \\
\text { França Trad. }\end{array}$ \\
\hline 1855 & $\begin{array}{l}\text { Manuel d u } \\
\text { baccalauréat }\end{array}$ & $\begin{array}{l}\text { sem nome do } \\
\text { autor }\end{array}$ & França * \\
\hline 1862 & $\begin{array}{l}\text { História da } \\
\text { Idade Antiga } \\
\text { e Idade Média }\end{array}$ & $\begin{array}{l}\text { Justiniano } \\
\text { J.da Rocha }\end{array}$ & Nacional \\
\hline 1865 & $\begin{array}{l}\text { Compêndio de } \\
\text { História } \\
\text { Antiga } \\
\text { Compêndio de } \\
\text { História Média }\end{array}$ & $\begin{array}{l}\text { Moreira } \\
\text { Azevedo } \\
\text { J.B. } \\
\text { Calógeras }\end{array}$ & $\begin{array}{l}\text { Nacional } \\
\text { Nacional }\end{array}$ \\
\hline 1895 & $\begin{array}{l}\text { História } \\
\text { Universal }\end{array}$ & Webber & Alemanha Trad. \\
\hline 1901 & $\begin{array}{l}\text { Histoire de la } \\
\text { civilisation } \\
\text { Histoire de la } \\
\text { civilisation }\end{array}$ & $\begin{array}{l}\text { Ch. Seignobos } \\
\text { Crozals }\end{array}$ & $\begin{array}{l}\text { França } \\
\text { França }\end{array}$ \\
\hline 1907 & História Geral & Raposo Botelho & Portugal \\
\hline
\end{tabular}

Fonte: HAIDAR, Maria de L. Mariotto - op. cit. e FORJAZ, Djalma, op. cit.

* O Mannuel du baccalauréat indicado foi, provavelmente, a obra de Duruy. ${ }^{46}$

46 DURUY, Victor- Nouveau manuel du baccalaureat És Lettres- histoires Ancienne, du Moyen Age et des Temps Modernes, regidige conformement aux programmes de 1852. Paris: L. Hachette et Cie., 1853 
Por este repertório fica evidente a vinculação direta com a produção externa, particularmente a européia, constatando-se que a escolha dos manuais correspondeu aos pressupostos dos programas escolares calcados no ideário da França: "Adaptou o Conselho os últimos programas publicados para os liceus nacionais da França, fazendo-lhes as modificaçōes e alteraçōes que exigiam a organização diferente dos estabelecimentos públicos de instrução secundaria desse país e do Colégio de Pedro II, e a falta de livros apropriados para a diferença das matérias indicadas nos mesmos programas. (-)na falta de obrás nacionais, adotaram-se para o estudo das ciências fisicas e naturais, da historia e da geografia e da filosofia, compêndios franceses." 62

A partir desta relação, passamos, então, a averiguar se a "importação" cultural francesa na constituição da disciplina histórica foi efetivamente submissa aos ditames do mundo europeu ou, ao contrário, se sofreu distorções e adaptações, resgatando, nessa análise, os conflitos inerentes ao processo de transposição didática.

Limitando inicialmente a questão em torno das obras estrangeiras e pelas traduções dos livros de História, destacamos dois aspectos.

Primeiramente, verifica-se que as mudanças quanto à adoção dos livros de História, no decorrer do período, indicaram a passagem de uma concepção de História dominada pelos católicos para a obra positivista por excelência, representada por Charles Seignobos e um retorno a uma História profana conciliada com a Igreja, pela escolha de Raposo Botelho.

Considerando a estreita vigilância exercida pelas autoridades escolares sobre o livro didático, pareceu-nos que a interferência do corpo docente foi inevitável ao se estabelecerem os critérios para a escolna das obras. 0 Colégio Pedro II contou com a presença, no seu início, de professores religiosos em número significativo. Este perfil foi sendo modificado, passando, pouco a pouco, a

62 HAIDAR, M.- op. cit., p. 102-103 
prevalecerem professores leigos e, dentre eles, figuras proeminentes do movimento intelectual cientificista, notadamente figuras da chamada "escola de Recife". Faziam parte do corpo docente da escola na década de oitenta, entre outros, Silvio Romero, Schiefler, Capistrano de Abreu e João Ribeiro, figuras representativas de un grupo de intelectuais que se opôs, no campo educacional, ao domínio religioso e à hegemonia cultural da França. As mudanças do corpo docente repercutiram nas disputas quanto à organizaçāo curricular e, consequentemente, quanto à adoção das obras didáticas.

As disputas internas entre os professores parecem ter produzido algumas alterações no sentido da laicização do ensino da escola como demonstra a lista dos manuais adotados mas, não conduziram a outras transformações quanto ao predomínio francês em relação ao ensino de História .

A obra de Webber, traduzida en 1895, expressou, pelo prefácio de João Ribeiro, as divergências latentes entre o corpo docente: "A falta que há, em linguagem, de um bom resumo de História Universal, nas proporções que o programa do Ginásio Nacional exige, fez-nos aconselhar aos srs. Cunha \& Irmãos, editores, a publicação de um compêndio que, como o conhecido resumo de Webber, correspondesse ao mesmo tempo aos reclamos do ensino e não consistisse, como os livros franceses usuais, de pura história da França com algumas vistas gerais sobre a história do resto do mundo." 63 A adoção desta obra teve curta duração. En 1901 o francês Seignobos, com a História centrada em Paris, foi o preferido. 64

As traduções de obras didáticas de História foram fundamentais para o ensino nas demais escolas secundárias. Diferentemente das escolas oficiais, as escolas particulares não ousavam contemplar, em suas listas de obras obrigatórias, livros em idiomas estrangeiros para jovens que possuiam dificuldades no domínio da própria língua patria. Tanto para os colégios particulares com regime seriado, como

63 RIBEIRO, João- Prólogo. In WEBBER- História Universal. Prólogo de João Ribeiro. Rio de Janeiro: Cunha \& Irmãos, 1895, p. V

64 O Iivro de Seignobos foi o adotado na Escola Normal de são Paulo apos sua reforma de 1893. Cf. ESCOLA NORMAL DE SÃO PAULO- Programas de ensino para o ano letivo de 1894 . São Paulo: Tipografia a vapor de vanorden \& Cia., 1894, p.58. O livro de Charles Seignobos teve uma tradução feita em 1914, por D. A. Cohen e editado pela Francisco Alves. 
- Colégio Abílio do Rio de Janeiro, como para os diversos estabelecimentos confessionais espalhados pelas províncias, a história universal era ensinada, especialmente, por obras traduzidas, ficando a escolha a critério dos seus dirigentes. $E$, a adoção dos livros expressava a interpretação da direção da escola frente aos programas curriculares.

Vejamos algumas situações.

A "Escola Americana" de são Paulo, construída por um grupo de protestantes metodistas, na gestão de Horace Lane, na década de 80 , adotou a Historia Universal de Parley no curso secundário, obra utilizada nas escolas norte-. americanas e traduzida pelo Desembargador Lourenço José Ribeiro, "para uso das escolas do Império do Brasil" por volta de 1857.65

As escolas dirigidas pelas irmãs de são José de Chamberry, coerentes com seu projeto educacional fundamentado nos princípios do catolicismo ultramontano, optaram pela obra do Monsenhor Daniel, bispo francês de Coustances e d' Avranches. 66

Os cursos "preparatórios", frequentados pela maioria dos jovens que se encaminhava para o ensino superior, foram responsáveis por uma produção diferenciada dos manuais mais densos adotados na escola seriada. Surgiram, a partir deste período, livros direcionados aos exames preparatórios que limitavam-se em conter os "pontos" a serem decorados pelos alunos e que, em certa medida, são correspondentes às atuaj.s apostilas dos "cursinhos" vestibulares. Eram textos preparados e concebidos segundo técnicas para a retenção rápida dos conteúdos exigidos pelas bancas examinadoras.

65 PARLEY, Pedro- História universal resumida para uso das escolas comuns dos Estados Unidos. Tradução de Lourenço José Ribeiro. Rio de Janeiro: $\mathrm{E}$. $\mathrm{H}$. Lxmmert, s.d. Esta obra também foi indicada para ser adotada pelo municipio da Corte em 1857 , segundo consta da Noticia da instrução primaria na capital federal. de Felisberto R. p. de Carvalho. Revista Pedagógica, Rio de Janeiro, 4(19): 133, maio, 1892 .

66 "O alicerce religioso e ultramontano dessa educação continuava na propria seleção de livros adotados. O relatorio do Inspetor de Itu, Carlos F. da Silva, em 07 de dezembro de 1876, informava que os compêndios adotados no colegio do "Patrocinio" eram os seguintes: (-) Historia Universal- Mons. Daniel. "escreve MANOEL, Ivan- - op. cit, p. 197. Tratava-se do livro de DANIBL, Monsenhor- Curso de história Universal. Tradução de Joaquim Maria de Lacerda. Rio de Janeiro: B.L. Garnier, 4 v., $1877-1878$. 
Faziam-se quadros sinóticos, esboços cronológicos, noções gerais de "pontos" usualmente exigidos pelos examinadores. 67 A maioria deles não chegava a ser impresso, constituindo-se nas "apostilas" ou anotações dos professores, difundidas no nível interno dos cursos preparatórios.

o outro aspecto que abordamos quanto às traduções de livros didáticos refere-se às infidelidades que nelas predominaram. Os tradutores de obras didáticas, geralmente, adaptavam, com bastante liberdade, os textos aos programas escolares nacionais, acrescentando ou retirando capítulos. o livro de victor Duruy, Compêndio da história universal, traduzido pelo padre Francisco Bernardino de souza é um bom exemplar deste tipo de tradução. 68

- livro original de Duruy denomina-se Nouveau manuel du baccalauréat ès lettres, escrito de acordo com o programa de 1852 originário da lei Falloux. Era um programa marcado por uma política conservadora do Império francês, desejosa de fazer refrear as idéias socialistas divulgadas em 1848 e que procurou reaproximar-se dos catolicos, facilitando-lhes - acesso às escolas públicas e a disseminação de escolas confessionais. A Historia e seu ensino haviam tido um período auspicioso no período anterior, na Monarquia de Julho, "uma primeira idade de ouro" onde a politica foi dominada pela presença de célebres historiadores, Guizot e Thiers, além da atuação de Michelet como chefe dos Arquivos Nacionais, conferindo à História um lugar proeminente na configuração e legitimação do poder que se estabelecia. No secundário, a História projetava-se, tornando-se uma disciplina "de primeira ordem". 69

67 para o ensino de Historia encontramos 2 livros impressos com estes objetivos: JUNIOR, A.Q.A.- Pontos de historia para prova escrita compilados conforme o novo programa de 1883. Rio de Janeiro: J.G. de Azevedo, 1883 e LEITĀo, Antonio Pereira- Pontos de historia média e antiga, conforme o programa de exames preparatorios de 1876 e 1878 . Rio de Janeiro: Nicolau Alves, 1878.

68 DURUY, victor- Compêndio da historia Universal. Trad. padre Francisco Bernardino de Souza. Rio de Janeiro, 1865. Este livro sofreu várias reimpressōes durante o Império. Em 1869 (25 ed), 1873 (3: ed.), 1877 (40 ed.), 1886 (50 ed.) e varias delas encontram-se na Bibliothèque Nacionale de Paris.

69 Cf. FURET, François- O nascimento da historia. FURET, F.- A oficina da historia- Trad. Adriano D. Rodrigues. Lisboa: Gradiva, s. d., p. 109-135 
Victor Duruy tentava, então, disseminar e assegurar o ensino de História, visto na década de 50 como uma matéria subversiva, tendo sido Michelet expulso do Collège de France. A obra de Duruy expressava uma certa conciliação, uma "história ecumênica e meio-termo de Guizot (que) esbarrava à sua direita na tradição reacionária, possuída pela idéia da politização dos espíritos jovens, e à sua esquerda nos dois intérpretes democráticos da história nacional e européia: Michelet e Edgar Guinet." 70 Duruy não excluiu a História sagrada do ensino mas esta estava separada da História Nacional e de uma História Geral profana, fundada na tríade Antiguidade, Idade Média, Tempos Modernos.

A tradução do professor do Colégio Pedro II, um clérigo, não obedeceu exatamente aos princípios do historiador francês. A intervenção do tradutor foi responsável por algumas alterações importantes na obra. Houve uma redefinição dos capítulos iniciais do livro, procurando acentuar a origem sagrada do homem. No original, no primeiro capítulo denominado Monde connu des anciens, Duruy buscou apresentar uma configuração geral dos continentes e as formas de comunicação estabelecidas entre os diversos povos. No capitulo II, Temps primitifs, o autor apresentava as tradições bíblicas sobre os primeiros homens para explicar que as 3 raças humanas estavam presentes na versão religiosa católica e que a "(..) la science aussi a reconnu trois grandes divisions dans 1 'spèce humaine répandue sur 1 'ancien continent" 71 o tradutor brasileiro inverteu a apresentação dos capítulos. Iniciou o livro com o - Tempos primitivos- Tradições bíblicas- fundação dos Impérios "e no final incluiu, resumidamente " os limites do mundo conhecido pelos antigos". 72 A inversão dos temas, iniciando pela origem do homem segundo as tradições bíblicas, indicou um reforço quanto à versão cristã da história do homem, interpretação que Duruy atenuou ao

70 Idem, p. 125

71 DURUY, V.- Nouveau , , op. cit.-p. 7

72 DURUY, v.- Compêndió..., op. cit., p. 1 a 7 
enxertar os pareceres científicos quanto à origem das raças humanas.

No livro de Duruy há um total de 62 capitulos organizados em 340 páginas. A versão brasileira é de 443 páginas onde houve mudanças na disposição e apresentação dos capítulos ( 20 capítulos para cada período), com omissões de alguns sub-ítens e há acréscimos de conteúdo com a inclusão de um capítulo final da História da Idade Média, "xxPortugal- Breve resumo da história de Portugal até o reinado de Afonso $\boldsymbol{V}^{\mathbf{7 3}}$ e outro ainda sobre o reino português durante o período da História Moderna, "desde o reinado de $D$. João II até o de $D$. Pedro $V^{m} .{ }^{74}$

A infidelidade das traduções pode ser entendida, entre outras questōes, como uma necessidade intrínseca dos textos didáticos que deveriam estar subordinados aos programas escolares. Mas este trabalho que realizamos, acompanhando paralelamente os dois livros, indicou-nos que as traduções dos livros didáticos eram articulados profundamente às necessidades sociais e politicas internas e o tradutor transformava o texto de acordo com seus interesses $e$ ideologia.

Ao lado das obras estrangeiras ou traduzidas, encontramos uma produção nacional de livros sobre História Universal que, em sua maioria, abrangeu apenas alguns períodos. Os autores valiam-se das dificuldades dos alunos em memorizar textos escritos em outra lingua, nem sempre compreensíveis, para produzir seus próprios livros. Esta argumentação foi fornecida pelo editor Garnier, ao divulgar o trabalho de Justiniano José da Rocha:

"(..) o que levou este distinto publicista a escrever um curso d'história universal, cujas duas primeiras partes ora anunciamos, foi por certo muito louvável e digno d'incitação. Quis o dr. Rocha subtrair seus jovens compatriotas à exclusiva influência dos livros franceses, que, além de corromperem a linguagem vernácula pela falta que tem a mocidade e do necessário antídoto, apresentam

73 Idem- op. cit., p. 291 a 297

74 Idem- op. cit., p. 401 a 407 
desfigurados os fatos históricos quando a gloria ou o interesse do seu país a isso convida. Acresce que nos compêndios franceses ocupa a história da França um lugar tão saliente, tão grande desenvolvimento se lhe dá, que quase desaparece a dos outros povos." 75

Apesar das intenções do autor no sentido de construir uma História Universal com uma ótica mais livre do ufanismo universalista francês, os compêndios do professor Justiniano José da Rocha não contribuíram para mudanças na produção da história escolar. Este autor, como a maioria dos intelectuais vinculado ao poder, militante ele mesmo do Partido Conservador, estava limitado a uma pesquisa em história no IHGB, sem condições ou perspectivas de ampliar pesquisas historiográficas fora do território brasileiŗo. A este grupo de intelectuais faltava erudição e condições efetivas para se aventurar em estudos de uma documentação ampliada, no sentido de elaborar pesquisas próprias. Podiam apenas valer-se de uma bibliografia européia permeada de valores e ideologias e acabaram por submeter-se ao domínio dos franceses.

Justiniano José da Rocha limitou-se a resumir os compêndios franceses, na tentativa de fazer os alunos decorarem mais facilmente o conteúdo. Sem intenções em aprofundar as questōes historiográficas da denominada "história universal", o autor apenas empobreceu os livros franceses, mal conseguindo fazer um resumo traduzido do que estava contido nos manuais originais, conforme afirmou no prefácio de una de suas obras:

"(-.) o que nos parece incontestárel, o que de certo ninguém dos que tem a menor prática do magisterio desconhecerá, é que cumpre $1^{\circ}$ resumir, resumir muito os compêndios, $2^{\circ}$, dá-los em lingua comum. Em um compêndio de história não se pode procurar coisas novas: aproveitamo-nos dos trabalhos existentes, especialmente do compêndio francês admitido no ensino público, e do que à mocidade brasileira ofertou o muito digno ex-professor Calógeras. Teríamos respeitado a prioridade desse compêndio da idade média na

75 Catálogo n²3 da B.L. Garnier, Rio de Janeiro, 1866 
lingua comum, se não nos parecesse em extremo extenso, para nossas aulas;

(..) ainda uma vez repetimos: a par da exatidão e de boa escolha dos fatos em razão de sua importância, e da clareza da sua exposição, o que mais deve procurar quem escreve um compêndio é atender à brevidade, cumpre ter sempre presente a lembrança de que escreve para moços da idade de 12 a 16 anos; que estudam outras matérias, que só tem para cada aula da partes sessenta e setenta lições, e que devem neles decorar todo o compendio e decorá-1o de modo a conservar de tudo profunda e quase indelével recordação do que uma vez houverem aprendido..." 76

Em vista de tal produto, foi mais usual a continuidade dos franceses traduzidos e, dentre eles, o texto traduzido de Duruy. A obra de victor Duruy permaneceu como modelo, marcando os períodos e a seleção dos conteúdos. Na História Universal ditada e construída dentro dos parâmetros dos franceses não havia lugar para o continente americano e o Brasil não era sequer mencionado no espaço histórico elaborado, mesmo quando anunciaram "as grandes descobertas portuguesas".

3.2 Divergências entre os autores de História da Civiliżação

A partir da década de oitenta a obra didática começava a se emancipar dos pressupostos históricos de inspiração divina. Destacaram-se obras de uns poucos autores nacionais, editados, em sua maioria, pela livraria Francisco Alves e que traziam como cabedal para aceitação do público o fato de serem professores do Colégio Pedro II.

Tivemos acesso às obras de três autores: João Maria da Gama Berquó, professor substituto de História e Geografia do Imperial Colégio Pedro II (1887), João Ribeiro que escreveu em 1892 uma Historia do Oriente e Grécia e para uso das Escolas Normais encontramos do professor José E.C. de sá e Benevides Lições de História da Civilização, cuja primeira

76 ROCHA, Justiniano $J$. da-Compendio de Historia Universal- Historia Antiga. Rio de Janeiro: Tipografia do Regenerador de Justiniano $J$. da Rocha, 1860, Prefácio. 
edição foi de 1907. Estas obras mostram diferenças em relação às anteriores, e mais importante, estes autores divergiam entre si quanto à aceitação dos pressupostos da historiografia positivista e suas concepções de "civilização" e "progresso".

A divisão da História em períodos e a definição dos seus marcos separavam os historiadores dos livros de História Geral. A História profana havia criado, desde a Renascença, a Idade Média como oposição aos tempos que "renasciam", ao Tempo Moderno. Victor Duruy reforçou esta divisão, compondo um manual único que abrangia a História Antiga, a Idade Media e os Tempos Modernos mas introduziu, separadamente, uma História Contemporânea cujo marco inicial era o Congresso de Viena, em 1815.

Para os historiadores do século XIX era evidente a separação entre "moderno" e "contemporâneo". o mundo industrial que se espalhava era incorporado e expresso na produção escolar como necessidade de iluminar as transformações rápidas das "sociedades modernas":

"Na moderna sociedade, na qual, como diz Babinet, cada decênio corresponde a um século dos priscos anais, na época do vapor e da eletricidade, deixar no olvido um período de cinquenta anos, como o fizeram todos os autores de compêndios de história, era por certo grave erro, que primeiro reconheceu em França o ilustrado Duruy, quando fez com que Napoleão III ordenasse o ensino da referida matéria nos colégios e liceus imperiais." 77

o tempo da modernização era incorporado pela literatura didática. A preocupação com a modernização, concebida como as mudanças que a industrialização è urbanização desencadeavam, obrigou os autores a definirem outra periodização para tais transformações temporais. Tanto autores católicos, mais tradicionais, como os liberais adeptos do cientificismo, concordavam sobre este ponto e os marcos destacados situavam-se no papel do Estado e sua

77 RESUMO de história contemporânea desde 1815 ate 1865 por um professor. Rio de Janeiro: B.L. Garnier, 1866. Este livro anônimo foi escrito pelo cônego Fernandes Pinheiro, conforme contrato da editora Garnier com o autor, tendo sido a 1 ediçāo realizada em 1861 . 
atuação politica capaz de acelerar ou refrear as transformaçōes. As divergências surgiram quanto ao fato político fundamental desencadeador das mudanças.

Para os monarquistas, a escolha recaia na queda de Napoleão e o restabelecimento de uma ordem monárquica liberal. Para os republicanos era a Revolução Francesa. O livro de Max Fleiuss, Elementos de História Contemporânea, produzido em plena fase republicana brasileira mas que, intencionalmente foi dedicado aos monarquistas mais famosos da época, Affonso Celso e Antonio Nogueira, tem como capítulo inicial a Santa Aliança, com o subtítulo significativo - "a Restauração Monárquica". ${ }^{78}$ A ação da Santa Aliança representava para os historiadores mais conservadores a tentativa de terminar "com as guerras intestinas, guerras externas, terríveis embates de paixões contrárias, desastres," provocados pela Revolução Francesa e pela política de Napoleão I. 79

$\mathrm{Na}$ visão republicana defendida pelo positivismo de Seignobos, a Revolução Francesa era o marco definidor do Período Contemporâneo. Seignobos havia dividido, com precisão, os períodos históricos em suas obras didaticas, separando em 3 volumes a História Antiga ( Oriente, Grécia e Roma) e reunindo a Idade Média, os Tempos Modernos e o Período Contemporâneo em um único livro. 80

os marcos definidos por seignobos, sob o regime republicano, acabaram tornando-se os vencedores. A História estruturada para os cursos secundários do historiador francês marcou fortemente a produção didática nacional. o tema "civilização e progresso" foi incorporado sem grandes contestaçōes, ora elaborando-se uma produção histórica

78 FLEIUSS, Max-Elementos de história contemporânea ( 1815- 1897). Rio de Janeiro: Læmmert \& Cia- Editores, 1900, p.1

79 SILVA, Alfredo do Nascimento e- História moderna. Rio de Janeiro: Tipografia Universal de Læmmert Cia., 1885., p. 407

${ }_{80}$ As obras didaticas de seignobos foram:

SEIGNOBOS, Charles- Histoire narrative et descriptive de la Grèce ancienne. Paris: Armand Coli, 1896;

- Histoire narrative et descriptive du peuple romain. Paris: A. Colin, 1897

- Histoire narrative et descriptive des anciens peuples de I'Orient. Paris: A. Colin, 1897 - Histoire de la civilisation- Au Moyen Age et dans le temps Modernes. Paris: Masson \& Cie, 1886 
própria para a formação da elite nacional, ora usando os próprios textos franceses, conforme atestam as listas de livros adotados em algumas das renomadas escolas oficiais do Rio de Janeiro e São Paulo.

Os livros de História da Civilização escritos por brasileiros assumiram o discurso dos países imperialistas, aderindo e utilizando os mesmos argumentos :

\section{"A EXPANSÃo DA CIVILIZAÇĀO EUROPÉIA}

Desde a antiguidade o desenvolvimento da civilização se mede pelo progresso às vezes lento mas contínuo das nações cristãs da Europa. Povoam elas, atualmente, toda a América e a Oceania; acabam de partilhar a Africa e disputam a Asia.

Esta expansão prodigiosa, lentamente preparada nos séculos anteriores, teve no século $x I X$ como causa principal as "explorações científicas." 81

A aceitação dos paradigmas de Seignobos pelos nossos historiadores e educadores explica-se por várias razões. Duas delas são mais evidentes.

Sendo o programa de História da Civilização destinado a um grupo minoritário escolar, o discurso do historiador francês era pertinente porque incorporava o Brasil no tempo do progresso, localizando-o no lugar correto e no papel histórico que deveria desempenhar:

"Tous ces peuples ont une civilisation commune née de la civilisation antique, transmise à tous les pays chrétiens et que tous travaillent à perfectionner.

Ils ont mêmes instruments de travail, mêmes procédés d'industrie, mêmes moyens de transport; tous ont les usines, les machines à vapeur, les chemins de fer, les télégraphes, tous exploitent leurs mines et leur sol. Les pays de l'Amérique et de l'oceanie, nouvellement peuplés, sont des pays agricoles, les parties chaudes donnent le coton, le riz, le café et les épices. (...)"

81 SÁ e BENEVIDES, José E. C. de - História da civilização. Rio de Janeiro: Francisco Alves \& Cia., 1912, 3 ediçāo., p. 222- 223 
Dans tous les pays civilisés, le genre de vie tend à devenir le même; partout on retrouve les mêmes grandes villes avec les rues alignées, les grandes places, les pavés, les trottoirs, les omnibus, le gaz, les égouts, les eaux amenés de loin. (...) 82

Para as elites brasileiras, o mesmismo divulgado por Seignobos representava seus desejos, seus sonhos. País agrícola pertencente ao mundo civilizado, com um papel definido no concerto das nações que buscavam "se aperfeiçoar". Ora, dentro desse contexto civilizatório, o Brasil possuía um destino, um lugar e caminhava no tempo da modernização, junto aos demais povos, confirmando a ideologia do " país do futuro". Deveria apenas seguir a trilha esboçada pela Europa.

Assim, a questão sobre o marco fundador do mundo contemporâneo foi sendo esquecida. Revolução Francesa ou Santa Aliança confundiam-se porque o mais importante era a inserção do Brasil no mundo civilizado:

"Somos irresistivelmente levados a considerar única verdadeira a civilização européia, que é a nossa, e a esperar que ela absorva ou rechace as suas rivais. Já tem invadido a Asia, onde, graças à sua benéfica ação, a Pérsia e a India estão rejuvenescidas e a China e o Japão começam a abrir-se à influência da cultura moderna. o próprio continente africano não escapa a esta fecunda iniciação, nem tão pouco o longínquo arquipélago oceânico, chamado pela Inglaterra, pela holanda e pela França ao convívio da civilização européia." 83

- caminho a ser percorrido pelas futuras elites brasileiras estava traçado, e cabia aos futuros proprietários e políticos da nação continuarem este projeto civilizatório.

A História deveria ser estudada, pelo programa pedagógico organizado por seignobos, dentro de uma trajetória onde o Tempo Moderno da era tecnológica e do progresso, construído pelos europeus se tornasse inevitável

82 SEIGNOBOS, C.- op. cit.- p. 560.

83 SA e BENEVIDBS, E. C; de- op. cit., pp. 237-238. Grifo do autor 
e a explicação do presente e do futuro encontrava-se no percurso histórico cuja origem remontava ao Tempo Antigo:

"Tous ces peuples ont une civilisation commune née de la civilisation antique, transmise à tous les pays chrétiens et que tous travaillent à perfectionner. ${ }^{84}$

Apesar de negar a História Sagrada, criando uma História profana segundo os pressupostos dos iluministas que procuravam evidenciar a racionalidade do homem como o fundamento da História da Humanidade, Seignobos estabeleceu um tempo evolutivo impossível de ser violado, uma predestinação do povo europeu, da raça branca cristã, originária da Grécia e de Roma. A Antiguidade devia, portanto, integrar os estudos escolares, organizando o tempo sequencial, partindo das origens da civilização até seu estágio atual.

o caráter dos Tempos Modernos, da modernização que abarcava a História Contemporânea, nas obras e programas didáticos, não visava destruir os valores do Tempo Antigo, preservando o estudo das "obras clássicas", justificando a manutenção dos currículos das "humanidades". Mantinha-se o Latim e autores clássicos. A Antiguidade era ensinada não apenas nas aulas de História mas pela literatura e estudos de Linguas. 85

Para os intelectuais brasileiros, o período da Idade Média era pouco prestigiado e a valorização dessa época introduzida pelos românticos europeus, apenas tardiamente começou a despertar interesse maior. o programa para os exames preparatórios de 1883 é significativo para demonstrar esta postura. De um total de 40 pontos de História Geral, somente 5 deles referiam-se ao período medieval. 86 os livros didáticos dos autores nacionais resumiam consideravelmente os conteúdos, limitando-se a temas sobre os Bárbaros, as cruzadas e a Formação dos Reinos dos quais nasceriam as monarquias modernas.

84 SEIGNOBOS, C- op. cit., p. 559

85 o texto básico, por exemplo, para o ensino de inglês era GOLDSMITHHistory of Rome, em 3 volumes.

86 Programa para os exames de preparatórios em 1883. Revista do Ensino. Rio de Janeiro, ano $1, \mathrm{n}^{\circ} 6$, jun. $1883, \mathrm{p} .84$ e 85 
o interesse maior dos autores e dos que redigiam os programas escolares nacionais residiu na Antiguidade e no Tempo Moderno associado à divisão de um Tempo Contemporâneo, evidenciando uma concepção de história como exigência social.

Nos escritos didáticos, comumente, havia uma introdução sobre a concepção de História. Acompanhando as introduçōes foi possível avaliar a evolução do conceito, entendido inicialmente como narrativa, até a concepção de uma ciêncià regida por leis:

"Chama-se história o conhecimento do passado da humanidade, o sentido etmológico dessa palavra diz testemunha" 87

"Chama-se história a narração dos fatos. 88

"I. - Definição da história- História é a ciência que tem por fim tratar dos acontecimentos notáveis da vida da humanidade e estudar as leis que presidem ao progresso e decadência das sociedades humanas." 89

87 Apud "Consideraçōes preliminares" de ROCHA José Justiniano Compêndio de história Universal -op. cit., p.1. Interessante foi observar a divisão da história proposta pelo autor: "Embora nos pareça defeituosa essa divisāo, forçoso nos $\epsilon$ adotá-1a desde que so escrevemos um resumo clássico" $E$ apresentou a seguinte divisão: "10 persodo pagão, estendendo-se do tempo primitivo ate o triunfo do Cristianismo, e o aparecimento do -In hoc-signo-vinces- na bandeira dada a Constantino.; $2^{\circ}$ periodo cristão, que iria de Constantino a lutero, do triunfo da fe, até a insurreiçăo da razăo e da liberdade contra a autoridade religiosa; $3^{\circ}$ periodo filosofico, envolvendo no movimento religioso o movimento polftico e indo terminar-se na revoluçäo dos Estados Unidos e da França; $4^{\circ}$ período industrial, desenvolvendo-se com - triunfo da liberdade religiosa, polftica e civil, nas diversas expansōes que hoje nos maravilham."- op. cit., p.v

88 In Idéias preliminares de AzBVEDO, Móreira de- Compendio de história antiga. Rio de Janeiro: B.L. Garnier, 1866, 2a ediçāo, p. 1 . Este autor tamberm possui uma interessante proposta sobre a divisão do tempo historico: "Chama-se tempos primitivos aqueles que compreendem a narração dos acontecimentos antes do dilưvio; chamam-se tempos mitológicos ou fabulosos aqueles que compereendem fatos obscuros, incertos, envolvidos ou desfigurados pela fabula; começa este período com a fundação dos primeiros imperios e abrange mais de treze séculos; Chama-se tempos historicos aqueles que compreendem fatos certos, claros, verificados, como são os acontecimentos ocorridos desde a fundação de Roma até a queda do imperio romano do ocidente.", p. 3-4 89 In Introduçāo de BERQUo, João Maria da Gama- História antiga do oriente. Rio de Janeiro: Livraria Clássica de Alves \& Cia., 1887, Introduçāo, p. I 
"A história tem por objeto narrar metodicamente os fatos notáveis, sucedidos nas sociedades humanas civilizadas, procurando deduzir tanto quanto possível as relações que os ligam." 90

As definições expressam as mutaçōes da historiografia erudita que resultaram em novas formas de composição do texto didático. Ensinar "história da civilização" significava optar por mudanças no enfoque e na abordagem dos temas:

"Abolida a idéia, já hoje depreciada, de uma História Universal, é conhecida a tendência atual no ensino para transforma-se a velha história das batalbas e das datas em História da Civilização.

Exige-se modernamente, a informação minuciosa dos costumes, do viver, do pensar, do crer das gerações passadas; - conhecimento cabal da existência simultânea e das relaçōes recíprocas das classes superiores, médias e inferiores, em que as sociedades se dividiam; o painel exato e colorido, enfim, do que foram elas com seus matizes, suas condiçōes, suas paixōes e sues usos peculiares." 91

Apesar das afirmações explícitas de que "Historia da Civilização" deveria englobar o estudo dos "costumes dos povos do passado", os livros didáticos continuaram a se ater ao político, às guerras e a conter muito pouco sobre artes e crenças dos diferentes povos e sociedades. Cabe ressaltar que a única obra a cumprir tais objetivos foi exatamente a de seu idealizador, Charles Seignobos. Em seus textos houve inovações no conteúdo e na forma, incluindo uma série de ilustrações, produzidas para situar o aluno na vida cultural dos povos considerados dignos de serem considerados "civilizados", embora predominassem cenas de guerras.

A tendência historiográfica de Seignobos, dentro das perspectivas de un programa educacional, era perfeita para determinadas facções das classes dominantes. Houve, entretanto, questionamentos quanto ao lugar do Brasil no mundo civilizado determinado pelo positivismo francês.

90 SÁ e BENEVIDES, José B. C. de- op. cit.- Proêmio, p. 4.

91 Idem, p. 4 
Do grupo de intelectuais ligados à educação que discordava de tal abordagem histórica destacou-se Manuel Bomfim. No cargo de Diretor da Instruçāo Pública do Distrito Federal, entre outras atuações, cuidou de transformar o discurso pedagógico das obras didáticas, tentando introduzir - conhecimento histórico do continente americano em nossas escolas.

A História da América foi por ele concebida como uma disciplina a ser ministrada no curso de formação de professores primários, devendo, por intermédio dos mestres, ser disseminada para as escolas elementares. Para efetivar a proposta foi aberto um concurso para a composição de um " compêndio de História da América para servir aos alunos da Escola Normal", conforme a publicação do edital de abril de 1897 do Conselho Superior da Instrução do Distrito Federal. 92 o primeiro compêndio de História da América nasceu sob os auspicios governamentais que, inclusive responsabilizaram-se pela sua impressão. Trata-se do Compêndio de história da América de Rocha Pombo que representou, paradoxalmente, uma nota dissonante no conjunto da produção historiográfica que buscava se pautar no modelo europeu. 93

Para Manuel Bomfim, em seu parecer sobre o texto, um dos méritos da obra residia no acento que o autor impôs ao caráter de dominação da civilização européia sobre o continente americano ou Novo Mundo. Bomfim concordava com o autor que a colonização européia na América havia sido " "uma verdadeira exploração, um saque, quase", uma invasão que exterminou civilizações e povos.94

As qualidades da obra residiam ainda, segundo 0 parecerista, na ênfase sobre o sentido da independência política da América Latina, na qual os partidos conservadores e retrógrados lutavam mais pela continuação de

92 As referencias sobre este concurso encontram-se no capitulo I.

93 Trata-se do livro de POMBo, José Francisco da Rocha- Compêndio de Historia da América. Obra didatica premiada com o primeiro prêmio em concurso perante a Diretoria Geral da Instrução pública đa capital federal e adotada para os estabelecimentos do mesmo distrito. Rio de Janeiro: Lxmmert \& Cia., 1900. A 1 ediçāo traz o Parecer sobre o livro assinado por Manuel Bomfim, datado de 22 de abril de 1899 .

94 Idem, op. cit. p. X 
"seus privilégios, esforçando-se para que a emancipação politica se limite à simples questão da autonomia governamenta1 . " 95

No texto de Rocha Pombo podemos efetivamente ler inúmeras passagens sobre a opressão imposta pelos europeus:

$"($ (..)E eis aí a massa de gente que tinha de eliminar as populações indígenas do Novo-Mundo. Por toda parte andava essa gente proclamando o seu direito de raça mais culta e mais nobre e sem ver desde logo nos habitantes das terras conquistadas mais do que raças inferiores $e$ vis, contra as quais tinha o europeu os mesmos privilégios que tem o homem sobre toda a animalidade. E portanto, em todas as colonias, foi-se cuidando de tirar o maior proveito possível da pobre besta." 96

Na introdução do livro, Rocha Pombo expôs o problema da violência no contato entre as diferentes civilizações, a européia e as americanas, e os problemas que envolveram tal dominação:

"O antagonismo entre os dois mundos era, portanto, inevitável. Com o tempo, esse antagonismo, em vez de se disfarçar, foi-se aprofundando cada vez mais. E hoje, a própria situação econômica e internacional da Europa é o móvel supremo dessa temerosa política de força e de expansão exterior das grandes potências do Continente; e semelhante política, cuja fase crítica parece iminente, tem criado uma situação excepcional para os povos do Novo Mundo, pondo-se quase em conflito com os interesses, os direitos e quantas vezes com a própria soberania das nacionalidades americanas.

Esse conflito não é mais possível disfarçar, nem mesmo seria explicável esquecer um instante, desde que nos é imposto pela lógica fatal dos acontecimentos humanos." 97

o tema do imperialismo foi apresentado, assim, em um discurso oposto ao de seignobos e de seus seguidores brasileiros. A civilização européia era apresentada com sua truculência e não como forma de benefício tal como

95 Idem, op. cit.- p. xIV

96 Idem, op. cit., p. 4

97 Idem, op. cit.- Introduçāo, p. XXXI 
pretendiam demonstrar os historiadores da IIIa República francesa.

Tanto para o idealizador do programa de História da América como para o autor que se preocupou em concretizar uma visão histórica fundamentada no espaço americano, o continente atravessava um momento de perigo frente à nova política européia, o que nos forçava a voltar o olhar não apenas para o próprio país mas para o continente latino americano. Tornava-se, sob esta ótica, necessário buscar uma identificação histórica e cultural pela formação de uma população mestiça, na configuração de uma sociedade que conviveu durante trezentos anos com o regime escravo que aí deixou marcas indeléveis. Em Rocha Pombo, então em fase de contato com os anarquistas, surgiu a concep̧ão pacifista que o fez antever a América como uma nova civilização, uma "Terra da Mediação":

"A América vai ser a sede definitiva da civilização que vem, na qual o vasto patrimônio espiritual da família humana se refundirá sob a dupla influência do gênio do ocidente, irrequieto e fervido, e do antigo genio oriental, contemplativo, misterioso e amplo como a História. Terra da Mediação há de ser, pois, esta América formosa e ingente, para conciliar os dois mundos que há 50 séculos vêm empenhados em luta tremenda."98

A concep̧ão de História do autor se evidenciou pelos temas selecionados e pela periodização que estabeleceu.

Uma primeira parte foi dedicada ao período précolombiano onde apresentou a situação social e o destino das civilizações dos povos "aborígenes". o "tempo antigo", as origens não estavam na Europa, na Grécia ou Roma mas no próprio continente.

A segunda parte, o período colonial, analisava a dominação dos europeus sobre os povos nativos e a terceira parte, dividida en dois tópicos, a emancipação das colônias americanas e integração das nacionalidades americanas, explicava as lutas pela libertação contra a metrópole e as lutas civis internas dos novos Estados que se criavam.

98 Idem-op. cit., p. 350 
Nos capítulos finais do livro, o autor anunciava a necessidade de se estudar o Brasil como integrante desse processo histórico, caminhando ao lado das demais repúblicas americanas, e, finalmente, expunha as razões da crença em um futuro promissor: a América era a terra onde se fundiu a civilização ocidental e a nativa, um amálgama cultural, uma nova civilização na qual seriam abolidas discriminações.

Esta abordagem sobre a História americana não foi, evidentemente, a que predominou. Há poucas notícias referentes à sua adoção nas escolas e o número de edições, apenas duas e a segunda ocorreu em 1925, indica sua fraca aceitação, mesmo considerando que era adotada em algumas escolas renomadas, como a Escola Normal Caetano de Campos de São Paulo.

o ensino da História foi alvo de confrontos entre a História Sagrada e a profana. Confrontaram-se os defensores de uma História laica que situava e inseria nosso tempo no mundo "civilizado e moderno" e os que concebiam uma especificidade temporal "nacional", com outras raízes. As divergências ocorreram face a uma subordinação ou independência no tratamento do nosso passado e quanto às opções futuras.

Nesse sentido foi mais tranquilo conciliar uma História Sagrada a uma profana, como a que realizou Jonathas Serrano. Era inviável, por parte significativa de nossas elites, aceitar e propor os temas da dominaçāo e exploração a que fomos submetidos pelos países civilizados, aos nossos alunos.

o discurso expresso nos primeiros textos didáticos de meados do século passado apontavam para uma conciliação entre o tempo laico e o religioso. As transformaçōes históricas seguiam um plano divino ao qual estava associado - Estado:

"A história pode naturalmente dividir-se em duas grandes partes: história antiga, compreendendo os fatos sucedidos desde o aparecimento do homem até o nascimento de Cristo; e história moderna, abrangendo os fatos ocorridos do nascimento de Cristo até nossos dias. "O Calvário é o ponto 
culminante da história": o Cristianismo foi a maior transformação social de todos os tempos.

Essa não é, porém, a divisão geralmente adotada. (..)" 99

$E$, em seguida, o autor citava a periodização difundida por Seignobos.

A ambiguidade de Serrano é vísivel no título, evitando - termo "civilização", mas, na introdução do texto acatou as concepções científicas do conhecimento histórico. Buscou incorporar os avanços das ciências educacionais, utilizandose de Ernest Lavisse como exemplo a ser seguido quanto aos aspectos metodológicos na elaboração de materiais didáticos, mas procurava, primordialmente, como militante católico, conciliar a "ciência histórica" com "a verdadeira História" cujo progresso emanava de um caminho traçado por Deus, de forma inexorável. Serrano aceitava um ensino de História referenciado nas conquistas das ciências e do progresso mas não emancipado da Igreja.

A História Geral foi elaborada em meio a tais confrontos, ficando, no entanto, esboçado com nitidez o sentido do seu ensino. A História servia para introduzir o aluno no mundo civilizado.

o primeiro programa constituído para o ensino de História oriundo do poder governamental, datado de 1837, sofreu inúmeras reformulações que demonstram o caráter conflituoso inerente à disciplina escolar, tanto ao nível interno do conhecimento que construía e buscava transmitir, quanto ao papel da permanência da própria disciplina frente às demais que se agrupavam ou se integravam em uma proposta mais global de saber escolar.

Acompanhando a elaboração dos livros didáticos percebese que ocorreu, para as escolas elementares, o embate entre uma História Sagrada fundamentada nos pressupostos de uma História teleológica e um ensino cívico pretensamente fornecedor de uma moral profana. Para o nível secundário a História Sagrada foi combatida mais veementemente à medida em que a História civil se configurava como campo científico.

99 SERRANO, Jonathas. EpItome da historia Universal. Rio de Janeiro: Livraria Francisco Alves, 1912, p. 18 
Nessa perspectiva, surgiram novos confrontos e diferentes interpretações para uma "história da civilização" que, fundamentalmente, dividia os intelectuais frente aos projetos políticos do Brasil.

A evolução histórica expressa na História Sagrada foi a base da História Geral profana construída para o ensino nas escolas públicas. A literatura didática de História Universal expressou as diferentes versões dos autores frente à História teleológica proclamada pela Igreja. Os livros didáticos foram testemunhos de um movimento que separou grupos tendentes a uma conciliação e aproximação com a história salvacionista, de outro, que fêz oposição à concepção do tempo determinista divino, defendendo a difusão de um tempo laico.

A primeira fase da produção da História Universal correspondeu a um certo consenso entre os intelectuais, submetendo-se ao passado cristão, seguindo os franceses com relativa docilidade. Os anos oitenta do século XIX marcaram o início dos conflitos frente aos pressupostos da História Santa que prosseguiram nas décadas seguintes, alternando obras de autores comprometidos com a laicização e outros que insistiam na permanência exclusiva da memória cristã. 


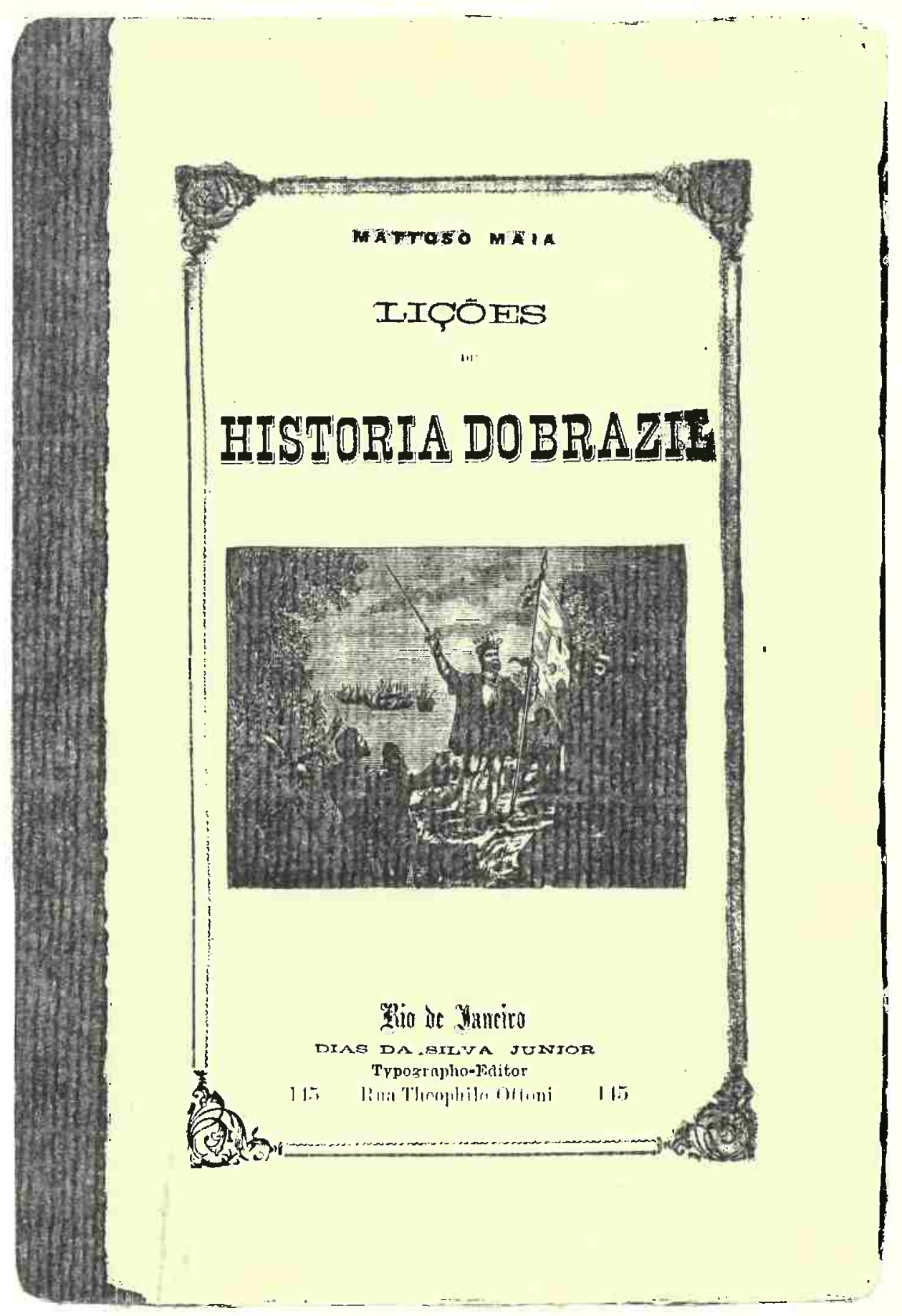

"A história pátria por sua natural divisão nos quatro períodosDescoberta, Época colonial, Império e República, assim como pela simplicidade com que pode-se estabelecer a evolução da sociedade brasileira, pelo estudo de seus fatores perfeitamente determinados, como sejam-descobridores, indigenas, govemo, invasores, opressores e patriotas, pode ser dada no terceiro ano por meio de uma série de quadros históricos característicos das quatro épocas e dos principais grupos de fatos." 


\section{CAPITULO IV}

\section{HISTORIA DO BRASIL NOS LIVROS DIDATICOS}

Os livros didáticos produzidos para o ensino da Historia do Brasil tiveram um processo de criação diferente dos demais. Os autores não podiam recorrer a traduções, por tratarem de temas nacionais, transformando os manuais de História, juntamente com as obras de Geografia, em produção necessariamente original. A construção dos livros de História do Brasil vinculou-se à produção do conhecimento erudito elaborado por intelectuais nacionais. Tais características nos levaram a indagar sobre a autonomia dos livros didáticos de História do Brasil, levando-nos a investigar qual teria sido o grau de liberdade e independência dessa produção frente às concepções do fenômeno nacional engendradas pelos europeus e pelo papel das "histórias pátrias" na construção de um passado da nação.

A Historia do Brasil, como as demais histórias nacionais, tendia a tornar-se a grande instância legetimadora do Estado-nação e do regime político que se instaurara. Considerando estas perspectivas para a História nacional e seu ensino, averiguamos as mudanças que ocorreram com a nova disciplina escolar, iniciando por sua gênese, durante a formação do Estado monárquico brasileiro até a instalação do regime republicano.

Ao acompanharmos o percurso dos manuais escolares de Historia do Brasil, situamos o lugar ou lugares dessa produção buscando, pelas interpretações que os autores deram aos programas curriculares, desvendar os confrontos inerentes à disciplina e as formas de transposição do saber erudito.

A leitura dos livros didáticos realizada paralelamente à da historiografia denominada acadêmica permitiu-nos avaliar a interferência da produção de autores 
estrangeiros, tais como southey e Ferdinand Dénis, na elaboração dos textos didáticos de História do Brasil e a posterior relação com os trabalhos dos Institutos Históricos e Geográficos da sede governamental e das províncias.

Pelo "corpus" documental, constituído de 43 livros de História do Brasil, compreendendo as publicações entre 1831 e 1910, pudemos perceber três momentos na composição dessa literatura. Uma primeira fase, "o nascimento do livro escolar de História do Brasil", correspondeu aos anos de trinta e quarenta do século passado, no decorrer do conturbado período regencial. Um segundo momento teve. início com a introdução da disciplina de História do Brasil nos currículos oficiais escolares, para o secundário e escolas elementares do $2^{\circ}$ grau, na fase da Conciliação. Na década de oitenta, iniciou-se um período de elaboração de livros compostos segundo os pressupostos positivistas, ou ainda segundo uma história cientificista, correspondendo à propaganda e depois instauração do regime republicano.

Considerando que o ensino de História do Brasil estava sendo construído em meio aos confrontos entre a História Sagrada e a História Profana, buscamos identificar os demais textos veiculados na escola, especialmente os livros de leitura, que auxiliavam a divulgar a História oficial da nação. E, para aprofundarmos a questão da transposição do saber erudito em saber escolar e das formas como se estabeleceram as articulações entre História Sagrada e História Nacional, escolhemos dois autores, reconhecidos intelectualmente e produtores dé textos didáticos variados, com ampla vendagem.

\section{Autores e compêndios de História do Brasil}

1.1 Militares e História nacional

Os primeiros livros didáticos de História do Brasil, Resumo da história do Brasil de Henrique Luiz de Niemayer Bellegarde e Compêndio da história do Brasil de Abreu e 
Lima tiveram uma característica peculiar no que se refere a seus autores: ambos eram militares. Esta constatação nos levou a refletir, inicialmente sobre o "lugar da produção" histórica e seu papel político na configuração do Estado nacional. 1

Indagamos inicialmente a relação possível entre a carreira profissional e o interesse que levou militares a redigir obras de divulgação escolar. Acompanhando a história dos dois livros, verificamos que possuem trajetórias diferentes em seu processo de elaboração e principalmente de divulgação.

Henrique Luiz Niemayer Bellegarde pertencia a uma família de militares portugueses tendo seu pai emigrado para o Brasil junto com a familia real em 1808. Estudou na Academia Militar do Rio de Janeiro e completou estudos em Paris, tornando-se bacharel em letras pela Universidade de Paris. Tornou-se major do corpo de engenheiros no Rio de Janeiro e chegou a ser sócio do IHGB pouco antes de seu falecimento. 2

A obra que passou a ser considerada como didática de Henrique Bellegarde foi a $2 \underline{a}$ edição do Resumo da história do Brasil de 1834, ao ser "adotada pelo governo como compendio escolar para instrução pública". 3 Houve uma primeira edição que, segundo o próprio autor, foi uma tradução com muitas adaptações de textos do francês Ferdinand Dénis sobre a História do nosso país. A $2 \underline{a}$ edição foi modificada, deixando de ter o carater de mera tradução, apresentando-se como uma criação do autor, segundo a introduçāo: "agora, porém, melhor investigando à cerca do poucos fatos que daquele escritor trasladamos, nos chegamos a convencer de que, sem embargo das numerosas correçōes que

1 Trata-se das obras de BELLEGARDE, Henrique Luiz de Niemeyer- Resumo da história do Brasil. Rio de Janeiro: Tip. Dous de dezembro de $P$. Brito, 1855, 4 ed. e de LIMA, José Inácio de Abreu- Compêndio de história do Brasil. Rio de Janeiro: Eduardo Henrique Lammert, 1844 $1 \mathrm{v}$. O livro de Bellegarde foi, provavelmente editado em 19 ediçāo em 1831 .

2 Henrique Luiz Niemayer Bellegarde nasceu em Lisboa, em 1802 e morreu em Cabo Frio em 1839. Cf. BLARE, Sacramento- op. cit., v. VII, p. 226227

3 o livro foi aprovado por circular da câmara municipal de 26 de abril de 1834. Cf. Frontispicio do livro BELLBGARDE, L. N.- op. cit. 
por então lhes fizemos, ficaram eles os menos circunstanciados de toda a obra: por isso, abandonamos de todo o primeiro original, e compusemos a íntegra desta segunda edição, que damos ao público." 4

o Resumo da história do Brasil de Bellegarde teve outras edições, com acréscimos e adaptações feitas pelo seu irmão, também militar, Pedro de Alcântara Bellegarde. Foi feita uma $3 \underline{a}$ edição em 1845 e uma $5 \underline{a}$ e última em 1855.

o primeiro compêndio de História do Brasil a ser introduzido em nossas escolas foi, assim, um texto escrito por um português criado no Brasil, pertencente a uma família de militares ligados ao poder. Trata-se de uma História na qual predominava uma visão estrangeira sobre a "pátria brasileira", uma tradução francesa onde se introduziu a perspectiva portuguesa. o autor rejeitou as críticas européias relativas às formas de dominação portuguesa sobre a colônia brasileira. Na primeira parte do livro, Brasil antes da conquista, Bellegarde justificou o extermínio dos povos indígenas pelos portugueses:

"A rápida despovoação da América Meridional, depois das conquistas européias, $e$ um dos fenómenos que mais tem dado que fazer e explicar aos historiadores desta parte do mundo: é necessário, contudo, não a contemplar tão crescente, como a tem figurado alguns escritores estrangeiros, que ciosos dos descobrimentos dos portugueses, tem tratado de torná-los odiosos, exagerando aqueles excessos que sempre se cometem en conquistas, e que eles querem atribuir à barbaria da Nação. Povos errantes, que só viviam dos recursos que espontaneamente lhes apresentava a natureza, e em contínua guerra recíproca; apesar da vastidão do nosso território, e da riqueza do seu solo, bem se vê que não podian ser numerosos".5

continuava o texto relatando sobre as nações indígenas, evidenciando o "atraso" cultural das tribos, notadamente quanto às estratégias de guerras e' a submissão ao pagé e outras crendices, acrescentando que as doenças

4 BELLEGARDE, L. N.- op. cit. - p. II., Advertência.

5 Idem, op. cit. - p. 15 
trazidas pelos brancos causaram mortes aos indígenas pela ignorância em que viviam, sem condiçōes de prevenção de moléstias facilmente curáveis.

As demais partes do texto estão repletas de ações de valentia na conquista de uma terra de selvagens. Em seguida mostrava a luta portuguesa pela defesa do novo território conquistado que tornava-se alvo de cobiça dos países estrangeiros. Conquista e defesa territorial constituíramse nos marcos da periodização da história brasileira:

"Segunda época- o Brasil conquistado pelos portugueses $p$. $41-74$

Terceira época- o Brasil no domínio espanhol p. 75116

Quarta época- 0 Brasil livre do jugo da Espanha p.117-186

Quinta época-o Brasil sede da monarquia portuguesa p. 187-224

Sexta época- 0 Brasil império constitucional independente p. 225-274." 6

o compêndio de História nacional do general Abreu e Lima, possui uma história mais polêmica.

o general José Ignácio de Abreu e Lima, natural de Pernambuco, iniciou estudos militares no Rio de Janeiro, envolveu-se um disputas em sua província, acabando por ser preso durante os conflitos revolucionários de 1817 , partindo depois para os Estados-Unidos. o título de general foi obtido pela participação de lutas contra os espanhóis na Venezuela, junto às tropas comandadas por Bolivar. Regressando ao Brasil em 1832, instalou-se no Rio de Janeiro onde se aliou aos opositores do regente Feijo, tornando-se figura conhecida por ataques políticos em periódicos e outras publicações. Seus mais famosos opositores foram clérigos, alguns famosos, como Feijo e o cônego Januário da Cunha Barbosa, oposição que continuou após seu falecimento quando the foi "negado pela autoridade

6 Idem, op. cit. - Index 
eclesiástica uma sepultura em lugar sagrado só por discutir com liberdade de pensamento doutrinas da igreja." 7

o Compêndio de história do Brasil de Abreu e Lima, inicialmente publicado em dois volumes, tornou-se alvo de uma interessante polêmica que envolveu o então jovem Adolfo Varnhagen mas que, inicialmente, era travada entre o general e o cônego Januário da Cunha Barbosa, secretário do Instituto Histórico e Geográfico Brasileiro. Varnhagen fêz uma severa crítica ao livro, acusando-o de ser cópia do francês Beauchamp, "um plagiador de Southey". Abreu e Lima respondeu veementemente às críticas, obrigando Varnhagen a uma réplica. ${ }^{8}$

A polêmica foi significativa, considerando que o IHGB iniciava suas discussões sobre a construção de uma História nacional e os debates representaram as tendências dos intelectuais frente a construção da História oficial.

As críticas de Varnhagen não impediram que o livro, reimpresso pelos editores em um único volume, em formato pequeno, "para vulgarizar sua leitura", fosse adotado no Colégio Pedro II e em outros liceus provinciais. A adoção oficial do livro em escolas secundarias fêz com que houvesse novas edições, inclusive uma em 1882, feita após a morte do autor, nas quais os editores explicaram os acréscimos realizados no texto original:

"Uma outra circunstância, para a qual chamamos atenção do público, é a continuação da exposição histórica até nossos dias confeccionada por um distinto literato nacional. Era uma lacuna geralmente observada em quase todos os compendios da história patria, que quando muito atingiam ao período regencial e à inauguração do reinado atual. Podemos afirmar que é a primeira vez que um livro escolástico se depara com a narração breve e conscienciosa

7 A biografia de Abreu e Lima apresentada por sacramento Blake 6 bastante subjetiva, com elogios eloquentes ao general, criticando a atitude do clero frente às questōes defendidas, como a de sustentar a idéia do casamento civil, "de onde proveiu o odio do bispo de olinda". Apud BLAKE, Sacramento-op. cit. v. V, p. 455 a 459

8 Esta polêmica foi comentada por José Honorio Rodrigues em Teoria da Historia do Brasil e é citada por CARvalHo, Delgado de- Introdução metodológica aos Estudos Sociais. Rio de Janeiro: Agir, 1970, p. 38 
dos feitos memoráveis que assinalam o longo e próspero reinado de S.M. o sr. D. Pedro II."9

A periodização apresentada por Abreu e Lima, um dos pontos cruciais dos debates travados, foi marcada pela dominação política, datando com precisão os momentos das mudanças. A divisão da História brasileira foi feita em oito capítulos: Capítulo primeiro: 1500-1531, período da descoberta e exploração da região onde incluia a descrição da terra e dos índios; capitulo sequndo: 1532-1580, tratava da organização política até a dominação espanhola; Capítulo terceiro: 1580-1640 ou período do domínio espanhol incluia a invasão holandesa; o Capítulo quarto: 1641-1654 tratava das lutas contra os holandeses até sua expulsão; Capítulo quinto: 1654-1807 correspondia à descoberta do interior e das minas, guerras no sul contra os jesuítas; Capítulo sexto: 1808-1821 referia-se às lutas e ganhos obtidos com a família real portuguesa no Brasil; Capítulo sétimo: 1821-1831 expunha as diferentes lutas no processo de independência, destacando as guerras e suas batalhas e o Capítulo oitavo: 1831-1841 relatava as lutas políticas regenciais, enfatizando a atuação política de Feijó. 10

o livro destacava as campanhas militares em todas as fases e sendo o autor pernambucano, a luta contra os holandeses foi um dos grandes momentos, merecedor de 107 páginas em texto de 352 páginas. o Nordeste foi o centro da ação política brasileira.

o momento inicial da construção da "história pátria" foi pontuado pelas lutas empreendidas pelos portugueses e posteriormente por brasileiros, na conquista do território e das guerras internas entre as facções das elites econômicas para a conquista do poder. Os textos didáticos produzidos por um grupo de intelectuais militares registraram a preocupação em disseminar a imagem física do

9 LIMA, J.I. de Abreu e- op. cit. -1882 .

10 A edíção de 1882 foi acrescida de um nono capitulo sobre o governo de D. Pedro II..Cf. LIMA, J. I. de Abreu- op. cit...Introdução dos editores. 
"território nacional", do Estado que nascia, aliando os estudos geográficos ao histórico.

A descrição geral "da vasta região" tornava-se uma necessidade para a população, ou parte dela, a que iria comandar a nação, que desconhecia o país, sem contato ou informações sobre as diversas "riquezas" brasileiras. A Historia apresentava-se necessariamente associada à Geografia. Tempo e espaço eram percebidos como um conjunto, tornando-se visível esta concepção pelos primeiros programas do colégio pedro II onde as duas disciplinas eram objeto de um estudo integrado, a Corografia Brasileira e História Nacional, ministrado por um único professor. Os estudos geograficos separararam-se dos de História apenas em 1876, havendo, a partir desta data, um professor para cada disciplina.

A integração das duas disciplinas resultava de uma concepção de Estado Moderno que, no transcorrer do século XIX, transformou os princípios tradicionais relativos à delimitação do território, eliminando os princípios de legitimação do "uti possidetis" e introduzindo a noção de "fronteiras naturais". A noção de "fronteiras naturais" passou a justificar a incorporação de terras decorrente de guerras e, os acordos políticos deveriam se pautar em argumentos fornecidos pela História que legitimava as anexações ou a defesa " do território nacional" . Não era, portanto, inusitada a preocupação, entre os setores militares, de interferir nos conteúdos das disciplinas de História e Geografia, entendendo-se os cuidados que tiveram em elaborar obras de divulgação, visando atingir o público jovem, em fase de formação.

Tratava-se de um programa nacionalista, engendrado de acordo com as idéias liberais que, na primeira fase, limitaram-se a relacionar Estado-nação, excluindo o povo, mal vislumbrado e pouco citado nos textos didáticos dos autores deste período. Era um discurso que pretendia vincular nação e território, "pois a estrutura e a definição do Estado eram essencialmente territoriais." 11

11 HOBSBAWM, Eric- op.cit., p. 32 . 
A História do Brasil elaborada pelos militares baseou-se, paradoxalmente, em autores estrangeiros que, logo após a "abertura dos portos", passaram a se preocupar com a "nova" região americana que se desvendava para os demais países europeus.

Esta produção sobre o Brasil possuía finalidades pragmáticas, cuidando de retirar dados que interessavam aos propósitos de seu país de origem. As obras de História de Beauchamp ou southey possuíam objetivos utilitários, representando a disputa do mercado americano pela Inglaterra e França.

Beauchamp, por exemplo, informou que ao recuperar a História do Brasil, visava conhecer o vasto território e suas imensas riquezas que, há muito, eram alvo de cobiças das potências européias :

"Aucune possession du Nouveau-Monde n'a été si longtemps ni si souvent disputée, non seulement par les naturels, mais encore par des nations formidables de I'Europe, qui se sont portée tour-à-tour au Brésil, soit pour le piller, soit pour s'y établir." 12

As guerras de conquistas, temas preferenciais das nações comerciais européias, acabaram por servir aos interesses dos historiadores brasileiros desejosos em transformar as lutas contra "os estrangeiros" na configuração das idéias "nativistas", do nacionalismo, exatamente no momento em que as regiões se sublevavam contra o poder central na fase regencial. Era o momento de reforçar a idéia da "unidade territorial" e do poder centralizado expresso no texto de Bellegarde:

"Aqui o fim de nossa tarefa; feliz se nossos jovens acharem neste livro auxilio a seus primários estudos, único incentivo que a tal publicação nos animou. A penas mais hábeis, que não a nossa de ruim estilo, e de pior critério, pertence a arrazoada narrativa da completa historia Brasileira; praza ao Céu que um venturoso porvir lhe ministre dourada matéria; praza ao céu que o saber e

12 BEAUCHAMP, M. Alphonse- Bistoire du Brésil depuis sa découverte en 1500 jusqu'en 1810. Paris: D'Alexis Bymery, 1815. Préface, p.VI. 
patriotismo dos Poderes a quev cabe o grave encargo de promover o bem da patria, consigam extirpar fatais rivalidades. Sirvam os estranhos paises de exemplo ao nosso; embora se objete com diferenças de localidade, o gênio das Nações depende mais das leis que a regem, do que da atmosfera que as cobre; o Grego da natureza é hoje o mesmo que o dos séculos de ouro, mas os vícios do Governo tem privado Atenas de novos Péricles, e novos Phidias." 13

o investimento dos militares na elaboração de textos de divulgação escolar prendeu-se, portanto, a uma visão de História nacional representativa da configuração do poder que se instalava e das novas concepções de Estado-nação. Para o caso das nações da América Latina nas quais os militares não se originaram de castas aristocráticas, estes setores sociais se identificaram prontamente com o poder do Estado e suas necessidades de formação de quadros burocráticos como forma de sustenção política. Lutaram, em vários setores, para a constituição de uma ideologia de pátria e de nação associando-as a uma História de conquista territorial, dando-lhes uma dimensão de poder predestinado.

os setores militares continuaram a se dedicar a esta literatura escolar e perfilaram as listas de autores de livros de História no decorrer do período estudado.

1.2 Os sócios do IHGB e a História oficial do Brasil

A partir dos anos finais da década de cinquenta podemos identificar uma historiografia didatica diferenciada. o momento político era outro e outra a política educacional.

o volume de obras e autores cresceu em decorrência da obrigatoriedade do ensino de História para os exames preparatórios em várias escolas superiores, da introdução da Historia do Brasil no programa do Pedro II e para as escolas de ensino elementar. Surgiram textos para os diferentes públicos estudantis, especificando o nível para

13 BRLLEGARDB, Benrique Luiz de N.- op. cit., p.275 e 276 
- qual foi produzido: curso primário, preparatórios, aulas de Iiceus, de Escolas Normais.

A ampliação do público consumidor determinou o interesse de editoras na fabricação de compêndios escolares, iniciando uma fase de competição entre a editora de B.L. Garnier e a dos irmãos Læmmert, situação que incentivava o aparecimento de novos autores.

As editoras voltaram-se para nomes consagrados da elite intelectual para a elaboração de seus textos, preferencialmente professores do Colégio Pedro II e ou sócios do IHGB. As duas instituiçōes corresponderam a uma espécie de credenciamento para os autores de Historia, dando-lhes uma idoneidade intelectual capaz de promover a aceitação junto ao público docente.

As figuras que se destacaram como secretários do IHGB, foram, quase todos, autores de livros didáticos. Foram eles, o cônego Caetano Fernandes Pinheiro (18591876), Dr. Duarte Moreira de Azevedo (1880-1886), Joaquim Manuel de Macedo (1852-1856) e Max Fleiuss (1905-1907).14 No papel que desempenharam na entidade, enquanto secretários, era visível una atuação dinâmica, conciliando seu trabalho de "cientistas" com outros cargos, quer como professores, quer como profissionais liberais. Os secretários compuseram o segundo escalāo, importante para a sobrevivência da instituição e deles dependiam a imagem e a produção científica do estabelecimento. Sem serem nomes famosos, eram os que lutavam para conseguir aproximar-se e desfrutar dos privilégios do poder.

- IHGB abrigou outros nomes, entre seus sócios efetivos, que deixaram textos escolares como uma de suas contribuições culturais sem que, entretanto, alardeassem estas atividades. Em suas bibliografias é difícil encontrar as obras didáticas que produziram. Foi o caso de silvio Romero, João Ribeiro, José Justiniano da Rocha, Capistrano de Abreu. Os editores, por outro lado, buscavam a instituição, valorizando o autor pela sua condição de sócio ou de professor do Colégio Pedro II, tentando garantir a

14 Cf. SCHWARCZ, Lilia M.- op. cit. 
aceitação da obra entre o público mediante o currículo exposto na página de rosto do compêndio.

Tivemos assim, na geração dos iniciadores da produção didática de História e de outras disciplinas, figuras próximas ao governo, escritores de obras literárias mas, sobretudo, os encarregados principais do "fazer erudito" da época. Os compêndios que escreveram para o público estudantil eram, principalmente, textos de Literatura, Gramática, História e Geografia, dedicados ao ensino secundário, majoritariamente, mas também em número significativo para o primario.

Os primeiros escritores de textos didáticos tiveram, estreitas ligações com o saber oficial não apenas porque eram obrigados a seguir os programas estabelecidos mas, porque estavam "no lugar" onde este mesmo saber era produzido. A primeira interlocução que eles estabeleciam era exatamente com o poder educacional institucionalmente organizado. o "lugar" de sua produção situava-se junto ao poder e era para o poder, nos colégios destinados à formação das elites, dialogando com intelectuais e políticos assentados no governo e participantes do IHGB. O mesmo ocorreu com alguns dos autores das províncias que estavam ligados a institutos congêneres. 15

A importância dos textos didáticos como divulgadores de uma versão da História oficial, pode ser avaliada pela produção de Joaquim Manuel de Macedo. Como membro do IHGB, "escreveu muito pouco, destacando-se o ensaio publicado na Revista do Instituto, intitulado Dúvidas sobre alquns pontos da história do Brasil (-). Afora este único ensaio, os demais documentos se compõem de relatórios e orações necrológicas, bem como biografias de colegas do Instituto"17 mas, em contrapartida, além de seus romances, redigiu textos didáticos que se tornaram famosos na literatura didática. Seu primeiro manual escolar, Lições de

15 Um pernambucano representante da elite local era, além de sócio do IHGB da capital da Corte, "Membro instalador e $2^{\circ}$ secretario do Instituto Arqueologico e Geografico Pernambucanon. Esta informaçāo faz da página de rosto de ALBUQUERQUE, Salvador Benrique de- Compêndio da Historia do Brasil. 22 ed. Pernambuco: G. de Lailhacard, Editor, 1869. 17 SCHWARCZ, Lilia M.- op. cit. , p. 15 
história do Brasil, originou-se das aulas que organizava para seus alunos do $4^{\circ}$ ano do Colégio Pedro $I I$, onde era professor de Corografia e História do Brasil. Suas experiências pedagógicas levaram-no a compor mais dois textos didáticos: Lições de corografia brasileira que foi objeto de traduções para o francês e Mulheres célebres. 18

Assim, paradoxalmente, como autor de livro didatico ele foi, provavelmente, o historiador mais lido do século $X I X$, considerando-se que apenas o Lições de história do Brasil teve 11 edições, publicando-se em média, seis mil exemplares em cada uma delas.

A partir da segunda metade do século XIX, portanto, evidenciava-se a importância da produção didática como veículo de divulgação da História do Brasil. Por seu intermédio, intelectuais conceituados, ligados ao poder ou não, puderam disseminar seus trabalhos sobre uma História oficial da nação.

1.3. Expansão da produção

Os trinta anos finais do século passado marcaram o início do crescimento da rede de ensino escolar e os anos 70 corresponderam ao surgimento de escritores provenientes de esferas sociais mais modestas. Pfromm Netto assinalou que o movimento responsavel pelo crescimento do ensino elementar possibilitou "as condiçōes favoráveis que estimularam, em educadores brasileiros, o desejo de elaborar livros de leitura e de outros textos didaticos para uso dos alunos e professores do ensino elementar. 0 baiano abílio Cesar Borges, primeiramente, e mais tarde, Felisberto de Carvalho, Hilario Ribeiro, Romão Puiggari,

18 MACEDO, Joaquim M. de- Liçōes de corografia do Brasil * Rio de Janeiro: B.L. Garnier, 1873. Este livro foi traduzido para o francês, segundo seu tradutor, para um melhor entendimento sobre a questāo da Guerra do Paraguai. o Brasil passava a ser alvo de interesse por causa da guerra do Paraquai, segundo consta do avant-propos do tradutor, sendo incompreensivel para os europeus que os tres maiores paises latino-americanos nāo conseguissem vencer um desconhecido Paraquai. Cf. MACEDO, J.M. de- Notions de chrographie du Brésil. trad. J.F. Halbout. Leípzig: Imprimerie de F. A. Brockhauss, 1873.E seu Gltimo texto didatico, Macedo escreveu para as escolas femininas. MACBDO, J.M.- Mulheres célebres. Rio de Janeiro: B. L. Garnier, 1878. 
Arnaldo de Oliveira Barreto, Francisco Vianna, João Köpke e outros produziram nossas primeiras séries graduadas de livros de leitura. Livros que(-) foram verdadeiramente nacionais.. concorrendo de modo nada desprezível para a unidade brasileira de sentimento" 19

Esta nova fase da produção escolar caracterizou-se por autores diferenciados quanto à formação e experiências quando comparados com os escritores sócios do IHGB, composto por um grupo mais homogêneo.

Os autores da geração de oitenta possuíam, na maioria das vezes, experiências pedagógicas provenientes de cursos primários ou de Escolas Normais. A pratica pedagógica desses autores refletiu, parcialmente, uma preocupação menos limitada quanto às opções educacionais, saindo da esfera do ensino puramente destinado à formação das elites.

Surgiram autores que se especializaram em elaborar textos para um público infantil, tornando-se verdadeiros "campeões de venda", conhecidos por várias gerações de alunos.

Foi o caso do livro A Pequena história do Brasil por perguntas e respostas de Joaquim Maria de Lacerda. Surgiu nos anos finais de 70 , com edição promovida pelo próprio autor em Paris e a encontramos " revista e atualizada" no catálogo das edições de F. Briguiet no ano de 1936.20 É impossível contabilizar o número total de ediçōes que este livro sofreu. Consta que a 1 a edição foi rapidamente esgotada, segundo relata o próprio autor no Prefácio da 2 a edição datada de 1880 ainda feita em Paris. Em 1887 houve uma sexta edição composta após a morte do autor, falecido em 1886, organizada por Luis Leopoldo Fernandes Pinheiro, contratado pela B.L. Garnier. Este autor, a partir desta data, encarregou-se de aumentar e atualizar as obras de Lacerda, alcançando A Pequena história do Brasil a $9 \underline{a}$ edição em 1893.21

19 PFROMM NETO, samuel e outros- op.cit., p.170. Grifos do autor.

20 Cf. Catálogo das Ediçōes F. Briguiet \& Cia. Rio de Janeiro, 1936, $p: 7$

$2 i$ LACERDA, J. M. de - Pequena historia do Brasil-op.cit. A Bibliothèque Nationale de Paris possui da 69 a 99 edição dete livro. 
Outro autor de grandes vendagens foi o citado cônego Fernandes Pinheiro. Para as aulas de História, o cônego escreveu o Episódios da história pátria contados à infância que atingiu a $13 \underline{a}$ edição em trinta anos, com tiragens que variavam de 5.000 a 6.000 exemplares e, com o pseudônimo de Estácio de sá e Menezes, fêz a História do Brasil contada aos meninos. 22

Da editora Læmmert, o livro de História mais vendido foi o de José Pedro Pinheiro Xavier, "adotado para as aulas públicas de ensino primário", tendo atingido a 10 a edição em 1891. Sobre este compêndio, os editores anunciavam que era "livro admitido ao uso das escolas públicas do municipio neutro e de algumas províncias do Imperio, recomenda-se especialmente pelo excelente método da exposição, de todo acomodado ao entendimento dos meninos, e pela apurada vernaculidade do seu estilo, dois importantes requisitos que realçam a rigorosa fidelidade da narração dos fatos e muito deven influir para a escolha de livros destinados à instrução primária." 23

Diferentemente dos demais autores ligados às editoras mais renomadas que anunciavam e facilitavam a venda de livros, Antonio Alvares Pereira Coruja conseguiu sucesso com suas Lições de historia do Brasil, obra que nasceu das aulas que ministrava em seu colégio do Rio de Janeiro, editada sob sua responsabilidade . 24

22 PINHeIRo, J. C. Fernandes- Episodios da história patria contados à infância Rio de Janeiro: Garnier, 1860 e sa e MENEZES, Estácio deHistoria do Brasil contada aos meninos. Rio de Janeiro: Garnier, 1870 . (4) ed. revista e aumentada ate 1888 por Luiz Leopoldo Fernandes Pinheiro), 1889. Arroyo informa que este livro "entrava em sua 9. ediçāo em $1907^{\prime \prime}$. ARROYo, L- op. cit., p.167

23 PINHEIRo, Jose Pedro Xavier-Epítome da Historia do Brasil- desde seu descobrimento até 1857- adotado para uso das aulas públicas do ensino primário. 2a ed. Rio de Janeiro: Tip. Lxmmert, 1860, 423 p.,1 v. IN NOVO CATALOGO SISTEMATICo de escolhidos livros em português públicados e à venda no Rio de Janeiro na Livraria Universal de $E$. \&H. Lxmmert., s.d., p. 50. Este autor, nascido na Bahia em 1822 e falecido no Rio de Janeiro em 1882 , era filho de uma familia humilde, tendo iniciado sua vida como professor de 1 letras nas fazendas do Recôncavo baiano. Seu livro de História foi publicado pela primeira vez em 1854 na Bahia e sua 3a ediçāo ocorreu no Rio de Janeiro onde o professor passou a morar, tornando-se funcionário público. Cf. BLARE, S.- op. cit., II t., p. 119.

24 CoRUJA, Antonio Alvares Pereira. Liçōes de historia do Brasil. Rio de Janeiro: Tip. Do Figaro de Aguiar \& Velloso, 1877. Depois da morte do autor este livro passou a pertencer a Editora Francisco Alves conforme atestam os Catalogos da editora de 1891, com o titulo de Noçōes de historia do Brasil "adaptadas a leitura nas escolas". 


\title{
EPISODIOS
}

DA

\section{HISTORIA PATRIA}

GONTADOS Á INFANCIA

\author{
PELO CONEGo \\ DR. J. C. FERNANDES PINHEIRO
}

Professor de Rhetorica e Poclica do Imperial Collegio de

Yedro II., Membro do Instiluto Historico e lieographico Brasileiro, etc., ele.

OBRA ADOPTADA PII.O CONSELHO DIRECTOR

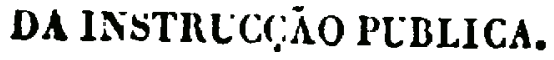

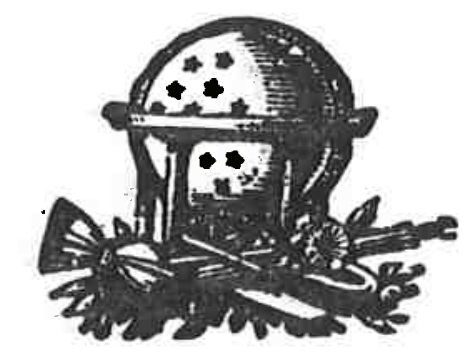

\section{RIO DE JANEIRO.}

B. L. GARNIER, LIVREIRO-EDITOR

69 rua do Ouvidor 69.

1860.

Fig. 14

Episódios da História Pátria . $1^{\mathrm{a}}$ edição da obra do cônego Femandes Pinheiro.

Bibliothèque Nationale de Paris. 
Dentre o grupo de escritores de livros de História desse período, constatamos uma inovação: a presença de duas escritoras. Foram elas Herculana Firmina vieira de Sousa com seu citado Resumo da história do Brasil (15001840), "desconhecida professora pública de primeiras letras" do Maranhāo e Maria Guilhermina Loureiro de Andrade, "autora de uma cartilha e também de uma série de livrinhos de leitura e de uma História do Brasil, a melhor que conhecemos para o ensino elementar dessa matéria".25 Maria Guilhermina foi professora do Colégio Aquino do Rio de Janeiro depois de ter sido graduada pela Normal School de New York. Na República, tornou-se mais conhecida pela. sua atuação na escola-modelo junto à Escola Normal de são Paulo, após a reforma educacional de Rangel Pestana e Caetano de Campos em 1890 .

Também foram exceções duas obras de História destinadas exclusivamente às escolas femininas. Brasileiras célebres de J. Norberto de S. Silva, um raro livro didatico do autor mineiro, foi um expressivo exemplar da literatura didática sobre o papel da mulher na sociedade e na História:

"Apresentando estas leituras a nenhuma de vós, quero seduzir com o exemplo de mulheres guerreiras ou puramente literatas; mero historiador não curo de fazer prosélitos. ringuém ignora que os séculos que aí jazem com suas geraçōes extintas prescreverão a missão da mulher. "A ciência mais apreciável nas pessoas de nosso século, disse- Lacedemoniana, é o governo da casa", e nem é outra a lei dos povos japoneses ainda semi-bárbaros. Nestas poucas mas sublimes palavras cifra-se a missão do ente que o Criador destinou ao homez por sua companheira, da mulher que na sacra familia será Ana, tendo sobre os joelhos o livro por onde se ensine a Maria, aquela que tem de ser a esposa de Deus, aquela em cujas entranhas tem de encarnar o verbo do Senhor para viver entre nós." 26

25 PFROMM NETO, S.- op. cit.- p 161

26 SILVA, J. Norberto de S. - Brasileiras célebres. Rio de Janeiro: Livraria de B.L. Garnier ; Paris: Garnier Irmãos Editores, 1862, p.5 Sobre a questão da condição feminina e a ideologia nacionalista ver 
Com uma visão semelhante foi elaborado também para escolas femininas, o livro anteriormente citado de Macedo, Mulheres Célebres.

A História a ser ensinada na escola não estava contida apenas nos compêndios. Temas da História universal podiam ser lidos em outros manuais, em textos de mitologia ou de história da literatura. A História, incluindo-se a do Brasil, fazia parte de outros textos da literatura didatica: as seletas, destinadas ao curso secundario, livros de leitura do ensino elementar e em livros de coletâneas, espécie de pequenas enciclopédias juvenis.

As seletas, compilações de trechos de autores diversos, que serviam, em princípio para o estudo da língua, traziam, invariavelmente extratos sobre temas históricos. Uma das primeiras seletas coligidas por um professor brasileiro, com excertos que buscavam vangloriar feitos dos reis e clérigos portugueses, trazia, por exemplo, um capitulo Como Pedro Alvares descobriu o Brasil extraído do livro "Asia ou feitos dos portugueses no oriente, em quatro décadas" de João de Barros. 27

No fim do século, a difusão do nacionalismo educacional promoveu a inclusão de autores brasileiros nestas compilações. Podemos citar inúmeros exemplos como o Florilégio contemporâneo, manual da Coleção João köpke, que trazia textos como Suplício de Manoel Beckmann, Revolução de Pernambuco, Guerra do Paraguai e de outros eventos históricos, permeados por trechos de prosadores e poetas.28 $\mathrm{Na}$ Seleta em prosa e verso dos melhores autores brasileiros e portugueses, Alfredo Pinto, além de trechos de romancistas, narradores e cientistas, o autor incluiu poesias majoritariamente de temas históricos: Descobrimento da América, Partida de Vasco da Gama, Batalha de

LEITE, Miriam Moreira L.- Uma construçāo enviesada: a mulher e o nacionalismo. Ciência e Cultura. São Paulo, 42 (2): 144-149, fev.1990. 27 CORREA, Filipe da Mota de Azevedo- Seleta de clássicos ou coleção de trechos extraídos dos autores clássicos portugueses para servirem ao Imperial Colegio de Pedro II e nos exames gerais de instruçāo pública. Rio de Janeiro: Livraria de Agostinho Gonçalves Guimarāes, 1871 , p. 46 a 50

28 Cf. PESTANA, Rangel (serie)-Florilegio Contemporâneo para uso das escolas secundárias. São Paulo: Miguel Melillo, 1900. (Coleçāo de Joāo Köpke) 
Aljubarrota e contos onde estavam mescladas "histórias populares" como Cristóvão Colombo e o ovo.29

os excertos "históricos" selecionados eram, geralmente, narrações provenientes da tradição oral ligadas aos feitos de grandes personagens, como reis ou "descobridores" e "cientistas" que passavam, lentamente, a concorrer com os "heróis" das Histórias sagradas.

Em livros de coletâneas para alunos mais jovens, como o Tesouro da Infância de Joaquim Maria de Lacerda, "destinado às escolas primárias, para servir não só de livro de leitura corrente, como tambén de primeiro manual para as crianças aprenderem os princípios de Gramatica. Portuguesa, Aritmética, geografia Geral, Geografia do Brasil e História Pátria.", o conteúdo de História tinha como título Ligeiro Esboço da História do Brasil.30 Era um resumo de sete páginas do seu livro de História no qual o autor destacava cronologicamente os acontecimentos políticos do Brasil a partir dos descobrimentos. No citado Livro do Povo, do maranhense Antonio Marques Rodrigues, existem algumas páginas de História do Brasil entremeada de Um Hino ao trabalho, répteis, Evangelho dos Lavradores, numerosas gravuras de Jesus Cristo e de animais em geral. 31

os livros de leitura, destinados ao público mais jovem, apresentavam invariavelmente conteúdos de Historia. A percepção de que a História pudesse ser objeto de estudos desde o início da alfabetização estava contida no primeiro esboço de programa emitido oficialmente, em 1827, pretendendo-se que a Constituição e a História do Brasil fossem os textos preferenciais para a leitura das escolas elementares.

Foram nos livros de leitura da fase "nacionalista", entretanto, que a História do Brasil passou a ocupar um

29 Cf. PINTO, Alfredo Clemente- op. cit. Pudemos constatar igualmente que a literatura de cordel no Brasil comumente utilizada nas escolas, incluia obras de tradiçāo popular, especialmente narrações de figuras históricas. Dos livros de literatura de cordel mais divulgados e posteriormente incorporado pelas editoras, encontramos a Historia do Imperador Carlos Magno e dos Doze Pares da França e a Historia dos Filhos de Carlos Magno. Cf. ARROYo, L.- op. cit., p. 126

30 LACERDA, J. Maria de- Prólogo de tesouro da infância- op. cit., p.III

3 i Cf. ARROYO, L.- Op. cit. ,p. 169 e 170 


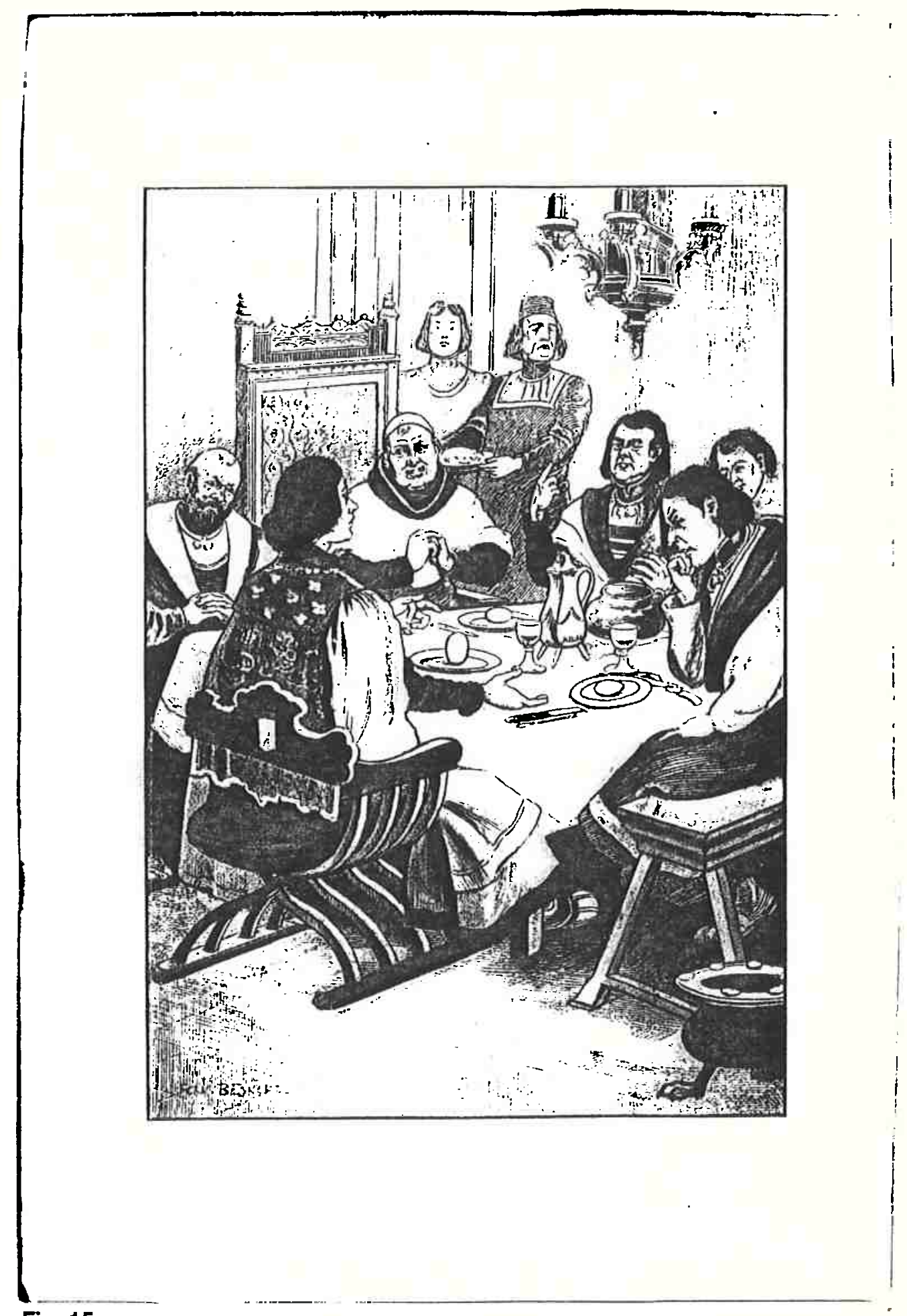

Fig. 15

Cristovão Colombo e o ovo. Narrações, contos e lendas. Seleta em Prosa e Verso. Porto Alegre, 1883 
lugar mais destacado. Começaram a ser escritas historias sobre tradições brasileiras, informações sobre "costumes indígenas", "heróis nacionais" e seus feitos. Biografias de figuras da História nacional engrossavam, frequentemente, - repertório dessa literatura. Os livros de leitura que se constituiram como os mais representativos na divulgação da História nacional foram os de olavo Bilac, especialmente Contos pátrios e Através do Brasil . 32

De uma maneira geral, a "história" contemplada por estes livros apresentava-se de maneira fragmentária, opondo-se ao cuidado meticuloso de vários compêndios que primavam pela sequência cronológica. Os temas históricos apresentados eram incorporados, na maioria das vezes, atendendo a outros objetivos, tais como análise de estilo ou de linguagem. Narrações, descrições, contos de ficção, poemas eram compilados e neles a história surgia como gênero literário.

\section{Temas e periodização da História do Brasil}

\subsection{Cronologia e "heróis nacionais"}

A introdução do ensino de História nas escolas públicas foi o fator determinante do crescimento de compêndios onde podemos vislumbrar um esforço dos autores no sentido de selecionar os acontecimentos considerados históricos e, principalmente, de ordená-los em períodos encadeados e coerentes.

Inicialmente, percebe-se a preocupação quanto à determinação de uma periodização para a História brasileira marcada pelos eventos que levaram à constituição da nação brasileira, domesticando o tempo para a construção do sentimento de nacionalidade. Denotouse, por outro lado, ao se construir uma História civil, a

32 BILAC, O. e COBLHO NETO- Contos patrios. Rio de Janeiro: Francisco Alves, 1904 e BILAC, Olavo e BONFIM, M.- Através do Brasil. $22{ }^{\circ}$ ed. Rio de Janeiro: Francisco Alves, 1932. Nestas obras a historia misturava-se à fiç̧ão. Ver outras obras de Bilac na Fig.16 


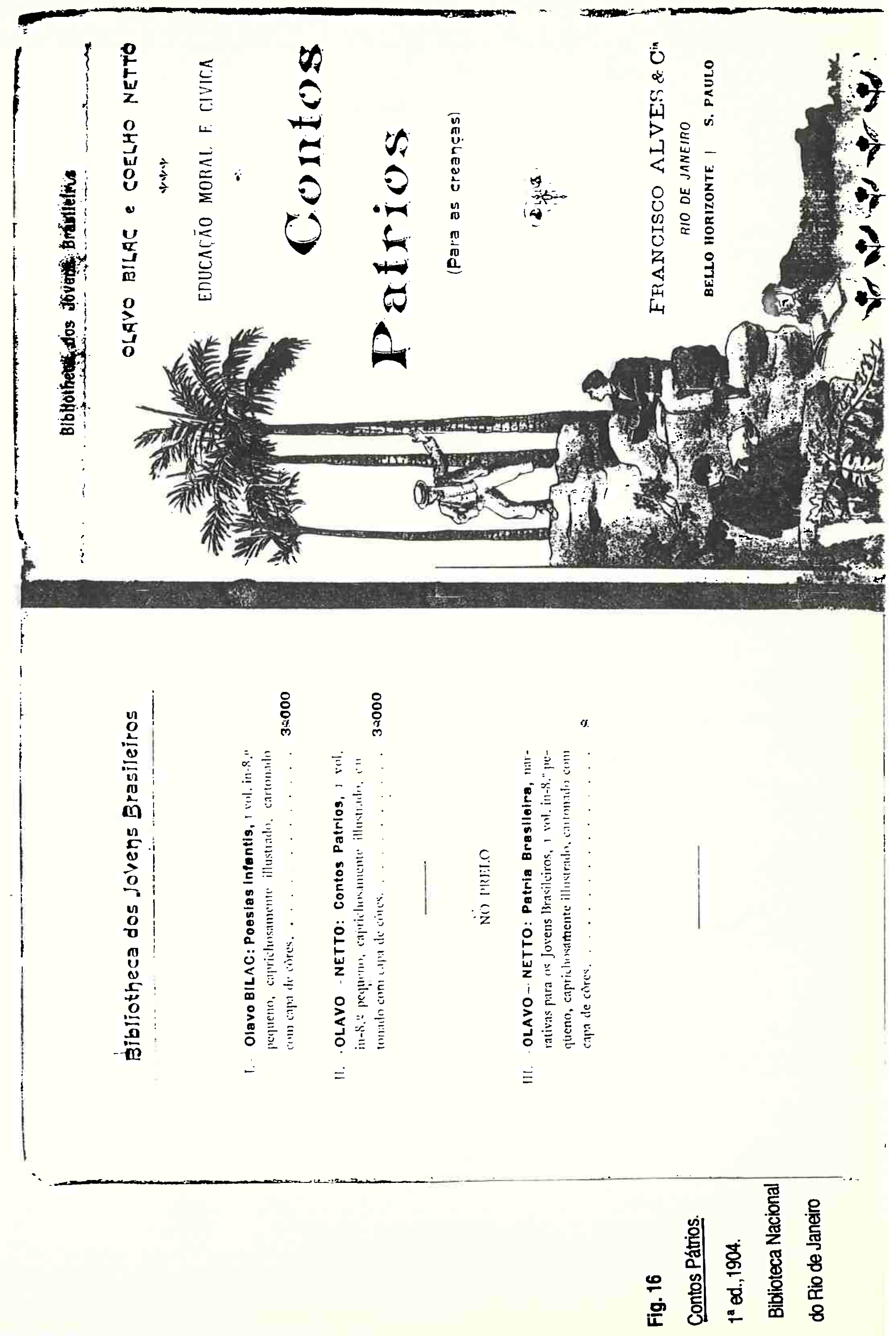


busca em situar os heróis, as figuras que deveriam permanecer na memória social como exemplos, seguindo os pressupostos de uma concepção de História "como mestra da vida".

A questão básica dos autores residia no tempo cronológico, hesitantes entre uma cronologia ordenada por uma datação minuciosa, de ordem quantitativa ou aritmética e uma cronologia situada em uma periodização, em épocas bem organizadas semelhante à História Sagrada. A construção da História Profana da nação enfrentava o problema de estruturar e articular os períodos para estabelecer a noção de um tempo histórico no qual o sujeito era o Estado. Retiraram os ensinamentos da História Sagrada, elencando a sucessão de reis, as lutas contra estrangeiros, ordenando os fatos para se chegar ao grande "evento", a Independência e a constituição do Estado nacional. A Independência e o Estado monárquico conduziriam o Brasil ao seu destino, uma "grande nação". Dentro desse objetivo, o discurso didatico enfatizava o tempo futuro. 0 Brasil era o "país do futuro", predestinado a um futuro brilhante pela grandiosidade do território e pelas imensas riquezas de seu solo.

As indecisões dos autores didáticos na construção do tempo histórico são visíveis. O Epítome cronologico da história do Brasil é um desfilar de datas, iniciando por 1500 vindo em seguida 1503 e assim sucessivamente, finalizando o texto em 1840 depois de apresentar 349 páginas repletas de informações administrativas, especialmente criação de vilas e cidades. 33

J. Manuel de Macedo optou por uma cronologia baseada "na História Geral do Brasil do sr. Varnhagen, que especialmente em verificação de fatos $e$ datas $e$ a melhor de quantas até hoje temos estudado."34 Macedo dividiu seu texto em trinta e nove lições, fixadas por datas, sendo as

33 MOURA, Dr. Caetano Lopes de- EpItome cronologico da historia do Brasil, para o uso da mocidade brasileira. Paris: P. Aillaud, Moulon \& Cie, 1860 .

34 MACEDO, J. M. de- Liçoes...-op. cit., p. 4 Prefácio. Macedo refere-se a obra de varNHAGEN, Francisco Adolfo- História Geral do Brasil. Rio de Janeiro: E.\&H. Lrmmert, 1854-57, 2 v. 
três últimas compostas como "índice cronológico". Toda a obra foi composta de maneira a fazer o aluno fixar a cronologia, apresentando ao final de cada lição, "quadros sinóticos" com os eventos e respectivas datas.

Joaquim Maria de Lacerda separou a História do

Brasil em seis períodos:

"1'Período-Desde o seu descobrimento até o donínio espanhol (1500-1580)

$2^{\circ}$ Período- o Brasil debaixo do domínio espanhol (1580-1640)

$3^{\circ}$ Período- Desde a Restauração de Portugal até a chegada da familia real ao Brasil (1640-1808)

$4^{\circ}$ Período- Desde a chegada da família real até a independência do Brasil( 1808-1822)

$5^{\circ}$ Período- Reinado de $D$. Pedro I (1822-1831)

$6^{\circ}$ Período- Reinado de D.Pedro II. " 35

O autor inspirou-se nos padrões da História Sagrada, esforçando-se por dar uma ordem qualitativa, estipulando períodos com certo rigor no sentido de configurar uma História secular. O princípio de seleção dos fatos de um período foi determinado por eventos políticos, destacando os monarcas e suas guerras de dominação. Esta divisão, que havia sido esboçada por Abreu e Lima, tornou-se a predominante entre os autores.

A formação de sentimento nacionalista aliada à concepção de História como "mestra" da vida, foi responsável pela solidificação dos personagens históricos como modelos a serem seguidos, exigindo-se a composição das galerias de "brasileiros ilustres" cujos feitos deveriam ser conhecidos e divulgados.

o historiador Norberto da Silva acreditava que "nação de ontem, o Brasil já escreve a sua história, já tem os seus heróis, que enumeram gloriosas batalhas, que apontam os lugares de suas vitórias, ja possui a sua literatura, ao princípio pálida cópia, depois elegante imitação, e por fím donosa originalidade; já conta com seus artistas, de não

35 Cf. LACERDA, J.M.- Pequena historia... op. cit. Ver obras do autor na Fig. 9 
pequena nomeada, já mostra seus homens científicos com sua reputação européia; já apresenta uma tríplice pleiade de oradores que honram o púlpito, que enobrecem a tribuna parlamentar, abrilhantam a cadeira judiciária; já se honra de seus estadistas, já se gloria de ver as suas princesas adornando o solo das cortes da velha Buropa; (.) " 36

E, ao selecionar as " brasileiras célebres" situou os critérios históricos determinantes da escolha:

"Pálidos, como são, encontrareis com tudo nestes esboços muitos fatos memoráveis da história nacional e não poucas ações magnânimas, feitos de valor, provas de amor da pátria, rasgos de desinteresse, exemplos de virtudes, atos. de piedade e mostras de ilustração devidas ao sexo feminino, lidas nas crônicas da patria ou ouvidas nas tradições nacionais...." 37

Os critérios encontrados em outras obras para selecionar os "brasileiros ilustres" não diferenciaram das propostas de Norberto Silva. variando, no entanto, entre personagens civis ou religiosos.

A Breve Notícia de alguns brasileiros ilustres, introduzida como parte final de compêndio de Historia de Joaquim Maria de Lacerda ficou repleta de figuras políticas, chefes militares, homens "de letras", poetas e clérigos da alta hierarquia eclesiástica como D. J. J. da C. de Azevedo Coutinho, conêgo Januario da Cunha Barbosa, Frei Francisco do Monte-Alverne. 38

o regionalismo dos autores apareceu sem hesitação na escolha dos heróis ou heroínas. o mineiro Norberto da Silva enalteceu as heroínas da "conjuração mineira", Marília de Dirceu e Barbara Heliodora, a infeliz esposa de Ignacio José de Alvarenga Peixoto, enquanto Salvador $H$. de Albuquerque destacou as lutas "patrioticas" dos pernambucanos Vidal de Negreiros, Antonio Felipe Camarão e Henrique Dias. As divisões internas e regionais dificultaram a escolha de "heróis" nacionais, reinando incertezas quanto ao papel histórico de cada personagem

36 SILVA, J. Norberto de s.- op. cit., p.1.

37 Idem-p. 4

38 LACERDA, J.M. de- op. cit., p.136 a 160 
para o conjunto da nação. Tiradentes era excluido do rol de "brasileiros ilustres" mas" figurava em capítulos especiais:

\section{"CONSPIRAÇÃO DE TIRA-DENTES}

P. Qual foi o acontecimento mais importante que ocorreu no governo de Luiz de Vasconcelos?

R. No governo de Vasconcelos deu-se a conspiração de Tiradentes, que se tramou em Minas Gerais com o fin de proclamar a independência daquela capitania. (-)"

P. Qual foi dos chefes da conspiração o que sofreu a pena última?

R. Foi o Tira-dentes, que foi enforcado e esquartejado no Rio de Janeiro, sendo a sua casa arrasada e seus filhos declarados infames." 39

Tiradentes havia sido um líder de uma revolta local, da "capitania de Minas Gerais", mas sua morte não o credenciava, na época, como uma representação nacional.

A configuração de Tiradentes como o principal "herói nacional", digno de comemoração em festa nacional, ocorreu na fase republicana. A consagraçāo do inconfidente mineiro se fez em meio a confrontos com os nordestinos, desejosos de construir o mito de um dos revolucionários de 1817.40 Para garantir a unânimidade na aceitação de Tiradentes, houve a transformação de um inconfidente mal sucedido em "mártir", associando-o à figura de Cristo:

"(-) os juíes compreenderam e resolveram que a comutação não alcançasse tiradentes, que foi executado no dia 21 de abril de 1792, em uma das praças da cidade, achando-se toda a guarnição postada na rua. (..) Quando o carrasco the pediu perdão e vestiu-lhe a alva, exclamou ele com a maior severidade: "Ohl meu amigol Deixe-me beijar-lhe

39 Idem-op. cit.- p. 76 e 77.

40 Sobre a criação de Tiradentes como herói nacional ver FELICIANO, Jose- Tiradentes e a educação clvica. Sāo Paulo: Tipografia do Diário oficial, 1907. Nesse trabalho,Feliciano, para justificar os feitos nobres e o martirio de Tiradentes pela causa republicana, confronta as obras de Varnhagen e J. Norberto da Silva. 
as mãos e os pés; também o nosso redentor morreu por nós. " 41

\section{2 "Nacionalismos"}

o número de títulos e de ediçōes dos manuais de História a partir da introdução oficial dos estudos de História do Brasil nas escolas mereceu atenção, considerando que eram vendidos anualmente perto de 20.000 exemplares dessa disciplina, para uma população estudantil escassa. Ampliava-se o número de leitores de História mas a qualidade das obras não era a desejada, segundo afirmava José Veríssimo, no início da era republicana: "a história pátria, en geral, existe apenas nos programas e, quando excepcionalmente ensinada, cifra-se na decoração ininteligente de péssimos compêndios tão feitos para despertar os sentimentos nacionais cono se tratasse da história do Congor (-). " 42

A crítica à produção didática de História ocorreu no momento em que a História como disciplina escolar passava a vigorar como "disciplina da formação da cidadania", como matéria obrigatória para as geraçōes escolares. Os avanços da História no campo científico reforçaram seu processo de laicização, conferindo-lhes novo status, especialmente à História nacional. Surgiram compêndios empenhados na valorização "do sentimento nacional" que foram a marca de uma nova fase da produção em História. Eram manuais que se destacaram pelo tom nacionalista, claramente ideológico, associado, paradoxalmente, ao cientificismo baseado em princípios de rigor e objetividade.

A produção da História do Brasil limitara-se a criar um tipo de nacionalismo onde aliava-se Estado-nação e excluía-se o povo. A partir do final dos anos 70, com os avanços do processo abolicionista, foi retomado o discurso sobre democracia, renascendo alguns dos princípios da

41 FREIRE, Felisberto- Historia do Brasil- Io grau. Rio de Janeiro: Livraria Clássica de Alves, 1896. Grifos meus

42 VERISSIMO, Jose- op. cit.,p.54 
Revolução Francesa e tornou-se urgente equacionar nação=Estado=povo .43

As exigências econômicas e políticas criavam diferentes projetos e os discursos didaticos foram representativos da divisão das facções liberais. Os liberais concordes com a disseminação da alfabetização, com o cerceamento do voto ao analfabeto, situavam a escola como instituição privilegiada na constituição da cidadania. A História escolar teve como missão aliar-se ao ensino do civismo, encarregando-se da formação moral do cidadão. Este foi o período da consolidação da História como sustentáculo da "pedagogia do cidadão". 44

As novas obras de História emergiram, sobretudo, das regiões onde o processo de "modernização" ocorria de forma mais acelerada, com a expansão da economia cafeeira exigindo uma mão-de-obra assalariada, com a chegada de imigrantes e onde o processo de urbanização era mais intenso. São Paulo e o Rio de Janeiro foram o "locus" das obras mais inovadoras da Historia nacional escolar. os historiadores do Rio de Janeiro, muitos deles originarios de outras regiōes do Brasil, buscavam a configuração de uma História nacional, buscando desenvolver um espírito de "amor à pátria", evitando regionalismos.

Em são Paulo, ao contrário, com o advento do regime republicano e as mudanças das elites políticas no centro do poder, apareceu nos anos iniciais da instalação do regime federativo, uma História regional ufanista. Nos programas escolares para o primário, durante o Império, havia propostas de Histórias regionais mas sem uma correspondente produção de obras escolares. No final do século e início do século $\mathrm{XX}$, os novos estados, com suas fronteiras delimitadas, sobretudo pelas disputas das oligarquias locais, buscaram pela Geografia e História legitimar sua condição "independente", construindo "tradições" comuns para os "paulistas", os "gauchos", os

43 Cf. HOBSBAWM-, Eric- op. cit., p. 32

44 Cf. FURET, François- o nascimento da historia- In: A oficina da historia. Trad. Adriano D. Rodrigues. Lisboa: Gradiva, s. d. 
"mineiros", destacando suas especificidades e suas contribuições para a "grandeza " da nação. 45

A História tornou-se mais fortemente aliada ao ensino cívico e à Geografia. Os manuais de Geografia do Brasil passaram a se organizar de maneira a destacar uma parte, geralmente a mais extensa, sobre cada uma das províncias, descrevendo o território em seus aspectos físicos, populacionais e econômicos e finalizando com "noções históricas" da região, explicando sua origem a partir da chegada dos portugueses. Outros iniciavam o estudo geográfico com as "notícias históricas", apresentando a História do Brasil como um capítulo ou introdução. 46

vários autores transitaram confortavelmente entre compêndios de Geografia e de História. Nesta categoria de autores, encontramos sua origem junto às Escolas Militares. Alfredo Moreira Pinto foi um dos mais conhecidos autores da editora Francisco Alves, 47 ao 1 ado de Anibal Mascarenhas, major honorário do Exército brasileiro que ao escrever seu Curso de história do Brasil, na introdução advertia que a História só poderia ser entendida se "possuirmos uma noção exata da estrutura do solo em que pisamos e sobre o qual vão desdobrar-se os acontecimentos históricos, muitas vezes por ele impressionados." 48

45 No primeiro ginásio oficial de são paulo, criado em 1889, assim foi programado o curso de historia para o último ano letivo : " o sexto ano sera destinado ao estudo detalhado da capitania de $S$. Vicente desde sua fundação por Martim Afonso de souza até sua ulterior reversão à coroa de Portugal. Assim tambem far-se-á neste ano a revisão geral da Bistoria do Brasil e a explanação do seu desenvolvimento sob o regime republicano." Apud NADAI, Elza- op. cit., p. 157

46 Os autores dessa literatura são nomes mais desconhecidos, com livros sem referências de muitas ediçōes. Dois deles são exemplares : REIS, Antonio Alexandre Borges dos- Corografia e historia do Brasil especialmente do estado de Sāo Paulo. Bahia: Lito- tip. Wilcke, Picard \& Cia. 1898 e ARAUJO, Francisco Lentz-Geografia do estado de Minas Gerais, seguida das noçōes de história do mesmo Estado. Rio de Janeiro: Livraria Clássica de Alves \& Cia., 1895

47 Alfredo Moreira Pinto escreveu várias obras de Geografia, entre as quais um Dicionário Geográfico do Brasil. Era apresentado em seus livros como "bacharel e professor jubilado de Historia e Geografia da escola Militar da capital federal". Para o ensino de Historia, entretanto escreveu um único compêndio.PINTO, Alfredo Moreira- Epitome da historia do Brasil. 3 ed. Rio de Janeiro: Alves \& Cia, 1892

48 MASCARENHAS, Anibal- Curso de historia do Brasil. Rio de Janeiro: Livraria do Povo- Quaresma e Cia, 1898., p. 2 


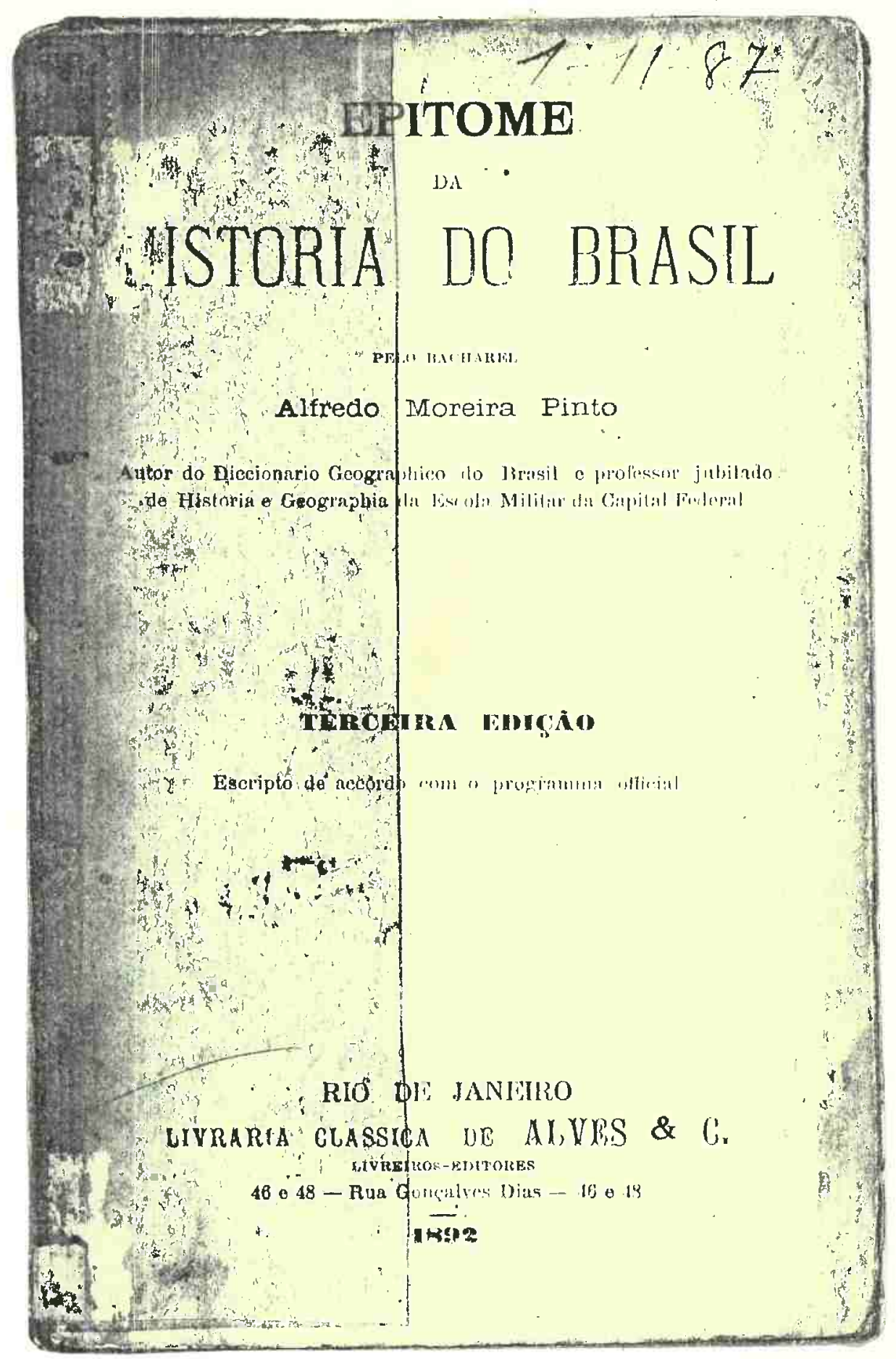

Fig. 17

Epítome da História do Brasil de Moreira Pinto. Biblioteca

"Paulo Bourroul", Feusp 
Para os intelectuais que vivenciaram o conturbado período de tensões sociais, políticas e mudanças no cenário cultural do final do Império com a instalação do regime republicano, a questão do nacionalismo transformou as obras de História do Brasil em um veículo privilegiado para divulgar suas idéias. Fruto de intelectuais renomados do período, os livros de História tornaram-se testemunhos das divergências entre as concepções nacionalistas.

pudemos distinguir dois tipos de autores e obras. A questão do nacionalismo manifestada pelos autores provenientes do setor militar voltava-se para a necessidade de um reconhecimento da "pátria", com uma delineação do "corpo" da nação em seus aspectos físicos, em suas tradições de lutas de conquistas, mas percebiam o "povo" segundo a visão européia: mestiços que resistiam a se submeter à civilização. Era um nacionalismo que se curvava diante da europeização. O núcleo dessa postura "europeizante reverente" residia no Ministério das Relações Exteriores, em torno do barão do Rio Branco. 49

- famoso ministro deixou uma obra didática de História do Brasil, na qual explicitava sua concepção de sociedade e suas divisões hierarquizadas. Suas simpatias estavam direcionadas para a aristocracia, para os "grandes personagens" de "boa estirpe". Defendeu, no relato sobre o Império, o Partido Conservador, elevando-o como principal responsável pela abolição dos escravos : "Nesse mesmo ano, os senadores Correa de Oliveira(João Alfredo) e Antonio Prado, dois chefes conservadores, pronunciaran-se pela necessidade de uma nova lei, e este último pôs-se à frente da propaganda, na província de $s$. Paulo.

Um grande número de fazendeiros, entre os quais todos os membros da família Prado, começaram a libertar os seus escravos, e esse movimento de generosidade estendeuse pelo país inteiro." 50

49 Cf. SEVCENKo, Nicolau- Literatura como missão- tensōes sociais e criação cultural na primeira república. sāo paulo: Editora Brasiliense, 1989 , p. 124

50 RIO BRANCO, Barão do- Bistoria do Brasil. Trad. Joāo vieira de Almeida - São paulo: Livraria teixeira \& irmãos, 1894. Este livro foi escrito inicialmente em francés para o Le Brésil em 1889 , com o objetivo de divulgar a historia brasileira na França. Posteriormente 
Este grupo de intelectuais esmerou-se na divulgação de um nacionalismo entendido como um amor ao bem comum, congraçamento, festejando as belezas e as riquezas de uma jovem pátria que se abria para o mundo. Mas, contraditoriamente à admiração que expressavam pelo mundo civilizado de além-mar, temiam o imperialismo que podia tornar o Brasil alvo das ambições expansionistas européias.

Rio Branco alertou para esse perigo que ameaçava a nação e outros o seguiram nessa análise. Os autores que mais se destacaram como defensores de uma "patria ameaçada" foram Olavo Bilac e Coelho Neto. Nos livros escolares de ambos era flagrante a difusão do militarismo como necessidade de proteção da pátria, do território, da unidade nacional:

"Grandes acontecimentos, porém, tinham de vir reconciliar os partidos, e salvar o Brasil desse delirio político, em que esterilmente se esgotavan as suas forças. As guerras contra Rosas, Aguirre e Solano Lopes vieram unir, num mesmo impulso de patriotismo, todos os brasileiros. 0 segundo Império não estava fadado para se consumir en lutas inglórias e fúteis. A Guerra do Paraguai tinha de dar ao Brasil o seu batismo de sofrimento e heroismo. (-)"51

A questão nacional teve também outras abordagens nas quais buscava-se uma originalidade nacional capaz de dar "condições ao país de compartilhar em igualdade de condiçōes de um regime de equiparação universal das sociedades, envolvendo influencias e assimilações recíprocas." 52

Os intelectuais que forjaram esse tipo peculiar de nacionalismo eram representantes de um setor mais progressista das elites, aglutinando-se em torno do cientificismo da Escola de Recife, destacando-se as figuras de Silvio Romero e João Ribeiro. Defendiam e concebiam o

foi mandado publicar sob a direção de Sant'Anna Nery, transformando-se em obra escolar.

51 BILAC, Olavo e COELHo NETO- A pátria brasileira. Rio de Janeiro: Livraria Francisco Alves, 1911., p. 245

52 SBVCENRO, N.- op. cit., p. 123 
nacionalismo como busca de uma identidade, como meio de reconhecimento da especificidade da população e da cultura brasileira. A Historia do Brasil tinha como objetivo primordial no ensino situar o Brasil no mundo civilizado e projetar, junto aos jovens, a idéia de um futuro independente mas solidário ao conjunto da humanidade.

"Queremos formar aqui a mansão democrática do congraçamento, não dos deserdados da Europa sómente, mas dos deserdados de todo o mundo, e, pela reunião, pela igualdade de todos, formar o povo do porvir, o tipo novo, que não é oriundo do exclusivismo europeu, ou africano, ou asiatico, ou americano, o tipo novo que há de ser a mais perfeita encarnação do cosmopolitismo." escreveu silvio Romero, ao explicitar sua interpretação de História no livro que elaborou para as classes primárias. 53

Silvio Romero incorporou em seu texto didático de História os estudos antropológicos para travar um combate contra o racismo e o "exclusivismo" difundido pela literatura histórica proveniente da Europa ilustrada e incorporada com serenidade pelas nossas elites econômicas e pelos intelectuais que se encarregavam de perpetuar, nas escolas, o ideário civilizatório branco. Insistiu na impossibilidade de simplificar a questão racial, divulgada pelos livros europeus, demonstrando a impossibilidade da humanidade ser dividida em raças "puras": "não é tudo; os próprios três troncos principais de nosso povo já eram resultado de diversos cruzamentos especiais". 54

verifica-se, entretanto, que estas décadas conflituosas, onde as divergências quanto aos temas do nacionalismo, República, e abolicionismo dividiam intelectuais e educadores, foram marcadas pela continuidade da construção de uma História do Brasil fundada pela ação de heróis. o "herói" apareceu como o construtor da pátria, preocupando-se os autores em compor biografias que pudessem abarcar uma História da unidade do território, de um passado comum, explicando-se dentro da preocupação

53 ROMERO, Silvio- op. cit., p. 14

54 Idem, op. cit.- p. 21 
pedagógica, a divisão dos grandes períodos marcados pelas conquistas territoriais e independência.

Os dois grupos "nacionalistas" foram unânimes quanto a institucionalização da História profana na escola mas, a História Sagrada europeizante continuava a participar da vida dos alunos, com as reedições contínuas dos textos dos meados do século.

\section{A noção de tempo e espaço nas obras do cônego Fernandes Pinheiro e de João Ribeiro}

A produção didática de História, como vimos, esteve vinculada às instituiçōes onde se engendrava a História oficial, especialmente o IHGB do Rio de Janeiro e os das províncias. Os autores didáticos mais consagrados faziam parte do corpo de intelectuais ligados ao Colégio Pedro II ou da Escola Militar, escolas formadoras de parte significativa das elites políticas do país.

Para aprofundar a leitura dos textos didáticos com o objetivo de captarmos a articulação entre saber erudito e saber a ser ensinado pela escola, escolhemos a análise das obras de João Ribeiro e do cônego Fernandes Pinheiro, intelectuais prestigiados pela produção acadêmica e literária e que dedicaram-se à vida educacional com igual empenho. Analisamos Episódios da história pátria do cônego Fernandes, a História do Brasil contada aos meninos que o autor escreveu com o pseudônimo de sá e Menezes e os livros de João Ribeiro História do Brasil, para ginásios e escolas Hormais - curso superior e História do Brasiledição das escolas primárias. 55

Os textos, embora produzidos em momentos diferentes tiveram em comum, o sucesso ou aceitaçāo respeitada segundo demonstra o número de edições que obtiveram. 56

55 PINHEIRO, J.C. Fernandes- op. cit.; SÁ e MENEZES- op. cit. ; RIBEIRO, João- História do Brasil- edição das escolas primárias. 2 á ed. Rio de Janeiro: Livraria Francisco Alves, 1900.; RIBEIRO, JoāoHistória do Brasil . 29 ed. Rio de Janeiro: Livraria Francisco Alves, 1900 ,

56 Os livros do cônego Fernandes estiveram em uso até a década de quarenta, como ja foi comentado. Os livros de João Ribeiro, para o 
Ambos escreveram para seus iguais, destacando-se como intelectuais de grande erudição não sendo reconhecidos apenas como historiadores. Seus biógrafos enfatizam mais as contribuições que legaram à literatura. Eram hommes de lettres, autodidatas que ficaram conhecidos no campo educacional pelo número significativo de textos e traduções escolares, redigindo Gramáticas, Dicionários, compêndios de Geografia, livros de leituras, além das obras de História. Foram professores do Colégio Pedro II, lembrados por alunos pela capacidade intelectual e pela erudição. Tornaram-se conhecidos por um público mais diversificado, leitores das publicaçōes que fizeram em peribdicos, demonstrando que eram intelectuais zelosos na divulgação de seus trabalhos. Como autores de livros didáticos, ambos parecem ter sido preferidos pelos respectivos editores B. L. Garnier e Francisco Alves.

A correspondência entre Garnier e o cônego demonstra uma certa familiaridade, chegando o autor a pedir favores pessoais ao francês, como o apoio financeiro para a viagem de um seu sobrinho, provavelmente Luis Leopoldo, à Europa. o cônego escreveu incessantemente, deixando uma vasta obra didática, de Religião, Literatura, Gramática, História e Geografia. Depois do seu falecimento, as reedições de seus manuais ficaram a cargo de seu sobrinho Luis Leopoldo Fernandes Pinheiro que parece ter herdado também os bens do tio e, o que pode ser deduzido dos contratos com a Garnier, os livros forneceram uma renda razoável, considerando o período. 57

Uma amizade semelhante parece ter havido entre João Ribeiro e Francisco Alves. Sobre esta relação, um

ensino primário, sem identificarmos o $n^{\circ}$ da edição estava em uso em 1935. o seu livro para o ginásio foi o mais famoso, teve reediçōes até a década de sessenta.

57 os salários de professores do Colégio Pedro II variavam em torno de $1 \$ 500.000$ a $3 \$ 000: 000$ anuais e a renda obtida pelo cônego com seus livros era superior conforme atestam alguns contratos: "Recebi do $I \mathrm{Im}^{\circ}$ B.L. Garnier a quantia de novecentos e dezoito mil réis sendo oitocentos mil réis do preço ajustado pela primeira ediçao da minha Gramatica teorica e prática da lingua portuguesa, e cento e dezoito mil réis da diferença para mais no número de exemplares da última edição dos meus Epiśodios da historia pátria. Rio de Janeiro, 26 de novembro de 1870 Cônego Dr. Joaquim Caetano Fernandes Pinheiro". Manuscrito- Arquivo da editora Itatiaia, B.H. 
depoimento de João Ribeiro esclarece que "o que Alves estimava em mim era a minha vontade de trabalhar..contribuí com muito mais do que uma "gota d'água" para sua caudalosa fortuna. Das 150 edições dos meus livros didáticos correram e correm ainda muito perto de um milhão de exemplares. Mas... tudo isto foi a obra do editor. Em mãos de outros ou nas minhas, gramáticas e compêndios nada valeriam e disso fiquei certo por algumas experimentações decisivas. Era o editor com seu serviço admirável de propaganda.. Ele pagava - meu trabalho $e$ em melhores condições que outros quaisquer.. Era dedicado, pronto, fiel, liberal." 58

Os dois autores citados não foram contemporâneos. o sergipano João Ribeiro, nascido em 1860 de uma família sem recursos, que desembarcou no Rio de Janeiro em 1880 para continuar os estudos iniciados em Aracaju, não pôde conhecer o cônego Fernandes Pinheiro pois em 1876 "a morte veio surpreende-1o, em pleno fastígio, privando a cultura nacional de um dos luminares da geração do século passado." 59 Mas João Ribeiro conheceu e conviveu com as obras do cônego, ocupando a cátedra de História Universal do Colégio Pedro II, a partir de 1887.

As obras citadas são representativas de duas visões históricas diferentes. As do cônego figuram como exemplares de uma História brasileira construida sob os moldes da História Sagrada e a de João Ribeiro corresponde à criação de uma História nacional profana, alicerçada na busca de uma identidade cultural laica.

\section{1 o tempo sagrado na obra do cônego}

o cônego Joaquim Caetano Fernandes Pinheiro foi um dos pioneiros em estudos históricos do Império. As pesquisas do cônego, no campo histórico não podem ser desprezadas, tendo contribuído para "a história militar, a

58 Apud por HALLEWELL- op. cit.,p. 211

59 Apud PINHeIRo, Mario Portugal Fernandes- Apresentaçāo da 39 ed. do Curso de Literatura Nacional.Rio de Janeiro: Catedra., 1978, p. 9. 0 cônego Fernandes Pinheiro era descendente de aristocratas, sobrinho de "José Feliciano Fernandes Pinheiro, Visconde de são Leopoldo, historiador de alto conceito e político de ilibada projeção, criador dos cursos Juridicos do Brasil."Idem, p. 7 


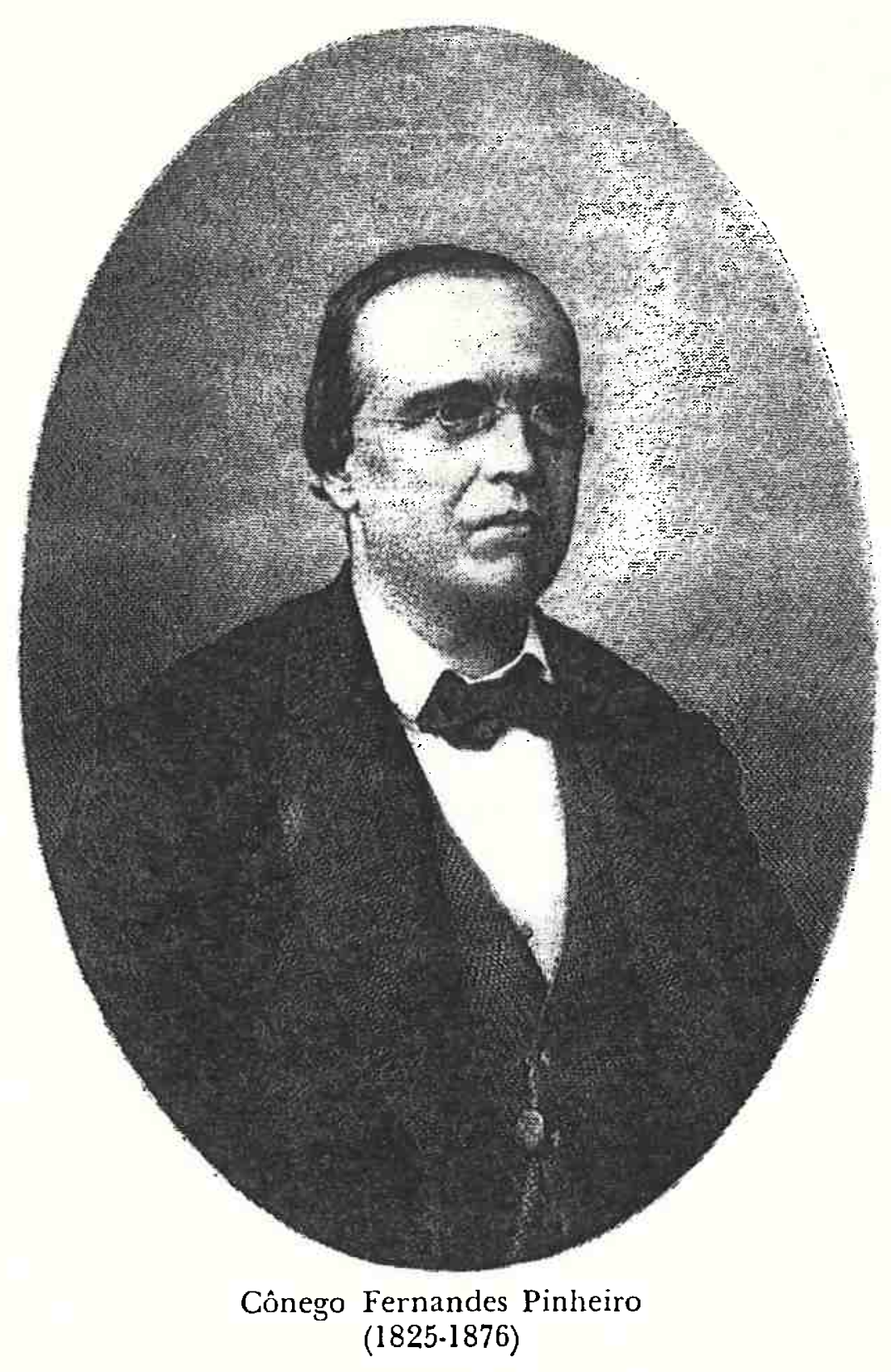

Fig. 18

Cônego Femandes Pinheiro. Fotogratia. Apresentação do Curso

de Literatura Nacional. Mario Portugal Fernandes Pinheiro. 
historia religiosa, a história literária, a história política, a história administrativa e a história urbana".60 Publicou vários artigos na Revista Popular da editora Garnier, principalmente biografias de "personagens ilustres" como as Henrique Dias, Amador Bueno da Silveira, Claudio Manuel da Costa, procurando divulgar o ideário do IHGB. A preocupação com a elaboração de textos didáticos deve ter se originado pelas experiências como professor, carreira a que se dedicou durante toda vida. Lecionou, inicialmente, no Seminário Episcopal de São José, no Rio de Janeiro entre os anos de 1849 a 1852. Tornou-se professor de História Sagrada e Dogma no Instituto dos Meninos Cegos antes de ingressar no Colégio Pedro II em 1857 na cadeira de Retórica e Poética e posteriormente na de Literatura Nacional e Gramática Filosofica, trabalho que exerceu até sua morte em 1876 .

A vinculação entre sua formação religiosa e a pesquisa histórica foi flagrante, determinando os temas preferenciais em seu trabalho como historiador. o Ensaio sobre os jesuítas com o qual foi admitido no Instituto Histórico e Geográfico, em 1854, mostrou que suas preocupações fundamentais eram a questão religiosa e o poder da Igreja e seus trabalhos subsequentes testemunham essas questões: Batalhas de Guararapes e a Carioca, Antonio José da Silva e a Inquisição, os últimos vice-reis do Brasil, a Academia Brasílica dos Esquecidos, a Academia Brasílica dos Renascidos e Motins políticos e militares do Rio de Janeiro foram trabalhos vinculados a estes problemas . 61

Em seu primeiro livro didático de História, Episódios da história pátria, o cônego Fernandes Pinheiro omitiu as fontes bibliográficas que utilizou para a elaboração de seus textos, afirmando ter sido fruto de investigações próprias e originais: "Segui sempre a ordem cronológica, e na escolha dos fatos preferi os que me pareceram mais

60 Idem, op. cit.,p. 11

61 o conjunto da obra do cônego Fernandes Pinheiro está documentada na publicação de Mario portugal F. Pinheiro acima referida e os artigos da Revista do Instituto Historico e Geográfico, vol. 238, jan./ mar. 1958 e vol. 240, jul./set. 1958 . 
importantes ou melhor averiguados. Recorrendo às mais puras fontes, deixei de citálas, porque entendi que num trabalho deste gênero a erudição seria deslocada; a redação e o método porém são meus, e por eles respondo". 62

o compêndio, destinado a alunos jovens, representou uma visão da História nacional segundo a 6 tica de um religioso, monarquista situado próximo ao poder, tendo sido nomeado, pouco antes de morrer, Cronista do Império. Os planos dos seus dois livros didáticos foram uma adaptação da História Sagrada à História profana. O tempo cronológico e os fatos que selecionou correspondem à logica do tempo transcendental, o tempo de uma nação predestinada que segue - caminho traçado pela ordem divina, cuja manifestação no presente era evidente: uma monarquia esclarecida pela moral da Igreja Católica.

Nos dos dois livros, a História do Brasil foi dividida em "Iições", separadas por datas fixas.63 Na sequência cronológica, o Descobrimento do Brasil foi uma consequência da necessidade da expansão da fé, descrevendo, com detalhes as celebrações de missas e as benções das autoridades eclesiásticas, na partida de Pedro Alvares Cabral e na celebração da 1 a missa em terras brasileiras: "Durante a missa e o sermão, que pregou o referido Fr. Henrique, mostraram-se os indigenas estupefatos, ajoelhando-se como os portugueses e imitando-os en todos seus atos de devoção." 64

Em seguida, as "lições" foram compostas para mostrar as diferenças entre os civilizados e os selvagens, definidos como aqueles que nāo seguiam os Evangelhos. A missão dos portugueses era a de levar a "verdadeira fé" para os indios, destacando a presença dos jesuítas, mas

62 PINHEIRO, J.C.F.- Episodios_- op. cit., p. VII, Prologo

63 I. O descobrimento do Brasil (1500); II. O Caramuru (1510); III. Martim Afonso de Souza- Fundação dse São Vicente (1532) -" No total são 33 lições narradas em 244 páginas. Cf. PINHEIRo-J.C. F.Episodios.-op. cit.. A história do Brasil contada aos meninos tem 28 "leituras" montadas diferentemente, mas que especificam com precisāo as datas: "Governo central na Bahia- Os primeiros jesuitas - de 1549 a 1556 ; Fundação da cidade do Rio de Janeiro -1567..". Cf. SÁ E MENEZES, Estácio de- A hist. do Brasil..- op. cit., Indice

64 PINHEIRO, J.C.F.- op. cit., p. 4 
valorizando como herói, o bispo Sardinha, devorado pelos índios, em descrição de cena de martírio:

"Consta pelo testemunho dos que sobreviveram que em tão doloroso transe mostrou o primeiro bispo do Brasil uma coragem e resignaçāo que todos edificou. Fortalecido com os sacramentos da Igreja, abençoou o rebanho que a seus pés se prostara, perdoou aos perseguidores, e, pedindo a Deus a conversão dos seus algozes, esperou, com os olhos no céu, que a terrível tangapema (maça) lhe esmagasse o cranio. Morreu como um márir depois de ter vivido como um santo. " 65

A expansão dos portugueses $e$ as invasões de estrangeiros em nossas terras foram interpretadas como um movimento religioso. A França Antártica representou a tentativa do calvinismo de se estabelecer e expandir nas novas terras descobertas. A invasão dos holandeses foi apresentada também como uma manifestação da ação dos calvinistas atuando em aliança com os judeus. Maurício de Nassau foi um personagem prestigiado notadamente pela prodigalidade em conceder a liberdade de culto, sem perseguição aos católicos.

o cônego, como membro da Igreja do século XIX, ao se referir à obra dos jesuítas teceu elogios ao serviço de catequese apenas no início da colonização. No capítulo "Sublevação das missões do Uruguai", os jesuítas representaram o papel dos vilões que incitaram os índios ao combate, ensinando-lhes o manejo das armas e responsáveis pela total destruição das Missões, justificando as medidas do ministro Pombal para suprimir a ordem em Portugal e nas colônias. 66

Na efetivação de uma História profana, o cônego Fernandes esforçou-se por fortalecer e legitimar a monarquia brasileira, dignificando a figura dos monarcas. os reis, representantes maiores da Historia secular eram bons e justos ou se destacavam como excelentes militares. Não eram jamais apresentados de forma negativa :

65 Idem, P. 29. Grifo do autor.

66 Cf. PINHEIRO, J.C.F.- op.cit., p.154 a 157 
"A piedosa rainha que então se sentava no trono português não confirmou a sentença; seus desejos eram poupar a todos a pena capital, mas seus conselheiros lhes fizeram ver que, em virtude das leis do reino, não podia ser agraciado o cabeça ou principal réu da conspiração, e sendo o alferes Joaquim José da silva Xavier o único que como tal devera ser considerado, por não haver mostrado arrependimento, ufanando-se do seu crime, era também o único que, para exemplo, cumpria fosse supliciado." 67

A associação entre a História Sagrada e a História profana levou-o à omissão dos conflitos sociais, acentuando as mudanças pelas ações políticas. A escravização indígena foi omitida da narrativa histórica. Os índios possuíam uma historia comum e, ao descrever "os costumes dos tupinambás", afirmava que estes "eram, com pouca diferença comuns a todos os selvagens". Descreveu a vida das mulheres entre os tupinambás, concluindo que "(..) sua condição porém era desgraçada, como por toda a parte en que não domina o Evangelho, e muito mais julgavam praticar un ato de caridade afogando suas filhas ao nascer." 68

A escravidão negra apareceu esporadicamente, como no episódio de Palmares, onde forneceu uma imagem de organização pouco democrática entre seus habitantes, justificando-a, porém : "Poucas e vigorosas eram as suas leis, como acontece com os povos primitivos ou semiselvagens. Presidia o regime de terror a essa república negra, porque a súbita passagem da escravidão para a liberdade poderia produrir a mais terrível anarquia." 69

Dentro de uma visão cristã sobre a escravidão, ela era justificada pela inferioridade racial mas havia entre os escravos figuras "dignas" e "boas". No capítulo do Bequimão, ap6́s narrar os eventos que levaram os líderes maranhenses à prisão, enalteceu a atitude de um "pobre escravo":

67 SA E MENEZES- op. cit.,p. 221

68 Cf. Capitulo II, o Caramuru. PINHeIRo, J.C. F.- op. cit., p. 6 a 15

69 Idem, p. 122 
"Contrasta o infame proceder de Lázaro com a magnânima conduta de um escravo de Francisco Dias Deiró, que recusou a liberdade que lhe oferecera para denunciar seu senhor, de quem se fizera confidente. Pena é que nossos cronistas não nos hajam transmitido o nome desse digno preto para recomendá-1o à vossa memória." 70

o espaço brasileiro era entendido como o "Império" tal qual ele se constituíra no século XIX. O território nāo foi conquistado. O Brasil sempre existiu, demarcado desde o momento da "descoberta" e confirmado pelas "expedições exploradoras" que denominaram de "Terra de Santa Cruz a todo o país". Na composição de uma História nacional baseada na História Sagrada, importava apenas o poder real e a administração que se exerceu em espaço territorial criado, aprentemente, de forma atemporal.

o conêgo Fernandes Pinheiro produziu uma História simplificada mas extremamente coerente com seus princípios doutrinários. Os objetivos do ensino da História foram explicitados e concretizados em seus livros. Ele desejou apenas "dar aos meninos noções rudimentares da história nacional, inicia-los nas glórias e também nos revezes pátrios, mas de modo agradável, apresentando-1hes como uma grinalda histórica, ou uma galeria de quadros em que vejam traçados os mais memorandos sucessos." 71

3.2 As temporalidades da História do Brasil de João Ribeiro

A História do Brasil de João Ribeiro teve uma outra trajetória. Foi um livro criado durante o movimentado período do após-abolição e quando as disputas políticas começavam a indicar os ganhadores do projeto liberal que se instalara com o regime republicano.

os compêndio de História de João Ribeiro que a editora Francisco Alves anunciou como destinada "aos ginásios e escolas normais", foi inovador em dois aspectos.

70 Idem, p. 116

71 Idem, Prólogo, p. VI 
No prefácio da segunda edição da História do Brasil, Araripe Junior enalteceu o valor pedagógico da obra:

"Neste ponto João Ribeiro abriu, se não estou enganado, una fase nova para o ensino de história no país; e oxalá que o seu exemplo não fique esterilizado, diante da indiferença dos que estudam a questão." 72

No prefácio da $14 \underline{a}$ edição de 1953, depois de meio século da $1 \underline{a}$ edição, o livro era considerado "estimado e procurado" não apenas pelas inovações pedagógicas mas pela "originalidade de seu plano de trabalho e, indiscutivelmente, de sua repercursão na orientação dos estudos histórico-sociais no Brasil." 73

o compêndio de João Ribeiro, feito segundo o programa do Colégio Pedro II, ultrapassou os intentos de seu autor, firmando-se como "fonte clássica" dos estudiosos de História. Trata-se de um livro didático de História, originalmente feito para ser divulgado entre o público escolar secundário mas que, segundo seus biógrafos, acabou por "renovar os estudos históricos no Brasil, imprimiu uma nova orientação metodológica e realizou uma nova síntese do nosso passado." . 74

A História do Brasil de João Ribeiro resultou dos estudos que fez na Alemanha onde permaneceu por dois anos, "comissionado pelo governo" para estudar o ensino superior de História. o espírito germânico esta presente na construção de seu texto pela concepção de História e pela dinâmica pedagógica que imprimiu no livro, diferente do padrão tradicional francês. Demonstrou uma concepção de livro didático diferenciada, sendo o "manual a carta de navegação pela qual o pior piloto pode levar o discípulo ao porto do destino". 75

A presença do pensamento germânico ficou marcada pelas indicações do autor quanto aos textos em que se baseou para compor seus escritos. Citou von Martius que lhe

72 ARARIPE JUNIOR, T.A.- Prefácio. In: RIBEIRO, João- História do Brasil. 139 ed. Rio de Janeiro: Livraria Francisco Alves, 1935, p.11 73 PREFACIO. In: RIBEIRO, Joāo- op. cit., 14 edição, p. 19 74 RIBEIRO, Joaquim- A posição doutrinaria de Joāo Ribeiro na historiografia nacional. In RIBEIRo, João -op. cit., 19 ediçāo, p.VI. 75 RIBEIRO, João- op. cit.- p. 9 
"forneceu indicações vagas e inexatas, mas (que) caracterizou a multiplicidade de origens e de pontos de iniciação no vasto território; (..)."76

Joāo Ribeiro referia-se ao texto publicado pela Revista Trimestral de História e Geografia de 1845, Como se deve escrever a História do Brasil, oferecida ao IHGB por von Martius. o cientista germânico insistiu na impossibilidade de se ignorar o estudo dos elementos de formação do homem para se entender a História de uma nação. Destacou que, para o caso brasileiro, as três raças, "a de cor de cobre ou americana, a branca ou caucaseana e enfim a preta ou etibpica", contribuíram fortemente para a formação populacional e mais ainda foi pela mestiçagem, "o cruzar das raças", do encontro, da mescla, das relaçōes mútuas e mudanças dessas trềs raças, [que] formou-se a atual população, cuja história por isso mesmo tem um cunho muito particular." 77

A organização do plano da obra de João Ribeiro se fez sob tal ótica e esta constituiu a singularidade do texto que produziu. Ao criticar os manuais escolares de História patria por darem "excessiva importância à ação dos governadores e à administração, puros agentes (e sempre deficientíssimos) da nossa defesa externa.", procurou enfatizar as questões sociais:

"O Brasil, o que ele é, deriva do colono, do jesuíta e do mameluco, da ação dos indios e dos escravos neqros. Bsses foram os que descobriram as minas, instituiram a criação do gado e a agricultura, catequisaram longínquas tribos, levando assim a circulação da vida por toda a parte até os últimos confins. Esta história a que não faltam episodios sublimes ou terriveis, é ainda hoje a mesma presente, na sua vida interior, nas suas raças e nos seus sistemas de trabalho, que podemos a todo instante verificar. Dei-lhe por isso uma grande parte e uma

76 Idem, p. 18

77 MARTIUS, Carlos Frederico P.- Como se deve escrever a historia do Brasil. Revista trimestral do Instituto Historico e Geografico Brasileiro. Rio de Janeiro, 24, jan.1845, p.390 
consideração que não é costume haver por ela, neste meu livro." 78

João Ribeiro, ao construir os períodos da História brasileira, dividiu-a em onze capítulos, iniciando pelos descobrimentos e terminando pelo Império, item que denominou de "Progresso da democracia" (posteriormente foram acrescidos em outras edições um capítulo sobre a República). Há um tópico central- a Formação do Brasil no qual ele fêz uma subdivisão: a) História comum e b) História local. Esta parte do trabalho correspondeu a um esforço do autor em situar as diversas temporalidades das populações e as formas de povoamento diferenciadas das regiões brasileiras, tema que foi retomado alguns anos mais tarde por Capistrano de Abreu:

"Ainda que sejam hoje numerosas as divisōes administrativas do Brasil e ainda que a gravitação da lingua e da tradição portuguesa lhes desse perfeita coordenação e unidade, é certo que a enorme extensão geografica e também a historia das antigas capitanais confirmam a existência de grandes grupos locais en que se reparte o imenso organismo nacional" 79

João Ribeiro, ao expor a formação da população e o contato das três raças não camuflou os conflitos :

"Logo cedo no Brasil, na sua capital, como nas demais poroações, a obra da civilização foi deturpada pelo conflito das raças, disfarçado em democracia, fruto antes da luxuria que da piedade dos peninsulares. Desde o primeiro momento o branco, 0 índio e o negro se confundem. o contato das raças inferiores com as que são cultas, quase sempre desmoraliza e deprava a umas e outras.

Principalmente, porém, deprava as inferiores pela opressão que sofrem, sem que este seja o pior dos contágios que vêm a suportar." 80

Mesmo considerando a raça branca superior, ela foi criticada pelas formas de dominação que exerceu:

78 RIBEIRO, João- Do autor- op. cit. , p. 17 e 18. Grifos do autor.

79 Idem, p. 315

80 Idem, p. 106 
"o branco procurava ( e isso já havia já dois séculos na península) o pretexto real do clima para evitar os duros trabalhos da agricultura tropical, e assim escravizava os negros, e agora, quanto podia, os índios. Começam as expediçōes escravistas manchadas na atrocidade de todos os crimes." 81

Na elaboração de uma História laica, a crítica à Igreja e ao papel que exerceu na história civilizatória merece destaque. Considerava os jesuítas verdadeiros heróis, como os responsáveis isolados da defesa de princípios morais os quais asseguraram uma certa dignidade em meio à decomposição das raças.:

"o jesuita, porém, era inflexível. Nunca cedia, nem condescendia. Combatia todos os escândalos e maldades, as perseguições inúteis aos índios, as relações ilícitas, e às vezes monstruosas que destruiam a constituição da sociedade civil". 82

Mas apontava, igualmente, a contradição da Igreja ao se omitir diante da escravidão negra: "se podemos juntar o nome do Padre vieira e de outros jesuítas à história da escravidão vermelha - quase não temos que registrar qualquer movimento de indignação contra a escravidão dos negros."83 Criticou as justificativas da escravização negra como sendo um "castigo predestinado à raça de cam e um beneficio feito à multidão irreligiosa e perdida para a fé e para a civilização" expressa por teológos católicos.

As interpretaçōes inovadoras sobre a História brasileira de João Ribeiro foram, entretanto, introduzidas precariamente no texto que organizou para as escolas primárias.

Na organização dos capítulos incorporou parcialmente as duas partes essenciais de seu trabalho para as escolas secundárias. Muitas das questões sobre a formação espacial e da população brasileira ficaram diluídas no trabalho. A inovação maior de seu livro residiu na incorporação de

81 Idem, p. 107

82 Idem, p. 113

83 Idem, p. 241 
ilustrações, escolhidas com critério, oriundas de iconografia original.

A questão do predomínio da civilização européia e a configuração de uma História laica fizeram parte do texto, enfatizando os interesses ecônomicos no processo de dominação:

"Outra missa foi celebrada no dia $1^{\circ}$ de maio, em terra firme e na presença dos índios que, em grande número, espantados, assistiam às cerimónias do culto examinando as vestes insólitas dos portugueses e a grande cruz de madeira que ajudaram a erguer ao pé do altar. A terra suposta ilha foi chamada da "Vera-Cruz", ao depois "Santa-Cruz. Prevaleceu o nome de Brasil, pois que a terra da Santa Cruz, desdenhada quase pelos seus descobridores, só chamou a atenção do mundo e deles próprios quando os atraiu o comércio do "pau-brasil" de que era a região muito abundante." 84

João Ribeiro e o cônego Fernandes Pinheiro foram lidos por alunos durante algumas gerações. As interpretações que realizaram e transpuseram para os textos didáticos marcaram duas versões de uma única proposta oficial da História do Brasil. Percorrendo simplesmente os índices dos livros, a sequência dos capítulos ou lições não se diferiam substancialmente. A forma de apresentá-los e seu conteúdo foram, entretanto, a expressão de duas posturas antagônicas frente ao espaço e ao tempo histórico.

Os diversos autores de História do Brasil, mesmo considerando as imposições institucionais e as exigências dos editores, participaram de um processo de criação do saber a ser ensinado, no qual registraram suas próprias interpretações diante do passado da nação. o número de intelectuais renomados que investiram na confeç̧ão de tal produção demonstra a importância que a escola assumia na organização de uma sociedade letrada e no papel a ser

84 RIBEIRo, João- História do ...- edição das escolas primarias- op. cit., p. 8 
desempenhado na produção e transmissão da "identidade nacional".

Os autores realizaram reduções e simplificações do saber erudito, buscando construir um discurso pedagógico capaz de ser veiculado em sala de aula. Ao elaborarem a transposição didatica, os autores não se eximiram de veicular claramente suas concepções de História nacional, e em meio a tais divergências, a História do Brasil surgia como disciplina escolar autônoma. Em alguns aspectos, contudo, a literatura escolar de História desse período teve pontos comuns. Configurou-se a criação das "galerias" de heróis civis em substituição às figuras da História Sagrada, desenvolvendo-se uma produção no sentido de laicizar o tempo histórico. Apesar da diferentes visões do passado, persistiu, entre os autores, o mito do Brasil como "país do futuro". 
3a Parte

Usos do livro didático 


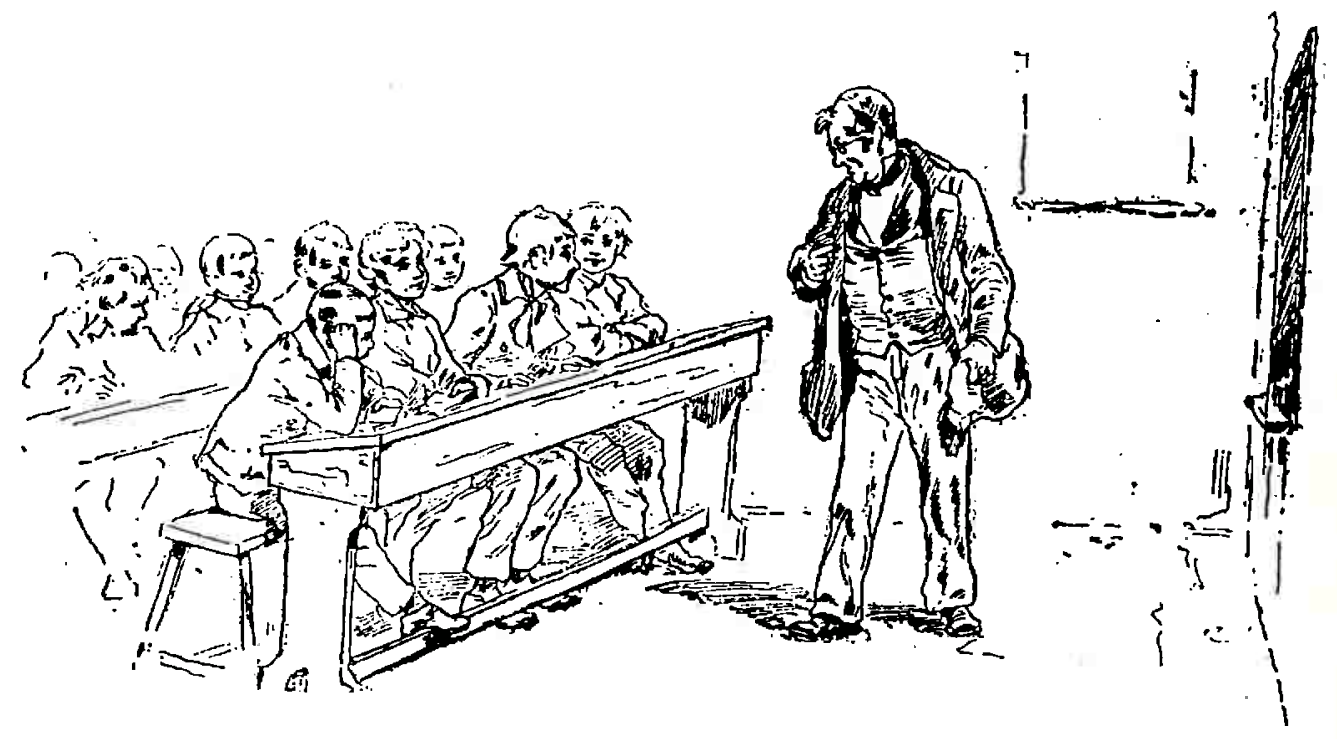

"São inúteis os livros, se o mestre é o livro vivo, uma enciclopédia falante: é só ouvi-lo, de braços cruzados. Os livros conservemo-los todos e obtenhamos novos se pudermos. Mas, usemos deles dando-lhes animação e vida, para que os meninos amem os seus e procurem ler outros."

Relatório de João B. Uchoa Caralcanti 


\section{LIVROS DIDATICOS E PROFESSORES}

o autor do livro, ao criar o "conteúdo explícito", sabia que este, para se transformar em saber ensinado, dependia da atuação do professor. o poder do livro como transmissor de um determinado conhecimento passava necessariamente pelas mãos do professor. O Estado Nacional, ao assumir a instalação de um sistema formal de educação, concebeu o livro escolar como objeto a ser utilizado pelo professor. A constituição de um corpo docente nos moldes do funcionalismo público, como vimos no $1^{\circ}$ capítulo, obrigou as autoridades educacionais a se ocupar da construção de instrumentos para que a tarefa do ensino se efetivasse sob controle, com relativa coordenação e unicidade. Os demais agentes responsáveis pela construção dos manuais escolares, aderirando integral ou parcialmente aos ensejos do poder educacional, eram concordes quanto à importância do professor na utilização do livro didático.

A relação que o professor estabeleceu com o livro escolar tornou-se, portanto, uma questão fundamental para désvendarmos o poder do livro didático na constituição da cultura escolar. Pela precariedade de formação dos professores, seriam eles os principais ou únicos instrumentos para a aquisição do saber escolar a ser transmitido aos alunos? Responder esta indagação significa refletir sobre a questão da "liberdade de ensino do professor" e de seu poder enquanto detentor de um determinado saber, temas ardorosamente defendidos pelos liberais. A possível dependência do professor frente a um material de ensino que, em princípio, direcionava e condicionava o conhecimento de cada disciplina escolar, redimensiona o papel e o poder do professor como o "único" detentor do saber transmitido pela escola. 
Tornou-se, assim, necessário desvendar, inicialmente, a atuação dos livros didáticos na formação do corpo docente, considerando-se as diferenças entre os professores secundários instalados nos principais centros urbanos e os mestres "de primeiras letras" espalhados pelos recantos das províncias.

Os vestígios encontrados para realizar a investigação foram limitados. Os professores, profissionais que diariamente dedicam-se ao trabalho com o ler e o escrever, contraditoriamente, deixaram poucos escritos sobre suas atividades. Utilizamos as publicações da iniciante imprensa pedagógica, especialmente as revistas dedicadas ao ensino e Anais de Congressos pedagógicos. A documentação foi completada por registros oficiais para atender à burocracia. A vida profissional dos professores pode ser recuperada pela versão dos alunos, geralmente os que se tornaram famosos e deixaram publicadas suas memórias. Foram fontes significativas os "prefácios", "prólogos", "advertências", "introduçōes" de livros didáticos nos quais buscamos entrever mensagens dos autores e possíveis diálogos com seu principal agente consumidor.

\section{Mestres normalistas ou leigos?}

\subsection{Primeiras Escolas Normais}

o professor era considerado como um profissional mal preparado desde o nascimento da escola pública, quando o clero deixou de exercer com exclusividade o papel de educador formal. Os discursos das autoridades políticas e educacionais insistiam na necessidade de cursos para formação dos docentes, como foi assinalado anteriormente. Mas, entre o discurso e a prática, o abismo sempre foi profundo.

Nos anos 80 estavam instaladas 24 Escolas Normais em todo o território brasileiro. Destas, apenas 2 eram particulares e as províncias de Mato-Grosso, Rio Grande do 
Norte, Paraíba e Maranhão não acusaram a existência de nenhuma escola de formação de professores. Oito delas localizavam-se na Província de Minas Gerais e as restantes estavam sediadas nas capitais das províncias.

As Escolas Normais foram criadas esparsamente e caracterizaram-se por um funcionamento descontínuo, dependentes de escassos recursos orçamentários. Foi o caso, entre outras, da primeira Escola Normal do Brasil, a de Niterói, criada em 1835 e extinta em 1851 para ser reinaugurada em 1862.1

Acompanhando o desempenho de algumas delas, ressaltamos ainda o número reduzido de formandos a cada ano. A Escola Normal da Província do Rio de Janeiro, entre os anos de 1862 a 1868, formou 32 alunos. A Escola Normal de São Paulo em seus vinte anos iniciais diplomou quarenta professores aproximadamente. 2

Em 1885, nas 24 Escolas Normais oficialmente instaladas, estavam matriculados 3.067 alunos, 1.749 do sexo feminino e 1.318 do masculino, sendo dificil computar o número de alunos que terminavam o curso. Considerando que, na mesma época, existiam 8.064 escolas elementares onde estudavam ou estavam matriculados 226.084 alunos, é flagrante a defasagem entre o número de professores formados pelas Escolas Normais e as necessidades das escolas primárias. ${ }^{3}$

Os dados, correspondendo a uma situação do final do século XIX, demonstram que apenas $37 \%$ dos professores teriam acesso a um curso de formação profissional, sendo que em determinadas regiōes esta proporção era zero pela falta de qualquer estabelecimento do gênero.

- número de Escolas Normais cresceu com o regime republicano mas o crescimento continuou sendo desigualmente

1 Sobre esta primeira Escola Normal fundada em Niteroi ver trabalho de VILLELA, Heloísa- A primeira escola Normal do Brasil: uma contribuição à historia da formação de professores. Dissertaçāo de mestrado, Faculdade de Educaçāo da UFF, 1990. Este trabalho foi publicado resumidamente em NuNEs, Clarice (org) o passado..-op. cit. 2 cf. Escola Normal (Monografia historia) In: Anuario de Ensino do Estado de Sāo Paulo, 1907-8 -op. cit., p. 82

3 Cf. "Quadro sinotico por provincia, escolas e estabelecimentos de instruçāo pública e particular, no Brasil, conforme dados mais recentes" . In ALMEIDA, José Ricardo Pires de-op. cit., p. 276 a 291 
distribuído, dependendo da atuação política de cada estado da federação, recordando que as escolas primárias e Escolas Normais estavam inteiramente subordinadas à política estadual e a destinação de seus recursos orçamentários.

Para o caso paulista, em 1896, o relatório de Alfredo Pujol informava que "Das 1954 escolas preliminares criadas no Estado, estão providas 819, (-) Esta simples enumeração, em face do número de escolas vagas, indica a insuficiência do contingente fornecido pela Escola Normal da capital e a necessidade de se multiplicarem as instituições formadoras dos mestres." 4

o crescimento de estabelecimentos para a formação dos mestres de primeiras letras no Estado de são Paulo foi um fato dos mais significativos, tendo em 1908 uma Escola Normal na capital com um total de 461 alunos matriculados (385 alunas e 76 alunos) e mais 6 escolas complementares, duas na capital e quatro em cidades do interior do Estado que atendiam a 1.623 alunos, sendo 596 do sexo masculino e 1.027 do feminino. 5 As escolas complementares representaram uma das soluções do governo paulista para a questão da formação de professores primários. Eram escolas com uma instalação menos dispendiosa em comparação às Escolas Normais e com um currículo menos abrangente.

o provimento das classes do ensino elementar se fazia por meio de exame em concurso público, geralmente efetuados nos meses de janeiro e junho de cada ano. $6 \mathrm{Na}$ prática, as exigências para se tornar professor de instrução primária em escolas públicas, embora houvesse variações entre as Províncias, não eram muitas e obedeciam aos seguintes parâmetros: ter 18 anos de idade, bom procedimento,

4 PUJol, Alfredo- Relatório sobre a Instruçāo Pública do estado de sāo paulo. In A Escola Pública. São Paulo, ano 1, n 11, 15 jun. 1896, p. 156

5 Cf. Anuario do ensino do Estado de são paulo- op. cit., 1907-08, pp. 99 e 133. As escolas complementares passaram a ser institutos profissionais diplomando professores "preliminares", segundo o Art. $1^{\circ}$ S único da lei $n^{\circ} 374$ de 3 de setembro de 1895 . No interior do Estado foram instaladas escolas em Itapetininga, Piracicaba, Campinas e Guaratingueta ate a primeira decada do século XX.

6 Cf. Relatórios e regulamentaçōes legislativas citadas nas obras de Primitivo Moacyr. 
conhecimento das matérias exigidas por lei, e, se possível, instrução prática do ensino.

o provimento dos cargos e os concursos não estiveram isentos de manipulações políticas e as queixas sobre o desempenho dos professores, nos relatórios de inspetores ou de outras autoridades, foram constantes. O último relatório do inspetor geral de instrução da Província de são Paulo, Diogo de Mendonça Pinto, apontava a interferência política na vida escolar como uma das maiores dificuldades para melhoria do ensino público:

"Por consequência, tomando a si tão inglória quão salutar missão, o mestre não se acha a serviço de conservadores, liberais ou republicanos, mas ao de todas as comunhões políticas, porque não sei de nenhuma mais digna deste século, que aspire ao obscurantismo do povo. Entretanto os partidos intervem aí com outras vistas. Tem correligionários ou servidores a acomodar, $e$ as escolas maravilhosamente os servem. No Brasil não é difícil pelo trabalho viver em abundância e não granjear riqueza. Os afilhados das influências políticas, porém, possuem braços vigorosos e preferem ser empregados públicos com pertinência e na razão direta da incapacidade. Ora os cargos não chegam para o arranjo de tantos pretendentes. Estes nada sabem às vezes para si, dão-se sabendo tudo; não tem vocação para o magistério, supõe-se que nasceram mestres e recebem as cadeiras e nelas se perpetuam." 7

A interferência política dominou fortemente a vida dos professores que, juntamente com o pároco, exerciam influência considerável ou poderiam exercer, junto às famílias. A política clientelista esteve presente nas nomeações, nas transferências e nas exonerações.

Em Minas Gerais, após o movimento de 1842, por exemplo, muitos professores foram demitidos, ou suspensos temporariamente, pela intervenção ou manifestações feitas durante a crise política: "O professor do arraial de são Domingos do Prata sofreu desconto em seus vencimentos $e$ foi

7 Citado por MOACYR, Primitivo- A Inst. $e$ as prov.- op. cit.,2 v. , p. 365-366 
censurado em 4 de março de 1843, porque fugiu à aproximação das forças legais, na revolução de 42 ." 8

Apesar das intervenções de políticos e conflitos constantes nas nomeaçōes e punições dos professores, parte da população buscava a segurança de cargos públicos como meio de aumentar o orçamento familiar. A política clientelística resolvia parcialmente o problema de provimento dos cargos, nomeando interinamente apadrinhados. As exigências quanto à qualificação eram, na prática, ignoradas e a questão da formação dos professores das escolas de primeiras letras foi sendo constantemente protelada, argumentado-se que faltavam verbas.

Algumas províncias, após a proibição do sistema lancasteriano, alegando que havia necessidade de uma formação mais rápida e menos dispendiosa dos mestres para o preenchimento das cadeiras vagas, propuseram o método austríaco-holandês que "consistia em formar o professor na prática, ensinando alunos pobres que funcionassem como auxiliares dos mestres, até estes poderem reger suas próprias turmas." 9

Assim, prevaleceu uma "formação na prática" e para remediar a precariedade de tal capacitação profissional, as autoridades das províncias/estados insistiram na criação dos inspetores escolares. Estes funcionários se encarregariam de vigiar a atuação dos professores e de instrumentalizá-los nas metodologias de ensino. Estas medidas demonstram que, para a maior parte do país, adotou-se a política de restrição econômica na formação dos professores, constituindo-se o corpo docente, majoritariamente, de professores leigos que se formavam na prática.

1.2 Condições de trabalho dos "mestres de primeiras letras"

Os mestres das escolas elementares não gozavam de regalias em seu trabalho. As condições do trabalho

8 mOURÃo, Paulo K. Correa- op. cit., p. 30

9 VILLELA, Beloisa- op. cit., p. 35 
pedagógico das escolas eram precárias e os salários insignificantes.

A necessidade da melhoria das condições de trabalho, especialmente quanto às questões salariais, estiveram presentes em todos os discursos que antecederam as reformas de ensino, no transcorrer do período estudado. o relatório do ministro Paulino José Soares de Souza de 1870 é exemplar pela atualidade dos problemas que apontou:

"Lastima-se geralmente em todo o Império a falta de professores habilitados. As causas, que se apontam, originam-se de várias circunstâncias. Exige-se muito e devese exigir tudo, dos professores; mas paga-se pouco. A mesquinhez da retribuição afugenta os concorrentes a um dos cargos mais pesados da sociedade. A mocidade, que busca habilitar-se para o magistério, não tira o sentido de outros empregos mais lucrativos, não aceita o magistério como situação definitiva, visa outro destino e só espreita ocasião asada para desampará-10. É por este motivo que comparativamente temos melhores professoras do que professores. Aquelas, não podendo servir outros empregos públicos contentando-se com sua sorte, resignando-se aos poucos vencimentos que têm, conservam as escolas em muito melhor ordem, capricham no cumprimento de seus deveres e desvelam-se mais na educação das alunas." 10

o discurso do ministro explicitava dois aspectos da situação educacional do período. Primeiramente percebe-se que as dificuldades das autoridades governamentais em prover as cadeiras criadas residiam, basicamente, na baixa remuneração.

O inspetor paulista Mendonça Pinto, em 1867, informava que era impossível convencer os jovens a seguir a carreira do magistério porque não seria "com mesquinhos vencimentos de $300 \$$ a $400 \$ 000$ anuais que poderemos atrai-los para o magistério, sobretudo numa região fértil de recursos como

10 SOUSA, Paulino José Soares de- Relatorio estatístico - Apud MOACYR, Primitivo - Inst. e Imp.- op. cit., 1v. p. 535- 536 
São Paulo, onde tão fácil é a vida e mais vantagens se colhem ensinando num colégio particular."11

Um segundo aspecto a ser considerado, no discurso de Paulino de Souza, refere-se à proposta para solução do problema de falta de professores: transformar o magistério primário em uma atividade feminina.

o encargo do magistério como tarefa feminina foi sendo paulatinamente construído.

A tendência inicial da formação do quadro de docentes públicos era a de preservá-lo como um encargo masculino conforme se verifica nas matrículas das primeiras Escolas Normais como a Escola Normal de Niterói que até 1862 não registrou a matrícula de nenhuma aluna. O mesmo se verificou com a Escola Normal de São Paulo, "instalada a 16 de fevereiro de 1875, numa sala do Curso Anexo à Faculdade de Direito, [que] destinava-se aos moços e tinha um curso de dois anos, começando com 33 alunos, dos quais nove professores de palácio." 12

As mudanças quanto à participação mais efetiva das mulheres na composição do corpo docente das escolas elementares ocorreu após a década de oitenta, quando a expansão da escolarização forçou uma nova postura no sentido de efetivar parcialmente as propostas educacionais. As autoridades perceberam a impossibilidade dos homens, chefes de família, de sobreviverem como mestres devido aos baixos salários e, iniciaram um discurso de valorização "da condição feminina" como a mais adequada para tal tarefa. A escola passou a ser considerada como "uma continuação do lar", a professora "uma segunda mãe". Empregando a mesma retórica, começaram a proliferar os discursos de autoridades governamentais na articulação magistério-lar- escola.

11 Apud EsCOBAR, J. R. - op. cit., p.166. Neste trabalho Escobar informa que os vencimentos dos professores em 1878 eram: "para cidades - 850\$, vilas - 750\$, freguesias e bairros- 650\$, Capital 950\$. O governo dava mobilia e o professor pagava a casa e outras despesas. Com 667 escolas providas, a dotação para mobilia era de 4 contos, quando devera ser de 50 contos. O presidente se revolta contra esse estado de coisas: "Por isso se vê, ao lado da escola pública despovoada, a particular bem frequentada. $E$, "os professores públicos sāo os mendigos do funcinalismo." idem- ibidem.

12 esCOBAR, J. R.- op. cit., p. 167. Grifo do autor. 
Nas "casas de caridade" onde eram educadas as meninas órfãs, administradas por particulares mas que recebiam subvenções públicas, havia preocupação em fornecer algum tipo de ensino profissional às jovens, evitando que "as meninas desvalidas", correspondentes ao grupo social onde a "miséria e ociosidade" ameaçava "a moral e a sociedade", ingressassem na prostituição. Era mister aproveitar as educandas pobres, "aplicando-as a alguma arte liberal, tal como a Música, o Canto, o Desenho, de que poderiam ser professoras, que faltam na província." 13 A partir da década de 70, as "casas de caridade", em sua maioria, passaram a estabelecer como um de seus objetivos formar "órfãs" para a "missão" de professoras.

Os dados númericos de alunos matriculados nas Escolas Normais apresentados demonstram a tendência que ocorreu na fase republicana de transformar o magistério primário em atividade preferencialmente feminina. 14

As condições de trabalho dos professores primários nos centros mais populosos eram, evidentemente, melhores quanto às instalações e recursos didáticos, passando o governo a preocupar-se em fornecer encontros pedagógicos para "promover conferências públicas nos quais sejam tratadas todas as questões que se prendem à organização, regime, programa, métodos de ensino e tudo enfim que se liga à instrução pública." 15

Na capital brasileira, no final do Império, iniciaramse efetivamente, a organização de Congressos pedagógicos, sendo o mais famoso o de 1883, que mesmo frustrado, resultou na criação do Museu Pedagógico que teve como objetivo ser um centro de aperfeiçoamento constante de professores, com exposiçōes de novos recursos didáticos, materiais de ensino e biblioteca com um acervo sobre as publicações internacionais pedagógicas.

13 Cf. DIAs, Gonçalves- Relatorio.-op. cit. p. 357

14 os dados de São Paulo indicaram que "nesta última fase da escola Normal, isto 6 , no período que decorre de 1894 a 1908, diplomaram-se 548 alunos, sendo 154 do sexo masculino e 394 do sexo feminino. "In: Anuário do E. E. S.Paulo, 1907-08 -op. cit., p. 98

15 MOACYR, P.- Inst. e Imp.- op. cit.- 1 v., p. 263 
Tais atitudes demonstravam um avanço em relação à questão da formação dos professores, entendendo-a como forma de suprir as deficiências iniciais mas, também, dentro de uma concepção de formação contínua do profissional em educação, o qual deveria se atualizar com as inovações pedagógicas. Cabe ressaltar, no entanto, que estas iniciativas limitavam-se a alguns centros mais populosos ou em desenvolvimento econômico, acentuando as disparidades entre os professores e sua formação nas diversas regiōes brasileiras.

A descrição abaixo retrata, ao que parece, a maioria da vida escolar do período, especialmente em lugares mais distantes, onde vivia espalhada a maioria da população brasileira:

"Chegando à hora letiva achei a escola fechada. Pouco depois aparece o cidadão J.J.F. e declarou que havia sido encarregado pelo professor de reger a escola em sua ausência; o que sucedia frequentemente desde a concessão da subvenção em julho de 1886 , porque o funcionário em questão empregava-se na medição de terras e em outros misteres da vida particular." E mais adiante, o autor do relatório, descreveu que estavam "presentes 4 alunos. A casa é péssima. Na sala principal há uma armação de venda, cujo balcão é a mesa de escrita. A mobilia consta de três bancos muito baixos e um tamborete. Em geral a desordem, e o custeio nulo". 16

A situação dos professores de escolas particulares é difícil de detectar pelas parcas informações disponíveis.

Em depoimento prestado ao diretor de instrução da Província de Minas Gerais, no ano de 1852, um dos relatores informava que era inviável esclarecer sobre as aulas particulares, acrescentando que "em todas as povoaçôes há aulas particulares e, em algumas, a frequência dos alunos sobrepujou a das aulas públicas. Bm cada uma fazenda, banca de sapateiro ou alfaiate encontra-se um mestre para seus 4 ,

16 Relatorio do diretor de Instruçāo da Provincia do Rio de Janeiro de 1888, José Bento de Araujo. In MOACYR, P. - Inst. e prov.- op. cit. $2 \mathrm{v}$, , p. 304 
6 e 8 discípulos. Escravos há que também têm seus mestres. "17

As condições de trabalho nas escolas particulares não pareciam ser muito auspiciosas. O relato de Ina von Binzer sobre suas experiências como professora em um colégio de meninas no Rio de Janeiro, revelou salários baixos e ausência de contratos, ficando "as mestras" sujeitas à dispensa a qualquer momento, além da inexistência de qualquer proposta de ensino, cabendo a cada professora a decisão sobre o método a seguir. 18

A preferência das classes dominantes por escolas particulares ou contratação de preceptores para educação dos filhos, foi flagrante, configurando-se como uma das características da política educacional brasileira. "As crianças das classes razoavelmente abastadas não vão à escola pública porque seus pais têm, com mais ou menos razão, o preconceito de cor ou porque temem, e com razão, pela moralidade de seus filhos, em contato com esta multidão de garotos cujos pais os enviam à escola apenas para se verem longe deles algumas horas. Deste modo, estas crianças aprendem melhor e mais depressa do que aqueles que frequentam a escola pública". 19

A opção das elites econômicas por um tipo de escolarização privada e o desprezo pelas escolas públicas, explica-se pelo preconceito em relação aos trabalhadores além do desejo de garantir formas educacionais diferenciadas para a manutenção de uma divisão nítida entre

17 MOURÃo, Paulo K.- op. cit. ,p. 47

18 A educadora alemā refere-se a sua experiência em um colégio do Rio de Janeiro como um desastre:

"Nessa ocasião nossa francesa mais moça, Melle. Serôt, prende-as dentro de um armário vazio até que se acalmem. Raramente vemos a diretora fora das horas de refeif̧ão. Ela é a única que possui autoridade sobre este bando selvagem, talvez por aparecer muito pouco. Esta sempre bem vestida, no seu gabinete, onde recebe os pais das alunas e dá apenas uma aula de leitura em cada classe. Não gosta de ser consultada sobre os trablhos escolares, e a mim, nāo me resta outro recurso senāo o arranjar-me sozinha, como Melle. Serôt. Até agora não pude descobrir um programa de estudos e muito menos um horário; por enquanto, tudo me causa a impressāo de caos num deserto. "BINZER, Ina von-op. cit.- os meus romanos-Alegrias e tristezas de uma educadora alemá no Brasil. Trad. Alice Rossi e Luisita da Gama Cerqueira. "3 ed. Rio de Janeiro: Paz e Terra, 1982, p. 65 a 67.

19 ALMEIDA, J. Ricardo Pires de -op. cit., p. 90 
os privilegiados e os despossuídos. Elite de um lado e "povo" do outro. 20

Assim, não havia interesse efetivo em despender verbas públicas para a formação dos mestres das escolas primárias. Por outro lado, o ensino particular era extremamente deficiente e superficial, mesmo considerando os professores estrangeiros contratados que limitavam-se a ensinar linguas modernas, buscando adaptar, com dificuldades, sua cultura de origem às condições brasileiras, levando uma professora alemã, depois de algumas poucas experiências com seus alunos, a desabafar desanimadoramente: "Você sabe quem afundei hoje nas profundezas mais profundas de minha mala? 0 Nosso Bormann, ou melhor, suas 40 cartas pedagógicas que não tem a qui a menor utilidade. E confiava tanto nelas!" 21

A melhoria de condições salariais foi uma questão que, aparentemente, pareceu preocupar as classes detentoras do poder mas as soluções não eram direcionadas para mudanças neste setor. Além de incentivar a formação de um corpo docente feminino, efetivou-se uma política que acabou sendo predominante para a manutenção dessa situação de escassez justificada por um discurso ideológico que construiu a imagem da atuação missionária do professor.

Criou-se nos cursos de formação do professor, um "currículo oculto" que prescrevia aos futuros professores o dever de se habituar a medidas severas, regradas, sistemáticas, "sem afetação e alarde" para seguir com sucesso sua vida posterior. As Escolas Normais deveriam, além de difundir ensinamentos científicos, encarregar-se de inculcar nos alunos-mestres " os hábitos de simplicidade, de

20 Em um trabalho sobre a Bahia no século XIX, Ratia de Queirós Mattoso informa que as Irmās de são vicente, ao se instalarem um colégio foram acolhidas com desconfiança porque permitiram alunas "de um especto social muito extenso" e as "moças de famlilia mantinham contato com internas pobres ou orfās e com externas que pertenciam a todas as camadas livres da sociedade." Esta permissividade das Irmās ocasionou uma "verdadeira revolta popular em 1858 , sendo obrigadas a mudar suas propostas educacionais. MATTOSO,K. de Queirós- Bahia, século $x I X$ - uma província no Império. Rio de Janeio: Nova Fronteira, $1992, \mathrm{p} .385$

21 BINZER, Ina von- op. cit., p. 21 
modéstia, de humanidade, o amor de uma vida retirada, o culto do dever, a religião do coração." 22

Ao magistério, concebido como uma "missão", um "sacerdócio", não caberia, portanto, reivindicações de caráter material, ou formas de recompensas financeiras. Tratava-se de un trabalho humanitário e social, desvinculado das necessidades materiais dos professores.

\section{$\mathbf{1 . 3}$ Mestres e livros}

Vários relatórios de inspetores e diretores de instrução registraram uma política de fornecimento de materiais didáticos para as escolas e mais especificamente para compensar a precariedade da formação dos professores das escolas primárias?"Além dos dois primeiros compêndios de rudimentos de leitura com algumas máimas morais e dos princípios de moral precedidos das orações da doutina cristã, já impressos e distribuidos pelas escolas, acham-se organizados também pelo diretor das aulas, o dedicado reverendo frei de Santa Gertrudes, outros dois, a saber um extrato de autores clássicos da língua para servir de leitura e análise gramatical, e outro de geografia, precedido de conhecimentos suficientes da esfera celeste. Ambos estão se imprimindo." escreveu Paulino de Souza, quando presidente da Província do Rio de Janeiro. 23 Em 1849, um outro inspetor de ensino da mesma Província informava sobre seus esforços em criar livrarias municipais onde os professores tivessem acesso e pudessem "se instruir pelos livros didáticos mais citados." 24

A questão, entretanto, foi identificar a visão do professor sobre o papel do livro didático. Encontramos registrados alguns pedidos de fornecimento de livros, dirigidos aos inspetores ou diretores de instrução de suas respectivas províncias, nos quais os professores

22 OTAVIANo, Francisco- Ensaios administrativos. Jornal do Comercio. Rio de Janeiro, 1851. Apud MOACYR, P.- Inst. e prov.-op. cit., vol. 2, p. 562

23 Apud MOACYR, P.- A Inst. e as prov...- op. cit., 2v., p. 199

24 Idem, p. 211 
manifestaram a necessidade desse material para distribuição aos alunos. Foi, por exemplo, este o teor do pedido que um professor de ensino primário, da região do Paraná, ao enviar ofício ao governo de São Paulo em 1844, solicitando "seis exemplares do catecismo histórico de fleury para uso de seus alunos em aula". 25

Mais interessante foi a solicitação de um professor de Curitiba que expediu uma lista de livros, com data de 1846, ao Diretor de Instrução da Província e sem ter obtido resposta, apresentou-a, novamente em 1848. Da lista constavam 16 obras e a quantidade de cada uma delas. Pelo número de volumes solicitados, percebe-se que parte das obras deveria ser para uso pessoal do professor e não para distribuição entre os alunos, variando a requisição entre 1 a 20 exemplares. 26

Havia uma demanda por livros didáticos dos diversos conteúdos das disciplinas escolares os quais deveriam ser fornecidos pelas autoridades provinciais. Notava-se a ausência de livros de conteúdo pedagógico, produção escassa e esporádica, pouco difundida entre o corpo docente. o mais conhecido texto destinado "aos alunos-mestres das escolas Normais primárias e aos institutores em exercício" foi a tradução do Curso prático de pedagogia de Daligault, que em 1874 atingia a 20 edição depois de um "geral acolhimento que teve a 1 edição que assaz demonstra que bem avisado andou - ilustre tradutor de tão importante livro, quando de preferência o escolheu para preencher a lacuna que havia de obras deste gênero na língua vernácula" .27

25 oficio do professor José Joaquim dos Passos oliveira ao presidente da Província de São Paulo. Freguesia de são José dos Pinhais, 12 de jan. 1844. Apud KuBo, Elvira Mari- A legislaçāo e a instruçāo pública de I letras na 5 a comarca da Província de São Paulo (Paraná), 18271853. Tese de doutorado. São Paulo: F.F.L.C.H. da USP, 1982, p. 300301 .

26 Idem- op. cit., p. 306 e 307. Na solicitação do professor estão, por exemplo, os compêndio de Geografia e História por João Henrique Freese, diretor do Instituto de Nova Friburgo.

27 DALIGAULT - Curso prático de pedagogia. Trad. Joaquim Pires Machado Portella. Rio de Janeiro: Tip. universal, 1865. A primeira obra do gênero que encontramos foi a de DEGERANDO, Marie Joseph- Curso normal para professoras das primeiras letras. Trad. Joāo C. Deus Silva. Niteroi: Tip. Niteroi, 1839 
As editoras, no final do século XIX, incentivavam os professores a comprar "livros úteis" a seu aperfeiçoamento profissional, oferecendo uma bibliografia mais variada, composta por livros didáticos e uma literatura pedagógica especializada. 28

Nas últimas décadas do século iniciou-se um movimento por parte dos próprios professores na difusāo de obras especializadas e didáticas. Esta forma de iniciativa ocorreu junto às incipientes associações de professores criadas para promoção de melhorias das condições de trabalho, mas que acabaram por incorporar as questões de aperfeiçoamento docente, responsabilizando-se algumas delas pela publicação de revistas pedagógicas e criação de bibliotecas.

o Grêmio dos Professores Primários de Pernambuco, provavelmente uma das mais antigas associações de professores, na década de 70 fazia interferências quanto à adoção de livros didáticos a serem utilizados nas escolas públicas da Província, chegando inclusive a enviar livros para publicação, como a impressão de Elementos de agricultura e se encarregando de distribuir "gratuitamente compêndios e livros pelas aulas primárias de seus associados". 29 A Associação Beneficente do Professorado Público de São Paulo foi outro tipo de organização de professores que, entre outras atividades, iniciou a publicação da Revista de Ensino que divulgava novos métodos de ensino, além de resenhas sobre os livros de educação, incluindo os didáticos.

Em algumas destas revistas pudemos constatar reclamações sobre as dificuldades dos mestres quanto ao atendimento de seus pedidos. Em o Ensino Primário, revista carioca "consagrada aos interesses do ensino", um professor denunciou a dependência do docente frente às autoridades educacionais: "Se precisa de um objeto para sua escola, um livro, uma cadeira, um banco, não pode dirigir-se ao almoxarife, pedindo-o. Há de obte-lo por intermédio do delegado, que, se não simpatiza muito com ele, pode negá-1o

28 Cf. Anúncios da Editora Alves \& C. In: Revista Pedagógica, n¹9, 1893 .

29 CAVALCANTI, J. U.- op. cit., p.290. 
ou demorar-1he a remessa, depois de julgar a seu talento da necessidade ou não necessidade de tal objeto." 30

Os textos organizados para a apresentação no Congresso da Instrução do Rio de Janeiro de 1883 foram importantes documentos para se obter uma avaliação dos professores sobre - livro didático. Trata-se, evidentemente, de uma visão parcial, representada por professores ligados às escolas particulares e a setores do poder educacional da capital do Império, portanto, uma parcela privilegiada do corpo docente.

Os textos apresentados para o Congresso registraram marcas de uma tendência a renovações metodológicas introduzidas pelo "ensino intuitivo", com citações frequentes de obras de Frœbel e Pestalozzi. As inovações pedagógicas eram demonstradas pela introdução de materiais didáticos "modernos", sendo que o livro didático passava por um momento de questionamento, especificamente quando se concebia a introdução das disciplinas de cunho "científico" para o ensino primário e seu método "lições das coisas". As propostas pedagógicas que acatavam o "método intuitivo" conferiam ao livro escolar papel secundário que acabava por aparecer nos discursos dos professores. Mas, na maioria dos trabalhos publicados, percebemos a incorporação de um discurso marcado pela contradição:

"O ensino intuitivo, tão preconizado hoje, aliás iniciado no século $17^{\circ}$ por Comenius, só pode ser aplicado às disciplinas, cujo objeto tem forma sensível; às outras só por meio de alegorias pode adotar-se. Eu vejo inconveniente na aplicação exclusiva do ensino intuitivo. (..)

A forma expositiva a que matérias convém? Pode ser aplicada exclusiva às que convier? A própria história, únicas liçōes dadas nas escolas elementares, a quem mais aproveita esta forma de ensino, não pode ser unicamente dada em exposições ou preleções.

A inteligência das crianças é fraca para guardar de uma vez o assunto de uma lição que para ser útil deve ser dividida em períodos, cujo assunto se ligue intimamente pela

30 o Ensino Primario. Rio de Janeiro, ano 2: 62, ag. 1885. 
compreensão, pela analogia ou pela associação de idéias. (...) . "31

E, o professor concluiu, após citar outros exemplos, que não se podia prescindir dos compêndios escolares na prática da sala de aula.

Os professores que expuseram suas opiniões sobre a questão dos métodos de ensino nas escolas primárias e adoção de compêndios, um dos temas proposto para debate no malogrado Congresso, concordaram, majoritariamente, sobre a impossibilidade de se abolir o livro na sala de aula, discordando de algumas propostas dos defensores dos métodos "intuitivos" :

"Importantíssimo é o papel que na instrução primária representam os livros: auxiliares do professor, não só instruem as crianças, mas, levados por elas ao lar doméstico, servem também muitas vezes à instrução das famílias. Devem, pois, reunir qualidades que os tornem aptos para aqueles fins." 32

Ressaltaram que o governo deveria ampliar a lista dos livros adotados para que o professor pudesse ter direito à escolha $e$ os editores deveriam cuidar para melhorar as edições, para "expurgá-las de inúmeros erros que escapam aos revisores descuidados, como para faze-los imprimir em tipo menos incômodo." 33

Trata-se assim de uma visão que pouco diferia da oficial, imprimindo ao livro um papel importante na prática pedagógica.

Não houve referências sobre $\circ$ papel que ele desempenhava como organizador e fornecedor dos conhecimentos das disciplinas, limitando-se a destacar o papel de "auxiliar do professor" na sala de aula e seu "substituto" nas tarefas escolares para casa. Nesse sentido, insistiram para que os livros fossem fiéis aos programas estabelecidos, demonstrando que este material seria o meio

31 Costa, Manuel olimpio Rodrigues. Métodos e programas de ensino nas escolas primarias. Adoção de compêndios. Atas e pareceres do Congresso da Instrução do Rio de Janeiro. Rio de Janeiro: Tipografia Nacional, 1884,6 questão, p. 2

32 SABINo, Januário dos santos- Metodos e ...-op. cit. , p. 9

33 FRAZÃo, Rosalina, Idem-p. 10 
mais apropriado para o professor preparar-se para o desempenho didático das matérias a serem ministradas.

o professor, formado em sua maioria, na prática, sem Escolas Normais, deveria necessariamente contar com o livro didático para dominar os conteúdos explícitos a serem transmitidos. o conhecimento a ser desenvolvido em sala de aula era o que estava contido nos manuais escolares e a dependência do professor tendia a crescer à medida em que estes conteúdos foram exigidos em exames para aprovação em cursos primários, situação que teve início nas primeiras décadas do atual século.

As autoridades educacionais paulistas do inicio do século atual, defensoras dos métodos "intuitivos", mais cautelosos quanto ao papel do livro no processo de aprendizagem dos alunos, selecionaram os livros a serem adotados nas escolas e enviaram uma lista de "1ivros que podem servir de guia aos professores no ensino das diversas disciplinas do curso preliminar".34 A lista, no entanto, constituíu-se de livros didáticos, com poucas exceções, fato que demonstra seu poder na formação dos professores.

\section{Professores secundários: leitores e escritores}

\subsection{Professores dos liceus}

Para o caso do ensino secundário, a situação do magistério diferenciava-se. Assim como havia uma nítida separação entre a escola elementar e a escola secundária, havia uma distinção entre professores secundários e primários. Existiam os professores, com hierarquias internas: lentes, interinos e havia os mestres de "primeiras letras", também separados hierarquicamente: os das escolas

\footnotetext{
34 Anexo do parecer da comissão sobre a adoção de livros didáticos Anuário do ensino do Estado de São Paulo op. cit., p. 391 . No caso de Bistoria, os livros indicados para os professores foram: "Historia pátria: 1)Historia pátria, Antonio Mendes da Silva; 2) pontos de historia patria, J. B.; 3)Epitome da historia do Brasil, Moreira Pinto; 4) Liçōes de historia pátria, Estácio de Sa e Menezes; 5) História do Brasil, João Ribeiro; 6) Liçōes de história do Brasil, Xavier pinheiro; 7) Historia do Brasil, R. G.."
} 
públicas e os das particulares, os das escolas dos povoados e os das grandes cidades, os adjuntos e os interinos.

Os professores secundaristas, geralmente, possuíam cursos superiores, mas sua formação, enquanto profissionais da educação, era predominantemente proveniente do que chamamos de autodidatismo. O perfil do professor de História como parâmetro para situar as condições de formação dos professores secundários.

Baseando-nos nas relações de autores de livros didáticos de História que, em sua maioria, eram professores secundários, encontramos um corpo docente formado em Faculdades como Medicina, Direito e pelas Escolas Militares. Havia um número significativo proveniente de escolas secundárias, bacharéis dos liceus ou do próprio Colégio Pedro II e de Escolas Normais, além de clérigos oriundos dos Seminários.

para os liceus públicos e cursos preparatórios para as Faculdades de Direito, a exigência do concurso de ingresso acabou por selecionar um grupo de elite de professores. No caso dos professores de História, como vimos anteriormente, estes se constituíram en um grupo de intelectuais com certo prestígio, responsáveis, em sua maioria, pela produção historiográfica da época.

A descrição que nos forneceu Carl von Koseritz do concurso para preenchimento da cadeira de História Nacional no Colégio pedro II foi sugestiva quanto ao perfil dos professores daquele prestigiado estabelecimento de ensino:

"Primeiramente apareceu o meu amigo Capistrano de Abreu, que tomou lugar em uma pequena mesa e teve de defender sua tese(..) A tese de Capistrano, que trata com verdadeira maestria e grande saber do descobrimento do Brasil e do seu desenvolvimento no século XVI, era sem dúvida a melhor e tão excelente era que ia muito além dos horizontes dos dois limitadíssimos examinadores Moreira de Azevedo e Matoso Maia." (...)

E mais adiante não escondeu sua decepção sobre os lentes do Colégio Pedro II: 
"o segundo candidato, dr. Berquó que tinha ocupado a cadeira interinamente, não é tão preparado como Capistrano de Abreu e a sua tese é muito mais insignificante que a do talentoso redator da "Gazeta de Notícias"; apesar disto ele era ainda superior aos examinadores e atravessou brilhantemente o torneio. No conjunto o concurso causou uma triste impressão, pois mostrou claramente em que mãos incapazes a instrução do colégio ainda se encontra parcialmente. Sem dúvida o estabelecimento ainda conta com professores excelentes como os senhores barão de Tautphaus, Schiefler, Carl Jansen e Sílvio Romero, mas a maior parte é da marca dos dois examinadores." 35

Diversamente dos professores do Colégio Pedro II, para as demais escolas secundárias, particulares ou públicas, o magistério se caracterizou pela polivalência. Dificilmente encontramos professores especializados em uma única disciplina. Prevaleceram tais situações:

"Uma moça formada, de anel no dedo, podia ensinar as meninas até o curso secundário. Podia até ensinar francês, se quisesse..." 36

"Sebastião Soares de Faria foi pau para toda obra no Ginásio Nogueira da Gama, tendo lecionado, durante 9 anos, quase todas as disciplinas do curso ginasial. No meu tempo prelecionava História Universal sobre a qual escreveria mais tarde, ainda em Jacareí, un compêndio didático" 37

A inexistência de professor especialista era a regra. As fronteiras entre as disciplinas escolares estavam sendo construídas, como aconteceu em História e Geografia ou entre as diversas disciplinas Iiterárias. Desta forma, a organização do ensino a ser ministrado, dividindo-o em "matérias" que, muitas vezes, se embricavam considerando que havia um eixo -as humanidades clássicas- em torno do qual os

35 KOSERTTz, carl von- op. cit.- p. 114

36 AMADO, Gilberto- História de minha infancia. Apud LEITE, Miriam M. Leite- o ensino da historia no primário e no ginásio. São paulo: Cultrix, 1969, p. 24

37 PRADO, A. de Almeida- Escolas de ontem e de hoje. são Paulo: Anhembi, 1961, p. 59 
diversos conteúdos se articulavam. Assim, as relações entre - ensino de História e o de Latim, por exemplo, estavam articuladas de maneira a possibilitar que um mesmo professor se encarregasse das lições de ambas as disciplinas.

Com exceção do Colégio Pedro II, com um sistema de concurso mais rígido, a especialização dos professores em uma única disciplina ocorreu dentro de um processo longo, efetivando-se depois de 1930 com a criação das Faculdades de Filosofia e a obrigatoriedade do curso secundário para chegar ao curso superior.

Nas escolas particulares o trânsito dos proféssores era ainda mais fluído. Podia-se passar, inclusive, com certa rapidez, de aluno para professor. Rapazes mais pobres que estudavam gratuitamente, subvencionados pelo governo, tornavam-se monitores ou "auxiliares". A vida estudantil do jurista Evaristo de Moraes comprova esta prática quando durante os anos de 1887 a 1889 foi professor do Colégio "São Bento", no Rio de Janeiro, como auxiliar de Português, Geografia e História. 38

Para professores encarregados de várias disciplinas, o livro didático era a provável fonte de seu conhecimento, lembrando que muitos dos livros didáticos nasceram das anotações organizadas para as aulas, criando-se os novos compêndios por compilações e cópias adaptadas de outros livros didáticos.

Os livros didáticos e os textos clássicos, para o caso dos professores das disciplinas do currículo humanístico, embasavam o conhecimento necessário para que se delineasse o perfil de um bom profissional. Os escritores ao rememorarem a vida escolar, em meados do Império, destacavam os professores ou pela sua incompetência ou pela sua erudição e eloquência:

No primeiro caso, a figura de um professor do interior de Minas Gerais, um "intelectual" bem conceituado na comunidade, foi assim descrita: "(..) o padre Mestre João Damasceno muito pouco sabia do que algumas noçōes de

38 Cf. MORAES, Evaristo de- Reminiscências de um rábula criminalista. Rio de Janeiro/ Belo Horizonte: Editora Briguiet, 1989, p. 10 e 11 
história e essas mesmas muito incompletas e muito superficiais. Todavia, por causa daquela sua reserva e daqueles seus modos mais ou menos misteriosos, ele passava para muita gente como um verdadeiro oráculo; (..)." 39

Mas havia os que se destacavam pela erudição:

"Era literalmente como um dicionário que a cada instante alguém manuseasse, ou uma enciclopédia que um abrisse no artigo Babilônia, logo outro nos artigos Invasão dos Bárbaros, Adam Smith, Lutero, Hieroglifos(...) Ele falava de um modo uniforme, sem ênfase, sem colorido, sem expressão mesmo, mas era um jorrar sem fim de ciência, de erudição " 40 escreveu Joaquim Nabuco do professor do Pedro II, o barão de Tautphœus.

Evidencia-se pelos relatos sobre os professores que estes não se constituiram como um grupo de formação homogênea. A questão da formação deste setor docente foi, entretanto, pouco debatida. Surgiram alguns projetos sobre a formação dos professores secundários no Congresso de 1883 do Rio de Janeiro nos quais incluia-se a criação de uma Faculdade de Letras. As discussões foram poucas ou quase inexistentes sobre esta questão e o que persistiu e permaneceu foi uma formação baseada no autodidatismo.

\subsection{Professores - autores}

A estreita vinculação entre professores e livros didáticos pode ser avaliada pela participação que os primeiros tiveram como autores. A expansão da produção didática a partir da segunda metade do século XIX se fez, como foi destacado, com a significativa atuação dos professores na confecção de livros.

Muitas obras surgiram das anotaçōes organizadas e sistematizadas pelos professores em seus cursos. O caso dos professores de História do Colégio Pedro II é exemplar.

39 REZENDE, Francisco de Paula Ferreira de- Minhas recordaçōes. Rio de Janeiro: José Olimpio, 1944, p.211

40 NABUCO, Joaquim- Minha formaçāo. São Paulo: Progresso editorial, 1947 , p. 208 
Iniciando por Justiniano José da Rocha e seguido por Joaquim Manuel de Macedo, Berquó, Moreira Pinto, João Ribeiro, Serrano entre outros, todos eles tornaram-se autores de compêndios.

A Escola Militar do Rio de Janeiro, desde sua instalação, teve igualmente que se haver com a questão dos compêndios a serem adotados. Esta Escola de difícil definição entre escola superior ou escola secundária, foi responsável pela elaboração de obras de ensino da Matemática e da Geografia, traduções realizadas pelos seus docentes. Entretanto, no início da década de quarenta, durante as disputas políticas e sociais da fase regencial, com a questão da unidade nacional e a nova configuração do papel político dos militares, houve a necessidade de uma produção de obras didáticas locais que se encarregaram de esboçar os contornos territoriais da nação independente. A Escola Militar foi o lugar institucional responsável pelo aparecimento dos primeiros compendios nacionais de Geografia e de História.

o primeiro livro didático de Geografia que temos notícias foi de Pedro de Alcântara Bellegarde, major imperial do corpo de engenheiros e "lente da academia militar".41 As obras de Matemática também foram preocupação dos lentes ligados à formaçāo militar e pudemos observar que, embora as primeiras edições do livro Elementos de Geometria do Marquês de Paranaguá tivessem sido produzidas em Lisboa, a sua utilização contínua na Escola Militar do Rio de Janeiro, levou a que se realizasse uma produção editorial local.

Posteriormente, na fase "nacionalista" da produção didática destacaram-se vários autores, cujos textos nasceram da prática em salas de aulas e que marcaram a literatura escolar. Foi o que ocorreu com Romão Puiggari. Este professor, após lecionar no interior do Estado, dirigiu o $1^{\circ}$ Grupo Escolar do Brás, na Capital paulista e seu primeiro

41 BELILGGARDE, Pedro de Alcântara- Introdução corográfica à história do Brasil. Rio de Janeiro: Tipografia de J. E. S. Cabral, 1840 . 
livro, Coisas Brasileiras "assinalou importante mudança nos rumos do livro didático." 42

Ainda compondo a lista de professores que se tornaram famosos como escritores de compêndios temos os oriundos de escolas protestantes de São Paulo, Antonio Trajano e Júlio Ribeiro. Antonio Trajano produziu livros de Matemática para as escolas primárias e secundárias e com uma premiada obra Aritmética elementar ilustrada, na Exposição de 1883 do Rio de Janeiro, tornou-se uma autor nacionalmente conhecido. Julio Ribeiro, mais famoso como romancista, foi "o verdadeiro introdutor, nas escolas, da nova e brilhante fase do ensino da lingua portuguesa", segundo depoimento de Almeida Pires. 43

A projeção de autores de origem protestante não significou a ausência de religiosos católicos na tarefa a que vinham se dedicando há tantos anos. Os jesuitas retomaram suas atividades pedagógicas lentamente no decorrer do século XIX e deixaram algumas obras escolares. O mais célebre escritor didático, dentre os jesuítas foi o padre Rafael Maria Galanti, professor no Colégio "Anchieta" em Nova Friburgo. 44

A contribuição maior dos padres católicos para a literatura escolar ocorreu com a vinda dos Irmãos Maristas que instalaram seus colégios juntamente com sua casa editorial. Os professores maristas, anonimamente escreveram obras didáticas de caráter marcadamente europeu, compondo um acervo que se opôs à tendência "nacionalista" então em voga. Os autores anônimos da F.T.D. começaram a disseminar livros impressos no exterior, traduções em sua maioria, que foram sendo consumidos pelo número crescente de escolas

42 PROMM NETO, s. e outros - op. cit., p. 175

43 ALMEIDA, Ricardo Pires de- op. cit., p. 159

44 A volta dos jesuítas ao Brasil ocorreu em meio a questão da campanha da secularização das ordens religiosas no século XIX. O historiador oscar Beozzo apresentou os seguintes dados sobre eles: nos jesuitas, sem muito alarde, reaparecem no su1 do pais, no Rio Grande do Sul em 1842 e em Santa Catarina (1845-54) e por breve período no Nordeste, em Recife (1866-1874). Em são Paulo firmam-se em Itu (1867)." BEOzzo, José Oscar- Decadência e morte, restauraçāo e multiplicaçāo das ordens e congregaçōes religiosas no Brasil -18701930. AzZI, Riolando(org)- A vida religiosa... -op. cit., p. 92. O livro didático mais difundido de Galanti foi Biografias de brasileiros ilustres- resumidamente expostos. São paulo: Duprat cia., 1911 . 
confessionais católicas nos inícios do nosso século. A questão do "nacionalismo educacional" encontrou em tais autores verdadeiros opositores, incluindo as questões metodológicas e pedagógicas persistindo em obras ainda mantenedoras do estilo "catecismo" com perguntas e respostas.

É certo que grande número dos livros produzidos pelos professores dessa época apresentavam poucas variações entre si, iniciando a prática de plágio, sistemática que passou a caracterizar a produção didática. Cabe ressaltar, no entanto, o papel desempenhado pela experiência do professor na elaboração dos manuais escolares. As aulas que os professores ministraram foram espaços onde iniciaram sua produção escolar, constatando-se que alguns deles se destacaram como inovadores dessa literatura. A transposição didática não ocorreu, assim, desvinculada da prática em sala de aula, como simples adaptações simplificadoras dos textos eruditos.

\section{Diálogos dos autores com os docentes}

\subsection{Metodologias do ensino}

o poder do professor na sala de aula, considerando-se que dele dependia a escolha do livro a ser lido pelos alunos e as formas como seria utilizado, obrigou os autores a travarem um diálogo com seu interlocutor mais autorizado por intermédio de "introduções", "prefácios" (prefação), "advertências" que, invariavelmente iniciavam o livro didático. Tais discursos introdutórios, ao lado do próprio "conteúdo explícito" dos capítulos do livro escolar, indicaram as diferentes concepções dos autores sobre o conhecimento escolar e sobre as metodologias a serem utilizadas no processo de aprendizagem.

Joaquim Manuel de Macedo na Introdução de Mulheres Célebres destacou que o"livro não passa de instrumento confiado à capacidade, ao zelo e a honra do professor ou do 
mestre(.) Não há livro que desempenhe o seu fim nas escolas, se lhe falta o socorro do mestre, a quem cumpre trazer à luz, explicar e desenvolver os preceitos e as doutrinas que ele encerra.

o mestre completa e vivifica o livro." 45

E foi enfático quanto ao papel do professor na opção por um método de ensino que pudesse tornar o livro um objeto inteligente, secundário ou nulo na aprendizagem:

"Mas especialmente nas escolas de instrução primária o professor é a alma do livro, e não há método que aproveite, se o professor não the dá vida, aplicando-o com paciência e consciência do ensino." 46

A concepção de que o livro só criava vida pela intervenção do mestre ou do professor foi, aparentemente, constante entre os autores, embora poucos explicitassem esta concepção diretamente ao professor, como o fêz Joaquim Manuel de Macedo.

o cônego Roquette após explanar sobre os vários métodos de alfabetização, o "individual", "simultâneo" e "mútuo", concluiu que cada um deles possuía suas vantagens e inconvenientes e que " o melhor método é um professor hábil e zeloso dos seus deveres...." 47

Os autores acreditavam no domínio do livro, com seu texto impresso, mas estavam cientes do poder da oralidade e da intervenção do professor. Nesse sentido, os autores de livros didáticos procuraram estabelecer uma certa cumplicidade dos professores na divulgação e aperfeiçoamento do seu trabalho, embora exprimissem, sem dubiedades, que falavam de um lugar superior à maioria do corpo docente. Possuíam a autoridade dos colégios oficiais de maior reputação, conheciam obras estrangeiras e estas eram citadas quase sempre para legitimar suas opções metodológicas e como fontes, mas também para distinguir sua prática dos demais professores.

45 MACEDO, Joaquim Manuel de- Mulheres celebres. op. cit., p. 19

46 MACEDO, Joaquim Manuel de- Liçōes de história do Brasil..-op. cit. , p. 2

47 ROQUETTE, I.J.- Alfabeto português...-op. cit., p. 7 
Abilio Cesar Borges e Joaquim Maria de Lacerda, citando alguns autores, assinavam seus prefácios em Paris e esta informação era fornecida aos professores para demonstrar o lugar que ocupavam na hierarquia educacional, como intelectuais diferenciados e com maior gabarito.

poucos escritores dedicaram suas obras aos professores, mas a interlocução entre ambos aumentava depois da aceitação da obra pelas autoridades oficiais. A partir da segunda edição passava a existir uma espécie de diálogo com seu público consumidor, chegando os autores a solicitar aos professores que encaminhassem sugestões para futuras correções, alguns aperfeiçoamentos, além de pedir que. apontassem os erros de impressão muito comuns e alvo de críticas. Os autores tinham consciência de que o livro didático dependia das autoridades mas que também precisavam da aceitação do corpo docente para que a obra alcançasse sucesso.

Joaquim Maria de Lacerda, no prefácio da 2 a edição, afirmou que o acolhimento de seu trabalho pelos professores e diretores de colégios havia sido responsável pelo esgotamento de dez mil exemplares da 1 ạ edição do seu livro de História para as classes elementares.48

A preferência dos professores havia sido de fundamental importância para a impressão da $6 \underline{a}$ edição da Gramática de Abilio Cesar Borges segundo ele próprio escreveu: "Mas a esse epítome destinado unicamente aos meus alunos, bafejou-o a consideração de muitos professores, que foram honrando com admiti-1o em suas aulas; e tal procura foi logo tendo, que cinco edições se esgotaram rapidamente umas após outras." 49

o professor era visto pelos autores como responsável pelo sucesso da obra mas foi sempre considerado como alguém que deveria ser ensinado pelos livros que compunham. o livro didático explicitava o conteúdo da disciplina e era, ao

48 LACERDA, J. M.- Pequena hist...- op. cit. O Prefácio é da 2 edição de 1880 e mantida em todas as demais ediçōes.

49 BORGES, Abilio Cesar Borges- Resumo da gramática portuguesa. s. d., [s. n. ], P. I 


\section{PRIMEIRO LIVRO}
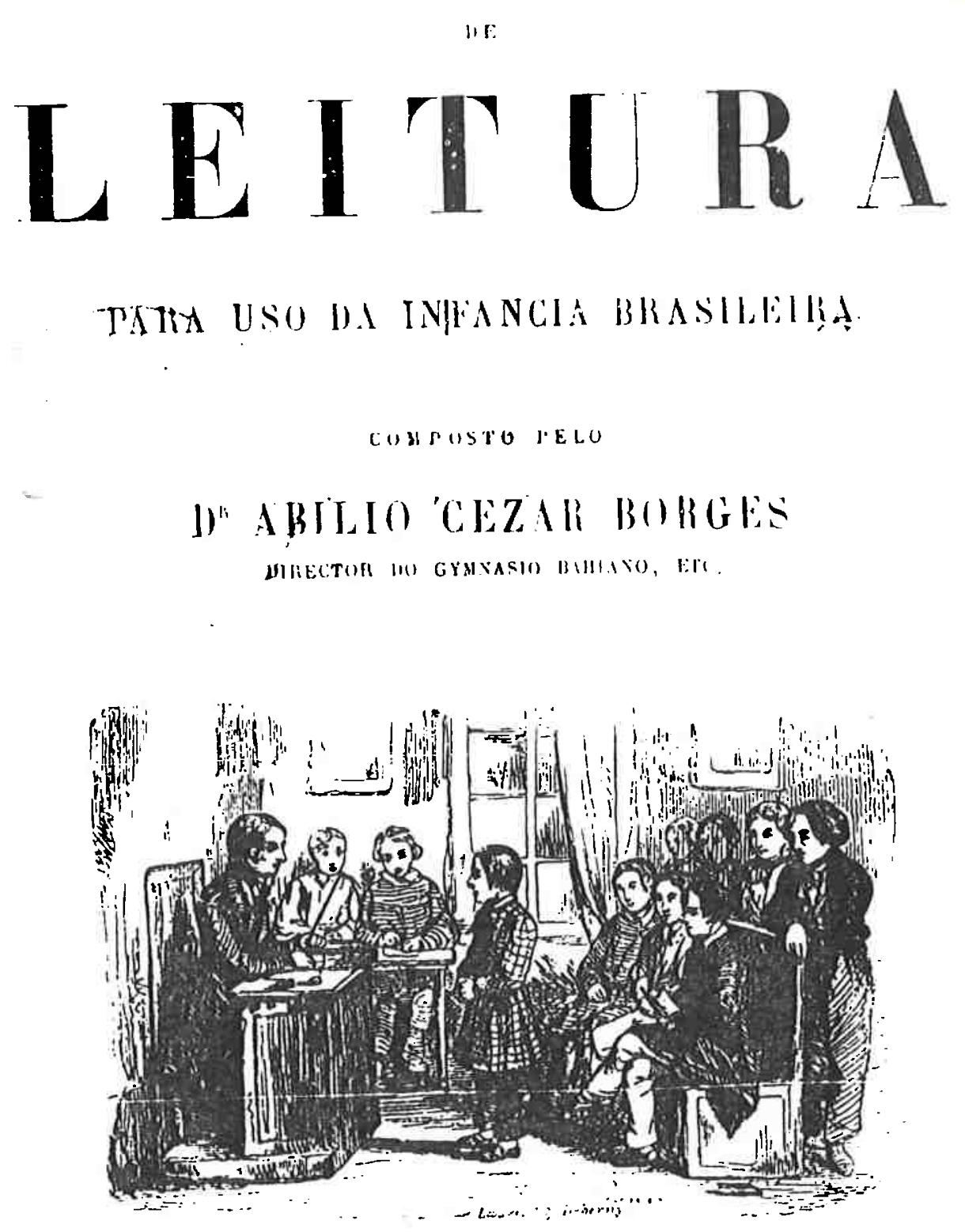

\section{PARIS}

LIYRARIA DE VVi J. P. ALLLALD, GULLLARDEし 4i, NUA SAINT-ANDIL-HFS-ARTS

$1 \overline{867}$

Fig. 19

Primeiro livro de leitura Página de rosto. Bibl. Nat. de Paris. 
mesmo tempo, o instrumento pelo qual o professor aprendia o método de ensino a ser utilizado em sala de aula.

A prescrição do uso do livro em sala de aula foi, em situações extremas, apresentada nos mínimos detalhes. Menezes Vieira era especialista nas especificações de cada etapa de leitura:

"Um exercício oral - amigável e animada palestraentre o educador e os educandos deve começar o trabalho letivo diário, que constará de:

$1^{\circ}$ transcrição no quadro preto, no caderno e na lousa de todas as palavras ou frases indicadas;

$2^{\circ}$ silabação ora individual, ora coletivamente;

$3^{\circ}$ explicação e interrogação quanto ao sentido das palavras, exigindo as respostas em proposições completas;

$4^{\circ}$ questōes gramaticais relativas ao objeto da 1 ição, reaviviando constantemente os conhecimentos adquiridos;

$5^{\circ}$ silabação de cor;

$6^{\circ}$ trabalho oral ou escrito, conforme a rubrica de cada exercício;

$7^{\circ}$ lição indireta de gramática por meio do livro de leitura." 50

o livro, em cada lição, ensinava, passo à passo, o momento em que o professor deveria escrever na lousa, o momento em que o aluno poderia ler, escrever ou repetir a Iição.

A intervenção dos autores sobre o processo de aprendizagem e uso do livro pelos professores, evoluiu para a confeç̧ão dos "livros do professor" que eram distribuídos junto com o livro do aluno, forma de garantir inclusive que os exercícios escolares fossem realizados corretamente e conforme o pensamento do autor. 51

o diálogo dos autores com os professores pode ser entendido, assim, mais como um monólogo em que o autor

50 VIEIRA, M.- Noçōes de gramática. Rio de Janeiro: Tipografia do Colégio Menezes Vieira, 1881, p. 4

51 o livro do professor foi introduzido sistematicamente nas coleçōes da F.T.D. conforme demonstra o catalogo da Nova Coleção de Livros Clássicos de 1909. 
buscava impedir formas diferenciadas e criativas de trabalhar com o texto que haviam produzido.

Nesse "diálogo", alguns autores apontavam as dificuldades na confecção das obras, situando duas questões principais.

* primeira delas era a idade de seus leitores e pudemos acompanhar a construção, cada vez mais delimitada, das classes escolares, divididas em séries com idades demarcadas:

"(..) este livro é particularmente dedicado à infância das escolas elementares, às crianças entre nove e treze anos". 52

Os maiores cuidados e dificuldades dos autores estavam reservados para esta faixa etária: "obrinha escrita com clareza, e de alguma maneira adaptada à capacidade das crianças" 53

"A obrinha que ora publico, bem pouco importante na aparência, e despida de qualquer pretenção literária, tem entretanto para mim bastante valor, já por parecer que vai satisfazer a um instante, e talvez até hoje mal compreendida necessidade da instrução da infância em nossa terra, já pelo grande trabalho que me deu sua composição." 54

Uma segunda questão centrava-se na confecção dos compêndios. No caso dos livros destinados a alunos a partir de treze anos, os autores tiveram por hábito expor as dificuldades do trabalho de "compendiar".

Os geógrafos: "Compendiar um manual de Geografia Universal não é tarefa azada. Em tal assunto, tratando-se da ciệncia de observação, verdade é que sobejam modelos. A dificuldade consiste em recorrer aos melhores e em cingir-se aos dados mais modernos, visto como, mormente nos

52 DE AMICIS- Coraçāo. trad. João Ribeiro. Rio de Janeiro: Livraria Clássica de Alves \& Cia., 1891. Advertência.

53 LACERDA, J M. DE- op. cit. Prefácio, p. I

54 BORGES, AbIlio Cesar- Segundo livro de leitura- Paris, Aillaud, 1867. A Introduçāo e particularmente oferecida aos "Senhores professores e professoras", acrescentando que conviria que fosse lida. 
nossostempos, a política militante dos diversos povos está constantemente a modificar o mapa-mundi." 55

"A obra que damos hoje à estampa, diminuta como é, deu-nos muito mais trabalho, que daria uma outra, sobre o mesmo assunto, redigida em mais larga escala.

Resumir, e resumir bem no meio do imenso material, que nos cercava, já era uma grande dificuldade; apropriar o resumo à juvenil inteligência para quem era destinado, parecia-nos além das nossas forças." 56

Os matemáticos: "Não é sem grande constrangimento que novamente apresentamos em público o fruto de incessantes vigílias; só a ambição de algum serviço podermos prestar à instrução da mocidade e a condescendência do benévolo leitor seriam capazes de fazer com que ainda uma vez apresentássemos ao ilustrado público um trabalho a respeito de tão difícil quanto importante matéria." 57

A transposição de um saber erudito para o livro escolar foi, portanto, uma das dificuldades fundamentais enfrentadas pelos autores e estes faziam questão de expo-la para seus leitores:

"(-) os tratados sistemáticos e especiais, cujo número aliás cresce diariamente, não podendo servir senão para aqueles que se destinam a profundos estudos sobre essas vastíssimas ciências, não satisfazem de forma alguma as necessidades da maioria da população.

A física e a química presidem hoje o destino das artes e da civilização. Por conseguinte, não podem continuar a ser partilha exclusiva dos sábios.

Para esses abundam, em todas as línguas, tratados especiais e completos. Não é, portanto, para eles que escrevemos, mas unicamente para os que precisam das noções gerais.

Recorrendo, pois, a esses tratados especiais e aos documentos mais recentes e exatos, foi nossa tarefa

55 NERY, Raimundo- Noçōes gerais de geografia universal. Paris: Guillard, Aillaud \& Cia., s.d., Ao Leitor.

56 PEREIRA, Jerônimo. Sodré - Compêndio de geografia elementar especialmente do Brasil. Bahia: Lopes da Silva.,1884. Pr6logo

57 AVILA, José Joaquim- Elementos de algebra. Rio de Janeiro. B.L. Garnier, 1857. Ao Leitor 
simplesmente resumir e simplificar as noções que mais importa vulgarizar, procurando, embora, em proporçōes mui reduzidas, conservá-las ao nível dos conhecimentos atuais." 58 Nesses "diálogos", os autores reconheciam-se como os divulgadores, como intermediários entre o conhecimento científico reelaborado e o conhecimento "simplificado" a ser transmitido à população. Identificavam-se como os elementos que se encarregaram de disseminar o saber:

"Como esta obra foi feita para ser entendida não só por pessoas que possuem conhecimentos de Geometria, mas ainda para aqueles que nas aulas de desenho, e Pintura, contentando-se com as únicas configuraçōes, não se aplicam àquela ciência; por esta razão emprego os termos que mais familiares são a estes últimos.(.) Evito igualmente os termos empolados, $e$ frases sublimes, porque estas não são próprias de uma obra didatica, e que deve chegar ao conhecimento de todos." 59

3.2 A imagem do professor e da escola nas obras didáticas

Os textos escolares insistiram sobre o poder do estudo formal fornecido pela escola e sobre a importância do saber letrado. A imagem da escola e de professor construída pelos livros de leitura visava mostrar a importância e a dignidade da instrução.

A instrução formal era visualizada pela figura do professor e do livro.

Os livros dos primeiros anos escolares eram repletos de contos, narrações e poesias, sobre os professores. As imagens dos professores eram apresentadas por ilustrações em seu trabalho diário, com postura de dedicação e sobriedade.

A necessidade do estudo como uma realização individual e como necessidade social foi tema comum encontrado nos livros de leitura para as classes elementares. O livro Coração, do italiano De Amicis pode ser considerado um

58 GAMA, Ayres de Albuquerque- Noções de fisica e química. Rio de Janeiro. Eduardo \& Benrique Læmmert, 1876. Proêmio.

59 SILVA, Roberto Ferreira- Elementos de desenho e pintura.- op. cit., . Advertência, p.9 
perfeito exemplar desse ideário. Nele encontramos histórias sobre o cotidiano da escola e dos professores. O livro obedecia aos ditames da literatura escolar da época, criando como personagem central um menino, Henrique, e relata o quotidiano de um aluno no decorrer de um ano escolar. Além da vida familiar, o livro focaliza os professores e sua atuação diária. Um dos episódios refere-se à visita que o pai de Henrique faz a um seu antigo mestre, já velho e aposentado, como gesto de reconhecimento e agradecimento pela instrução que outrora recebera. 60

o professor, nesta e em outras obras, era mostrado como uma pessoa devotada a uma causa maior -a instrução- e que deveria ter uma vida pobre, sem preocupações com recompensas materiais, trabalhando pelo prazer de ter instruido muitas gerações de pessoas que se tornaram importantes. Nesta perspectiva, havia histórias dos grandes mestres que ensinaram reis e sábios:

"O imperador romano Teodosio, persuadido das vantagens imensas de uma boa educação, pediu ao papa Damasio lhe escolhesse uma pessoa digna a quem pudesse confiar a educação de seu filho Arcadio. o papa lançou os olhos em Arsenio, diácono da Igreja Romana, de cujas virtudes e saber estava bem inteirado." 61

"Quem procurou Filipe da Macedônia para dar as primeiras lições a seu filho, que foi depois Alexandre o Grande?

o primeiro sábio da época, Aristóteles; " 62

Os livros de leitura eram permeados de capítulos sugerindo atitudes de respeito e confiabilidade no mestre. "Das obrigações dos meninos para com as pessoas encarregadas de educá-1os" 63 e "Terceira lição- Deveres para com os mestres"64 são alguns dos títulos sugestivos encontrados. Eram textos que explicitavam a visão do trabalho desse

60 cf. O mestre de meu pai. In DE AMICIS- op. cit., pp.221 a 233

61 LACERDA, J.M. de- Tesouro da infância.m-op. cit., p. 73

62 BORGES, Abilio C.- Segundo livro de leitura.- op. cit., p. XI (Introdução)

63 LACERDA, J.M.- Tesouro da infância-op. cit., p. 66-67

64 SCROSOPPI, H.- Instrução moral. São Paulo: Tipografia King, 1892, pp. 13-14 


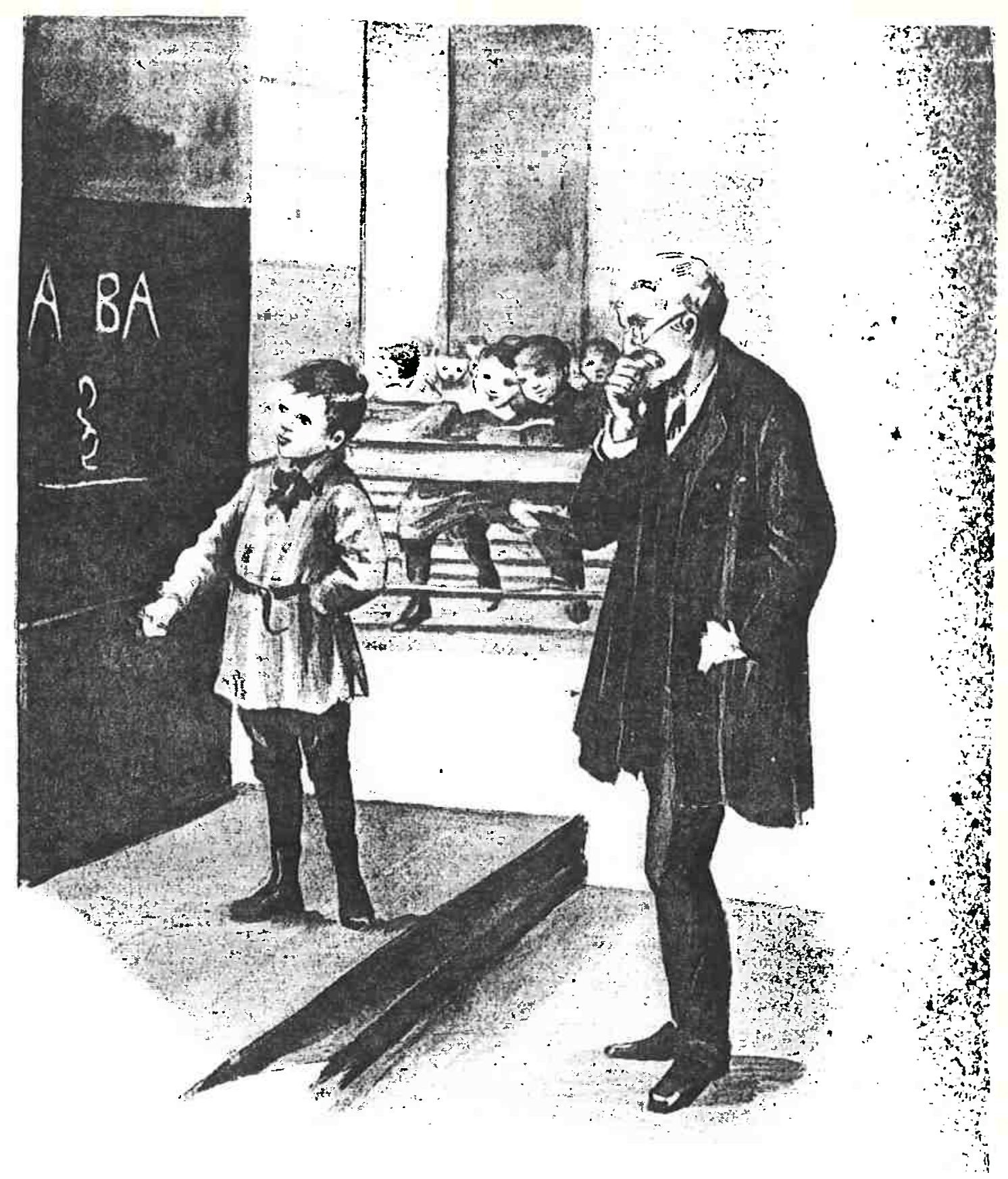

Fig. 20

Livro das donas e donzelas. Julia Lopes de Almeida, llustração de Jeanne Mathieu. 1906, p.192. Bibl. "Macedo Soares", Feusp. 
intelectual e sua missão social. Criaram e reforçaram a idéia do poder e da força da palavra do professor: "Além do amor, respeito e gratidão que deves a teus mestres, cumprete ainda mostrar suma docilidade aos seus conselhos e instruções: eles são teus guias; suas luzes excedem as tuas; deves portanto deixar-te governar por eles e antepor seus ditames às tuas próprias idéias. Os discípulos de Pitágoras respeitavam as suas palavras como oráculos, e quando alguém queria opor-se às suas máximas, só davam esta resposta: "Maqister dixit: o mestre o disse". 65

o poder do professor residia em seu saber que deveria ser respeitado e mesmo diante da punição, esta deveria ser entendida como um benefício. Como o pai castigava os filhos para colocá-1os no caminho do bem, assim deveriam ser compreendidos os castigos nas escolas.

"sim, amado rimoteo, persuade-te que a severidade de teus preceptores não tem outra origem que o zelo com que velam por teus interesses. Não se irritam contra $t i$, mas sim contra os teus defeitos; desejam prevenir os danos e males que essa má semente pode causar-te no futuro, se chega a arraigar-se em tua alma."66

o discurso expresso em alguns livros do inicío do século, começou a divulgar a ideologia da ação educativa do professor em sala de aula como uma prática sem conotação política, devendo o educador assumir uma atitude neutra e objetiva diante dos alunos. A educação liberal era definida sob este princípio:

"De outro lado, e apenas é preciso formular esta prescrição, o mestre evitará como uma má ação tudo o que, em sua linguagem ou em sua atitude, ofenderia as crenças religiosas dos meninos confiados a seus cuidados, tudo o que denunciaria da sua parte, em relação a qualquer opinião, uma falta de respeito, de tolerância, ou de prudência.

A única obrigação a que está sujeito, e ela é compatível com o respeito a toda as crenças, é zelar duma maneira prática e paternal sobre o desenvolvimento moral de

65 LACERDA, J.M.- Tegouro da infância- op. cit., 73

66 Idem- op. cit., p.71 
seus discípulos, com a mesma solicitude que pōe em seguir seus progressos escolares. Não se deve julgar desobrigado para com qualquer deles se não fizer tanto pela educação do caráter como pela inteligência. Só assim o professor terá merecido o título de educador e a instrução primária, o nome de educaçāo liberal." 67

Também encontramos textos nos quais era recomendado que o professor deveria ensinar a "verdadeira religião", incluindo a versão bíblica sobre a origem do homem e da Terra, assim como todo o processo de alfabetização deveria ser permeado da "palavra divina".

Ao lado da figura do professor ideal, os alunos também eram personagens importantes dos textos escolares. o incentivo ao estudo era mostrado sob duas formas, confrontando-se o bem com o mal. Havia histórias sobre alunos que cabulavam aulas e acabavam sofrendo sempre algum tipo de castigo ou então havia histórias exemplares dos "bons alunos". Em tais obras morais não faltaram conselhos, como os referenciados acima, sobre os deveres de um "bom" menino, surgindo ao lado de textos um discurso iconográfico eloquente.

o amor à instrução foi sempre mesclado pelo amor ao livro. Em inúmeras lições ou capítulos dos livros escreveuse sobre o respeito que deveria existir em relação ao livro escolar, apresentando-o como um objeto sagrado.

Um bom aluno deveria amar os livros: "Henrique era um menino talentoso, que amava muito seus livros; e estudou com tanto gosto, que chegou a ser um dos primeiros de sua aula." 68

As ilustrações dos manuais didáticos explicitavam a valorização do livro de estudo, símbolo e fonte do saber. Incluia-se neste discurso iconográfico as próprias vinhetas das editoras.

o respeito pelo livro e a confiança que nele deveria ser depositada levaram os autores a incluir capítulos que ensinavam "Como se deve cuidar dos livros". A lição, após

67 SCROSOPPI, H.- Pequenas liçōes de instrução moral- op. cit., p. 9

68 BORGBS, Abilio Cesar-Segundo livro..-op. cit., p. 13 


\section{LIÇÃO DE LEIT'URA.}

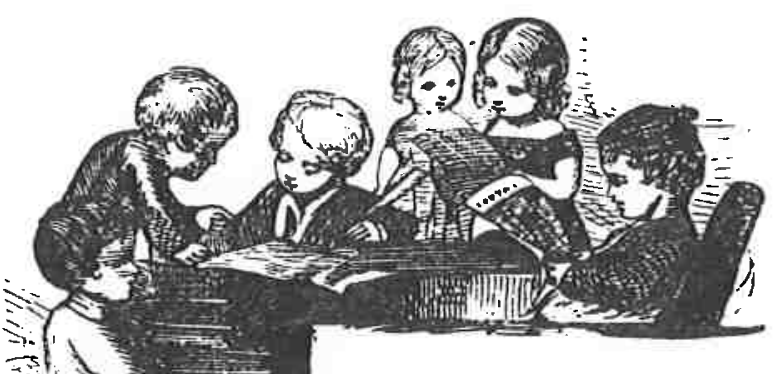

(1.) Não posso ver a Deus, porém Deus póde ver-me.

(2.) Os seus olhos estão sobre mim, assim de noite como de dia.

(3.) Quando estou em casa e fóra d'ella; na escola, e nos meus recreios.

(4.) Elle deu-me`o sentido da vista; e não me verá?

(5.) Deu-me c ouvido; e não poderá ouvir?

(6) Sim, elle póde ouvir o que eu digo, e ver o que faço.

(7.) Deus vê e sabe tudo o que nós pensamos, obramos e dizemos.

(8.) Quero pois obedecer-lhe e viver no seu temor.

Fig. 21

Silabário Português de R. Galvão, p. 23 


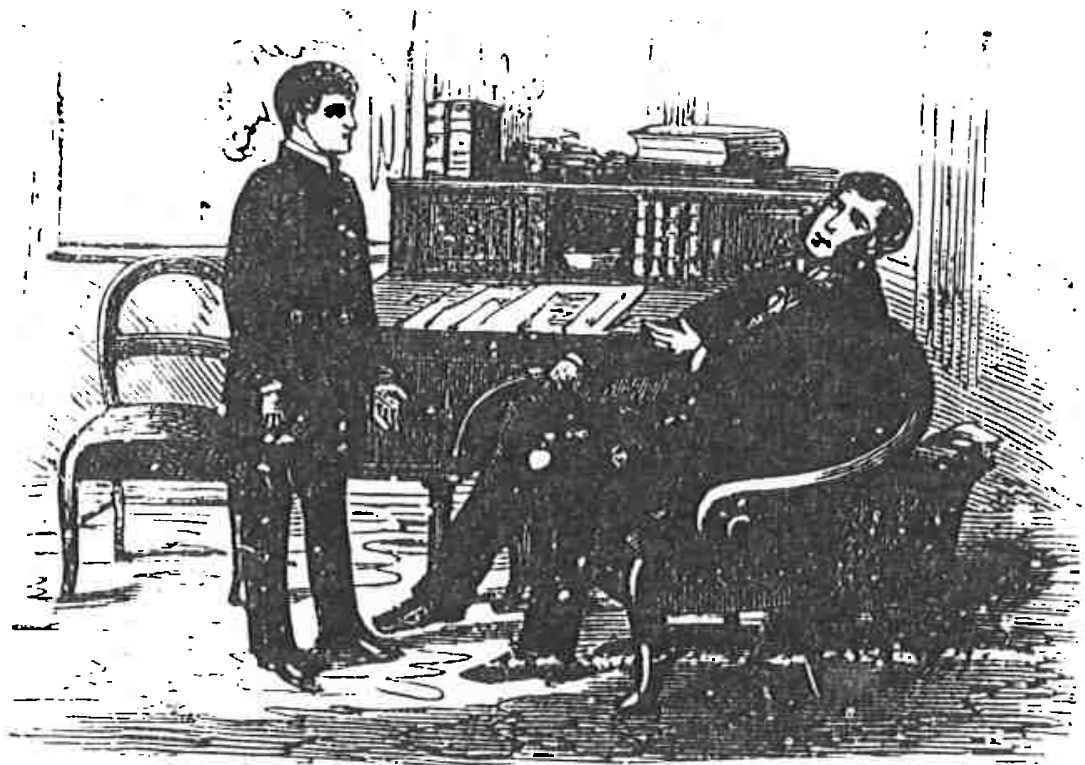

Fig. 22

O filho modelo ou discípulo exemplar. Segundo livro de leitura.

Landelino Rocha, p. 34. Bibl. Nat. de Paris.

\section{LIÇÃO DE LEITURA.}

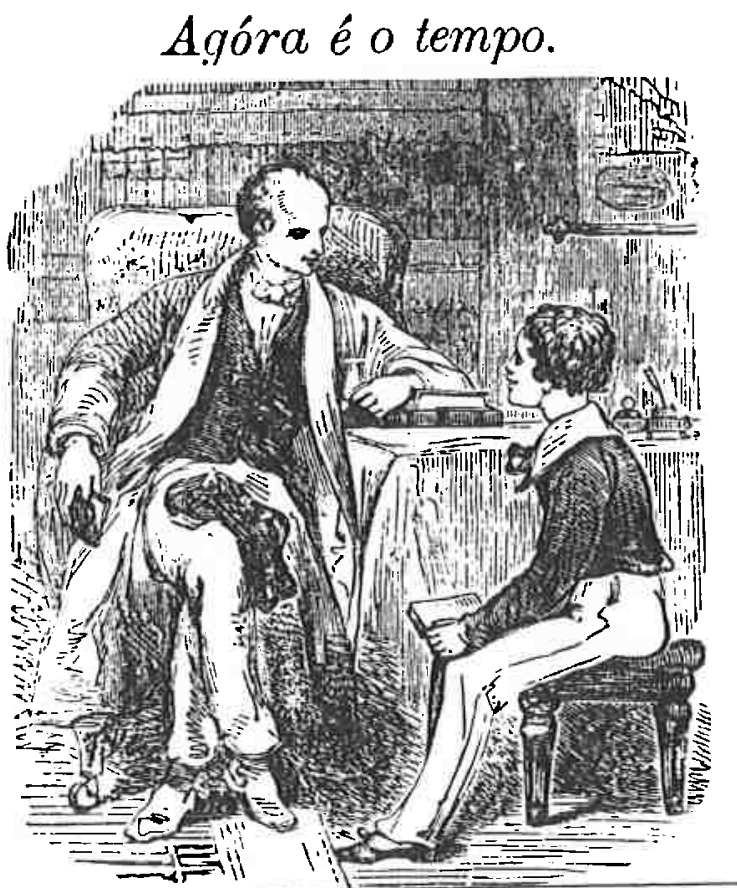

Fig. 23

Os bons alunos. Silabánio português. R. Galvão, p.36 

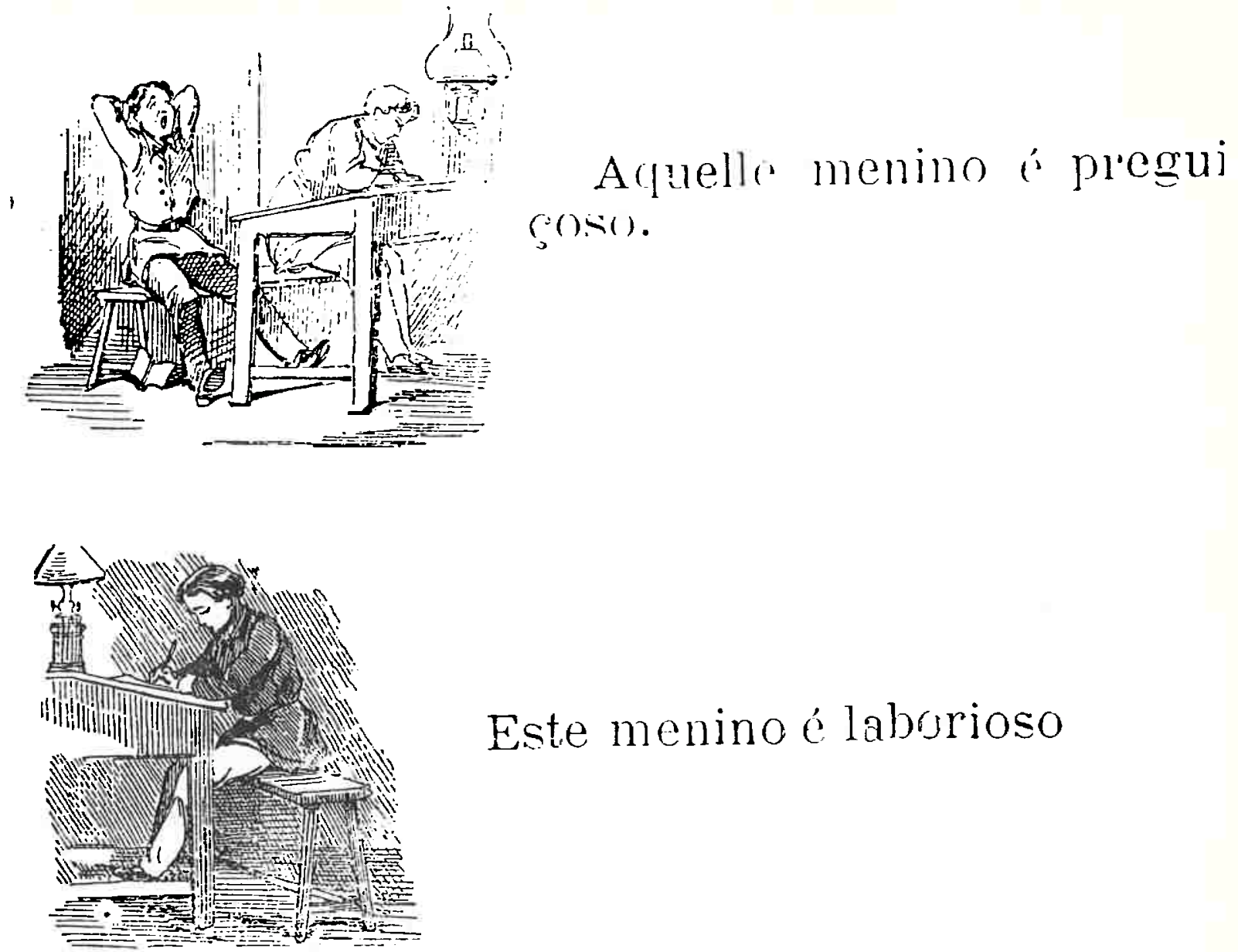

Este menino é labrurioso

intelligente

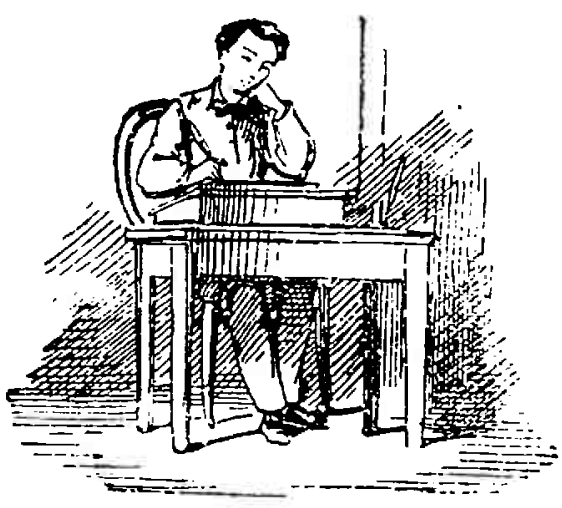

estupido
Fig. 24

Adjetivos. Ensino prático de língua materna. Menezes Vieira.

p. 31 e 45 .

Bibl. "Paulo Bournoul". 
nomear todos os cuidados para não sujar, amassar as páginas e prescrever a forma como o livro deveria ser lido, alertava para os perigos da leitura à noite junto aos candieiros ou velas.

Para os alunos em escolarização mais adiantada eram frequentes textos sobre os métodos de fabricação dos livros ou até sobre a história do livro. Geralmente, estas lições eram acompanhadas de gravuras. 69

os autores empreenderam, desta forma, a tarefa de divulgar e criar, de maneira indelével, junto aos alunos e professores, uma imagem do livro como objeto sagrado e detentor de poder ao mesmo tempo que impuseram uma forma de leitura, uma maneira de estudar e aprender.

o manuseio do texto escolar foi organizado como um ritual, valorizando-o como depositário de um saber exclusivo e redentor. o saber transmitido oralmente perdurava ainda e nos livros encontramos textos que expressavam a necessidade dos jovens ouvirem os mais velhos. Entretanto, a figura do velho como detentor e transmissor do saber foi desaparecendo, cabendo a ele apenas narrar experiências sobre condutas morais ou velhas histórias. A mãe, como educadora, deveria incutir a retidão, cultivar a bondade, o asseio e cuidar para que os filhos estudassem os temas impostos pela escola. o saber "verdadeiro" só seria obtido pela escola, pelo professor e principalmente pelos livros.

Este saber "verdadeiro", entretanto, contido no livro didático correspondeu, ou corresponde até nossos dias, a um processo de transposição didática complexo. Havia o problema da criação de uma linguagem acessível a alunos de idades variadas, jovens e crianças em diferentes níveis de maturidade que exigiam dos adultos escritores simplificações limitadoras de um saber produzido para outras finalidades, criado com certo rigor.

69 Encontramos no livro de Roquette editado pela Lammert, como capitulos finais, Da escrita e Invençāo da tipografia. ROQUETTE, Alfabeto portugues -op. cit., p.154 a $156 . \mathrm{E}$ em um dos mais conhecidos livros de Liçōes das coisas, deparamos com um capitulo sobre Historia do livro. SAFFRAY, Lições de coisas. trad. de Mesquita Portugal. Porto: Livraria Chardron; Rio de Janeiro: Livraria Alves, s.d., p. 252 a 260. 
E, o processo de transposição didática do livro escolar possuía um intermediário que deveria reelaborar o conhecimento contido no texto. O saber escolar para chegar à sala de aula passava por vários caminhos, enfrentando o poder do professor e sua capacidade de comunicação. Os livros escolares contaram com a interferência dos professores em vários níveis, incluindo a experiência didática da sala de aula, entendendo-se porque as autoridades foram obrigadas a preferir os docentes dentre os escritores da literatura escolar.

- livro didático independente da condição do professor, no transcorrer do século XIX, transformou-se em uma ferramenta de trabalho indispensável na sala de aula. 0 aperfeiçoamento técnico na fabricação do livro e a possibilidade de ser consumido por um número cada vez maior de alunos aliados à continuidade de uma precária formação do corpo docente fizeram do livro didático um dos símbolos da cultura escolar, um depositário privilegiado do saber a ser ensinado. 


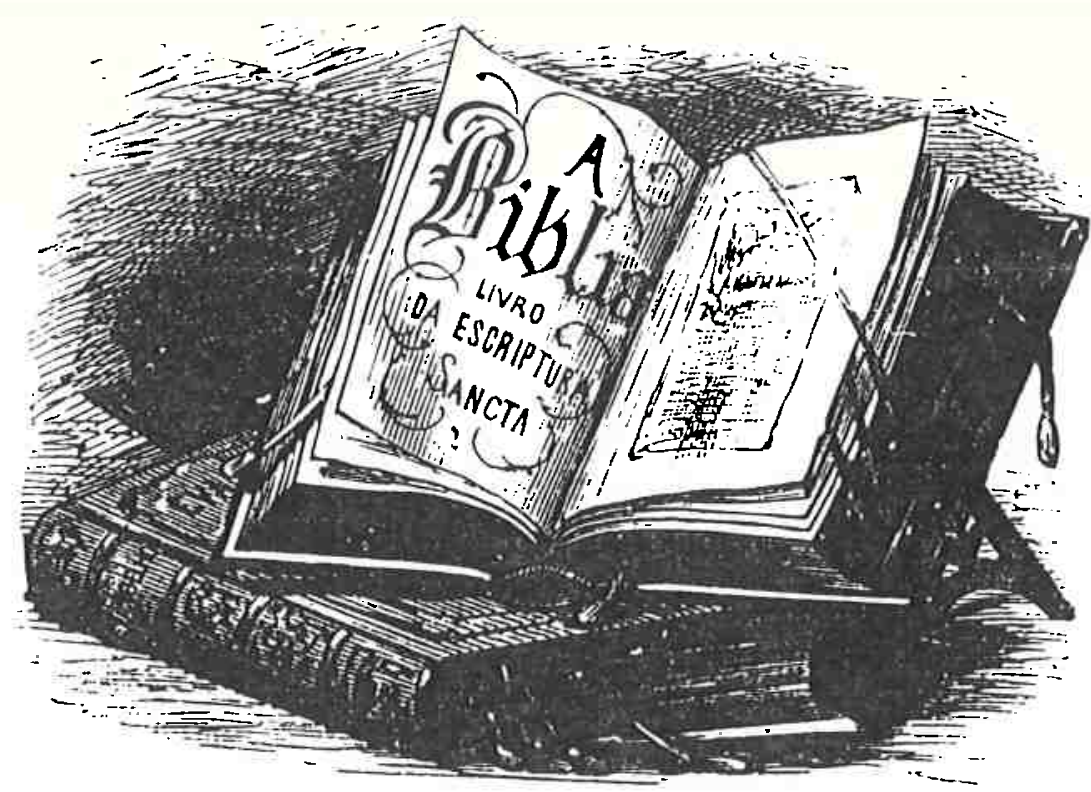

A palarrat biblin quer dizer o limes

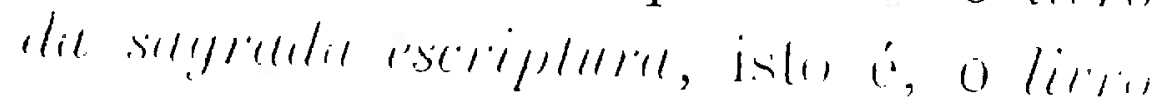

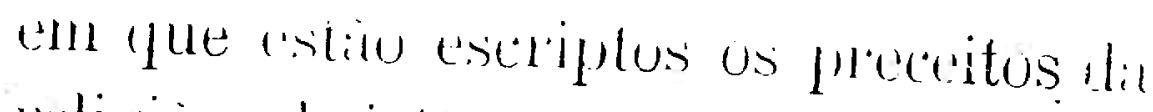

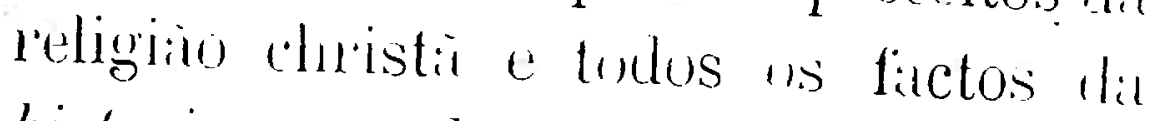
historia sugradu.

Fig. 25

A Bíblia. Segundo livro de leitura. LandelinoRocha, p. 19 Bibl. Nat. de Paris

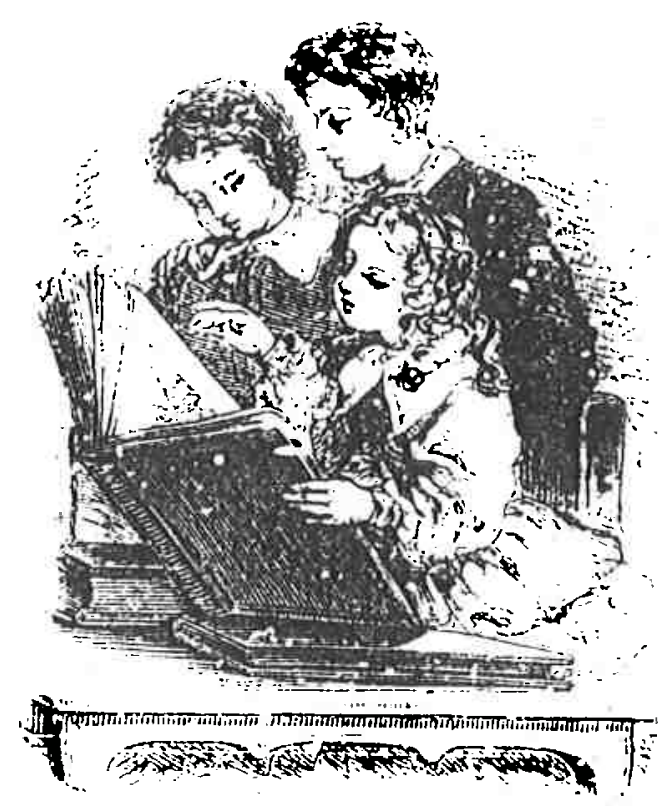

Fig. 26

Segundo livro de leitura de Abilio Cesar Borges.

Capa de rosto. Bibl. Nat. de Paris. 

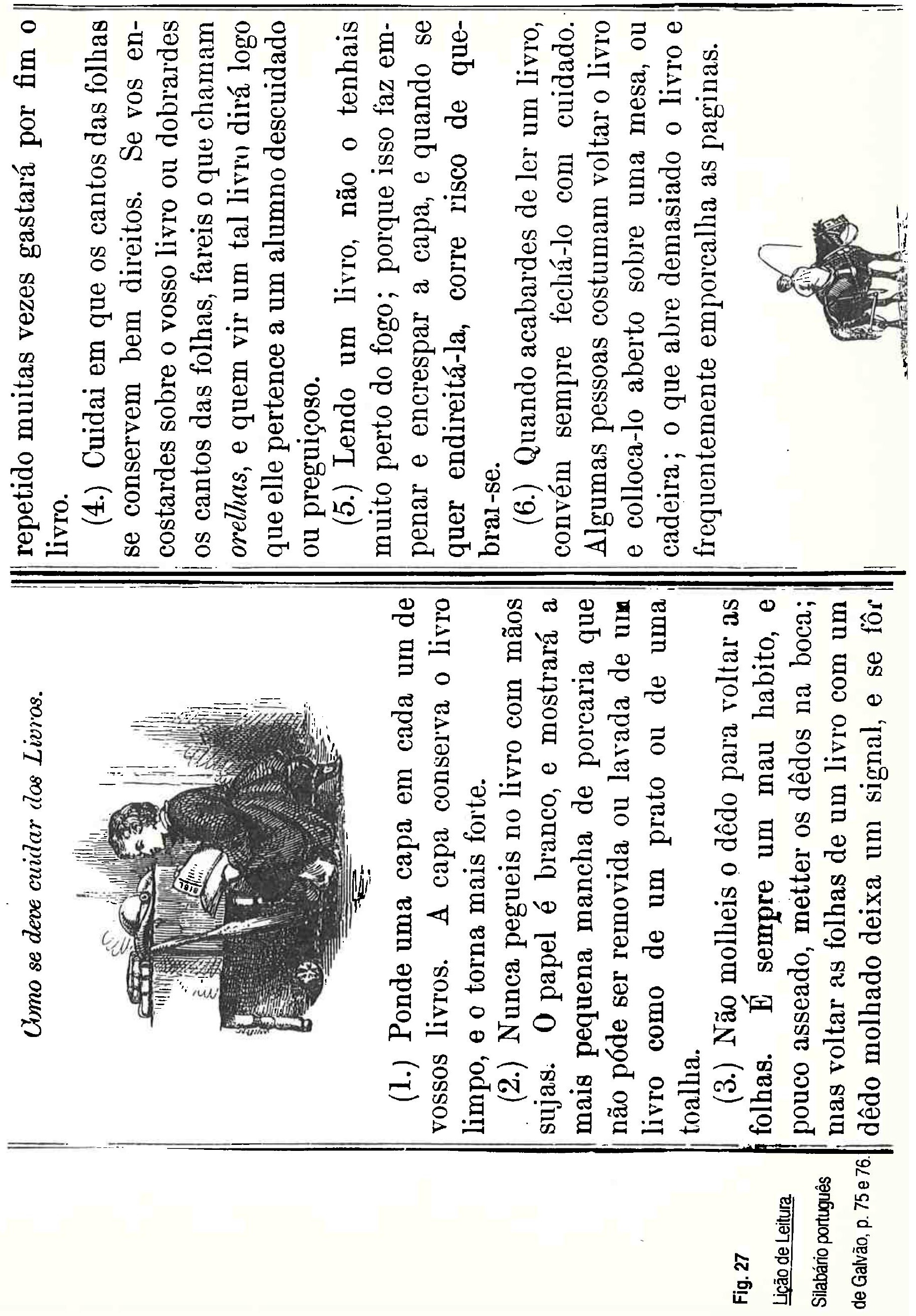


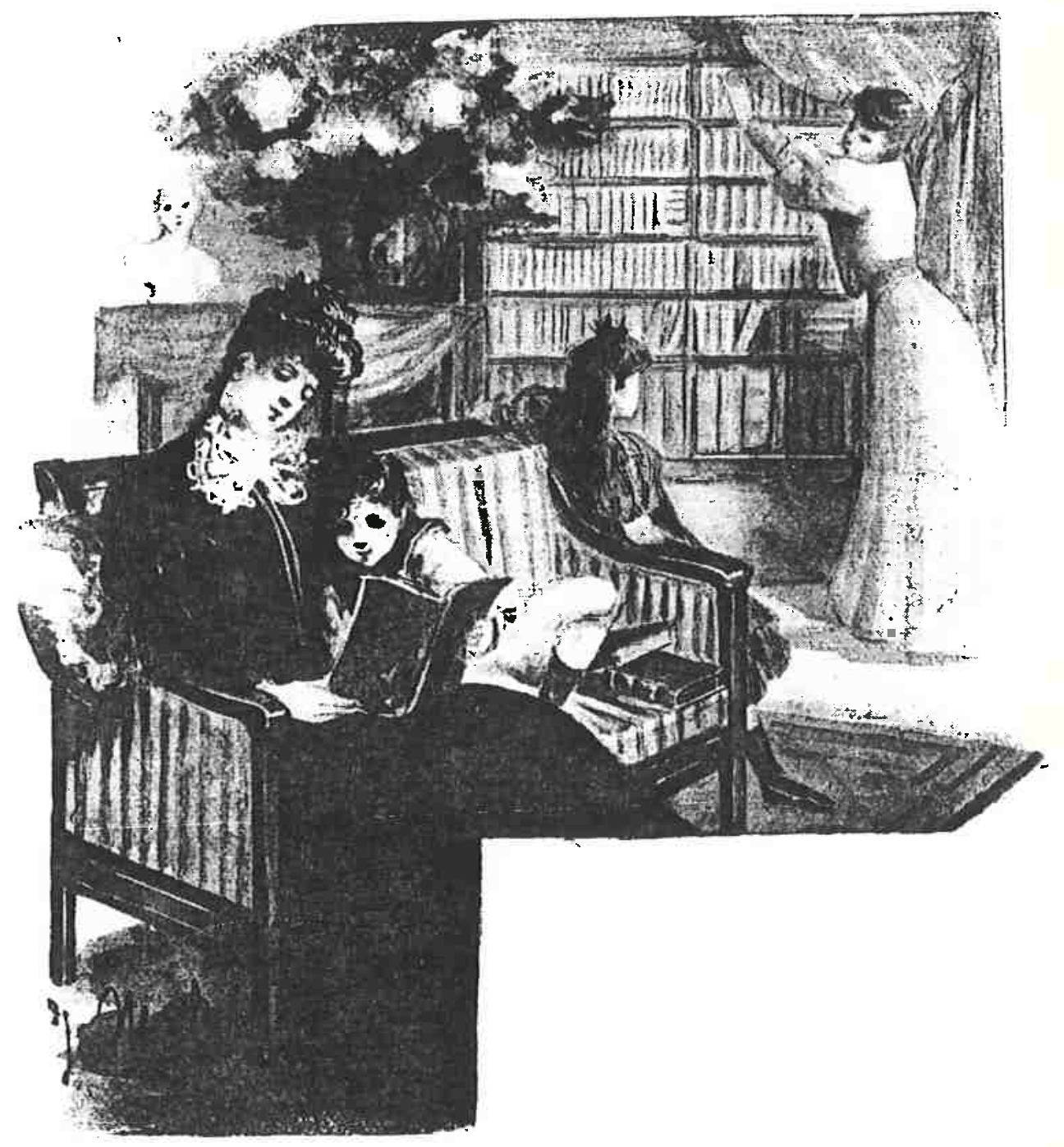

Fig. 28

Empenho matemo. Luvro das donas e donzelas. Julia Lopes de Almeida, p.81 Bibl. "Macedo Soares", Feusp. 


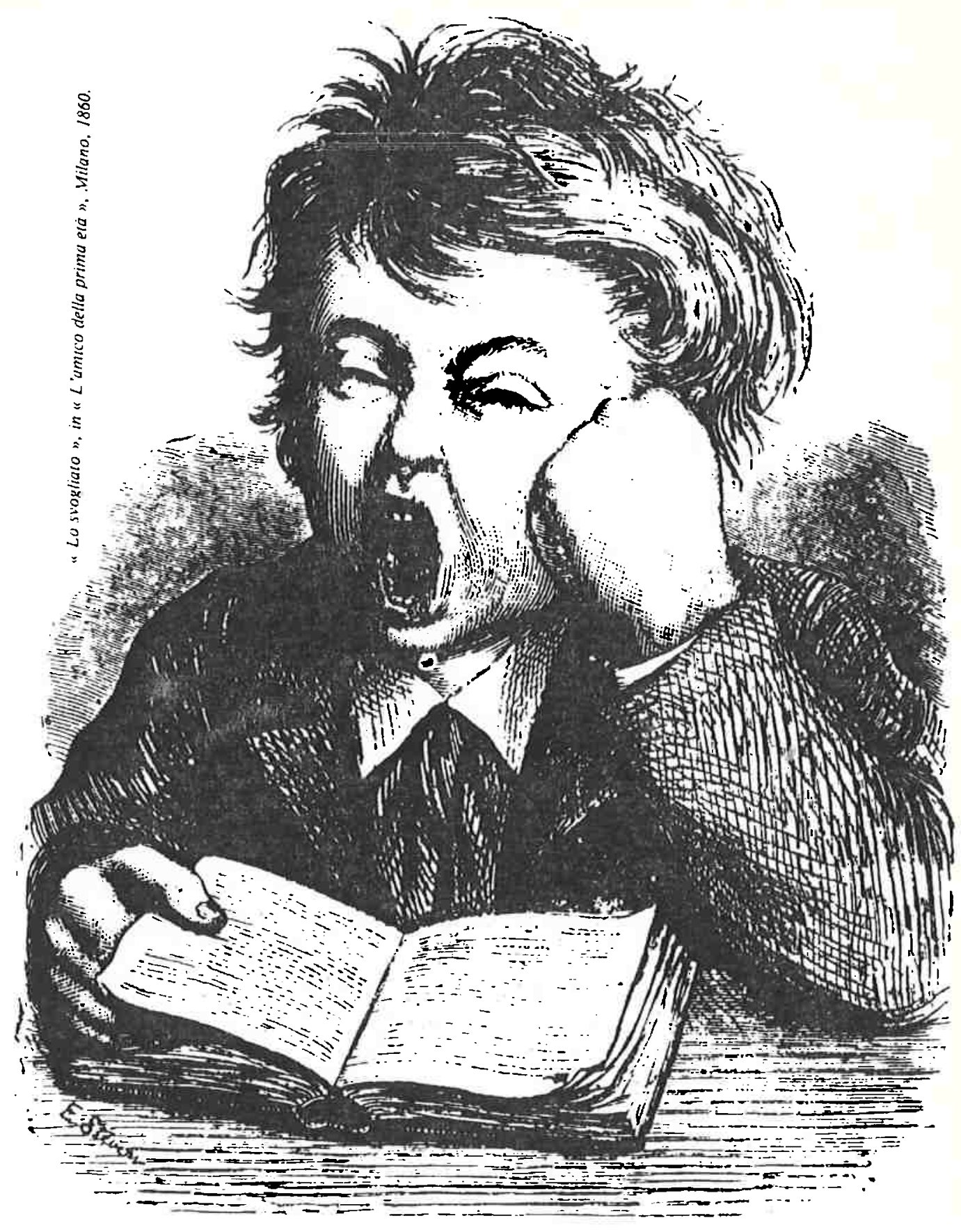

" Graças ao livro, pode cada um aprender inumeráveis coisas; é ele um companheiro que está sempre às nossas ordens e não tem caprichos; é um conversador cujos ditos vêm sempre a propósito. Cada dia, a cada hora podemos consultá-lo, ele nos fala, nos instrui, nos refere fatos, nos conta histórias. Que bela coisa é um livro! Que precioso instrumento, o instrumento do saber!"

Lições das coisas. Dr. Saffray 


\section{LIVROS DIDATICOS MAS SALAS DE AULA}

o poder da palavra impressa era inerente à concepção do livro didático, entendendo-se que o texto lido era um texto integralmente apreendido pelo leitor. Tal concepção, expressa por educadores desde condorcet foi, entretanto, permeada de interrogações por parte daqueles que efetivamente estavam engajados no processo de ensino e aprendizagem. Silvio Romero, em 1890, expressou suas dúvidas quanto ao poder de transmissão e apreensão linear do conhecimento contido nos livros didáticos:

"Eu geral, eu sou contra a confusão deplorável dos que concedem ao livro e à ilustração o poderio excessivo de formar a piedade, o caráter ou mesmo a ciência no homem. (...)

Quando e onde a cartilha fez um cristão?

Quando $e$ onde uma gramática fez um homem falar a lingua?

Quando e onde umas tinturas de direito público formaram um único cidadão?" 1

Estas interrogações nos remeteram à investigação do papel do público leitor na apreensão da leitura, das formas como se apropriava da palavra impressa e das relações que estabelecia com a obra didática. Indagamos inicialmente como articulava-se a recepção do texto proposta pelos autores e editores com o leitor e suas expectativas.

o livro didático, ao transmitir o conhecimento, realizava a socialização da leitura mas tinha igualmente, como tarefa, desenvolver hábitos individuais no leitor. Daí a multiplicidade de textos, cartilhas e catecismos para a aprendizagem da leitura e ou da escrita, compêndios com os conteúdos explicítos das ciências de referências das disciplinas, livros de leitura para formar e ilustrar o leitor. A multiplicidade de textos didáticos não excluía a

1 RIBEIRO, João- Prólogo. In: ROMERo, Silvio- A História do Brasil_op. cit., p. VII 
ação do professor que estabeleceu constante relaçāo entre textualidade e oralidade. o livro didático fez parte de una aprendizagem que envolvia leitura e transmissão oral. 0 livro escolar, isoladamente, não conseguia cumprir seus propósitos.

Ao recuperar as formas de leitura que professores e alunos realizavam com o livro escolar não pudemos nos desviar da peculiaridade de ser um texto criado e planejado para divulgar um conhecimento uniforme mas que, constantemente, foi manuseado por diferentes leitores, oriundos de experiências diversas.

A investigação sobre as práticas de leitura ainda são. esparsas considerando-se que "est grand le répertoire des situations de lecture, du for privé à l'espace public, celui de la salle de cours ou de la bibliothèque du travail solitaire aux maniements colletifs, de la spéculation intellectuele à l'utilisation immédiate. "2

No caso do livro didático, buscamos identificar os leitores na sala de aula, situando professores e alunos diante do livro, no ato de apreensão do texto, entendendo este espaço como um lugar de conflito. Nossas questões situaram-se, fundamentalmente, na abordagem a ser realizada frente a um material controverso que, democraticamente ensina a ler, desvenda os signos , tentando, em princípio, libertar o indivíduo mas que, ao mesmo tempo, condiciona o leitor na pretensão de refrear a própria liberdade que cria.

A situação paradoxal da literatura didática nos levou a buscar um método de pesquisa em que esta tensão pudesse ser apreendida. A principal dúvida refere-se à possibilidade de identificar a diversidade das leituras de professores e alunos e reconhecer as estratégias pelas quais autores e editores tentavam impor uma ortodoxia do texto, uma leitura forçada, porque como afirma Roger chartier, em tais estratégias,"umas são explícitas, recorrendo ao discurso (...) e outras são implicitas, fazendo do texto uma

2 CHARTIER, Roger e MARTIN Henri-Jean (org)- op. cit., p.1.

3 CHARTIER, Roger - A Bistoria cultural -entre práticas e ..., op. cit.., p. 1 
maquinaria que, necessariamente, deve impor uma justa compreensão. Orientado ou colocado numa armadilha, o leitor encontra-se, sempre, inscrito no texto, mas, por seu turno, este inscreve-se diversamente nos seus leitores." 3

Esta parte do trabalho tem como sujeitos principais professores, alunos e o livro escolar como o mediador entre a palavra do mestre e os conhecimentos divulgados pela escola. No resgate das práticas de leitura tivemos a preocupação de contextualizá-las junto aos discursos pedagógigos com o objetivo de ampliar a reflexão sobre o papel do livro no processo de aprendizagem dos alunos.

os vestígios encontrados foram poucos. Relemos os livros didáticos, destacando seus discursos metodológicos, exercícios, questionários, utilizando como referência principal o ensino e a aprendizagem dos manuais escolares de História. Percorremos as ilustrações dos textos didáticos e investigamos a literatura pedagógica, romances e publicações de memorialistas.

\section{Métodos pedagógicos e formas de leitura}

1.1 Exercícios e conceitos de aprendizagem

- livro didático era valioso para o professor porque nele estava depositado o conteúdo a ser transmitido aos alunos. Mas a importância do livro para a efetivação do trabalho do professor residia na metodologia do ensino que ele continha.

- livro didático possuía dois discursos que se integravam. Um texto no qual estavam expostos de maneira sistematizada e simplificada, os conteúdos explicitos da disciplina e um outro, o discurso pedagógico constituído por questionários, resumos, exercícios variados que indicavam como o conhecimento deveria ser apreendido pelos alunos. Os compêndios, mais especificamente, representavam, na íntegra, o saber a ser ensinado e progressivamente foram acrescidos 
de baterias de exercícios para fixação dos conteúdos da disciplina.

Os exercicios tornaram-se um complemento indispensável das obras didáticas e deles, muitas vezes, dependia seu sucesso.

A importância dos exercícios para a viabilização do aprendizado da disciplina foi assim expresso por chervel: 0 sucesso das disciplinas depende fundamentalmente da qualidade dos exercícios susceptíveis de serem realizados. De fato, se denominamos de exercício toda a atividade do aluno observável pelo professor, convem concordar que copiar uma aula ditada, este não se configurará como o melhor dos exercícios. Ao contrário, ocorre com uma redação ou composição, análise gramatical, problema de aritmética que incitam criatividade, espontaneidade ou espírito de rigor nas deduçōes ou na aplicação de regras. Os exercícios poden, portanto ser classificados dentro de escala qualitativa." 4

Para a análise de exercícios e métodos de ensino, recorremos novamente aos livros de História para acompanhar a evolução metodológica do ensino dessa disciplina, destacando o percurso da pedagogia durante o período estudado.

o livro de História do Brasil de Abreu e Lima e o de João Ribeiro não diferiam apenas pelo conteúdo mas também pela forma como os conteúdos estavam organizados e distribuídos. A concepção de aprendizagem pode ser percebida implícita ou explicitamente, dependendo do diálogo que o autor estabeleceu com os professores nas introduções e prólogos. A omissão de propostas metodológicas, como ocorre com o texto de Abreu e Lima, pode ser entendida como a manutenção de una forma de aprendizado onde o aluno deveria limitar-se a "decorar" o conteúdo exposto.

A ampla aceitação dos Iivros de Joaquim Manuel de Macedo não foi casual. No "Prefação" de sua mais importante obra, Liçōes de História do Brasil, Macedo explicitou o método a ser utilizado pelo professor, indicando como cada

4 CHeRVEL, André_ - Historia das disciplinas escolares: reflexōes sobre um campo de pesquisa. Teoria \& educaçāo. Porto Alegre, $n^{\circ} 2,1990$ [abril de 1991], p. 107-118. 
uma das partes do texto deveria ser apresentada aos alunos. A cada lição seguiam-se as explicações e " depois de bem compreendida assim a lição, as perquntas destacadas pōem em proveitoso tributo a atenção e a reflexão dos meninos, e enfim o quadro sinótico que eles devem reproduzir de cor na pedra ou no papel, gravando na memória toda a matéria estudada. Quer nos parecer que da aplicação deste método se podem colher em pouco tempo importantes resultados." 50 tratamento metodológico pioneiro em uma obra didática de Historia foi, ao que parece, o mais aceito pelos professores, sendo este "Prefação" da 1 a edição reproduzido até sua última impressão, em 1924.

Para as escolas primárias, os livros de Historia caracterizaram-se pela utilização e adaptação do método catequético, com "perguntas e respostas", método que teve prosseguimento no decorrer do século $\mathrm{XX}$ nos livros da editora F.T.D.

A questão maior dos livros de História residia no emprego de uma linguagem adequada à capacidade infantil. Os autores insistiam na dificuldade de expor a História "oficial" para crianças, tendo, geralmente, convicção de que estas iriam decorar o texto sem nada compreender. Tais dificuldades de linguagem associavam-se às dúvidas sobre a necessidade do ensino de História para a escola elementar:

"Penso que não são as aulas primárias onde se deva aprender a história pátria; pois que à infância que as frequenta falta o necessario desenvolvimento intelectual par bem apreciar as causas donde dimanaram os principais acontecimentos, nem tão pouco pode investigar a verdade no meio de diversas e muitas vezes contrárias opinióes dos historiadores." 6

As reticências dos autores sobre o ensino da História Pátria para a escola primária durante os anos 60 e 70 do século passado foram desaparecendo com o desenvolvimento do ideário "nacionalista". Nos anos oitenta, a preocupação residia na incorporação dos avanços pedagógicos ao texto

5 MACEDO, Joaquim M. de- Liçōes de história - op. cit., p. 2

6 PINABIRo, J. C. Fernandes-Episodios_-op. cit.,p. vI 
escolar. Os autores procuravam entender os "métodos intuitivos" e adequar uma linguagem capaz de atrair os alunos, de despertar interesse. A infância e a adolescência começavam a ser objeto de observação e a psicologia avançava seus estudos nessa direção. Começava a valorização da infância como uma idade privilegiada da existência, devendose investir no processo educacional para garantias de sucessos futuros. Compunha-se com nitidez a idéia de idades e acentuavam-se as diferenças quanto às leituras.

Até o século XIX, era comum encontrar nas salas de aulas alunos de idades variadas. O auditório escolar comportava jovens e crianças e podia um adulto "ouvir a leitura de Donat no mesmo momento em que um menino precoce repetia o Organon: não havia nisso nada de estranho". 7 Esta situação, comum nas escolas dos séculos anteriores, tendeu a desaparecer, como vimos, e cada vez mais os livros didáticos passaram a desempenhar o papel de diferenciador das leituras e de leitores. Era necessário motivar os leitores, respeitando sua linguagem e seus interesses. A escola e os livros foram os principais responsáveis pela identificação das idades, estabelecendo separações nítidas entre crianças e jovens.

Para as classes infantis, crianças até 10 anos aproximadamente, a fórmula encontrada que pareceu mais amena para se estudar a História da Pátria foi a de iniciar pela vida e feitos dos heróis, figuras que possivelmente despertariam o interesse das crianças e por narraçōes onde relatava-se curiosidades da vida de personagens famosos ou fictícios.

"Deste modo pode-se reconstituir a pátria pelos patriotas, a história anônima pelo documento autográfico, e sintetizar a espécie pelos exemplares mais nítidos do indivíduo." 8 A justificativa de João Ribeiro para o livro de Sílvio Romero significava a busca de uma História mais concreta, capaz de motivar os alunos, além de possibilitar o

7 ARIES, Philippe- Historia social da criança e da familia.. Trad. Dora Flaksman - 28 ed. Rio de Janeiro: Guanabara, 1986, p 166

8 RIBEIRO, João- Prólogo. In: ROMERO, Silvio- A história do Brasil-op. cit.-p. VI. 
desenvolvimento da aprendizagem por imitação, pelos exemplos de uma conduta digna, à semelhança dos demais autores que entendiam ser esta uma das bases do ensinamento dessa disciplina. João Ribeiro e Silvio Romero tinham, entretanto, outras expectativas em relação à História biográfica. Preocupavam-se pelas etapas que a aprendizagem deveria trilhar: " a biografia na escola primária, onde aliás ela deveria ser a primeira fase do estudo da história, pela simples razão de todas as pedagogias possíveis de que 으 particular deve preceder o geral. " 9

Foi possível perceber que parte dos educadores e autores de livros estava debatendo questões de aprendizagem que persistem até os dias atuais. Buscava-se produzir material didático capaz de situar o aluno em suas diferentes fases de aprendizado, compondo textos que possibilitassem uma passagem do concreto para o abstrato e do particular para o geral.

o estudo de personagens ou das biografias correspondia à fase inicial ou introdutória dos estudos históricos, própria para os primeiros ańos, aprendendo-se mais pelo relato oral do que pela leitura. Dava-se preferência às lições orais, consideradas como um método mais seguro e "mais frutuoso", capaz de despertar mais interesse:

"A lição oral, cheia de animação, de interesse, produz uma impressão mais pronta e sem comparação mais duradoura que as páginas frias e quedas do livro, onde de ordinário tão difícil é às inteligências infantis apanharem o sentido que as palavras como que parecem ocultar-lhes. Os meninos gostam de ouvir histórias, - prestam-lhes toda a atenção e retem-nas facilmente na memória." 10

A dificuldade em estudar História encontrava-se, ao que parece, no ensino do tempo, uma noção abstrata, levando autores a ponderar que "Antes do $4^{\circ}$ ano preliminar dificilmente se poderá dar um ensino metódico de história. $\hat{E}$ aí que o professor pode estabelecer a ligação lógica dos fatos esparsos estudados nos anos anteriores, mostrando sua

9 Idem, ibidem. Grifos do autor.

10 CAvalcanTI, João B. - Relatório.., op. cit., p.194 
filiação histórica, comparando-os, e tirando do emprego deste método o conhecimento da sociedade atual pelo da evolução das sociedades anteriores." 11 Para uma compreensão mais ampla da noção de tempo, criou-se a associação entre tempo cronológico e tempo simultâneo e nos livros, além dos quadros cronológicos que finalizavam os capítulos, começaram a surgir os quadros sincrônicos.

Uma outra solução encontrada para o ensino concreto de História foi a introdução de ilustrações nas obras didáticas, retomando a tradição dos livros de doutrina cristã que, desde o início do século, valorizavam as imagens como meio de fixar as mensagens religiosas.

\subsection{Ilustrações e aprendizagem}

o "mundo das imagens" nos livros didáticos tem sido objeto de poucos estudos entre nós. Existem raros trabalhos sobre as ilustraçōes em livros didáticos atuais que buscam apreender como determinados segmentos sociais têm sido representados. O índio tem sido um dos personagens mais pesquisados, seguido dos negros, mas são trabalhos que não se fixam exatamente nas ilustraçōes e sim no conjunto da obra didática.12 são inexistentes estudos sobre o histórico

11 PUIGGaRI, Romão- História patria.In: a Escola pública, são Paulo, ano $I, n^{\circ}$ III, set. 1896 , p. 193

12 para citar alguns exemplos temos MENEzEs, C.- As representações do índio no livro didatico. In: MUSEU DO INDIO - 30 anos ; 1953-1983. Rio de Janeiro, 1983, p. 51-58. Edição comemorativa. ; ROCHA, E.P. G.Um Indio didático; notas para o estudo de representações. In: ROCHA, E.P. G. e outros. Testemunha ocular. São Paulo: Brasiliense, 1984., p. 13-14; PINTO, R. P. e MYAZAKI, N. - o "indio" nas nossas escolas. são Paulo, F.G.V., 1985. O papel das ilustraçōes nos livros de história têm sido estudado por pesquisadores europeus, recaindo as interpretaçōes sobre os aspectos ideologicos, relacionando o impacto das imagens na fase infantil para a conformação de uma memória historica. Na França, alguns historiadores têm analisado as imagens do livros escolares do século passado e inf́cio do atual, buscando recuperar as diferentes formas de divulgaçāo da historia naquele determinado momento social e politico. Destacam-se, no caso francês, Christian Amalvi e Yves Gaulupeau, este último, com trabalhos onde associa as imagens dos livros didáticos com as de museus e a versão historica construida pelas ilustrações e "quadros históricos". Cf. GAULUPBAU, Yves-L'Histoire en images à l'école primaire. Un exemple: La Revolution française dans les manuels élémentaires(1870-1970). Histoire de l'Éducation. Paris, INRP, $\mathrm{n}^{\circ} 30$, mai 1986 e as já citadas de Amalvi. 
das ilustrações ou sobre as ilustrações dos livros escolares em geral.

Pelo acervo didático a que tivemos acesso, verificamos que a recorrência às imagens foi uma prática usual no trancorrer do século XIX, obedecendo às argumentações de intelectuais sobre sua utilidade na formação do espírito infantil. "C'est en vain, explicou Locke "qu'on parle aux enfants de ces sortes d'objets invisibles; ils ne sont point touchés par ces discours, ils n'y prennent aucun plaisir pendant qu'ils n'ont aucune idée des objets mêmes; et des idées ne peuvent être excitées dans leur esprit par le son des paroles, mais par les choses elles-mêmes ou par leurs images." 13

Efetivamente as imagens criavam uma maneira especial de leitura, sobretudo, na fase inicial de alfabetização onde se mesclava com a oralização. A presença de ilustrações favorecia, em princípio, o diálogo, suscitando comentários que deslizavam continuamente do escrito para o oral e do oral para o escrito.

Até o final do século XIX os livros didáticos nacionais eram ilustrados em preto e branco, excetuando algumas obras publicadas no exterior. o citado Livro do povo, publicado na década de sessenta no Maranhão, é um exemplo do esforço em introduzir ilustrações en obras destinadas ao público infantil considerando as precárias condições tipográficas da época. 14 Foi apenas nos primeiros anos do século $\mathrm{XX}$ que apareceram os primeiros livros didáticos ilustrados a cores no Brasil, com os textos de Felisberto de Carvalho, Romão Puiggari e Arnaldo Barreto. 15

13 Apud DOSSIRRS(Les)DU MUSÉE D'ORSAY- L'enfant et $I$ 'image au $X I X$ è siècle. Paris: Editions de la Rénion des musées nationaux , $\mathrm{n}^{\circ} 35$, 1989 , p. 56

14 Arroyo informa ainda que embora existissem desenhistas interessados nesse campo de trabalho, era um serviço de pouca remuneração e esporádico, fazendo com que estes artistas desistissem facilmente da profissão. Para ele foi apenas depois do advento da revista 0 TicoTico que se pode definir com precisão o trabalho e os nomes dos ilustradores nacionais. Nelson Wernek Sodré escreve que desde a instalação da Impressão Régia houve a necessidade da arte da gravura, "permitindo a impressão de obras em que aquele recurso era indispensavel, como o Elementos de Geometria de Legendre. Desenhistas, gravadores, tipógrafos começaram a aparecer, feitos aqui ou vindos de fora." SODRE, N.- op. cit. p. 36

15 Cf. ARROYO, L. - op.cit., p. 223 
Anteriormente, as poucas obras com ilustrações coloridas correspondiam a textos publicados no exterior. Encontramos, por exemplo, o livro do alemão Francisco Hoffmann, Novos contos recreativos e doutrinais de um pai a seus filhos, para lhes inspirar amor à virtude e mostrarIhes as consequências dos vícios, traduzido em 1869 pela editora Læmmert que anunciava com destaque 8 gravuras coloridas. 16

Dependendo dos conteúdos das disciplinas, as ilustrações tornaram-se uma necessidade, fazendo parte, em geral, como anexo ou nas partes finais da obra. Foi o caso dos livros de Física e Química e, em certa medida, os de Geografia que traziam uma dificuldade complementar com a questão das representaçōes espaciais, condição que tornava imprescindível a apresentação de mapas.

As ilustraçōes dos livros didáticos favoreciam, portanto, dentro das concepções de aprendizado, uma forma do aluno ter contato com situaçōes mais concretas. Entretanto, pelas condições em que ocorreu o processo de construção da obra didática, as ilustrações serviram como um instrumento a mais na veiculação da cultura européia.

A marca estrangeira nos textos didáticos é bastante visível pelas ilustrações, registrando-se cenários, vestimentas e animais europeus. Gestos e posturas "civilizadas" eram divulgados pelos livros escolares, e tanto na forma quanto nos conteúdos, os 1ivros didáticos prestavam-se a difundir o "ideal" europeu como padrão a ser incorporado pela nossa juventude. As ilustrações reforçavam e impunham o consumo de um "estilo francês de ler" embora pudessemos detectar algumas poucas resistências a tais imposições.

No caso dos livros de História do Brasil, considerando a questão da ilustração em seus aspectos de conteúdo e metodológico, pudemos observar uma evolução bastante significativa a partir do final do século XIX.

16 Catálogo sistemático da editora $E$. \&H. Lammert. Rio de Janeiro, 1885 , p. 16 


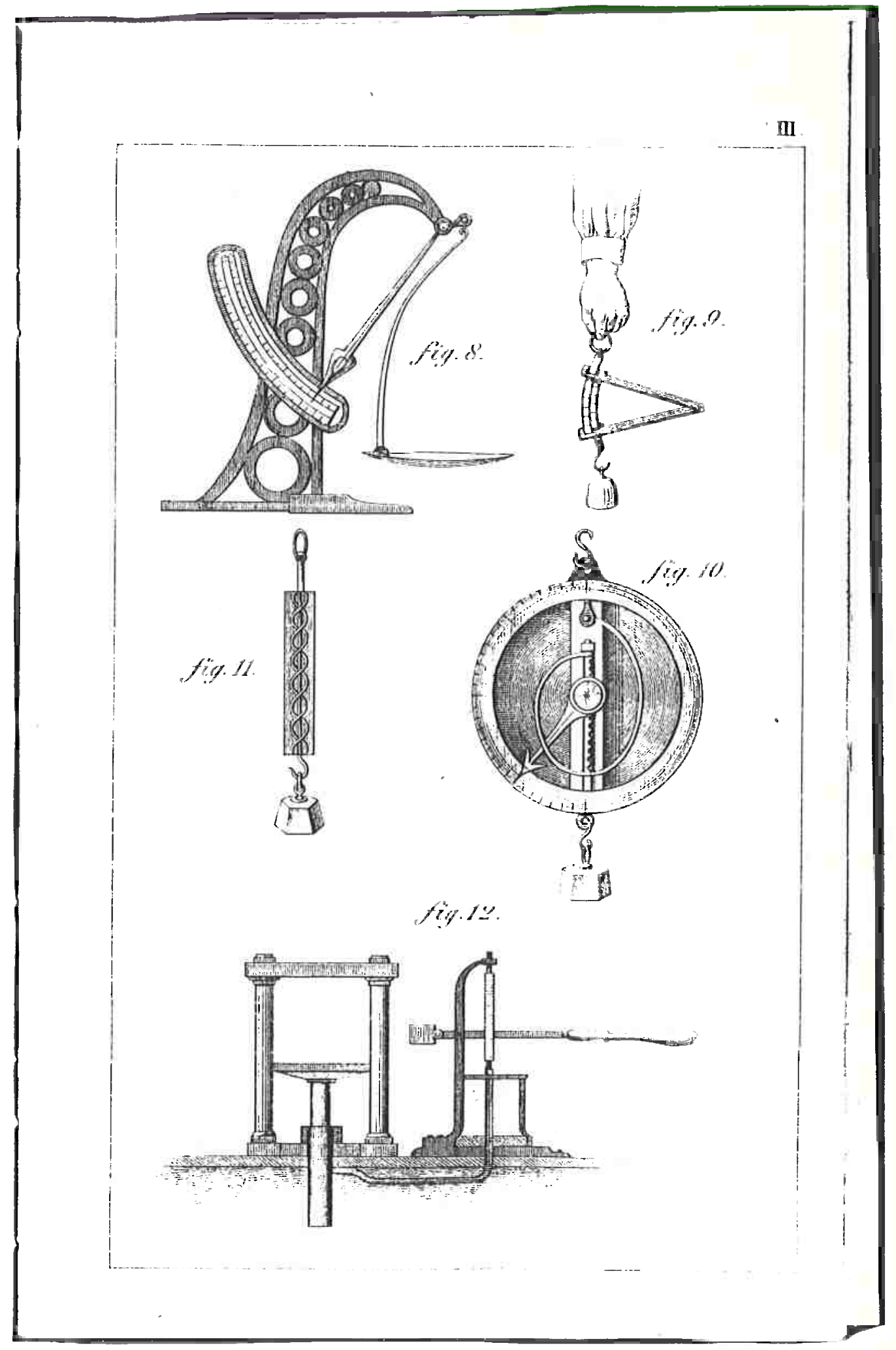

Fig. 29

Ponderabilidade. Noçōes de fisica e química de Aires de Albuquerque Gama, 1876. p. III. Bibl. "Pauio Bourrouid", Feusp. 


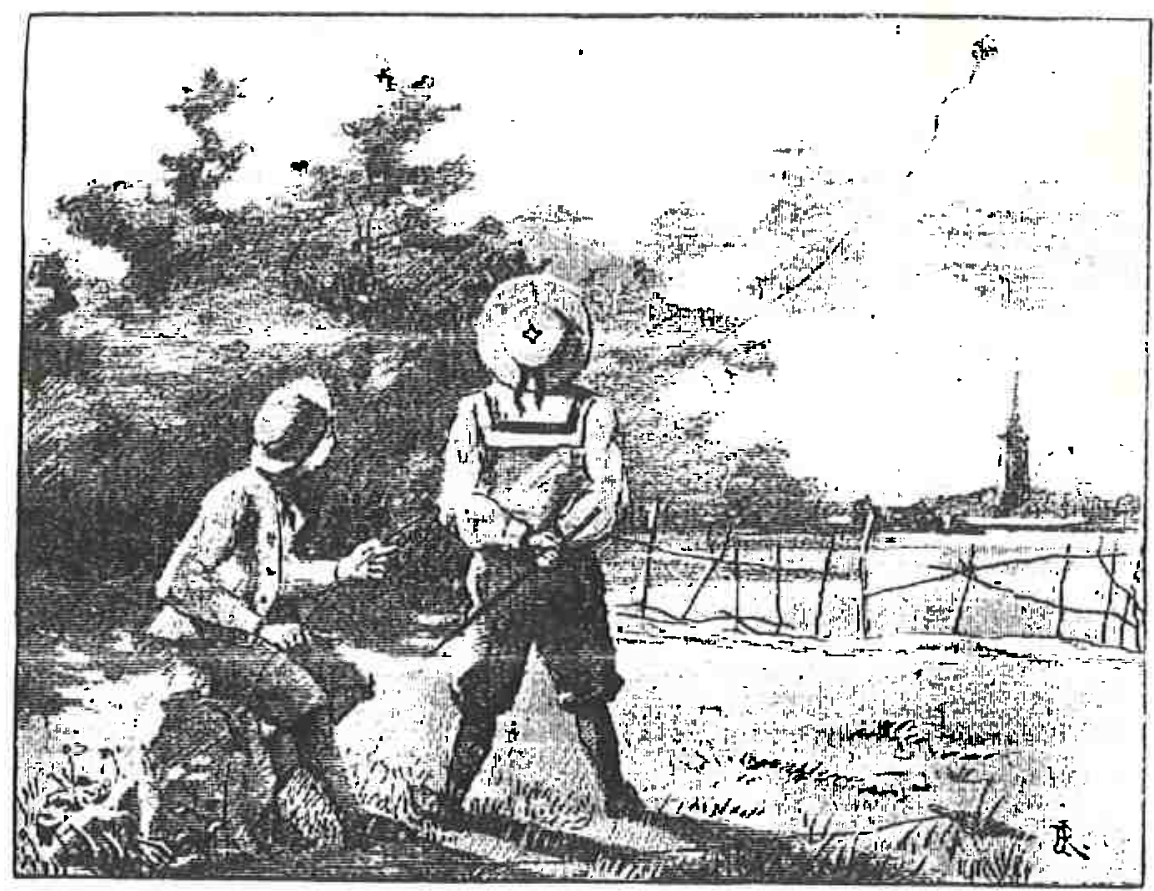

Fig. 30

O papagaio de papel. $O$ amiguinho de Nhonho- leitura corrente expressiva. Menezes Vieira, p. 54. Bibl. "Paulo Bourrould", Feusp

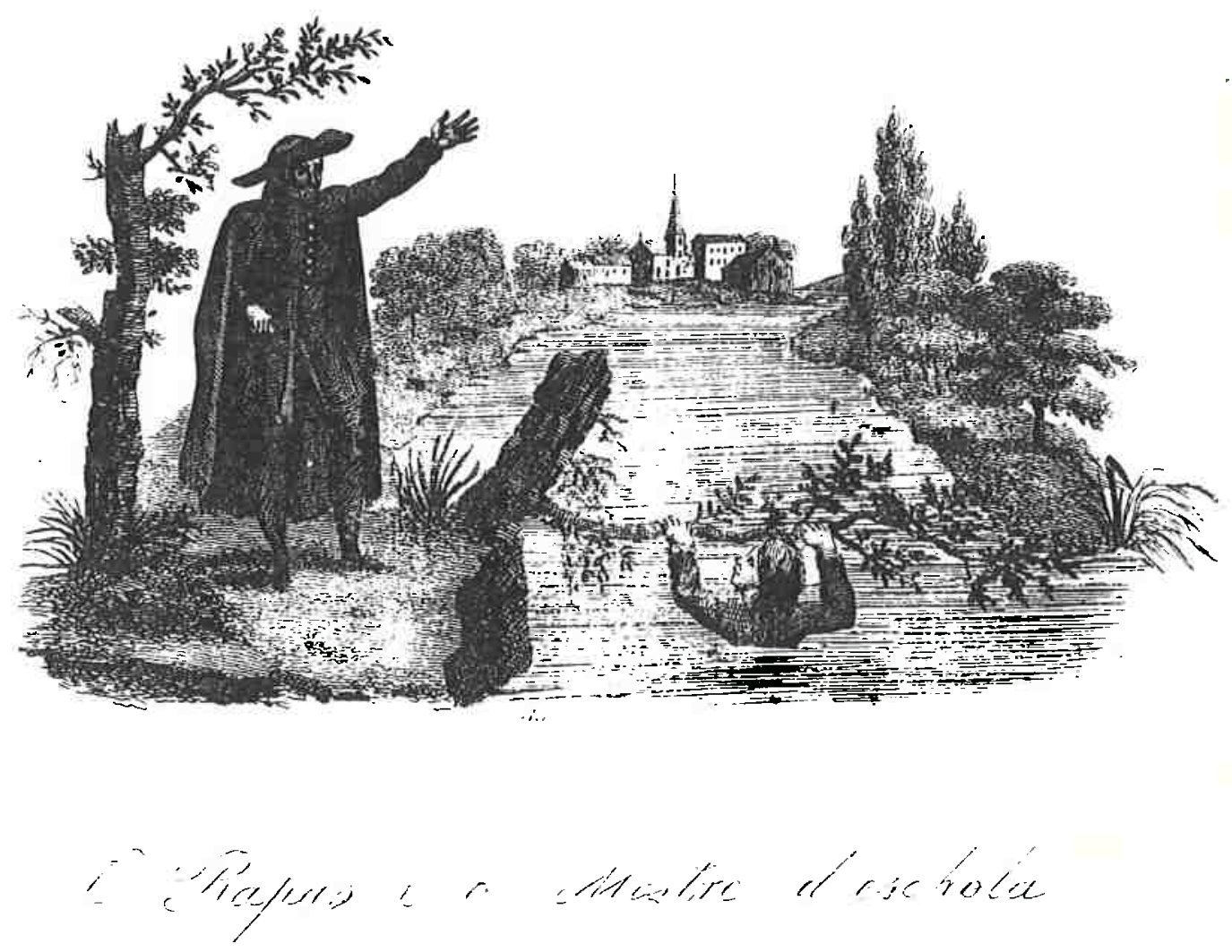

Fig. 31

Fábulas ( La Fontaine).p. 80. Bibl. "Paulo Bourrould", Feusp. 
o primeiro livro de História do Brasil ilustrado foi - de Joaquim Maria de Lacerda, feito para a escola primária, possuindo uma enorme galeria de vultos "ilustres", retratos de "grandes homens". Em um total de 160 páginas, há 41 personagens retratados e 7 reproduções de episódios como a Chegada de Tomé de Souza ou sobre os costumes indígenas.

o índio foi, desde os primórdios da ilustração na literatura escolar, o personagem preferencial dos livros de História. As cenas protagonizadas pelos índios evidenciam coerentemente as tendências e abordagens históricas dos autores. Comparando, por exemplo, os índios apresentados por João Ribeiro verificamos uma postura completamente diferenciada da belicosidade ilustrada por Olavo Bilac e Coelho Netto em seus textos escolares.17

o autor sergipano procurou desvendar, pelas ilustrações, a cultura indígena destacando suas características quanto às vestimentas, hábitos alimentares, advertindo sobre as características de cada grupo indígena, evitando as generalizações comuns sobre a vida dos nativos como ocorria com os demais autores. A cena escolhida para retratar a relação dos indígenas com os brancos foi uma reprodução do quadro o Ultimo Tamoio de Rodolfo Amoedo, ao contrário das sempre preferidas cenas de guerra ou de antropofagia, especialmente a morte do bispo sardinha.

Menezes Vieira foi pioneiro na divulgação de uma História Pátria baseada apenas em gravuras. Compôs um album de oito quadros murais "litografados para o ensino intuitivo de história". O trabalho mereceu prêmio da Comissão da Exposição Pedagógica de 1886 do Rio de Janeiro. O parecer da Comissão, entre outros elogios afirmou que "com segurança pode asseverar-se que não haverá criança por mais acanhada e distraída que daqui por diante ignore os oito históricos episódios contidos nesses quadros." 18 Mas, a premiação não

17 Cf. livros de Historia do Brasil anteriormente citados de Joaquim Maria de Lacerda, Joāo Ribeiro em sua versāo para a escola primáría e - citado Contos pátrios de olavo Bilac e Coelho Netto.

18 Catálogo da Livraria Alves \& Cia. RIo de Janeiro, 1890, p. 3. o Catálogo anunciava que Nossa historia pátria continha as seguintes estampas: I- Pedro Alvares Cabral tomando posse do Brasil. IIAnchieta, o apóstolo do novo mundo. III- o oceano é o único túmulo digno de um almirante batavo. IV- $O$ bravo guerrilheiro Henrique Dias. 
foi suficiente para evitar algumas críticas sobre as ilustrações da série Conheçamos nossa pátria:

"Nas ediçōes futuras porém, o autor deve reformar o tipo do nosso gaúcho que vem com uma calça que em nada se assemelha à classiva bombacha, e que devemos advertir também que o campeiro, quando dá o tiro de laço, este se acha apresilhado à sincha.

sustentar o boi no laço com este na mão - é materialmente impossível estando o campeiro a cavalo." 19

Os livros de História impressos no Brasil possuíam qualidade inferior aos impressos no exterior e, limitavam-se a retratos, como os livros de Silvio Romero e de Moreira Pinto, ornados com retratos de alguns dos biografados, mal visualizados. As mudanças quanto à qualidade de uma produção mais cuidadosa ficaram perceptíveis na obra de João Ribeiro, de 1900, que se destacou como um trabalho mais consistente sobre o papel das ilustraçōes para o ensino de História. surgiram cenas, escolhidas com critérios definidos cuidadosamente pelo autor, buscando sair da uniformidade do "preto e branco", introduzindo uma coloração monocromática. A História do Braśil editada para as escolas primárias demonstrou um esforço conjunto da editora e do autor na inovação do livro:

"Das gravuras que ornam esta edição dedicada à infância, a do frontispício e o Ultimo ramoio são reproduzidas de quadros de Amoedo; a do monumento de Cabral reproduz a concepção de $R$. Benardelli; a do índio Uapé foi extraida do livro Ao redor do Brasil do dr. João Severiano; as restantes são retratos autênticos. "20

Os livros de História do Brasil não podiam contar com as facilidades de importar ou utilizar material iconográfico existente nas gráficas do exterior, obrigando autores e editores a constituir um acervo original. Surgiu a preocupação em pesquisar fontes iconográficas para

V- Os bandeirantes 1707-1757. VI- Execuçāo de Tiradentes- 21 de abril de 1792. VII- Independência ou mortel. Interessante que deste Catálogo nāo consta a gravura sobre a morte do bispo sardinha, exclusão significativa considerando a época da separação entre Estado e Igreja.

19 VIEIRA, M.- Treze anos de ... op. cit., p. 163

20 RIBEIRO, João- op. cit., p. v 
Fig. 32

Indía Uapé. História do Brasil para escolas primárias. João Ribeiro, 1900, p.12 Bibl. "Paulo Bourrould", Feusp.

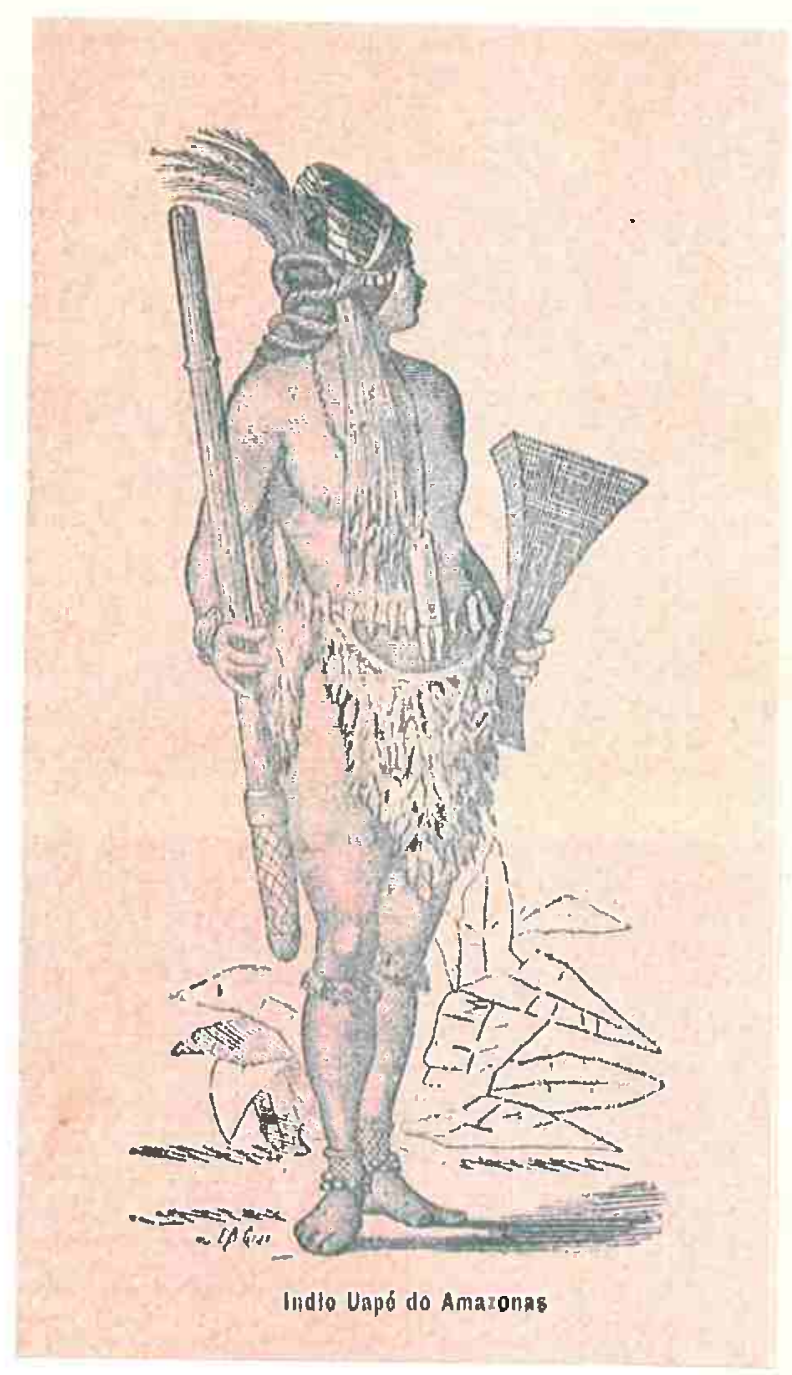

Fig. 33

O bandeirante. Contos pátrios.

O. Bilac e Coetho Netto.p. 154.

B.N. Rio de Janeiro 


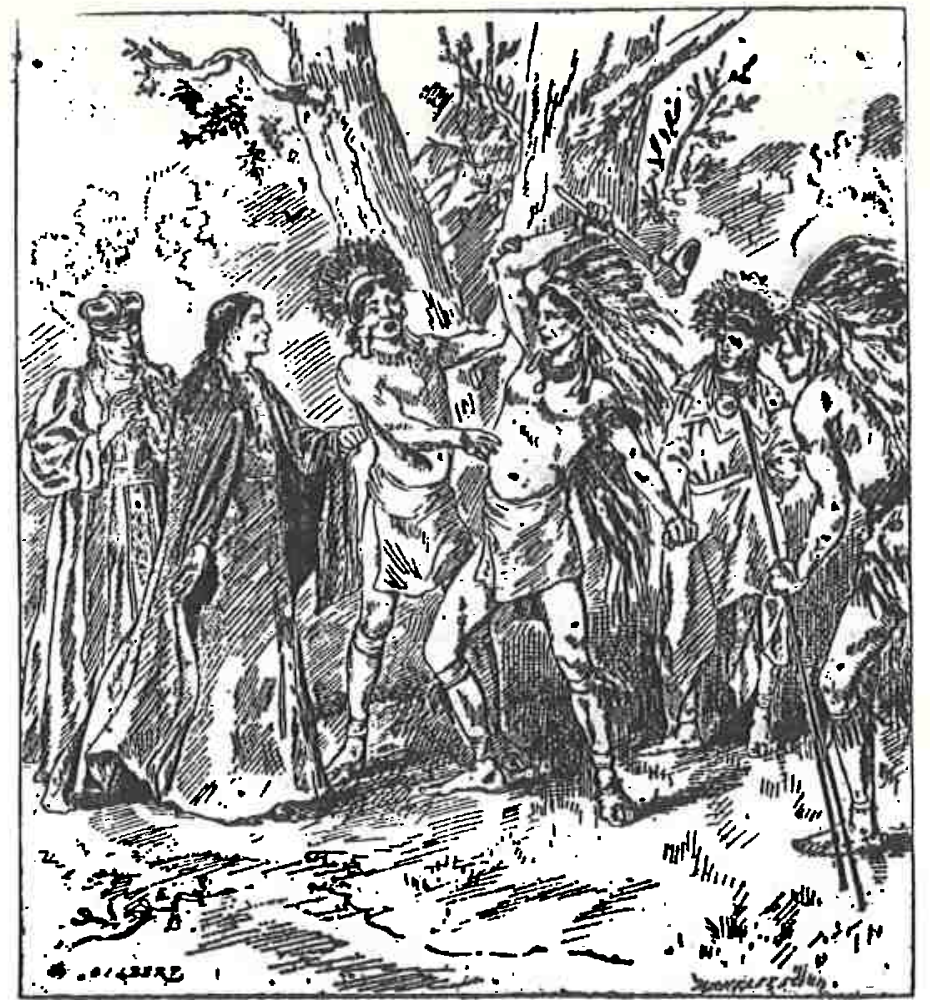

Fig. 34

A morte do $1^{\circ}$ Bispo do Brasil. Quadros de História do Brasil, Menezes Vieira, 1885. Bibl. "Paulo Bourrould", Feusp.

Fig. 35

Matanca do $1^{\circ}$ bispo da Bahia e seus companheiros.Pequena história do Brasil. J. Maria de Lacerda., $6^{\text {a }}$ ed.1887., p. 31. Bibl. N. de Paris.

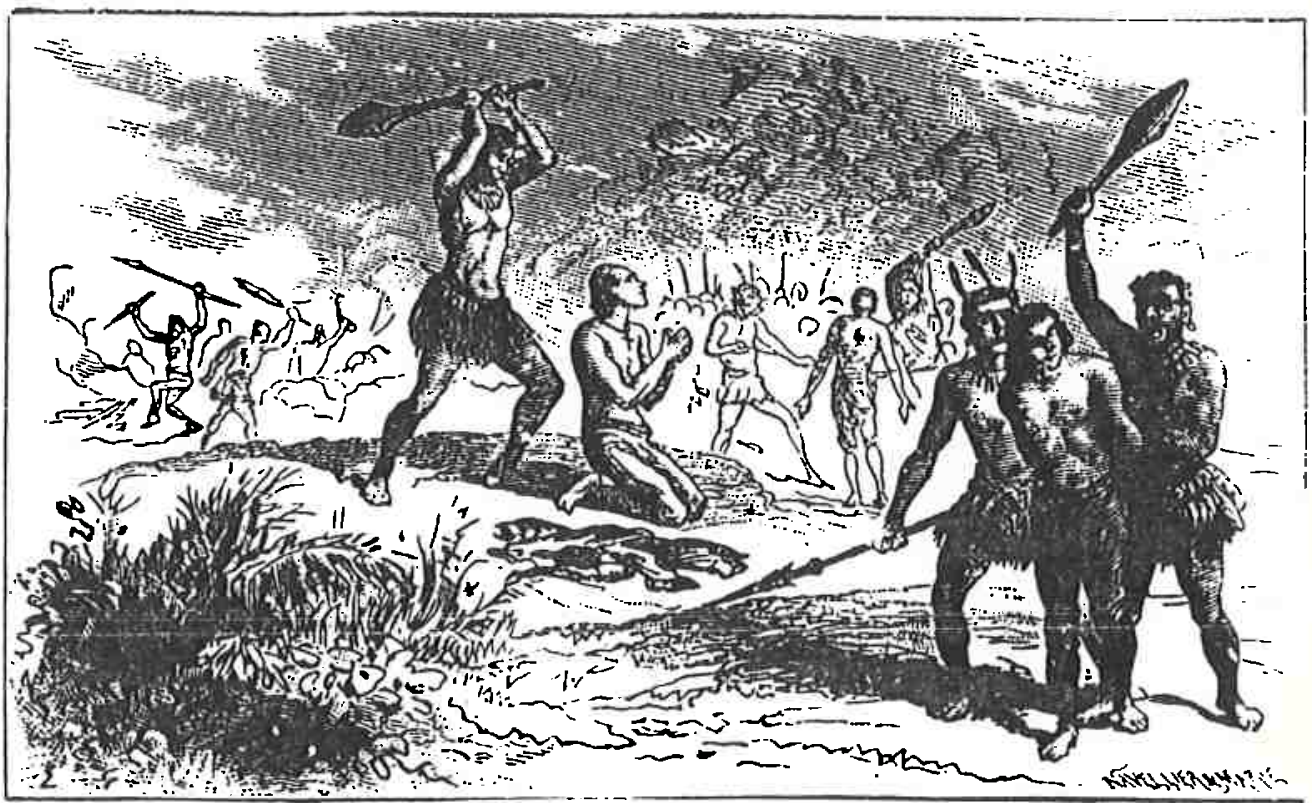




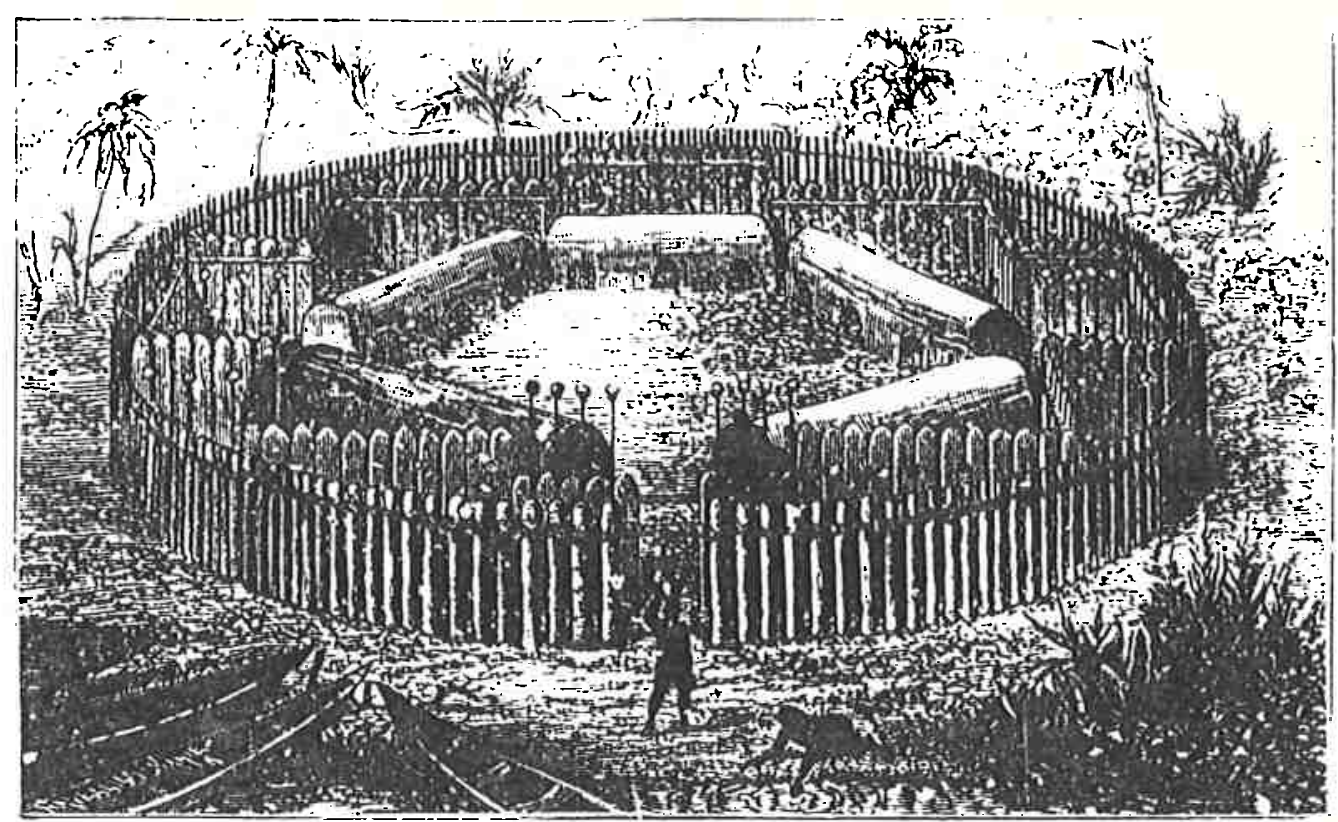

Fig. 36

Taba ou aldeia índia. Pequena história do Brasil. J.M. Lacerda, p.11 .Bibl. N. de Paris.

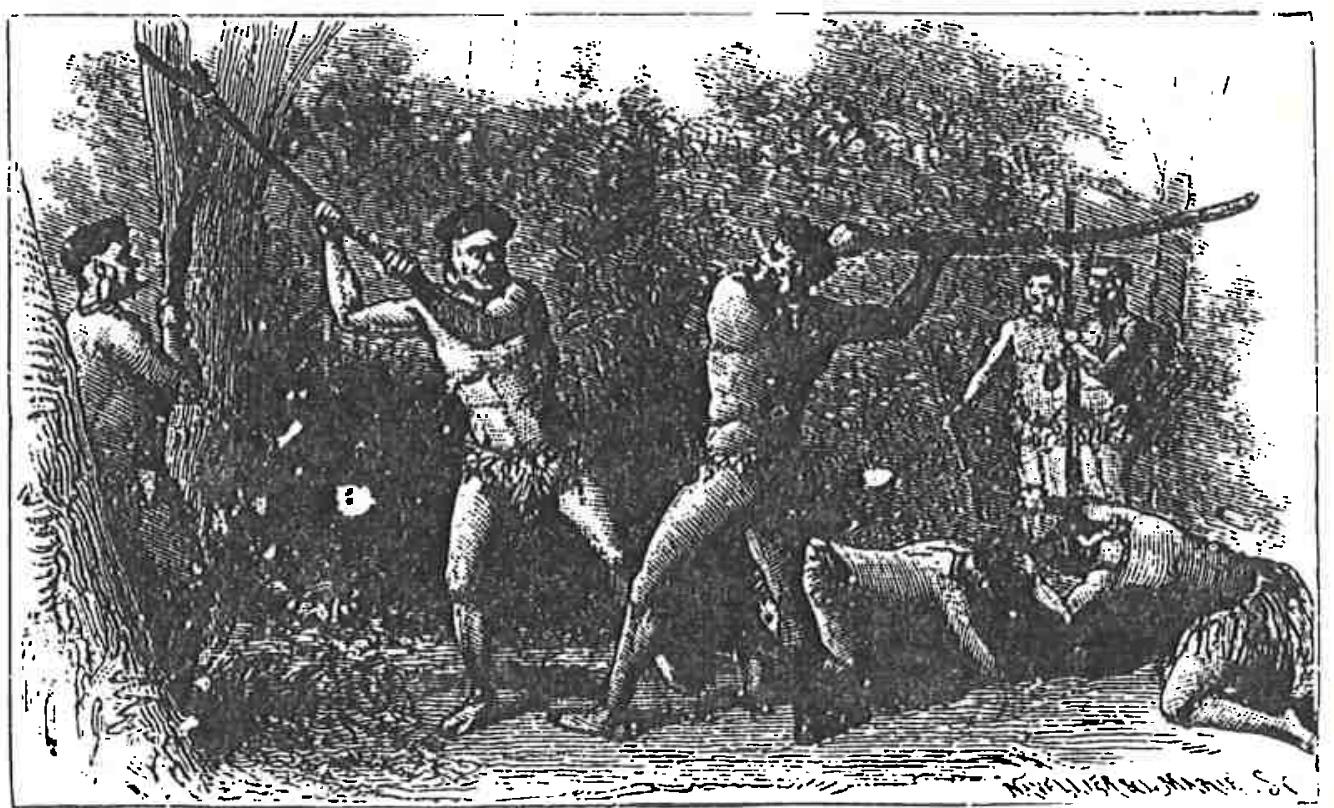

Fig. 37

Combate sinqular entre dois Aymorés.Pequena história do Brasil. J.M. Lacerda, p13.

Bibl. N. de Paris. 


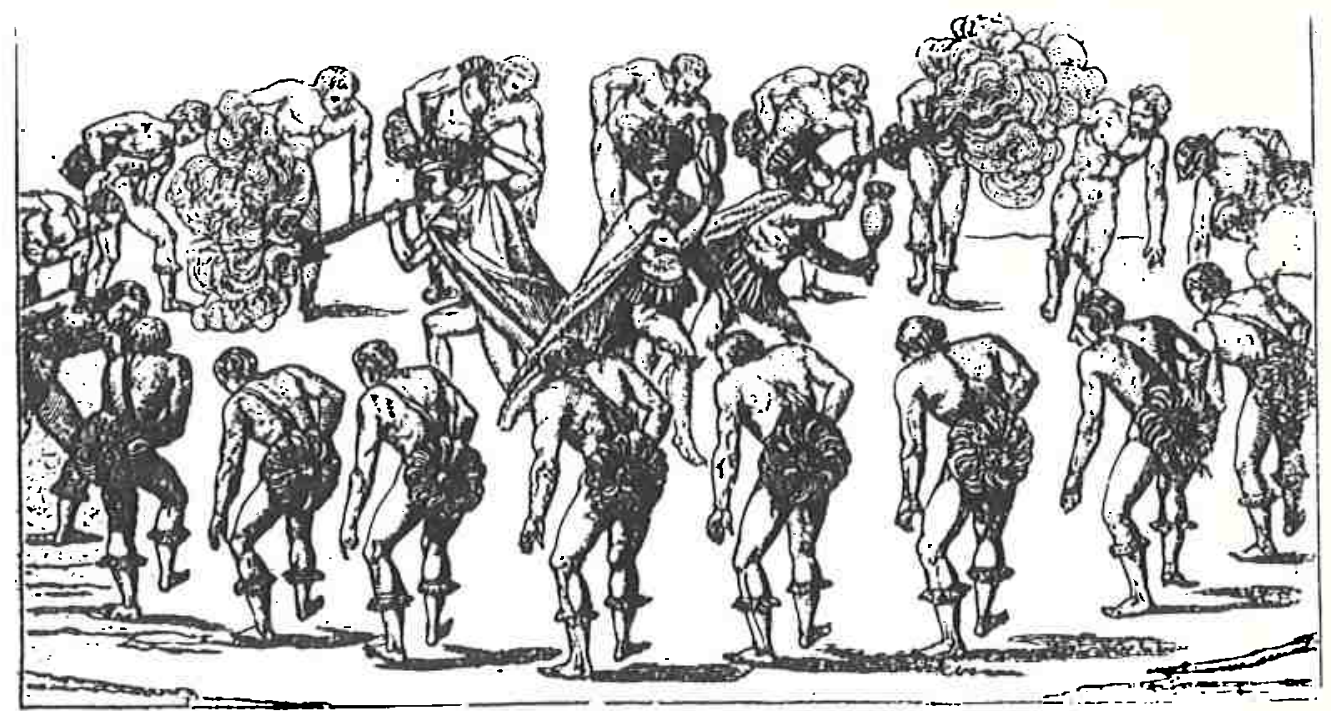

Fig. 38

Dança guerreira e religiosa dos Tupinambás. Pequena história do Brasil. J.M. Lacerda, p13 . Bibl. N. de Paris.

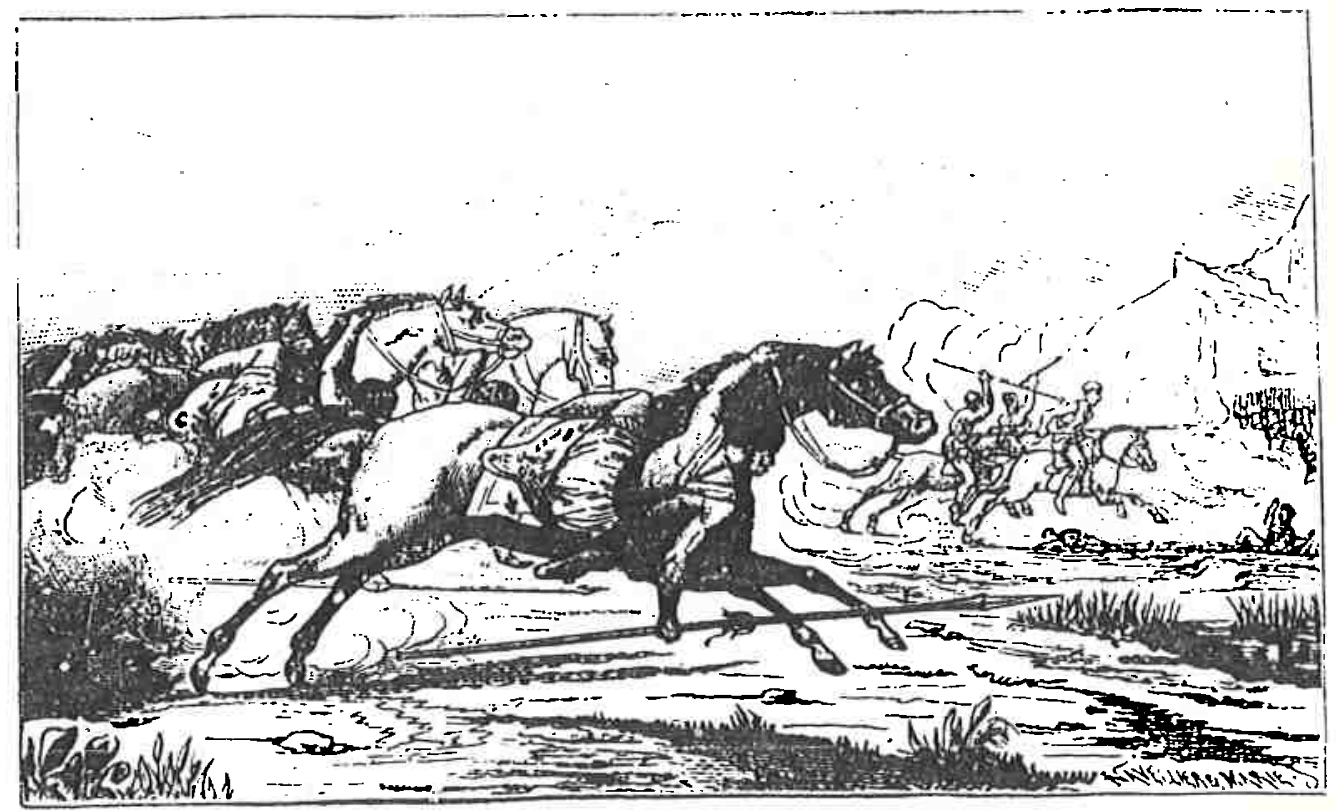

Fig. 39

Ataque dos índios Guaycurus.Pequena história do Brasil. J.M. Lacerda, 1887, p11 .

Bibl. N. de Paris. 
reproduzí-las, construindo um imaginário do passado nacional cujo alcance tem sido pouco estudado pelos historiadores. Os quadros da fase do romantismo acadêmico, destacando-se as de Victor Meireles e de Almeida Junior, obras encomendadas pelo governo para compor a galeria dos "fatos históricos" nacionais, foram as que mais contribuíram para a construção do acervo iconográfico dos manuais de História e que perduraram no decorrer do século $\mathrm{xx} .21$

No início do século, as ilustrações foram acrescidas de fotografias, mas para os livros de História predominaram as gravuras retratanto "ilustres personagens históricos". Os retratos testemunhavam e reforçavam uma visão de História baseada na ação política de indivíduos eminentes mas expressavam também uma limitação técnica, um "empobrecimento" para manter um preço acessível e as raras ilustrações eram objeto de propaganda para incentivar o consumo : "Epítome da história do Brasil, pelo Dr. Moreira Pinto, 2 a edição ilustrada com retratos de homens ilustres do Brasil." 22

Os livros de leitura também especializaram-se em veicular imagens históricas, especialmente nas coletâneas de textos, ampliando as informações por meio de representaçōes visuais. Os livros de leitura, sendo preferencialmente utilizados como leitura extra-classe ou leituras domésticas, necessitavam de maiores estímulos para o público leitor. Eram textos que pouco diferiam da literatura infantil, devendo ser utilizados dentro de uma perspectiva de educação recreativa, buscando formas de leitura agradáveis que não poderiam prescindir de gravuras, ilustraços preferencialmente coloridas, diferindo dos compêndios que recorriam ao processo mais econômico de gravação em madeira.

21 Começaram a ser reproduzidas obras de Almeida Junior, Partida das moncōes, de Vitor Meirelles de Lima, A primeira missa no Brasil e os quadros das batalhas da guerra do Paraguai. Pedro Americo igualmente foi preferido pela sua Batalha do Avaí e o Grito da Independência. entre outras. Um dos primeiros livros a introduzir tal acervo iconografico foi o de villa Lobos, Historia do Brasil, editado pela 1 vez pela Lxmmert em 1888 .

22 Anúncios do Catálogo da Livraria Clássica de Alves \& Cia.,Rio de Janeiro, 1890 , p. 6 
Os livros destinados aos adolescentes também contavam com gravuras. Encontramos fábulas ou livros de mitologia, por exemplo, editados em meados do século XIX, fartamente ilustrados. Para o ensino de História no nível secundário, a ilustração ganhou relevo a partir da produção de Histoire de la civilisation de Charles Seignobos, obra que se tornou modelar no aspecto da apresentação formal. As ilustrações passaram a ocupar e compor o espaço de maneira integral, renovando a composição tipográfica e visual do texto didático.

o mérito do livro residia, sobretudo, na profusão de ilustrações e na qualidade de impressão. Juntamente com os livros de Seignobos, os de Ernest Lavisse sobre a História da França, passaram a ser considerados as obras didáticas por excelência, marco da renovação dos livros didáticos de História. Eles se tornaram o modelo que as gerações de autores e editores, franceses e brasileiros, se esforçaram em seguir.

Para Lavisse as ilustrações eram fundamentais para a composição do texto escrito. Elas nāo eram consideradas apenas um mero complemento. Havia uma integração entre imagem e escrita e a composição da página era feita com uma leitura conjunta. Foram introduzidos comentários sob cada uma das ilustraçōes e previa-se um trabalho de leitura de imagens :

"Les enfants ont besoin de voir les scènes historiques pour comprendre $l$ 'histoire. C'est pourquoi les livres d'instruction sont à présent remplis d'images. Nous avons voulu forcer les enfants à bien regarder les images. Sans diminuer les nombre de gravures qui existaient dans le texte, nous avons composés des séries de gravures nouvelles, une série pour chaque livre. Chacune d'elles est accompagnée de questions auxquelles 1 'élève répondra par écrit, après avoir regardé le dessin et un peu réfléchi. c'est ce que nous appelons la revison par les images, et nous comptons beaucoup sur ce travail pour développer l'intelligence des 
enfants, en même temps que leur mémoire." 23

Para as séries seguintes foram excluídas a parte "révison par les images" e acrescidas cenas onde pudessem ser visualizados os costumes, destacando vestimentas e objetos. Uma inovação fundamental dos livros de Lavisse se fêz pela composição da página. Os capitulos foram divididos em parágrafos e sub-parágrafos que distinguiam os temas principais com títulos em negrito e para termos mais acessórios, porém de certa importância, usava-se a letra itálica. Acrescentaram-se no final dos capítulos os sumários e resumos, como partes destacadas para o aluno reter "de memória."

As ilustraçōes do compêndio de seignobos foram cuidadosamente escolhidas e, como Lavisse, criaram uma forma de leitura articulada entre os signos iconográficos e o escrito, direcionando a leitura pelas informações contidas abaixo de cada imagem apresentada.

os dois autores franceses aperfeiçoaram a construção das imagens para os livros escolares, mas estavam atentos à maneira de interpretá-las. Estavam vigilantes para os "perigos" eventuais de uma leitura livre das imagens e induziram seus leitores a uma leitura única sobre elas. Daí - cuidado em descrever as cenas ilustradas, antecipando a representação a ser construída pelo leitor. o critério para seleção das imagens articulou-se com a concepção de História do autor reforçando-a, formando um discurso homogêneo e conciso e, aparentemente, mais verossímil. Escolheram inúmeras cenas de guerra e acrescentaram uma série de mapas coloridos no final do livro, costume que remonta aos primeiros textos de História, incluindo os nacionais. ${ }^{24}$

Em 1912, Jonathas Serrano foi o primeiro autor brasileiro que tentou seguir os princípios pedagógicos de

23 LAVISSE, Ernest- Avis sur cette nouvelle edition. La nouvelle 1è annee d'histoire de France. Paris: Armand Colin, 1894. Grifo do autor. $24 \mathrm{Cf}$. SEIGNOBOS, Charles- Histoire narrative et descriptive des anciens peuples de 1 'orient. Paris: Armand Colin, 1897.Este livro traz no final 5 mapas coloridos. O livro de J. B. Calogeras, Compêndio da Bistoria da Idade Media de 1859 era " ornado de um grande e magnífico mapa da invasão dos bárbaros, e de quadros sincrônicos" e informava a livraria que " o mapa vende-se em separado". In: Catálogo da Livraria de B. L. Garnier de 1866 , p.12 
Vers le même temps on commençait à parler en Allcmagne des lansquenets (landskrecht, valet du pays) ${ }^{1}$. Eux aussi portaient la longue pique qui les défendait mieux |qu'une armure. Ils se réunissaient par bandes, élisaient un|

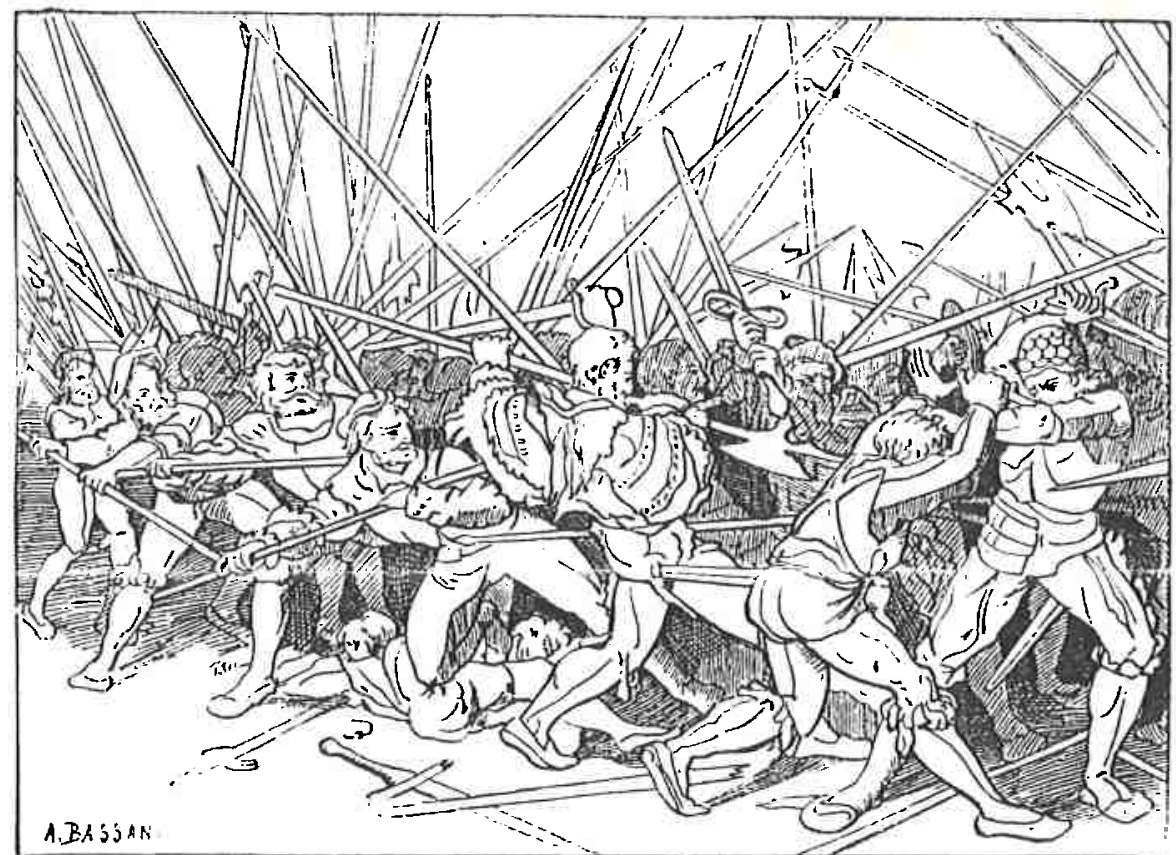

Fig. 40

Bataille de lansquenets. Histoire de la civilisation. Ch. Seignobos, p. 161, 1886 Bibl. "Macedo Soares", Feusp.

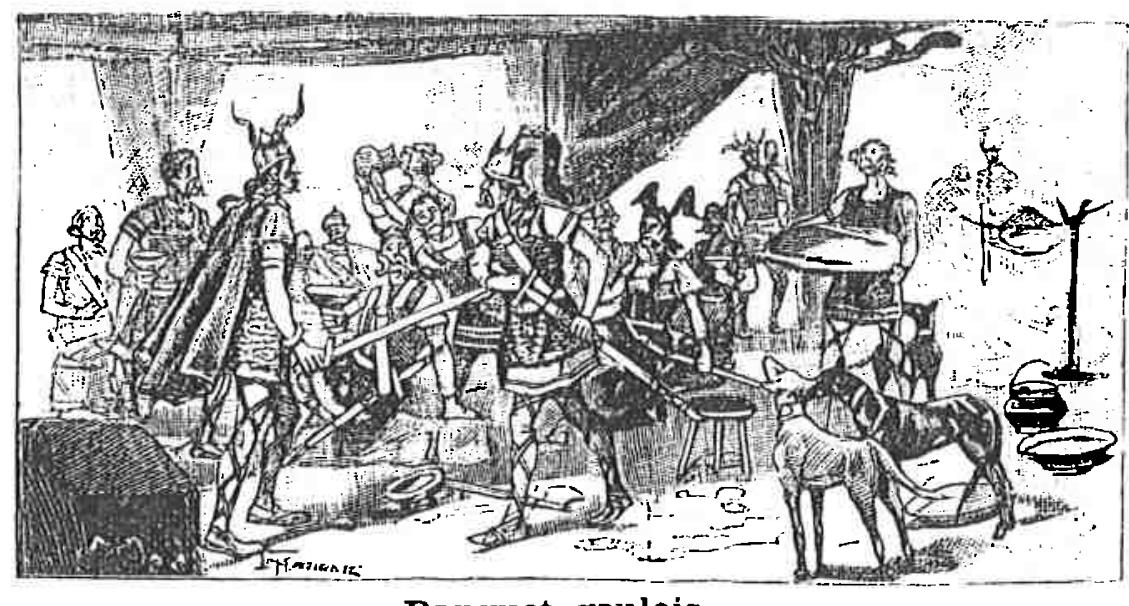

Banquet gaulois.

Los (iaulois, comme tous les peuples barbares, aimaient à se riunir dans des

bauruels, où ils riaient, criaient, ct souvent finissaient par se battre (p. 31).

Fig. 41

Os gauleses e os romanos. La deuxième année d'Histoire de France. Emest Lavisse, p.30. Bibl. "Macedo Soares", Feusp. 
Seignobos na composição tipográfica e na forma de inclusão das imagens e mapas ao escrever seu Epítome da história universal, tentando concorrer com a tradução do livro de Seignobos. 25

As ilustrações dos livros de História correspondiam a propostas pedagógicas diferentes das existentes nos textos de literatura, ou livros de leitura. As ilustrações das histórias infantis ligavam-se a um projeto articulado ao poder da imaginação da criança, ampliando a leitura, realizando uma espécie de jogo lúdico. Este não era o objetivo da ilustração nos livros de História.

As ilustraçōes, inicialmente compostas por reproduções. de retratos, desenhos de figuras consideradas dignas da galeria histórica, passaram a se integrar no texto, o que levou João Ribeiro a citar os autores das reproduções do seu livro ou a Seignobos preocupar-se em explicar que "les gravures, destinées à montrer le coutume, l'armement, les édifices, sont, pour la plupart, des scènes de mours reproduites $d$ 'après des dessins et des tableaux du temps."26

Existia, para os autores, a preocupação com a "veracidade" da imagem apresentada, configurando-a como um documento capaz de provar a narrativa do autor. A ilustração era instrumento de reforço da concepção de História do autor.

As melhorias técnicas das gráficas, ao lado do desenvolvimento de estudos pedagógicos foram responsáveis pela disseminação das ilustrações nos livros didáticos. Houve, paralelamente, um esforço dos autores em produzir textos para crianças, buscando um estilo mais familiar que pudesse aproximar o adulto ao mundo infantil mas os avanços evidenciados durante a passagem do século não significaram o fim de uma concepção sobre a aprendizagem: a memorização.

25 Cf. SERRANO, Jonathas- Epitome.., op. cit.

26 SBIGNOBOS, Charles- Histoire de la civililisation.-- op. cit.-p. III. 
1.3 A "memorização" no processo de aprendizagem

Lavisse, ao reforçar o uso das imagens nos livros escolares, pretendia desenvolver a inteligência da criança e sua "capacidade de memorização". A memorização era a tônica do processo de aprendizado e era esta a principal capacidade exigida dos alunos para o sucesso escolar. Aprender era memorizar:

"Feita assim a minha instalação e não havendo antigamente estudo de latim que não começasse sempre pelo Novo Método ou antes pela bem conhecida artinha do Padre Pereira de Figueiredo, que era toda mais ou menos decorada, eu também tive que começar por ela; $e$ no fim mais ou menos de três meses estava esta artinha decorada." 27

Esta concepção de aprendizado fundamentada no desenvolvimento da capacidade do aluno em memorizar não foi ignorada pela obra didática. A memorização era um pressuposto básico para a aprendizagem e o "saber de cor" se impunha como método de ensino que autores buscavam incentivar.

Uma obra que expressou de forma exemplar esta concepção de ensino foi o ornamentos da memória, do cônego Roquette. o Prologo da primeira edição especificava que "a primeira parte deste opúsculo é só destinada para exercícios da memória, mas assenta-lhe bem o título de Ornamentos da memória, porque sobre exercitar-se ficará ela ornada com mui nobres e vistosos adereços que darão relevante idéia da educação dos mancebos e lhes inspirarão o bom gosto para depois cultivarem a poesia, se para isto se sentirem propensos." 28

Entre o "exercício da memória" e a prática do ensino restava para os alunos "saber de cor" tal ou qual livro. Nenhuma escola escapava a esta regra, prevalecendo o mesmo sistema entre os mais famosos professores: "Infelizmente o que aprendemos de História foi diretamente nos livros de

27 REZENDE, Francisco de P. F. de- op. Cit., p. 213

28 In Prologo de ROQUETTE, I. J.- Ornamentos da memoria e exercicios seletos para formar o bom gosto e verdadeiro estilo pela Irngua portuguesa, extraídos dos melhores clássicos em prosa e verso... Rio de Janeiro: B.L. Garnier, 1877 
mestre João Ribeiro porque ele não prelecionava. Marcava Lição. Na próxima vez é o capítulo xxIII: Maomé e o Islamismo. A Invasão dos Arabes. E quero tudo na ponta da língua." 29

Para o ensino de História surgiu um método menmônico, conhecido como método zaba, difundido na Bahia na década de 70. Foi criado para o estudo de História Universal, podendo os alunos responder depois de duas ou três lições, com auxílio de mapas, às perguntas sobre os principais acontecimentos de cada século. o barão de Macaúbas adotou-o em seus colégios e o vemos exposto no plano de estudos do Colégio "Abílio", fundado na corte em 1871, para as duas primeiras séries de instrução secundária. o método, segundo - barão, não era destinado a ensinar toda a História Universal, mas para familializar o aluno com técnicas de memorização de fatos com suas respectivas datas, aprendendo "facilmente" a sequência cronológica dos principais acontecimentos. 30

Muitas críticas têm sido feitas quanto à memorização no processo educativo escolar. A luta contra o "método da decoração", sobretudo, que não podemos confundir com a memorização consciente, tem sido constante desde o final do século passado. Chama-nos a atenção, exatamente a persistência de tais críticas, significando tratar-se de um método educacional que se mantinha apesar das argumentações que passaram a considerá-lo inoperante ou secundário na aprendizagem.

Quando situamos a paisagem cultural do século passado ao primórdios do atual, podemos refletir com mais lucidez sobre o papel da memorização na formação dos alunos, especialmente para a História, disciplina considerada "decorativa" por excelência.

Nossa sociedade tem se caracterizado por uma tradição de comunicação oral. Arroyo, estudando a história da

29 NAVA, Pedro- Chão de ferro- memorias/3. Rio de Janeiro: José Olympio, 1976, p. 240-41.

30 Cf. Programa do Colégio Abilio. Apud HaIDAR, M. de L. M.- op. cit., p. 221 e no Relatorio de 1871 do presidente da província da Bahia, Francisco José da Rocha. Apud MOACYR, P.- Inst. e prov...-op. cit. v. 2, p. 155 


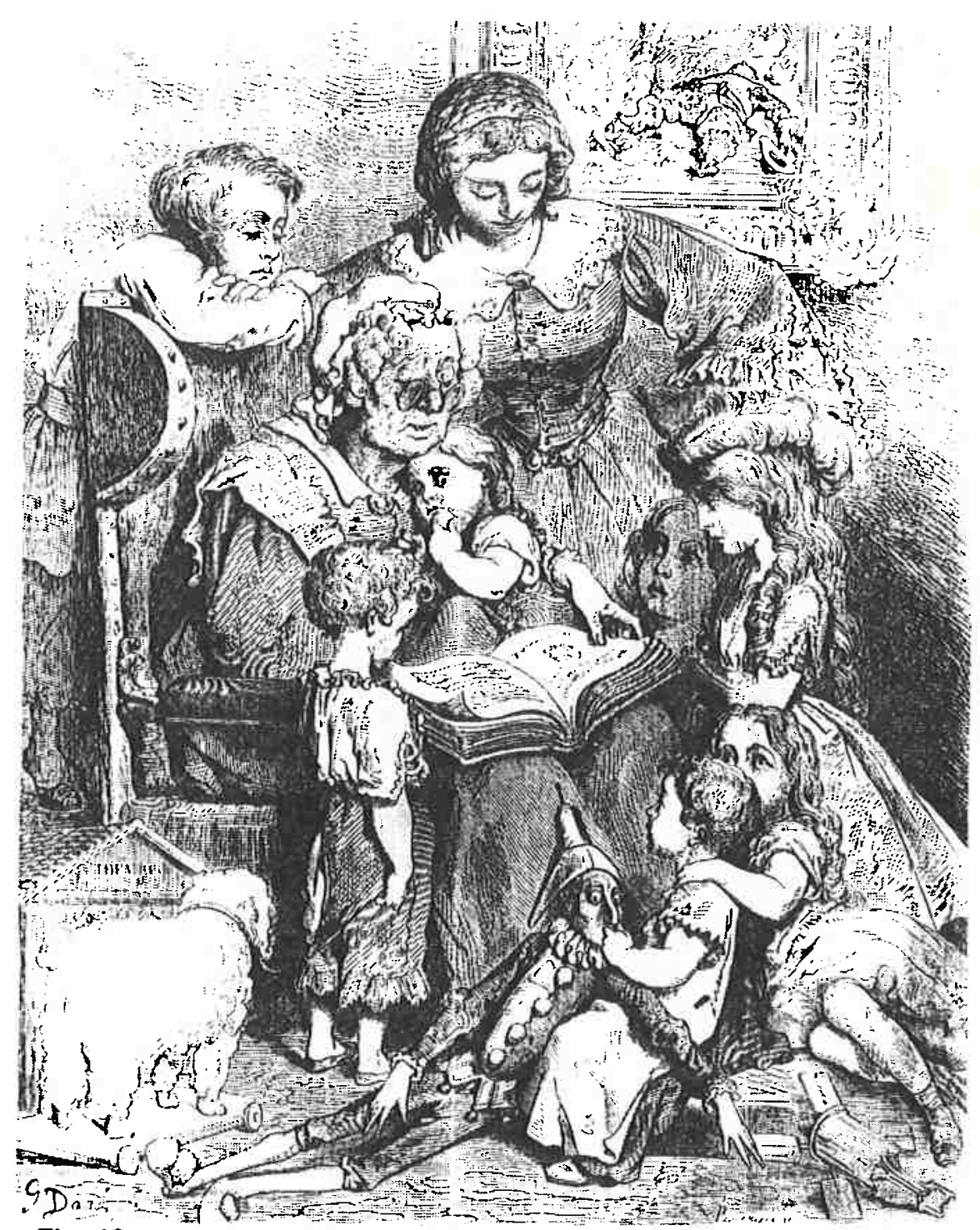

Fig. 42

Leitura do Pequeno Polegar. Fronstispício dos Contos de Perrault., 1862.

Bibl. N. de Paris. 
literatura infantil, mostra com clareza o papel da cultura oral na formação de nossa sociedade do século passado, com um número pequeno de leitores. o conhecimento oral e sua forma de transmissibilidade tem sido avaliado como uma marca da nossa cultura. A circularidade cultural predominava na sociedade escravocrata, convivendo senhores brancos, desejosos de se "civilizarem", com escravos indígenas e africanos ou de origem africana. A circularidade cultural, como a concebe Baktin e Carlo Guizburg, esteve muito presente na transmissão de um passado de difícil identificação, com origens mescladas e transpostas para um espaço dominado pelo mundo branco europeu. Mas os grupos dominados não se calaram. Os livros dos memorialistas aí estão com suas reminiscências para comprovar o poder dos narradores negros, sobretudo na construção de um conhecimento de mundo e na representação social dos diferentes segmentos de nossa sociedade patriarcal. ${ }^{31}$

As histórias narradas, ou estórias, que posteriormente pertencerão ao mundo erudito porque serão escritas, deixando de pertencer à cultura ágrafa, eram apreendidas pela oralidade, contadas pelos narradores durante à noite, nas fazendas, nas povoaçōes, nos serões. Os contos eram repetidos quase que diariamente para crianças, para fazê-las dormir ou como distração. Contos repetidos infinitas vezes.

o púlpito era outro lugar da repetição, do aprendizado pela oralidade. As preces e a História sagrada eram aprendidas pela repetição diária, cíclica, pelas festividades marcadas pelo calendário cristão.

A instituição escolar nasceu para criar uma nova forma de comunicação, o conhecimento pela escrita, mas não pôde afastar-se ou eliminar as relações sociais e suas formas de transmissão de saber tradicionalmente estabelecidas. A escola e seus livros didáticos foram obrigados a se submeter a mecanismos semelhantes para impor o saber erudito que pretendiam disseminar.

31 Ver GINZBURG, Carlo- o queijo e ..., op. cit. e BARHTIN, Mickail- A cultura popular na Idade Media e no Renascimento: o contexto de François Rabelais. São Paulo: Hucitec, 1987 
A escola de primeiras letras se esmerou em ensinar pela repetição intensiva:

"Era em um sábado; os bancos estavam cheios de meninos vestidos quase todos de jaquetas ou robições de lila, calças de brim escuro e uma enorme pasta de couro ou papelão pendurada por um cordel a tiracolo: chegaram os dois exatamente na hora de tabuada cantada. Era uma espécie de ladainha de número que se usava então nos colégios, cantada todos os sábados em uma espécie de cantochão monótono e insuportável, mas de que os meninos gostavam muito". 32

A literatura de ficçāo e os memorialistas nos revelam detalhadamente o método da "decoração oral":

"Os meninos, todos, decoravam a tabuada cantando: "Dois mais dois, quatro! Treis veis seis, dezoito!" 33

No secundário, mesmo no afamado Pedro II, a situação não diferia:

"O professor era o de frances.(..) professor detestável. Queria apenas que decorassem a gramática de sua autoria. Decoração mecânica. Havia para ele um tipo de bom aluno: o que podia responder de acordo com os números dos parágrafos do seu livro.

-Meu amiguinho, diga o parágrafo 287.

"Meu amiguinho" - era a sua fórmula predileta para se dirigir aos estudantes. E quando alguém hesitava na resposta, ele não lhe auxiliava a memória recordando o assunto: apontava a página da gramática lembrando em que altura estava o parágrafo.

-Lembre-se bem. Do lado de cá (e batia no livro) no meio da página... " 34

Memorizar, na prática, para a maioria dos professores, resumia-se a "decorar mecanicamente". "É fato sem dúvida triste para nós, confirmava o barão de Macaúbas, mas infelizmente real, que nossos meninos até a idade de 11 anos, e muitas vezes até 12 e 15, não ligam, em geral,

32 ALMEIDA, Manuel Antônio de- Memorias de um sargento de milícias. Belo Horizonte: Itatiaia, 1977, p 85

33 AMADO, Gilberto- Historia da minha infância. 39 ed. Rio de Janeiro: Liv. Jose Olympio., 1966, p. 50

34 MEDEIROS E ALBUQUERQUE- Minha vida- da infância à mocidade. Rio de Janeiro: Calvino Filho Editor, 1933, p. 38 
pensamento algum ao que lêem: São verdadeiros autômatos, ou papagaios, lendo o que não entendem, nem se inquietam de entenderem, nem sequer têm consciência de que devem entender.

Também se os pobres meninos, desde que encetaram a vida literária, nunca entenderam nada dos livros que lhes puseram nas mãos !!"35

o barão "amigo dos meninos", embora preocupado em produzir textos compreensíveis para o pequeno leitor, não conseguiu ser muito feliz em seus intentos de inovar a literatura escolar. As experiências das primeiras leitura de Graciliano Ramos com o barão de Macaúbas foram desastrosas:

"Um grosso volume escuro, cartonagem severa. Nas folhas delgadas, incontáveis, as letras fervilhavam, miúdas, e as ilustraçōes avultavam num papel brilhante como rasto de lesma ou catarro seco.

Principiei a leitura de má vontade. E logo emperrei na história de um menino vadio que, dirigindo-se à escola, se retardava a conversar com os passarinhos e recebia deles opiniões sisudas e bons conselhos.

-Passarinho, queres tu brincar comigo?"

-Forma de perguntar esquisita, pensei. $E$ o animalejo, atarefado na construção de um ninho, exprimia-se de maneira ainda mais confusa. Ave sabida e imodesta, que se confessava trabalhadora em excesso e orientava o pequeno vagabundo no caminho do dever." 36

E, perpetuava-se o ensino decorativo, apesar de rebeldias:

"Governadores gerais, holandeses e franceses começaram a importunar-me. Esquartejavam-se períodos, subdividiam-se e rotulavam-se as peças em medonha algazarra. Os meus novos amigos guardavam maquinalmente façanhas portuguesas, francesas e holandesas, regras de sintaxe- e brilhavam nas sabatinas. Segunda-feira estavam esquecidos, e no fim da semana precisavam repetir o exercício, decorar provisoriamente toda a matéria. A medida que avançavam, a

35 BORGES, Abilio Cesar- Segundo livro...-op. cit., p.VII (Introdução)

36 RAMos, Graciliano- Infância (Memorias), 50 ed. são Paulo: Martins Ed., 1961, p. 117 
tarefa ia se tornando mais penosa: ficavam apenas, algum tempo, as últimas lições.

Eu achava estupidez pretenderem obrigar-me a papaguear de oitiva. Desonestidade falar de semelhante maneira, fingindo sabedoria. Ainda que tivesse de cor um texto incompreensível, calava-me diante do professor- e a minha reputação era lastimosa." 37

Para facilitar a interiorização de uma memória histórica dos feitos dos grandes personagens e dos marcos fundamentais do nascimento da nação, ao lado das imagens dos livros, criaram-se as poesias com temas da História Pátria, linguagem adequada no emprego de mecanismos de aprendizado pela oralidade, da repetição, facilitadora da memorização. As poesias, declamadas em sala de aula e nas comemoraçōes das datas cívicas, foram composições representativas do papel da construção de um passado histórico pela oralidade:

\section{"A descoberta da América}

\section{Um tal Cristovão Colombo}

Sonhou que a Terra era esférica,

Que, roando como um pombo,

Havia de achar a América. (...) "38

Mas, ensinar História sempre foi um desafio.

Como transmitir uma História da pátria, com uma cronologia demarcada por eventos administrativos de reis e guerras, a História da "nação" para crianças e jovens provenientes de um aprendizado de narrações populares, mescladas de mitos e lendas?

o livro didático de História desafiava outros conhecimentos do passado, buscando "domesticar um tempo passado" com datas fixadas em calendários, com nomes de adultos poderosos que pouco se relacionavam com o mundo cotidiano. Cabia ao aluno conciliar saberes provenientes da "ciência" divulgada pelos livros didáticos com os que trazia de seu mundo religioso e "bárbaro" dos escravos. Como

37 Idem, p. 215

38 PEIXoTo, Antonio. A descoberta da America. Revista de ensino. São Paulo, Tipografia Nacional, 8, 3:39 set. 1909 . 
entender por que existiam negros, brancos e indios? A origem das raças expressa pelos livros enfatizava a superioridade da raça caucásia, originária de um meio físico favorável, enquanto a Bíblia falava da predestinação e de castigo para os filhos de Cam e as versões dos africanos, como a da negra Margarida, afirmava que Deus havia criado todos os homens negros mas como alguns homens desejassem ser de cor branca por acharem-na mais bonita, fizeram um pacto com Deus sobre a travessia de um rio gelado; os que o atravessaram tornaram-se brancos. 39

\section{Salas de aula e práticas de leitura}

2.1 Imposições de normas de leitura

o livro escolar relacionou-se duplamente com a oralidade. o professor apresentavava o conteúdo do livro, selecionava o que deveria ser lido, fazia a sua interpretação do texto. o discurso do mestre, com um ritual diferente dos outros narradores de estórias populares, era imprescindível para a utilização do livro.

o aluno deveria ler o texto, dominar as palavras escritas e repeti-las para o professor diante dos colegas. A "lição" do livro caracterizava-se por ser uma repetição oral.

o livro didático tem hoje como concorrentes os meios de comunicação de massa, o cinema e a televisão e seu mundo de imagens. No século anterior, o livro didático tinha que se impor a um mundo que se comunicava essencialmente pela oralidade onde a entonação da voz e o gestual mesclavam-se na apreensão do que era transmitido.

A medida em que o livro difundia-se na vida moderna, passando a ser um objeto cultural de fácil aquisição, permitia-se, ao leitor, a "privatização" da leitura. A difusão do manuseio do livro, sua posse, possibilitavam o desenvolvimento da capacidade de "ler com os olhos", de

39 Cf. REZENDE, Francisco de Paula R. de- op. cit. , p.115 
maneira solitária. Ler, a partir do século XV, para o mundo ocidental, passou a ser um ato cada vez mais individualizado e as novas práticas de leitura, anteriormente reservadas ao mundo eclesiástico, foram alvo de divisões sociais cujas nuances é preciso destacar.40

o domínio da leitura dividia a população. Os séculos XVIII e XIX corresponderam ao período em que ler e escrever tornava-se um direito do cidadão e, paradoxalmente, o livro escolar representou a tendência de democratização do saber escrito. Apesar de estar submetido a controles e vigilância constantes, o livro escolar era uma possibilidade de divulgar um saber, de socializar conhecimentos.

- livro didático foi construído para que a leitura se realizasse de duas formas. O primeiro momento era mediado pelo professor, o agente organizador da leitura em grupo. Os alunos deveriam ler em voz alta, na sala de aula, dividindo a leitura com seus companheiros de classe. o livro de leitura ou o manual escolar inscrevia-se no tecido de uma sociabilidade comunitária, característica de uma prática popular.

A sequência de leitura do livro didático, ou a etapa seguinte da leitura, levava-o a partilhar uma prática erudita e individualizada. O aluno teria que "privatizar" sua leitura, lendo individualmente para decorar textos ou realizar os exercícios pedagógicos ou outras formas de fixação da leitura.

"Escutar ler" foi outra prática frequente na sala de aula. O professor lia para seus alunos. "Acompanhamos com ele as traduções da Eneida e de uma seleta inglesa "Talks and Histories", opulento repositório dos grandes escritores ingleses" e adiante relembrava o aluno que seu falante professor de Inglês e Latim do ginásio público de Jacareí, ao ler o episódio da tempestade da "Eneida", de virgílio ficava possuído de "incontido entusiasmo.. como se degustasse um manjar dos deuses." 41

40 Cf. CHARTIER, Roger -As práticas da escrita. In ARIES, Philippe e DUBY, GEORGES(Org)-Historia da vida privada. Trad. Hildegard Feist. Säo Paulo: Companhia das Letras, 1991, v. 3, p. 113 a 129

41 PRADO, A. de Almeida- Escolas de ontem e de hoje- reminiscências e evocaçōes. São Paulo: Anhambi, 1961, p.56. 


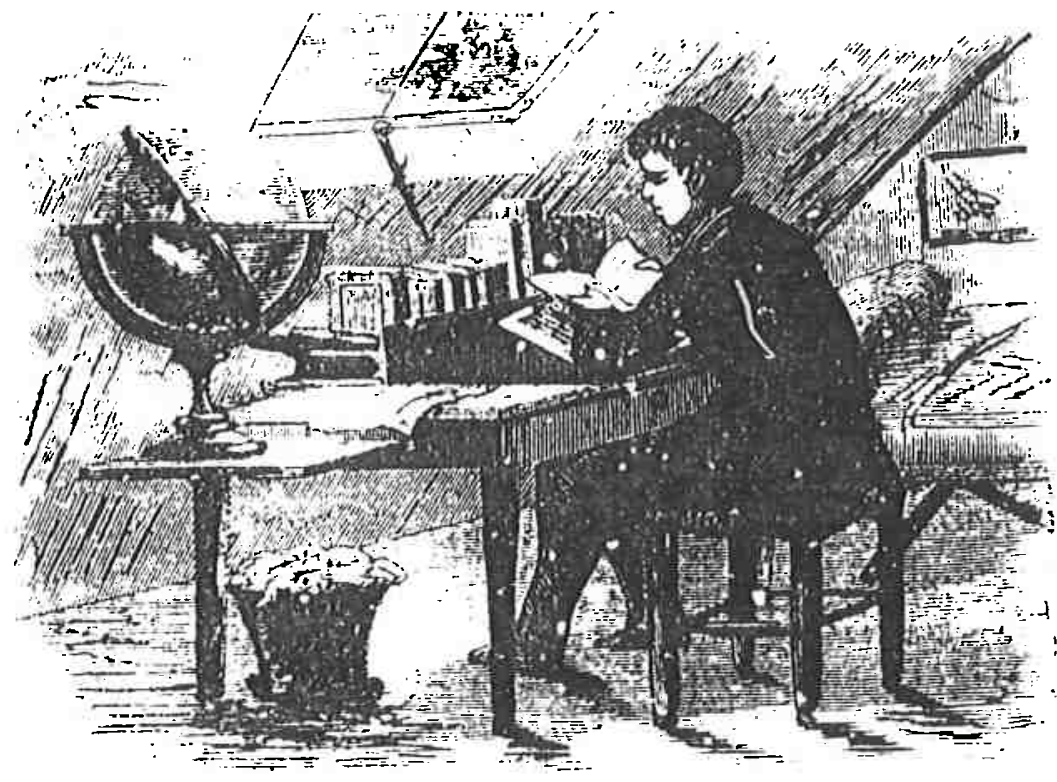

Fig. 43

O amor à instrução. Livro de leitura. Landelino Rocha, p. 173. Bibl. N. de Paris.

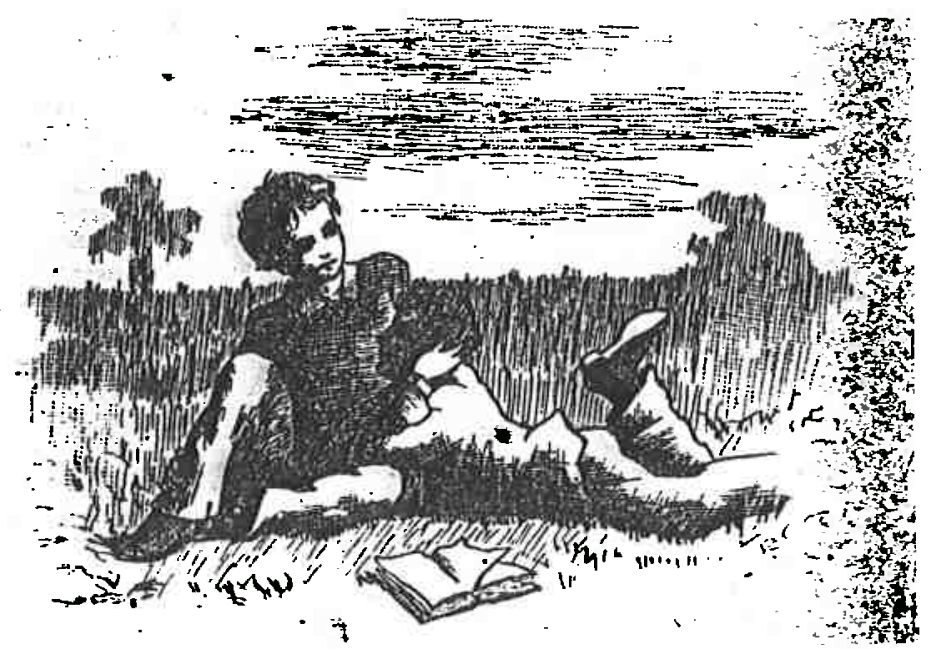

Fig. 44

llustração O Ateneu Edição de 1905, p.201. Bibl. "Paulo Bourrould", Feusp. 
Para as diferentes leituras dos livros existiam espaços também diferentes. A sala de aula foi se definindo lentamente. o espaço da sala de aula, inicialmente desordenado, com alunos de idades diversas até chegar ao grupo escolar e ginásios com classes homogêneas, divididas em "séries", percorreu uma trajetória tumultuada. professores, alunos e autoridades traçaram histórias variadas e conflitantes no espaço em que as autoridades educacionais organizavam ou, tentavam organizar, para a transmissão do saber escrito. Alunos com posturas diversas, sentados ou espalhados em um espaço indeterminado foram sendo agrupados com uma ordenação rígida, controlando seus corpos com materiais pedagógicos especificamente criados para assegurar uma determinada atitude diante do conhecimento escrito.

A carteira escolar foi um tipo de mobiliário introduzido nas escolas urbanas dos grandes centros, notadamente nas escolas particulares mais notáveis e foram alvo de interessantes avaliações pedagógicas. Na Exposição Pedagógica de 1883 do Rio de Janeiro, o parecer do juri encarregado de premiar o melhor conjunto de mobílias escolares é um documento interessante para perceber a intenção em se dominar atitudes e comportamentos do corpo e - gestual do aluno em suas práticas escolares. Um dos pareceres fez considerações sobre os prejuizos que os bancos escolares poderiam causar à saude das crianças:

"Se a mesa e o banco não tiverem entre si dimensōes, que estejam em relação com a estatura do aluno, que o ocupa, este ficará sujeito às congestōes, que se manifestam pelas hemorragias nasais, às dores persistentes da cabeça, ao desvio da espinha dorsal, ao alongamento do pescoço, à dissimetria dos ombros, à própria tísica, além da miopia, ambliopia, astenopia e outras afecçōes da vista." 42

Para remediar tantos malefícios, as carteiras deveriam ter "proporcionalidade com a estatura dos alunos", e estar fixadas ao solo para impedir qualquer mobilidade dos

42 Parecer do juri sobre "Mobilia escolar" (Grupo 3). In: Primeira exposição pedagógica... - op. cit. , p. 26 
alunos, forçando-os "a tomar a posição que a higiene aconselha". 43

As medidas propostas para os estudos de leitura e de escrita foram incorporadas aos poucos pelas escolas das cidades com condições financeiras para adoção dos materiais considerados "higiênicos". No início do século, nos grupos escolares, predominaram as carteiras fixas para dois alunos mas a maioria das escolas do interior continuou com bancos e mesas.

A diferenciação das salas de aulas foi, parcialmente, espelho da divisão social, de uma sociedade altamente hierarquizada, mesmo considerando que apenas uma parcela da população possuía direito de frequentá-las.

As salas de aulas deveriam ser separadas por sexo mas nem sempre esta separação tornou-se possível para a instrução elementar. Falta de professores e de espaço forçaram as autoridades a permitir classes mistas até determinada idade. Autorizações admitindo nas escolas femininas "os alunos do sexo masculino que não houverem excedido a idade de 9 anos" não eram raras. ${ }^{44}$ A precariedade do ensino público não possibilitou, como entre os franceses, que houvesse de forma significativa livros especificos para cada sexo. As exceções foram raras e dedicadas ao ensino secundário. As diferenças dos programas curriculares limitavam-se, em geral, a substituir conteúdos de Aritmética, Cálculo ou Geometria por aulas de "costura e bordados" para as futuras mães. Meninos e meninas, em sua maioria, liam textos semelhantes, considerando-se as escolas primárias.

As escolas públicas de instrução elementar primavam pela precariedade do mobiliário, alvo de constantes reclamações dos professores e inspetores:

"Na sala de aula atijolada, três bancos encostados às paredes. Bancos altos. Os meninos, em sua maioria, ficavam

43 Idem, op. cit. -p. 28

44 Cf. Relatório de diretor de instrução da província da paraíba de 1886. Apud MOACYR, P.- Inst. e prov...-op. cit, vol.1, p. 473 
com as pernas no ar. Depois da minha entrada, puseram mais dois bancos(...)." 45

A postura dos alunos para a leitura na sala de aula fazia parte de um planejamento pedagógico que não podemos ignorar. A descrição do professor Ramon Roca sobre uma leitura "perfeita" é elucidativa para avaliar o ritual exigido para dominar o saber escolar. Depois de dissertar sobre a importância da escolha do livro pelo professor, Ramon Roca expôs a forma como ocorreu uma leitura "perfeita" na sala de aula:

"Na lição da véspera eu $1 i$ aos alunos, pedindo que os estudassem, auxiliando-se do dicionário, dois pequenos períodos tirados da "Pátria em Perigo" de Silva Jardim.(..)"

Depois de discorrer sobre o conteúdo do texto, o autor descreveu as atividades seguintes da leitura :

"-Julio, leia a lição.

o aluno, levantando-se, e ficando na posição de sentido, com o braço direito naturalmente distendido ao longo do corpo, e segurando o livro com a mão esquerda, tendo o braço levemente dobrado, de modo que o livro ficasse quase na altura dos ombros e a vista caindo obliquamente sobre a respectiva página, fez a leitura." 46

A leitura em sala de aula, em voz alta, para toda a classe deveria ser cautelosa, aprendendo o aluno a dominar a respiração, respeitando as pontuações e pronunciando com a máxima clareza, modulando a voz:

"Abusar das notas altas, isto é, elevar demasiadamente a voz, produz irremediavelmente o cansaço e a fadiga em quem lê e en quem escuta.

Demais, os vários sentimentos que podem ser expressos pelo escritor, hão de ser traduzidos por quem lê com a máxima fidelidade; (..). " 47

A prática da leitura en sala de aula era imposta pelo professor que, preferencialmente, obedecia as prescrições das autoridades educacionais e autores de livros, na

45 AMADO, Gilberto- op. cit., p. 22

46 ROCA, Ramon- Leitura expressiva. Escola Pública, São Paulo, 1 (1): 8-10, maio, 1896. Grifo do autor.

47 Idem-op. cit., $1(2): 97$, jun. 1896. 


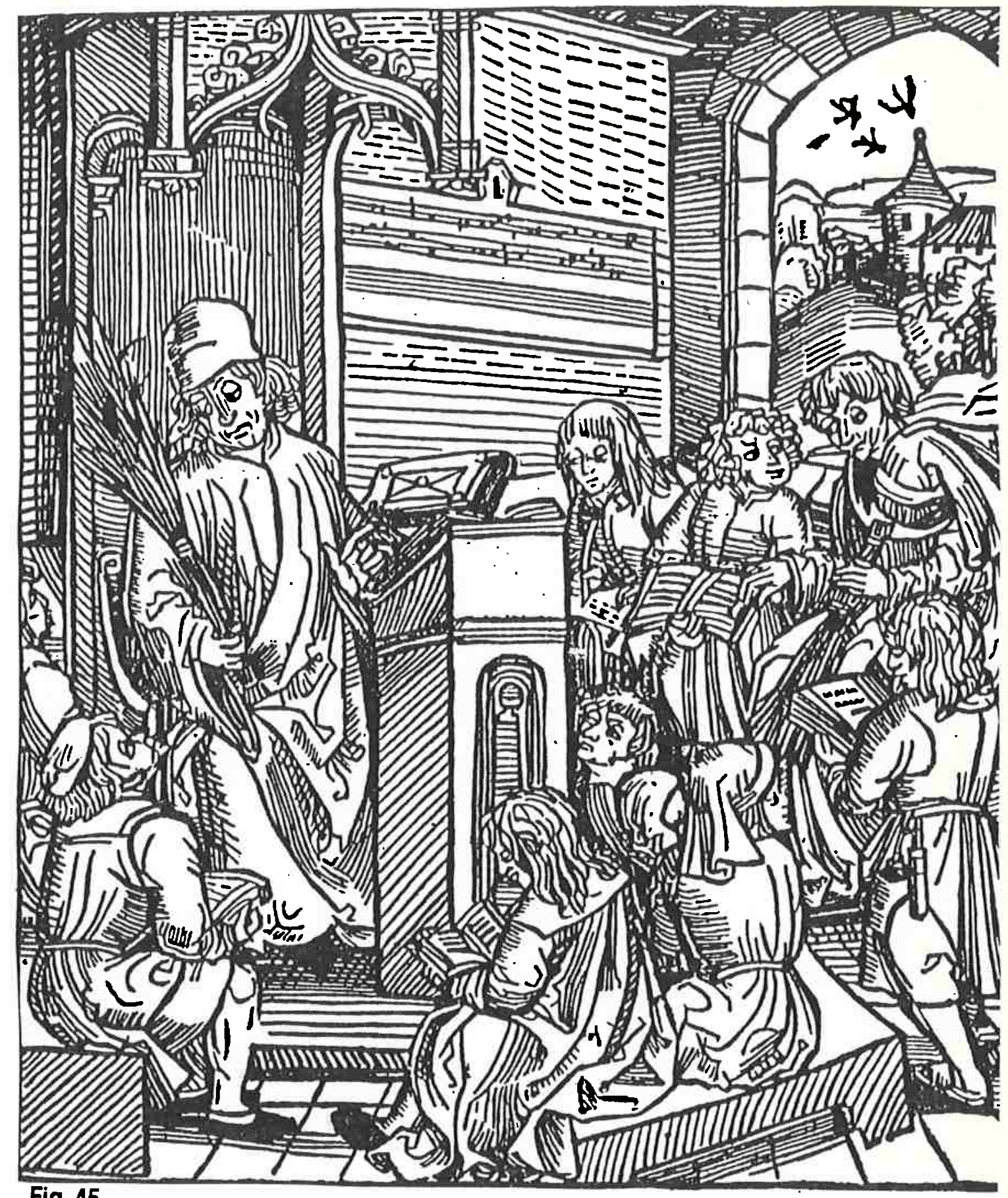

Fig. 45

Salas de aula em 1500. Bobeng, 1:60. B.N. Rio de Janeiro. 


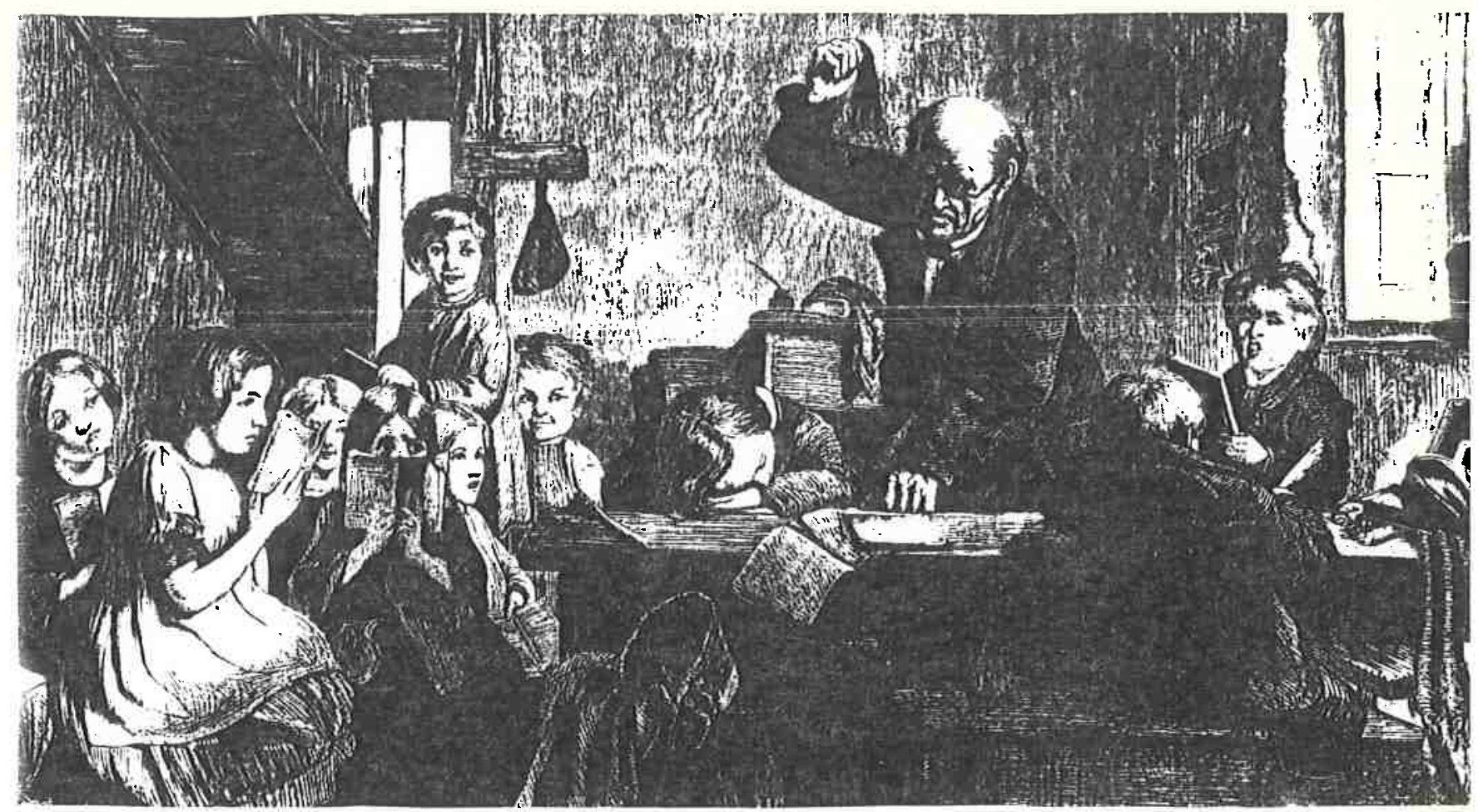

Fig. 46

O dorminhoco surpreso. H. da vida privada, v. 3, p. 159.

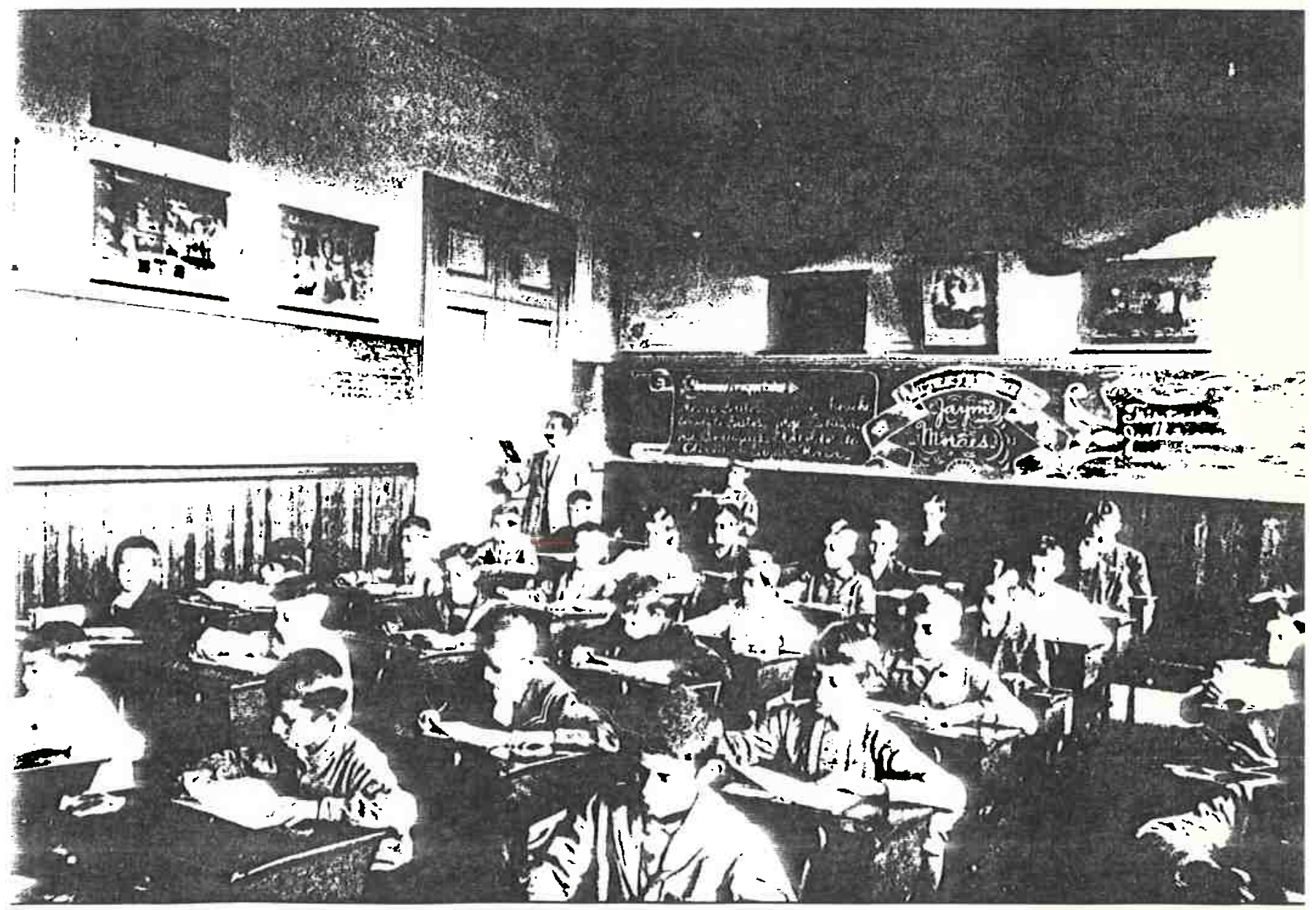

Fig. 47

Bala de aula da Caetano de Cámpos. Fotografia. Séc. XX. p. 159. 
tentativa de obter uma leitura sem "desvios", impossível de outras interpretações. o professor determinava como ler e o tempo de ler. Eram ensinadas as regras de pontuação, de respiração, de postura diante do livro e da leitura e, principalmente, do respeito ao texto escrito.

Recorrendo ainda uma vez ao barão de Macaúbas, vejamos como deveria ser o ritual da entrega ao aluno de seu primeiro livro escolar:

"Conviria muito que este primeiro livrinho não fosse posto nas mãos das crianças senão duas ou três semanas, depois de sua primeira entrada na escola. (..)

Estas duas ou três semanas, que eu chamaria de preparação para leitura sobre o papel, devem ser empregadas em exercícios de leitura de cor, aprendida pelo ouvido.

É assim que o mestre ensinaria perfeitamente de cor a seus discípulos o alfabeto seguido por ordem, $e$ a decomposição das palavras em silabas, e a recomposição destas nas mesmas palavras; e só quando eles soubessem recitar todo o alfabeto, $e$ soletrar todas as palavras contidas neste livrinho, é que ele seria posto nas mãos dos meninos, os quais, por este modo, em três ou quatro semanas mais, o leriam suficientemente bem(..)." "48

Entretanto, os professores nem sempre podiam seguir os conselhos do barão de Macaúbas ou das autoridades educacionais. Era fácil encontrar mestres que dominavam precariamente a leitura. No interior de Alagoas, Graciliano Ramos narra seu difícil aprendizado na "arte de ler":

"Samuel Smiles- Eu tinha visto esse nome várias vezes na seleta, mas, como não sabia pronunciá-1o, acostumei-me a tossir no fim das liçōes em que ele aparecia subscrevendo medonhas trapalhadas. (...)

Quando, porém, eu enrolova, tossindo, o nome do autor, faltava a emenda- e em consequência presumi, pelo menos nesse ponto, a rudeza da mulher coincidia com a minha. Certifiquei-me disso deixando de tossir e

48 BORGES, Abilio Cesar- Primeiro livro de leitura...-op. cit., p. 5. 
pronunciando Smiles de várias maneiras, sem que $D$. Angelina me repreendesse. (..) " 49

\subsection{Ler e escrever}

Aprender a ler, no século XIX, significava igualmente aprender a escrever. Este ensino simultâneo, ler e escrever, entretanto nem sempre foi um aprendizado usual. A alfabetização teve, como objetivo inicial, desenvolver o conhecimento das verdades da fé cristã, contentando-se as escolas, geralmente em formar leitores, especialmente as mulheres a quem, por muito tempo, foi negado o direito ao aprendizado da escrita.

Os métodos simultâneos foram introduzidos no decorrer do século XIX. Por seu intermédio, a criança aprendia em primeiro lugar a reconhecer todas as letras, dizendo-as em voz alta, depois começava a juntá-las, identificando as sílabas e ligando-as a palavras com algum significado. o objetivo era fazer as crianças decifrarem um código. Após esta etapa de decifração das letras ela poderia, então, ter uma caneta e papel. Começavam a traçar letras maiúsculas e minúsculas e muitas delas não passavam deste estágio, limitando-se à escrever sua "assinatura". Saber escrever corretamente, dominar uma caligrafia propriamente dita, exigia um ensino mais prolongado, com uma disciplina do corpo, das mãos que uma parte apenas da população tinha condições de fazer. 50

As rememorações de escritores famosos da nossa literatura registraram a penosa etapa do aprendizado da escrita a que foram submetidos:

"A certeza da minha burrice generalizara-se na familia.(-)Até a negra salomé já sabia soletrar e fazer. conta de diminuir.(..)Foi quando me mandaram para a aula particular de sinhá Gorda.(.) Conseguiu porém Sinhá Gorda, com paciência, empurrar as letras na minha cabeça. Maria Luisa ficava comigo a martelar as letras, a indicar as

49 RAMOS, Graciliano- op. cit., p. 193

50 Cf. INRP-Musée National de l'éducation. Lire, ecrire, compter: 2.000 ans d'alphabetisation..- op. cit. ,1981 
formas dos números, a me pegar nas mãos para os garranchos. sujara as mãos com tinta, lambuzava a roupa e aos poucos foram me chegando as palavras. Agora já sabia ligar as sílabas e escrever o abecedário. Gostava do x pela facilidade de riscar-lhe a grafia. Mas havia $0 \underline{1}$, e 0 n que tanto me confundia com as pernas, $e$ m que parecia, com milhares de pernas, com um embuá." 51

ou ainda os dissabores de un outro futuro literato famoso:

"Não me ajeitava a esse trabalho: a mão segurava mal a caneta, ia e vinha em sacudidelas, a pena caprichosa fugia da linha, evitava as curvas, rasgava o papel, andava à toa como uma barata doida, semeando borröes. De nada servia pegarem-me os dedos, tentarem dominá-los: resistiam, divagavam, pesados, úmidos, e a tinta se misturava ao suor, deixava na folha grandes manchas." 52

Para escrever era necessário tempo e ainda fazer gastos. o material escolar precário das escolas públicas obrigava os pais a fornecerem os objetos da escrita:

"Na segunda -feira voltou o menino armado com sua competente pasta à tiracolo, a sua lousa de escrever e o seu tinteiro de chifre." 53

No início do século $\mathrm{xx}$ foram incorporados novos objetos escolares mas as famílias continuavam encarregadas de fornecê-los:

"Lavaram-me, esfregaram-me, pentearam-me, cortaram-me as unhas sujas de terra. $E$, com a roupa nova de fustão branco, os sapatos roxos de marroquim, o gorro de palha, folhas de almaço numa caixa, penas, lápis, uma brochura de capa amarela, saí de casa, tão pertubado que não vi para onde me levavam." 54

Apesar das dificuldades na aprendizagem de ler e escrever, esta prática não se limitou aos setores privilegiados da sociedade. Os escravos, no convívio com

51 REGO, Jose Lins- Meus verdes anos. Rio de Janeiro: José Olympio, 1957 , p. 70

52 RAMOS, Graciliano- op. cit., p. 113.

53 ALMEIDA, Manuel Antônio de - op. cit., p. 86.

54 RAMOS, Graciliano.- op. cit., p. 107. 


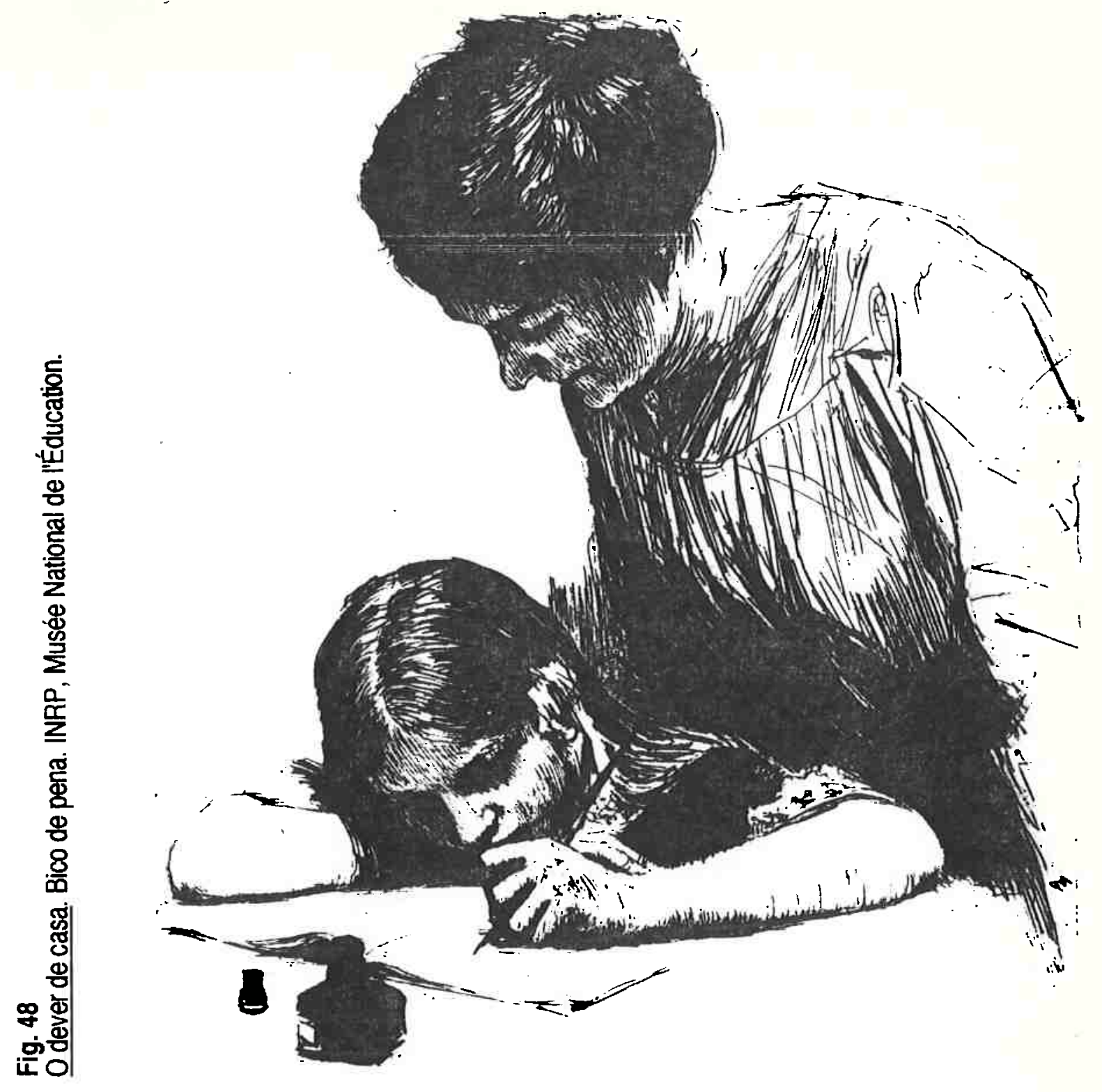

\section{Como ge dero pesar na penna.}

Pega-se na penna com os tres primeiros dedos da mão direita, a saber : o dedo pollegar, 0 index e o dedo do meio. - os dedos annulare o minimo devem ficar algum tanto dobrados, e chegados para a palma.da mão, sendo nelles que esta descansa rauando se escreve.

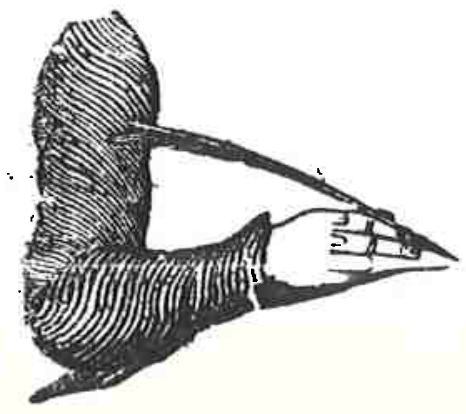

$$
\begin{aligned}
& \text { 용흘 } \\
& \text { 홍을 } \\
& \text { 킁유 } \\
& \text { 흥 }
\end{aligned}
$$

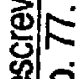

$$
\begin{aligned}
& \text { \& } \\
& \text { 용 }
\end{aligned}
$$$$
\text { 进过娄 }
$$ 
seus jovens senhores, aprendiam as lições dos professores particulares. Escravos e libertos, principalmente os que viveram em mosteiros puderam, eventualmente, desfrutar desse aprendizado. A pesquisa de Luiz Gonzaga de Piratininga sobre a escravidão do mosteiro de são Bento em São Paulo, baseouse exatamente nos registros de um desses escravos:

"Segundo suas anotações, em agosto de 1876, por exemplo, ele estava no Rio de Janeiro. Deriva desse período seu álbum de fotografias. Nele vemos negros baianos, paulistas e cariocas que sabiam ler e escrever, e muitos são ex-escravos de São Bento." 55

No difícil labirinto "do ler e escrever" os alunos nem sempre puderam gozar da paciência e amenidades dos professores. Aprender a ler e a escrever exigia muitos sacrifícios. Os memorialistas e a literatura de ficção, além dos relatórios e estudos pedagógicos estão repletos de cenas de punições nos alunos. O maior auxiliar do professor, no processo de aprendizado, além dos livros e lousa, parece ter sido a palmatória, também conhecida como férula e mais popularmente como santa luzia.

"Ele mesmo nos contava da sua aula no Pilar, onde aprendera a ler. 0 mestre era um negro vindo do sertão, homem de calibre, homem que não abria a boca para sorrir. A palmatória era a sua vara de condão. Fazia luz nos meninos à custa de surras e bolos. Cada letra que Baltasar aprendeu devia ter lhe custado uma dúzia." 56

os castigos corporais, aceitos até recentemente como um auxiliares eficazes para o aprendizado, eram utilizados para reprimir ações de indisciplina dos estudantes, como sanção infligida a contraventores da moral:

"-Venha cá! bradou o mestre.

Fui e parei diante dele. Ele enterrou-me pela consciência dentro um par de olhos pontudos; depois chamou o filho. Toda a escola tinha parado; ninguém mais lia, ninguém

55 PIRATININGa JUNIOR, Luiz Gonzaga- Dieterio dos escravos de são Bento. São Caetano do sul (SP): Hucitec/ Prefeitura Municipal, 1991, p. 92

56 REGo, Jose L.-op. cit., p. 70. Grifos meus 
fazia um só movimento. Eu, conquanto não tirasse os olhos do mestre, sentia no ar a curiosidade e o pavor de todos.

-Então o senhor recebe dinheiro para ensinar lições aos outros? disse-me o Policarpo.

$-E$ U...

-Dê cá a moeda que este colega lhe deul clamou.

Não obedeci logo, mas não pude negar nada. Continuei a tremer muito. Policarpo bradou de novo que lhe desse a moeda, e eu não resisti mais, meti a mão no bolso, vagarosamente, saquei-a e entreguei-lha. Ele examinou-a de um e outro lado, bufando de raiva; depois estendeu o braço $e$ atirou-a à rua. E então dissenos uma porção de coisas duras, que tanto o filho como eu acabáramos de praticar uma ação feia, indigna, baixa, uma vilania, e para emenda e exemplo íamos ser castigados. Aqui pegou da palmatória." 57

E a palmatoria servia para corrigir as falhas cometidas na exposição de lições ou atraso de entrega de qualquer das tarefas exigidas pelo professor:

"(..) e assim, tendo de repetir um dos exemplos da gramática, disse duas águias "avoaram", uma do oriente e outra do ocidente-. 0 mestre perguntou simplesmente- como? $E$ eu, que estava bem certo do exemplo e que não podia ter a menor consciência de o haver errado, o repeti pelo mesmo feitio com que antes havia feito e tomei os bolos; (...)" 58

A leitura e a escrita faziam-se em meio a conflitos diários, com uma socialização confusa, onde dificilmente o conhecimento era compartilhado entre os grupos. No secundário, especialmente nos internatos, a agressividade era constante. O romance $O$ Ateneu, mostra a amargura de uma experiência em um colégio afamado do Rio de Janeiro, considerado como exemplo dos avanços pedagógicos, onde a ausência da palmatória não diminuiu a violência imposta aos alunos.

o convívio escolar formava amizades e inimizades. As práticas de leitura realizadas nas salas de aula visavam individualizar, desenvolver a competição, distinguindo os

57 Assis, Machado de- Conto de escola. Belo Horizonte: Itatiaia, 1986, p. 26

58 REZENDE, Francisco de P. F. -op. cit., p. 169. Grifos meus 


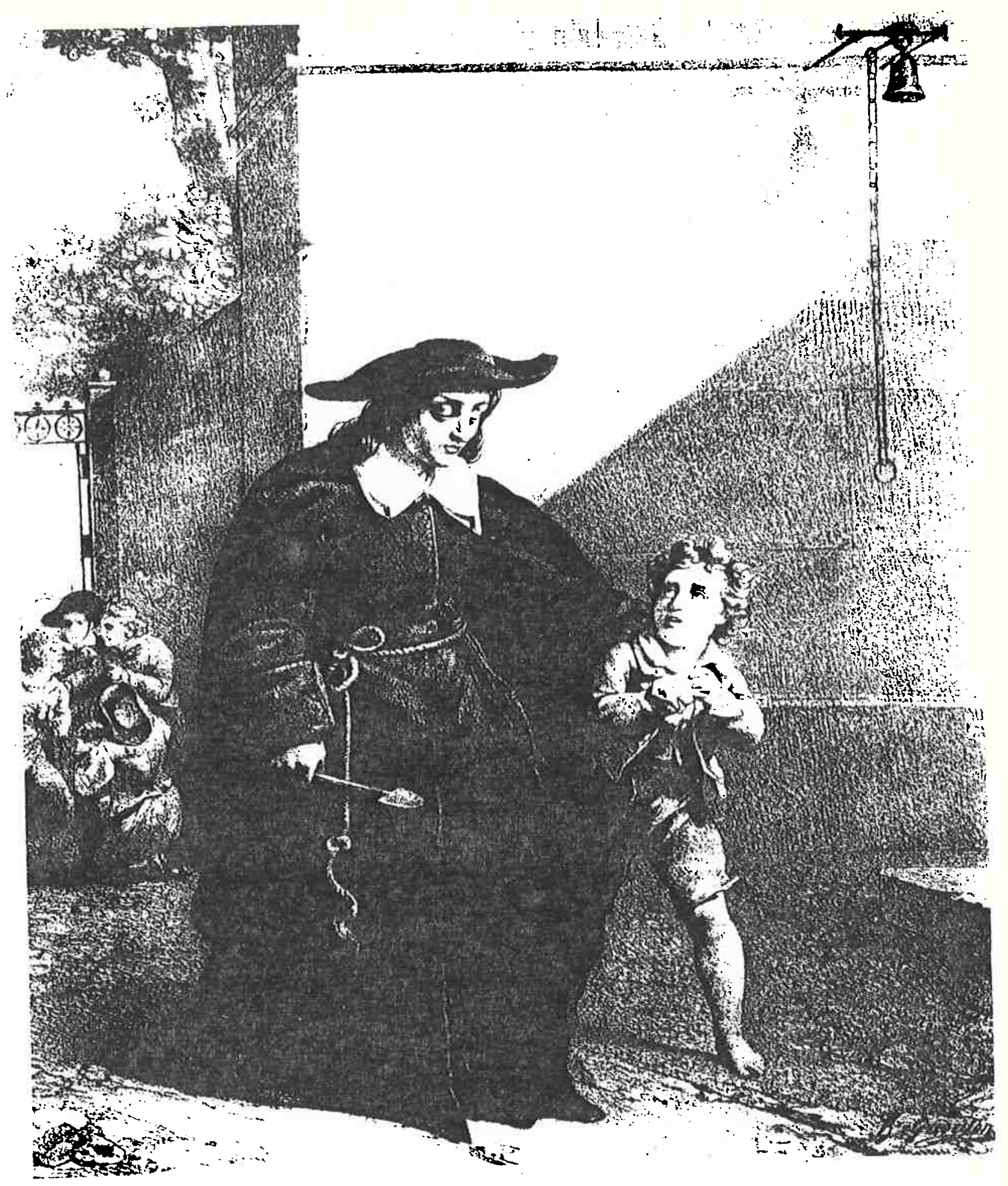

Fig. 50

A punição. Litografia do Sec. XIX. INRP, Musée N. de l'Éducation. 
melhores, em geral, beneficiando os filhos dos mais poderosos. o papel do livro nesse espaço foi, igualmente, ambíguo.

"Eu fui sempre, desde muito pequenino, muito apaixonado pela história. $E$ conquanto este estudo fosse então considerado de todos o mais difícil; e conquanto a aula quase que estivesse unicamente cheia de gente que se preparava para serem calouros; eu todavia, ali não fiz uma figura que fosse lá muito inferior a de outro qualquer.. Para que, porém, em meio de toda aquela gente eu não fizesse uma figura triste, ninguém faz idéia do imenso esforço que tive de empregar. Nem eu preciso mais do que dizer, que não tendo podido encontrar compendio um pouco mais resumido que tratasse da história do Império do Oriente, e em 24 horas cheguei a ler um grande e grosso volume, se não me engano de Segur." 59

Mas, ler os livros didáticos nem sempre foi uma prática que se configurou como um martírio para os alunos, especialmente pelas leituras que faziam fora da sala de aula, compartilhando com colegas:

"A história pátria deliciou-me em quanto pôde. Desde os missionários da catequese colonizadora, que vinham ao meu encontro, com Anchieta, visões de bondade, recitando escolhidas estrofes do evangelho da selva...Até as eras da Independência, evocação complicada de sarrafos comemorativos das alvoradas do Rocio e de anseios de patriotismo infantil.

(...)Cada página era um encanto, prefaciadas pela explicacão complacente do coleqa. Gracas à habilidade das suas apresentacões, apertei a mão aos truculentos figurōes do passado, aos mais poderosos. Antonio salema, o cruel, sorriu-me; o Vidigal foi gentil; D. João VI deixou-me rapé nos dedos. Conheci de vista Mem de Sá, Mauricio de Nassau; vi passar o herói mineiro, calmo, mãos atadas como Cristo, barba abundante de apóstolo das gentes, um toque de sol na fronte lisa e vasta, escalvada pelo destino para receber melhor a coroa do martírio."

59 Idem.-op. cit., p. 245 
A história santa revelou-me este épico, quem o diria?- cônego Roquettel $E$ eu bebi a embriaguez musical dos capítulos como o canto das catedrais. (...)" 60

o livro, além de servir para o ensino da leitura, deveria exercer a função de auxiliar o desenvolvimento da escrita.

Joaquim Manuel de Macedo foi pioneiro em introduzir no livro didático de História uma parte denominada "Perguntas", os famosos questionários que os alunos deveriam responder por escrito.

"A custa de quem foram fundados os dois núcleos coloniais de s.vicente e de Piratininga?

Quando e porque foram fundados esses dois núcleos coloniais?

Por que adotou D.João III em 1534 outro sistema de colonizar o Brasil?" 61

No final de cada capítulo continuavam as "Perguntas" com "comos", "quandos" e "porquês" que caracterizaram os demais questionários de outros livros didáticos de História, obrigando os alunos a responder, geralmente por escrito, mesmo que se limitassem a copiar as palavras do texto.

A escrita dos alunos foi incentivada pelos educadores dos métodos "intuitivos". A História pátria a ser ensinada no primário, segundo Puigari, deveria iniciar com uma participação intensa do professor na exposição dos acontecimentos:

"Narre a retirada de Nassau, suas causas e consequências; a substituição de seu governo, e os vexames que sofreu a população. Finalize a lição relatando a insurreição pernambucana mesmo contra as ordens de Portugal, mostrando aí a primeira e mais enérgica manifestação do patriotismo brasileiro" 62

60 POMPÉIA, Raul-.o Ateneu (Crônica de saudades). Rio de Janeiro: Francisco Alves, 1905, p. 55-56

61 MACEDO, Joaquim M.- Liçôes de historia..-op. cit., p. 66

62 PUIGGari, R.- A história pátria- $3^{\circ}$ ano. In: A Escola pública- op. cit., p. 95 
E depois da explicação oral, o professor deveria estimular os alunos a escrever algumas sentenças "espontâneas" sobre a lição explicada.

A leitura do livro deveria ser a sequência seguinte à explicação do professor, depois que os alunos já estivessem "tocados emocionalmente, pelo espírito e pelo coração":

"Depois então, o livro; que o leiam os alunos, mas só após a explicação do mestre; dos mais adiantados pode-se exigir o resumo escrito da lição, que, sendo bem explicada na aula, como convem, fica logo sabida por todo o auditório." 63

As "dissertações" resultantes das explicações do professor e da leitura dos livros tornavam-se repetições que não poderiam ter desvios porque os professores estavam atentos para corrigir os "erros".

No Colégio "Patrocínio" das Irmãs de são José de Chamberry, dentro do método jesuístico e do ultramontanismo adotado, a verbalização do professor era imprescindível e igualmente havia o incentivo à escrita:

"O exame de vários cadernos de alunas arquivados no colégio de Itu, mostra que esse tipo de exercício era constante, quase diário e as alunas discorriam sobre assuntos que tematizavam a vida de santos ou personagens ilustres, reais ou imaginários, cujo modo de vida pudesse ser uma constante e fecunda lição de moral e religiosidade. "64

Escrever, na sala de aula, não era uma atividade criativa mas mera repetição de temas controlados. A repetição era uma norma imposta para a leitura oral e para exercitar a escrita.

A prática mais comum na utilização do livro didático parece ter sido, no entanto, a do ditado. Os professores liam os livros, selecionando trechos que eram "ditados" para seus alunos, valendo-se desta atividade como meio de exercitar a escrita mas que servia igualmente para garantir um texto único para ser "estudado".

63 CaValcanti, J. U. op. cit.- p. 195

64 MANOEL, Ivan- op. cit., p. 231 


\subsection{Transgressões}

Os livros didáticos que passaram pelas mãos dos alunos mostram relações entre a escrita e o texto impresso que nem sempre foram condizentes com as normas prescritas. O livro, objeto sagrado, foi profanado por alguns alunos. Escrever no livro didático era uma contravenção mas, no convívio da sala de aula, alunos rabiscavam, acrescentavam informaçōes, divagavam ou se comunicavam por intermédio do "objeto sagrado".

os livros doados ou adquiridos nos "sebos" são reveladores desta faceta de "transgressão" de normas rígidas e das formas estabelecidas pelos alunos em relação ao livro.

É comum encontrar as marcas dos pontos a serem estudados ou que haviam sido explicados pelos professores. Eram marcas com " $\mathrm{X}$ ", trechos excluídos com um "não". Podemos, por estas informações dos próprios alunos, nos certificar em que medida uma disciplina cumpria o programa determinado oficialmente. As marcas dos "pontos" ou "lições" contidas em vários livros de História Geral, por exemplo, indicaram que o curso não ultrapassava o tempo medieval.

os alunos acrescentavam frases dos professores ou destacavam alguns trechos mais significativos nas margens dos livros. Em uma Lições de História do Brasil encontramos um registro significativo da criação de um dos "mitos" do nosso "atraso", registrado à tinta na primeira página do livro: "A suposição ou melhor a afirmativa de que seríamos mais adiantados se tivéssemos sido colonizados pelos holandeses". Verificando o texto do livro, esta interpretação está lá exposta em um de seus capítulos:

"Caso o Brasil fosse descoberto e colonizado por um povo amante do progresso, como os holandeses, nossos usos e costumes seriam outros, necessariamente outro seria nosso adiantamento, porque, como sabemos, tal raça, tal grau de civilização." 65

65 MAGALHĀEs, Basílio- Liçōes de história do Brasil-op. cit.., p. 15. A citação manuscrita da primeira página não tem assinatura e na página seguinte está ilegível o nome do proprietário do livro. 
Interessante foi a decisão de uma editora que, provavelmente, tentando evitar as anotações nas margens do livro, incluiu folhas sublinhadas entre cada página impressa. o usuário do livro deveria fazer as anotaçōes e complementações em tais espaços, destacando trechos e acontecimentos a serem estudados. O livro que analisamos, pertencente a um aluno, ao que parece, bastante atento, produziu uma espécie de vocabulário e anotou outras observações dos professores: "Servo: homem meio livre meio escravo.". Ou: "Circuncisão: é o ato pelo qual se é iniciado na religião judaica." 66

A escrita nos livros não foi usada apenas para. auxiliar o aluno na apreensão do conhecimento. Ela se prestou a outras formas de comunicação. Em um livro de História de uma aluna do início do século, provavelmente de uma escola Normal, estão desenhadas, nos finais dos capítulos, flores, jardins idílicos.... Os poucos espaços em branco do livro tornaram-se reveladores dos devaneios de adolescentes, de sonhos distantes da sala de aula. No mesmo livro, a alienação quanto ao estudo fica mais patente, pelo tema do recado registrado:

"Ritóca- Terça-feira, te contarei o que te prometi na aula. terça-feira, 4 de junho, de hoje a 8 dias, não é? No dia 11 de junho- Espera e verás." 67

Pudemos encontrar, portanto, nos escritos dos alunos afirmações reiterando a ideologia dominante que se disseminava mas, também nos livros estão registradas algumas formas de transgressão de uma leitura disciplinada. Pelos escritos esparsos, marginais, podemos observar alunos "bem comportados" e alunos rebeldes que, enclausurados nas salas de aula profanavam o objeto "sagrado", caricaturavam os retratos dos "homens célebres" espalhados pelas páginas dos livros de História brasileira com bigodes e outros acessórios. Nas margens de textos impressos, escreviam a

66 Anotaçōes de aluno nas páginas intercaladas do livro de BENEvides, José $\mathrm{E} . \mathrm{C}$. de Sá e- Liçōes de história da civilização. 3 a ed. Rio de Janeiro: Francisco Alves \& C., 1912

67 Anotaçóes manuscritas encontradas no livro de história de Joaquim Manuel de Macedo, pertencente a Rita de Azevedo oliveira, com data de 3 de setembro de 1907 . Desenhos e recados, p. 11 e 75 
lápis sonetos, desenhavam, ilustravam a seu modo, rearticulando seus interesses.

Professores também transgrediram as normas convencionais prescritas para a leitura e a escrita:

"Afastando a gramatiquice, ensaiava os alunos na produção literária, fazendo-os lerem e comentarem noticiários de jornais, dando-lhes exercícios de elocução e leitura expressiva, interpretação e apreciação das belezas literárias; (-)." 68

- livro didático projetado pelos educadores, passando pelos editores e autores, possuiu uma outra história nas mãos dos professores e dos alunos. Professores, jovens e crianças eram portadores de histórias diferentes, eram de regiões diversas, cujos valores e ideologias marcaram a leitura que realizavam, mesmo considerando o caráter impositivo e diretivo com que o livro didático construía o texto a ser lido.

Existiram diferentes professores e diferentes práticas escolares. As formas dos professores se relacionarem com os textos didáticos variaram entre uma atitude de total dependência e outra que fazia do livro um objeto capaz de informá-lo, de atualizálo sobre o conhecimento a ser transmitido. Alunos e professores confrontavam-se na sala de aula, no espaço criado para transmitir o saber escolar. Ler e escrever era um aprendizado difícil, que exigia uma disciplina do corpo, uma forma nova de organizar o tempo das crianças e jovens em um espaço que estava se estruturando em classes e séries, com idades delimitadas.

- livro didático deveria desempenhar o papel de homogeneizador do saber escolar, de reforçar os métodos de ensino baseados na memorização, em uma escola concebida como transmissora dos conhecimentos das diferentes disciplinas. o livro didático deveria ser utilizado como instrumento de memorização, ocasionando a prática do "saber de cor". paginas e páginas eram repetidas oralmente, diante do professor e dos companheiros, inculcando um conhecimento

68 Referências às aulas de Silva Jardim na Escola Normal de São Paulo em 1887. In: ESCOBAR, J.- op. cit., p. 169 
superficial de difícil avaliação quanto à sua efetiva apreensão.

Com a divulgação dos métodos intuitivos, os livros foram se transformando visualmente, buscando, autores e editores, através de uma linguagem mais adequada $e$, principalmente, pelas imagens, aproximar-se dos alunos e motivá-los no domínio da cultura escrita. As mudanças dos livros não representaram, entretanto, transformações quanto aos métodos de ensino. A aprendizagem continuou sendo entendida como a capacidade de retenção pela memória, dos conhecimentos escolares. Para facilitar esse processo, os livros didáticos foram sendo acrescidos de exercícios e questionários que passaram, igualmente, a ser "decorados" pelos alunos.

As concepções de ensino e aprendizagem fundamentaram, assim, a elaboração da literatura escolar, prescrevendo as formas de uso do material, evitando, cuidadosamente "desvios" de leitura. Estudar as práticas de leitura que professores e alunos realizaram na sala de aula, conduziunos, entretanto, a perceber o livro em sua dimensão mais ampla e em sua ambiguidade inerente. o livro didático era o instrumento que possibilitava ao aluno dominar a leitura e indiretamente a escrita. Facilitava a apreensão de um conhecimento mais elaborado, divulgando o saber erudito e sistematizado com o qual os alunos poderiam ampliar sua visão de mundo. Mas as práticas de leitura dos livros didáticos estabelecidas pelo ritual escolar eram também instrumentos de dominação ideológica tanto pelo seu conteúdo explícito como pelo seu "conteúdo oculto", determinante de posturas hierarquizadas, de submissão a um conhecimento que impedia dúvidas e questionamentos. Diante dessas imposições uns poucos registros demonstraram algumas brechas $e$ principalmente, os conflitos capazes de levar a outras transformações quanto à transmissão e produção do saber escolar. 
Compêndios, cartilhas, catecismos, livros de leitura foram compondo o acervo didático das escolas, avolumando-se e circulando cada vez mais pelas mãos de professores e alunos. O crescimento da produção acentuou-se com a expansão gradual das escolas elementares, distinguindo a natureza e o uso da literatura escolar. A. "gênese" do livro didático, apreendida a partir da sua criação paralelamente à da escola pública, recuperou o processo por intermédio do qual pudemos perceber as singularidades, permanências, mutações e recomposições diversas dessa produção cultural.

Livros de leitura mesclaram-se a uma nascente literatura infantil e compêndios passaram a ser definidos como um gênero peculiar de produção literária, portadores das noções essenciais de uma ciência cujos textos deveriam obedecer aos programas escolares.

A concepção iluminista que presidiu a construção dos manuais escolares conferia ao texto impresso um poder entendido como meio de impedir qualquer outra leitura a não ser a pretendida pelo autor e editor e de, efetivamente, transmitir um conhecimento novo de forma integral. Concebido como instrumento de trabalho do professor em sala de aula e auxiliar em sua formação autodidata, o livro foi se tornando um manual de uso diário dos alunos e com a variedade de leitores novos problemas surgiram para sua confecção.

Tratando-se de uma obra controlada, o Estado teve de elaborar uma legislação especial para o livro didático, criando mecanismos burocráticos de vigilância. Os "desvios" da produção tendiam a crescer à medida em que se espalhava sua fabricação pelas províncias, levando o governo a articular-se com algumas casas editorais sediadas no Rio de Janeiro cujos interesses comerciais poderiam ser cooptados em uma política cultural conjunta que visava disseminar o saber letrado para parcelas da população, integrando-se à modernidade ocidental. 
o aval do governo significava vendagens garantidas e o livro escolar foi se tornando o texto impresso preferencial de empresas que cuidavam de difundí-lo a nível nacional por intermédio de uma rede de livrarias, reforçando a ideologia oficial na divulgação de um ensino escolar uniforme $e$ padronizado.

A estruturação material do livro didático continha uma forma de composição que direcionava o leitor, introduzindose uma diagramação e uma organização tipográfica que evidenciavam relações espaciais entre títulos e capítulos, liçōes e sumários e entre o escrito e as imagens. Cada vez mais diferenciava-se a leitura de acordo com as idades, criando-se estilos peculiares para essa literatura. A linguagem era necessariamente simples e familiar para desenvolver a inteligência sem fatigar, com uma dosagem de termos técnicos graduados segundo as idades ou séries que começavam a se estruturar nas escolas elementares ou secundárias.

Os livros didáticos acompanhavam as divisões entre a infância e a adolescência. Criava-se para a infância a noção da criança "bem educada", a criança escolar padronizada pelos primeiros livros de leitura. Separada da infância, surgia a adolescência configurada como a "idade crítica", fase da identidade sexual detectada pelos internatos que cuidavam de estabelecer regras cuidadosas para uma "idade perigosa" tanto para o indivíduo quanto para a sociedade. Rapazes e moças passaram a ser objeto de investigação, cabendo aos livros escolares identificar e acentuar claramente as separações sexuais e etárias determinadas pela escola.

Os aperfeiçamentos técnicos nas artes gráficas colaboraram para a construção de uma literatura especial para a infância, com um acervo de ilustraçōes que se ampliou incessantemente. Dificuldades de ordem econômica e ausência de políticas industriais impediram o desenvolvimento de uma produção verdadeiramente nacional do livro escolar. Ao lado das questōes econômicas, razões culturais e ideológicas fomentaram o intercâmbio com a produção francesa que se 
constituiu no padrão dominante para os livros didáticos brasileiros durante os cem primeiros anos de sua história.

Entre os propósitos das autoridades educacionais e dos editores, situavam-se os escritores dos textos escolares encarregados de transpor os conhecimentos específicos de uma determinada área do saber erudito para o saber escolar.

Acompanhando a elaboração realizada pelos autores de livros de História, detectamos a inviabilidade de se pensar a literatura didática como uma produção que evoluiu de forma gradual e contínua. As alternâncias que sofreu em seu percurso prenderam-se às transformações provenientes das disciplinas com suas "crises" e às transformações do meio escolar. As propostas da "nacionalização" dos conteúdos didáticos são representativas de um desses momentos de turbulência, podendo-se assistir ao nascimento de determinadas obras mais audaciosas que se destacaram, impondo-se como uma espécie de "modelo" referencial, sendo posteriormente plagiadas.

Dependendo do "lugar" de onde provinha o autor, pudemos identificar interpretações históricas variadas e contraditórias mesmo considerando a dependência do livro frente aos programas curriculares. Os livros didáticos expressaram as divergências e os conflitos inerentes do saber histórico proposto enquanto disciplina escolar. A disputa entre História sagrada e civil ficou flagrante na produção escolar do período. Opuseram-se autores defensores da História veiculada pelo poder religioso católico dos que pretendiam a laicização do passado e do devir histórico. opuseram-se os positivistas impregnados das teorias francesas de imperialismo e os que iniciavam a luta por uma História centrada nos problemas internos de um país mestiço onde as classes dominantes se dividiam diante da questão da escravidão e do papel histórico das classes trabalhadoras.

A defasagem das obras didáticas, na atualidade, em relação à historiografia e pedagogia não foi a tônica do período inicial de sua criação. Parte significativa dos autores era proveniente do meio acadêmico, vivenciando o processo de construção da História erudita. A obra didática 
era produzida concomitantemente ao processo de criação da História oficial, sendo difícil identificar um "atraso" em relação à produção dos institutos conceituados, tais como o IHGB. Um número considerável de historiadores utilizou a obra didática como um instrumento privilegiado na divulgação do conhecimento que elaborava.

Apesar da tendência das autoridades em direcionar a produção de uma memória histórica escolar única, capaz de desenvolver o sentimento nacional, com um passado histórico homogêneo, sem conflitos ou contradições, os livros didáticos não expressaram esse caráter. As variaçōes ocorreram a nível do conteúdo histórico e do discurso pedagógico que se ampliava com o desenvolvimento dos estudos educacionais.

As experiências vivenciadas pelos autores em sala de aula interferiram na construção dos textos, desempenhando o papel de formador dos métodos de ensino, servindo como complemento ou prolongação das lições orais dos mestres. Os livros didáticos foram sendo acrescidos de baterias de exercícios que fundamentavam os métodos de aprendizagem mas que, em essência, não transformaram a aprendizagem baseada exclusivamente na memorização.

Por intermédio dos livros didáticos pudemos, então, identificar as concepçōes de aprendizagem no decorrer da expansão da escolarização do século XIX. As mutações que ocorriam com a escolarização vinculavam-se à ampliação do conceito de cidadania e que não podia mais restringir-se a formar futuras elites aristocratizadas.

Em meio aos nascentes debates entre currículo "humanístico" e "científico", entre método "tradicinal" e "método intuitivo", o livro escolar expressava igualmente as dificuldades na constituição de uma sociedade letrada que vivia mergulhada na tradição da transmissão oral. A memorização, base metodológica do ensino de uma sociedade que estava enraizada em um aprendizado pela repetição e pela oralidade, impregnou a construção dos livros escolares. A questão que resultou dessa construção foi a diferenciação 
das formas de recepção do público leitor frente a esse. material didático.

As leituras que se fizeram com o livro didático nem sempre seguiram as normas impostas uma vez que se tratava de uma produção cultural que atingia um público numeroso, heterogêneo, portador de representações sociais diferenciadas que dificilmente fariam leituras idênticas, sem "desvios".

Os autores, ao elaborarem os textos escolares, realizavam uma transposição didática que se completava pelo trabalho do professor em sala de aula. A apreensão do conhecimento escolar pelo aluno não correspondeu a um processo harmonioso e tranquilo. As salas de aula foram espaços onde ocorreram conflitos, castigos corporais, exclusões e transgressões. A história da leitura em suas práticas escolares possibilitou desvendar tais mecanismos de atuação à medida em que obrigou a situar todos os agentes do processo educacional.

Ao elucidarmos o saber escolar definido e praticado nas escolas por intermédio de um material didático amplamente utilizado, pretendemos avançar nas análises parciais da historiografia educacional que tem se limitado, geralmente, a denunciar o caráter elitista e precário da educação do período. Trabalhando, na maioria dos casos, com as categorias de "dependência cultural" e "importação de idéias" e utilizando-se de fontes tradicionais como a legislação e relatórios oficiais, tais pesquisas chegam a conclusões semelhantes à da historiografia idealista produzida pelos escolanovistas: uma elite poderosa mas incapaz não soube conduzir a educação para a maioria da população ou que propostas "importadas" não foram condizentes com a realidade do país, mesmo aceitando o fato de que a educação não foi jamais intencionalmente voltada para a nação em seu conjunto.

Acreditamos, contrariamente, que o saber escolar construído e praticado nas escolas da época foi eficazmente conduzido e efetivado, tendo as elites burguesas criado uma escola edequada aos seus interesses. Elas assimilaram o 
saber escolar "importado", recriando-o e moldando-o para a manutenção de seus privilégios e buscaram transmitir o conhecimento científico e escolar de acordo com a representação social que engendravam. Entretanto, as mudanças e tensões sociais obrigaram-nas a repensar a escola, criando-se dissidências entre os próprios grupos do poder ou próximo a ele.

A abordagem da história do livro escolar utilizando um método de análise abrangente, envolvendo as diversas facetas de sua natureza, permitiu-nos apontar para novas investigações no campo educacional. A inserção do livro didático na história das disciplinas é uma delas.

A pesquisa sobre a história das disciplinas deve ser entendida como pertencente à história educacional mas não como mero acessório. Abordagens que concebem a disciplina em sua autonomia, como criadora de um saber próprio, permitem novas problemáticas para a história do ensino e aprofundamento das questões epistemológicas do conhecimento produzido para e pela escola.

A história do livro didático nos mostrou a necessidade de se rever a historiografia educacional que tem situado os marcos de mudanças significativas ou a revolução de 1930 ou a instalação do governo republicano. As soluções oferecidas pelo poder constituído, monárquico ou republicano, não foram tão diferentes como parte da historiorafia tem procurado demonstrar, desvinculando a inserção dos projetos educacionais junto ao liberalismo que sustentava os dois regimes politicos. Ao acompanharmos o percurso de algumas obras escolares verificamos que conteúdos e práticas escolares não se transformaram radicalmente. A tutela da Igreja não desapareceu com a simples separação do Estado. Livros escolares modelados pelos princípios católicos continuaram a permear o quotidiano das escolas públicas e formavam-se jovens, em número crescente, nas escolas privadas confessionais protegidas e subvencionadas pelo poder governamental. Reedições constantes de livros didáticos indicam uma continuidade que merece reflexão atenta. Nesse sentido é que apontamos para o desvendamento 
do saber escolar como necessário para se repensar a escola brasileira em seus diferentes momentos, em suas mudanças mas também como pertencente a um tempo mais longo.

A história do livro didático forneceu-nos elementos para entender a continuidade de seu uso. Nele estão contidos o "conteúdo explícito" e o método de ensino, discursos que viabilizam uma prática na sala de aula, nas mais variadas circunstâncias educacionais. Pudemos igualmente confirmar as constatações de pesquisas sobre este material didático que destacam seu papel na reprodução do conhecimento que o poder educacional vigente pretende impor. o saber escolar contido no livro escolar, entretanto, passa pela intervenção dos professores $e$ alunos que podem transformar esse veículo ideológico em instrumento de trabalho, de socialização do saber sistematizado. o livro didático tem sido um dos raros objetos culturais possíveis de veicular um conhecimento organizado e sistematizado com certo rigor e em condições de circular em meio a um público leitor heterogêneo cujo saber é fortemente construído pela intervenção das mídias. É evidente que o livro, pelo seu caráter de mercadoria inserido na lógica da indústria cultural, tem sido objeto mais de vulgarização do conhecimento do que divulgador de um saber capaz de auxiliar os alunos em seu processo de domínio de leituras críticas. Podemos, entretanto, pela continuidade de pesquisas que não se limitem a expor seu caráter ideológico e reprodutor, avançar em métodos de leituras mais abrangentes, como a que aqui buscamos realizar, desvendando a complexidade da natureza do livro didático e disseminando tais metodologias junto aos professores, principais agentes da construção do saber escolar. o uso dos manuais pode ser múltiplo, pode instigar a produção de conhecimento e, principalmente, a história do livro didático nos mostrou que ele pode sofrer mutações qualitativas. 


\section{FONTES E BIBLIOGRAFIA}

\section{FONTES}

\section{Manuscritas}

Arquivo da editora Itatiaia -Belo Horizonte:

Contratos do editor B.L. Garnier com o conêgo Joaquim Caetano Fernandes Pinheiro dos anos de 1865, 1867, 1869, $1870,1873$.

Contratos do editor B. L. Garnier com o autor Joaquim Manuel de Macedo dos anos de 1864, 1865, 1871.

Contrato do editor B. L. Garnier com o autor Visconde de Taunay no ano de 1882 .

Correspondência entre B. L. Garnier e o Conêgo Joaquim Caetano Fernandes Pinheiro nos anos de 1867 e 1870 .

\section{Impressas}

\section{Catálogo das editoras}

Catálogo de obras instrutivas e recreativas para infância da Casa de $E . \& H$. Lxmmert. Rio de Janeiro, 1862.

Catálogo $n^{\circ} 6$ dos livros de Agricultura, Geografia, matemática, economia rural e doméstica, taquigrafia, música, desenho, colonização, arte militar, magnetismo, maçonaria, etc.. Rio de Janeiro. E. \& H. Læmmert, 1872.

Novo catálogo sistemático de escolhidos livros em português. Rio de Janeiro: Livraria Universal de E.\& H Lammert, 1882.

Catálogos da editora Nicolau Alves \& C..Rio de Janeiro, 1883. 
Catálogos da Editora Francisco Alves C. Rio de Janeiro, 1891 a 1910 .

Catálogos da B. L. Garnier. Rio de Janeiro, 1865, 1869, 1874,1882 .

Catálogo Geral- Livraria Garnier. Rio de Janeiro, 1928.

Catálogo F. Briguiet \& Cia. (Ex-Livraria Garnier)., Rio de Janeiro, 1936 .

Catálogo da F.T.D.- Coleção de livros clássicos. são Paulo, 1909 .

Catálogo da Exposição de História do Brasil. Rio de Janeiro: Biblioteca Nacional do Rio de Janeiro, Typ. de Leuzinger \& Filhos, 1881 .

Catálogo das obras existentes na Biblioteca Popular do Liceu de Artes e ofícios. Rio de Janeiro, 1890.

Catálogo da Biblioteca do Museu Escolar Nacional. Rio de Janeiro: Typ. de G. Leuzinger \& Filhos, 1885 .

Catálogo do material de livros aprovados para uso das escolas públicas primárias no ano de 1891. Revista Pedagógica. Rio de Janeiro,v. 21891.

\section{Livros didáticos de História do Brasil}

ALBUQUERQUE, Salvador Henrique- Compêndio da História do Brasil. 2a ed. Pernambuco: G. de Lailhacar, 1869 . ALBUQUERQUE, Salvador Henrique d'- Resumo da história do Brasil. Pernambuco: Tip. Imparcial, 1848

ANDRADE, Maria Guilhermina Loureiro de- História Pátria. [s. n.] 
ARAUJO, Francisco Leutz- Geografia do estado de Minas Gerais seguida de noções de história do mesmo estado. Rio de Janeiro: Livraria Clássica de Alves \& Cia., 1895.

BARAO DO RIO BRANCO- História do Brasil. Trad. Joāo Vieira de Almeida. Esboço escrito para Le Brésil em 1889 publicada sob a direção do Sr. F. J. Sant'anna Nery. São Paulo: Livraria Teixeira, 1894

BELLEGARDE, Henrique Luiz de Niemeyer- Resumo da história do Brasil. Rio de Janeiro: Tip. Dous de dezembro de P. Brito, $1855,4 \underline{a}$ ed.

BELLEGARDE, Pedro Alcântara- Introdução corográfica à história do Brasil. Rio de Janeiro, Tip. de J.E.S. Cabral, 1840

BILAC, Olavo e COELHO NETO- A pátria brasileira. Rio de Janeiro: Livraria Francisco Alves, 1911.

CORUJA, Antonio Alvares Pereira. Lições de história do Brasil. Rio de Janeiro: Tip. Do Fígaro de Aguiar \& Velloso, 1877

FREESE, João Henrique- Compêndio de geografia e história seguido de um breve epítome sobre os globos e seus círculos e de uma tabela cronológica dos principais acontecimentos da história do Brasil, desde seu descobrimento até a coroaçāo de S.M.I. D.PedroII. Rio de Janeiro: Tip. de J. E. S. Cabral, 1842

FREIRE, Felisberto- História do Brasil- I grau. Rio de Janeiro: Livraria Clássica de Alves, 1896

FREITAS, Dr. Joaquim de- Noçōes de geografia e história do Brasil.7a ed. Pará: Tip. Comercial de L. da Costa Junior, s.d.

GALANTI, Rafael Maria de- Biografia de brasileiros ilustres. São Paulo: Duprat \& Cia, 1911

LACERDA, Dr. Joaquim Maria de- Pequena história do Brasil por perguntas e respostas para uso da infância brasileira. Rio de Janeiro: Garnier, 1887.

LIMA, José Inácio de Abreu-Compêndio da história do Brasil. Rio de Janeiro: Eduardo \& Henrique Læmmert, 1843. 2v. LIMA, José Inácio de Abreu- Compêndio de história do Brasil. Rio de Janeiro: Eduardo \& Henrique Lammert, $18441 \mathrm{v}$. 
MACEDO, Joaquim Manuel de- Lições de História do Brasil para uso dos alunos do Imperial Colégio de Pedro II. Rio de Janeiro: Tipografia Imparcial de J.M.N. Garcia, 1861.

MACEDO, Joaquim Manuel de- Lições de história do Brasil para uso das escolas de instrução primária. Rio de Janeiro: Garnier, 1875.

- Mulheres célebres. Rio de Janeiro:

B.L. Garnier, 1878

MAGALHĀES, Basilio de- Lições de História do Brasil. São Paulo: Tip. Ribeiro, 1895.

MAIA, Dr.Luis de Queirós Mattoso- Liçōes de história do Brasil proferidas no internato do imperial Colégio de Pedro II. Rio de Janeiro: D. da Silva, s.d.

MASCARENHAS, Annibal- Curso de história do Brasil. Rio de Janeiro: Livraria do Povo de Quaresma \& Cia Livreiroeditores, 1898

MELO, Américo Brasiliense de Almeida- Lições de história pátria. São Paulo: Tip. da Província, 1876.

MENEZES VIEIRA, - Nossa história pátria (Quadros murais da história do Brasil)- Rio de Janeiro : Francisco Alves, 1891. MOURA,Dr. Caetano Lopes de- Epítome cronológico da história do Brasil, para o uso da mocidade brasileira. Paris: P. Aillaud, Moulon \& Cie, 1860.

OLIVEIRA, José Joaquim Machado- Quadro histórico da província de São Paulo para uso das escolas de instrução pública. São Paulo: Marques, 1864.

PINHEIRO, J. C. Fernandes- Episódios da história Pátria contados à infância Rio de Janeiro: Garnier, 1860.

PINHEIRO, José Pedro Xavier-Epítome da História do Brasildesde seu descobrimento até 1857- adotado para uso das aulas públicas de ensino primário. Rio de Janeiro: Tip. Læmmert, $1860,1 \mathrm{v}$.

PINTO Alfredo Moreira- Epítome da História do Brasil. Rio de Janeiro: Livraria Clássica de Alves \& Cia, 1892.

-Pontos de historia do Brasil organizados

segundo o novíssimo programa dos exames gerais de Instrução Pública. Rio de Janeiro:I.G. Azevedo, 1881. 
PRALON, A. e MATTOSO, E.- Quadro sinótico e cronológico da história do Brasil. Rio de Janeiro: J. D. de Oliveira, 1879 REIS, Antonio Alexandre Borges do- Corografia e história do Brasil especialmente do estado de são Paulo. Bahia: Litotip. Wilcke, Picard \& Cia. 1898.

RIBEIRO, João- História do Brasil- edição das escolas primárias. Rio de Janeiro: Livraria Francisco Alves, 1900.

- História do Brasil.Rio de Janeiro: Livraria Francisco Alves, 1900

ROCHA, Antonio Vieira da- Resumo da história do Brasil. Rio de Janeiro: Livraria da Viuva Azevedo \& Cia- editores, 1905.

ROMERO, Silvio- A história do Brasil - ensinada pela biografia de seus heróis. Rio de Janeiro: Livraria Clássica de Alves, 1890.

Sá e MENEZES, Estácio de- História do Brasil contada aos meninos. Rio de Janeiro: Garnier, 1870.

SANTOS, Lery- Epítome da história do Brasil. Rio de Janeiro: Nunes de Oliveira, 1876.

SEIXAS Romualdo Antonio de- Synopse da história do Brasil composta sob um plano especial para instrução primária e secundária. Bahia: Typ. de Affonso Ramos \& C. , 1878.

SILVA, João Manuel Pereira da - Curso de história dos descobrimentos, colonização, instituições, civilizaçāo, independência e progresso até nossos dias dos diferentes estados americanos. Rio de Janeiro: Eduardo \& Henrique Lxmert, 1876.

SILVA, J. Norberto - Brasileiras célebres. Rio de Janeiro: Livraria de B.L. Garnier ; Paris: Garnier Irmāos Editores, 1862 .

SOUSA, Herculana Firmina Vieira de- Resumo da história do Brasil- uso das escolas primárias. São Luiz: Bellarmino de Mattos, 1868.

VILLA-LOBOS, R.- História do Brasil (resumo didático). Rio de Janeiro: Companhia Tipografica do Brasil- antiga tipografia Lammert, 1891. 


\section{Livros de Historia Geral}

AZEVEDo, Dr. Moreira de- Compêndio de história antiga. 5a ed. Rio de Janeiro: B.L. Garnier, 1883.

BENEVIDES, José E.C. de Sá- História da Civilização.3a ed. Rio de Janeiro: Francisco Alves, 1912 .

BERQUó, João Maria da Gama- História Antiga do oriente. Rio de Janeiro: Livraria Clássica de Alves \& C., 1887.

BERQUó, João Maria da Gama - História da Grécia e de Roma. Rio de Janeiro: Livraria Classica de Alves \& C., 1887.

CALógeras, J.B.-_Compêndio da História da Idade Média. Rio de Janeiro: B. L. Garnier Livreiro-editor, 1859.

DANIEL Monsenhor- Curso de História Universal. Trad. Joaquim Maria de Lacerda. Rio de Janeiro: Garnier, 1871 a $1877,4 \mathrm{v}$.

DURUY, Victor- Compêndio de História Universal. Trad. padre Francisco Bernardo de Souza .Rio de Janeiro: B. L. Garnier, 1865

FLEIUS, Max -Elementos de Historia contemporânea.(18151897). Rio de Janeiro: Lammert, 1900

LACERDA, Joaquim Maria de - Compêndio de história universal.

Paris: Guillard, Aillaud \& C., 1882.

LEITÃo, Antonio Pereira- Pontos de história média e antiga, conforme os programas de exames preparatórios em 1876 e 1878. Rio de Janeiro: Nicolao Alves, 1876 e 1878.

JUNIOR, A.Q. A.- Pontos de história para prova escrita compilados conforme o novo programa de 1883 . Rio de Janeiro: I.G. Azevedo, 1883.

HISTORIA UNIVERSAL (rudimentos). Trad. D. Maria Emília Leal. Rio de Janeiro: Alves \& Cia., 1893

PARLEY Pedro- História Universal resumida (para uso das escolas comuns dos Estados Unidos da América do Norte) Trad. Desembargador Lourenço José Ribeiro. 3 a ed.,. Rio de Janeiro: Læmmert, s.d..

PEDROSO, $\mathrm{z}$. Consiglieri. Manual de história universal. Paris: Guillard, Aillaud \& C., 1884. 
PELITZ, H. L.- Resumo de história Universal para uso das aulas de história e geografia. São Paulo: Costa Siqueira, 1839.

POMBO, Rocha- Compêndio de História da América- Rio de Janeiro: Lxmmert \& C. Editores, 1900 .

RIBEIRO, João- História do Oriente e Grécia. Rio de Janeiro: Alves \& C., 1893.

Resumo da História Contemporânea desde 1815 até 1865 por um professor. Rio de Janeiro: B.L. Garnier; Paris, Augusto Durand Livreiro, 1866.

ROCHA, Justiniano José da - História Antiga - Rio de Janeiro: Tipografia do Regenerador de J. da Rocha, 1860, Iv. - Idade Média. Rio de Janeiro:

Typographia do Regenerador de Justiniano da Rocha, 1860, 2v. SERRANO, Jonathas- Epítome da História Universal. 17 ạ ed. Rio de Janeiro: Livraria Francisco Alves, 1937.

TRINOCQ, Camillo- Curso de estudos elementares. (coleção de tratadinhos separados: Resumo da história da Europa antiga; Resumo da história da Europa durante a idade média; Resumo da história da Europa moderna. Rio de Janeiro: Garnier, s.d.

WEBBER- História universal. Tradução brasileira s/ nome do tradutor. Rio de Janeiro :Cunha \& Irmãos, 1895

\section{Livros didáticos citados (outras disciplinas e estrangeiros))}

ALBUQUERQUE, Salvador Henrique- Compêndio de geografia universal, especial do Brasil e da província de Pernambuco. 2a ed.Rio de Janeiro: Eduardo \& Henrique Læmmert, 1880.

ALMEIDA E SA, Luiz de França- Compêndio de geografia da província do Paraná. Rio de Janeiro:Eduardo \& Henrique Læmmert, 1871

ALMEIDA, Julia Lopes de- o livro das donas e donzelas. Rio de Janeiro: Francisco Alves \& C., 1906.

AMARAL, Tancredo do- Geografia elementar. 8 a ed. Rio de Janeiro: Livraria Francisco Alves \& Cia., 1904. 
AMARAL, Tancredo do- o Estado de São Paulo- ensino cívico.. Rio de Janeiro;São Paulo: Alves \& C., 1896.

ARAUJO, Francisco Leutz- Geografia do estado de Minas Gerais seguida de noçōes de história do mesmo estado. Rio de Janeiro: Livraria Clássica de Alves \& Cia., 1895.

BARBOSA, Ricardo-Instrução moral e cívica. 1ạ ed. Rio de Janeiro: H. Lombært \& Cia., 1895.

BARKER, Antonio Maria- Rudimentos aritméticos (completada por um professor). Rio de Janeiro: Nicolau Alves, 1891.

BILAC, Olavo e COELHO NETO- Contos pátrios. Rio de Janeiro: Francisco Alves \& Cia., 1904.

BILAC, Olavo e BONFIM- Manuel- Através do Brasil. 38 a ed. Rio de Janeiro: Livraria Francisco Alves, 1951.

BORGES, Abilio Cesar- Primeiro livro de leitura para uso da infância brasileira. Paris: Alllaud, Guillard, 1867.

- Segundo livro de leitura para uso da infância brasileira. Paris: Aillaud, 1867.

CAIRU, José da Silva Lisboa (visconde de)-Cartilha da escola brasileira para instrução elementar na religião do Brasil. Rio de Janeiro: Tipografia Nacional, 1831.

CARVALHO, Felisberto de- Primeiro livro de leitura. Rio de Janeiro: Alves \& Cia., 1892.

- Segundo livro de leitura -ornado de numerosas ilustrações, sendo parte coloridas.Rio de Janeiro: Alves \& Cia., 1892.

CosTA, D. Antonio de Macedo- Resumo da história bíblica ou narrativas do Velho e Novo Testamento. Nova-York: Carlos \& Nicolao Benziger irmãos, [1872].

DALIGAULT - Curso prático de pedagogia ; trad. Joaquim Pires Machado Portella. Rio de Janeiro: Tip. universal, 1865. DE AMICIS, Edmundo- Coração. Trad. João Ribeiro. Rio de Janeiro: Alves \& C., 1891.

DEGERANDO, Marie Joseph-Curso normal para professoras das primeiras letras. Trad. João C. Deus Silva. Niterói: Tip. Niteroi, 1839.

DURUY, Victor- Nouveau manuel du baccalauréat És Lettreshistoires Ancienne, du Moyen Age et des Temps Modernes, 
regidigé conformément aux programmes de 1852. Paris: L. Hachette et Cie., 1853

FLEURY - Catecismo histórico em compêndio resumindo a história sagrada e a doutrina cristã. Rio de Janeiro: Felix Ferreira, s.d.

FRAZÃo, Manuel José Pereira- Noções de geografia do Brasil. Rio de Janeiro: Tipografia Esperança de J. Aguiar \& Cia, 1883

GALVÃo, J. R.- Silabário Português-ou novo método para aprender a ler em breve tempo a lingua portuguesa e o sistema métrico. [s. n.], ( 1879?).

GAMA, Ayres de Albuquerque- Noções de física e química. 2 a. ed. Rio de Janeiro:Eduardo \& Henrique Læmmert, 1876.

LACERDA, Dr. Joaquim Maria de-Novo atlas universal da infância. Rio de Janeiro: Garnier; Paris: Frères Garnier, s. d.

- Tesouro da Infância ou novo manual das escolas primárias. Rio de Janeiro: B.L. Garnier, 1885.

LAVISSE, Ernest- Histoire de France- cours élémentaire. Paris: A.Colin, 1887 .

-Nouveau manuel d'histoire. Paris: Hachette,

1883.

MACEDO, J.M. de- Notions de chrographie du Brésil. trad. J.F. Halbout. Leipzig: Imprimerie de F. A. Brockhauss, 1873. MAIA, Dr. Muniz - Tesouro das escolas. Rio de Janeiro: Alves \& Cia, 1 v., s.d.

MOURA, Dr. Caetano Lopes de- A mitologia da mocidade. Paris: Aillaud, Monlon \& Cie., 1856

NERY, Raymundo- Noçōes gerais de geografia universal contendo particularmente a geografia do império do Brasil e a da província do Amazonas. Paris: Guillard Aillaud,s.d. Novo manual de geografia- curso elementar. São Paulo: F.T.D., 1907.

oTTONI, C.B. - Elementos de aritmética. Rio de Janeiro: Eduardo \& Henrique Læmmert, 1846.

PARANAGUÁ (Marquês de)-Elementos de geometria. Rio de Janeiro: Typografia Universal de Lxmmert, 1846. 
PARENTE, Alberto Petroni Martins Maciel-Cartilha Imperial para uso do senhor D. Pedro II. Pará: Justine H. da Silva, 1840.

PEREIRA, P. Antonio- Novo método da Gramática Latina.Rio de Janeiro: B.L. Garnier, 1881.

PINHEIRO, J.C.Fernandes- História sagrada ilustrada. Rio de Janeiro: B. L. Garnier, 1866.

PINTO, Alfredo Clemente- Seleta em prosa e verso dos melhores autores brasileiros e portugueses. $24 \mathrm{a}$ ed.. Porto Alegre: Selbach \& Mayer, 1912.

PINTO Alfredo Moreira - Rudimentos da corografia do Brasil.2a ed. Rio de Janeiro: Alves \& Cia, 1891.

- Geografia das províncias do Brasil.2a ed. Rio de Janeiro: Livraria Nicolau Alves, 1885. PUIGARRI, Romão- Coisas Brasileiras. Rio de Janeiro: Francisco Alves e C., 1896.

REIS, Francisco sotero dos - Postilas de Gramática Geral aplicada à lingua portuguesa pela análise dos clássicos. Maranhão: Bellarmino de Mattos, 1870.

RIBEIRO, Julio Cesar- Gramática portuguesa para uso dos alunos de 1 ạ letras.São Paulo: Jorge Seckler,1881

REIS, Antonio Alexandre Borges do- Corografia e história do Brasil especialmente do estado de são Paulo. Bahia: Litotip. Wilcke, Picard \& Cia. 1898.

ROCHA, Justiniano José da- Coleção de fábulas imitadas de Esopo e de La Fontaine.9a ed. Rio de Janeiro: Francisco Alves \& Cia. Paris: Aillaud, Alves \& Cie, 1913. ROCHA, Landelino- Primeiro livro de leitura ou Carta do A$B-C$ para uso da infância brazileira.2a ed. Recife: J.W. Medeiros, 1877, .

infância brasileira Recife: J.W. de Medeiros, 1883. ROQUETTE, J. I.- Alfabeto português ou novo método para aprender a ler. Rio de Janeiro: E.\&H. Lxmmert, 1862.

-Ornamentos da memória e exercícios seletos para formar o bom gosto e verdadeiro estilo pela língua portuguesa, extraídos dos melhores clássicos em prosa e verso... Rio de Janeiro: B.L. Garnier, 1877 
RUBIM, Joaquim Frederico Kiappe da Costa- Novo método de gramática portuguesa. Rio de Janeiro: Eduardo \& Henrique Læmmert, 1862.

SAFFRAY Dr.- Lições de Coisas.- para uso das classes de instrução primária. Porto: Chadron; Rio de Janeiro: Livraria Alves, s. d.

SILVA, J. Diogo Esteves da- Elementos de instrução moral e cívica. Rio de Janeiro: Alves \& Cia., 1897.

SCROSOPPI, Horácio- Pequenas liçōes de instrução moral. são Paulo: Duprat \& Cia., 1909.

SEIGNOBOS, Charles- Histoire de la civilisation- Au MoyenAge et dans les temps Modernes. Paris,: Masson, 1886. TRAJANO, Antonio- Algebra elementar. Rio de Janeiro: Leuzinger \& Filhos, 1888.

- Aritmética elementar ilustrada. 136a ed.

Rio de Janeiro: Francisco Alves, 1958. (1 1 a ed. 1879)

VIEIRA, Menezes- $O$ amiguinho de nhonhô- leitura corrente $e$ expressiva. Rio de Janeiro: Alves \& Cia. e Paris:Guillard, Aillaud. , 1895.

VILLA-LOBOS, R.- Corografia do Brasil (resumo didático). Rio de Janeiro: Læmmert \& Cia- editores, 1906.

\section{Literatura pedagógica-século XIX}

ALMEIDA, José R. Pires de- L'instruction publique au Brésil: histoire et législation. Rio de Janeiro: Imp. Leuzinger \& Filhos, 1889.

-História da Instrução Pública História e Legislação. Trad. Antonio Chizzotti. São Paulo/EDUC; Brasília/INEP MEC, 1989.

AZAMBUJA (Conselheiro)-Doutrinas pedagógicas e elementos de instrução pública organizados para o uso das escolas de ensino primário. Pará: Tip. do Livro do Comércio, 1884. BARBOSA, Rui - Reforma do ensino secundário e superior. Parecer e projeto. Rio de Janeiro, Imp. nacional, 1882. 
BARBOSA, Rui- Reforma do Ensino Primário e várias Instituições Complementares da Instrução Pública, V. X.. Rio de Janeiro: Imprensa Nacional, 1883.

BARROSO, José Liberato - A instrução pública no Brasil. Rio de Janeiro: B.L. Garnier, 1867.

BINZER, Ina Von- Os meus romanos- Alegrias e tristezas de uma educadora alemã no Brasil. Trad. Alice Rossi e Luisita da Gama Cerqueira. Rio de Janeiro: Paz e Terra, 3a ed., 1982.

BORGES, Abílio Cesar, barão de Macahubas-Vinte anos de propaganda contra o emprego da palmatória e outros meios aviltantes no ensino da mocidade. Fragmentos de vários escritos publicados no "Globo" em 1876. Bruxelas: Tip. e Litografia E. Guyot, 1880.

CALKINS, Norman Allison- Primeiras lições de cousas; trad. Rui Barbosa. Rio de Janeiro, Imp. nacional, 1886.

CARVAlHo, Leoncio de- 1ạ Exposição pedagógica no Rio de Janeiro. Rio de Janeiro: Tip. Nacional, 1884

CAYRU- José da Silva Lisboa, visconde de- Escola brasileira ou instrução útil a todas as classes. Rio de Janeiro: Typ. de P. Plancher-Seignot, $1827,2 \mathrm{v}$.

CosTA, Manuel Olympio Rodrigues da- Métodos e programas de ensino nas escolas primárias; adoção de compêndios. Rio de Janeiro: Tip. Nacional, 1884. Trabalho apresentado no Congresso de Instrução do Rio de Janeiro.

MAGALHÃES, Valentim - Lições de pedagogia . Rio de Janeiro: Lxmmert \& Cia editores, 1900.

PARANHOS, José Maria da Silva- Cartas ao Amigo ausente. Rio de Janeiro, Ministério das Relaçōes Exteriores - Instituto Rio Branco, 1953.

SousA, Paulino José Soares de- Instrução pública • Rio de Janeiro: Tip. nacional, 1870 .

VERISSIMO, José- A educação nảcional. Pará: Editores Tavares Cardoso \& Cia, Livraria Universal, 1890.

VIEIRA Joaquim José de Menezes- o pedagogium brasileiro. Rio de Janeiro, Tip. Camões, 1892.

VIEIRA, Menezes- Treze anos de Magistério no Rio de Janeiro 1875 a 1887. Rio de Janeiro: Laemmert \& C., 1887. 
FORJAZ, Djalma- Do ensino e fiscalização nos institutos de instrução secundária equiparados ao ginásio nacional.são Paulo, Tipografia Maré, Monti \& C. [1907].

ATAS E PARECERES do Congresso de Instrução do Rio de Janeiro de 1882. Rio de Janeiro: Imprensa Nacional, 1884 .

Conferências efetuadas na Exposição Pedagógica. Rio de Janeiro: Tipografia Nacional, 1884.

\section{Historiografia- sec . XIX}

BEAUCHAMP, Alphonse de- Histoire du Brésil. Paris: Alexis Eymery, 1815

-L'Indépendance de l'Empire du Brésilpresentée aux monarques européens. Paris: Chez Delaunay, 1824.

CONSTANCIO, Francisco Solano- História do Brasil desde Alvares Cabral até a abdicação do imperador D.Pedro $I$. Paris: J. P. Aillaud, 1839. 2 vol.

DENIS, Ferdinand- Résumé de l'histoire du Brésil-suivi de résumé de I'histoire de la Guyane. Paris, Lecomte et Durey Librairies, 1825.

MARTIUS von- Como se deve escrever a história do Brasil. Revista do Instituto Histórico e Geográfico. Rio de Janeiro VI, 1845, pp. 381-95.

LIMA, José Inácio de Abreu-Compêndio da história do Brasil. Rio de Janeiro: Eduardo \& Henrique Læmmert, 1843. 2v.

PINHEIRO, Dr. Joaquim Caetano Fernandes- Estudos históricos. Rio de Janeiro: Garnier, 1876, 2 vol.

SOUTHEY, Robert- História do Brasil. trad. Dr. Luiz Joaquim de Oliveira e Castro e anotada pelo Cônego Dr. J. C. Fernandes Pinheiro. Rio de Janeiro: Livraria de B.L. Garnier, 1862, Tomo I

TAUNAY, Hyppolyte et DENIS, Ferdinand- Le Brésil. Paris: Nepveu, 1822 .

VARNHAGEN, Francisco Adolfo- História geral do Brasil. Rio de Janeiro :E.\& H. Laemmert, 1854-1857- 2 tomos em 1 vol. 


\section{Relatórios}

Relatório Gonçalves Dias. Instrução pública em diversas províncias do Norte, 1852. Vol. 12 Col. de Memórias, fls. 336 a 375 .

Relatório sobre o estado da Instrução Pública provincial no ano de 1854 apresentado ao $\mathrm{Exm}^{\circ}$ presidente da Província pelo inspetor geral da mesma Instrução Pública, Diogo de Mendonça Pinto. São Paulo: Tipografia 2 de dezembro, 1855.

Relatório sobre o estado da Instrução pública da província de São Paulo no ano de 1871, apresentado ao $\mathrm{Exm}^{\circ}$ presidente da Província pelo inspetor geral da mesma instrução pública Diogo de Mendonça Pinto. São Paulo: Tipografia Americana, 1872 .

Relatório sobre o estado da Instrução Pública na província de São Paulo no ano de 1879 apresentada ao presidente da província Dr. Laurindo Abelardo de Brito pelo inspetor geral Francisco de Souza Carvalho. Santos: tipografia à vapor do Diario de Santos, 1880 .

CAVAALCANTI João Barbalho Uchoa- Relatorio apresentado ao presidente de Pernambuco- estudo sobre o sistema de ensino primario e organização pedagógica das escolas da Corte, Rio de Janeiro, São Paulo e Pernanbuco. Recife:Typ. de Manoel Figueiroa de Faria \& filhos, 1879.

Relatório apresentado ao $\mathrm{Exm}^{\circ}$ Dr. Jorge Tibiriçá, presidente do Relatório sobre escolas de $1^{\circ}$ e $2^{\circ}$ graus anexas à escola Normal pelo Dr. Caetano de Campos. São Paulo, Typ. de Vanorden \& Cia., 1891.

Relatório da Escola Normal de S. Paulo apresentado ao Dr. da Costa Bueno por Gabriel Prestes. São Paulo, Typographia do "Diario official, 1897. 
Relatório da Escola Normal apresentado ao dr.Alfredo Pujol por Gabriel Prestes. São Paulo, Typographia do "Diario official", 1896.

Programas de ensino para o ano letivo de 1894. Escola Normal de São Paulo. São Paulo: Tipografia a vapor de Vanorden, 1894 .

\section{Legislação e regulamentos de ensino}

1827- lei de 15 de outubro

1834 - Ato Adicional

1854- Reforma de Couto Ferraz

1870- Reforma Paulino de Souza

1879- Reforma de Leôncio de Carvalho

1890- Reforma de Benjamin Constant

Programa para os exames preparatórios em 1883. Rio de Janeiro, Diario oficial, 1883.

Regimento interno das escolas públicas do Estado de são Paulo. São Paulo, Tipografia do Diário Oficial, 1894.

Regulamento da Escola Normal de São Paulo. São Paulo, Tipografia do Correio Paulistano, 1887.

Leis e regulamentos sobre Instrução Pública. São Paulo: Tipografia do Diário Oficial, 1893.

\section{Revistas}

Revista Popular. 1859 a 1862. Rio de Janeiro: B.L. Garnier Editor

Revista do Ensino- 1883. Rio de Janeiro: Neville- Francisco Alves de Oliveira. 
Revista de Ensino- 1902 a 1907. São Paulo: Typ. do "Diário oficial" - revista da Associação Beneficente do professorado público de são Paulo

Revista Pedagógica- 1890 a 1894

Revista Didática- 1903 a 1906

\section{Anuários}

Anuário do Ensino do Estado de São Paulo. São Paulo: Siqueira \& Cia.- 1907-1908.

Anuário do Ensino do Estado de São Paulo. São Paulo: Tip. do "Diario Oficial" - 1909-1910

\section{Memórias e literatura}

ALMEIDA, Manuel Antonio de-Memórias de um sargento de milícias Belo Horizonte: Itatiaia, 1977.

AMADO, Gilberto- História da minha infância. 3 ạ ed. Rio de Janeiro: Liv. José Olympio., 1966.

LUCCOCK, John- Notas sobre o Rio de Janeiro e partes meridionais do Brasil. trad. Milton da Silva Rodrigues. Belo Horizontz: Itatiaia; São Paulo: EDUSP, 1975.

MORAES, Evaristo de- Reminiscências de um rábula criminalista. Rio de Janeiro; Belo Horizonte: Editora Briguiet, 1989

NABUCO, Joaquim - Mínha formação. Rio de Janeiro: José Olympio, 1957.

MACHADO DE ASSIS- Várias histórias. Rio de Janeiro: Livraria Garnier, 1989.

MEDEIROS, Albuquerque- Minha vida- da infância à mocidadememórias (1867-1893). Rio de Janeiro: Calvino Filho, 1933 POMPéIA, Raul- O Ateneu. (Crônica de saudades). Edição definitiva (conforme originais e os desenhos deixados pelo autor). Francisco Alves \& Cia.. Rio de Janeiro, 1905.

REZENDE, Francisco de Paula Ferreira de - Minhas recordaçōes. Rio de Janeiro: José Olympio, 1944. 
KOSERITZ, Carl von- Imagens do Brasil. Trad. Afonso Arinos de Melo Franco. Belo Horizonte: Itatiaia; São Paulo: EDUSP MEDEIROS E ALBUQUERQUE- Minha vida- da infância à mocidade. Rio de Janeiro: Calvino Filho Editor, 1933

NAVA, Pedro- Chão de ferro-memórias/3. Rio de Janeiro: José Olympio, 1976

RAMOS, Graciliano- Iñfância (Memórias), 5ạ ed. São Paulo: Martins Ed., 1961

REGo, José Lins- Meus verdes anos. Rio de Janeiro: José Olympio, 1957

\section{BIBLIOGRAFIA CITADA (livros, teses e artigos)}

ABUD, Katia Maria-o livro didático e a historiografia. In: Anais do Seminário Perspectivas do ensino de história. são Paulo: FEUSP, 1988, p. 202-209

ALMEIDA, Isaias Alves de - Esboço da vida e obras do Amigo dos meninos. Bahia: Imp. Oficial do Estado, 1924.

ALVES, Claudia M. da Costa- A reforma de 1847: significado da criação do Liceu Provincial de Niterói. Dissertação de Mestrado- Universidade Federal Fluminense, Niterói, 1990.

AMALVI, Christian - De l'art et la manière d'accommoder les héros de I'histoire de France- De Vercingétorix à la Revolution-, Paris: Albert Michel, 1988.

AMALVI, Christian- Les héros de l'Histoire de France, Paris: Phot'œil, 1979.

ANDRADE, Antonio Alberto da Banha- A reforma pombalina dos estudos secundários no Brasil. São Paulo: EDUSP/Saraiva, 1978

APPLE, Michael W.- Edúcação e poder. Trad. Maria Cristina Monteiro. Porto Alegre: Artes Médicas, 1989

ARIES, Philippe e DUBY Georges (orgs) Histoire de la vie privéé. De la Révolution à la Grande Guerre -T. 4. Paris: Éditions du Seuil, 1987

ARIES, Philippe- Historia social da criança e da família. Trad. Dora Flaksman .2 a ed. Rio de Janeiro: Guanabara, 1986 
ARROYO, Leonardo- Literatura infantil brasileira - ensaio de preliminares para sua história e suas fontes. São Paulo: Melhoramentos, 1968.

AZZI, Riolando (org)- A vida religiosa no Brasil- enfoques históricos. São Paulo: Edições Paulinas, 1983.

BAKTHIN, Mikhail- A cultura popular na Idade Média e no Renascimento. Trad. Yara Frateschi Vieira. São Paulo, Hucitec/ Editora Universidade de Brasília, 1987.

BARBANTI, Maria Lúcia A.H.-Escolas americanas de confissão protestante na Província de São Paulo: um estudo de suas origens. Dissertação de Mestrado- Faculdade de Educação da USP, São Paulo, 1977.

BAUDEMONT, Suzanne - L'histoire et la légende dans l'école elementaire victorianne 1862-1901. Paris: Klincksieck, 1980 BERGER, Manfredo- Educação e dependência. Porto Alegre: Difel, 1976 .

BLAKE, Sacramento- Dicionário Bibliográfico Brasileiro. Rio de Janeiro: Imprensa Nacional, 1937

BRASIL, Etienne- La France au Brésil. Rio de Janeiro: Besnard Frères, 1920

BRESCIANI, Stella - Liberalismo: ideologia e controle social- um estudo sobre São Paulo. Tese de Doutorado. F.F.L.C.H./USP, São Paulo, 1976

BURKE, Peter -Cultura Popular na Idade Moderna. Trad. Denise Bottmann. São Paulo: Cia. das Letras, 1989

CARVALHo, Delgado de - Introdução metodológica aos estudos sociais. Rio de Janeiro: Agir, 1970

CHARTIER, Roger- A História Cultural-entre práticas e representaçōes. Trad. Maria Manuela Galhardo. Lisboa: DIFEL; Rio de Janeiro: Bertrand do Brasil, 1990 - As práticas da escrita. Ariès Philippe; Chartier Roger (org) História da vida privada- Da Renascença ao Século das Luzes. Trad. Hildegerd Feist. São Paulo: Companhia das Letras, 1991

et MARTIN H. J. (org) Histoire de l'Edition française. Paris: Promodis, 1982 a 1985. 
CHERVEL, André -L'Histoire des disciplines scolairesRéflexion sur un domaine de recherche. Histoire de I'éducation. Paris INRP, 38: 59-119, mai 1988.

-História das disciplinas escolares:

reflexões sobre um campo de pesquisa. Teoria \& educação. Porto Alegre 2: 107-118, dez. 1990/abr. 1991.

- Quando surgiu o secundário? Trad. Circe

M. F. Bittencourt. Revista da Faculdade de Educação. São Paulo, 18 (1): 99-112, jan./ jun., 1992

CHOPPIN, Alain - L'histoire des manuels scolaires: une approche globale. Histoire de I'éducation. Paris, INRP, 9: 1-25, déc. 1980 .

- Le livre scolaire. Histoire de l'édition française. t. 4: Le livre concurrancé, 1900-1950/Publié sous la dir. de Henri-Jean Martin; Roger Chartier et Jean- Pierre Vivet. Paris: Promodis, 1986, p. 280-305.

- Perspectives de recherche sur l'histoire du livre scolaire. Rapport manuscrit. Paris: INRP- SHE, 1979 CRUBELIER, Maurice-L'enfance et la jeunesse dans la société française 1800-1950. Paris: Armand Colin, 1979

- De l'histoire sainte à l'histoire de France. Les Cahiers Aubois, Paris, $\mathrm{n}^{\circ}$ spécial, 1986.

- Lire, 1880- 1980. Au cœurd'une histoire

culturelle. Histoire de I'Education, Paris, INRP, 53: 3-13, jan. 1992

DOMINIQUE, Julia- Livres de classe et usages pédagogiques dans Histoire de l'édition française, T.2: Le livre triomphant (1660-1830), 1986, p.468-497.

ESCOBAR, José Ribeiro - Histórico da instrução paulista. Revista de Educação. São Paulo, 4(4): 138-140, dez. 1933.

FALCON, Francisco José Calazans- A época pombalina: política econômica e monarquia ilustrada. São Paulo: Atica, 1982

FRANCO, Maria Sylvia - As idéias estão no lugar. Cadernos de Debates. São Paulo, n 1, 1976

FREITAG, Bárbara et alii-o livro didático em questão. são Paulo: Cortez, 1989

FURET, François- o nascimento da história. In: A oficina da história. Trad. Adriano D. Rodrigues. Lisboa: Gradiva, s. d. 
GARIN, E.- $L$ ' éducation de I'homme moderne. Paris: Fayard, 1968.

GAULUPEAU, Yves- L'Histoire en images à l'école primaire. Un exemple: La Révolution française dans les manuels élémentaires (1870-1970). Histoire de I'Éducation, Paris, 30:29-52, mai 1986

GINZBURG, Carlo- o queijo e os vermes. Trad. Betania Amoroso. São Paulo, Companhia das Letras, 1987.

GLENISSON, Jean - Le livre pour la jeunesse. Histoire de l'édition française- Du Romantisme à la Belle Epoque. Paris: Promodis/ Centre National des Lettres, p.417 à 443 .

GLEZER, Raquel- Novos livros e velhas idéias. Revista. Brasileira de História, 7, Rio de Janeiro, Marco Zero, 1984 HAIDAR, Maria de L. M.- O ensino secundário no Império brasileiro. São Paulo: EDUSP/Grijalbo, 1972

HALLEWELL, Laurence - O livro no Brasil (sua história). São Paulo: T. A. Queirós/ EDUSP, 1985.

HOBSBAWM, Eric J. - Nações e nacionalismo desde 1870programa; mito e realidade. Trad. M. Celia Paoli e Anna Maria Quirino . Rio de Janeiro: Paz e Terra, 1990.

HOLANDA, Sérgio Buarque de- o Brasil monárquico - Do Império à República. São Paulo: Difel, 1972, 5 v., t. II

HOLLANDA, Guy de- Um quarto de século de programas e compêndios de história para o ensino secundário brasileiro 1931-1956. Rio de Janeiro: INEP/MEC, 1957

INRP- Musée National de l'Éducation. Lire, écrire, compter: 2.000 ans d' alphabétisation. Rouen,1981

INFANTOSI, Ana Maria- $A$ escola na república Velha. São Paulo: EDEC, 1983.

JULIA, Dominique- Enfance et citoyenneté. Bilan historiographique et perspectives de recherches sur l'éducation et l'enseignement pendant la période révolutionnaire. Histoire de I'éducation. Paris, INRP, 49: 348, jan. 1991 .

KUBO, Elvira Mari- A legislação e a instrução pública de $I$ a letras na 5 a comarca da Província de São Paulo (Paraná), 1827-1853. Tese de Doutorado. São Paulo: F.F.L.C.H. da USP, 1982 . 
LAJOLO, Marisa -Usos e abusos da literatura na escola.Bilac e a literatura escolar na República velha. Rio de Janeiro: Globo, 1982

-o livro didático: velho tema revisitado. Em aberto, Brasilia, 6(35):1-9, jul.set. 1987.

LE GOFF, Jacques- Histoire et mémoire. Paris: Gallimard, 1986 .

LEITE, Miriam Moreira L.- O ensino de história no primário e no ginásio. São Paulo: Cultrix, 1969

- Uma construção enviesada: a mulher

e o nacionalismo. Ciência e Cultura. São Paulo, 42 (2): 144149 , fev.1990.

LIMA, Mario de Barbosa- Les français dans l'histoire du Brésil. Trad. Clément Gazet. Rio de Janeiro: F. Briguiet/ Paris: Albert Blanchard, 1923

MANOEL, Ivan Aparecido- Igreja e educação feminina: os colégios das Irmãs de são José de Chambéry (1859-1919). Tese de Doutorado. São Paulo, F.F.L.C.H./USP, 1988.

MARTIN, H. J.- Livre, pouvoir et societé à Paris au XVIIè siècle (1598-1701). Genève: Dioz, 1969

- Le livre français sous l'Ancien régime. Paris:

Promodis, 1987

Perrin, 1988.

- Histoire et pouvoirs de l'écrit. Paris:

MARTINIèRE, GuY , CARDOSO, Luiz Claudio- France- Brésil vingt ans de coopération (science et technologie). Paris: IHEAL/ PUG, 1989.

MARTINS, Ana Luiza- Gabinetes de leitura da província de São Paulo: a pluralidade de um espaço esquecido (1847-1890). Dissertação de Mestrado.São Paulo, F.F.L.C.H./USP, 1990.

MATTOS, Ilmar Rolhoff- $O$ tempo saquarema. São Paulo: Hucitec; Brasília: INL, 1987.

MATTOSO, Katia de Queiroz-Bahia, século XIX-Uma Província no Império. Rio de Janeiro: Nova Fronteira, 1992.

MENEZES, Raimundo de - As primeiras e mais antigas livrarias de São Paulo. Revista do Arquivo Municipal, São Paulo, 182: $195-218,1971$ 
MOACYR, Primitivo - A instrução e as províncias. São Paulo: Editora Nacional, $1940,3 \mathrm{v}$.

- A instrução e o império. São Paulo: Editora

Nacional, 1936-37. $4 \mathrm{v}$.

MORAES, Carmem S. Vidigal- A socialização da força de trabalho- instrução popular e qualificação profissional no Estado de São Paulo- 1873 a 1934. Tese de Doutorado. São Paulo, F.F.L.C.H./USP, 1990.

MOREIRA, Antonio Flavio B. - Currículos e programas no Brasil. Campinas: Papirus, 1990

MOURÃO, Paulo K. Correa- o ensino em Minas Gerais no tempo do Império. Belo Horizonte [s.n.]

NADAI, Elza - o ginásio do Estado de São Paulo: uma preocupação republicana' 1889-1896). (Estudos e Documentos), São Paulo: FEUSP, 1987.

NOGUEIRA, Emilia- Alguns aspectos da influência francesa em são paulo na segunda metade do século XIX. Revista de História, 7(16):317-34, dez.1953.

NUNES, Clarice- (org)- O passado sempre presente. São Paulo: Cortez, 1992.

OLIVEIRA, J.B. A., GUIMARĀES S.D.P., BOMéNY H. M. B.- A política do livro didático. São Paulo: Summus; Campinas: Ed. UNICAMP, 1984 .

PFROMM NETTO S.; ROSAMILHA N.; DIB, C.Z.- O livro na educação. Rio de Janeiro: Primor, INL, 1974.

PILETTI, Nelson- Evolução do currículo do curso secundário no Brasil. Revista da Faculdade de Educação, São Paulo, 13, (2) : p.27-72, jul./dez, 1987

PINHEIRO, Mario Portugal Fernandes- Apresentação da Terceira Edição do Curso de Literatura Nacional.Rio de Janeiro: Cátedra., 1978.

PIRATININGA Junior, Luiz Gonzaga - Dietério dos escravos de São Bento. São Caetano do Sul: Hucitec/Prefeitura Municipal, 1991.

PROST, Antoine- Histoire de 1 'enseignement en France 18001967. Paris: Armand Colin, 1968. 
RIBEIRO, J. Quirino- A memória de Martim Francisco sobre a reforma dos estudos na capitania de são Paulo; ensaio sobre a sua importância e significaçōes. Separata do Boletim LIII da F.F.C.L. da Universidade de São Paulo, 1945.

RIBEIRo, Maria Luiza Santos- História da educação brasileira. São Paulo: Cortez, 1986.

RIZZINI, Carlos-o livro, o jornal e a tipografia no Brasil (1500-1822). São Paulo: Imprensa Oficial do Estado, 1988

SCHWARCZ, Lilia K. Moritz- os guardiães da nossa história oficial. Os institutos historicos e geográficos brasileiros. São Paulo: IDESP, 1989

SEVCENKO, Nicolau- Literatura como missão: tensões sociais e criação cultural na Primeira República. São paulo: Brasiliense, 1983

SODRé, Nelson Werneck- História da imprensa no Brasil. Rio de Janeiro: Civilização Brasileira, 1966

TAKEYA, Denise Monteiro- Europa, França e Ceará a expansão comercial francesa no Brasil e as casas comerciais. Tese Doutorado. São Paulo, F.F.L.C.H./USP, 1992.

TRENARD, Louis- Une Révolution...La naissance du manuel scolaire, 1760-1800. Les Cahiers Aubois, Paris, $\mathrm{n}^{\circ}$ spécial, 1986.

Universidade Estadual de Campinas - Catálogo Analítico - Que sabemos sobre livro didático. Campinas: Editora da Unicamp, 1989.

XAVIER, Maria Elizabete. Poder político e educação de elite. São Paulo: Cortez, 1980.

ZAMBONI, Ernesta- Que historia é essa? uma proposta analítica dos livros paradidaticos de História. Tese de Doutorado. Campinas, Unicamp, 1991.

ZILBERMAN , R.- o livro didático e o ensino da literatura na escoła. Ciência e Cultura, são Paulo, 38 (5):836-44, maio $19 \varsigma 6$. 


\section{HISTORIA DO BRAZIL}

J. Mr. Lacerda, Pequena historia do Brazil. Garnier, \& ed. Sylvio Roméro, A Historia do Brazil. Alves \& C. 1890.

Menezes Vieira, Quadros murass da historia do Brasil.

\section{LIÇŌES DE COUSAS}

B. A. Carneiro, (trad. Saffray). Liçoes de cousas. Garnier, 3a ed. 1889.

Ruy Barbosa, (trad. Calkins). Primeiras liçð̋es de cousas, Imprensa Nacional 1886.

\section{SCIENCIAS PHYSICAS E HISTORIA NATURAL}

Perier, Phrsica e cosmographia. Garnier 1878.

F. P. Barros, Compendio de physies para leitura. 4" ed. 1889.

Garrigues, Leituras sobre seioncias. Garnier, 2a ed. 1883.

\section{DESENHO}

A yres A. Gama. Elementos de deseaho linear. Garaisr, 34 ed. 1888.

\section{GYMNASTICA}

P. Mf. Borges, Manual theorico e practico de gymanstica escholar. Garnier, 1a ed. 1888.

\section{MUSICA VOCAL}

Canticos infantis originaes ou traduzidos para os jardins do infancia, escholas primarias e familias. Alves \& $C$.

Bario de Maeahubas, Cantos em portuguez, francez, inglez, c allemāo, colligidos, arranjados e publicados para escholas, collegios e familias. Laemmert 1888.

Garaudé, Exercicios.

Miguel Cardoso, Compendio de musica. I. Bevilaqua.

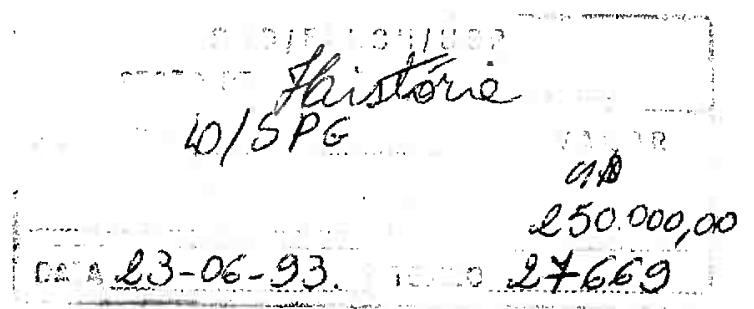

